\title{
TARIHSEL, SOYUT, ÇELIŞKILI: 1923'TEN GÜNÜMÜZE TÜRKIYE’DE KENTSEL TOPLUMSAL MEKÂN
}

Husik Ghulyan 



\title{
TARIHSEL, SOYUT, ÇELIŞKILI: 1923'TEN GÜNÜMÜZE TÜRKIYE'DE KENTSEL TOPLUMSAL MEKÂN
}

\author{
Husik Ghulyan
}


e-ISBN: 978-605-136-531-2

ANKARA ÜNIVERSITESI BASIMEVI

Incitaşı Sokak No:10, 06510, Beşevler/ANKARA

Tel: 0 (312) 2136655

Basım Tarihi: 24/09/2021 


\section{ÖNSÖZ}

1953 yılında, Siyasal Bilgiler Fakültesi bünyesinde, İskân ve Şehircilik Enstitüsü olarak kurulan merkezimiz, 1980 sonrasında İskân ve Şehircilik Araştırma ve Uygulama Merkezi biçiminde yeniden yapılandırılmıştır. Adı da Ernst Reuter İskân ve Şehircilik Araştırma ve Uygulama Merkezi olmuştur. Ernst Reuter, Nazi Almanyası'ndan kaçarak Türkiye'ye gelen ve 1938-1946 yılları arasında, Mülkiye olarak da anılan Siyasal Bilgiler Fakültesi'nde yerel yönetim ve şehircilik konularında dersler vermiştir. Reuter, aynı zamanda, hem bu konularla uğraşan bir anabilim dalı kurmuş, hem de İskân ve Şehircilik Enstitüsü'nün kurulması için çalışmaları başlatmıştır.

Bugün Merkezimiz Ankara Üniversitesi'ne bağlı olarak çalışmalarını sürdürmekte; yurt içinden ve yurt dışından üniversiteler ile ortak konferanslar; bilim insanlarıyla, yazarlarla ve uygulayıcılarla söyleşiler düzenlemektedir. Hem akademide hem de uygulamada kullanılmak üzere yayın yapmak da merkezimizin alana önemli bir katkısıdır. Bu çerçevede, Dr. Husik Ghulyan'ın "Tarihsel, Soyut, Çelişkili: 1923’ten Günümüze Türkiye'de Kentsel Toplumsal Mekan" başlıklı bu kitap da kent, çevre ve yerel yönetim politikaları alanında bilim insanlarına, öğrencilere, politikacılara ve yöneticilere çok yararlı olacaktır.

Prof. Dr. Ayşegül MENGİ Ankara Üniversitesi

Ernst Reuter İskân ve Şehircilik Araştırma ve Uygulama Merkezi Müdürü 



\section{SUNUŞ}

Yaşadığımız yüzyılın kentler çağı olacağı, bir öngörü ya da kehanet olmaktan artık çıkmış görünmektedir. Gezegensel düzeyde yapılan pek çok politika analizinin hareket noktasının kent olması bu nedenle şaşırtıcı değildir. Toplumsal, ekonomik ve siyasal yaşamın merkezi haline gelen kentleri, fiziksel büyüme ve demografik bağlamının ötesinde, sosyal mekân olarak çeşitli disiplinlerin kesişme noktasında incelemeye yönelik araştırmaların önemi artmaktadır. Nitekim kenti farklı bakış açıları ve yöntemsel yaklaşımlarla ele alıp değerlendiren bu çalışmalar, son dönemlerde artan bir ilgi görmektedir.

Kent araştırmaları alanında mekânın farklı kullanımlarını özellikle de sosyal ve politik boyutlarını inceleyen bilimsel çalışmalar akademik yazında dikkat çekmektedir. Bu çalışmalar kapsamında mekânın ve mekân planlamasının yansız olmadığı da giderek daha çok kabul görmektedir. Mekânı yansız ve boş bir hazne olmanın ötesinde politik bir bağlamda ele alan çalışmaların ana esin kaynaklarından biri ünlü kent filozofu Henri Lefebvre'in mekân üzerine düşünceleridir. Mekân felsefesi ve kent çalışmaları alanında yeni yaklaşımların önünü açan bir düşünür olarak $\mathrm{H}$. Lefebvre'in ortaya koyduğu mekânın üretimi kuramını kendisine temel alan Dr. Husik Ghulyan çalışmasında iktidar-mekân ilişkisini başkent Ankara örneğinde analiz etmektedir.

Cumhuriyetin kuruluşundan günümüze Türkiye'nin mekânsal tarihini H. Lefebvre'in düşünsel mirasına uygun biçimde diyalektik bir bakış açısıyla dönemlendiren yazar, fillozofun önerdiği "mekânsal üçlü” yaklaşımıyla da başkent Ankara'yı pasif olarak değil, "algılanan", "yaşanan" ve "tasarlanan" boyutlarıyla aktif ve dinamik açıdan ele alıp incelemiştir. Kitapta, 2000'lerin Ankara'sının panoraması ayrıntılı bir şekilde sergilenirken, "mekânda üretim" yaklaşımından "mekânın üretimi" sürecine geçiş derinlikli bir bakış açısıyla örneklerle gösterilmiştir. Titiz bir çalışma ve araştırmanın sonucu olarak ortaya konmuş bu eser, başkent Ankara'nın sosyo-mekânsal özelliklerini incelemek isteyen okurlar için başucu kitabı olacak niteliklere sahip görünmektedir. Dr. Husik Ghulyan elinizdeki kitabıyla yaşadığımız mekânın çok katmanlılığına ve politik unsurlarına dikkat çekmekte; sosyal bilimlerde mekânsal boyutun yöntemsel olarak analizinin önemini bir kez daha çarpıcı bir biçimde ortaya koymaktadir.

Prof. Dr. Tayfun Çınar Ankara Üniversitesi Siyasal Bilgiler Fakültesi Kent, Çevre ve Yerel Yönetim Politikaları ABD Öğretim Üyesi 



\section{TEŞEKKÜR}

Ankara Üniversitesi Sosyal Bilimler Enstitüsünde Mekânın Üretimi Kuramı ve Türkiye'de Kentsel Mekânın Üretimi: Ankara Örneği başlıklı doktora tezimde bazı değişiklikler yapılarak hazırlanan bu kitabın ortaya çıkmasında birçok kişi teşekkürü hak ediyor. Doktora tez çalışmamın yapım sürecinde başından beri önerileri ve eleştirileriyle beni sürekli yönlendiren, değerli desteğini esirgemeyen tez danışmanıma, değerli hocam Prof. Dr. Tayfun Çınar'a sonsuz teşekkürlerimi sunarım.

Kayıtlı olduğum doktora programında ufuk açıcı dersleri için değerli hocalarım Prof. Dr. Tayfun Çınar'a, Prof. Dr. Nesrin Algan'a, Prof. Dr. Ayşegül Mengi'ye, Prof. Dr. Aykut Namık Çoban'a ve Doç. Dr. Bülent Duru'ya teşekkürlerimi sunarım.

Tezimin izleme komite üyesi olup değerli katk1 ve önerileri için Prof. Dr. Kıvılcım Akkoyunlu Ertan'a, Prof. Dr. Ayşegül Mengi'ye ve Doç. Dr. Bülent Duru'ya teşekkürü bir borç bilirim. Ayrıca değerli öneri ve katkıları için değerli hocalarım Prof. Dr. Nesrin Algan'a ve Yrd. Doç. Seçil Gül Meydan Yıldız'a teşekkürlerimi sunarım.

Güzel sohbetiyle akademik rutinimden 'kaçmamı' sağlayan, samimiyeti ve anlayışı için değerli dostum Arif’e ve hep yanımda olup desteğini eksik etmeyen Büşra'ya sonsuz teşekkürlerimi sunarım.

Dr. Husik Ghulyan 



\section{IÇiNDEKILER}

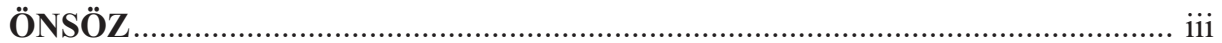

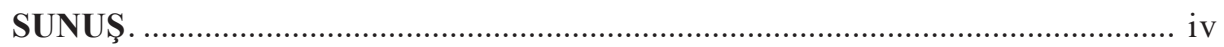

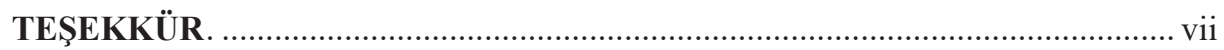

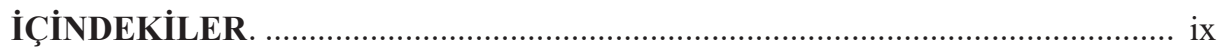

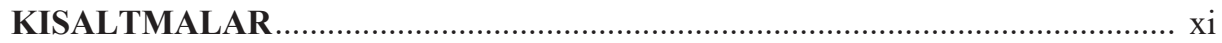

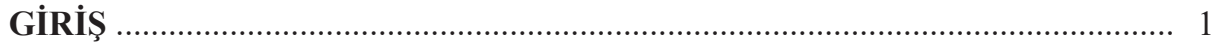

BİRINCİ BÖLÜM:

KENTSEL MEKÂNIN ÜRETIMININ KURAMSAL VE KAVRAMSAL

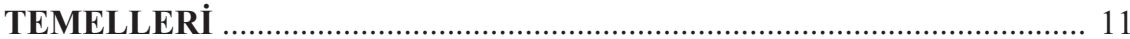

1.1. Eleştirel Sosyal Teoride Mekân Tartışmaları .................................................. 13

1.2. 'Mekânsal Dönüş’ ve Mekânın Üretimi Paradigması ....................................... 22

1.3. Mekânın Üretiminin Araştırılmasının Yöntembilimsel Temelleri.................... 36

1.4. Lefebvre'in Mekânın Üretimi Kuramının Kavramsal Çerçevesi ..................... 43

1.4.1. Toplumsal Olarak Üretilen Mekânın Tarihi: Mekân

Dönemselleştirmesi ................................................................ 43

1.4.1.1. Mutlak Mekân .................................................................... 45

1.4.1.2. Kutsal Mekân ................................................................ 48

1.4.1.3. Tarihsel Mekân............................................................... 52

1.4.1.4. Soyut Mekân ..................................................................... 57

1.4.1.5. Çelişkili Mekân ............................................................... 63

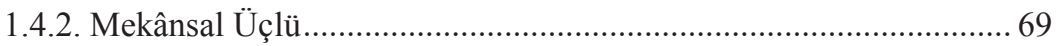

1.5. Türkiye'de Mekânın Üretimi Literatürünün Kapsamı ................................... 76

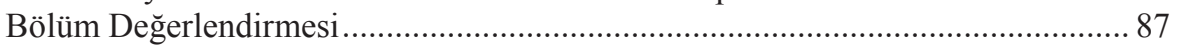

İKINCİ BÖLÜM:

TÜRKIYE'DE KENTSEL MEKÂNIN ÜRETIMI: 1923-2002 _.................. 91

2.1. İmparatorluğun Tarihsel Mekânı Egemenliğini Korurken...............................93

2.2. Ulus-devletleşme ile Kapitalistleşmenin Soyut Mekânı Yerleşerek

Yaygınlaşırken

2.2.1. 1930-40'lar: Mekân Üreterek Tarihe Emretmek: Ankara'da Modernleşme ve Mekân

2.2.2. 1950-70'lerde Modernliğin Durumu: Altyapısal Yeterlik, Üstyapısal Așinma

2.3. Neoliberal İslamcı İleri Kapitalizmin Çelişkili Mekânı Yükselirken . 


\section{ÜÇÜNCÜ BÖLÜM:}

\section{SONRASI DÖNEMDE ANKARA'DA MEKÂNIN ÜRETIMI}

3.1. Neoliberal Mekânsal Rejim Tamamlanırken: Mekânda Üretimden

Mekânın Üretimine

3.1.1. Tasarlanan, Algılanan ile Yaşanan Üçlüde Kentsel Dönüşüm ve Anakentleşme.

3.1.2. "Dünyada En Rahat Trafik Akışı" Sağlanırken ...............................205

3.1.3. En Yüksek Geliri Olan Kentin En Yoksul Halleri ..........................213

3.2. Muhafazakarlığın Mekânsallı̆̆ı: Yeniden Tanımlanan Kamusal Mekân .......219

3.2.1. Aile Yaşam Merkezleri ................................................................220

3.2.2. Gençlik Parkı'ndan 'Aile Parkı'na................................................228

3.2.3. Eymir Gölü’nü ‘Halka Açmak' '.....................................................241

3.3. Popülizmin ve Oryantalizmin Mekânsal Tezahürleri .....................................244

3.3.1. Temsil ile Karşı Temsil Mekânları Olarak Yer İsim

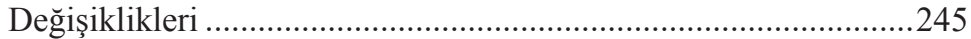

3.3.2. Söylemsel, Toplumsal ile Anıtsal Düzlemlerde Ankara'nın

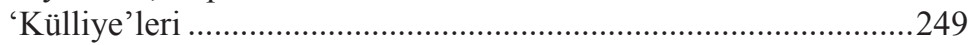

3.3.3. Oryantal Bir Kent İmgesine Doğru ................................................257

3.4. Küresel Ölçekte Kenti Temsil Etmek: Ankara'nın 'Markalaşması'................267

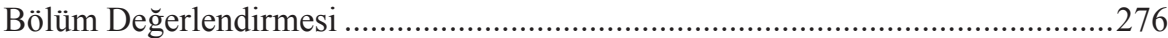

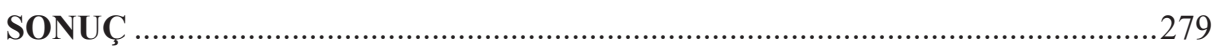

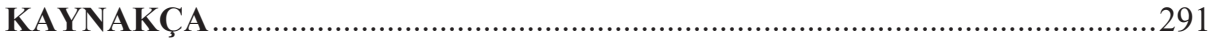

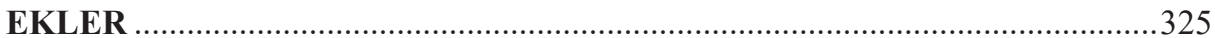

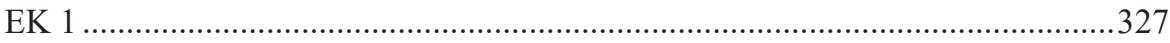




\title{
KISALTMALAR
}

\author{
ABB : Ankara Büyükşehir Belediyesi \\ AKP : Adalet ve Kalkınma Partisi \\ ANAP : Anavatan Partisi \\ AP : Adalet Partisi \\ AYM : Aile Yaşam Merkezi \\ BBP : Büyük Birlik Partisi \\ CGP : Cumhuriyetçi Güven Partisi \\ CHP : Cumhuriyet Halk Partisi \\ DP : Demokrat Partisi \\ IMF : International Monetary Fund (Uluslararası Para Fonu) \\ MHP : Milliyetçi Hareket Partisi \\ MSP : Milli Selamet Partisi \\ RG : Resmî Gazete \\ RP : Refah Partisi \\ SHP : Sosyaldemokrat Halkçı Parti \\ TOKI : : Toplu Konut İdaresi \\ TÜİK : Türkiye İstatistik Kurumu \\ akt. : Aktaran \\ bkz. : Bakınız \\ krş. : Karşılaştırınız
}





\section{GíRiş}

Tarihsel, Soyut, Çelişkili: 1923 'ten Günümüze Türkiye'de Kentsel Toplumsal Mekân başlıklı bu kitap, Türkiye'de cumhuriyetin kuruluşundan günümüze dek - 2000 sonrası dönem üzerine özel vurguyla - Ankara örneğinde mekânın üretimi süreçlerini incelemeyi amaçlamaktadır.

Çalışmanın problemi, Türkiye'de Ankara örneğinde mekânın üretimi süreçlerinin Henri Lefebvre tarafından ortaya konulan ve sosyal teorideki mekân tartışmalarında önemli yer tutan mekânın üretimi kuram1 ${ }^{1}$ bağlamında değerlendirilmesidir. Böyle bir araştırma probleminden hareketle çalışmanın kapsam ile amacının iki boyutundan söz edilebilir.

Çalışma kapsam bakımdan kuramsal kapsam ile araştırma kapsamı olarak iki eksende değerlendirilmelidir. Kuramsal kapsam açısından, çalışmada eleştirel sosyal teoride mekân tartışmaları ele alınarak temel kuramsal ve kavramsal çerçeve olarak Henri Lefebvre'in birtakım çalışmalarında öne çıkan ve özellikle Lefebvre'in Mekânın Üretimi ${ }^{2}$ eserinde detaylı olarak ele alınan mekânın üretimi kuramı benimsenmiştir. Çalışmanın kuramsal tartışmalarında mekân sorunsalı bağlamında öne çıkan çok sayıda kuramcının önermeleri ele alınmakla beraber, çalışmanın temel kuramsal kapsamı Lefebvre'in mekânın üretimi kuramıdır. Söz konusu kuramsal kapsam bağlamında bu çalışmanın amacı, bir taraftan ilgili kuramın detaylı bir okumasının gerçekleştirilmesi ve kuramda öne çıkan yapısal ve kavramsal çerçevelerin değerlendirilmesidir. Çalışmada Lefebvre'in özellikle Mekânın Üretimi kitabının detaylı bir okumasıyla kitapta öne çıkan yapısal ve kavramsal bileşenlerin değerlendirilmesi ve somut bir bağlamda mekân araştırmaları için ilgili kuramın işlevselleştirilmesi amaçlanmaktadır. Diğer taraftan çalışmanın diğer amacı ilgili kuramın işlevselleştirilen çerçevelerinin somut bir bağlamda uygulanmasıyla bu kuramın epistemolojik açıdan değerlendirilmesidir, başka bir deyişle söz konusu kuramın somut bir zamanmekân bağlamında imkân ve sinırlamalarının dolaylı olarak anlamlandırılmasıdır.

\footnotetext{
1 Lefebvre, Mekânın Üretimi.

2 Ibid.
} 
Çalışmanın somut araştırma kapsamı ise 2000 sonrası döneme özel vurguyla 1923'ten günümüze Türkiye'de - Ankara örneğinde - mekân ve mekânın üretimi süreçleridir. Böylece zamansal kapsam olarak 1923'ten günümüze uzanan bir dönem, mekânsal kapsam olarak ise Ankara kenti öne çıkmaktadır. Böyle bir kapsamın seçilmesi ise birkaç açıdan gerekçelendirilebilir. İlkin, Türkiye'de cumhuriyetin kuruluşundan günümüze uzanan süreç için kent, kentleşme ve mekân ile ilgili kayda değer literatür birikimi söz konusudur. Bununla beraber mevcut literatürde temel araştırma odağı ya mekân ve onun üretimi süreçleri olmadığı ya da mekân olduğu takdirde mekânın farklı mesleki açılardan incelendiği görülmektedir. Mevcut literatür birikiminde özellikle Lefebvre'in kuramsal önermelerini farklı biçimlerde benimseyen çalışmaların da yine mekân ve onun üretimi süreçlerini dar açılardan veya mesleki çerçevelerden ele alındığı görülmektedir. Böylelikle, Cumhuriyet'in kuruluşundan günümüze uzanan süreçte Türkiye'de mekânın üretimi süreçleri herhangi bir perspektife veya mesleki alana indirgenmeden ele alınması önem kazanmaktadır. İkinci olarak, çalışmanın birinci bölümünde ele alınacağı üzere Lefebvre'in mekân kuramında tarihsel süreçte mekânın üretimi süreçlerini ele almak için kayda değer bir mekân dönemselleştirme çerçevesi önerilmektedir. Oysa Türkiye'de konu ile ilgili literatüre bakıldığında kent ile mekân bağlamındaki araştırmaların, genel kabul görmüş siyasal tarih dönemlerine göre yürütüldüğü görülmektedir, dahası Lefebvre'in mekân kuramsallaştırmalarına dayanan çalışmalarda bile söz konusu mekân dönemselleştirmesine neredeyse başvurulmadığı görülmektedir. Dolayısıyla, Cumhuriyet'in kuruluşundan günümüze dek mekânın üretimi süreçlerini Lefebvre'in kuramı bağlamında yeniden değerlendirmek önem arz etmektedir.

Çalışmada zamansal kapsam açısından özellikle 2000 sonrası dönem üzerine yapılan vurgu ve mekânsal kapsam olarak ise Ankara'nın örnek alan olarak belirlenme hususları beraber değerlendirildiğinde açıklanabilir. Cumhuriyet'in kuruluşundan hemen önce yeni başkent olarak ilan edilen ve yeni bir ulus devlete özgü mekânın üretimi süreçlerinin ve önemli mekânsal boyutu içeren Türk modernleşme projesinin 'sahnesi' haline dönüştürülen Ankara'nın, bu süreçleri belirleyen altyapısal ve üstyapısal denklemleri ve sözkonusu mekânsal faktörlerin Lefebvre'in mekân kuramı çerçevesinden yeniden değerlendirilmesi Cumhuriyet'in kuruluşundan günümüze dek Türkiye'de toplumsal olarak üretilen mekâna ve bu üretimi belirleyen süreçlere farklı bir bakış açısı sağlayabilir. Cumhuriyet'in kuruluşundan günümüze Türkiye'de üretim güçlerinin ile ilişkilerinin -mekânın gerçek üreticisi olan bu iki önemli hususun - ve birikim rejimlerinin değişim ve dönüşümü, farklı dönemlerde öne çıan üstyapısal paradigmaların ve bunlara tekabül eden temsiliyet hususlarının başkent Ankara'da üretilmekte olan toplumsal mekân bağlamında Lefebvre'in 
sunduğu kuramsal ve kavramsal çerçeveyle değerlendirilmesi Türkiye'de mekân tartışmalarına farklı bakış açısı sunabilir.

Çalı̧̧mada mekânsal kapsam olarak belirlenen Ankara özellikle başkent olma statüsünden dolayı öteden beri mekânın politik kullanım değeri açısından ilginç bir örnek teşkil etmiştir. Şöyle ki Ankara'nın mekânı Türkiye'de değişen üretim güçleri ile ilişkilerin ve genel olarak toplumsal formasyonun etkisiyle farklı dönüşümler geçirmekle sınırlı kalmamış aynı zamanda farklı dönemlerde toplumsal formasyonunda öne çıkan üstyapısal paradigmalar doğrultusunda da önemli temsiliyet dönüşümleri geçirmiştir. Dolayısıyla, 1980'lerden beri Türkiye'de yükselen siyasal İslam doğrultusunda toplumsal mekânın dönüşümleri ve 2000 sonrası dönemde bunun daha ileri aşaması hem de özellikle bu dönemde sık sık öne çıkan Osmanlı-Selçuklu tarihsel göndermeleri, farklı bir yakın ve uzak tarih yazımının öne sürülmesi ve Ankara'da toplumsal mekânı için bunların içerimlerinin farklı bir açıdan - Lefebvre'in kuramı açısından - yeniden değerlendirilmesi önem kazanmaktadır. Bir diğer husus 1980 sonrası dönemden beri yerleşmekte olan neoliberal paradigma ve 2000 sonrası dönemde bu paradigmanın daha ileri aşamasında mekânın üretimi süreçlerinin yeniden değerlendirilmesinin önem kazanmasıdır. Ankara bu yeni paradigmatik değişimlerin kesişiminde önemli mekânsal dönüşümlerin yaşandığı bir kenti teşkil ettiğinden, Ankara örneğinden söz konusu süreçlerin ele alınmasını gerektirmektedir. Lefebvre'in, tarih içerisinde mekânın üretimi süreçlerinin anlamlandırılmasına ve mekânın tarihi kavramsallaştırılmasına yönelik mekân dönemselleştirmesi çerçevesi, ayrıca her toplumsal formasyona özgü mekânın fiziksel, zihinsel ve toplumsal boyutlarını anlamlandırması için Lefebvre'in önerdiği mekânsal üçlü çerçevesi yukarıda belirlenen hususları incelemek için kayda değer imkanlar sunmaktadır.

Lefebvre'in Mekânın Üretimi çalışması ilk kez 1974'te Fransızca olarak yayımlandığından ${ }^{3}$ beri Batı'da eleştirel sosyal teoride mekân sorunsalı bağlamında önemli tartışmalara yol açtığı, söz konusu çalışmanın 1991'de İngilizce çevirisi ${ }^{4}$ ise gerek Batı'da gerekse Türkiye'de mekân tartışmaları bağlamında daha sık ele alınmaya başlandığ 1 ve bu çalışmada öne sürülen belirli kuramsal önermelere daha s1k başvurulduğu görülmektedir. 2014'te ise bu kitabın Türkçeye çevrilmesi, kitapta öne sürülen kuramsallaştırmaların daha yaygın olarak ele alınma ve başvurulma imkanlarını sunması açısından da kayda değerdir. Genel bir mekân teorisi ortaya koyma iddiasında bulunan bu kitapta belirli saptamalar, kavramsal çerçeve ve varsayımlar söz konusudur ve bunlar ilgili kitabın ilk yayımlandığından beri hep tartışmalara konu olmuştur. Aynı zamanda bunlar sık sık başvurulan analitik çerçeveler haline de gelmiştir, bu 
bakımdan mekân ile ilgili çalışmaların en çok başvurulan kaynaklarından birisinin bu kitabın olması tesadüf değildir. Fakat bu bağlamda kayda değer husus, öteden beri kuramsal düzlemdeki tartışmaların (veya tartışmalar tarafindan) 'parçalanmış' bir mekân teorisine kıyasla genel bir mekân teorisi olma yönündeki bu kuram yine hem kuramsal düzlemde hem de somut araştırmalarda parçalanıp ele alınıp benimsendiği gerçeğidir. Bu ise bu kuramın bir bütünlük olarak yeniden ele alınması ve somut bağlamda bir bütün olarak uygunlaştırılması hususuna önem kazandırmaktadır. Dolayısıyla, bu çalışmanın kuramsal bölümünde söz konusu kuramı birtakım kavramlar veya çerçeveler olarak değil, bir bütünlük olarak - bugünlerde yaygın Post-yapısalcı ve Postmodernist tartışmaların reddettiği bir 'yapı' olarak - ele alınması ve yeniden okunması amaçlanmıştır. Böyle bir yaklaşım aynı zamanda çalışmada belirlenen zaman ile mekân kapsamı bağlamında bu kuramın bir bütün olarak uygunlaştırılmasına imkân sağlamıştır.

Ankara ile ilgili mekânla doğrudan ve dolaylı olarak ilişkin tartışmalara genel bir bakış, konu ile ilgili geniş bir literatür birikimi söz konusu olduğu görülmekte, bunlar gerek zaman kapsamı gerekse ele alınan konular açısından çok farklılık göstermekte, ayrıca bu çalışmalar dayandıkları kuramsal çerçeveleri açısından da kayda değer çeşitlilik göstermektedir. Bu durum hem Cumhuriyet tarihi boyunca hem de çalışmamızın daha detaylı bir biçimde ele aldığ 2000 sonrası dönemde Ankara'nın mekânı için geçerlidir. Kayda değer diğer husus Lefebvre'in farklı kuramsallaştırmalarına dayanan ve Ankara ile ilgili farklı konulara odaklı çeşitli çalışmaların varlığıdır. Fakat yine göze çarpan temel eğilim, mevcut çalışmaların, ilgili kuramı bir bütünlük olarak ele alınıp benimsemek yerine, bu kuramdaki birtakım kavramlara, bazen kuramın bazense ilgili kavramların parçacı okumalarına dayanması, ayrıca Ankara'yı bir bütün olarak değerlendirmek yerine Ankara'da farklı ölçekteki mekân veya olgulara odaklanmasıdır. Dolayısıyla, Cumhuriyet'in kuruluşundan günümüze uzanan tarihsel süreçte ve 2000 sonrası dönemde Ankara'nın mekânının kendisi bir süreç ve bir bütünlük olarak - Lefebvre'in kuramındaki birtakım kavramlar aracılığıyla değil, onun kuramının bir bütünlük (bir 'yapı') olarak ve detaylı biçimde işlevselleştirilmiş bir okumasına dayanarak - yeniden değerlendirilmesi önem arz etmektedir.

Lefebvre, "toplumsal mekân toplumsal bir üründür"5 iddiasını mekân kuramı için başlangıç bir önerme olarak öne sürmektedir ve bu önermenin birtakım içerim ve sonuçlarından söz etmektedir. Bu çalışmanın konusu açısından yukarıdaki önermenin "her toplum (dolayısıyla, içerdiği çeşitliliklerle birlikte her üretim tarzı, genel kavramın kendi gösterdiği tikel toplumlar) bir 
mekân üretir, kendi mekânını üretir"6 sonucu önem taşımaktadır. Önem arz eden diğer içerim ise "mekânın üretimi ve mekânın üretimi süreci varsa, tarih de vardır" sonucudur, bu mekân tarihi ise mekânsal biçim ve temsillerin, sosyoekonomik ya da kurumsal yapıların, fikir ve ideolojilerin ardışıklı̆̆ıyla, "'tarihsel" (belli bir tarihe bağlı) olguların nedensel zincirlenişiyle" karıştırmamalıdır, zira toplumsal mekân üretici güçler ve üretim ilişkileri tarafından üretilir. ${ }^{7,8} \mathrm{Bu}$ önermelerden yola çıkarak Lefebvre, genel bir mekân tarihine dair mekân dönemselleștirmesi öne sürmektedir. Kabaca bir tanımıyla Lefebvre'in mekân kuramındaki bu dönemselleştirme bileşeni kapitalist öncesi üretim ilişkilerinin (kabile toplumu veya ilkel komünizm, Asya tipi üretim tarzi, antik veya klasik üretim tarzı, feodalizm) egemen olduğu toplumlar mutlak mekân, kutsal mekân veya tarihsel mekân, kapitalist üretim ilişkilerinin erken aşamalarında olduğu toplumlar (erken kapitalizm) soyut mekân ve kapitalist üretim ilişkilerinin ileri aşamasında olduğu toplumlar (geç kapitalizm) çelişkili mekândan ibarettir.

Yukarıdaki önermeler bağlamında Lefebvre, herhangi bir toplumsal mekânın ele alınması için üç momentli bir kavramsal çerçeve - mekânsal üçlüönermektedir. Bunlar mekânsal pratik, mekân temsili ile temsil mekânı (veya sırasıyla algılanan mekân, tasarlanan mekân ile yaşanan mekân) kavramlarıdır. Kabaca bir betimlemeyle, bunlar, toplumsal mekânın fiziksel, zihinsel ve toplumsal boyutlarına belirli ölçüde denk düşmekte ve fiziksel, zihinsel ile toplumsal boyutlardan oluşan toplumsal mekânın üretimi ile yeniden üretiminin anlamlandırılmasına ve bu boyutların birbirine bağlantılı biçimde değerlendirilmesine yönelik karşılıklı bağımlı olan ve birbirinden bağımsız olarak düşünülmez kavramlardır.

Lefebvre'in söz konusu önermelerinden yola çıkarak çalışmanın temel sorunsalı Türkiye'de Ankara örneğinde Cumhuriyetin kuruluşundan günümüze kadar değişen üretim güçleri ile ilişkileri bağlamında mekânın üretimi ve üretilmekte olan mekânın tarihinin ele alınmasıdır. Bu bakımdan Lefebvre'in

\section{Ibid., s. 61.}

Ibid., s. 75, 223-224.

8 Lefebvre'in, mekân tarihi mekânsal biçim ve temsillerin, sosyo-ekonomik ya da kurumsal yapıların, fikir ve ideolojilerin, tarihsel olguların ardışıklığıyla karıştırılmaması gerekliliğine yaptığ1 vurgu, onun kuramının doğru anlamlandırılması ve uygulanması bakımdan önem arz eder, zira söz konusu kurama sık sık başvuran çalışmalarda genel eğilim, mekân tarihinin kâh belirli temsil ve biçimler kâh tarihsel olguların ardışıklığıyla anlamlandırılmaya çalışılması ve mekân tarihinin bunlara indirgenmesidir. Oysa, ilerleyen bölümde detaylı olarak ele alınacağı üzere söz konusu kuram üretimi temelinde bulunduran bir kuramdır, yapısal niteliktedir, içerisinde bazen temsil, biçim gibi hususları öne çıssa da söz konusu kuramda, Post-modern ve Post-yapısalcı söylemde görülen temsil ve biçim 'takıntıları' (obsessions) ön planda değildir, zira söz konusu biçim ve temsiller de son kertede bir üründür veya üretime yöneliktir. 
önerdiği dönemselleştirmede, ulus-devletleşme ve kapitalistleşme aşamasında olduğu toplumlarda üretilmekte olan mekânın tarihsel mekân ile soyut mekân, ileri kapitalist gelişme aşamasında olan toplumlarda üretilmekte olan mekânın ise çelişkili mekân olarak kavramsallaştırılması kayda değerdir. Bu doğrultuda çalışmada Türkiye'de Ankara örneğinde Cumhuriyetin kuruluşundan günümüze uzanan süreçte mekân tarihini ele almak için Cumhuriyet'in kuruluşundan 1930'lu yıllara dek Türkiye'de tarihsel mekânın egemen olduğu varsayımı öne sürülmektedir. Türkiye'de ulus-devletleşme ile kapitalistleşme bağlamında soyut mekânın üretiminin ise çalışmada 1930-1980 arası dönemde gerçekleştiği ve bu dönem, üretilmekte olan soyut mekân açısından bir bütünlük arz etmediği, bunun ilk evrede ulus-devletleşmenin soyut mekânı ile kapitalistleşmenin soyut mekânı olarak iki müteakip evreden oluştuğu varsayımı öne sürülmektedir. Son olarak, çalışmada 1980 sonrası dönemden itibaren ileri kapitalizmin çelişkili mekânının üretildiği varsayımı öne sürülmektedir. Böylece çalışmanın Türkiye'de Ankara örneğinde mekânın üretimi süreçlerinin ele alınışı bu temel varsayımlar doğrultusunda gerçekleştirilmiştir.

Çalı̧̧mada ayrıca 2000 sonrası dönemde Ankara'da mekânın üretimi süreçlerinin daha ayrıntılı bir incelemesi amaçlandığı için bu bakımdan ilgili döneme dair şu temel varsayım öne sürülmektedir: 2000 sonras1 dönemde Türkiye'de neoliberal İslamcı üstyapısal paradigma ile ileri kapitalizmin esnek sermaye birikimi bağlamında Ankara'da neoliberal bir kentsel rejimin inşası tamamlanmıştır ve neoliberal rejim ancak 2000 sonrası dönemde önemli bir mekânsal boyut kazanarak mekânın algılanan, yaşanan ile tasarlanan boyutlarında somut ifadesini bulmuştur. Bu bağlamda ilgili dönemde mevcut neoliberal rejim bağlamında Ankara'da mekânda üretimden mekânın üretimine geçişin gerçekleştiği varsayımı öne sürülmektedir.

2000 sonrası dönemde mekânın üretimi süreçlerine dair çalışmanın diğer temel varsayımı; 2000 sonrası dönemde sık sık öne çıkan İslamcı ile OsmanlıSelçuklu söyleminin, gerek yapılı çevrenin üretimi gerekse mekân üzerine söylem bağlamında baskın bir nitelik kazanması ve mekânsallaşması ve kentsel mekânın algılanan, yaşanan ile tasarlanan boyutlarında farklı dişavurumlarla ve ifadelerle üretilmekte olan çelişkili mekânda gündelik gerçeklik ile kentsel gerçeklik, toplumsal mekânda mekân temsili, temsil mekânı ile mekânsal pratikler arasında ve bu üç unsurun her biri içerisinde farklı çelişkilerin ortaya çıkmasına yol açtığı varsayımıdır.

Lefebvre'in mekân kuramının birkaç temel varsayıma veya saptamaya indirgenmesi, benzer biçimde herhangi bir bağlamda mekân ve üretimi süreçlerinin birkaç temel varsayıma göre ele alınmasının uygun bir yaklaşım olmadığını, dolayısıyla bu çalışmada söz konusu temel varsayımlar ve iddialarla birlikte ilgili kuramda öne çıkan birtakım diğer önerme, varsayım veya 
saptamalar da ele alınıp çalışmanın konusu bağlamında incelendiği ve somut bağlamda bunların sınanmaya çalışıldığı belirtilmelidir.

Çalışmada, konuyu ele almak için birkaç temel yönteme başvurulmuştur. Bunlardan ilki, kapsaml literatür değerlendirmesi yöntemidir. $\mathrm{Bu}$ yöntemle çalı̧̧mada benimsenen kuramsal çerçeveye (Lefebvre'in mekân kuramına) dayanan ve Türkiye'yi konu edinen mevcut çalışmalar sistematik olarak taranarak değerlendirilmiştir: bu çalışmalar gerek kuramsal kapsamları gerekse ele aldıkları konular, mekân ve zaman örneklemleri açısından değerlendirilip sınıflandırılmış, bunlarda ele alınan konuların ilgili kuramın hangi bileşenleri bağlamında ele alınıp alınmadığı ortaya çıkarılmıştır. Bu yönteme, çalışmanın konusunun Türkiye'de ne derecede ve nasıl ele alınıp alınmadığ 1 hususlarının araştırılması için başvurulmuştur. Ayrıca bu yöntemle ortaya çıkarılan çalışmaların bazıları, bu araştırmanın somut değerlendirmelerinde yardımcı ve yönlendirici işlev görmüştür.

Başvurulan ikinci yöntem - ki bu çalışmada Ankara'da mekânın üretimi süreçlerinin 1923-2000 arası dönemi için yaygın olarak başvurulmuştur - Ankara ile ilgili ve mekân üretimi süreçleriyle doğrudan veya dolaylı ilişkili çalışmaların taraması olmuştur. Bu çalışmalar, kent planlaması, mimarlık, kent tarihi ve diğer alanlarda yapılmış olan çalışmalardır. Bu çalışmalardan elde edilen veriler veya bunlarda mevcut bazı saptama ve değerlendirmeler aracılığıyla çalışmada benimsenen kuramsal çerçeve bağlamında Ankara'da mekânın üretimi süreçlerinin değerlendirmesi yapılmıştır. Ayrıca, bazı konular için plan raporları, istatistiki veriler, görseller veya edebiyat eserleri gibi birincil el kaynaklarına da başvurulmuştur.

Son olarak, çalışmanın özel olarak üzerine yoğunlaştığı 2000 sonrası dönem için çeşitli resmi yayın organlarının taraması ve konu ile ilgili haber, yayın, görsellerin analizi yapılmıştır, bunun için özellikle içerik ve söylem analiz yöntemlerine başvurulmuştur. Aynı zamanda çeşitli medya yayınlarında tarama yapılmış ve çalışmamızın konusuna ilişkin haberlerin içerik ve söylem analizi gerçekleştirilmiştir. Ayrıca farklı istatistik kaynaklarına da başvurulmuştur. $\mathrm{Bu}$ dönemde Ankara'da mekânın üretimi süreçlerinin ele alınması için Ankara Büyükşehir Belediyesi'nin (ABB) kapsadığı alan mekânsal ölçek olarak tanımlanmıştır. Böyle bir ölçekte inceleme yapılması için ise özellikle ABB'nin proje ve uygulamalarına odaklanılmış, $\mathrm{ABB}$ yönetimince mekân üzerine yapılan söylemlerin incelemesi yapılmıştır. Ayrıca merkezi iktidarın doğrudan Ankara ile ilgili proje ve uygulamaları ile söylemleri de incelenmiştir. ${ }^{9}$ Dolayısıyla

9 İncelenen dönemde gerek belediye yönetiminin gerekse merkezi hükümetin AKP'li olduğu, ayrıca mekânın üretimi süreçleri konusunda her iki düzlemin de benzer söylem, yaklaşım ve politikalar benimsemesinden dolayı ilgili dönemin değerlendirmelerinde iktidar sözcüğüyle 
incelemeler daha çok resmi yayınlara dayanmıştır. Bu açıdan özellikle ABB tarafından yayınlanan Büyükşehir Ankara bülteninin sistematik olarak taranarak incelenmesinin yapıldığı belirtilmelidir. $\mathrm{Bu}$ yayın organına özellikle odaklanılması sadece belediyenin resmi yayını olmasından kaynaklanmamıştır. Söz konusu yayında 2006 yılından itibaren kesintisiz biçimde ABB'nin proje ve uygulamalarına yer verilmektedir. Dolayısıyla öne çıkan (veya ABB tarafindan öne çıkarılan) çeşitli projeleri tespit etmek ve değerlendirmek için bu yayın önemli bir kaynak oluşturmaktadır. ${ }^{10}$ Ayrıca, genele hitap edecek nitelikte bir yayın olması itibarıyla mekân üzerine söylemi değerlendirmek açısından söz konusu yayın kayda değerdir. Bir diğer önemli husus, bu yayının ABB tarafından ücretsiz olarak halkın yoğun olarak kullandığı belirli alanlarda (metro durakları, belediye otobüsleri vs.) dağıtılmasıdır. Dolayısıyla, bu yayının, genel olarak resmi yayın organlarında olduğu gibi soyut bir dili olan, yayınlama zorunluluğu olan dolayısıyla sayfa dolduran, ama hiç okunmayan bir yayın olmadığı söylenmelidir. Zira, gözlemlerden anlaşıldığı üzere bu yayın, Ankara halkının belirli kesimleri tarafından ilgi görmektedir. Bu açıdan ise yayının, en azından iktidarın, başta mekân olmak üzere diğer konular üzerine söylemini halkın belirli kesimlerine ulaştırması açısından belirli etkinliği olduğu söylenebilir. İlgili bölümdeki incelemeler için başka yayınlara ve kaynaklara da başvurulmuştur. Bunlar farklı konularda çeşitli gazetelerde yayımlanan haberlerdir. ABB'nin yıllık faaliyet raporlarından veya farklı istatistiki veriler için TÜIK'in veri tabanlarından da yararlanılmıştır. Böylece bu çalışma, benimsenen yöntemsel çerçeve açısından niteliksel bir araştırmadır.

Yukarıda ele alınan hususlar doğrultusunda bu çalışma üç ana bölümden oluşmaktadır. Birinci bölümde kuramsal tartışmalara yer verilmiştir. Burada eleştirel sosyal teoride, özellikle Marksizmin bünyesinde ortaya çıkan mekân tartışmaları ele alınmıştır. Lefebvre'in mekân üzerine yazılarından özellikle Mekânın Üretimi kitabının detaylı bir okumasıyla bu çalışmanın dayandığı kuramsal ve kavramsal çerçeve çizilmiştir. Bu bölümde aynı zamanda Türkiye ile ilgili 'mekânın üretimi' literatürünün (Lefebvre'in kuramsallaştırmalarını temel alan veya onlara başvuran çalışmaların) değerlendirmesi ve mevcut araştırmalardaki (tartışmalardaki) genel eğilimlerin ortaya çıarılması amaçlanmıştır.

eğer özel bir husus söz konusu değilse gerek yerel gerekse ulusal düzeyde iktidar olan AKP kastedilmektedir.

10 Resmi bir yayında belirli projelere sürekli vurgu yapılması veya onların sık s1k ele alınması, iktidarın mekân üretimi politikaları açısından bu projelerin önemini göstermektedir. Dolayısıyla iktidarın mekân üretimi politikalarını anlamak açısından sıkça vurgulanan bu projelerin önemli olduğu söylenebilir. 
İkinci bölüm, Türkiye'de Ankara örneğinde 1923-2000 aras1 dönemde mekânın üretimi süreçlerini ele almaya ve ilgili zaman diliminde Ankara'nın mekân tarihini yeniden değerlendirmeye yöneliktir.

Kitabın üçüncü bölümünde ise 2000 sonrası dönemde (AKP dönemi) Ankara'da toplumsal mekânın (yeniden) üretimi süreçlerinin yönelimleri, eğilimleri ve üretilmekte olan toplumsal mekânın algılanan, yaşanan ile tasarlanan boyutları değerlendirilmektedir. 



\section{BÖLÜM}

KENTSEL MEKÂNIN ÜRETIMININ KURAMSAL VE KAVRAMSAL TEMELLERI 



\section{KENTSEL MEKÂNIN ÜRETIMININ KURAMSAL VE KAVRAMSAL TEMELLERI}

\subsection{Eleştirel Sosyal Teoride Mekân Tartışmaları}

Aydınlanma Dönemi’nden ve özellikle endüstriyel kapitalizmden itibaren sosyal teoride egemen bir mekân anlayışı var olagelmiştir. Bir üretim tarzı ve toplumsal düzen olan kapitalizm ve onun bir evresi olan endüstriyel kapitalizm bir taraftan kendine özgü bir mekân anlayışının gelişmesine yol açarken, diğer taraftan sanatta, edebiyatta, bilimde ve diğer alanlardaki mekân anlayışının değişimi, kapitalist toplumsal düzenin gelişip derinleşmesine katkıda bulunmuştur. Ancak 20. yüzy1lın 60'l1 yıllarından itibaren bahsi geçen mekân anlayışı en azından sosyal teoride sistematik bir şekilde sorgulanmaya başlanmıştır.

17.-19. yüzy1llarda hâkim olan mekân anlayışı, yüzyıllar boyunca var olan Öklid geometrisine ve yeni ortaya çıkan Kartezyen koordinat sistemine dayanan bir mekân anlayışıdır. Özellikle, Kartezyen sistemin gelişimi mekânın matematiksel temsilinin kolaylaştırılmasına ve mekânın araçsallaştırılmasına katkıda bulunmuştur. $\mathrm{Bu}$ ise aydınlanmanın teknokratik ve insan tarafindan doğaya ve doğanın bir parçası olan mekâna hâkim olma eğilimini daha da hızlandırdı, çünkü koordinat sistemi vasitasıyla tek bir temsil, mekânın araçsallaştırılmasına ve ona hâkimiyetine zemin hazırlamıştır. Aydınlanma Dönemi'nde hâkim olan tek bir temsil tarzının arayışları da bu sürecin temelinde yatmaktadır. Zaten Aydınlanma projesi de hep tek bir temsil tarzinın arayışındaydı ve Aydınlanma için, diğer olgular gibi mekân konusunda da tek bir temsil arayışı söz konusuydu ve tüm çabalar mekânı 'doğru' biçimde resmederek ve temsil ederek onun kontrol altına alınmasına yönelikti. Kısacası, Aydınlanma projesi mekânın tek doğru temsilini varsayıyordu ve bütün çabalar buna yönelikti. ${ }^{11}$

$11 \mathrm{Bu}$ dönemdeki hâkim anlayış ve yönelimler için bkz. Harvey, The Condition of Postmodernity: An Enquiry into the Origins of Cultural Change, s. 27; Lefebvre, Mekânın Üretimi; Soja, Postmodern Geographies: The Reassertion of Space in Critical Social Theory, s. $122-126$. 
Böyle bir hâkim anlayış çerçevesinde mekân, insan yaşamı ve faaliyetleri için bir ortam olarak görülmekteydi ve doğanın bir parçası sayılmakta, ona hâkim olup insanın ihtiyaçlarına göre biçimlendirmesi amaçlanmaktaydı. Mekâna yönelik böyle bir araçsal anlayış, özellikle sosyal teoride kendi baskın konumunu 20. yüzyılın 60-70'li yıllarına dek farklı dönüşümlere uğrayarak hâkimliğini korumuştur. Hatta, belli başl1 etkenler ve eğilimler nedeniyle daha da belirgin hale gelmiştir. Bu bağlamda, burada özellikle belirtilmesi gereken önemli bir husus, kapitalizmin gelişmesi ile hâkim mekân anlayışı arasındaki karşılıklı ilişkidir.

Kapitalist üretim ilişkilerinin gelişmesi, beraberinde meta mübadelesi ilişkilerinin yaygınlaşmasına, dolayısıyla somut mekân ve zaman bağlamında gerçekleştirilen emek süreçlerinin soyutlaşmasına yol açmıştır. Bu durum, mekân konusunda ilginç sonuçlar doğurmuştur. Nitekim, Smith'e göre mekânın doğrudan pratikten kopuk bir kavram olarak soyutlanması meta mübadelesiyle yakından ilgilidir. ${ }^{12}$ Mübadele sürecinde bir metanın kullanım ve maddi taraflarının soyutlanması söz konusudur. Bu durum ise mekânın, doğrudan maddi deneyimden soyutlanma olasılığına yol açmaktadır. Meta mübadelesi etkisiyle soyutlanmış olan zaman ve mekân, her türlü doğal ve maddi içerikten yoksun olup, homojenlik ve süreklilik özelliğiyle karşımıza çıkmaktadır. Başka bir ifadeyle, meta mübadelesine dayanan toplumsal ekonomilerin gelişmesiyle ikinci bir doğa ortaya çıkmaktadır, bu ise yer ile doğa arasındaki ayrıma yol açar. $\mathrm{Bu}$, mekânın fizik biliminde kullanılan soyut anlayışının ortaya çıkışına da damgasını vurmuştur. Böyle bir mekân anlayışı, yakın yer (immediate place) ile bağlı değildir, aksine yakın yerden soyutlanmasına ve doğrudan deneyimin ötesine geçen mekânsal uzantı tasavvuruna işaret etmektedir. Sonuç olarak, toplumun ve mekânın kavramsal birliği ortadan kalkmakta ve mekân bağımsız bir kavram olarak gelişmeye devam etmektedir.

Lefebvre kapitalizme özgü mübadele ilişkilerinin yaygınlaşması, emeğin soyutluk kazanmasına ve soyut mekân arasındaki ilişkilere dikkat çekmektedir. Ona göre, birikime dayalı tarihsel mekândan veya kutsal mekândan geç feodalizmde farklı bir mekân ortaya çıkmıştır. Bu dönemde, üretim faaliyeti (emek) toplumsal hayatın devamını sağlayan yeniden üretim sürecinden ayrıldı ve ondan bağımsız hale geldi, emek soyutlanmaya maruz kaldı, bundan dolayı ise soyut toplumsal emek ve soyut mekân ortaya çıtı. ${ }^{13}$

Somut emek süreçleri söz konusu olduğunda, mekân anlayışı genelde mutlaktır. Emeğin somutluğu, onun mekânsal özelliklerinin somutluğu anlamına gelmektedir. Fakat, soyut emek durumu farklıdır. Soyut emeğin değer olarak gerçekleştirilmesi meta mübadelesi, para ilişkileri, kredi araçları ve hatta emek

12 Smith, Uneven Development: Nature, Capital, and the Production of Space, s. 102, 107-108.

13 Lefebvre, Mekânın Üretimi, s. 76-78. 
gücü hareketliliğinin mekânsal olarak bütünleştiği bir sisteme ihtiyaç duymaktadır. $\mathrm{Bu}$, somut üretim yerleri arasında ulaşım ve iletişim bağlantılarının kurulmasını gerektirir, dolayısıyla mekânın hem göreceli hem de mutlak olarak tasavvur edilmesini gerektirir. Eskiden ayrı olan üretim yerlerinin ulusal veya uluslararası ekonomiyle bütünleşmesi, onun mutlak konumunu değiştirmemektedir, fakat onun göreceli konumunu değiştirerek değer olarak soyut emeğin gerçekleştirilmesini genişletmektedir. ${ }^{14}$

Böylece "kapitalizmin tarihsel gelişimi, değerin soyut emek biçimi olarak aşamalı evrenselleşmesine neden olmaktadır", dolayısıyla dünya pazarının oluşması ve mübadele ilişkilerinin yaygınlaşmasıyla "mutlak mekânların göreceli mekâna dönüşmesine ve bütünleşmesine" tanık olmaktayız. ${ }^{15}$

Soyut mekânın ortaya çıkışı konusunda Smith'in devletin ortaya çıkışına vurgusu kayda değerdir. ${ }^{16}$ Bir kurum olarak devletin ortaya çıkmasından önce (burada burjuva devrimlerinden sonra ortaya çıkan ulus devletten söz edildiği unutulmamalıdır) toplum bir mekânsız örgütlenme olarak algılanmaktaydı. Toplumu mekânsız bir örgütlenme, yani soyut mekânsız bir ikincil doğa (toplumsal mekân) olarak kavrayışın ilk imaları, devletin belirgin mekânsal tanımıyla olanaklı oldu. Fakat bu, iki yönlü bir süreçti ve bu süreçte somut ve soyut olanın diyalektiğiyle karşı karşıyayız. Bir taraftan, "mekân, toplumsal gelişme için artan öneme sahip bir dayanak haline geldi." Yani, küçük alanlardan başlayıp sonralarda dünyanın tüm coğrafi mekânı toplumsal genişleme sürecinin bir parçası olarak bölündü. Coğrafi genişleme, toplumsal genişleme ve gelişmenin eşanlamı haline geldi. Bu genişleme ve gelişme ise mekânın toplumsal olarak üretildiği coğrafi alanın genişlemesiyle gerçekleşti. Kısacası, toplumsal gelişme ve ikincil doğanın genişlemesi için mekân somutluk kazandı. Diğer taraftan, mekân aynı zamanda toplumsal ilişkiler için gittikçe daha gereksiz hale geldi. Yani ekonomik, teknolojik, siyasi ve kültürel ilişkilerin gelişmesi ve genişlemesiyle bu ilişkileri örgütleyen kurumsal çerçeve daha karmaşık hale geldi ve kendi içkin mekânsal tanımını gittikçe kaybetti. Yani, toplumun mekândan 'özgürleşmesi' ve mekânın soyutlanması söz konusuydu. İşte böyle bir diyalektik ilişki nedeniyle, Lefebvre, mekânı bir 'somut soyutluk' olarak tanımlamaktadır.

Fakat Smith'in bu saptamaları önemli olmakla beraber, şu açıdan sorunludur. Smith'e göre "nihayet coğrafi mekânın göreceliliğini belirleyen, Einstein veya fizik bilimi ve felsefe değil, sermaye birikiminin fiili sürecidir."17 Yani bahsi geçen mekânın ortaya çıkışı sürecinde Smith, sermaye ve birikim

14 Smith, Uneven Development: Nature, Capital, and the Production of Space, s. 113.

15 Ibid., s. 113.

16 Ibid., s. 110-111.

17 Ibid., s. 113. 
süreçlerine temel rol atfeder, oysa kapitalizmin soyut mekânının ortaya çıkışında sermaye birikiminin önemli rolü olmakla beraber, bilim, felsefe, sanat ve mimari alanlarındaki paradigmatik değişimlerin de bu süreçte önemli bir rolü vardı ve ortaya çıkan yeni mekân anlayışı ve pratiği bu değişimlerden kaynaklanan süreçlerin ürünüydü.

Yukarıda değinildiği üzere, Aydınlanma düşüncesi, evrenin oldukça mekanik 'Newtoncu' bir imgelemi çerçevesinde hareket ediyordu. Böyle bir imgelemde, homojen zaman ve mekânın varsayılan mutlaklığı, düşünce ve eylemini sınırlayan bir çerçeve oluşturuyordu. Bu mutlak anlayışların zamanmekân sıkışmasının basıncı altında çöküşü, modernizmin 19. yüzyılın sonu ve 20. yüzyılın başındaki biçimlerinin doğuşunun merkezinde yer alıyordu. ${ }^{18}$ Harvey'e göre:

"Mekânın fethi ve denetimi, öncelikle, mekânın kullanılabilir, şekillendirilebilir ve dolayısıyla insan eylemi aracılığıyla hâkimiyet altına alınabilir olarak düşünülmesini varsayar. Perspektivizm ve matematiksel haritacılık bunu, mekânı nitelikleri bakımından soyut, türdeş ve evrensel olarak, düşünce ve eylemin sabit ve bilinebilir bir çerçevesi olarak kavrama yoluyla yaptılar. Söylemin temel dilini sağlayan Öklid geometrisiydi. İnşaatçılar, mühendisler, mimarlar ve araziyi yönetenler de nesnel mekânın Öklidyen gösterimlerinin mekânsal olarak düzenlenmiş bir fiziksel peyzaja nasıl dönüş̧ürülebileceğini ortaya koydular. Tüccarlar ve toprak sahipleri bu uygulamaları kendi sınıf çıkarları uğruna kullanırken, mutlakiyetçi devlet de (toprağın vergilendirilmesi sorununa ve kendi hâkimiyet ve toplumsal denetim alanının tanımlanmasına duyduğu ilgi nedeniyle) belirlenmiş mekânsal koordinatları olan mekânların tanımlanabilmesinden ve üretilebilmesinden büyük memnuniyet duyuyordu. Ama bunlar, her türden başka mekân ve zaman anlayışlarının (kutsal ya da dünyevi, sembolik, kişisel ya da animistik) engellenmeksizin hüküm sürmeye devam ettiği bir toplumsal faaliyetler denizinde adacıklardı. Mekânın toplumsal hayat içinde pratikte evrensel, türdeş, nesnel, soyut kullanımı için başka bir şey daha gerekiyordu. Sayısız ütopik planın varlığına rağmen, zamanla hâkimiyeti ele geçiren bu "başka bir şey", toprakta özel mülkiyet ve mekânın bir meta olarak alınıp satılması olacaktı."19

Fakat 19. yüzyıl sonuna doğru Aydınlanma döneminden beri hüküm süren tek mümkün gösterim tarzı çökmeye başladı. Aydınlanma düşüncesinin kategorik sabitliği gittikçe daha çok sorgulanır oldu ve sonunda yerini farklı temsil sistemleri üzerindeki vurgusuna bırakt1. ${ }^{20}$

18 Harvey, The Condition of Postmodernity: An Enquiry into the Origins of Cultural Change, s. 252.

19 Harvey, Postmodernliğin Durumu: Kültürel Değişimin Kökenleri, s. 285.

20 Harvey, The Condition of Postmodernity: An Enquiry into the Origins of Cultural Change, s. 28. 
Bu eğilimin doruk noktası 20. yüzyılın ilk çeyreğiydi. Bu dönemde sanat, mimari ve bilim alanındaki paradigmatik değişiklikler, aynı zamanda mekân paradigmasının değişimine yol açtı. Lefebvre, Mekânın Üretimi çalışmasında 1907 yılını bu dönüm noktası olarak tanımlar. Ona göre, bu dönemde Pablo Picasso resim yapmakta yeni bir yöntem keşfetti. Picasso'nun temsil ettiği bu değişimin özü sanattaki mekân temsilinin değişimiydi. Picasso, yapıtlarında bu değişimi yansıtmaktaydı, modernitenin "eşzamanlı olarak homojen ve parçalanmış"21 mekânını yansıtmaktaydı. Picasso'nun sanatındaki mekân temsiline koşut olarak bilimde de böyle bir dönüm noktası yaşandı ve bu mekânın daha da soyutlanmasına ve insanın da bu mekândan soyutlanması pratiklerine yol açtı. Özellikle Lefebvre tarafindan Picasso'nun sanatı ile ilgili şu saptaması kayda değerdir: "Picasso'nun beden karşısındaki, özellikle de binlerce şekilde işkence edilen, karikatürleştirilen kadın bedeni karşısındaki acımasızlığı, hâkim mekânın, gözün ve fallusun, şiddetin buyruğudur."22

Ayrıca, bu dönemde plastik sanat alanında Jean Metzinger, Marcel Duchamp, Robert Delaunay, Georges Braque, Kandinsky'nin faaliyetleri de vurgulanmalıdır. Çoğu kübizm olarak tanımlanan sanatsal akımın temsilcisi olan bu sanatçıların eserleri, dönemin mekân anlayışını hem yansıtan hem de biçimlendiren önemli unsurları oluşturmaktaydı, çünkü bir sanatsal akım olarak "kübizm için tipik olan mekânın parçalanma ve dağılma"23 eğilimi, yeni bir mekân temsili ortaya koymaktadır.

Aslında Lefebvre'in Picasso'ya yönelik böyle bir eleştirisi dönemin tüm kübist sanatçıları için geçerlidir (bkz. Şekil 1). Fakat şu da belirtilmelidir; zamanmekân sıkışması yaşanan ve hareketliliğiyle nitelenen bu dönemde, Picasso başta olmak üzere diğer kübistlerin amacı bu zaman-mekân sıkışmasını ve hareketliliğini anlama, anlamlandırma ve yansıtmaktır. Kübizm, ortaya çıkan yeni modern gerçekliği temsil etmeye çalışmaktadır. Bu yeni gerçeklik karmaşık ve muğlakt1, yeni keşifler, felsefi yorumlar ve kültürel farlılıklarıyla biçimlenmekteydi. Aydınlanma Dönemi'nden beri durağanlıkla nitelenen yaşam ritmi, 19. yüzyılın sonlarına doğru iyice hareketlilik ve değişkenlik kazandı ve bu hareketin (Kübizmin) hâkim olduğu dönemde doruk noktasına ulaştı. Geçmişteki durağan yaşam ritmi, yeni gelişmelere koşut olarak modern insanın zaman, hareket ve mekân deneyimlemesini iyice değiştirdi. Ayrıca, yukarıda da değinildiği üzere, Aydınlanmanın başta mekân olmak üzere diğer olgularının tek bir temsilinin çöküşü, dönemin hareketliliğiyle birlikte belirsizlik yaratmıştı. Özellikle Alfred Whitehead'in fikirleri ve daha sonra Einstein'in Öklidyen

21 Lefebvre, Mekânın Üretimi, s. 307.

22 Ibid., s. 308-309.

23 Harvey, The Condition of Postmodernity: An Enquiry into the Origins of Cultural Change, s. 269. 
olmayan geometrilere dayanan görelilik kuramı ve ortaya çıkan yeni matematik, yeni bir anlayış için zemin hazırladı. Bu gelişmeler, mekân açısından birbiriyle iç içe geçmiş ve ayrılmaz olan, fakat analitik amaçlarla burada ayrılabilecek iki önemli sürece yol açtı.

Birincisi, görelilik kuramının gelişmesi sadece fizik bilimi ve matematikle sınırlı kalmayıp, sosyal bilimlerde de mekân konusunda paradigmatik değişime yol açtı. Göreceli mekân anlayışı gittikçe yaygınlaştı, çünkü bir taraftan yaşam ritminin değişkenliği, zaman-mekân sıkışması ve bilimde ortaya çıkan görecelik anlayışı, değişen perspektifler dünyası anlayışını hâkim konuma yükseltti. Böyle bir dünyada nesnelerin ve olayların görünümü takip edilen perspektife göre sürekli değişen akışı temsil eder. Mekân başta olmak üzere her olgu ve süreç göreceli olarak görülmeye başlandı. Ayrıca, farklı etkenler sayesinde ortaya çıkan ve artık bütünleşik bir kapitalist dünya pazarının varlığı ve "sermayenin evrenselleştirici yönelimi”", ${ }^{24}$ dünya çapında göreceli mekân olarak bir coğrafi mekân üretmekteydi. Daha fazlası, değerin evrenselleştirilmesi sayesinde, taşımacılığa harcanan zaman ve maliyetler asgariye indirilmeliydi. Dolayısıyla, üretim ve tüketim yerleri arasındaki göreceli mesafe sermaye birikimine, meta çeşitliliğinin artışına vs. koşut olarak önem kazanmaktadır. Sonuç olarak, bunların hepsi göreceli mekânın üretimine yol açtı. ${ }^{25}$ Ayrıca, yine bu dönemde dilbilimde Saussure tarafından, sözcüklerin anlamının nesnelerle ilişkileri temelinde değil, başka sözcüklerle ilişkileri içinde belirlenildiğini ileri süren yapısalcı dil teorisinin ortaya atıldığı da belirtilmelidir. ${ }^{26}$ Kısacası, kapitalizm öncesi dönemdeki sabit ve mutlak mekân ${ }^{27}$ anlayışına kıyasla, kapitalizmde göreceli mekân anlayışıyla karşı karşıyayız.

24 Smith, Uneven Development: Nature, Capital, and the Production of Space, s. 153.

25 Ibid., s. 115-116.

26 Harvey, The Condition of Postmodernity: An Enquiry into the Origins of Cultural Change, s. 28.

27 Lefebvre'in dar anlamdaki mutlak mekân kavramıla karıştırmamalıdır. 


\section{Şekil 1. Kübizm}

a) Pablo Picasso,1910, Mandolinli Kadın

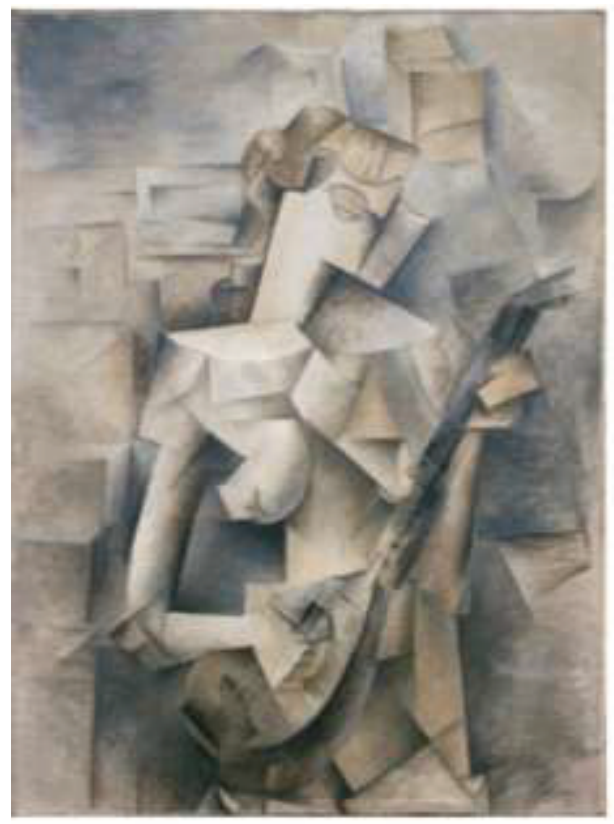

b) Jean Metzinger, 1910-11, İki Nü

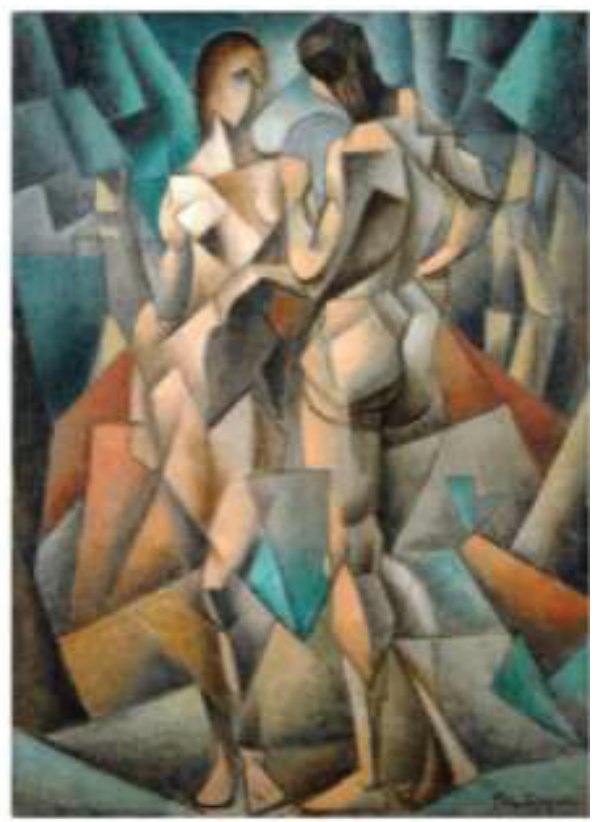

Kaynak: a) MoMA, 23 Kasım 2016 tarihinde https://www.moma.org/collection/works/80430 adresinden erişildi. b) Göteborgs Konstmuseum, 23 Kasım 2016 tarihinde http://empweb34.zetcom.ch/eMuseumPlus?service $=$ ExternalInterface\&module $=$ collection\&object $\mathrm{Id}=8474$ adresinden erişildi.

İkinci olarak, özellikle 19. yüzy1l, Bernhard Riemann ile birlikte Öklidyen olmayan geometrilerin gelişmesine tanık oldu. Fakat görelilik kuramının gelişimine dek bunlar maddi deneyimden kopuk, tamamen soyut matematiksel kurgular olarak kaldılar. Mekân n-boyutlu çok-katmanlılık olarak kavramsallaştırılıyordu. Çalışmalarını bu matematiğe dayandıran Einstein ile beraber, n-boyutlu mekân belirli maddi imlem (material referent) kazandı. Üç boyutlu veya dört boyutlu mekân-zamanın yerini n-boyutlu matematiksel mekân aldı; matematiksel mekân fiziksel mekânın yerini aldı. Fiziksel mekân kavramı her zaman pratik insan deneyimine gönderme yaparken, matematiksel mekân bundan öteye geçen tam bir soyutlanma haline geldi. ${ }^{28}$

İşte bu gelişmeler, bir taraftan farklı nitelikleri olan mekânın ortaya çıkmasına, diğer taraftan hem kuramsal boyutta yeni bir mekân paradigmasına hem de farklı bir mekân deneyimlenmesine yol açtı. Bu, biçimsel ve

28 Smith, Uneven Development: Nature, Capital, and the Production of Space, s. 99. 
niceliklendirilmiş, farklılıkları inkâr eden soyut mekândır. ${ }^{29}$ Fakat bu mekân farklılıkları inkâr edilmekle birlikte homojen değil, homojenlik onun amacıdır. ${ }^{30}$

20. yüzyılın başındaki bu gelişmeler, en az aynı yüzyılın 60-70'li yıllarına kadar süregelen gelişmeler üzerine damgasını vurdu ve ileri modernizm olarak tanımlanan dönemin hem düşünce hem de pratiğinin temelinde yatan etkenlerdendi. Özellikle yukarıda değinilmeyen fakat yine de bu yüzyılın başında Henry Ford tarafından üretim süreçleri için geliştirilen yürüyen bant tekniği ve onun aracılığıyla görevleri mekân içinde dağıtarak etkinliğin azamiye çıkarılarak üretimin akışında sürtünmenin asgariye indirilmesi; daha sonra ise Fordizm olarak yükselen ve 70'li yıllara kadar hâkimiyetini sürdüren birikim tarzı yüksek modernizm döneminin özelliklerinden biriydi. $\mathrm{Bu}$ dönemde, rekabetçi kapitalizme kıyasla üretim süreçleri için mekânın yeni bir örgütlenmesi ve farklı bir mekânın üretimiyle karşı karşıyayız. Lefebvre'in kavramlarıyla tanımlanırsa, mekân açısından 19. yüzyıl rekabetçi kapitalizme özgü içe patlama (implosion) $)^{31}$ mekân örgütlenmesi ve üretimi yerine, ileri modernizme özgü mekânın dışa patlamasına (explosion) tanık olunmaktadır. Bu süreçlerin mekânsal yansıması olarak çok-çekirdekli kentleşme, banliyöleşme gibi olgular hem bir taraftan dönemin mekânın üretimini belirleyen olgular, hem de gündelik hayat ve mekân deneyimlenmesini etkileyen önemli unsurlardır. Bunların temelinde Fordist birikim tarzı yatarken, bu birikim tarzının 60-70'li yıllarda krize girmesiyle hem onun unsuru olan Keynesçi iktisadi politikalar gözden geçirilmeye başlandı, hem de sosyal teoride bu süreçlerin yeniden anlamlandırma ve yeniden yorumlama çabaları ortaya çıktı. Bu zamandır ki eleştirel sosyal teoride genel olarak mekân sorunsalı ve özel olarak kapitalist üretim tarzında, onun farklı biçimlerinde ve farklı birikim tarzlarında mekânın rolü incelenmeye başlandı ve bu sosyal teoride 'mekânsal dönüş' olarak nitelendirildi.

İleri modernizm olarak nitelendirilen bu dönemin özellikle mekân ve kentsel mekân açısından diğer önemli unsurlarından biri, bu dönemde Avrupa'da mimarlık, kent planlaması ve bunlarla çok yakından ilgili alanlarda faaliyet gösteren çok sayıda araştırmacı, planlamacı, mimar ve diğer uzmanların, Bauhaus akımı çatısı altında birleşmesidir. Bu akım, hem Avrupa'da hem de daha sonra Avrupai modernizm projesini benimseyen toplumlarda, mekân anlayışı ve mekânsal pratiklerde önemli değişimlere yol açmıştır.

29 Lefebvre, Mekânın Üretimi, s. 77.

30 Ibid., s. 294.

31 Üretim zincirlerinin aynı mekânda, birbirine çok yakın yerleşmesi ve buna göre de emek gücünün bu mekânlara yakın yerleşimi, dolayısıyla buna tekabül eden kentleşme ve mekân biçimleri. 
Birinci Dünya Savaşı'nın büyük felaketinden sonra Weimar Cumhuriyeti'nde Walter Gropius tarafindan kurulan Bauhaus Okulu'nun mimari alandaki projeleri ve uygulamaları, özellikle teknoloji çağının gelişmelerini ve modern sanatı birleştirerek, rasyonel fakat aynı zamanda özgürleştirici bir nitelik taşımaktaydı ve akımı temsil edenlerin ideolojik yöneliminden dolay1 ${ }^{32}$ işçi sınıfına yönelikti. Harvey'in belirttiği gibi,

“Bir dizi kültür üreticisi, özellikle 1920’li yılların etkili Bauhaus akımı içinde ve çevresinde çalışanlar, toplumsal olarak yararlı amaçlar uğruna rasyonel bir düzeni kabul ettirmek üzere harekete geçmişti. Toplumsal olarak yararlı amaçlar, insanlığın özgürleşmesi, proletaryanın kurtuluşu ve benzeri şeylerdi, "rasyonel" kavramı ise teknolojik etkinlik ve makinalı üretim aracılığıyla tanımlanıyordu." 33

İleri modernizmin temellerini atan Bauhaus tarafindan toplum için bütünsel bir tasarım konsepti dile getirilmekteydi. Bu konsept, birliklerin (mobilyadan eve, evden şehre kadar) uyumlu biçimde tasarlanmış dizisiyle, içi ve dışı birleştirmekteydi. ${ }^{34}$ Fakat Bauhaus'un etkisi salt bir tasarım konseptinden öteye geçen yeni mekân anlayışının ortaya çıkmasına yol açtı. Lefebvre'in belirtiği gibi,

\begin{abstract}
"Bauhaus sadece mekânın içinde bir "nesne konumu" ya da mekân üzerine perspektifler getirmekle kalmadı, bir mekân anlayışı, genel bir konsept de getirdi. $\mathrm{Bu}$ dönemde ileri ülkelerde pratik olarak zaten düşünülmüş, fakat henüz rasyonelleştirilmemiş bir bağlantı keşfedilir: Sanayileşme ile kentleşme arasında, çalışma yerleri ile ikame yerleri arasındaki bağdır bu... Bauhausçular, gözlemcinin toplumsal mekân içinde -ki, evler, binalar, saraylar gibi nesneler arasında yer alır- her bir nesnenin etrafinda dönüp duracağını, yoksa sadece uzun uzun bakmakla, onu ayrıcalıklı bir yanıyla ele almakla yetinmeyeceğini keşfettiler... Ayn dönemde, avangart ressamlarca da çok yakın önermelere varıllı. Bir nesnenin bütün veçheleri eşzamanlı olarak ele alınabilir; eşzamanlık içinde zamansal bir ardışıklı̆̆ barındırır ve özetler." 35
\end{abstract}

Yukarıdaki Lefebvre'den yapılan alıntı, onun Picasso'ya yönelik eleştirisi bağlamında bizi ilginç bir diyalektikle yalnız bırakmaktadır. Bir taraftan Picasso, sanatında nesneleri parçalayıp, "binlerce şekilde işkence edip" ve "karikatürleştirip" yeni bir temsilin, anlayışın ve sonuç olarak pratiğin öncülerinden biriydi. Diğer taraftan, Kübizm, "bir nesnenin bütün veçheleri eşzamanlı olarak ele alınabilme, eşzamanlılık içinde zamansal bir ardışıklık barındırma ve özetleme" sağlamak için nesneleri parçalayarak birleştirme gibi

32 Okul, Almanya'nın solcu kesimini temsil eden mimar ve tasarımcılardan oluşmaktaydı.

33 David Harvey, Postmodernliğin Durumu: Kültürel Değişimin Kökenleri, s. 46.

34 Mark Gottdiener, The Social Production of Urban Space, s. 130.

35 Lefebvre, Mekânın Üretimi, s. 146-147, vurgu eklenmiştir. 
bir pratik uygulamaya başladı (bkz. Şekil 1). Böyle uygulamaların ürünü ise ileri modernizm olarak tanımlanan dönemin bölünmüş fakat aynı zamanda bütünsel mekânıdır.

\section{2. 'Mekânsal Dönüş' ve Mekânın Üretimi Paradigması}

1960-70'li yıllarda, krize yönelimli kapitalist sistem tekrardan kriz dönemine girdi. Fakat bu dönem sadece sistemin kendi iç dinamiklerine özgü bir iktisadi ve finansal krizle tanımlamak mümkün değildir. Bu kriz dönemi, aynı zamanda toplumsal hayatın her alanının ve mekânın önemli değişiklikler ve dönüşümler yaşadığı dönemdi. Lefebvre'in Kentsel Devrim ${ }^{36}$ çalışması özellikle bu dönemde dünya çapında meydana gelen değişiklikler bağlamında değerlendirilmelidir. Onun Kapitalizmin Hayatta Kalışı ${ }^{37}$ çalışması ise üretim ilişsilerinin yeniden üretim ile mekân arasındaki diyalektik ilişkisi açısından çok önemlidir. Bu dönüm noktasında, eleştirel sosyal teoride de önemli bir değişim yaşanmaktaydı. Genelde "mekânsal dönüş" olarak tanımlanan bu dönem, sosyal teoride mekâna dönük ve mekânı ele alan önemli çalışmaların ortaya çıkışına tanik oldu.

$\mathrm{Bu}$ kapsamda özellikle Edward Soja'nın Postmodern Coğrafyalar ${ }^{38}$ çalışması vurgulanmalıdır. Soja'nın "postmodern coğrafyalar" başlığının ve çalışmasının içeriğinin bazı vurgularına katılmamakla birlikte ${ }^{39}$, bu çalışma, dönemin eleştirel sosyal teorideki mekânın ele alınışını gayet kapsamlı bir biçimde değerlendirmektedir, dolayısıyla, bu alt bölümde ele alınacak konuların bir kısmına cevap verebilir niteliktedir.

Soja'nın çalışmasının merkezi konusu, çağdaş sosyal teori ve analizde eleştirel mekânsal perspektifin tekrar öne sürülmesidir. Ona göre, en azından geçen yüzyılda, zaman ve tarih, Batı Marksizminin ve eleştirel sosyal bilimin pratik ve kuramsal bilincinde ayrıcalıklı bir yer tutmaktaydı. Fakat bugün,

36 Lefebvre, Kentsel Devrim.

37 Lefebvre, Survival of Capitalism: Reproduction of the Relations of Production.

38 Soja, Postmodern Geographies: The Reassertion of Space in Critical Social Theory.

39 Soja, çalışmalarında hem Foucault'nun mekân ile ilgili fikirlerinden (özellikle onun heterotopia kavramından) hem de Lefebvre'in çalışmalarından yararlanarak önemli saptamalarda bulunmasına rağmen, özellikle Foucault’ya başvurduğu için tutarlı bir kuramsal dayanağını kaybetme yönelimi göstermektedir. Ayrıca, Soja bahsi geçen çalışmasında, 196070'li yıllarda Lefebvre tarafından mekân sorunsalına odaklanılmasını "postmodern coğrafya" ve akademiye bir tür postmodern düzeltme olarak tanımlamaktadır. Bu açıdan Gottdiener'in Soja'ya yönelik eleştirisi yerindedir; Lefebvre Marksistti ve ancak Marksizmle ve onu doğru biçimde anlamakla ilgilendi. Marksizmin kusurları belli olunca, onu daha iyi hale getirmekle ilgilendi. Daha ayrıntılı olarak bkz. Gottdiener, "Lefebvre and the Bias of Academic Urbanism: What Can We Learn from the 'new' Urban Analysis?", s. 94. 
zamandan ziyade mekân bize önemli sonuçlar önermektedir. 'Tarihe emretmekten' ziyade 'mekâna emretmesi' en açıklayıcı taktiksel ve kuramsal dünyayı sunabilir. ${ }^{40}$ Soja'nın haklı olarak nitelendirdiği gibi, 19. yüzyılın son dönemlerinde (kapitalizmin ikinci modernizasyonu) eleştirel sosyal teori, tarihselciliğin yükselmesine ve ona koşut olarak mekânın sönümüne tanık oldu. Sosyalist eleştiri Marx'ın tarihsel materyalizmi etrafinda birleşirken, Comte'un ve neo-Kantçı etkilerinin karışımı ise liberal sosyal felsefeyi yeniden biçimlendirdi. Her iki durumda da, kapitalizmin gelişimi daima tarihsel olarak ve sadece istisnai durumlarda mekânsal olarak ve mekân açısından anlamlandırılmaya çalışıldı. ${ }^{41}$

Marx, Weber, Durkheim ve diğerlerinin ortak özelliği coğrafya ve mekâna kıyasla tarih ve zamana öncelik vermeleridir. Onlar tarafından mekân ele alındığında bile, mekân, sorunsalı olmayan ve tarihsel eylem için sabit bir bağlam veya konum olarak görülmektedir. Marx, mekânın ve yerin önemini yazılarında sıkça kabul etse de, mekânsal ilişkilerin ve coğrafi biçimlerin üretimini genelde ihmal etmiştir ve coğrafi varyasyonu 'gereksiz karmaşıklık' (unnecessary complication) olarak analiz dışı bırakmıştır. Dolayısıyla, Marx'ın vizyonunun ve teorisinin zayıflığı, onun düşüncesinde sistematik, özgün coğrafi ve mekânsal boyutu hesaba katmamasından kaynaklanmaktayd. ${ }^{42} \mathrm{Bu}$ durum için Soja, Foucault'nun sosyal teori ile ilgili eleştirisini sunar: "Mekân ölü, sabit, diyalektik dışı, durağan olarak ele alınmaktaydı. Aksine, zaman zenginlik, doğurganlık, hayat ve diyalektikti." 43

Böyle bir durum, yaklaşık olarak Ekim Devrimi'nden başlayan ve 60' ${ }_{1}$ yı1ların sonuna dek hâkimiyeti süren Fordizm'in ve bürokratik devlet yönetiminin döneminde (kapitalizmin üçüncü modernizasyonu) de devam etti. Ancak son zamanlarda mekânsızlaştırılan tarihselciliğin bu yükselişi tanınmaya ve incelenmeye başladı. 1960'lı yılların sonunda, kapitalizmin kriz kaynaklı dördüncü modernleşmesiyle, bu uzun süren modern eleştirel geleneği değişmeye başladı. ${ }^{44}$ Postmodern durumun bir parçası olarak, bu çağdaş bağlamda zaman

40 Soja, Postmodern Geographies: The Reassertion of Space in Critical Social Theory, s. 1.

41 Ibid., s. 60.

42 Harvey'den akt. Soja, Postmodern Geographies: The Reassertion of Space in Critical Social Theory, s. 65.

43 Foucault'dan akt. Soja, Postmodern Geographies: The Reassertion of Space in Critical Social Theory, s. 4-5. Foucault'nun bu saptamasıyla ilgili farklı bir değerlendirmesi için bkz. Harvey, The Condition of Postmodernity: An Enquiry into the Origins of Cultural Change, s. 205. Foucault'nun orijinal metni için bkz. Foucault, “Questions on Geography”. Foucault'nun mekân ve coğrafya ile ilgili görüşler için özellikle bkz. Crampton ve Elden, Space, Knowledge and Power: Foucault and Geography; West-Pavlov, Space in Theory: Kristeva, Foucault, Deleuze.

44 Soja, Postmodern Geographies: The Reassertion of Space in Critical Social Theory, s. 4-5. 
ve mekânın yeni bir kültürü ortaya çıktı, bu kültür modern dünyada gündelik hayatın doğası ve deneyimiyle birlikte, sosyal teorinin tüm bünyesi de yeniden tanımlanmaktadır. ${ }^{45}$

Soja, 1960'lı yılların sonuna denk gelen dönemi, postmodernizme geçiş olarak tanımlar. Ona göre, "bu postmodernizasyonun coğrafyasının ilk haritac1ları" Lefebvre, Foucault, Berger ve Mandel idiler. ${ }^{46}$ Foucault veya Berger için böyle bir tanım sorunlu olmasa da Marksist gelenekten olan Lefebvre'yi ve Mandel'i böyle tanımlamasının sorunlu olduğuna yukarıda kısaca değinmiştik. Burada parantezi açarak Lefebvre'yi böyle tanımlamasının uygun olmadığının biraz daha detaylı olarak ele alınması yerinde olur. Lefebvre'yi "postmodernizasyonun coğrafyasının ilk haritaciları"ndan biri olarak tanımlamasıyla Soja, Lefebvre tarafından mekân sorunsalına odaklanılmasını akademiye bir tür postmodern düzeltme olarak tanımlar. Oysa "Lefebvre Marksistti ve ancak Marxizmle ve onu doğru biçimde anlamakla ilgilendi. Marksizmin kusurları belli olunca, onu daha iyi hale getirmekle ilgilendi." 47 Mekân diyalektiği konusunda ve Soja'nın sistematik olarak ele aldığ1 sosyomekânsal diyalektiği konusunda Lefebvre'in sunduğu katk1, dahası onun mekân teorisine Marksist bakışı, Marksizme ise mekânsal boyutu sağlaması gibi hususlar, Lefebvre'in asla bir "postmodernizasyonun haritacısı" olmadığının dolayısıyla Gottdiener'in eleştirisinin çok yerinde olduğunun açık göstergeleridir. Lefebvre'in giriştiği projesiyle ilgili kendisinin de belirttiği gibi,

\begin{abstract}
"Günümüzde modern dünyanın bilimsel ve teknolojik dönüşümleri Marxist düşüncenin yeniden ele alınmasını kaçınılmaz kılmaktadır. Burada sunulan tez şöyle formüle edilebilir: "Marksizmin bütün kavramları yeniden ele alınıyor, teorinin hiçbir önemli momenti yok olmadan, bir üst düzeye taşınıyor. Buna karşılık, Marx tarafından sunumları içinde ele alındıklarında, bu kavramların ve teorik zincirlenişlerinin nesnesi yoktur. Marksist kavramların yeniden ele alınışı, mekânı tamamen dikkate alındığında optimal şekilde gelişir..." 48
\end{abstract}

Görüldüğü üzere, Lefebvre'in amac1 Marksist "teorinin hiçbir önemli momenti yok olmadan" onun kavramlarının "mekânı tamamen dikkate alınmasıyla" yeniden ele alması ve bu teorinin "bir üst düzeye" taşınmasıdır. Bu amaç ise günümüzdeki dönüşümlere ve özellikle mekân sorunsalına mekânsal boyuttan ve mekânsal kavramsallaştırmadan yoksun Marksist teorinin tam olarak cevap veremediğinden kaynaklanır.

45 Ibid., s. 60.

46 Ibid., s. 60-61.

47 Gottdiener, "Lefebvre and the Bias of Academic Urbanism: What Can We Learn from the 'new' Urban Analysis?", s. 94.

48 Lefebvre, Mekânın Üretimi, s. 347. 
Bu dönemde eleştirel sosyal teoride mekân sorunsalını konu eden önemli diğer düşünürler arasında Mandel'in rolü de belirtilmektedir. En önde gelen Marksist teorisyenler arasında yer alan Mandel, farklı araştırmalarca ${ }^{49}$ böyle bir bağlamda ele alınsa ve 'mekânsal dönüşün' önemli isimlerinden biri sayılsa da, Mandel'in katkısı en azından bu çalışmada benimsenen çerçeve dışında kalmaktadır, çünkü Mandel, mekânı sadece eşitsiz gelişme bağlamında ele alır ve geç kapitalizmde mekânın sadece araçsal rolüne vurgu yapar. Mandel'e göre, "sermaye tarafından emek gücünün sömürüsüyle aynı düzeyde, bölgeler ve uluslar arasındaki eşitsiz gelişme kapitalizmin tam özüdür." ${ }^{50}$ Başka bir deyişle, Mandel, eşitsiz gelişmenin mekânsal yapısını sosyal sınıfa tabi olan bir durum olarak görmemektedir. ${ }^{51} \mathrm{Bu}$ açıdan, Mandel'in (kendisi de genelde bir ortodoks Marksist olarak tanımlanan) yaklaşımı, ortodoks Marksizmin her şeyi sınıfsal yapıya tabi kılmasından ayrılsa da, eşitsiz gelişme açısından konuya bakması ileri kapitalizmde mekânın sadece araçsal rolüne vurgu yapar. Oysa daha sonra ele alınacağı üzere, ileri kapitalizmde mekânın rolü sadece merkez-periferi çelişkisi ve eşitsiz gelişme ile sınırlı değildir. Ayrıca, aynı Smith tarafından bu bağlamda ele alınmış Lenin, Luxemburg ${ }^{52}$ veya Soja tarafindan ele alınan Gramsci ${ }^{53}$ hesaba katıldığında Mandel'in katkısı pek büyük görülmemektedir. Dahası Lefebvre, bu konuda çok genel de olsa daha kapsamlı bir analiz sunduğu için, Mandel'in görüşleri önemli olmasına rağmen, burada ele alınan sorunsalın dışında kalmaktadır.

Burada özellikle ele alınan iki düşünüre; Harvey ile Castells' ${ }^{54}$ ve onların mekân teorisine olan katkılarına değinilmelidir. Özellikle bu iki kuramcıya değinilmesi, onların, 70'lerde ortaya çıkan mekân paradigmasına etkileri açısından önemlidir.

70'lerdeki 'mekânsal dönüşte' yer alan ilk önemli eserlerden biri Harvey'in Sosyal Adalet ve Şehir ${ }^{55}$ çalışmasıdır. Aslında bir coğrafyacı olduğu için Harvey'in çalışmalarının 'mekânsal dönüş' kapsamında değerlendirilmesi pek uygun değildir. Fakat bahsi geçen çalışmasıyla Harvey, pozitivist coğrafyadan uzaklaşıp, eleştirel sosyal teori ve onun kapsamında mekâna

49 Bkz. Smith, Uneven Development: Nature, Capital, and the Production of Space; Soja, Postmodern Geographies: The Reassertion of Space in Critical Social Theory.

50 Mandel'den akt. Soja, Postmodern Geographies: The Reassertion of Space in Critical Social Theory, s. 81-82.

51 Soja, Postmodern Geographies: The Reassertion of Space in Critical Social Theory, s. 82.

52 Bkz. Smith, Uneven Development: Nature, Capital, and the Production of Space, s. 123-131.

53 Bkz. Postmodern Geographies: The Reassertion of Space in Critical Social Theory, s. 89-91.

54 Burada, konu ile ilgili çalışmaları olan Soja ve Gottdiener analiz dışı bırakılmıştır, çünkü bu çalışmada farklı yerlerde belirli konular ile ilgili bu düşünürlere başvurulması genelde onların mekân teorisine katkılarını dolaylı olarak ortaya koymaktadır.

55 Harvey, Social Justice and the City. 
(kentsel mekâna) yönelik yeni ve önemli fikirler sunmuştur. 56 Özellikle kent sorunsalına ve kentsel mekâna Harvey'in ekonomik politik açıdan katkısı kayda değerdir. Marx'ın kavramsal ve kuramsal çerçeveden kent ve kentsel mekânı kavramsallaştırması kentsel araştırmalarda ve kentsel mekân konusunda dönemin akademik tartışmalarına damga vurmuştur. Harvey'in bu 'ilk' çalışmasındaki geleneksel Marksist analize dayanan tartışmaları daha sonraki çalışmalarında biraz farklı nitelik göstermektedir ve bu en bariz şekilde Postmodernliğin Durumu ${ }^{57}$ çalışmasında görülebilir. Bu çalışmasında, Harvey postmodernizmi "entelektüel moda" olarak niteleyerek ve çalışmasını yine sermaye birikimi süreçleri üzerine temellendirerek, önceki çalışmalarına göre daha kapsayıcı bir çalışmayla karşımıza çıkmaktadır. Şöyle ki postmodern söylemin farklı boyutlarını (örneğin toplumsal cinsiyet, kimlik vs.) da analizine dâhil etmeye çalışmış ve aslında sosyal teoride ve sanatta post-yapısalcı ve postmodern çıkışına Harvey'in ilk cevabı olmuştur. Fakat çalışmanın özellikle bu bölümündeki sorunsalı açısından Postmodernliğin Durumu'nun en önemli tarafı Harvey tarafindan Marksist çerçeveden postmodern durumun ve postmodern kentsel mekânın ele alınmasıdır. Sosyal Adalet ve Şehir çalışmasında ele aldığı mutlak, göreli ve ilişkisel mekânları bu kitapta daha sistematik biçimde ele alan ve Lefebvre'in mekânsal analizinden de yararlanan Harvey, mekânsal pratikler başta olmak üzere mekân sorunsalının diğer bileşenlerinin önemli bir analizini sunar. Harvey'in mekân üzerine yazılarının detaylı olarak ele alınması, bu çalışmanın kapsamı dışında olduğu için, sadece belirtilebilir ki onun çalışmalarında mekânın ele alınışının temel özelliği ekonomik politik analizdir. Özellikle 80-90'lı yıllardaki diğer çalışmalarında Harvey başka boyutları da

561969 yılında Harvey'in yayınladığı Coğrafyada Anlatım eseri dönemin pozitivist coğrafyasında en öne çıkan çalışmalarından biriydi. Coğrafya biliminin metodolojik sorunlarının tartışıldığı bu çalışmasında, Harvey neyin bilimsel teori olup olmayacağına dair tartışmasında, bir teorinin 1) matematiğe dayalı olduğunu, 2) birbiriyle anlam çıkarımı açısından bağlanılabilecek, net olarak tanımlanmış kavramlardan oluşan, 3) doğrulamak için net kurallardan oluşan, 4) rasyonel açıklamaya dayanan bilgi sistemi olduğunu savunmaktadır. Böylece, Harvey birkaç sene sonra yayınlayacağı Sosyal Adalet ve Şehir çalışmasında kendisi de eleştirdiği pozitivist bilim felsefeci Thomas Kuhn'un "ön sosyal" bilim yaklaşımını savunmaktadır. Bu yüzden, Harvey'in Sosyal Adalet ve Şehir çalışması bir tür 'mekânsal dönüş' olarak tanımlanabilir, çünkü bu çalışmayla Harvey eskiden yer aldığı pozitivist coğrafya bilimi anlayışından vazgeçerek tarihsel materyalizme ve eleştirel sosyal teoriye geçiş yaptı. Eski anlayışından tamamıyla kopuşu ise onun Sermayenin Sinırları çalışmasıyla gerçekleşti. Bkz. Harvey, Explanation in Geography; Harvey, Social Justice and the City, s. 120-152; Harvey, The Limits to Capital; Kuhn, The Structure of Scientific Revolutions.

57 Harvey, The Condition of Postmodernity: An Enquiry into the Origins of Cultural Change. 
analizine dâhil etse de ${ }^{58}$, son çalışmalarında ${ }^{59}$ mekânın ekonomik politik analizi yine hâkimdir. Fakat bu durum, 70'li yıllarda ortaya çıkan eleştirel sosyal teoride ve yeni mekân paradigmasının oluşumunda Harvey'in rolünü hiç de azaltmamaktadır. Aksine, Lefebvre'in üzerinde kısaca durduğu fakat kapsamlı olarak ele almadığı bazı sorunsallara Harvey ciddi katkılar sağlamıştır. ${ }^{60}$

70'lerin mekân tartışmalarının diğer önemli ismi Manuel Castells'tir. 1972'de Kentsel Sorun: Marksist Bir Yaklaşım çalışmasıly,a, ${ }^{61}$ konu ile ilgili tartışmalara damga vuran Castells, burada ele alınan sorunsal bağlamında birkaç açıdan önem taşımaktadır.

İlk önce, eleştirel sosyal teoride yeni ortaya çıkan mekân paradigmasında Castells'in Marksist çerçeveden yola çıkarak şu katkısı belirtilmelidir: Castells, dönemin kentsel sorunsalını kolektif tüketim açısından ele alırken, aynı zamanda mekân konusunda geleneksel Marksist yaklaşımdan farklı olarak ekonomik indirgemecilikten öteye geçmiştir. Şöyle ki Harvey'in tüm külliyatında devletin ontolojik statüsü genel olarak sermaye için bir araç olarak değerlendirilirken, yani Harvey, devleti geleneksel Marksist tanımıyla yönetici sınıfın bir aracı olarak değerlendirirken devlet ile mekân arasındaki çok karmaşık ilişkiyi belirlememektedir. Oysa Castells, Harvey'e kiyasla teorisinde devlet, toplum ile mekân arasındaki ilişkilerin detaylı bir analizine girişmektedir. Bu dönemde, çok sayıda kuramcı tarafından sermaye süreçlerinde devletin rolünün ele alındığı bir gerçektir fakat mekân bağlamında, dahası mekânın üretimi bağlamında devletin rolü ya göz ardı edilmiş ya da mekânsal biçimlerin ortaya çıkışı sermaye birikim süreçlerinin veya devlet politikalarının bir türevi olarak değerlendirilmiştir. Bu yüzden, Lefebvre ile birlikte Castells'in bu konuya katkıları önemlidir. Ayrıca, mekân konusunda Castells'in yaklaşımının diğer önemli özelliği, Lefebvre gibi, mekânı sosyal formasyonun bir maddi ürünü olarak görmesi ve analizini ona dayandırmasıdır. ${ }^{62}$ Castells' in de belirttiği gibi,

58 Burada kastedilen çalışma, Harvey'in Adalet, Doğa ve Farklılı̆̆ın Coğrafyası çalışmasıdır. Bu çalışmada Harvey post-yapısalcı, feminist, postmodernist vd. yaklaşımlar ile tartışmaya girerek, geçmişte ele almadığ farklılık, kimlik vd. konuları da çok yoğun bir analize tabi tutmaktadır. Bkz. Harvey, Justice, Nature and the Geography of Difference.

59 Bkz. Harvey, Rebel Cities: From the Right to the City to the Urban Revolution.

60 Lefebvre tarafindan Kentsel Devrim ve Mekânın Üretimi çalışmalarında sermayenin ikinci zincirinin tartışmaya açılması ve daha sonra Harvey tarafından bunun çok detaylı olarak ele alınması bunun en bariz örneklerinden biridir. Bkz. Lefebvre, Kentsel Devrim, s. 151 vd.; Lefebvre, Mekânın Üretimi, s. 339 vd.; Harvey, The Limits to Capital.

61 Bkz. Castells, The Urban Question: A Marxist Approach.

62 Örneğin, Harvey tarafından da bunun kabul görülmesine rağmen, onun analizinde ekonomik analizin ağır bastığına yukarıda değindik. 
"Mekân, diğer maddi bileşenlerle ilişkili olan maddi bir üründür; diğerleri arasında, insanların belirli toplumsal ilişkilere girişimi mekâna (ve birleşimin diğer bileşenlerine) biçim, işlev ve toplumsal anlam kazandırmaktadır. Dolayısıyla, mekân toplumsal yapının konuşlandırılması için sadece bir vesile değildir, bir toplumun belirlendiği her bir tarihsel topluluğun somut ifadesidir. Böylece, soru (herhangi başka bir gerçek nesne durumunda olduğu gibi), mekânın varlığını ve dönüşümünü, tarihsel bir gerçekliğin diğer bileşenleriyle onun boğumlanmasının özgüllüğünü etkileyen yapısal ve konjonktürel yasaların tanımlanmasıdır. Bu, genel sosyal teorinin parçası olmayan mekân teorisi olmadığı anlamına gelir. Kentsel mekân yapısaldır, başka bir ifadeyle rastgele olarak organize edilmiş değildir. Mekânı işleyen toplumsal süreçler ise, toplumsal organizasyonun her tip ve her dönemin determinizmlerini ifade eder."63

Castells'in diğer önemli saptaması, 'kentsel' (urban) kavramının, geleneksel toplum/modern toplum ideolojik ikilemine ait olduğu tespitidir. ${ }^{64}$ Dolayısıyla 'kentsel'in (urban) tartışılması onunla ilişkili olan gelişme sorunsalının tanımlanmasını gerektirmektedir. Ayrıca, 'kentsel'in deneysel (ampirik) olarak tanımlanmasının imkânsız olduğunu belirten Castells, kentleşme yerine mekânsal biçimlerin toplumsal üretiminden söz eder ${ }^{65}$ ve bunlardan yola çıkarak kentin ve dolayısıyla kentsel mekânın tanımını tüm sosyal grupların günlük hayatına göre kolektif tüketim araçlarının örgütlenmesine, ${ }^{66}$ dolayısıyla emek gücünün yeniden üretilmesine dayandırmaktadır.

Böylece mekânın toplumsal formasyonunun bir ürünü olarak tanımı, kentin ve kentsel mekânın tanımlanmasını emek gücünün yeniden üretimi bağlamında temellendirmesi (ki bu büyük ölçüde ileri kapitalizmde işlevsel olan bir tanımlama olacağını unutmamalıdır), Castells'in mekân tartışmalarına ve özellikle Marksist mekân teorisine katkılarıdır. Fakat Castells'in bu saptamaları ve onun genel teorisinde mekân sorunsalı ile ilgili birtakım sorunlu noktalar da söz konusudur. Castells'e yönelik Gottdiener'in eleştirisinden ${ }^{67}$ yararlanıp bu noktalar şu şekilde açıklanabilir.

Kendi ilk çalışmalarını ve teorisini Althusserci yaklaşıma dayandıran Castells, doğal olarak kendi analizi için bir kuramsal nesne belirlemeye girişmiştir, yani kentsel sorunsalı ele almak için onun ilk adımı kentselin kavramsal sınırlandırılmasıydı. Fakat kentsel ile ilişkili kıstas göreli ve tarihsel

63 Ibid., s. 115.

64 Ibid., s. 15.

65 Ibid., s. 17.

66 Castells, City, Class and Power, s. 3, 16.

67 Bkz. Gottdiener, The Social Production of Urban Space, s. 115-121. 
olduğu için, yani kentsel olan, farklı biçimde tanımlanabileceği ve tarihsel süreçte farklı nitelikler taşıdığı için, kentseli bir araştırma nesnesi olarak sınırlandırması Castells için bir sorun olmuştur. ${ }^{68}$ Dolayısıyla, Castells modern topluma özgü olan mekân biçimine, yani kentsel mekâna ve onu üreten temel toplumsal ilişkilere odaklanıp 'kentsel' in ideolojik, siyasi-hukuki veya ekonomik düzlemlerdeki tanımlamalarını incelemektedir. ${ }^{69}$ Kentselin ideolojik tanımı kentsel kültüre dayandığı, Alman Sosyoloji Okulu'nun evrimsel-işlevselci düşünceye ve sonradan Chicago Okulu'nun ekolojik yaklaşımına dayalı olduğu için eleştirmektedir. ${ }^{70}$ Kentselin siyasi-hukuki tanımı ise ileri kapitalizmde özellikle metropoliten bölgelerde anlamını yitirdiği, yani kentselin siyasi-hukuki sınırları ile onların sosyal içeriğinin örtüşmediği için reddetmektedir. ${ }^{71}$ Nihayet, Castells, kent ve kentsel mekân tanımını ekonomik düzlemle sınırlandırır. Fakat kent veya kentsel bölge ekonomik olarak kendine yeterli bir sistem ve bütünlük oluşturamaz (ancak bir bölge kendine yeterli bir bütünlük olabilir), çünkü bir kent emek gücünün ikamesi ve yeniden üretimini kapsarken, üretim süreçlerinin tüm zincirlerini kapsamayabilir. ${ }^{72} \mathrm{O}$ yüzden, Castells analizini bölgesel düzeye kaydırmamak için kentseli sadece emek gücünün yeniden üretimi süreçleriyle tanımlayıp sinırlandırır:

"Böylece kentsel mekân emek gücünün bir kesimiyle, onun hem iş piyasasıyla hem de günlük hayatın (göreli) birliğiyle sınırlanmış ve tanımlanmış olur... Emek gücünün yeniden üretimi sürecine tekabül eden 'kentsel' kavramı ve böyle bir süreçte etkileşim içinde olan birliklere tekabül eden 'kentsel mekân' kavramı, bize kanımca bu sorunlara kuramsal biçimde yaklaşmaya imkân tanımaktadır."73

Gottdiener tarafindan "yapisalcı fonksiyonalizmin teleolojik refleksi" olarak tanımlanan Castells'in bu yaklaşımı Althusserci şemaya göre sosyomekânsal ilişkileri ekonomik yapıya tabi tutar, başka bir deyişle, Castells, Althusserci analizin gerekliliğine göre ve ona sadık kalmak için kentseli tanımlamasında ekonomik düzlemi kullanmaktadır. Böylece, kentsel sistemin keşfi Althusserciliğin söylemsel doğasına tipik olan indirgemeci bir argüman aracılı̆̆ıyla gerçekleşir. ${ }^{74}$

68 Gottdiener'e göre eğer Castells, 'kentsel'in ne anlama geldiğini kuramsal açıdan tanımlamasaydı, o zaman 'mekân' kavramıyla baş başa kalırdı, bu ise onu Lefebvre'yle aynı seviyede konuşlandırırdı (Bu, Althusserci yaklaşımı benimseyen Castells için tercih edilmeyen bir durumdur). Bkz. Gottdiener, The Social Production of Urban Space, s. 116.

69 Castells, The Urban Question: A Marxist Approach, s. 235.

70 Ibid., s. 75-85, 235.

71 Ibid., s. 235.

72 Ibid., s. 236.

73 Ibid., s. 236.

74 Gottdiener, The Social Production of Urban Space, s. 117-118. 
Kısacası, Castells'in mekân teorisine yaklaşımı şu özelliklere sahiptir: 1) yapılı çevrenin üretimini açıklamak için Althusserci yaklaşıma başvurulur. 2) 'Kentsel'i, yapılı çevreyi üreten yapısal sistemde mekânsal bir birim olarak tanımlar. 3) Castells'in mekân teorisini geliştirme çabası ve bu konuda onun başarısızlığı mekân teorisi yerine kentsel sorunların teorisiyle sonuçlandı, böylece 4) Castells'in analizi mekânın üretimini açıklamak yerine kentsel sorunların üretimini açıklar. 5) Mekân teorisi geliştirme konusunda Althusserci yaklaşımın başarısızlığı ortaya çıkınca, Castells bu teorinin özel bir boyutunu; devlet ile yerleşim yerleri mekânı arasındaki ilişkiyi geliştirdi. ${ }^{75}$

$\mathrm{Bu}$ sorunlara rağmen, Castells'in 70'lerde ortaya çıkan mekân paradigmasındaki ve eleştirel sosyal teoride yükselen mekân söylemindeki rolünün önemi açıktır.

Mekânın üretimi konusuna gelince, bahsi geçen kuramcılarda mekânın üretiminin farklı biçimlerde ele alındığı görülmektedir. Örneğin, Harvey veya Smith mekânın üretimini genelde sadece yapılı çevrenin üretimi olarak analiz ederken, Castells'te mekânın üretimi ve mekânsal örgütlenme kavramlarının eşanlamlı olarak kullanıldığ 1 ve ikisinin de yine yapılı çevrenin üretimi anlamına geldiği görülmektedir. Ayrıca, bahsi geçen çalışmalar, mekânın bir toplumsal ürün olduğunu, yani toplumsal olarak üretilmekte olduğunu vurgulamakla birlikte, daha çok ileri kapitalizmde yapılı çevrenin üretimini çözümlerler. Dolayısıyla, bunlarda mekânın üretimi kavramı, Lefebvre'in kullandığı anlamından şu açıdan farklılık göstermektedir: Lefebvre'in mekân analizi sadece ileri kapitalizmde mekânın üretimini incelemekle sınırlı olmayıp, farklı tarihsel dönemlerde ve üretim tarzlarında mekânın üretimini inceler ve böylece bize tarihsel süreçte mekânın üretimini açıklar. Ayrıca, Lefebvre'in mekânın üretimi kavramı sadece yapılı çevrenin üretimiyle sınırlı değildir, başka bir deyişle sadece mekânın ekonomik politiğini içermez. Fakat belirtilmesi gereken önemli husus, tüm bu yaklaşımların (Harvey, Castells, Smith vs.) ortak noktasıdır: mekânı ve onun üretimini hâkim üretim tarzına özgü üretim ilişkilerinin ışı̆̆ altında incelemek.

Bir sonraki bölümde 70 'lerde yükselen mekân söylemi çerçevesinde mekânın üretimi paradigması ve özellikle Lefebvre'in mekân kuramı ele alınacaktır. Fakat ondan önce burada başka bir hususa da değinmekte yarar vardır. 70'li yıllarda ortaya çıkan yeni mekân anlayışını daha çok kent araştırmaları ve özellikle Marksizmin bünyesinde yer alan tartışmalar üzerine odaklanıp ele alındı. Oysa bu, diğer alanlarda 'mekânsal dönüşün' var olmadığı veya tartışılmadığı anlamına gelmez. Aksine, aynı zamanda sosyal teorinin diğer 
alanlarında da mekân üzerine önemli tartışmalar söz konusuydu. Örneğin, Michel Foucault'nun bu döneme denk gelen mekân üzerine yazılar1 ${ }^{76}$ ve özellikle onun geliştirdiği heterotopia kavramı bunun sadece bir örneğidir. Fakat diğer alanlarda benzer tartışmaları burada ele alınmamasının nedeni ilk önce çalışmada benimsenen kuramsal çerçeveden kaynaklanmaktadır. Başka bir ifade ile Lefebvre'in, mekânın Marksist analizine dayanan bu çalışmada Marksizm alanındaki az çok tutarlı mekân yaklaşımlarına ve analizlerine odaklanma tercih edilmiştir.

1970'lerden sonra eleştirel sosyal teoride ve kentsel araştırmalardaki mekân tartışmaları genelde Harvey, Castells ve Lefebvre'in tartışmalarından ve yaklaşımlarından beslenerek gelişmiştir. $\mathrm{Bu}$ süreçte, özellikle Lefebvre'in mekânın üretimi kuramının etkisi çok büyüktür. $\mathrm{O}$ zamandan beri ortaya çıkan kent ve kentsel mekân ile ilgili çalışmalara bakıldığında Lefebvre'in mekânın üretimi kuramının hem kuramsal tartışmalar hem de somut araştırmalar için önemli bir zemin hazırladığı görülmektedir. Örneğin, yukarıda değinilen Edward Soja'nın kuramsal incelemeleri, ${ }^{77}$ onun Lefebvre'in mekân analizine dayalı ve postmodern mekânları ele alan çalışmalar1 ${ }^{78}$ belirtilmelidir. Neil Brenner ve diğerlerinin mekânsal ölçek meselesi, ${ }^{79}$ ileri kapitalizmde mekânın üretimi olarak mekânsal yeniden ölçeklenme süreçleri ile yeni devlet mekânları üzerine çalışmaları ${ }^{80}$ da Lefebvre'in mekân kuramına doğrudan veya dolaylı olarak dayandığ 1 da belirtilmelidir. Burada Mark Gottdiener'in, Lefebvre'in mekânın üretimi kuramına dayanan ve metropolitenleşme süreçlerini bir mekân üretim

76 Bkz. Foucault, "Questions on Geography"; Foucault, "Of Other Spaces: Utopias and Heterotopias".

77 Bkz. Soja, Postmodern Geographies: The Reassertion of Space in Critical Social Theory; Soja, Postmetropolis: Critical Studies of Cities and Regions.

78 Bkz. Soja, Thirdspace: Journeys to Los Angeles and Other Real-and-Imagined Places; Soja, My Los Angeles: From Urban Restructuring to Regional Urbanization.

79 Bkz. Brenner, "Global, Fragmented, Hierarchical: Henri Lefebvre's Geographies of Globalization"; Brenner, "The Limits to Scale? Methodological Reflections on Scalar Structuration"; Brenner ve Elden, "Henri Lefebvre on State, Space, Territory"; Brenner ve Schmid, "Towards a New Epistemology of the Urban?".

80 Bkz. Brenner, "State Territorial Restructuring and the Production of Spatial Scale: Urban and Regional planning in the Federal Republic of Germany, 1960-1990"; Brenner, "Globalisation as Reterritorialisation: The Re-scaling of Urban Governance in the European Union"; Brenner, "The Urban Question as a Scale Question: Reflections on Henri Lefebvre, Urban Theory and the Politics of Scale"; Brenner, "Decoding the newest "Metropolitan regionalism" in the USA: A Critical Overview"; Brenner, "Metropolitan Institutional Reform and the Rescaling of State Space in Contemporary Western Europe"; Brenner, New State Spaces: Urban Governance and the Rescaling of Statehood; Brenner, "Urban Governance and the Production of New State Spaces in Western Europe, 1960-2000”. 
süreci olarak çözümleyen, ${ }^{81}$ ayrıca ileri kapitalizmde mekânın rolünü ele alan ${ }^{82}$ çalışmaları belirtilmelidir. Gottdiener'in mekânın üretimi kuramına diğer önemli katkıs1, Lefebvre'in mekânın tüketimi kavramının, ${ }^{83}$ mekânın üretimi süreçlerindeki rolünün daha kapsamlı bir biçimde araştırmasıdır. Gottdiener, son dönemlerde gittikçe daha yaygın olarak görülen mekânın tüketimi süreçlerini ve tematik mekânların üretimini ele alarak mekân semiyolojisi konusunda da önemli katkılar sunmuştur, ${ }^{84}$ böylece mekânın semiyolojisi boyutları Lefebvre'in kuramının önemli sınırlamalarından biri olduğunu hesaba katılırsa, Gottdiener'in bu konuları ele almasının çok önemli bir katkı olduğu söylenebilir.

Son olarak, burada Neil Smith'e kısaca değinmelidir. Smith'in özellikle Eşitsiz Gelişme: Doğa, Sermaye ve Mekânın Üretimi ${ }^{85}$ eseri konumuz açısından önemlidir. Bir Marksist coğrafyacı olan Smith'in bu çalışması, mekân ve mekânın üretimi tartışmalarına önemli katkılar sağlamıştır. Çalışmada Smith, kapitalizmde eşitsiz gelişmenin rolünü ve bu bağlamda mekânın üretimini incelemeyi amaçlarken, analizinde genelde Harvey'e benzer bir yaklaşım (mekânın geleneksel Marksist ekonomik politik analizi) ve kavramsal çerçeve (mutlak mekân, göreli mekân vs.) benimser. Smith, eşitsiz gelişmeyi kapitalizmin coğrafyasının özelliği ve sermayenin yapısında var olan çelişkilerin coğrafi ifadesi olarak tanımlar. ${ }^{86}$ Fakat burada dikkat edilmesi gereken husus, Smith tarafından kapitalizmde mekânın üretimi olarak eşitsiz gelişmenin üretimi salt sermaye hareketlerinin ve birikim süreçlerinin bir ürünü olarak görülmemesidir. Smith'e göre, bu süreçlerde daha derin bir olgu söz konusudur;

\section{"Soru, kapitalizmin coğrafyaya ne yaptığ değil, coğrafyanın kapitalizm için neler yapabileceğidir. Böylece, öncelikli olarak coğrafi soruya ek olarak, eşitsiz gelişme teorisi siyasi soruya da cevap vermektedir: mekânın (landscape) coğrafi düzenlenişi kapitalizmin hayatta kalışına nasıl katkıda bulunmaktadır?" 87}

Görüldüğü üzere Smith, Lefebvre tarafindan dile getirilen çok önemli bir soruya, kapitalizmde mekânın ve mekânın üretiminin, sistemin hayatta kalışındaki rolüne dikkat çeker ve böylece analizi bunun doğrultusunda yürütür.

81 Bkz. Gottdiener, The Social Production of Urban Space.

82 Bkz. Gottdiener, "Space as a Force of Production: Contribution to the Debate on Realism, Capitalism and Space".

83 Lefebvre, Mekânin Üretimi, s. 343-344, 355-357 vd.

84 Bkz. Gottdiener; "Disneyland: A Utopian Urban Space"; Gottdiener, The Theming of America: American Derams, Media Fantasies, and Themed Environments; Gottdiener, "The Consumption of Spaces and the Spaces of Consumption"; Gottdiener, "Socio-Semiotics and the New Mega Spaces of Tourism: Some Comments on Las Vegas and Dubai".

85 Bkz. Smith, Uneven Development: Nature, Capital, and the Production of Space.

86 Ibid., s. 4.

87 Ibid., s. 4, vurgu eklenmiştir. 
Fakat Smith analizinde Lefebvre'den farklı bir kavramsal dile başvurur. Lefebvre'de, mutlak mekânın kapitalizm öncesi üretim tarzlarının hâkim mekân olarak nitelendirildiği ve bu mutlaklığa sadece doğallık atfedilmediğini, aynı zamanda siyasi, kutsal ve diğer nitelikler de atfedildiği görülürken, Smith tarihsel süreçte iki çeşit mekânın tezahüründen söz eder. Bu iki mekân, insan eli değmemiş, doğal olan mutlak mekân ve kapitalizme özgü olan, kapitalizmde üretilmekte olan göreceli mekândır. Smith'e göre, "erken kapitalist gelişme, doğal mekânın (miras kalan mutlak mekânın) üretilen göreceli mekâna devamlı bir dönüşümüydü... Kapitalizmin coğrafyası göreceli mekânın üretimi aracılığıyla ilerlemişse, bu başlangıçta mutlak mekânın ilerlemesiyle gerçekleşmiştir."88 Başlangıçtaki mutlak mekânın ilerlemesi, siyasi örgütlenmenin şehirden ulusal devletlere ve daha sonra sömürge imparatorluklara geçişiydi, başka bir ifadeyle toplumsal yayılma, coğrafi yayılma yani mutlak mekânın genişlemesiyle gerçekleşti. Fakat kapitalist gelişmenin son yüzyılında göreceli mekânın üretimine tanık olmaktayız;

"Kapitalist gelişmenin son yüzyılı, benzeri görülmemiş düzeyde mekânın üretimi içermektedir. Fakat bu, belirli bir mekânda mutlak genişlemesiyle değil, küresel mekânın iç farklılaşmasıyla gerçekleşti, yani göreceli mekânın daha geniş ortamında farklılaşmış mutlak mekânların üretimiyle gerçekleşti." 89

Bu farklılaşmış mekân, "fabrikalar, makineler, ulaşım yolları, depolar ve bir sürü başka tesisler biçiminde, nispeten uzun dönem için mekânsal olarak sabitlenmiş üretken sermayenin geniş miktarı" sonucunda ortaya çıktı. Ayrıca, "sermayenin böyle mekânsal sabitlenmesi veya ulus devletin sınırlarıla sınırlanan ulusal sermayeler, aynı zaman farklılaşmış coğrafi mekânın üretimidir." 90

Yukarıdaki alıntılardan da anlaşıldığı üzere Smith'in mutlak ve göreli mekân kavramsallaştırması sadece kapitalizme özgü üretim ilişkilerine ve sermaye hareketlerine dayanan bir kavramsallaştırmadır, dolayısıyla Smith'in mekân analizi geleneksel Marksist ekonomik politik analizdir ve bu açıdan Harvey'inkinden farklılık göstermemektedir. Ayrıca, Smith, kapitalizmde mekânın rolünü vurgulasa ve analizini bu doğrultuda yürütse de, fonksiyonel bir çözümleme yapmanın tuzağından çıkamaz ve mekânın üretiminde temel etken olarak sermaye hareketi ve birikim süreçlerini konuşlandırır veya mekânı sermaye için mekânsal sabit (spatial fix) olarak varsayar. Böylece, mekânın üretimindeki karmaşık toplumsal süreçler analiz dışı kalıp, salt ekonomizme tabi olan bir analizle karşı karşıyayız. Ayrıca Smith, mekân ve mekânın üretimini,

88 Ibid., s. 119.

89 Ibid., s. 120.

90 Ibid. 
çok tartışmalı olan doğanın üretimi bağlamında incelediği ve temel hedefi de eşitsiz gelişme teorisini geliştirmek olduğu için, çalışmada mekânın üretiminin karmaşık etmen ve süreçleri incelenmemiştir. Nihai tahlilde eşitsiz gelişme "kapitalizmde mekânın üretiminin somut tezahürü"91 olarak görülmekte ve çok kapsamlı ve çok boyutlu süreç olan mekânın üretimi sadece sermaye hareketi ve birikim süreçleri ile bağlantılı bir sürece indirgenmiştir.

Fakat Smith'in çalışması, mekânın üretimi bağlamında bir diğer açıdan önem taşımaktadır. Söz konusu olan, doğanın üretimidir. Smith, doğanın üretimi argümanını Lefebvre'in mekânın üretimi argümanından esinlenerek ödünç aldığını belirterek, Lefebvre'in doğanın üretimini ciddi ve kapsamlı şekilde ele almadığını, kuramında mekâna, doğaya kıyasla öncelik tanıdığını ve doğanın mekân içinde "yer bulduğunu" varsaydığını belirtir. Lefebvre, mekân konusunda geleneksel anlayıştan ayrılmasına rağmen, doğa konusunda geleneksel kaldı ve doğanın ele alınışı tamamen başarısız oldu. ${ }^{92}$ Bunun için, Smith, mekânı gittikçe daha yoğun biçimde üretilmekte olan doğanın bir ürünü olduğunu ve mekânın üretimini doğanın üretimi bağlamında ele almayı önerir. Mekânın üretiminin doğanın üretimi bağlamında incelenmesi, dahası onun bir boyutu olarak ele alınması da söz konusu olabilir, fakat burada sorunlu olarak gördüğümüz hususlar şöyle tartış1labilir.

Lefebvre tarafindan mekânın üretiminin ele alınması doğanın üretiminin analiz dışı bırakılması anlamına da gelmeyebilir. Burada mevzu, Lefebvre'in ve Smith'in, doğa ve mekân kavramlarıyla ne kastettikleridir. Lefebvre'in, kapitalizm öncesi toplumlardan başlayarak ileri kapitalizme kadar uzanan toplumlarda üretilen ve hâkim olan mekânların analizine bakıldığında ${ }^{93}$ mekânı bir 'ikinci doğa' olarak ele aldığı görülmektedir. O yüzden, Smith'in kastettiği 'doğa' Lefebvre'de "başlangıçtaki ortak alan" olarak görülmektedir. Mekânın üretimi ise bu "başlangıçtaki ortak alan"dan başlamıştır. O yüzden, Lefebvre'in çok tartışılan ve başvurulan "toplumsal mekân toplumsal bir üründür" saptamasının birinci içerimi, "doğa-mekânın geri dönüşsüz bir şekilde ortadan kaybolmasıdır" çünkü doğa-mekân, "köken, toplumsal sürecin başlangıc1, belki de her 'özgünlüğün' temeli” dir. ${ }^{94}$ Ayrıca Smith' in belirttiği “"gittikçe daha yoğun biçimde üretilen" doğa ile ilgili Lefebvre'in görüşlerini, şu satırlar en iyi şekilde yansitir;

"Teorik olarak doğa uzaklaşır, fakat doğanın ve doğal olanın sembolleri artar, gerçek 'doğa'nın yerini alır. Bu semboller kitlesel şekilde üretilir ve satılır. Bir ağaç, bir çiçek, bir dal, bir koku, bir kelime, var olmayan

91 Ibid., s. 122-123.

92 Smith, Uneven Development: Nature, Capital, and the Production of Space, s. 249-250.

93 Lefebvre'in bu mekân dönemselleştirmesi detaylı olarak ileri alt bölümde ele alınacaktır.

94 Lefebvre, Mekânın Üretimi, s. 60. 
sembollerin haline gelir: Yanılsamalı ve kurgusal bir varlıktır bu. Eş zamanlı olarak ideolojik doğallaştırma da saplantılaşır. Tüm reklamlarda, ister gıda ve tekstil ürünlerinin, ister ev ve tatil reklamları olsun, daimi olarak doğaya bir gönderme vardır. Doğanın temsilinde, retoriğin kullandığı tüm 'değişken gösterge'ler, (yanılsamal1) bir anlam ve içerik bulmak için birbirine bağlanır. Artık bir anlam taşımayan şeyler, 'doğa' fetişini kullanarak bir anlam kazanmaya çalışır. Bulunmayan, yitirilmiş, harap olmuş, kentleşme ve sanayileşmenin artığı haline gelmiş doğa, dişilikten en küçük nesneye kadar her yerde kendini gösterir. Kentin iyi niyet ve kötü temsillerinin son ifadesi olan 'yeşil alanlar'a gelince, bunlar için doğanın cılız bir temsili, özgür mekânın, yani buluşma ve oyun alanlarının, parkların, bahçelerin, meydanların niteliği bozulmuş bir görüntüsünden başka ne denebilir?"95

"Mekânın üretiminin hammaddesi, tikel nesneler olduğu gibi, özel bir malzeme değildir. $\mathrm{Bu}$, doğanın ta kendisidir; ürüne dönüştürülmüş, hırpalanmış, bugün tehdit altında olan ve belki de çökmüş, hatta paradoksun doruğu! - kesinlikle belli bir yerle sinırlandırılmış doğa." 96

Bunlardan anlaşıldığı üzere, Lefebvre, mekânın toplumsal olarak üretildiği tarihsel süreçte mekânı bir ikinci doğa olarak görür ve doğanın üretiminden söz etse de, bunu bir ikinci doğanın üretimi olarak tanımlar, ikinci doğa ki gerçek doğanın taklidi, simge veya temsilidir. O yüzden endüstriyel kapitalizmle ortaya çıkan ve Smith tarafından çok kapsamlı olarak ele alınan "doğanın ideolojisi"97 Lefebvre'in "obsesif hale gelen" "ideolojik doğallaştırma" ve diğer saptamalarına benzerdir. Dolayısıyla, Smith tarafından "mekânın gittikçe daha yoğun biçimde üretilmekte olan doğanın bir ürünü olduğu" saptaması yukarıda ele alınan hususlar 1şığında bakıldığında pek uygun değildir. Unutulmamas1 gereken diğer bir husus, Smith'in, kendisi bir coğrafyacı olup ve coğrafya bilimindeki mekân anlayışına dayanarak analizini "insan faaliyetinin mekânı olarak, en küçük ölçek olarak mimari mekânından gezegenin tüm yüzeyin ölçeğine kadar coğrafi mekânla"98 sınırlandırması ve mekânın üretimini coğrafi mekânın üretimi olarak ele almasıdır. Dolayısıyla, "psikolojik ve antropolojik literatürdeki mekânın ele alınışını ki coğrafi mekânın ele alınışıyla örtüşmektedir" 99 analiz dışında bırakan Smith'in çalışması ve orada tartışılan mekânın ve doğanın üretimi, Lefebvre'in, psikolojik ve antropolojik boyutları da dâhil ederek daha kapsamlı olarak tanımladığı mekânın üretiminin sadece bir boyutudur. Smith de kendisinin ifade ettiği gibi, "mekânın doğadan epey ayrı bir

95 Lefebvre, Kentsel Devrim, s. 30-31.

96 Lefebvre, Mekânın Üretimi, s. 145.

97 Neil Smith, Uneven Development: Nature, Capital, and the Production of Space, s. 10-48.

98 Ibid., s. 93.

99 Ibid., s. 276-277. 
gerçeklik olduğunu kavramsallaştırmadıkça, mekânın üretimi doğanın üretiminin mantıksal bir sonucudur."100 Oysa önceden belirtildiği üzere, Lefebvre'de mekân ilk önce toplumsal olarak üretilen, başlangıcı birinci doğaya dayanan ve coğrafi mekândan (dolayısıyla doğadan) öteye geçen, daha kapsamlı bir tanımdır, dahası böyle bir mekân kavramsallaştırması doğadan epey ayrı olmak yerine, onu kapsadığı da söylenebilir.

Smith'in çalışması ve onun eşitsiz gelişme kuramı ile ilgili daha fazla tartışma yürütmesi, bu çalışmanın kapsamı dışındadır. Fakat Smith'in çalışması üzerinde daha detaylı olarak durmamızın nedeni, onun hem coğrafya hem de sosyal teorideki mekân ve mekânın üretimi konusunda son zamanlarda üzerinde sıkça durulan ve başvurulan bir çalışma olmasıdır. O yüzden onun yaklaşımı en azından mekânın üretimi açısından bu çalışmada ele alınması gerekmekteydi. Bir sonraki alt bölümde mekânın üretimi paradigmasına ve mekânın üretiminin araştırılmasının yöntembilimsel temellerine kısaca değinerek Lefebvre'in mekânın üretimi kuramına değinilecektir.

\subsection{Mekânın Üretiminin Araştırılmasının Yöntembilimsel Temelleri}

$\mathrm{Bu}$ alt bölümde, mekân ve mekânın üretiminin araştırılmasının yöntembilimsel temellerini ve özellikle yöntembilimsel açıdan Lefebvre'in mekânın üretimi kuramının sunduğu imkânlar ve bazı sınırları ele alınacaktır.

Yöntembilimsel açıdan mekânın üretimi kuramının en temel özelliği, Marksizm bünyesinde ortaya çıkan bir kuram olduğu için, Marksizme özgü diyalektik çözümleme yöntemine dayalı olmasıdır. Geleneksel olarak tarihsel analizine dayanan Marksist analize ve kuramına mekânsal boyutu sağlamayı amaçlayan bu kuram, aynı zamanda mekân analizine Marksizme özgü diyalektik ile tarihsel analiz ve kuramsal ile kavramsal çerçevesi sağlama yönündedir. Dolayısıyla, bu kuram geleneksel sosyal teorideki (Marksizm de dâhil) kentselin ve kentsel mekânın bölme ve parçalama yaklaşımına kıyasla, kentselin sosyal ve mekânsal dinamiklerinin daha kapsamlı ele alınışını sağlamaktadır.

Genel kabul görmüş Marksist yaklaşım (yukarıda kısmen ve kısaca ele alınan), maddi ilişkilerin doğrudan mekânda ortaya çıktığını ve mekânın üretimini bu ilişkilerin tezahürü olarak değerlendirmekte, mekânın üretimini doğrudan emek ile sermaye çelişkisine tabi tutmakta ve sosyo-mekânsal biçimlerin, "kapitalizm" veya "kapitalistler" tarafından üretildiğini varsaymaktadır. Oysa mekânın üretimi kuramı, mekânı kapitalist toplumsal 
ilişkiler başta olmak üzere çok karmaşık ve çelişkili olan toplumsal süreçlerin bir ürünü olduğunu varsaymaktadır.

Diğer önemli husus, geleneksel Marksizmin, her konuda olduğu gibi mekân konusunda da kendi analizini kullanım değeri ve değişim değerinin diyalektiğine dayandırması ve böylece mekân sorunsalını ekonomik hususlar çerçevesinde ele almasıdır. Mekân sorunsalının böyle bir analizine Lefebvre'in kuramında da tanık olmaktayız. Lefebvre'in temel savlarından biri, kapitalizmin gelişmesi ve kapitalist toplumsal ilişkilerin yaygınlaşmasıyla birlikte günlük hayatın maddi dayanağı olan ve kullanım değerine tekabül eden mekân yerine gayrimenkul gelişim ve devlet idaresi için gerekli olan soyut mekânın ve değişim değerinin hâkim konuma yükselmesidir. Geleneksel Marksist analiz, mekânın soyutlanma süreçlerinin ekonomik boyutunu ve çelişkilerini analiz odağına yerleştirip ${ }^{101}$ mekânı arsaya indirerek, mekânın ve onun üretiminin siyasi, kültürel ve genel ideolojik boyutunu genelde analiz dışı bıraktı. Analiz odağı, rant teorisine ve arsanın ekonomik analizine dayanarak rant paylaşımı üzerine sınıfsal kesimlerin etkileşimi ve bu süreçte ortaya çıkan yapılı çevre ile sınırlı kald1. İdeolojik ve kültürel boyutu ise sadece kapitalist devletin 'birikim ve meşrulaştırma işlevleri' çerçevesinde ele alındı. Oysa

"yerel ölçekte tüketim gruplarının ve çelişkili yaşam tarzlarının, çekişmeli ihtiyaçlarının yarattığı sorunlar sadece ekonomik değerlendirmelerle çözülemez. Ayrıca kültürün temel sorunlarına hitap edilmelidir. Dolayısıyla, mekânın sınıfsal analizi mümkün olmakla beraber, toplumsal mekân etrafinda örgütlenmiş olan meseleler, araştırmacıyı sosyo-mekânsal nitelik taşıyan sorunları ele almaya zorlamaktadır, bu ise daha genel bir yaklaşım gerektirmektedir." 102

Türkiye gibi çok sayıda kimlik barındıran, her konuda bu kimlik meselesinin doğrudan veya dolaylı olarak söylemde tartışma, pratikte ise gerilim ve çekişme konusu olduğu bir toplum için bu saptamanın ne kadar önemi olduğu açıktır. İşte bu açıdan Lefebvre'in mekân analizi, çok genel nitelikte bir kuramsal çerçeve (mekânın genel bir teorisi) sunduğu için, bunları hesaba katmaya imkân tanımaktadır. Bu yüzden Lefebvre'yi ve onun hem analizini hem de tahayyül ettiği toplumsal düzeni, geleneksel Marksizme ve Marksist analize sığmadığı için "anarşist anlayışlarla Marksist bir kent bilimci"103 veya "liberter"104 olarak tanımlamaları s1kça görülmektedir.

101 Günümüzde en çok başvurulan Harvey'in çalışmalarına göz atıldığında, gayrimenkul sektörünün, onun analizinde hâkim olması bunun en bariz örneğidir.

102 Gottdiener, The Social Production of Urban Space, s. 173.

103 Merrifield, The Politics of the Encounter: Urban Theory and Protest Under Planetary Urbanization, s. 143, dipnot 13.

104 Castells, The Urban Question: A Marxist Approach, s. 89. 
Lefebvre'in mekân analizi ve mekânın üretimi kuramı şu temel özellikleriyle karşımıza çıkmaktadır.

İlk önce, Lefebvre benimsediği diyalektik mantığa uygun olarak mekânı bir süreç olarak ele almaktadır ve çağdaş kapitalizmde sosyo-mekânsal biçimlerin süreçsel bir kavramsallaştırmasını önermektedir. Buna göre, mekân, zaman ve tarihselliğe karşıt değildir, onun diyalektik olarak ayrılmaz bileşenidir. Dolayısıyla, çağdaş kapitalizmde sosyal mekânın tüm boyutları, süregelen toplumsal çekişme ve dönüşümlerin dinamik süreçlerinin alan, sonuç ve önkoşulu olarak değerlendirilmelidir. Böyle bir kavramsallaştırma, "şey olarak mekân" veya "düzlem olarak mekân" gibi geleneksel Kartezyen anlayışlarını, diyalektik "süreç olarak mekân" anlayışıyla ikame etmektedir. ${ }^{105}$

Lefebvre'in kuramın bir diğer özelliği, 'sosyo-mekânsal diyalektiğe' dayalı olmasıdır. Lefebvre, çalışmanın herhangi bir bölümünde böyle bir kavram kullanmamasına rağmen, Soja tarafindan böyle bir kavramsallaştırma önerilmesi ${ }^{106}$ aslında Lefebvre'in yaklaşımını iyice ifade etmektedir.

Soja'ya göre, Lefebvre'in "mekân ve mekân politikası toplumsal ilişkileri 'ifade eder'; aynı zamanda onu etkiler de"107 ifadesi sosyo-mekânsal diyalektiğin temel dayanağını yansıtır: toplumsal ve mekânsal ilişkiler diyalektik olarak birbirini etkiler, birbirine bağımlıdır, toplumsal üretim ilişkileri hem mekân biçimlendiren hem de mekân koşulludur. ${ }^{108}$

Bir analitik çerçeve olarak sosyo-mekânsal diyalektiğin amacı sınıf analizini ikame etmek veya mekânı "bilimsel nesne" seviyesine yükseltip, mekânın örgütlenmesini temel üretim ilişkiler arasında otonom bir yapı olarak ele alması değildir. ${ }^{109}$ Örgütlenmiş mekânın yapısı, ne kendine özgü yapılanma ve dönüşüm yasaları olan ayrı bir yapıdır ne de toplumsal üretim ilişkilerinden ortaya çıkan sınıfsal yapının ifadesidir. Bu yapı, hem sosyal hem de mekânsal olan genel üretim ilişkilerinin diyalektik olarak belirlenen bir unsurudur. ${ }^{110}$ Dolayısıyla, kapitalizmde aynı üretici yapılarda ortaya çıkan üretim ilişkilerinin dikey ve yatay ifadeleri benzerdir ve diyalektik olarak bağlıdır. Farklı toplumsal formasyonlarda ve farklı tarihsel bağlamlarda farklılık gösteren karmaşık

105 Brenner, New State Spaces: Urban Governance and the Rescaling of Statehood, s. 32.

106 Bkz. Soja, "The Socio-Spatial Dialectic"; Soja, Postmodern Geographies: The Reassertion of Space in Critical Social Theory.

107 Daha detaylı olarak bkz. Lefebvre, Kentsel Devrim, s. 19.

108 Soja, "The Socio-Spatial Dialectic", s. 211.

109 Ibid., s. 224-225.

110 Soja, Postmodern Geographies: The Reassertion of Space in Critical Social Theory, s. 78. 
karş1lıklı ilişkilerde her biri diğeri tarafından biçimlendirilmekte ve diğerini biçimlendirmektedir. ${ }^{111}$

Lefebvre'in kuramının diğer temel özelliği, onun mekânı ele alması ile ilgilidir. Bu konuyu burada tartışmak için Lefebvre'in eserlerinden, özellikle 1960-70'li yıllarında art arda yayımlanan ve az çok tutarlı bir çerçeve ortaya koyan üç çalışması ve onların odak noktalarının seyrini incelemek gerekir. ${ }^{112}$

1968-70 y1llarında Lefebvre tarafından kent hakkl ve küresel düzeyde kentleşme eğilimleri üzerine çalışıldığ 1 görülmektedir. Bunun sonucu 1970 yılında yayınlanan Kentsel Devrim çalışmasıdır. Çalışmada, Lefebvre kentselin hem mekânsal boyutları açısından hem de yaşam biçimi olarak küresel bir olgu haline geldiğini belirterek küresel çapta bir kentsel devrim gerçekleştirmekte olduğu savını öne sürmektedir. Lefebvre'in bu çalışması, özellikle Marksist eğilimli kent tartışmalarında önemli yer tutmuş olsa da, tartışmalar genelde kentleşmenin mi birikim süreçleri ve endüstriyelleşme altında yattığını, yoksa birikim süreçleri ve endüstriyelleşmenin mi kentleşme eğilimlerinin altında yattığı çerçevesinde yürütülmüştür. ${ }^{113}$ Fakat ontolojik açıdan önemli bir nokta bu tartışmaların gölgesinde kalmıştır; bu devrimle beraber ortaya çıkan mekânın kentsel ile kentsel olmayan olarak ayrılmasının gittikçe imkânsız olduğu, dolayısıyla mekânın da ele alındığında geleneksel mekân anlayışının geçersiz hale geldiği ontolojik noktası. Halihazırda yeni bir fenomenle, kentsel ve ona tekabül eden diferansiyel mekânla karşı karşıyayız ve meydana gelen herhangi bir çelişki artık kent ile kır arasında gerçekleşmemektedir. Temel çelişki bizzat kentsel fenomene kaymıştır. ${ }^{114}$

Fakat geleneksel mekân anlayışı, sadece mekâna müdahale edilebilecek ve insan tarafindan biçimlendirilebilecek bir ortam olarak gören Kartezyen anlayış, ayrıca modernizm olarak tanımlanan dönemde daha da baskın görülen kent-kır ayrımı değildi. $\mathrm{Bu}$ aynı zamanda, bunlarla koşut olarak gelişen, onlardan beslenen ve onları destekleyen, mekânı parçalayarak incelemeyi amaçlayan sayısız akademik alanları ve çalışmalarıydı. Lefebvre'in belirttiği gibi,

"Çok sayıda yayın ve çalışmanın uzun süredir aradığı bir ekseni mekân bilimine sağlamamıştır. Araştırmalar, (analitik momente erişemeden; teorik olana hiç erişemeden) ya tanımlara ya da mekânın parçalamasına ve

111 Soja, "The Socio-Spatial Dialectic", s. 225; Soja, Postmodern Geographies: The Reassertion of Space in Critical Social Theory, s. 78, 82, 127 vd., ayrica krş. Gottdiener, The Social Production of Urban Space, s. 22-23.

$112 \mathrm{Bu}$ yıllarda, Lefebvre'in farklı konular üzerine çalıştığı görülmektedir. Fakat konumuz açısından burada sadece kent ile mekân üzerine yazıları ele alınmıştır.

113 Bkz. Castells, The Urban Question: A Marxist Approach; Harvey, Social Justice and the City.

114 Lefebvre, Kentsel Devrim, s. 159. 
kopmasına varmıştır. Oysa, tanımların ve kopmaların ancak mekân içinde olanın envanterini çıkarmış, en fazla mekân üzerine bir söylem oluşturmuş, ama asla mekânın bilgisini ortaya çıkarmamıştır...[Sonuçta] üst üste ya da iç içe olmak üzere, sonsuz sayıda mekânla karşı karşıyayız: coğrafi, ekonomik, demografik, sosyolojik, ekolojik, politik, ticari, ulusal, kitasal, dünyasal... Doğanın (fiziksel), mekânını, akışlarının (enerjilerinin) mekânlarını da unutulmamalı." 115

Bu sayısız çalışmalar tarafindan aranmakta olan mekân bilimi aslında 1) bilginin neo-kapitalist kullanımını temsil eder, 2) bu kullanımı maskelemeyi amaçlayan bilgi kisvesi altındaki ideolojiyi içerir, 3) mevcut üretim tarzının çerçevesinde teknolojik bir ütopyayı kapsar. ${ }^{116}$

Oysa karşımıza çıkan kentsel fenomen (ve ona tekabül eden mekân ve mekânın üretimi) "bütünlüklü toplumsal fenomendir"117, yani bütünselliğe ulaşmadan ona yönelir, esasen bütünselleştiren merkezliktir fakat bu bütünsellik hiçbir zaman gerçekleşmemektedir, hiç bir kısmi determinizm, hiçbir parçalı bilgi onu kapsayamaz; o, aynı anda tarihsel, demografik, coğrafi, ekonomik, sosyolojik, psikolojik, semiyolojiktir vs. Fakat ne fragman ve içerik ayırması ne de onların karışık birleşimi kentsel fenomeni tanımlayamaz (dolayısıyla ifade etmez). Böylece,

"Kent fenomeni, coğrafyacıların, demografların, iktisatçıların, sosyologların, göstergebilimcilerin, vs. sözcüklerini (kısmı okumaları) birleştiren bütünlüklü bir okumayl gerektirir. $\mathrm{Bu}$ okumalar farklı düzeylerde birbirini izler. Fenomen, bunların toplamı ya da senteziyle de, üst üste konulmalarıyla da tanımlamaz." 118

Bunları temel alarak, Lefebvre kentselin ve mekânın geleneksel kabul görmüş sorunsallaştırılmasını eksik görmektedir ve bir sonraki çalışmalarında kent odağını bir kenara bırakmasa da, temel odak noktası mekândır ve bunun sonucu ise mekânın üretimi kuramıdır. Lefebvre'in çalışmalarında böyle bir ontolojik dönüşün diğer önemli nedeni, kentselin topyekûn, bütünselleştirici ve küresel bir olguya dönüşümüyle beraber, onun biçim ve kapsam olarak da dönüşümüdür. $\mathrm{Bu}$ durumda, Castells kentsel olanın, bir araştırma nesnesi olabileceği konusunu sorunlu olarak görüp, kentsel olanı emek gücünün yeniden üretimiyle tanımlarken, Harvey, çalışmalarında mekânı genelde arsaya indirgeyip ele alırken, Lefebvre tamamıyla aksi yönde hareket ederek, kendi analizinin odağına mekânı yerleştirmektedir. Çünkü

115 Lefebvre, Mekânın Üretimi, s. 38-39.

116 Ibid., s. 40.

117 Lefebvre, Kentsel Devrim, s. 161.

118 Ibid. 


\begin{abstract}
"salt çevresel indirgemeciliği aşma, hızlıca merkezsizleşen toplumsal formasyonda kentsel kavramın dayattı̆̆ 1 sınırlamaların ötesine geçme gerekliliğinden dolayı Lefebvre, bizzat mekânı da dâhil etmek için kendi teorisinin genelleştirmesine ihtiyaç duydu." 119
\end{abstract}

Böylece, Lefebvre'in araştırma odağındaki kentselden ve kentsel mekânından genel mekâna doğru ontolojik bu seyri ve sonuçta karşımıza çıkan genel mekân ve mekânın üretimi teorisi, ele almaya gerek duyulan diğer önemli noktasıydı. Böyle bir ontolojik duruşu da yukarıda ele alınan özelliklerle beraber, Lefebvre'in mekân kuramını özgün, daha kapsamlı ve tutarlı kılmaktadır.

Mekân tartışmaları söz konusuyken, ele alınacak diğer nokta mekân kavramının kullanımıdır. Mekân tartışmalarında mekân kavramına farklı anlam ve içerik atfedildiğini, bazen ise mecazi anlamda kullanıldığı görülmektedir. Böyle bir kullanımın söz konusu olduğuna Lefebvre de dikkat çeker ve onun eleştirisi, Foucault Lacan, Derrida, Kristeva başta olmak üzere post-yapısalcı olarak tanımlanan birtakım düşünürlere yöneliktir.

"Bunun ve/veya şunun mekânı söz konusu edilir daima: edebi mekân,
ideolojik mekânlar, düş mekânı, psikanalitik topos'lar, vb. Oysa, temel ya
da epistemolojik denen bu araştırmalarda "bulunmayan" şey sadece
"insan" değil, aynı zamanda mekândır, ama yine de her sayfada bundan
söz edilir. "Bir bilgi, aynı zamanda bir mekândır; özne bu mekân içinde
konumlanarak kendi söyleminde geçen nesnelerden söz eder" diye açılar
M. Foucault sakin sakin ve hangi mekândan söz ettiğini, teorik
(epistemolojik) olandan pratiğe, zihinselden toplumsala, filozofların
mekânından nesnelere işi olan insanların mekânnna nasıl atıldığını
düşünmez. (Edinilmiş bilgi üzerine "epistemolojik" denen düşünüm
yoluyla tanımladığımız) bilimsellik ve mekânsallık, bilimsel söylem için
aşikâr olan ve asla kavrama yönelik olmayan, varsayımsal bir bağlantıya
göre "yapısal olarak" birbirine eklemlenir."120

$\mathrm{Bu}$ durumda, Lefebvre'ye göre "felsefi-epistemolojik kökenli mekân fetişleşir ve zihinsel mekân, fiziksel mekânla toplumsal mekânı kapsar" ve zihinsel mekân ile gerçek mekân arasında "varsayılan kısmen mantıksal özdeşlik şu üç terim arasındaki uçurumu iyice derinleştirir: zihinsel, fiziksel, toplumsal." 121 Bundan dolayı bir taraftan mekânı parçalayarak inceleyen ve böylece sadece "tanımlara varan", "mekân içinde olanın envanterini çıkaran" ya da "en fazla mekân üzerine bir söylem oluşturan" epistemolojik-felsefi düşünümle karşı karşıyayız. Diğer taraftan, mekânın fiziksel ve toplumsal mekânla ilişkisi olmayan, mecazi anlamda kullanılan bir anlayışla karşı

119 Gottdiener, The Social Production of Urban Space, s. 152.

120 Lefebvre, Mekânın Üretimi, s. 35.

121 Ibid., s. 37-38. 
karşıyayız. Fakat Foucault'nun mekân yaklaşımında Lefebvre tarafından ele alınmamış önemli bir husus da söz konusudur. Lefebvre'ye göre,

\begin{abstract}
"Uzmanlık yazıları, okulların özel olarak uzmanlaşmış her türlü mekân üzerinde bilgilendirirler: boş vakit mekânları, çalışma, oyun, ulaşım, donanım, vb. mekânları. "Hasta mekân"dan ya da "mekânların hastalı̆ı̆"ndan, deli mekândan ya da delilik mekânından söz etmekten bile çekinmeyenler vardır."122
\end{abstract}

Yukarıdaki alıntıda, Lefebvre'in "deli mekândan ya da delilik mekânından söz etmekten çekinmeyenler" tanımıyla büyük olasılıkla Foucault'yu kastetmektedir. Bu bağlamda, Foucault'nun mekâna yaklaşımının diğer zaafinı değerlendirmek yerinde olur. Örneğin, Foucault'un Disiplin ve Ceza çalışmasına göz atıldığında, ${ }^{123}$ yukarıdaki değerlendirmeden farklı bir tablo karşımıza çıkmaktadır. Burada Foucault'un mekân anlayışı ve mekânın rolü analizi zihinsel mekândan ziyade mekânsal örgütlenmenin yapısal önemiyle sınırlıdır. Başka bir deyişle, mekânı ele alışı panoptikon ${ }^{124}$ veya vebaya yakalanmış şehri denetlemek için yeterli görülen mekânsal örgütlenmenin rolünün analiziyle sınırlıdır. Kısacası, Foucault'nun iktidar mekanizmaları analizinde mekânın çok kapsamlı ve çok düzlemli ele alınmasından ziyade mekânsal yapıya ve örgütlenmesine vurgu söz konusudur. ${ }^{125}$

Mekânın mecazi olarak kullanılmasına gelince, bu da yaygın olarak görülen bir durumdur. ${ }^{126} \mathrm{Bu}$ durum dikkate alınması gereken bir tehlike barındırmaktadır, şöyle ki

"Geleneksel sosyal teoride mekânın genelde tartışmasız bir konumu vardı; tarihin akışını sağlayan site, zemin, istikrarlı temel. Mekân, tarihsel değişimi tutarlı kılan sabit bir koordinat dizisi tanımlar. Dolayısıyla iliş̧i asimetriktir; tarih [zaman] bağımsız değişkendir, coğrafya [mekân] ise bağımlı. Mekânsal mecazlar, mekânın bu zemin (ya da ayrı zeminler birleşimi) anlayışına hitap ederler; mekân, zamanın canlandırılmasına, mekânın durgunluğunun karşısında zamanı ölçebilmek, değerlendirebilmek için yaşamla doldurmaya hizmet eder. Mekânsal mecazların, çağdaş dünyanın özellikle bölünmüş birliğini açılayacak

122 Ibid., s. 39.

123 Foucault, Discipline and Punish: The Birth of the Prison, s. 195-228.

124 Hücreleri gardiyana bakan dairevi hapishane yapıs1

125 Böyle bir yaklaşım, Foucault'nun başka bir çalışmasında da görülebilir, bkz. Foucault, Security, Territory, Population: Lectures at the College de France 1977-1978, özellikle Bölüm 1, s. 1-27.

126 Lefebvre, Mekânın Üretimi, s. 35. Birtakım yabancı dillere (özellikle Fransızcaya) kıyasla, Türkçede 'mekân' sözcügünün daha somut anlam taşıdığı, dolayısıyla mecazi anlamda kullanılmasına pek elverişli olmamasına rağmen, kuramsal açıdan yabancı tartışmalardan beslenen ve onlara dayanan çalışmalarda da bazen Türkçede mecazi olarak mekân tartışmalarına rastlamak mümkündür. 
gücü ne olursa olsun, onlar mekânın durağanlığını pekiştirerek, böylece dünyayı çözümlemek için uygun olan mekânsal kavramların kullanımını engellerler. Mecaz, doğası gereği zıtlıkların yan yana dizilmesidir; bir gerçeği ortaya koymak için, onu bir başka olarak öne sürer... Böylece, mekânsal ile toplumsal arasında uzlaşma arayışında mecazi ile gerçek mekân arasındaki kavramsal uçurumun doldurulması gerekecek.”127

Smith'in bu saptaması doğruysa, Foucault' da bir çelişkiden söz edilebilir; Foucault'nun kendisinin de itiraf ettiği "mekânsal takıntıları"128 ve mekânsal mecazların kullanımı sosyal teoride mekânın, Foucault'nun eleştirdiği “ölü, sabit, diyalektik dişı, durağan olarak ele alınışı"n1 ${ }^{129}$ pekiștiren ve farklı mekânlar arasındaki uçurumu doldurmayan niteliktedir. O yüzden, Lefebvre tarafından mekânın bir süreç olarak değerlendirilmesi; toplumsal ile mekânsalın karşılıklı ilişkilerinin diyalektik çözümlenmesi (sosyo-mekânsal diyalektik); zihinsel, toplumsal ile fiziksel mekânları birleştirmek için önerilen mekânsal üçlüsü, sosyal teoride yukarıda ele alınan (veya tartışmamız dışında kalan) farklı düşünürlerin kuramsal önermelerinden daha kapsamlı ve tutarlı niteliktedir.

\subsection{Lefebvre'in Mekânın Üretimi Kuramının Kavramsal Çerçevesi 130}

\subsubsection{Toplumsal Olarak Üretilen Mekânın Tarihi: Mekân Dönemselleştirmesi}

Lefebvre, "(toplumsal) mekân (toplumsal) bir üründür” varsayımının bir içerimi olarak, önemli bir saptamada bulunur:

"Mekân üretimi ve mekânın üretimi süreci varsa, tarih de vardır... Mekânın tarihi, mekânın 'gerçeklilik' olarak üretiminin, biçim ve temsillerinin tarihi, 'tarihsel' (belli bir tarihe bağl1) olguların nedensel zincirlenişiyle, ya da gelenek ve yasaların, fikir ve ideolojilerin, sosyo-ekonomik ya da kurumsal yapıların (üstyapılar)-ereklilikli ya da erekliliksiz-ardışıklığıyla karıştırılmamalıdır. Üretici güçler (doğa, çalışma ve çalışmanın örgütlenmesi, teknik ve bilgiler) ve elbette üretim ilişkileri, mekân üretiminde-belirlenmesi gereken-bir role sahiptirler. Bir üretim tarzından diğerine geçiş çok büyük önem taş[1r]; çünkü bu, mekânı altüst ederek

127 Smith, Uneven Development: Nature, Capital, and the Production of Space, s. 224.

128 Foucault, "Questions on Geography", s. 69.

129 "Mekân ölü, sabit, diyalektik dışı, durağan olarak ele alınmaktaydı. Aksine, zaman zenginlik, doğurganlık, hayat ve diyalektikti". Bkz. Foucault, "Questions on Geography", s. 70.

130 Bu alt bölüm ilk kez Lefebvre'nin Mekân Kuramının Yapısal ve Kavramsal Çerçevesine Dair Bir Okuma başlığı altında Çağdaş Yerel Yönetimler dergisinin Cilt 26 Sayı 3’te yayımlanmıştır. 
mekâna dâhil olabilen toplumsal üretim ilișkileri içindeki etkisidir. Her üretim tarzı-hipotez gereği-kendine uygun mekâna sahip olduğundan, bu geçiş sırasında yeni bir mekân üretilir."131

Bundan yola çıkarak Lefebvre bize mekân konusunda önemli bir dönemselleştirme önermektedir. Bu dönemselleştirme, Lefebvre'in belirtiğine göre ${ }^{132}$ ve çalışmasının içeriğinden de görüldüğü üzere mekânın belirli bir kodunun oluşumu, yerleşmesi, çöküşü ve parçalanması gibi özel durumları incelemekle sınırlı değildir. Ayrıca, dönemselleştirme genel üretim tarzları ve bu üretim tarzlarının hâkim olduğu toplumların tarihini ve kurumlarını da hesaba katma yönündedir.

$\mathrm{Bu}$ dönemselleştirmede beş mekândan söz edilmektedir; mutlak mekân, kutsal mekân, tarihsel mekân, soyut mekân, çelişkili mekân ve diferansiyel mekân. ${ }^{133}$ Böyle bir dönemselleştirmenin, özellikle Marksist teoride yaygın olan üretim tarzlarının dönemselleştirilmesiyle belirli ölçüde örtüştügü söylenebilir. Fakat nasıl her müteakip üretim tarzında bir öncekinin tamamen kaybolmadığ gibi, hatta bazı durumlarda birbiriyle iç içe geçmiş üretim tarzlarının ve toplumsal ilişkilerin söz konusu olduğu gibi mekân konusunda da böyle bir durumla karşı karşıyayız. Shields tarafından bu dönemselleştirme, haklı olarak "çizgisel ve tarihsel gelişimin Avrosentrik modellemesi"134 olarak nitelendirilmesine rağmen, Lefebvre'in mekân ve mekânın üretimi konusunda böyle bir dönemselleştirme önermesi şu ana dek eleştirel sosyal teoride en temel ve tutarlı olandır. Dolayısıyla, bu önermelerin epistemolojik sinırları ve geçerliliği ancak somut zaman-mekân bağlamında (bu çalışma gibi) tartışıldığında daha netleşebilir. Dolayısıyla, Lefebvre'in bu "Avrosentrik" yaklaşımı onun farklı dönem mekânları ile ilgili farklı saptamaları ve genel olarak bu dönemselleştirmesi belirli zaman-mekân bağlamlarında aynı biçimde kullanılamayacağı göz önünde bulundurulmalıdır.

Boer, Marksist teorideki üretim tarzları ve Lefebvre'in dönemselleştirmesini değerlendirerek (bu arada Shields'in bahsi geçen eserinden de yararlanarak) kayda değer bir şema önerir (bkz. Tablo 1).

131 Lefebvre, Mekânın Üretimi, s. 75.

132 Ibid., s. 76.

$133 \mathrm{Bu}$ dönemselleştirme ile ilgili daha detaylı tartışmalar ve değerlendirmeler için bkz. Boer, Marxist Criticism of the Hebrew Bible, özellikle 5. Bölüm; Grönlund, Lefebvre's Ontological Transformation(s) of Space; Shields, Lefebvre, Love, and Struggle: Spatial Dialectics.

134 Shields, Lefebvre, Love, and Struggle: Spatial Dialectics, s. 170. 
Tablo 1. Marksist Teorideki Üretim Tarzları ve Lefebvre'in Mekân Dönemselleștirmesi

\begin{tabular}{|c|c|}
\hline$\ddot{U}$ retim Tarzı & Mekân \\
\hline $\begin{array}{l}\text { Avcılık ve toplama, tarım ve hayvancılık (kabile } \\
\text { toplumu, ilkel komünizm) }\end{array}$ & mutlak mekân (doğa) \\
\hline $\begin{array}{l}\text { Neolitik tarım (gens veya hiyerarşik akraba } \\
\text { toplumları) }\end{array}$ & mutlak mekân \\
\hline $\begin{array}{l}\text { Asya tipi üretim tarzı ('oryantal despotizm've } \\
\text { tanrlsal krallar) }\end{array}$ & kutsal mekân \\
\hline $\begin{array}{l}\text { Antik veya klasik üretim tarzı (polis veya } \\
\text { oligarşik kölelik toplumu) }\end{array}$ & $\begin{array}{l}\text { tarihsel mekân (siyasi devletler, Yunan şehir } \\
\text { devletleri, Roma imparatorluğu) }\end{array}$ \\
\hline Feodalizm & kutsal mekân \\
\hline Erken kapitalizm (klasik ve monopol biçimler) & soyut mekân (politik-ekonomik mekân) \\
\hline Geç kapitalizm & $\begin{array}{l}\text { çelişik mekân (küresel sermayeye karşı yerel } \\
\text { anlam) }\end{array}$ \\
\hline Komünizm & $\begin{array}{l}\text { diferansiyel mekân (farklılığa ve yaşanan } \\
\text { deneyime yeniden değer biçen gelecek) }\end{array}$ \\
\hline
\end{tabular}

Kaynak: Boer, Marxist Criticism of the Hebrew Bible, s. 123.

Bu şemayı göz önünde bulundurarak ve Lefebvre'den yararlanarak, mekân dönemselleştirmesini daha detaylı olarak ele alalım. Fakat bu şemadaki mutlak mekân üzerine çok kısaca durmak gerekir, çünkü çalışmamızda benimsenen zaman çerçevesi, mutlak mekân üzerine uzunca durmayı gerektirmemektedir.

\subsubsection{Mutlak Mekân}

Lefebvre, (toplumsal) tarihin başlangıcını doğanın mutlak mekânına dayandırmaktadır. Onun "kökeni tarımcı-pastoral bir mekân parçasıdır, yani köylülerin, göçebe ya da yarı göçebe çobanların adlandırdığı ve çalıştığı yerler kümesidir." 135 İnsan eli değmemiş birinci doğa üzerine köylülerin, göçebelerin ya da yarı göçebe çobanların ilkel pratikleri sonucunda toplumsal mekân yükselir ve onun sınırları ve kapsamı belirlenir. Mutlak mekânın temel özelliği insan 
yaşamının doğayla, doğanın ritimleri ve güçleriyle, dolayısıyla henüz doğallıktan kopmamış mekânla yakın bir ilişki ve uyum içinde olmasıdır. O yüzden mutlak mekânın üretildiği toplumlarda insan faaliyeti ne kadar bu mekânı dönüştürmeye çalışsa da, ona farklı bir nitelik ve karakter atfetse de, yine "bu mekân tasarlanan değil, 'yaşanan' mekândır, mekân temsilinden ziyade temsil mekânıdır." 136 Başka bir ifade ile ilkel topluluklar kendi mekânlarıyla ve doğa ile iç içe geçmiş olarak yaşadıkları ve bir şekilde doğayla uyum içinde üretim ve yeniden üretim faaliyetlerini sürdürdüklerinden dolayı, insanın mekâna tahakküm boyutları ve kapasitesi mekânı tamamıyla doğal bağlamdan koparıp, tasarlanan mekâna dönüştürme seviyesinde değildi. Ayrıca teknolojik gelişmişlik boyutu nedeniyle, mekân deneyimlemesi ve mekânsal pratik de farklıdır. Genelde ilkel araçlarla avcılık, toplayıcılık veya tarımla uğraşan bu toplumlarda doğaya ve doğal mekâna bağlılığı ve bağımlılığı her açıdan daha güçlü olduğu için, mekân deneyimlemesi tamamıyla doğrudandı ve her şey doğal olan mekânın özelliklerine göre algılanıp değerlendirilmektedir. Günlük hayatın ritimleri de doğanın ritimleriyle uyum içerisindedir. Doğayla böyle sıkı ilişki söz konusu olunca bu topluluklarda yaşlanma, cinsellik, doğurganlık gibi faaliyetler ile ilgili ritüeller ve seremoniler hep doğaya ve doğal mekâna hitap etmektedir. O yüzden bu topluluklarda birbirinden ayrılması zor olan tasarlanan mekân (mekân temsilleri) ile yaşanan mekân (temsil mekânları) insan bedenine ve özellikle doğa ve doğurganlıkla tekabül eden kadın bedenine benzetme yoluyla biçimlendirilmekteydi. Örneğin, tasarlanan mekân konusunda

“Kadının varlığı köyün her bölümünde kendini hissettirmekteydi; simgesel anlamlarını psikanalizin yeni gün ışığına çıkarmaya başladığı o korunaklı çevre duvarlarına bakarak, köydeki fiziksel yapıların da kadının varlığından etkilendiği rahatça söylenebilir. Güvenlik, karşısındakini anlama yeteneği, sarmak, beslemek - bütün bunlar kadına ait işlevlerdir ve bu işlevler köyün dört bir yanında, evde ve ocakta, ahırda ve ambarda, sarnıçta, erzak çukurunda, tahıl ambarında yapısal bir ifade kazanır; oradan da kente intikal edip, surlarda ve hendekte, ayrica atriumdan revaklara kadar bütün iç mekânlarda kendini gösterir. Ev, köy ve nihayet kentin kendisi genel anlamda kadının fermanıdır."137

Temsil mekânı da insana ve bedene örtük bir şekilde hitap eder, Mısır'daki 'anne' simgesi anlamina gelen 'ev' veya 'kasaba' hiyeroglifleri böyle bir temsil mekânının örneğidir. ${ }^{138}$ Mutlak mekân insanların sadece günlük yaşamını

136 Lefebvre, Mekânın Üretimi, s. 247. Mekân temsil, temsil mekânı ve mekânsal pratikler kavramları bir sonraki alt bölümde ele alınacaktır.

137 Mumford, Tarih Boyunca Kent: Kökenleri Geçirdiği Dönüşümler ve Geleceği, s. 24-25.

138 Lewis Mumford'un Tarih Boyunca Kent çalışması farklı bir açıdan kentin ortaya çıkış ve gelişim seyrini inceleyen önemli bir çalışmadır. Bu çalışmaya Lefebvre'in önerdiği kavramsal 
sürdürdüğü süreçte üretildiği ve yeniden üretildiği anlamına gelmez, "mutlak mekân, aynı zamanda ve özellikle ölümün de mekânıdır."139 Mekânın üretimi açısından özellikle ölümün mekânının, mezarlıkların önemi vurgulanmalı. Mumford'a göre,

"İlk insanın ölüye olan saygısı... belirli bir topluma mekânı ve sonuçta daimi bir yerleşim yeri aramasında pratik ihtiyaçlarından daha önemli bir rol oynamıştır belki de. Paleolitik çă̆ insanının huzursuz göçebeliğin ortasında ilk kalıcı yerleşim alanına sahip olanlar ölülerdi... Her ne kadar toplayıcılık ve avcılık insanları belli bir alanı sürekli bir yerleşim yeri olarak kullanmaya teşvik etmiyorduysa da, en azından ölüler bu ayrıcalığa sahipti... Canlıların kentinden önce ölülerin kenti vardı. Bir anlamda, ölülerin kenti her canlılar kentinin öncülü, neredeyse onun özüdür." 140

$\mathrm{Bu}$ bağlamda Mumford'un saptaması doğruysa, yerleşik toplulukların oluşma ve mekân üretimi konusunda mezarlıkların önemli rolüyle karş1 karşıyayız. Lefebvre'ye göre ise "mezarların mekânı eğer bir tanrı ya da kral mezarı değilse, doğumun, ölümün ve unutmanın mekânına benzemekle yetinir." Bir tanrı ya da kral mezarı durumunda ise "sivil birliğin, dolayısıyla-bölge insanları da dâhil olmak üzere-site mensupları arasındaki bağın bekçisi olan mutlak mekân, bütün dağınık güçleri toplayarak kendi içinde barındıran" ve böylece "canlılar üzerindeki mutlak iktidarının mekânıdır."141 Bunun örneği, Misır veya Meksika'daki piramitler, Mezopotamya'daki ziguratlardır. Mumford, dağ mağarası erken insanın ilk mimari mekân anlayışını oluşturduğunu varsayarak, piramit, zigurat ve benzeri yapıların "tümüyle insan elinden çıkma bir dağ olan ve bilinçli olarak dağa benzetilerek inşa edilmiş"142 ve mağarayı model olarak alan yapılar olarak belirtmektedir. Yani, Lefebvre'in kavramıla, bu mutlak mekânlar organik toplulukların doğayı andıran mekân temsilleridir.

Fakat bu mekân, zamanla siyasi ve dini iktidar tarafindan işgal olunmaya başlamıştır. Doğanın parçaları kutsanarak büyüsel ve dini iktidar tarafından işgal edilerek, bu mekân siyasi denetim aracı haline getirilmiştir. Böylece, mutlak mekânın (daha doğrusu onun bir kısmının) gittikçe kutsal mekâna evrilmesine tanık olmaktayız. Lefebvre'ye göre,

"Bu mekânın bir parçası, efendilerin ya da fatihlerin eylemi sayesinde başka bir şeye tahsis edilir. Bundan böyle, aşkın, kutsal (tanrısal güçlerin

ve kuramsal çerçevesi açıdan bakıldığında, Mumford'un hem saptamaları hem de derlediği tarihsel bilgi, daha anlamlı ve tutarlı biçimde karşımıza çıkmaktadır. Bkz. Mumford, Tarih Boyunca Kent: Kökenleri Geçirdiği Dönüşümler ve Geleceği .

139 Lefebvre, Mekânın Üretimi, s. 247.

140 Mumford, Tarih Boyunca Kent: Kökenleri Geçirdiği Dönüşümler ve Geleceği, s. 17-18.

141 Lefebvre, Mekânın Üretimi, s. 247.

142 Mumford, Tarih Boyunca Kent: Kökenleri Geçirdiği Dönüşümler ve Geleceği , s. 20. 
damgasını taşıyan), büyülü ve kozmik olarak görülür. Paradoks, böyle bir mekânın yine de doğa olarak algılanmaya devam etmesidir. Dahası, onun sırrı, kutsal lanetli karakteri doğanın güçlerine atfedilirken, burada uygulanan siyasi iktidarın eylemi onu doğal bağlamdan çıkarır ve ancak bu kopuş sayesinde anlam edinir."143

Fakat "kan, toprak, dil topluluklarının ürettiği mutlak mekân” tamamıyla kaybolmad1, müteakip toplumsal mekânların "tabakası ya da tortusu olarak, temsil mekânlarının dayanağı olarak"144 birinci doğanın kalıntılarında varlığını sürdürmüştür ve müteakip toplumlarda dinsel, büyüsel, politik sembolizmlerle temsil mekânlarının dayanağını oluşturmuştur.

Aslında Lefebvre'in çalışmasında mutlak mekânın çok geniş anlamda kullanıldığ1 görülebilir, şöyle ki bu kavram kutsal mekân anlamına da gelir ya da onlar arasında ayrım yapılmamaktadır. O yüzden bazen bir mekândan diğerine 'geçişi' Lefebvre'de bazen anlaşılır değildir. Ayrıca bu anlaşılmazlık, onun çalışmasında kutsal veya tarihsel mekân için ayrı bir bölüm ayrılmadığından, "mutlak mekândan soyut mekâna" geçiş gibi bir başlığın varlığından ve kutsal mekân kavramını neredeyse hiç kullanmadığından kaynaklanmaktadır. Fakat bunlara rağmen kutsal mekân onun mekân analizinde ve dönemselleştirmesinde önemli bir yere sahiptir. Dolayısıyla Lefebvre'in mutlak mekân kavramı kutsal mekân kavramıyla karıștırılmamalıdır.

\subsubsection{Kutsal Mekân}

Kutsal mekânın ortaya çıkışı ilk şehir devletlerinin kurulmasına, Asya tipi üretim tarzına ve feodalizme denk geldiği söylenebilir. Bu mekânın paradoksal özelliklerinden biri, bir taraftan uygulanan siyasi iktidarın eylemiyle, onun doğal bağlamdan çıkarılmış olması, diğer taraftan onun yine de doğa olarak algilanmaya devam etmesidir. ${ }^{145}$ Dinsel olduğu kadar siyasal da olan kutsal mekân "kendisini özdeşleşme-taklit etme şeklindeki iki büyük prosedüre tabi kılan dinsel kurumlar içerir. İmgelemin ve düşünümselliğin de kategorileri olacak bu zihinsel kategoriler mekânsal formlar şeklinde ortaya çıkar."146 "Evrenin özetleri olan bu formlar ya karedir (mandala), ya çember ve küredir, ya üçgendir, ya da tanrısal ilkenin işgal ettiği rasyonel bir hacimdir, ya da haç şeklindedir..."147 Kutsal mekânın hâkim olduğu toplumlarda merkezi iktidar bu formları içeren belirli sitelere toplanmıştır ve artık toplumsal mekânda merkez

143 Lefebvre, Mekânın Üretimi, s. 245-246.

144 Ibid., s. 77.

145 Ibid., s. 245-246.

146 Ibid., s. 248.

147 Ibid. 
ile periferi arasında, şehir ile kasaba arasında ayrım ortaya çıkar. Bu formların ortaya çıkmasıyla beraber, gittikçe mutlak mekânın maddi genişlemesi söz konusudur. Bu genişleme "ruhban kastının ve elinde tuttuğu ya da kullandığ1 siyasal gücün yararına, bu prosedürler (özdeşleşme-taklit etme) sayesinde meydana gelir."148 Ayrıca, önceden var olan mekân bu genişleyen ve daha da merkezileşen kutsal düzenin ve merkezin tahakkümüne maruz kalmaktadır.

Eskiden "şehir, kentsel mekân, kimi zaman güçlükle de olsa, kontrol ettiği kırsal mekânla simbiyoz halinde yaşar[d1]", fakat Şehir-Devletin ortaya çıkışıyla beraber, sabit bir merkez oluşur, şehir-devlet "kendini merkez ve ayrıcalıklı yer haline getirir ve etrafını da damgasını taşıyan bir periferiyle çevirir. Önceden var olan geniş mekân artık tanrısal bir düzene tabidir."149 $\mathrm{Bu}$, aynı zamanda toplumsal ve doğal dünyalar arasında mekânsal ayrımın başlangıcı, toplumsal mekânda merkez ile periferi arasındaki ayrımın başlangıcıydı.

Kutsal mekânın gittikçe özdeşleşme-taklit etme gibi imgelem ve düşünümsel prosedürler aracılığıyla sürekli yeniden üretilmesi, genişlemesi ve daha da siyasi ve dini nitelik kazanması, ona kurmaca bir nitelik kazandırır, şöyle ki bu mekânın,

“zihinsel, dolayısıyla 'kurmaca' bir varoluşu vardır. Fakat toplumsal bir yaşama da sahiptir; özgül ve güçlü bir 'gerçekliği' vardır. 'Zihinsel' olan 'toplumsal' bir faaliyet zinciri içinde 'gerçekleşir', çünkü kurmaca, Tapınağın, Sitenin, anıtların, sarayların içinde gerçeğe dönüşür." 150

Bu mekân yine de mutlaktır, fakat mutlaklığın kaynağı doğadan ziyade dini ve siyasi referansıdır, başka bir ifade ile bu mekânın mutlaklığının temel kaynağı "sembolizm aracıllğıyla politikaya tahsis edilmesi" 151 ve kutsanarak ritüel ile törenler aracılığıyla dini nitelik kazandırılmasıdır. Şöyle ki,

"etrafindakiler için o doğru mekândır, (görünmeleri, yani diğer zamanları ve diğer mekânları yok eden) ani belirişleriyle birlikte, hakikat mekânıdır. Boş olsun dolu olsun, aşırı faal bir mekândır; toplumsal enerjilerin olduğu kadar doğal güçlerin de toplandığ 1 ve teşvik gördüğü yerdir... Bu mutlak mekân hiçbir yerdedir. Onun yeri yoktur, çünkü bütün yerleri birleştirir ve ancak sembolik bir varlığa sahiptir. $\mathrm{Bu}$ onu dilin kurmaca-gerçek mekânına ve 'özne'nin bilincinin ya da 'kendinin bilinci'nin biçimlendiği, mekânsallıktan (kurmaca olarak) büyülü bir şekilde kurtulmuş bu zihinsel mekâna yakınlaştırır. Bundan yararlanan ruhban kastıdır. Ruhban, bu mekânı kutsar ve kutsama, metafizik olarak herhangi bir mekânı temel

148 Ibid.

149 Ibid., s. 246.

150 Ibid., s. 261.

151 Ibid., s. 76-77. 
kutsal mekânla özdeşleştirir. Mabetlerin mekânı, küçük bir tapınakta, mütevazı bir köy kilisesinde bile olsa, mutlak mekândır."152

O yüzden, "aşağı yukarı her yerde, bütün toplumlarda, mutlak mekân, tehditlerle, cezalandırmalarla, hep hissedilen duygularla, zihne değil bedenlere hitap eden anlamla yüklüdür."153 Bu mutlaklık niteliği sayesinde ise "söz konusu toplumlardaki her şey bu yerlere göre yerleşir, algılanır, yorumlanır... $\mathrm{Bu}$, ayrılmaz biçimde zihinsel ve toplumsal olan ve söz konusu grupların (önce ŞehirDevlet) bütün varlığını içeren ve böyle anlaşılması gereken bir mekândır."154

Kutsal mekânla beraber değişen diğer önemli unsur önceki "biyomorfik ve antropolojik olan toplumsal mekânın” dolayımsızlığının aşılmasıdır. Şöyle ki, ilkel grupların ürettiği mekân, onların üyelerinin hiyerarşik sınıflandırılmasına denk düşerdi ve "bu sınıflandırmayı her daim güncel ve mevcut kılan bu mekândır." Fakat bu hiyerarşinin içcerdiği normlara topluluk üyeleri bilmeden uyarlar ve bu normları daha çok mekânsal olarak ve dolayımsızlık içinde yaşarlar. ${ }^{155}$ Kutsal mekânın üretimiyle beraber tehdit ile cezalandırmalar, ayrıcalıklı ile belirlenmiş yerler, kutsal ile lanetli yerlerden oluşan bu mekânda, toplumsal normların da mekânsal olarak yaşanmasına devam edilir. Fakat artık dolayımsızlık içinde değil, bu süreçte kutsal mekânın içerdiği dini/siyasi kurumların dolayımlığı öne çıkmaktadır.

Ayrıca, bu dolayımlığı nedeniyle, önceden simbiyoz, uyum veya "organik bir bağdaşıklık” halinde yaşayan kent ile kır arasında kopuş ve çatışmalı bir ilişki ortaya çıkar. Dinsel ve siyasi merkez şehir ile kır, kentsel mekân ile tarımsal mekân arasındaki bu çatışmalı ilişkinin damgasını taşır. Yasaklama ve koruma kuralları ile merkezi mekânlara dinsel ve büyülü nitelik kazandırması, dışarıdan, kırdan gelen gerçek tehditlere cevaptır. Ayrıca böylelikle siyasi ve dini merkez kırsal kesimdeki artı ürüne el koyma da sağlamaktadır. Çünkü idari, siyasi ve askeri yetkileri elinde tuttuğu için kırsal alana koruma sağlar. ${ }^{156}$ Böylece,

"Şehir-Devlet sabit bir merkez oluşturur, kendini merkez ve ayrıcalıklı yer haline getirir ve etrafını da damgasını taşıyan bir periferiyle çevirir. Önceden var olan geniş mekân artık tanrısal bir düzene tabidir. Fakat şehir

152 Ibid., s. 248.

153 Ibid., s. 247.

154 Ibid., s. 251-252.

155 Ibid., s. 241-242.

156 Ibid., s. 246. Mumford'da da benzer saptamalar görülebilir. Ona göre, dağınık kırsal ekonomi ve örgütlenmeden hayli merkezileşmiş kentsel ekonomiye ve örgütlenmeye geçişini tetikleyen en önemli etken Kral veya Kraliyet kurumuydu. Bu değişimi etkileyen diğer temel unsur dindi. Dolayısıyla, kırsal topluluğa kıyasla, kent, ayrıcalıklı sınıf tarafından yönetilen topluluktur. Bkz. Mumford, Tarih Boyunca Kent: Kökenleri Geçirdiği Dönüşümler ve Geleceği , s. 44-55. 
kendi çevresindekilerin-doğal ve tanrısal olan, yeryüzünün kötücül ve iyicil güçleri dâhil-toplama yeri olarak belirtir. Evrenin imgesi (imago mundi) olan kentsel mekân, mevcut haliyle elinde bulundurduğu ve içerdiği kırsal mekâna kendini yansıtır. Böyle bir ilişkinin içinde, ekonomik, dinsel ve siyasal belirlenmenin yanı sıra, bir sembolizm, imge ve yansı veçhesi zaten vardır..."157

Kutsal mekânın ortaya çıkışı bağlamında Lefebvre önemli başka bir gelişmenin ipuçlarını da sunar; ona göre kent ile kır arasında süregelen ilişkilere koşut olarak 'doğa ve kültür' teması ortaya çıkmaya başlamış ve 'doğa ve kültür' teması kent ile kır arasındaki ilişkileri yansıtır hale gelmiştir. ${ }^{158} \mathrm{Bu}$ tema Aydınlanma döneminden başlayarak şimdiye dek tartışmalarda, söylemde ve pratikte önemli yer tutmaktadır ve modernite denilen düşünce akımının ve pratiğinin temel unsurlarından biridir.

Kent ile kır arasındaki bu tarz ilişkiler bağlamında üç kavramın ele alınması gerekir. Bunlar birbiriyle diyalektik olarak bağlantılı olan kırsallı, kentsel doku ve merkez kavramlarıdır. Kırsal alan üretimin ve yapıtların (ceuvre) yeridir. Kırsal alanın da kendisi tarımsal üretimin sonucu olan yapitların bütünüdür. $\mathrm{Bu}$ yapıt burada yaşayan topluluklar tarafindan kutsallaştırılan (consecrated) bir mekândır, dolayısıyla kent ve kentsel yaşama kıyasla kırsal alan rasyonaliteden uzaktır. Sonradan ise kent bu alanı kutsallıktan çıkartıp rasyonaliteye dâhil etmeye çalışır. $\mathrm{Bu}$ süreçte önemli olan, politik şehir tarafından toprağın (ve kırsalın) kutsal-lanetli özelliğini kullanarak ekonomik (ticari) kente kırsalın kutsallıktan çıkarılmasına imkân sağlamasıdır. ${ }^{159}$

Böylece, ilk şehir-devletlerin ortaya çıkışından yukarı Ortaçağ'a (10001300) dek kutsal mekânın üretim ve yeniden üretimi söz konusudur. Bu dönem için siyasi, ekonomi ve dini düzlemleri birbirinden ayırmanın mümkün olmadığını belirterek, yine de böyle bir mekânın, siyasi ile dini iktidarın, ekonomik işlevlerin ve daha çok söz konusu toplumda kozmolojik ve dinsel kodlar (evrenin imgesi) ile ilgili temsillerin toplam ürünü olduğu söylenebilir. Yukarı Ortaçağ' da kutsal mekânın yerine yeni bir mekân yerleşmeye başlamıştır. Bu zamandan itibaren dinsel ve kozmolojik kodlar olmadan mekânın üretimi söz konusu olabilmiştir. Lefebvre'in tabiriyle “Roma'nın dinsel ve siyasal mekânını laikleştiren yeni bir mekân yerleşmiştir. Bu da onu tarihsel mekâna, birikim mekânına dönüşmeye hazırlamıştır-zorunlu ama yetersiz koşul." 160

157 Lefebvre, Mekânın Üretimi, s. 246-247.

158 Henri Lefebvre, Writings on Cities, s. 118.

159 Ibid.

160 Lefebvre, Mekânın Üretimi, s. 264. 


\subsubsection{Tarihsel Mekân}

Yukarıda değinildiği üzere, tarihsel güçler mutlak mekânın doğallığını durmadan parçalayarak, onun kalıntıları üzerine birikim mekânını tesis ettiler. $\mathrm{Bu}$ sürecin temelinde yatan, özel mülkiyetin niteliğinin değişimi ve kamusal ile özel arasında ortaya çıkan ayrımdı. Kutsal veya mutlak mekânın parçalanması Lefebvre'ye göre Roma'yı istila eden 'barbarlar' tarafindan gerçekleşti. Bu istila birkaç yönden yeni bir mekânın üretimine imkân sağladı. Roma dünyasını altüst eden önemli değişimlerden biri Cermen barbarları tarafından Avrupa'da ilk büyük tarım reformunun gerçekleştirilmesiydi. ${ }^{161} \mathrm{Bu}$ değişim, sistematik tarıma geçişi, böylece feodalizm olarak tanımlanan üretim tarzına ve ona özgü üretim ilişkilerine geçişi sağladı. Bu değişim, Barbarların yerleşmesiyle özel mülkiyetin niteliğinin değişimi ile ortaya çıtı. Barbarlar, Roma İmparatorluğu'ndan kalan "kutsal mülkiyete tecavüz ederek onu döllediler... mekânı temizlediler; en eski işaret noktalarını, tarımcı-pastoral döneminkileri, daha doğrusu tarımcı olmaktan ziyade pastoral dönemindekileri yeniden ortaya çıkardılar."162 Böylece, kutsal özel mülkiyeti laikleştiren yeni mülkiyet ilkesi "doğanın, kozmosun ya da dünyanın seyrine son vererek, yorumlamak yerine dönüştüren mütehakkim eylemlerin yolunu gösteriyordu."163

Böylece, barbar istilası Roma özel mülkiyetinin yarı kutsal ve mutlak niteliğini laikleştirerek, eski sosyo-mekânsal düzenin mutlaklığını parçalayarak tarihsel ve soyut mekânların yeni biçimlerinin ortaya çıkmasına imkân tanıdı. Bu parçalanan mekân üzerine, gelişen ticari ilişkilere koşut olarak "bütün zenginlik ve servetlerin: bilgiler, teknikler, para, değerli nesneler, sanat eserleri ve semboller"in mekân1 ${ }^{164}$, kısaca birikim mekânı oluşmaya başladı. Bu evrede "hâkim olduğu topraklarla birlikte Batı'nın tarihsel şehri"165 egemen bir özne durumundadır. Şehirlerin pazar halinde örgütlenmesi ve ticaretin gelişmesiyle değişim değeri yaygınlık kazanır. Küçük çaplı üreticilerin bir araya gelip

161 Ibid., s. 243.

162 Ibid., s. 263-264.

163 Ibid., s. 263. Pirenne, Cermen istilaları sırasında Kilise örgütlenmesinin ve bunun mekânsal kurumsallaşmasının hiç değişmediğini, daha fazlası müteakip imparatorluklarda kendi mekânsal örgütlenmesini koruduğunu ve Roma kentlerinin özeliklerinin korunmasında büyük ölçüde katkıda bulunduğunu belirtir. Ayrıca, ona göre 16. yüzyıldan beri civitas sözcüğü "piskopos kenti" (yani piskopos bölgesinin merkezi) özel anlamını kazandı. Böylece, mekânın üretimi konusunda dinin etkisi farklı boyut kazand1. O yüzden Lefebvre tarafından "laikleştirme" kavramının kullanılması tesadüf değildir. Bununla Lefebvre, mekân temsilinde dinsel nitelik taşıyan eski imago mundinin yerine dinden ayrılmış yeni bir imago mundinin yerleşmesini kasteder. Bkz. Pirenne, Medieval Cities: Their Origins and the Revival of Trade, s. 13-14.

164 Lefebvre, Mekânın Üretimi, s. 77.

165 Ibid. 
loncalar, dernekler halinde örgütlenmesi sayesinde ise şehirde ayrıca "toplumsal olarak üretebilen kolektif emekçi sahneye çıkar"166 ve böylece değişim değerinin yaygınlık kazanması ve soyutlanmasına koşut olarak emeğin soyutlanması da söz konusu olur. ${ }^{167}$

Üretim faaliyetinin merkezileşmesi ve "kolektif emekçinin sahneye çıkışı"yla beraber emek süreçleri (üretici faaliyet) toplumsal hayatı sürdüren yeniden üretimden ayrılmaya başladı. ${ }^{168}$ Eskiden ailevi alanla sınırlı olan ve bütünleşik olan bu süreçlerin ayrımıyla tarihsel mekânda kamusal ile özel alanlar arasındaki ayrım oluşmaya, dolayısıyla mekânsal pratikler de bu ayrıma göre biçimlenmeye başladı.

$\mathrm{Bu}$ birikim mekânın ortaya çıkışında, Marksist literatürde yaygın olan tartışmalardan ayrı olarak Lefebvre ilginç bir perspektif sunar. Örneğin, Maurice Dobb'a göre Batı Avrupa'daki feodal sistemin içkin özellikleri olarak serflerin çıkarlarının ihmali, asalak sınıfın genişlemesi, savaş ile eşkıyalık ve soylu ailelerin artan savurganlığını görür. Ayrıca, ona göre bu özellikler Batı Avrupa feodalizminde emek gücünün aşırı sömürülmesine, dolayısıyla feodalizmin çözülüşüne ve kapitalizme geçiş için zemin hazırlayan birikim süreçlerine yol açtı. ${ }^{169}$ Fakat Lefebvre'ye göre böyle bir teorik analiz' ${ }^{170}$ 'neden bu birikim sürecinin bazı koşullarına sahip olan Antikçağda başlamadı' sorusuna tatmin edici hiçbir cevap vermemektedir. Ona göre, bu soruya cevap,

“12. yüzyılda Batı Avrupa'da doğan ve yavaş yavaş genişleyen (Fransa, İngiltere, Hollanda, Almanya ve İtalya) mekân, birikimin mekânıdır, onun beşiği, doğum yeridir. Neden ve nasıl? Çünkü bu laikleşmiş mekân, 'dünya'yı ve yeraltı güçlerini tabi kılan Logos ile Kozmos'un dirilişinden kaynaklanır. Logos ve mantıkla birlikte, hukuk yeniden oluşur; sözleşmeye dayalı (şart koşulan) ilişkiler âdetlerin ve geleneksel zulümlerin yerini alır." 171

Böylece, görüldüğü üzere, Lefebvre birikim mekânın oluşmasında hukukun ve mantığın önemine vurgu yapar. Burada önemli olan husus önceki

166 Ibid., s. 266.

167 Birbirinden ayrılmaz olan bu gelişmeler, daha sonra hâkim olan feodal üretim tarzının çöküşünü tetikleyen süreçlerdir. Bu sürecin daha detaylı aktarımı için bkz. Pirenne, Medieval Cities. Konu ile dolaylı ilgili olup fakat önemli olan diğer kaynaklardan Feodalizm'den Kapitalizme Geçiş tartışmalarına (Geçiş Tartışması olarak da bilinen) da başvurulabilir, bkz. Dobb ve diğerleri, The Transition from Feudalism to Capitalism.

168 Lefebvre, Mekânın Üretimi, s. 77.

169 Dobb, Studies in the Development of Capitalism.

170 Lefebvre, çalışmasında Dobb'a doğrudan atfetmese de, eleştirileri tamamıyla Dobb'un argümanlarına yöneliktir (krş. Lefebvre, Mekânın Üretimi, s. 273).

171 Lefebvre, Mekânın Üretimi, s. 273, vurgu eklenmiştir. 
dönemde, Roma döneminde "Logos'un değil, Yasa'nın işareti altında neredeyse aynı adımlarla ilerleyen örgütlenme, düşünce ve mekânın üretiminin"172 hem bilginin ayrılmaz parçası olan Logos'un hem de praksisin parçası olan Yasa'nın işareti altında ilerlemesidir. Dolayısıyla, birikim süreçlerinin ve birikim mekânının temelinde ve özellikle bahsi geçen dönemde böyle bir mekânın doğuşu konusunda mantığın ve hukukun rolü büyük öneme sahiptir.

Avrupa' da birikim süreçlerine koşut olarak laikleşen (bazen ise bu birikim süreçlerinin etkisiyle) mekânda başka bir süreç de baş gösterir. Lefebvre, bunu mekânın de-kripte edilmesi, yani kriptten ve kriptik mekândan kurtulması olarak tanımlar. ${ }^{173}$ Bunun anlamı, bir önceki evredeki mekân ile karşılaştırarak ortaya çıkar. Hristiyanlık, mezarları kutsayarak ölümü kodlar, "onu ritüelleştirir, seremonileştirir, yıldönümünü kutlar", dolayısıyla "kriptik özlü din" kutsanmış bir kişinin kemikleri bulunan kilise mahzenleri etrafinda döner. ${ }^{174}$ Azizlerin işaret ve temsilleri bulunan kriptlerde ve mezarlarda "ender olarak heykele rastlanır ya da hiçbir zaman heykel bulunmaz", buralarda genelde ruhban kastı hariç hiç kimse tarafından görülmeyen, zaten "görülmek için değil, 'var olmak' için ve orada 'oldukları'nın bilinmesi için yapılmış" resimler bulunur. Bu mekânın yeryüzündeki devamı ise sadece kilisedir. ${ }^{175}$

Ortaçağ'ın tarihsel mekânında, 12. yüzyıldan önceki yeraltı mekânı tersine çevirildi. Büyük katedraller, "önceki dinsel yapılar karşısında, mekânın tersyüz oluşunu göstermektedirler." $176 \mathrm{Bu}$ başkalaşım sırasında, yeraltı dünyası artık sadece kilise sıfatıyla dünyanın yüzeyine çıkmaz, aynı zamanda "heykel kriptik resim üzerine zafer kazanır. Binaların cephelerinde sütün başlıklarının, heykellerin çoğalması bundan kaynaklanır."177 $\mathrm{Bu}$ aynı zamanda bedenlerin yüceltilmesinin başlangıcıdır. Ön cephe düzenlenişleriyle başlayan bu süreçte mekân beden işaretleriyle dolduruldu. Fakat yine "canlı ve çılak beden çok kısıtlı bir yer tutar: Havva, Âdem. Çile çekenler ve mahkûm edilmişler dışında, pek az dişi bedeni vardir." 178 Şiddete işaret eden dikeyliğin ve kırık çizgilerin çoğaldığı bu mekânda "dikeylik, kulelerin politik kibri, kulelerin feodalizmi, Göz ile Fallus arasındaki ittifakı şimdiden belirtmektedir." ${ }^{179}$ Dolayısıyla, çoğalan

172 Ibid., s. 257.

173 Ibid., s. 267.

174 Ibid., s. 264.

175 Ibid., s. 265.

176 Ibid., s. 267.

177 Ibid., s. 270.

178 Ibid., s. 271, vurgu eklenmiştir.

179 Ibid., s. 272. 
kırık çizgiler ve dikeylikler aracıllğıyla "bir yanda soyutlama, geometri ve mantıkla, diğer yanda güçle bir gizli anlaşma yapılır."180 Böylece,

\begin{abstract}
"dünyanın simgesi olan dişi organ gizli kalır. Güç ve doğurganlık sembolü, prestijli Fallus dikilerek kendini gösterir. Gözün ayrıcalıkları kendine mal ettiği mekânın içinde fallik ayrıcalıklar edinecek ya da üretecektir. Bakış, Tanrı'nın, Baba'nın, Şef'in gözüdür. Bakışın kendine hizmet edeni ele geçirdiği bu mekân, kendi imkânlarından başka sırrı olmayan, gücün, şiddetin, iktidarın mekânı olacaktır. Üçlü tanrının ve Kralların mekânı, artık kriptik işaretlerin değil, yazıların ve tarihselliğin mekânı olacaktır. Dolayısıyla, askeri, yani eril şiddetin mekânı."181
\end{abstract}

Görsele doğru bu gelişmeyle beraber, köklü diğer bir değişim, kentin, dolayısıyla kentsel mekânın işlevinin (elbette beraberinde yine görsel ve biçimsel başkalaşma yaratan) değişimidir. Bir önceki, yani kutsal mekânda ticaret ve tüccar sınıfı genelde surlarla çevrilmiş olan kentin dışındaydı. Bunlar kentteki siyasi ve dini kurumsallaşmalara yabancıyd,, hatta onlar tarafindan iyi karşılanmazd.. ${ }^{182}$ Fakat 14. yüzyıldan itibaren tüccar kenti siyasi (ve dini) kentin yerini aldı ve ticaret, kentsel işlev haline gelerek kentsel ve mekânsal biçimi önemli ölçüde etkiledi. Bu mekânsal başkalaşma sonucunda kentsel mekânda "bilginin ve iktidarın sembollerini taşıyan şey artık çan kulesi değildir: Gözetleme kulesi mekâna ve hatta zamana egemendir, çünkü üzerine derhal bir saat eklenecektir." 183 Girişi serbest olan pazar meydanının kent merkezi haline gelmesi (eskiden bu merkezlik işlevi girişi serbest olmayan agoraya ve foruma aitti), onun yol ve sokak ağlarıyla her tarafa açılması, merkezde olan ve saatle donatılan gözetleme kulesi ile beraber gündelik hayatın ritimlerini, mekânsal pratikleri dolayısıyla mekân deneyimlemesi ve anlayışını değiştiren önemli bir süreçti. ${ }^{184}$

Mutlak/kutsal mekânın parçalanması ve üzerine müteakip tarihsel mekânın gelişimi sorunsuz bir süreç değildi. Bu birikim mekânının gelişiminde şiddete işaret eden bazı hususlar yukarıda dolaylı olarak ele alındı. Fakat

180 Ibid., s. 271.

181 Ibid., s. 272.

182 Örneğin, İsa tarafindan tüccarları tapınaktan kovalama olayını, Lefebvre, siyasi ve dini kurumsallaşmanın ticarete karşı yaklaşımı ve kente onun girişini yasaklamasının örneği olarak değerlendirir. Siyasi ile ticari kent arasındaki bu çelişkili ilişkiler için bkz. Lefebvre, Kentsel Devrim, s. 7-25. Konu ile ilgili daha detaylı değerlendirmeler için ayrıca Pirenne'nin yukarıda değinilen çalışmasına başvurulabilir.

183 Lefebvre, Mekânın Üretimi, s. 275.

$184 \mathrm{Bu}$ bağlamda, Avrupa'nın çok sayıda kentinin merkezi hala "pazar" anlamına gelen sözcüklerle tanımlanması tesadüf değildir. Bunun örneği İtalyanca "piaza", Lehçe "rynok" veya Almanca "markt" sözcükleri ve ilgili toplumlarda kentsel mekânın tanımında bu sözcüklere çok sık rastlanmasıdır. 
konunun doğrudan da ele alınması önem taşır. Lefebvre'in tarihsel mekânı ele alışında şiddet ve savaşa vurgusunu ilk önce Marx'ın ilkel birikim teorisi çerçevesinde ele almak ve zamanı temel eksen olarak kabul eden bu teoriye bir katkı olarak görmek gerekir.

12. yüzyıldan 19. yüzyıla dek birikim mekânına "savaşların mekânı" eşlik eder. Birikim etrafında dönen bu savaşlar, biriktirilen zenginliklerin harcanmasına ve birikimin daha da büyümesine katkıda bulundu, çünkü "savaş üretici güçleri her zaman güçlendirdi ve tekniği yıkım için kullanırken bir yandan da yetkinleştirdi" ve birikim mekânı böyle canland1, zenginleşti. ${ }^{185}$ Fakat bu dönem için "şiddetin ekonomi dışı bir rolü olmasını"186 da unutmamak gerekir. İlerleyen dönemlerde ise şiddet toplumsal hiçliğe gömülmedi ve "zengin ve kalabalık mekân halini alıp, kapitalizmin beşiği oldu" ve sadece "kapitalizmle ve dünya pazarıyla birlikte şiddet birikimde bir rol edindi" 187 daha doğrusu, şiddet birikim süreçlerinden ayrılamaz hale geldi. Bu savaş ve şiddet "Batı Avrupa'yı, tarihin, birikimin, yatırımın mekânı, ekonominin zafer kazandığı emperyalizmin temelini" üretti ve kendini "(Roma menşeili) kemerlerde, kapılarda, meydanlarda, zafer yollarında" kutlad1. ${ }^{188}$

Bu gelişmeler sonucunda tarihsel mekânda en önemli "özne" haline gelen şehir "kendi imgesini buldu." Fakat bu imge önceki dönemdeki kozmosun merkezi imgesinden farklıdır. Şehir kendi kimliğini buldu ve grafik olarak görselleştirilmeye başlandı, kent planları yaygınlık kazandı. Fakat bunların henüz indirgemeci bir rolü yoktu, planların bu rolü soyut mekânın yükselişiyle beraber önem kazanacaktır. Şehir planları çoğalırken, bunlarda şehir "bir savaş alanı gibi perspektife konulur ve çoğu zaman bir kuşatma görünümü altındadır, çünkü savaş şehirlerin etrafında döner."189 Fakat hiçbir zaman bitmeyen bu savaşlar sonucunda ne kadar şehirler yağmalansa, tahrip edilse de "bu çatışmalar aracılığıyla, bunlar sayesinde, bunlara rağmen şehirler 1ş11 1ş1l parladılar."190 Ancak (feodalizmden kapitalizme geçiş sürecini de tamamlayan) burjuva devrimleriyle yükselen ve tüm coğrafi mekânı kendi egemenliğinin sınırlarıyla parçalayan, dağınık bölgeleri ve kent sistemleriyle bütünleştiren ulus devletleriyle, kent ve kentsel mekân geçmişin görkemlilik ve parlaklığını yitirdi. Birikim süreçlerinde kentlerin rolü azalmasa, hatta sanayi kentinin ortaya çıkışıyla daha da önemli hale gelse de ulus devlet ve onun soyut mekânı temel özne haline geldi. Lefebvre'in tabiri terse çevrilirse, "kentleşen mekân ve

185 Lefebvre, Mekânın Üretimi, s. 284.

186 Ibid., s. 284.

187 Ibid.

188 Ibid., s. 285.

189 Ibid., s. 286

190 Ibid. 
zaman"191 yerini devletleşen mekân ve zamana bıraktığı söylenebilir. Başka bir deyişle eskiden zamana ve mekâna hâkim olan kent, yerini mekâna ve zamana hâkim olan devlete bıraktı. Hâkim "özne" olan ulus devletin soyut mekânında kent ve kentsel mekân eski imago mundi yerine imago statum (devlet imgesi) kazandı. Kent ve kentsel mekân artık biçim, içerik ve işlev açısından belirli bir dünya imgesi benimseyen devletin imgesidir.

\subsubsection{Soyut Mekân}

Artık kısmen belirtildiği üzere, Lefebvre, soyut mekânı şiddet ve savaşın bir ürünü olarak görür, bu siyasal olandır, bir devlet tarafindan kurulmuştur, dolayısıyla kurumsaldır. Ayrıca bu mekân birikim süreçleri ve sermayeye tabi olan ve büyük ölçüde onlarla şekillendirilen bir mekândır. Fakat Lefebvre'in analizinde göze çarpan en önemli nokta, soyut mekânın siyasal boyutuna vurgusudur.

Soyut mekânın temel özellikleri onun doğuşu ve temelinde yatan unsurlardan dolayı, homojenlik ve ondan kaynaklanan araçsallıktır. Temelinde ve doğasında şiddet bulunan, şiddet tekelini elinde bulunduran devletin ilk icraatlarından biri 'yerleştiği' mekânda "direnen ve tehdit eden her şeyi, kısaca söylersek farkl11ıkları yerle bir ederek"192 dolayısıyla homojenleştirerek, bu "homojen mekân, bir marangoz rendesi, bir buldozer ya da bir savaş arabas1 olarak"193 kendi hizmeti altına almasıdır. O yüzden "böyle bir mekânın kullanım değeri münhastran siyasidir. Eğer ondan falanca hedefi ve falanca eylem arac1 olan bir "özne" olarak söz edebiliyorsak, gerçekten de siyasal bir özne, mevcut haliyle iktidar, mevcut haliyle devlet var olduğu içindir."194

Soyut mekânın felsefi temeli, devleti mekânın efendisi olarak gören, devlete rasyonellik atfeden Hegelcilikte yatar. Bu mekânın diğer önemli felsefi temeli doğanın ve mekânın mantıksal ve mekanistik analizine vurgu yapan Kartezyen felsefedir. Özellikle Kartezyen anlayış nedeniyle soyut mekân, "beyaz kâğıdın, çizim tahtasının, planların, kesimlerin, yükseltilerin, maketlerin, yansıtmaların"195 mekânıdır. "Kavranılır olanı siyasetle, bilgiyi iktidarla kaynaştıran" 196 felsefi temellere dayandığ 1 için, ilk önce bir siyasi araç ve aygıt olan soyut mekânda "dar ve duyarsız bir rasyonellik"197 söz konusudur. Bu

191 Ibid.

192 Ibid., s. 292.

193 Ibid.

194 Ibid., s. 294.

195 Ibid., s. 215.

196 Ibid., s. 314.

197 Ibid., s. 215. 
rasyonellik, otoriter ve kaba bir mekân pratiğine yol açtı. Mutlak devlet gibi kurumsal bir dayanağı olan bu mekân pratiğinin öncüsü Haussmann'dı. Düz çizgiler, hizalanma ve geometrik perspektifle yöneltilen bu düzen, en yüce kurum olan Devlet tarafindan desteklenmekteydi. ${ }^{198}$ Sonradan bunun devamcisı "dik açının diktatörlügünü”'199 ilan eden Bauhaus ve Le Corbusier olacaktır. Bunların hepsinin kodlandırdığı mekân pratiği, "dağılma, ayrılma, ayrımcılık yoluyla (ve bunlar içinde) analitik anlayışın etkinliğiı"ni sağladı, ${ }^{200}$ yüksek modernizmin soyut mekânın homojen fakat aynı zamanda bölünmüş dolayısıyla çelişkili özelliğini pekiştirdi. Le Corbusier ve ona eşlik eden modern mimarlar, projelerinin temelinde doğanın ritimleri ve doğanın şartları olarak tanımladıkları güneş 1şığ1, açık mekân ve yeşilliği koydular ve projelerini "özgürlük" namına yürüttüler. Fakat bu girişimlerin sonucu "mekânın parçalanmasıdır, "mesken makinesi' ve insan-makinenin yaşam alanı olarak tasarlanan mimari kümenin homojenliğidir, birbirinden ayrılmış ve kentsel kümeyi ayıran unsurların - sokak, şehir - eklemlerinden ayrılmasıdır." $201 \mathrm{Bu}$ uygulamalarda kargaşa, oyun ve öğrenme yeri olan sokak tek bir işleve, genelde konut ve iş yeri arasında ulaşım sağlamaya tahsis edildi, sokağın öğretici, sembolik ve oyun işlevleri Le Corbusier tarafından görmezden gelindi. ${ }^{202}$

Böyle bir rasyonelliğe dayalı pratiğin sonucunda Marx'ın yabancılaşma kavramı başlangıçta üretim süreçleri için açıklayıcı kapasiteye sahipken artık gündelik hayatı da kapsamaya başladı. Böyle bir pratik aracılığıyla bedenin mekândan kopuşu, onun duyu organlarıyla mekânın çok taraflı deneyimlemesi ortadan kaldırdı. Soyut mekân kendi başına bir soyutluk değildir, onun deneyimlenmesi soyutluk içerir203 yani bu mekân "soyut bir öznenin algısıyla tanımlanır", şöyle ki

"Trafikte dolaşan kişi (arabayla) gidebilmek için bakar ve sadece işine yarayanı görür; dolayısıyla (maddileşmiş, makineleşmiş, teknikleşmiş) kendi güzergâhından başka bir şey görmez ve bunu da tek bir açıdan işlevsel yararcılık açısından- görür: hızlılık, okunurluk, kolaylık... Mekân artık indirgemeleri içinde kendini gösterir." 204

Önceki dönemlerde temel referans sistemi olan eş yönlü ve homojen Öklidçi mekân böylece daha da indirgenmektedir. Aynı zamanda diğer bir önemli alanda soyutlanma meydana gelir: "yaşam alanı, meskenin yerine geçer;

198 Lefebvre, Kentsel Devrim, s. 105.

199 Ibid.

200 Lefebvre, Mekânın Üretimi, s. 314.

201 Ibid., s. 309-310.

202 Lefebvre, Kentsel Devrim, s. 22.

203 “Köpek kavramı havlamaz!”, Lefebvre, Mekânın Üretimi, s. 306.

204 Ibid., s. 318-319. 
yaşam alanı işlevsel soyutlamayla nitelenir." ${ }^{205}$ Le Corbusier tarafindan evin "yaşama makinesi" olarak tanımlanması ${ }^{206}$ ve bu tanıma dayanan praksis bunun en bariz örneğidir.

Böylece, rasyonellik ve makine mitine dayanan bu teknolojik ütopya (dönemin temel belirtisi aynı zamanda),

"mekânın özünü ve temelini, bütünsel bedeni, beyni, el kol hareketleri, vb. ihmal eder. Mekânın, entelektüel bir temsil yansımasından, okunurgörünür olandan ibaret olmadığı; öncelikle işitildiği ve (el kol hareketleri ve fiziksel yer değişmeler aracıllğıyla) etkide bulunduğu unutulur."207

Fakat soyut mekân ne kadar homojen olarak tanımlansa da, aslında homojen değildir, onun "amac1, anlamı, "homojenliktir" 208 ve ancak görünümü homojendir. Bu mekân çok birimlidir, çatışmalı ve çoğuldur, karşıtlıkların zorla birleşimidir. Soyut mekân aristokratlar ile burjuvalar arasındaki toplumsal ve siyasal düzlemdeki uzlaşması sonucunda ortaya çıkmasına rağmen çelişkilidir, kapitalist üretim tarzındaki sermaye ile işçi sınıf arasındaki temel çelişkiyi yansıtır, o çelişkiyi etkiler. Hatta birikim süreçlerinin mantığı ve eşitsiz gelişmesi bağlamında değerlendirildiğinde onun asla homojen olamayacağı da söylenebilir. Çünkü sermaye akışları görünüşte homojenleştirici etkiye sahip olsa da sermaye akışının (ve her akışın!) temeli, farklılık ve eşitsizliktir. Harvey'in yaratıcı ylkım kavramı ve Smith'in eşitsiz gelişmenin tahterevalli kuramı soyut mekânın en azından politik-ekonomik düzlemde homojen olamayacağını kanitlayacak niteliktedirler.

$\mathrm{Bu}$ homojenlik tarihsel mekânda ortaya çıkan ve soyut mekânda tam olgunluğa varan üç unsurla daha da güçlenmektedir. Bunlar geometrik, görsel ve fallik özelliklerdir (oluşturuculardır). Geometrik oluşturucu, homojen olan Öklidçi referans sistemine dayanır. Mekânın tüm biçimlerini ‘ölçmek' için bu referans sistemine başvurulması doğal ve bütün toplumsal mekânın çok boyutluluğun indirgenmesini ve dolayısıyla homojenleşmesini sağlar. Mekânın homojenleşmesini pekiştiren diğer unsur görsel oluşturucudur. Görsel, diğer duyular karşısında başatlık elde eder, böylece

"tat almaktan, koklamaktan, dokunmaktan ve hatta işitmekten gelen şey, çizgi, renk, ş̧ık karşısında önce silikleşir, sonra silinir; nesnenin ne verdiği şeyin bir bölümü böylece bütün yerine geçer... Toplumsal yaşamdaki her şey, özümsenerek, taklit edilerek bir mesajın gözlerle deşifre edilmesi, bir metnin okunması olur; optik dışındaki bir izlenim -örneğin dokunmayla ya

205 Ibid., s. 319.

206 "Une maison est une machine à habiter".

207 Ibid., s. 215.

208 Ibid., s. 294. 
da kaslarla (ritimler) ilgili olan izlenim- sembolik olmaktan başka bir şey değildir ve görsele doğru geçiştir... Sadece görülen şey bir imgeye, donmuş bir soğukluğa indirgenir."209

Böylece "toplumsal pratiğin bütününü ele geçiren” görsel oluşturucu, geometrik olanla beraber her şeyi birbirine benzetir, homojenleştirir, sadece bir duyu organına hitap ederek, mekânın çok taraflı deneyimlenmesini engeller. Dolayısıyla mekânın soyut bir deneyimlenmesini sağlar, sadece görsele dayanan soyut mekânda tek bir duyu organına işlev yüklenmiş soyut özneyi doğurur.

Soyut mekânda gücü, eril doğurganlığ1, erkek şiddetini, "şiddete muktedir bir iktidarın mevcudiyetini" simgeleyen fallik oluşturucu, bölünmüş²10, parsellenmiş soyut mekânın bütünlüğünü sağlar, yani parçadan bütüne ve bütünden parçaya geçişi sağlar ve "yerlerin ayrımını homojenleştirir, bu homojenliği varsayar ve dayatır."211 Görselin ortasında dikeyliğini yükselten fallik oluşturucu böylece belirgin okunurluk ve bütüncüllük sağlar. Fakat eril doğurganlığı simgeleyen bu fallokraside çelişki doğar. "Bedeni kendi dişına, ideal-görsel'in içine taşıyarak başkalaştıran" bu mekânda kadının imgesinin kadının yerine geçmiş, beden (imgesi) parçalanmıştır, "cinsiyetin temsili 'cinsellik' adı altında cinsiyetin yerini al[mıştır]" ve doğal olarak karşılıklılık içeren cinsel ilişki ve cinsellik soyut mekândaki fallik yalnızlığın ve diktatörlüğün karşısında değerini yitirmiştir. Doğanın böyle soyutlanması "hadım edilmenin (hem kurmaca hem gerçek, hem sembolik hem somut) zihinsel mekânı"nı doğurur. 212

Fakat bu oluşturucular bağlamında birtakım ikiliklerin var olduğu da belirtilmelidir. Bu ikilikler görünüşte homojen olan soyut mekânın aynı zamanda basit ve pek homojen olmadığının diğer belirtisidir. Geometrik homojenlik (mekânın temsili, tasarlanan mekân) soyut mekânda bir pratik için dayanaktır, fakat aynı zamanda bu başka bir pratik için kısıtlayıcıdır, engel oluşturur, hatta bir süre sonra hizmet ettiği pratiğe engel oluşturabilir. Öklidçi sistemi referans aldığı için soyut mekân boş ve sınırsızdır, fakat aynı zamanda sınırlar, yakınlıklar ve mesafelerle doludur. Hem yaşanandır, yani pratik eylem alanıdır hem de algılanandır (temsil mekânıdır) yani imgeleri işaretler ve semboller içerir. ${ }^{213}$ Kısacası homojenliğin amacı olan soyut mekân, mekânsal pratikler (yaşanan), mekân temsili (tasarlanan) ve temsil mekânı (algılanan) üçlünün karmaşık etkileşiminin, kaynaşmanın ve çelişkilerin bütünüdür.

209 Ibid., s. 293-294.

210 Yukarıda farklı yerlerde ele alındığı üzere bölünmüşlük, parçalanmışlık soyut mekânın bir diğer temel özelliğidir.

211 Lefebvre, Mekânın Üretimi, s. 123, 294.

212 Ibid., s. 315.

213 Ibid., s. 295. 
Bölünmüşlük ve homojenleşme eğilimlerinde, mekânın hiyerarşik düzenlenişinde, soyut mekânın bir diğer önemli özü yatar. Burada söz konusu olan sadece merkez ile periferi arasındaki daha çok ekonomik hiyerarşiye dayanan ilişki değildir. Bu hiyerarşik düzenleniş çok boyutlu ve karmaşıktır. Bu hiyerarşik düzenlenişte devletin ve iktidarın rolü belirgin bir biçimde ortaya çıkar. Devlet, toplumsal 'düzen' sağlamak için mekânı bir siyasi araç ve aygıt olarak görür ve sürekli mekânın üretimine müdahale eder. Altyapı sağlayan, kaynakları yöneten, planlama yetkisine sahip olan devlet soyut mekânın hiyerarşik düzenlenişinden sorumludur; yerler ve mekânları, işlev ve özelliklerine göre hiyerarşik bir düzene sokarak sorumlu olduğu toplumsal düzenin temellerini sağlar. Fakat bu hiyerarşik düzenleniş bir bütünlük olarak ele alındığında evrimsel ve rastlantısal bir süreç değildir, merkez tarafindan periferilerin örgütlenmesinin stratejik mantığının sonucudur. Lefebvre, mekânla ilişkisi açısından ulusun iki moment (durum) içerdiğini saptar; pazar ve şiddet. ${ }^{214}$ Pazar, "az çok uzun bir zaman boyunca yani ticari ilişkilerin ve iletişim ağların karmaşık kümesi boyunca yavaş yavaş inşa edilmiştir." Bu süreç farklı yerlerde farklılık gösterse de "sonuç aşağı yukarı aynıdır: (esasen ticari, ama aynı zamanda dinsel, "kültürel", vb.) merkezlerin hiyerarşisiyle birlikte, ana bir merkezle, başkentle birlikte merkezi bir mekân." Fakat bu hiyerarşik düzenlenişin tamamlanması ve sağlaması ancak askeri bir devletin şiddetiyle, "pazarın kaynaklarını ya da üretici güçlerin büyümesini kullanan ve güç hedefleriyle birlikte bunu ele geçiren siyasal iktidarla mümkündür. Dolayısıyla, Lefebvre'ye göre bu iki moment "bir mekân üretmek için [ulus devletin mekânını üretmek için] etkilerini birleştirmişlerdir."

Soyut mekânın belirli özellikleri ve onlarda siyasal iktidarın rolü söz konusu olunca, "siyasi iktidarın siyasal iktidar olarak mekân üretici olmadığı" da belirtilmelidir, yani mekânın üretimi kendiliğinden bir amaç değildir, siyasal iktidar "(ona emanet edilmiş olan) toplumsal ilişkilerin yeniden-üretim yeri ve ortamı olarak mekânı yeniden üretir." 215 Bu durum özellikle kapitalist üretim ilişkilerinin gelişmesiyle beraber çok kritik bir rol kazanmıştır. Bir önceki üretim tarzlarında üretim ilişkilerinin sürdürülmesi ve yeniden üretimi söz konusu olunca bu, mekânda gerçekleştirilirdi ve üretim ve toplumsal ilişkilerin devamlılığ için genel olarak mekân sorun teşkil etmemekteydi. Oysa kapitalist toplumsal ve üretim ilişkileri, tamamıyla mekânın üretimi, topyekûn ve yekpare bir mekân üretimi aracılığıyla gerçekleşir. Önceki üretim tarzlarına kıyasla kapitalizmde mekânın üretimine yapılan vurgu, sadece bu üretim tarzının kendi devrimci potansiyeline dayanarak üretici güçlerin atılım sağlamasından, bu atılımdan yararlanarak boyut ve ölçek açısından geçmişe kıyasla topyekûn bir 
mekânın üretimine girişimden kaynaklanmamaktadır. $\mathrm{Bu}$ girişimin temeli kapitalizmin stratejik mantığında aranmalıdır, şöyle ki

\begin{abstract}
“despotik olarak aydınlanmış burjuvazi ve kapitalizm, soyut mekândan yararlanarak, meta pazarına kısmen hâkim olmuşlardır. Sermaye pazarına hâkimiyet ise daha güçtür... Çok güçlü bir politik tahakkümden, üretici güçlerin atılımından ve pazarlara yetersiz hâkimiyetten, komşuluk adacıklardan bütün gezegene dek, her kademede mekânsal bir kaos doğar. Burjuvazi ve kapitalizm, kendi tahakküm ürün ve araçlarına-mekânahâkim olmakta bundan böyle güçlük çekmiştir. Pratiği... kendi soyut mekânlarına indirgeyememişleridir. Yeni çelişkiler, mekânın çelişkileri ortaya çıkmış ve tezahür etmiş̧ir. Devletin gücüne ve rasyonelliğine rağmen kapitalizmin yarattığı mekânsal kaos, onun zayıf tarafi, gövdesinin dayanıksızlığ $1[\mathrm{~d} ı r] . " 216$
\end{abstract}

Dolayısıyla, kapitalizm ve genel olarak büyüme ${ }^{217}$ varlığını ancak bütün mekâna yayılarak sürdürebilmiştir, önceden var olan mekânı ele geçirmekle kalmamış, üretici güçlerin bu yayılmasına üretim ilişkilerinin yeniden üretimi de eşlik etmiş ve sonuç olarak kendi mekânını da üretmiştir. Bu üretim tarzı, öncekiler gibi şeylerin üretimiyle ve yerlere yatırım yaparak başladı, fakat bu süreçte toplumsal ilişkilerin yeniden-üretimi problem oluşturur. Dolayısıyla kapitalizm doğayı yeniden-üretmeye, kapitalizmin siyasi mekânını gezegen çapında üretmeye ve böylece bu mekâna hâkim olmaya ${ }^{218}$, yeni toplumsal ilişkilerin üretimini engellemek için zamanı indirgemeye, yeniden-üretebilir ve tekrarlanabilir olan yasası altında, mekân ve zaman içindeki farklılıkları ortadan kaldırmaya gerek duydu. ${ }^{219}$ Dolayısıyla Lefebvre'in "mekânın içinde şeylerin üretiminin yerine mekânın üretimine geçiş" saptaması bu bağlamda değerlendirilmelidir. Mekân içinde şeylerin üretimi, ona eşlik eden üretim araçlarına sahip olma, üretimin denetimi ve idaresi gibi sorunlar da halen devam eder, hatta mekânın üretimi bağlamında bu sorunlar daha çelişkili, yoğun ve

216 Ibid., s. 90.

217 Burada büyümeye vurgu önemlidir, çünkü sosyalizm olarak tanımlanan, fakat büyüme mantığı açısından kapitalizmden neredeyse farklı olmayan Sovyet deneyimi de bir toplumsal ve üretim ilişkiler sistemi olarak ayakta kalmak için hem ekonomik hem de politik açıdan mekâna tahakküm stratejisi benimsemiş ve kapitalizmden neredeyse farklı olmayan homojen, bölünmüş, hiyerarşik soyut mekân üretimine girişmiştir.

218 Özellikle İkinci Dünya Savaşından günümüze dek küresel ve yerel ölçekteki uygulamalar, gezegen çapında kapitalizmin siyasi mekânının sürdürülmesine yöneliktir. Uluslararası çalışmalarda çok bilinen 'Domino Teorisi', Marshall Planı, demokrasi namına savaş ve işgal politikaları, hatta son dönemlerde IMF ve Dünya Bankası tarafından özellikle üçüncü dünya ülkelerine farklı araçlarla neo-liberal politikaları dayatması gibi sayısız örnekler bu varsayımı kanıtlayacak yöndedir.

219 Lefebvre, Mekânın Üretimi, s. 330-331. 
şiddetli biçim alırlar. 220 Dolayısıyla, hâkim sınıflar tarafından "siyasal eylemin sonucu olan fakat bu eylemle örtüşmeyen"221 soyut mekânın ele geçirilmesi, ondan bir aygıt olarak yararlanılması kapitalist toplumsal ve üretim ilişkilerinin sürdürülmesi ve yeniden üretilmesi bağlamında değerlendirilmelidir.

Böylece, soyut mekân çok derin ve yoğun çelişkilerle doludur, çelişkilerin yansımasıdır, ayrıca var olan çelişkileri daha da derinleştiren özellikler barındırmasaydı, kendisi bir çelişki olmasaydı (yukarıda ele alınmasından anlaşıldığı üzere) iktidar tarafından bu mekâna bu denli önem atfedilmezdi. Bu denli çelişkili olduğu için Lefebvre'in mekân dönemselleştirmesinde soyut mekânın bir uzantısı olarak çelişkili mekân'a rastlanır. Soyut mekân halen hâkim mekân konumunu sürdürmektedir, fakat son dönemlerde (60-70'li yıllardan itibaren) ileri kapitalizm gelişmeleri, genel olarak mekânın üretimi süreçlerine ve mekân çelişkilerine farklı bir nitelik ve nicelik kazandırdı. Dolayısıyla, günümüzün soyut mekânının temel özelliği çelişkili olmasıdır.

\subsubsection{5. Çelişkili Mekân}

Soyut mekânı ele alırken, onun temel özelliklerine doğrudan ve bu mekâna özgü çelişkilerine dolaylı olarak değindik. Bu kısımda, ileri kapitalizmde soyut mekânın bir uzantısı olan çelişkili mekânın temelinde yatan çelişkiler kısaca ele alınacaktır. Çelişkili mekân, soyut mekânın yukarıda belirtilen tüm özelliklerine sahiptir, fakat kapitalizmin son dönemdeki gelişmeleri soyut mekâna özgü çelişkileri daha da derinleşmiştir. Böylece, soyut mekân, niceliksel ve niteliksel açısından yeni bir sıfatla, çelişkili mekân sıfatıyla ve geçmişe kıyasla daha çok keskin ve görünür bir çelişkiler dizisiyle karşımıza çıkmaktadır. Ayrıca, kapitalist toplumsal ilişkiler gündelik hayatın her alanına yayılırken, önceki evrede, yani endüstriyel kapitalizmde hâkim olan emek ile sermaye arasındaki çelişki, başkalaşmış biçimleriyle hala varlığını sürdürürken, gündelik hayatın her alanına yayılan kapitalist toplumsal ilişkiler yeni çelişkilere yol açmıştır. Böylece emek ile sermaye arasındaki çelişki, üretim ilişsilerinin mekânsal olarak yeniden üretiminin daha genel çelişkiler kapsamına girmiştir. Bu yeni ya da derinleşen çelişkilerin bir bölümü ise dolaylı ve dolaysız olarak mekânın üretimiyle bağlantılıdır.

Soyut mekânın birinci çelişkisi niceliksel ve niteliksel arasındaki çelişkidir. ${ }^{222}$ Soyut mekânın temelinde Öklidçi referans sistemi yatar, dolayısıyla bu mekân ölçülür. Fakat "sadece geometrik mekân olarak nicelemekle kalmaz, toplumsal mekân olarak da niceliksel manipülasyonlara tabi olur." Bu niceleme 
sürecinde niteliksel olan yok olma eğilimi gösterir. Fakat bu sürecin temelindeki en önemli unsur geometrik bir referans sistemi değildir, çünkü bu referans sistemi çok önceden de vardı. Bu çelişkinin temelinde, kullanım ile mübadele değerleri arasındaki çelişki ve bu çelişkinin mekânsal boyut alması yatar. Mekânın geometrik temsili niceleme sürecine sadece hizmet eder, asıl çelişkiyi açıklamaz. Bu geometrik temsil, genel olarak doğanın ve özellikle mekânın parçalanmasına, parsellenmesine imkân sağlamıştır, böylece mekân da alınıp satılabilecek ve mübadele süreçlerine dâhil olabilecek bir hammaddeye, metaya dönüştürmüştür. $\mathrm{Bu}$ süreç kapitalist gelişmenin ilk evrelerinde başlamasına rağmen günümüzde kapitalist üretim ilişkileri her alana yayıldığı için mekânın nicelemesi aşırı boyutlara ulaşmıştır. Özellikle hızlı kentsel yayılma ve küresel çapta kentsel gelişmeler, eskiden doğa olarak tanımlanan mekânları parçalayıp mübadele süreçlerine dâhil eder, bu mekânlar "niceliksel manipülasyona tabi olur", sonuç ise nitelikselin yok olmasıdır. ${ }^{223}$

Fakat niteliksel olan hiçbir zaman yok olmaz, buna olan ihtiyaç her zaman kendini hissettirir. Nitelikselin kendini var etmesinin temel nedeni nicelikselin belirli sınırlara tabi olması değildir, şöyle ki mekân genel olarak ve coğrafi mekân özel olarak ne kadar da sınırlı olsa, dolayısıyla niceleme süreçleri için belirli sınırlamalar oluştursa kapitalist toplumsal ilişkilerde başka bir sınır ortaya çıkar. Lefebvre, bunu tüketim mekânından mekânı tüketmeye doğru hareket olarak tanımlar. ${ }^{224}$ Buna göre,

"insanlar, genellikle, sermaye birikim alanıyla, üretim mekânıyla ve üretilmiş mekânla, dolayısıyla katı bir şekilde nicelendirilmiş mekânla örtüssen tüketim mekânını belli bir momentte terk ederler... başlangıçta toplumsal olup sonra zorunluluk olan moment. Bu durumda 'insanlar' niteliksel bir mekân talep ederler. Bu niteliklerin adı, güneş, kar, denizdir. Doğal ya da taklit olmaların pek önemi yoktur." 225

$223 \mathrm{Bu}$ süreçleri doğa bağlamında çok detaylı olarak ele alması açısından Paul Burkett'in çalışmasına başvurulabilir. Burkett'e göre, doğanın mübadele süreçlerine dâhil edilmesi mübadele süreçlerini temsil eden, niceliksel olan, homojen dolayısıyla parçalanabilen, sınırı olmayan/sınır tanımayan bir soyutluk olan değer (mübadele değeri) ile niteliksel olan, homojen olmayan dolayısıyla parçalanmaz, sınırları olan, somut olan doğa arasında bir gerilim nedenidir. Dolayısıyla, kapitalizmde doğanın, mübadele süreçlerine dâhil olması, kaçınılmaz olarak onun sınırlarını zorlamasına, homojenleşmesine, nitelikselin yok olmasına yol açacak. Kapitalist üretim ilişkilerinin temelinde değer ile doğa arasındaki bu çelişkiler yatar. Burkett'in doğa ile kapitalizm arasındaki bu analizi tamamıla Lefebvre'in yukarıdaki analizine benzerlik gösterir, fakat daha detaylıdır, dolayısıyla mekân konusunda da başvurulabilir önemli bir eserdir. Bkz. Burkett, Marx and Nature: A Red and Green Perspective, s. 77-143, özellikle s. 83-90.

224 Lefebvre, Mekânın Üretimi, s. 355.

225 Ibid. 
Böylece "niteliksel olan mekânsal olarak yeniden belirir." Fakat bu süreçte, yani tüketim mekânından mekânı tüketmeye doğru harekette ve nitelikselin baskın hale gelmesinde mekânın niteliği ve kullanım değeri saf haliyle kalmaz. Burada yine kâr oranları yüksek sektörlerin gelişmesine imkân oluşur, sanayi ve üretim buraya nüfuz etmeye başlar, "bir doğal yaşam simülasyonu"na ${ }^{226}$ hizmet eder. Dolayısıyla, niceliksel ile niteliksel arasındaki çelişkiyi temsil eden bu süreçte "(ikili) bir karşıtlık değil, üç terimli bir hareket"227 görülür:

- Birinci hareket tüketim mekânından boş vakitlerle ve boş vakit mekânı içinde mekânın tüketimine yönelik hareket, yani gündelik olandan gündelik olmayana yönelik harekettir. $\mathrm{Bu}$, emek harcamasının ertelenmesi ve sorgulanması dolayısıyla, çalışmadan çalışma olmayana yönelik harekettir (bkz. Şekil 2). Bu bağlamda ayrıca toplumsal yeniden üretimi sağlayan üretim mekânı ile mekânın tüketimi arasındaki çelişki belirtilebilir (ikinci hareket), çünkü mekânın tüketimi üretici tüketime ihtiyaç duyar.

- Üçüncü hareket, emek gücünün ve şeylerin yeniden üretimini sağlayan yaygın anlamdaki tüketim, yani tüketim mekânı ile üretim mekânı arasındadır. Bu hareket "mekân içindeki şeylerin ve (yeniden-üretim amacıyla planlanmış) mekânın yeniden üretilebilirliğinin güvencesi altında, devlet iktidarın denetlendiği bir mekân"da gerçekleşir.

Şekil 2. Soyut Mekânın Nicelik-Nitelik Çelişkisinin Üç Terimli Hareketi 228

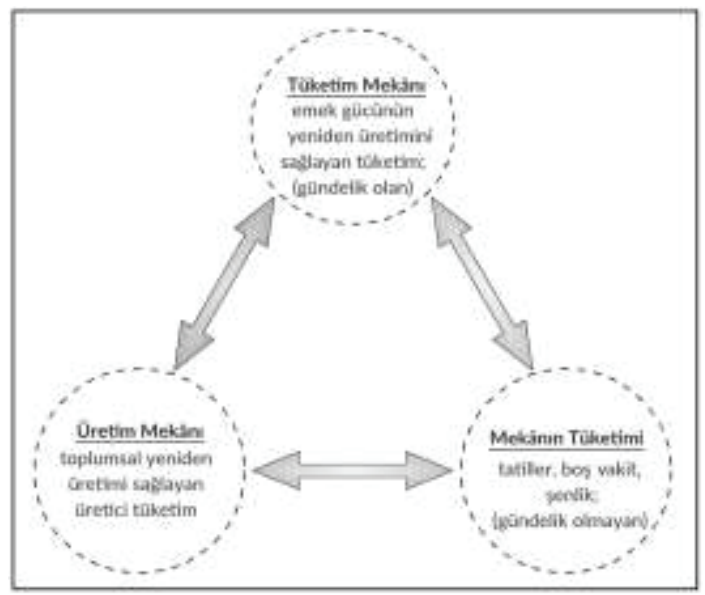

226 Ibid., s. 356.

227 Ibid., s. 357.

$228 \mathrm{Bu}$ şema Lefebvre'in kuramına dayanarak yazar tarafından hazırlanmıştır. 
Yukarıda doğanın sınırlarından ve onların kapitalist gelişme tarafından zorlanmasından söz edildi. $\mathrm{Bu}$ sınır zorlaması kaçınılmaz olarak (kapitalist toplumsal ilişkilere özgü ve toplumsal olarak üretilen) kitlığa yol açar, dolayisıla

\begin{abstract}
"bundan böyle mekân giderek ender bulunan hal alan enerji, su, 1şık, bitkisel ve hayvansal kimi hammaddeler gibi kaynakların aranışına bağlı olarak yeniden örgütlenir. $\mathrm{Bu}$, geniş bir çatışmalı sürecinde mübadele karşısında kullanım (potansiyel olarak) yeniden değer kazanmasını sağlar. Mekânın üretimi, kullanım değerlerinin kaynağı (şeylerin maddiliği) olarak “doğa"nın yeni önemine eşlik eder. Mübadelenin artı-değerinin (toplumsal artı ürünün) bir kısmını uzun süre tüketicisi olmuş mekân üretimi, kullanım değerinin onarılmasıyla birlikte bașat bir hal alır. Büyük ölçekli bu onarım siyasete nüfuz eder, fakat siyasal strateji halini almaz."229
\end{abstract}

Niteliksel olanın, kullanımın siyasete nüfuz etmesi (Lefebvre'in saptamasını doğrulayacak şekilde) bugün yaygın olarak görülebilir, dahası bugünlerde bu nüfuzun aşırı biçim aldığına da tanık olunabilir. Doğaya ve doğal olana vurgu bugünlerde saplantısal (obsesif) bir hal almıştır: ideolojik boyutta çevre, çevrecilik ve çevre korunması adı altında (toplumsal düzenin temellerini hiç de sorgulamayan yönelimle), pratik boyutta ise artık yeni bir kârlı sektör oluşturan çevre ve doğa dostu üretici olup ya da olmayan tüketim adı altında (çevre dostu iş makineleri, çevre dostu ürünler, doğal yaşam vs.). Sonuç: çevre sorunu olarak tanımlanan, mekânın üretimi genel sürecinden ayrılmazdır, ona eşlik eder ve soyut mekânın nitelik-nicelik, kullanım-mübadele, mülk edinmesahiplenme çelişkilerinin yansımasıdır, o çelişkinin körükleyicisidir. Siyasete nüfuz eden bu çelişkili durum ise, en iyi durumda mekânda şeylerin üretimiyle palyatif çözümlere neden olur, en kötüsünde ise artık belirttiği gibi doğanın ve doğal olanın son kalan parçalarını yok eden, doğanın ve doğal olanın simülakrasi olan mekânın üretimine neden olmaktadır. Çözüm siyasi strateji olmadan, iki seçeneğin ortasındadır diyenler de bulunmaktadır. Lefebvre'ye göre ise çözüm onun ütopyası olan diferansiyel mekânda yatmaktadır.

Soyut mekânın bir diğer çelişkisi bütün ile parça veya genel ile parsel arasındaki olandır. ${ }^{230}$ Kapitalizmin kendi varlığını ancak bütün mekâna yayılarak sürdürebildiğini ve bunu, bu üretim tarzının üretici güçlerinde ileri atılım

229 Ibid., s. 353, vurgu eklenmiştir.

230 Aynı zamanda Lefebvre, bu çelişkinin, Marx'ın ortaya koyduğu üretici güçler ile üretimin (ve mülkiyetin) toplumsal ilişsileri arasındaki çelişkilerine denk düştüğünü saptar. Bkz. Lefebvre, Mekânın Üretimi, s. 359. 
sağlaması aracılığıyla gerçekleştirdiği ve sonuçta mekânda şeylerin üretiminden mekânın üretimine geçiş yaptığı ele alındı. Bu süreçte soyut mekânda gittikçe daha çelişkili bir ilişki ortaya çıkmaktadır. Bütün mekâna yayılma, mekânda şeylerin üretimi yerine mekânın üretimine geçiş "mekânı global ölçekte (dünya çapında) tahayyül etme ve ele alma kapasitesi" 231 gerektirir, bu kapasite kuşkusuz kapitalizmde vardır, dahası teknolojik gelişmişlik ve pozitif bilim günümüzde bu kapasiteyi eşsiz biçimde artırmıştır. Diğer taraftan bu düzeyde ele alma ve tahayyül etme kapasitesi söylemde hâkim konum edinmiştir. ${ }^{232}$ Fakat bunun karşısında sayısız prosedür ve süreçlerde bölünmüş ve parçalanmış bir mekân da söz konusudur. Bu parçalanmışlığı makro düzlemde, mekânın devletlere, idari bölgelere ayrılmasından, meso ve mikro düzeyde ise kentsel mekânın parsellenmesine kadar uzanır. Bu parçalanmışlığı da tıpk1 mekânı global ölçekte tahayyül eden "dünya düzdür"233 söylemi gibi belirli bir ideoloji içerir, belli bir ideolojiye hizmet edip işlem görür. Fakat "asıl katkısı perakende (hisselerle) satışa yöneliktir." ${ }^{234}$ Ama yine de bu parçalanmışlı̆̆ın her zaman daha yüksek düzlemdeki tahayyülü ve yerel ölçekteki pratik için bir engel oluşturacağı unutulmamalıdır. Bu ise birikim süreçleriyle ve meta mübadelesiyle doğrudan bağlantılıdır. Kapitalizmin soyut mekânının mekân temsili ile mekânsal pratiği arasındaki uyuşmazlıktan kaynaklanır. Şöyle ki meta zincirleri (mübadele ağları) dünya çapında örgütlenmiş ve düzenlenmiştir: ulaşım ağları, satış ve satın alma ağları (para dolaşımları ve transferleri de dâhil). Böylece, "potansiyel olarak sonsuz sayıda metayı birbirine ekleyen meta dünyası, mekân üzerine, hatta belli bir mekân kavramı üzerine önerme ve eylemlere yol açar." 235 Bu bağlamda akla gelen yine "dünya düzdür" önermesi veya Lefebvre'in kavramını kullanırsak "dünya düzdür" mekân temsilidir. Oysa kullanım (tüketim), mekân temsiliyle değil mekânsal pratiğiyle tanımlanır, yani kullanım her zaman yerel ve somuttur, onun "her zaman yerel bir özelliği vardır. Mübadele dünya mekânını işgal etse de (dolaşımlar ve ağlar) burada ya da orada tüketilir."236 Bütünü temsil eden mübadele ağları, para dolaşımları, para transferleri ve buna tekabül eden belirli bir soyut mekân temsili ile parçayı temsil eden kullanım (tüketim) ve buna tekabül eden somut mekânsal pratik arasındaki makul karşıtlık, diyalektik çelişkiye dönüşür ve böylece mekân soyut-somut, homojen ama yine de parçalı

231 Ibid., s. 357.

$232 \mathrm{Bu}$ açıdan neo-liberalizmin savunucularından özellikle Thomas Friedman'ın, neo-liberal söylemi tam olarak özetleyen "dünya düzdür" tabiri ve onun çok tartışılan aynı başlığı taşıyan kitabını belirtmek gerekir. Bkz. Friedman, The World Is Flat : A Brief History of the TwentyFirst Century.

233 Ibid.

234 Lefebvre, Mekânın Üretimi, s. 358.

235 Ibid., s. 345.

236 Ibid. 
bir nitelik kazanır. ${ }^{237} \mathrm{Bu}$ diyalektik çelişki söz konusu olduğu için toplumsal mekân "hem bütün ve kırık, hem de genel ve parçalı'dır'."238

Soyut mekânın bütün-parça çelişkisi çerçevesinde, bunun sonucu olan merkez-periferi çelişkisi de söz konusudur. Hatta merkez ile periferi arasındaki çelişki bütün ile parça çelişkisinin içindeki hareketini belirler. ${ }^{239}$ Zihinsel olsun veya toplumsal olsun, merkezlik belirli bir mekân içinde olanları bir araya getirir ve onların buluşmasını sağlar, dolayısıyla sıkışıklık ve yoğunluk merkezliğin özellikleridir. Bir biçim olarak merkezlik anlık olanı genel olana bağlar, yerel olanı küresel olana bağlar. Merkezlik ve merkez ile periferi karşıtlığı her zaman var olmuştur, fakat kapitalizmin soyut mekânında merkezliğin farklı bir yönelimi vardır. Soyut mekânda merkezlik bütünsel olmak ister, "yüksek bir siyasaldevletçi ya da "kentsel" - rasyonelliği tanımlama iddiasında bulunur."240 Merkezlik belirli nesneleri kendine çekip bir araya getirir, dolayısıyla biçim edinir, ayrıca işlevsel bir gerçeklik de kazanır, şöyle ki merkezin etrafında belirli bir mekânın yapısı örgütlenir ve merkezin biçimi ve işlevi bir pratiğe katkıda bulunur. ${ }^{241}$ Fakat her şeyin yoğunlaşmasını ve içermesini sağlayan merkezlik aynı ölçüde dışlama ve dağıtma üzerinde de temellenir, dışlama ve dağıtma da onun işlev kapsamına girer, tıpkı yoğunlaştırma aracılığıyla biçimsel ve işlevsel gerçeklik edindiği gibi, dışlama aracılığıyla da merkezlik kendi varlığını bulur, periferi ve dışlanmış olan karşısında merkezlik olarak karşımıza çıkar. Dolayısıyla, merkezlik (merkez-periferi çelişkisi) hem yoğunlaştıran hem de dağıtan, hem kapsayan hem dişlayan işlevleri aracılığıyla bütün-parça çelişkisi içerisindeki hareketi belirlemektedir.

Merkezlik, farklı olanı (periferide olanı) önce dışlar sonra saldırıya geçip kendine katar, yoğunlaştırır, bu süreci dünya çapında tahayyül etme ve ele alma gibi işler, fakat kendi varlığı için hem periferiye ihtiyaç duyar, hem kendi periferisini özellikle mekânsal olarak, mekân olarak üretir, ya da onun üretimini tetikler.

Yukarıda ele alınan çelişkilerin ileri kapitalizmin soyut mekânının en temel çelişkileri olduğu söylenebilir. Bu çelişkiler bağlamında bunlardan ayrı olmayan başka çelişkiler de söz konusudur (örneğin mülk edinme ile sahiplenme arasındaki çelişki). Fakat onların ele alınması, kendi özellikleri nedeniyle somut bağlamlarda incelenmesi daha uygun olabilir. Ayrıca, somut bir bağlamda çelişkili mekânın incelemesi yukarıdaki genel ve temel çelişkilere ilaveten,

237 Ibid., s. 345-346.

238 Ibid., s. 358.

239 Ibid.

240 Ibid., s. 336-337.

241 Ibid., s. 397. 
belirli bir toplumda ileri kapitalizmin işleyişine ve ona tekabül eden (üretilen) mekâna özgü çelişkiler dizisini de ortaya çıkartabilir.

\subsubsection{Mekânsal Üçlü}

Her üretim tarzına denk düşen mekânı ve onların temel özelliklerini ele aldıktan sonra diğer önemli konu, Lefebvre tarafından mekân analizi için sunulan mekânsal üçlüdür. Lefebvre'ye göre mekânın deneyimlenmesi üç temel unsurdan, algilanan, tasarlanan ve yaşanan unsurlardan oluşmaktadır ve bize bu unsurların mekânsal kavramsallaştırması olarak mekânsal pratik, mekân temsili ve temsil mekânından oluşan üçlüyü önerir. Üçlü, hem her üretim tarzında ve toplumda mekânın üretimini anlamlandırmasına ve mekânın deneyimlenmesinin incelenmesine hem de zihinsel, toplumsal ile fiziksel mekânların karşıllklı ilişkileri, karşıtlıkları ve düzenlenişlerini incelemeye imkân sağlamaktadır. Yukarıdaki mekân dönemselleştirmesi ve burada ele alınan mekânsal üçlü Lefebvre'in mekân teorisinin temelidir. ${ }^{242}$

Lefebvre, üçlü ve onun unsurları konusunda çalışmasının başlangıcında belirli bir tanımlamaya girişse de, ${ }^{243}$ bu unsurların kapsam ve içerik ile ilgili detayları, Lefebvre'in somut tarihsel dönemlerin mekân analizinde ortaya çıkmaktadır. Tüm çalışmasında rastlanan üçlünün unsurlarının ele alınışı "mekanik bir çerçeve veya topoloji değildir, üç momentin (mekân temsili, temsili mekân ve mekânsal pratikler) birbirine bulaştı̆̆ı, akışkan ve canlı diyalektik bir yalınlaştırmadır."244 Fakat böyle bir tarzın kullanımı, aslında Lefebvre'in

242 Mekânsal üçlü, bugünlerde akademide özellikle gündelik hayat ve ilgili konularda yaygın olarak kullanılan bir araştırma çerçevesi haline gelmiştir. Bu, Lefebvre'in teorisinin ve özellikle mekânsal üçlüsünün epistemolojik önemini gösteren bir husus olmakla beraber, üçlünün ve onun farklı unsurlarının, Lefebvre'in teorisi bağlamından çıkarılıp, kapitalist toplumsal ilişkileri hesaba katmadan çeşitli konuların araştırılması için kullanıldığında, üçlü sadece betimleyici bir çerçeve olarak karşımızda çıkmaktadır. Ayrıca mekânsal üçlü, Lefebve'nin mekân kuramının en temel unsuru olarak tanımlandığı ve böylece onun kuramının mekânsal üçlüye indirgendiği görülmektedir. Oysa mekânsal üçlü Harvey’in de haklı olarak belirttiği gibi Lefebvre'in özgün önerisi değildir. Zira Lefebvre, mekânsal üçlünün kurgusunu Cassirer'den yararlanarak geliştirip ortaya koymuştur. Dolayısıyla, Lefebvre tarafindan mekânsal üçlü önermesi önemli olmakla beraber kendi başına pek özgün bir önerme olmasa da, mekân dönemselleştirmesi bağlamında özgün bir çerçeve olarak karşımıza çıkmaktadır. Benzer biçimde mekân dönemselleştirmesi Marksist teoride kabul gören üretim tarzlarına denk düştüğünden dolayı kendine özgü bir önerme değildir. Dolayısıyla, Lefebvre'in kuramı ancak bu iki unsur bir arada değerlendirildiği zaman özgünlüğe kavuşmaktadır. Bkz. Harvey, "Space as a Keyword"; Cassirer, An Essay on Man: An Introduction to a Philosophy of Human Culture.

243 Bkz. Lefebvre, Mekânın Üretimi, s. 67-75.

244 Merrifield, Henri Lefebvre: A Critical Introduction, s. 109. 
sunduğu çerçevenin hem gücünü hem de zaafını oluşturmaktadır. Şöyle ki Lefebvre'in argümanlarının tarzı, onları "kolaylıkla özetlemesine" imkân tanımamaktadır ve "tartışma ve merak uyandıracak biçimde tasarlanan projesinde kullandığı metaforlar ve örnekler basit parametreler dizisine indirgenemez", bu ise Lefebvre'in taraftarlarına göre onun güçlü yönlerinden biri, eleştirmenler için ise sorunlu yönüdür. ${ }^{245}$ Bunlardan yola çıkarak, Lefebvre'in, üçlünün unsurlarının tanımına burada kısaca yer vererek bunları artık somut bağlamda ele alınması daha anlaşılabilir olur ve Lefebvre'in yaklaşımına da daha sadık kalınır, çünkü kendisinin de belirttiği gibi,

"Üçlü: algılanan - tasarlanan - yaşanan (mekânsal olarak: mekân pratiği - mekân temsili - temsil mekânları), soyut bir "model" statüsü atfedilirse kapsamını yitirir. Ya somutu ("dolaysız"1 değil) ele geçirir ya da kısıtlı diğer ideolojik dolayımlardan biri olarak - bir önem taşır."246

Mekânsal pratik (algllanan mekân): Lefebvre'ye göre bir toplumun mekânsal pratiği kendi mekânını yaratır. Bu mekânsal pratik ise mekânı deşifre ederek keşfedilir. İleri kapitalizmde mekânsal pratik gündelik gerçekliği ile kentsel gerçekliği sıkı sıkıya birleştirir. ${ }^{247}$ Mekânsal pratik, "üretimi ve yeniden üretimi nispi bir bağl1lık içinde sürekliliği sağlayan her toplumsal oluşuma has özgül yerleri ve mekânsal kümeleri" kapsar. ${ }^{248}$ Mekânsal pratik ilk olarak maddi bir gerçeklik olan mekân ile ilgilidir. Binalar, yapılar, çalışma yeri, özel alan ve boş vakit alanlarını birbiriyle bağlayan yol ve ağları kapsar, dolayısıyla "ampirik olarak gözlemlenir." 249 Lefebvre'in somut örneğine başvurulursa modern zamanların mekânsal pratiği "banliyödeki bir toplu konutta oturan birinin gündelik hayatıyla tanımlanır." ${ }^{250}$ Fakat mekânsal pratik aynı zamanda fiziksel yapılı çevrenin üretim ve yeniden üretim süreçlerini kapsar, dolayısıyla planlama ve ilgili disiplinlerin pratikleriyle ilgilidir ve bunun aracilığıla mekânsal pratik, tasarlanan mekân ile sıkı bir ilişki içine girer. Kendi nitelikleri dolayısıyla, yani fiziksel mekân ile ilgili olduğu için, bu, aynı zamanda algılanan mekândır, çünkü mekânsal pratikler mekânın doğrudan deneyimlenmesini sağlar. O yüzden Lefebvre mekânsal pratikleri aynı zamanda algılanan mekân olarak tanımlamaktadır. Bu nitelikleri nedeniyle mekânsal pratikler "mimari, (resmi söylemden alınan terimle) şehircilik, parkur ve yerlerin (toprağın) düzenlenmesi,

245 Unwin, “A Waste of Space? Towards a Critique of the Social Production of Space...”, s. 13.

246 Lefebvre, Mekânın Üretimi, s. 69, vurgu eklenmiştir.

247 Ibid., s. 67.

248 Ibid., s. 63.

249 Ibid., s. 410.

250 Ibid., s. 68. 
gündelik hayat ve elbette kent gerçekliği gibi çeşitli düzeylerde saptanır, tarif edilir, analiz edilir." 251

Mekân temsilleri (tasarlanan mekân): Bu, planlamacıların, şehircilerin, teknokratların, kimi sanatçıların mekânıdır, bir toplumun (bir üretim tarzının) içindeki egemen mekândır. ${ }^{252}$ Mekân temsilleri varoluşuyla "parçalayan ve düzenleyen teknokratlar" ${ }^{253}$ borçlu olduğu için "bilgilere, işaretlere, kodlara, 'cephesel' ilişkilere bağl1"dır"254 ve "sözel, dolayısıyla entelektüel olarak oluşturulmuş bir göstergeler sistemine yönelme eğilimi gösterir." 255 Mekân temsilleri, etkin bilgi ve ideoloji aracılığıyla bu bilgi ve ideolojiyi mekânsal dokularında yansitırlar, dolayısıyla "mekân üretiminde mekân temsillerinin önemli bir kapsamı ve özgül bir etkisi olur." ${ }^{256}$ Bu kapsamı ve rolü nedeniyle mekân temsilleri, kurulu düzenin yani siyasi iktidarın, hâkim ideolojinin (veya söylemin) ve hâkim ekonomik düzenin mantığına göre düzenlenmiş, örgütlenmiş ve üretilmiş mekândır ve "ideoloji tarihinin parçasıdır." 257 Zihinsel olarak düşünülmüş, 'tasarlanmış', sonradan nesneleşmiş planlardan, simgelerden vs. oluşan bu mekân soyutlama içerir, şöyle ki bu mekân zihinsel olarak düşünülmüş ve belirli bir mekânsal pratik aracılı̆̆ıyla nesneleşmiştir. Bu nedenle temsil mekân aynı zamanda tasarlanan mekân olarak da tanımlanır. Fiziksel dokuya etki kapsamı ve öneminden dolayı mekân temsilleri, mekânsal pratiklerinden ve onunla ilişkili olan mekân deneyimlenmesinden ayrılmaz. Onunla sıkı bir ilişki içerisindedir.

Genel bir somutlama yapılırsa, mekân temsilinin, mekânın bölgelere ayrılması, parsellenmesi, mekânın bir iş bölümüne ve uzmanlaşmaya dâhil edilip, işlevlerin, insanların ve şeylerin mekândaki ayrım veya birleşimini sağlayan uygulama ve pratiklerin dayanağı olduğu söylenebilir.

Temsil mekânları (yaşanan mekân): Temsil mekânlarının, üçlünün diğer iki unsuruna kıyasla daha zor saptanabilecek bir unsur olduğu söylenebilir. Bunun temel nedeni, temsil mekânının, imgelem ile ilişkili olması, "toplumsal yaşamın yasadışı ve yeraltı tarafına bağlı" olması veya "karmaşık sembolizmler"den ${ }^{258}$ oluşmasıdır. Bir diğer önemli neden, temsil mekânlarının öznel olmasıdır, şöyle ki "kullanıcıların her günkü edimlerin"in"259 somut 
mekânıdır, hesapların değil "öznelerin" mekânıdır, "bir halkın ve bu halka mensup her bir kişinin tarihi" 260 ile ilgilidir, dolayısıyla hesaplar içeren tasarlanmış mekân ve mekânsal pratiklere kıyasla "ne tutarlığa ne de bağlantıya mecburdur."261 Bu kullanıcıların ve oturanların mekânıdır, şöyle ki bu mekân "yaşanır, konuşur; duyumsal bir çekirdeği ya da merkezi vardır: Ego, yatak, oda, konut ya da ev; meydan, kilise, mezarlık... Bu mekânlar, tutku ve eylem yerlerini, yaşanan durumların yerlerini kapsar, dolayısıyla zamanı doğrudan içerir."262 Tasarlanmış mekân karşımıza teknokratların mekânı olarak çıkar, dolayısıyla sadece hesaplar içermez aynı zamanda kendine özgü (ve hesapları ifade eden) bir teknik dil (jargon) içerir, oysa temsil mekânı yaşananların ve kullananların sembollerini, imgelerini ve argo dilini içerir, o yüzden "niteleyicidir, akışkandır, dinamikleşmiştir- çeşitli nitelemeler edinebilir."263

Aktarıldığı üzere, mekânın üretimi içerisinde mekân temsilinin (tasarlanan mekânın) rolü ve kapsamı çok önemlidir, oysa ona kıyasla temsil mekânlarının ürünü genellikle sadece sembolik eserlerdir, yani mekânın üretimi açısından temsil mekânı pek üretici değildir. Bu eserler, hatta bazen "estetik" bir akım veya eğilime yol açarlar, fakat bu belli bir süre sonra yok olur ${ }^{264}$ veya açıkça gözlenebilen durumdan yine toplumsal mekânın yasadışı ve "yeraltı" kısmına saklanırlar. Mekânsal bir tezahürü de bulan ve aslında belirli bir toplumsal mekân üretimi anlamına da gelen, gündelik hayatta neredeyse hiç gözlemlenemeyen (çünkü toplumsal mekânın yasadışı tarafında yer alırlar) LGBT yürüyüşleri, karnavallar veya şenlikler temsil mekânlarının öne çıktığı en basit örneklerdir.

Gündelik hayat, temsil mekânları içinde şekil bulur, ${ }^{265}$ fakat gündelik hayatın sıradanlığı, belirli kurallara göre düzenlenişi ve standartlığı, toplum üyeleri tarafından bu mekânın kavranmasını zorlaştırır. Kavrama söz konusu olunca ise standartlığ 1 içine sığmadığ 1 için tepkiye neden olur veya farklı bir gündelik hayatın mümkün olacağına işaret eder. Dolayısıyla, temsil mekânları aynı zamanda özgürleştirici bir potansiyel de taşırlar; egemen söylemi ve pratiği alt üst edebilirler. Bu potansiyel için temsil mekânı,

"aynı zamanda kimi sanatçıların ve belki de o mekânı tarif edenlerin ve sadece tarif ettiğine inananların-yazarlar, filozoflar mekânları. Bu, imgelemin değiştirmek ve sahiplenmek istediği, egemen olunan, dolayısıyla maruz kalan [pasif olarak deneyimlenen] mekândır. Fiziksel mekânı, nesnelerini sembolik olarak kullanarak kapsar. Öyle ki, bu temsil

\footnotetext{
260 Ibid., s. 70.

261 Ibid.

262 Ibid., s. 71.

263 Ibid.

264 Ibid.

265 Ibid., s. 139.
} 
mekânları sembollerin ve sözel olmayan göstergelerin az çok bağdaşık sistemlerine (öncekiyle aynı çekincelerle) yönelir."266

Bu potansiyel ve az çok bağdaşık sistemlerine yönelim için temsil mekânı aynı zamanda egemen söylem tarafından marjinalleştirilmeye çalışılır, dolayısıyla "hegemonyacı söylemlerin kenarlarında, kurumların boşluklarında ve iktidar-bilgi aygıtının açık ve çatlaklarında" 267 yer almaktadır.

Toplumsal mekânı anlamlandırmaya yönelik bu üç mekân birbirinden hiçbir zaman ayrı görülmemeli, çünkü artık yukarıda da görüldügü üzere bunlar süregelen bir etkileşim, karşıtlık ve çelişki içerisindedirler. Ancak analitik kolaylık sağlamak ve kavramsal bir çerçeve belirlemek için bunlar ayrı ayrı tanımlanır, dolayısıyla nihai analiz bunları hep beraber analiz etmelidir, onların etkileşimi, karşıtlık ve diyalektik çelişkileri incelenmelidir. Bunlar arasında her zaman bir ayrım yapıldığında "böyle bir ayrım fazlasıyla ihtiyatla kullanılmalıdır. Üretici birliği tesis etmesi gerekirken, tam tersine hemen ayrışmalara yol açar." 268 Bu bağlamda bir diğer önemli husus, belirtildiği üzere Lefebvre'in analizinin 'Avrosentrik' olmasidır. Lefebvre'in kendisi de bunun farkındadır ve örneğin Uzak Doğu'da (Çin'de) temsil mekânı ile mekân temsilleri arasındaki farklılığın tanınmış olup olmadığı sorusundan bahseder. ${ }^{269}$ Dolayısıyla, hem mekânın bir bütünlük olarak kavranışının sağlanması için üçlünün unsurlarının birbirinden ayrılmasına ihtiyatla yaklaşılmalıdır hem de "bu ayrımın genelleşebileceği baştan kesin olmadığı" 270 için somut bir bağlamda bu unsurların ne kadar birbirinden ayırabileceği sorusuna cevap aranmalıdır.

Kendi özellik ve niteliklerine göre, farklı üretim tarzı ve toplumlara göre mekânsal pratikler, mekân temsilleri ve temsili mekânlar, mekânın üretimine farklı ölçüde müdahale ederler, ayrıca bunlar arasındaki ilişkiler hiçbir zaman basit ve istikrarlı değildir ve bu ilişkiler " "negatif'in, deşifre edilemezin, söylenmeyenin, yasağın, bilinçdışının karşıtı anlamında 'pozitif' de değiller."271 Mekân ve onun üretimi nasıl çok taraflı ve çok boyutlu bir süreç ise bu unsurlar arasındaki ilişkiler de bir süreç temsil ederler (bkz. Şekil 3). Bu süreçte, üç moment arasında sürekli hareket, örtüşme, yer değiştirme, "sürtüşme" ortaya çıkabilir, temsil mekânı mekân temsili tarafından işgal edilir, yerini ona bırakır ya da farklı süreçler nedeniyle temsil mekân yasadışı tarafından çıkıp toplumsal mekânda kendi yerini kazanır. Bu süreçlerde özellikle 'beden' hep dikkate

266 Ibid., s. 68.

267 Soja, "Thirdspace: Expanding the Scope of the Geographical Imagination", s. 272-273.

268 Lefebvre, Mekânın Üretimi, s. 71.

269 Ibid., s. 71-72.

270 Ibid., s. 71.

271 Ibid., s. 74. 
alınmalıdır, çünkü Lefebvre, üçlüyü, mekânı ve mekânın üretimi süreçlerini insan ve onun bedeni tarafından deneyimlenmesinin incelenmesi için sunar. Başka bir deyişle, beden bu üçlüde 'merkezi' bir konuma sahiptir ve temel eksendir. ${ }^{272}$

\section{Şekil 3. Beden, Mekân ve Mekân Deneyimlenmesi' ${ }^{273}$}

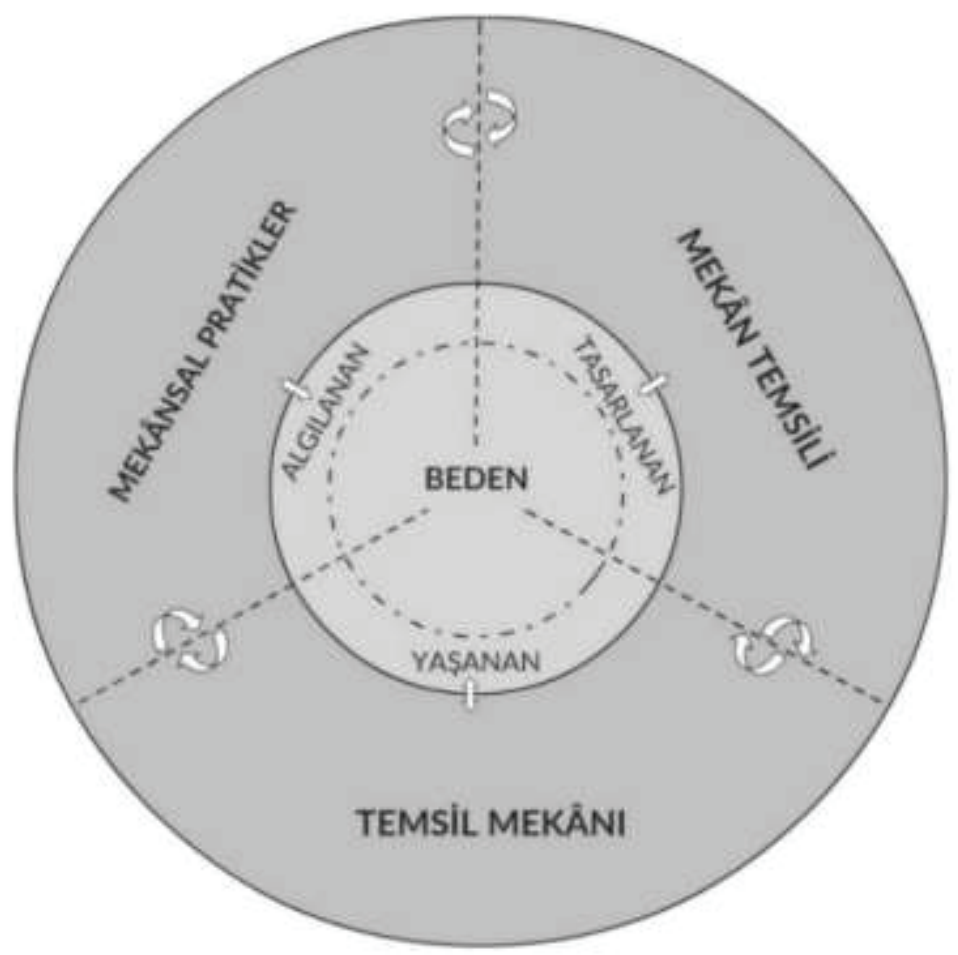

272 Konu ile ilgili aktardıklarımızı yani beden, mekân ve mekân üretim süreçlerinde mekânın üç momentin ilişkileri ve konumu tarafımızca Şekil 3'te grafik olarak yansıtılmaya çalışılmıştır. Herhangi bir sürecin, karşıtlık ve çelişkinin grafik olarak yansıtmanın sorunlu olduğu bir gerçektir. Konu ise mekân, beden, deneyimleme gibi süreçler olunca, böyle bir girişiminyani çok boyutlu, canlı ve akışkan olanın burada da hep eleştirel açıdan değerlendirdiğimiz geometrik olan, tek düzlem ve tasarlanan aracılığıyla yansıtması - daha da sorunlu olduğu bir gerçektir. Dolayısıyla, böyle bir girişimin analitik amaçlarla yapıldığı belirtilmelidir, son tahlilde Lefebvre tarafından mekânın üretimi süreçleri ve mekânın kavramsallaştırması da bir soyutlama içerir.

$273 \mathrm{Bu}$ şema Lefebvre'in kuramına dayanarak yazar tarafindan hazırlanmıştır. 
Mekânsal pratikler "üretimi ve yeniden üretimi, nispi bir bağl1lık içinde süreklilik sağlayan her toplumsal oluşuma has özgül yerleri ve mekânsal kümeleri kapsa[dığ1]"274 için üretim ve yeniden üretimin iç içe girmiş olan üç düzeyle (biyolojik yeniden üretim düzeyi, iş gücünün yeniden üretimi düzeyi, toplumsal üretim ilişkilerin yeniden-üretimi) sıkı bir bağ içerisindedir ve bu bağ aracılığıyla temsil mekânı ve mekân temsili ile bir araya gelir, genel olarak toplumun ve onun her üyesinin, toplumsal mekânla ilişkilerinde yeterlik ve performans sağlamaktadır. ${ }^{275}$ Fakat bu (mekânsal) uyum ve devamlılık dolayısıyla toplumsal üretim ve yeniden-üretim sağlama işlevini görmesi için mekânsal pratikler sembolik temsillere ihtiyaç duyar, çünkü

"Sembolik temsiller aracilığıyla, bu ilişkileri var kılar ve bağdaşık halde tutar. Doğa'nın yardımıyla ve Doğa zemininde bu ilişkilerin yerini değiştirerek, dolayısıyla sembolik tarzda gizleyerek onları sergiler. Yeniden-üretim ilişkilerinin temsilleri-gençlik ve yaşlılık gibi yaşla ilgili semboller olsa da olmasa da- cinsel sembollerden, dişilik ve erkeklik sembollerinden oluşur. Bu sembolleştirme gösterdiğinden fazlasını gizler. Öyle ki bu ilişkiler, cephesel, kamusal, ilan edilmiş ve dolayısıyla kodlanmış ilişkilere ve gizli, yasadışı, bastırılmış ve bundan böyle-sadece mevcut haliyle cinselliği içermekle kalmayan, koşulları ve sonuçlarıyla birlikte cinsel hazzı da içeren- ihlalleri tanımlayan ilişkilere bölünürler. Dolayısıyla mekân, bu işe ayılmış yer ve alanlarda, bu sayısız kesişmeyi içerir. Güç iliş̧kileri içeren üretim ilişkilerinin temsillerine gelince, bunlar da mekânın içinde gerçekleşirler ve mekân bunların temsillerini binalarda, anıtlarda, sanat eserlerinde içerir. Cephesel ilişkiler dolayısıyla çoğu zaman sert olan ilişkiler, yasadışı ve yeraltı veçheleri tamamen engellemez, işbirlikçiler ve polis olmadan iktidar yoktur."276

Bu çalışmanın kuramsal temeli olan Lefebvre'in mekân teorisi ve bu teorinin temel unsurlarının (mekân dönemselleştirmesi ve mekânsal üçlü) somut bir araştırmada kullanılabilmesi için burada yeterli ölçüde ele alındığı ve

274 Lefebvre, Mekânın Üretimi, s. 63.

275 Lefebvre, kendisi de belirttiği üzere yeterlik ve performans kavramlarını Chomsky'nin "Üretici dilbilgisi" kuramından ödünç almıştır. Fakat çalışmasında bu kavramların üzerinde fazla durmadığı ve tanımlamadığı için belirtelim ki Chomsky'nin kuramında yeterlik, bireyin cümleler kurma ve onları anlamaya yönelik temel bilinçaltı yeteneğidir. Bu bir bireyin belirli dilbilgisi kurallarıyla tanıklığıdır, yani "konuşan-dinleyenin kendi dilinin bilgisidir". Yeterlik, bireye sayısız cümleler kurma ve anlamasına imkân sağlar, dahası gramer kurallarına uygun olmayan cümleleri anlamaya da imkân sağlar. Oysa performans "somut durumlarda dilin fiili kullanımıdır" yani belirli bir dilin pratik kullanımını içerir, bu ise yeterliğe her zaman uymayabilir. Daha detaylı bilgi ve açılama için bkz. Chomsky, Aspects of the Theory of Syntax, s. $4 \mathrm{vd}$.

276 Lefebvre, Mekânın Üretimi, s. 62. 
tartışıldığı kanısıyla, bir sonraki bölümlerde artık somut zaman-mekân bağlamında mekânın üretimi süreçleri incelenecektir.

\subsection{Türkiye'de Mekânın Üretimi Literatürünün Kapsamı277}

Bu alt bölümde Türkiye'de mekânın üretimini konu eden araştırmalar ele alınmaktadır. ${ }^{278}$ Türkiye'yi konu eden araştırmalarda mekânın üretiminin sıkça başvurulan bir kuram olduğu görülmektedir ve çok yaygın alanlarda söz konusu kuramın tamamıyla veya onun farklı bileşenlerinin benimsendiği söylenebilir. Bu bakımdan, söz konusu kurama dayanan çalışmalar sadece ele aldıkları konular bakımından değil, ele aldıkları mekânsal ölçek ve zaman dilimi bakımından da kayda değer çeşitlilik göstermektedirler. Örneğin, Lefebvre'in söz konusu kuramının farklı kavramsal çerçeveleri edebiyat, ${ }^{279}$ iletişim, ${ }^{280}$ sinema, ${ }^{281}$ performans, ${ }^{282}$ toplumsal cinsiyet ve queer ${ }^{283}$ araştırmalarında kullanılması gittikçe yaygınlaşmakla beraber, mekânla daha doğrudan ilişkili mimarlık,

277 Bu alt bölüm ilk kez, SAGE Open dergisinde Lefebvre's Production of Space in the Context of Turkey: A Comprehensive Literature Survey başlıklı makalede yayımlanmıştır. Bkz. Ghulyan, Husik. "Lefebvre's Production of Space in the Context of Turkey: A Comprehensive Literature Survey." SAGE Open, (July 2019). doi:10.1177/2158244019870537.

$278 \mathrm{Bu}$ alt bölümdeki gerek nitel gerekse nicel değerlendirme ve saptamalar, birtakım akademik veri tabanlarında bulunan akademik yayınların, belirli kriterlere dayanarak yapılan birkaç aşamalı taramasının ve ortaya çıkan yayınların belirli sorular doğrultusunda incelenmesine dayanmaktadır. Veri tabanlarında yapılan taramanın kriterleri, ortaya çıkan çalışmaların listesi ve söz konusu çalışmaları belirli sorular doğrultusunda incelemesine dair nicel ve nitel detaylar için bu kitabın EK 1'inde yer alan açıklamalar ve sunulan tabloya başvurulmalıdır.

279 Mirze, "Disorientation: 'Home' in Postcolonial Literature"; Salman, "Didem Madak Şiirinde Zaman ve Mekân"; Şişmanoğlu, "Behçet Necatigil ve Şiirin Ev Hali"; Yeşil, "Psikocoğrafya ve Bir Şehir Gezgininin Anıları"; Kutlar, "Sa'dâbâd Şiirlerinde Mekân”.

280 Demirkol, "Gündelik Hayat ve Basın: Gırgır Mizah Dergisinde Gündelik Hayatın Dönüşümü, 1972 - 1989".

281 Aslan, “Aaahh Belinda' Filmini Lefebvre İle Okumak Nasil Olurdu?”; Atabey, "Representing a (Post-)Modern City: The Portrayal of Istanbul in Recent Turkish Films"; Ercan, "Türkiye Sinemasında Müphemleşen Mekân: A Ay ve Karanlık Sular"; Sarı, "Türk Sinemasında Sosyal Yaşam Kurgusunun Mekan Kullanımına Yansıması"; Uzunali, "Zeki Demirkubuz Sinemasında Mekân Kullanımı".

282 Selen, "The Work of Sacrifice: Gender Performativity, Modernity, and Islam in Contemporary Turkish Performance (1980s-2000s)"; Selen, "The Stage: A Space for Queer Subjectification in Contemporary Turkey"; Kılıç-Çalgıcı, "Gündelik Hayatın Tiyatrosu: Alsancak'ta Teatral Etkinlikler".

283 Pasin, "A Critical Reading of the Ottoman-Turkish Hamam as a Queered Space"; Selen, "The Work of Sacrifice: Gender Performativity, Modernity, and Islam in Contemporary Turkish Performance (1980s-2000s)"; Selen, "The Stage: A Space for Queer Subjectification in Contemporary Turkey." 
kentsel planlama ile kent araştırmaları, ${ }^{284}$ kentsel toplumsal hareketler ${ }^{285}$ gibi alanlarda söz konusu kuramın doğal olarak daha yaygın biçimde benimsendiği görülmektedir. Özellikle Gezi Hareketi'nden sonra Türkiye ile ilgili mekânın üretimi literatüründe Lefebvre'in kuramı bağlamında bu hareketi ele alan çok sayıda çalışma ${ }^{286}$ bulunduğu belirtilmelidir. ${ }^{287}$

Özellikle 2000 sonrası dönemde yaygınlık kazanan kentsel dönüşüm ve gelişim projeleriyle ilgili süreçleri incelemek için bu kurama sıkça başvurulduğ ${ }^{288}$ da görülmektedir. Mevcut çalışmalarda yaygın olarak görülen

284 Baş, "Production of Urban Form As the Reproduction of Property Relations Morphogenesis of Yenişehir - Ankara"; Çınar, "Beyond Possibilities: Re-Reading Republican Ankara"; Gegelioğlu ve Aydınlı, "Mimarlık Üretimi Üzerine Bir İç Hesaplaşma: Tüketim Dinamiklerinin Uzantısında Mimari Bir Duruş"; Karakaya, "Construction of the Republic in City Space: From Political Ideal to Planning Principles"; Kaypak, "Atatürk'ün Kent Ve Kentleşmeye Bakışı;Ankara'nın Kentleşmesi”; Kaypak, "Türk Aydınlanması'nın Kent ve Kentleşmeye Bakışı"; Koçak, "Social and Spatial Production of Atatürk Boulevard in Ankara"; Turhanoglu, "Spatial Production of Ankara as Capital City of Republican Turkey"; Wilson, "Remembering and Forgetting in the Funerary Architecture of Mustafa Kemal Atatürk: The Construction and Maintenance of National Memory".

285 Ergin, "An Analysis of Urban Struggles in the Process of Practices of Urban Commoning: Resistance on 'Uncommon Ground' 'in, for and beyond' İstanbul”; Firat, "'Ve madem ki sokaklar kimsenin değil",": Talan, dolandırıcılık ve hırsızlığa karşı kentsel müşterekler yaratmak"; Batuman, "Imagination as Appropriation: Student Riots and the (Re)Claiming of Public Space"; Erdi-Lelandais, "Citizenship, Minorities and the Struggle for a Right to the City"; Erdi-Lelandais, "Right to the City as an Urban Utopia? Practices of Every Day Resistance in a Romani Neighbourhood in Istanbul"; Erdi-Lelandais, "Space and Identity in Resistance against Neoliberal Urban Planning in Turkey"; Ergin, "Grassroots Resistance Against Urban Renewal: The Case of Güzeltepe, İstanbul".

286 Hornstein, "Spatial Perspectives of Contention: Space, Place, and Policing in the 2013 Gezi Park Protests"; Batuman, "Gezi'nin Söz Hali: Mekan, Temsil, Dil”; Castagno, "Lightning in the Night: Transgression in Urban Design"; Erol, "Re-Territorialisation and the Sites of Autogestion within the Periphery: Counter-Hegemonic Socio-Spatial Movements in Turkey."; Erol, "Kamusal Alanda Muhalif Beden"; Eryılmaz, "The Spatial Analysis of Gezi Movement in Turkey”; Batuman, “"Everywhere Is Taksim': The Politics of Public Space from Nation-Building to Neoliberal Islamism and Beyond"; Işıklılar, "Heterotopic Practice of Space: Taksim Gezi Park Revisited”; Karasulu, “If a Leaf Falls, They Blame the Tree': Scattered Notes on Gezi Resistances, Contention, and Space"; Koyuncu, "Yeni Bir Kentsel Mekanın Göstergesi Olarak Taksim Gezi Parkı Eylemleri”; Şengül, "Gezi Başkaldırısı Ertesinde Kent Mekânı ve Siyasal Alanın Yeni Dinamikleri”; Yılmaz, "Gezi Movement: An Analysis in the Context of Place/Space, the Discursive Practices and the Society".

287 Burada Gezi Hareketi, Lefebvre'in kent hakkı bağlamında ele aldığı çalışmalar değil, Lefebvre'in, mekânın üretimi kuramının farklı kavramsallaştırmalara dayanan çalışmaları kast edilmektedir, fakat Gezi Hareketi'nin özü itibarıyla daha çok kent hakkı bağlamında ele alındığı da belirtilmelidir.

288 Basa, "Kentsel Hafızanın Sürdürülebilirliği: Bir Mimarlık Stüdyosu Deneyimi”; Baydar ve diğerler, "Digitizing Lefebvre's Spatial Triad"; Eranıl, Tuna, ve Demirtaş-Milz, "A SocioSpatial Analysis of Urban Transformation at a Neighborhood Scale: The Case of the 
diğer eğilim, tekil olgu, olay, süreçler, bina ve projelerin incelenmesi için söz konusu kuramın benimsenmesidir ${ }^{289}$ ki bu tür çalışmalara yukarıda belirtilen edebiyat, sinema vb. alanlardaki araştırmaları da katmak gerekir.

Mevcut çalışmalar, benimsedikleri mekânsal ölçek ve inceledikleri tarihsel kesit açısından da ilginç bir tablo sunmaktadır, şöyle ki somut mekânsal ölçek benimsenen çalışmaların yaklaşı \%80'i İstanbul, Ankara ve İzmir'de farklı mekânsal ölçek ile tarihsel dönemleriyle ilgili süreçleri konu etmekte, böylece Türkiye'de kent ve mekân çalışmalarının İstanbul ve Ankara odaklı olması genel eğilimiyle paralellik göstermektedir. Çalışmaların ele aldığ tarihsel dönem de bu açıdan ilginç bir tablo sunmaktadır. Çeşitli mekânsal ölçek, olaylar ve süreçleri konu eden çalışmaların önemli bir bölümü 2000 sonrası dönem üzerine yoğunlaşmaktadır. Kayda değer sayıda çalışma tarafindan konu edilen diğer tarihsel dönem Erken Cumhuriyet dönemidir yani 1930-40 aras1 dönemi kapsamaktadır. S1k sık ele alınan üçüncü dönem ise 1960-70 arası dönemdir.

Ele alındığı üzere, Lefebvre'in mekânın üretimi kuramında birbiriyle sıkı ilişkili iki temel bileşen mevcuttur - mekân dönemselleştirmesi ve mekânsal üçlü - ve belirtildiği üzere Lefebvre'in mekân kuramının özgünlüğü bu iki bileşen beraber değerlendirildiğinde görülmektedir. Bu bağlamda Türkiye'de mevcut çalışmalara detaylı olarak bakıldığında Lefebvre'in kuramının benimsemesi ile ilgili birtakım kayda değer eğilim görülmektedir. ${ }^{290}$

Relocation of Kadifekale Inhabitants to TOKİ Uzundere in İzmir"; Demirtaş-Milz ve Saraçoğlu, "Space, Capitalism and Kurdish Migrants in İzmir: An Analysis of Kadifekale's Transformation"; El-Kazaz, "Building Politics: Urban Transformation and Governance in Cairo and Istanbul"; Önder, "A Tale of an Uneven Urban Development: The Socio-Economic and Socio-Cultural Contradictions of Tarlabasi Renewal Project"; Penpecioglu, "The Political Construction of Urban Development Projects: The Case of Izmir".

289 Atıc1, "The Construction of Public Realm in Contemporary Art: Reading on International Istanbul Biennial"; Casier, "Beyond Kurdistan? The Mesopotamia Social Forum and the Appropriation and Re-Imagination of Mesopotamia by the Kurdish Movement."; Gür, "Sculpting Turkish Nationalism: Atatürk Monuments in Early Republican Turkey"; Pasin, "Dişil bir Temsili Mekân Olarak Türk Hamamı"; Pasin, "A Critical Reading of The OttomanTurkish Hammam as a Representational Space Of Sexuality"; Pasin, "A Critical Reading of the Ottoman-Turkish Hamam as a Queered Space"; Pekasil, "Mardin Süryanilerinde Belleğin Teolojik-Kültürel Çerçevesi"; Sarıtaş, "Video in the City Possibilities for Transformation in the Urban Space"; Turan, "Mekan-Müzik İlişkisi Açısından Türkiye'de 'Taverna”".

290 Bundan sonraki saptamalar, değerlendirilmiş olan çalışmaların (bkz. EK 1) her biri için geçerli olmadığı ve değerlendirilmiş çalışmaların her birinin bu saptamalara tabi olmaması, var olan saptamaların Türkiye ile ilgili mekân ve mekânın üretimi literatüründeki sadece genel eğilim ile ilgili olduğu öncelikle belirtilmelidir. 
İlk olarak, çalışmaların büyük çoğunluğunda, Lefebvre'in mekân kuramının sadece mekânsal üçlü unsuru ${ }^{291}$ veya bu üçlünün bir veya iki unsuru benimsenerek ${ }^{292}$ somut bağlamlarda kullanıldığı görülmektedir. Aynı zamanda

291 Hornstein, "Spatial Perspectives of Contention: Space, Place, and Policing in the 2013 Gezi Park Protests"; Ağlargöz, "We Are at This Campus, There Is Nothing in This Campus ...': Socio-Spatial Analysis of a University Campus"; Basa, "From Praise to Condemnation: Ottoman Revivalism and the Production of Space in Early Republican Ankara"; Basa, "Producing Representational Spaces for the Republican Memory in Samsun, Turkey."; Baydar ve diğerler, "Digitizing Lefebvre's Spatial Triad"; Ceylan, "The Impacts of PostDisaster Spatial Structure on Low Income Women: The Case of Düzce"; Eran1l, Tuna, ve Demirtaş-Milz, "A Socio-Spatial Analysis of Urban Transformation at a Neighborhood Scale: The Case of the Relocation of Kadifekale Inhabitants to TOKİ Uzundere in Izmir"; El-Kazaz, "Building Politics: Urban Transformation and Governance in Cairo and Istanbul"; Ergin, "Grassroots Resistance Against Urban Renewal: The Case of Güzeltepe, İstanbul"; Erkıllç ve Bayraktar, "Resimli ve Temsili Bir Triyalektik Mekân Okuması Olarak Ekümenopolis"; Gegelioğlu ve Aydınlı, "Mimarlık Üretimi Üzerine Bir İç Hesaplaşma: Tüketim Dinamiklerinin Uzantısında Mimari Bir Duruş"; Genç, "Politics in Concrete: Social Production of Space in Diyarbakir, 1999-2014"; Altay, "Urban Spaces Re-Defined in Daily Practices: The Case of "Minibar', Ankara"; İlkay, "The Political Struggle on and at Public Space: The Case of Kizilay Square"; Kayalıgil, "Spaces of Conflict: Memory, Musealization and Heterotopia in the City of Sivas, Turkey"; Khakee ve Grassini, "Understanding Multiple Aspects of Present Space With the Help of Future Scenarios: The Case of Izmir, Turkey"; Koyuncu, "Yeni Bir Kentsel Mekanın Göstergesi Olarak Taksim Gezi Parkı Eylemleri"; Kulözü, "Transformation of Public Space: The Case of Hacibayram Square"; Önder, "A Tale of an Uneven Urban Development: The Socio-Economic and Socio-Cultural Contradictions of Tarlabasi Renewal Project"; Salah, "Sayfiye to Banlieue: Suburban Landscape Around Anatolian Railways, from Mid-Nineteenth Century to the World War II"; Sand1kc1, "Strolling Through Istanbul's Beyoğlu: In-Between Difference and Containment”; Turhanoglu, "Spatial Production of Ankara as Capital City of Republican Turkey"; Y1lmaz, "Gezi Movement: An Analysis in the Context of Place/Space, the Discursive Practices and the Society"; Yüksekli, "Balıkesir Atatürk Parkı: Erken Cumhuriyetten Günümüze Türkiye'de Değişen Söylem ve Tasarımın Bir Kent Park Üzerinden Örneklenmesi”; vd.

292 Aslan, "Söylem ve Deneyimde Kamusal Mekanın Dönüşümü: Bursa Kent Meydanı Örneği”; Mert, "Postyapısalcı Mekan Analizine Doğru: İstanbul, Kent ve Müzik”; Aslan, "Aaahh Belinda' Filmini Lefebvre İle Okumak Nasıl Olurdu?”; Ateş, “A Spatial Impromptu: Green Resistance by Guerrilla Gardening"; Basa, "Kentsel Hafızanın Sürdürülebilirliği: Bir Mimarlık Stüdyosu Deneyimi”; Batuman, “Gezi’nin Söz Hali: Mekan, Temsil, Dil”; Berber, "Metropol Mimarlık ve Yerleşme Sorunu"; Demirtaş, "Artificial Nature: Water Infrastructure and Its Experience as Natural Space"; Gulhan, "The Honorable Exception: State and the Social Production of Concrete Space in Istanbul"; Jongerden, The Settlement Issue in Turkey and the Kurds : An Analysis of Spatial Policies, Modernity and War; Kılıç-Çalgıcı, "Gündelik Hayatın Tiyatrosu: Alsancak’ta Teatral Etkinlikler"; Akaslan, "Etkinliğini Yitirmiş Kentsel Mekanların Kent Yaşamına Katılması"; Mirze, "Disorientation: 'Home' in Postcolonial Literature"; Özgün, "The Sounds of Political Actions in the Streets of Istanbul"; Pasin, "Femaleness, Femininity and Feminotopia: The Female Hamam as a Homosocial Space"; Salman, "Didem Madak Şiirinde Zaman ve MekâN"; Serin, "The Promised Territories: The Production of Branded Housing Projects in Contemporary Turkey"; Şişmanoğlu, "Behçet Necatigil ve Şiirin Ev Hali"; Tirben, "Lived Space of White Collar Industrial Employees: A 
çalışmalarda söz konusu kuramın mekân dönemselleştirmesi unsurunun kullanımı genellikle mevcut değildir. Elbette bazı konuların incelenmesi için söz konusu kuramın mekân dönemselleştirmesi unsuru araştırmacılarca bir çerçeve olarak benimsenmesini beklemek gerçekçi olmaz, zira özü itibarıly belirli konular için söz konusu çerçeve müsait bir çerçeve değildir, fakat bazı çalışmaların Lefebvre'in kuramına dayanmasına ve çok geniş bir tarihsel dönem için inceleme gerçekleştirmelerine rağmen, mekân dönemselleştirmesine başvurmamaktadırlar, onun yerine incelemeleri Türkiye'de yaygın kabul gören siyasal tarih dönemlerine göre yapmakta, böylece analizler mekânın tarihi yerine tarihin mekânını öne çıkartmaktadırlar.

Söz konusu kuramdan örneğin sadece mekân temsili veya temsil mekânı kavramlarını benimseyip kullanıldığı durumlar birtakım içerimler barındırmaktadır. Belirli konuların incelenmesi için mekânsal üçlünün bir veya iki unsurunu üçlüden ve kuramdan ayırıp benimsenmesi ve somut bağlamda kullanılması ilgili çalışmalarda ele alınan konulara göre aslında uygun bir yaklaşımdır. Şöyle ki örneğin Lefebvre tarafından temsil mekanları edebiyatçıların 'mekânı', mekân temsili planlamacıların ve mimarların 'mekânı', mekânsal pratikleri ise üretim ilişkilerinin (yeniden) üretimini sağlamaya yönelik mekân olarak tanımlandığı için, bir edebiyat eserinin (roman veya şiir) temsil mekânı bağlamında, bir projenin mekân temsili bağlamında veya kentsel mekânın kullanımının mekânsal pratikleri bağlamında değerlendirilmesi uygun tercih olabilmektedir ve Lefebvre'in kuramının bu denli farklı alanlarda uygunlaştırılması kayda değerdir. Fakat böyle bir yaklaşım eğer kendi başına sadece bir edebiyat eseri, bir proje veya mekân kullanımının sadece bir veya iki tarafinın incelenmesini hedefliyorsa, böyle bir yaklaşımın, Lefebvre'in, pozitivist bilimin mekânı ayrıştırıp incelemesi hususuna defalarca yönelttiği eleştirisinden muaf kalmadığı söylenebilir. Ayrıca söz konusu üç unsurun ayrıksın incelenmesi eğer Lefebvre'in kuramının - üretimi ve üretim ilişkilerini merkezinde bulunduran bir kuramın - temellerini göz önünde bulundurmuyorsa, bunların kullanımı sadece müsait mecaz kavramları olarak karşımıza çıkma ve sadece betimleyici gücü olan kavramsallaştırmalara dönüşme ihtimalini doğurmaktadır, ki yine Lefebvre'in defalarca eleştirdiği bir durumdur. Son olarak, örneğin pozitivist coğrafya, mekânsal pratikleri ve mekân kullanım ritimleri konusunda gerek yöntemsel gerekse kavramsal açıdan önemli imkanlar sunmaktadır (örneğin Torsten Hägerstrand'ın külliyatı bunun en iyi örneğidir),

Case From Kocaeli"; Turan, "Mekan-Müzik İlişkisi Açısından Türkiye'de 'Taverna"”; Uludağ, "The Social Construction of Meaning in Landscape Architecture: A Case Study of Gençlik Park1 in Ankara"; Wilson, "Remembering and Forgetting in the Funerary Architecture of Mustafa Kemal Atatürk: The Construction and Maintenance of National Memory"; Yildiz, "'Precarity' of the Territorialized State: Immigrants Re-Drawing and ReMapping the Borders"; vd. 
hatta pozitivist özelliğinden dolayı olguların bir veya iki tarafı daha iyi ve detaylı incelemesine imkân sağlamaktadır. Benzer biçimde pozitivist bilim planlamacılarının ve mimarların 'mekanlarını' incelemek için önemli kavramsal çerçeve ve yöntemler sunmaktadır. Bu bakımdan herhangi bir araştırma eğer mekânın farklı boyutlarını ayrıştırıp onlardan bir veya ikisini incelemeyi hedeflemekteyse ve bu doğrultuda Lefebvre'in bütünsel niteliğinde olan kuramını da ayrıştırıp bir veya iki kavram benimsemektense (üretimi ve üretim ilişkileri hesaba katmadan), pozitivist bilimlerin imkanlarına başvurulması ontolojik, epistemolojik ve metodolojik aç1lardan belki daha uygun bir tercih olabilir.

Gözlemlenen diğer ilginç eğilim, mekânsal üçlü somut bağlamlarda kullanıldığında, üçlünün farklı unsurlarının da birbirinden ayrılmasıdır. Şöyle ki, örneğin bir park ele alındığında temsil mekânı olarak ya da bir yapı ele aldığında mekân temsili olarak değerlendirilmekte veya tanımlanmaktadır. Böyle bir yaklaşım ise, bir parkın mekân temsili boyutu ya da bir yapının temsil mekânı boyutunu analiz dışı bırakmaktadır. Oysa Lefebvre'in kuramında her bir mekân, yap1 veya sürecin mekânsal pratikler, mekân temsili ve temsil mekânı boyutu olması ve mekânın incelenmesinde bu üç unsurun hesaba katması gerekliliğinden söz edilmektedir.

Bu kuramın mekân dönemselleştirmesi unsuruna başvuran çoğu çalışmada ise söz konusu dönemselleştirmeye göre inceleme yapıp somut bağlamda bir dönemselleştirme önermek yerine, dönemselleştirmenin farklı unsurlarını (soyut mekân, çelişkili mekân vs.) bağlamından ayırıp, belirli süreçleri açıklamak ve değerlendirmek için kullanmaktadırlar. Bununla yakından ilgili diğer eğilim, dönemselleştirmenin bazı unsurlarının farklı okumalarıdır, şöyle ki bazen soyut mekânı ele alındığında tartışma soyut mekân ile sosyal mekân (ya da soyut mekân ile somut mekân) karşıtlığına dayandırılmaktadır, bu husus ise sosyal mekânın soyutlaşma ve mekânın algılanan boyutunu soyutlama hususunu hesaba katmamaktadır. Böyle bir kullanımla aynı zamanda soyut mekân ile mekân temsili kavramları eşanlamlar olarak değerlendirilmektedir. Böyle bir okuma belirli durumlar için uygun olabilir (örneğin planlama aracıllğıyla belirli bir mekân temsilinin üretimi soyut bir mekâna yol açabilir), fakat böyle bir okuma ile soyut mekân kavramı mekânın tarihinin bir evresi olmaktan çıkmaktadır ve şu soruyu öne çıkarmaktadır: eğer soyut mekân ile mekân temsili aynı şeyi ifade ediyorlarsa o zaman soyut mekânın olmadığı toplumlarda mekân temsili neye tekabül etmektedir? Kısacası, Lefebvre'in mekân kuramının böyle bir okunmasiyla kuramda soyut ile somut (veya soyut ise sosyal) mekân arasındaki ayrım ve çelişkilerden söz ettiği iddia edilmektedir, böyle bir okumayla böylece bir taraftan soyut mekân kavramı mekân temsili kavramının eşanlamlısı haline getirilmektedir, diğer taraftan soyut ile somut (sosyal) mekânlar arasındaki 
çelişkileri bir mekânsal evre olan soyut mekân kapsamında geliştiği hususu ihmal edilmektedir.

Diğer kayda değer eğilim, soyut mekânın sadece kapitalist üretim ve mülkiyet ilişkileri bağlamında ortaya çıkmasını ve soyut mekânın politik boyutlarını hesaba katmama eğilimidir, politik boyutu ise ancak kapitalist gelişmelerin politik faktörleri bağlamında ele alınmasıdır. Örneğin, Baş, Sulukule'de Roman mahallesinde gerçekleştirilen kentsel dönüşüm projesiyle mahalledeki mülkiyet ilişkilerinin değiştiğini ve bununla burada soyut mekânın ortaya çıktığını belirtmektedir, ${ }^{293}$ ki soyut mekân tanımına göre çok yerinde bir tespittir. Fakat aynı araştırmada belirttiği üzere Sulukule'de yaşayan Romanlar, kendilerini ilk önce Türk, sonra Müslüman ve ancak sonra Roman (Çingene) olarak tanımlamaktadır, bu ise toplumsal mekânın üretimi süreçlerinde soyut mekânın bir başka boyutunun çok daha önce ortaya çıtığııı göstermektedir ulus devletleşme ile ortaya çıkan soyut mekân.

Son olarak çalışmalarda görülen bir diğer eğilim, soyut mekân kavramının çok genel anlamda, bir nevi deus ex machina ${ }^{294}$ olarak kullanılmasıdır, şöyle ki soyut mekân tanımı gereğince, kapitalizmde üretilmekte olan bir mekân olması itibariyle, bazı çalışmalarda somut bağlamlarda mekânın tanımlanması için soyut mekân kavramına başvurulmaktadır, oysa soyut mekânın somut bağlamlarda nasıl ortaya çıktığı, ne özellikler gösterdiği hususlarına odaklanılmamaktadır. Öyleyse nas1l 'kapitalizm' ve 'kapitalistler' sözcüğ̈̈ kimilerince her şeyi açılabilecek nitelikte bir nevi deus ex machina kavramı olarak kullanılıyorsa, mekân araştırmalarında da benzer biçimde soyut mekân, her şeyi açıklayabilen, zor durumlarda araştırmacıların yardımına koşan ve argümanları 'zenginleştiren' bir nevi deus ex machina niteliğinde içi boş ve sadece betimleyici bir kavram olarak karşımıza çıkmaktadır.

Lefebvre'in kuramını yorumlayan bir diğer yaygın eğilim, kuramdaki mekân dönemselleştirmesini ele alan çoğu çalışmada genellikle birbirini takip eden mutlak mekân, soyut mekân ile diferansiyel mekânlardan söz ederek, Lefebvre tarafindan ele alınan kutsal mekân, tarihsel mekân (veya birikim mekânı) ile çelişkili mekân kavramlarının ihmal edilmesidir. Daha önce de belirtildiği üzere, Lefebvre'in çalışmasında kutsal mekân veya tarihsel mekân kavramı özel olarak vurgulanan bir kavram olarak öne çıkmamaktadır, hatta çalışmanın yapısında bu mekân ile ilgili ayrı bir bölüm mevcut değildir ve Lefebvre tarafindan söz konusu mekânlara yapılan vurgu ancak onun eserlerinin

293 Bkz. Baş, "Reading Sulukule As a Social Production of Space: Ownership/Possession and Boundaries of the Dwelling".

$294 \mathrm{Bu}$ deyim, bir romanda veya tiyatro oyununda beklenmedik zamanda yetișen ve zor durumlara son veren, çözülemeyen sorunlara çözüm bulan güçler, kişiler veya nesnelerin tanımı için kullanılmaktadır. 
detaylı bir okuması yapılarak ortaya çıkmaktadır. Ayrıca, Lefebvre, soyut mekân ile çelişkili mekân kavramlarını muğlak ve karmaşık biçimde ele aldığı için, bu kuramı 'benimseyenler' soyut mekânın çelişkili mekâna tekabül ettiğini ve çelişkili mekânın soyut mekândan farklı olmadığını öne sürmektedirler. Böyle bir okuma ise söz konusu mekânsal dönemselleştirme çerçevesini sadece üç mekân evresine indirgemektedir.

Fakat mevcut literatürde birtakım çalışmalar söz konusu kuramın parçacı okumas1 yerine hem mekân dönemselleştirmesinin hem de mekânsal üçlünün unsurlarını bir arada değerlendirerek somut bağlamda kayda değer incelemeler sunmaktadır. Bu çalışmalardan söz edilirse Ali Ekber Doğan'ın Kayseri örneğinde yapılan ve 1994-2004 dönemi kapsayan İslamcı belediyecilik ile mekânın üretimi süreçlerini konu eden çalışmasını belirtmek gerekir. ${ }^{295}$ Doğan gerek kuramsal tartışmasında gerekse somut incelemelerinde ilgili dönem için söz konusu kavramsal çerçevelerinin uygunlaştırılmasının iyi bir örneği sunmaktadır. Bu çalışma Kayseri'de mekânın üretimi süreçlerinin genel kabul görmüş siyasal tarih dönemlerine göre ele alınmasına rağmen, çalışmada incelenen temel dönem olarak 1994-2004 arası dönemde mekânın üretimi süreçleri özellikle çelişkili mekân bağlamında ele alınması ve İslamcı belediyecilik pratiklerinde üretilmekte olan mekânın algılanan, yaşanan ve tasarlanan boyutlarının değerlendirilmesi kayda değerdir. Neslihan Demirtaş'ın, Ankara'nın Mamak İlçesinde, Boğaziçi Mahallesi örneğinde 1950 sonrasi dönemde Türkiye'de gecekondu oluşumunun Lefebvre'in çerçevesiyle alternatif bir yerel tarih okuması sunan çalışması gecekondu araştırmalarında Lefebvre'in kuramının yerelleştirilmesinin önemli bir örneği olarak öne çıkmaktadır. ${ }^{296}$ İlker Cörüt'ün, AKP'nin asimilasyon stratejisi ve mekânın üretimi bağlamında Hakkâri'de doktorların zorunlu kamu hizmetlerini ele alan etnografik çalışması ise doktorlara yönelik mecburi kamu hizmetini düzenleyen yasayı soyut mekân bağlamında değerlendirmektedir. ${ }^{297}$ Cörüt’ün çalışmasında öne çıkan husus, soyut mekân kavramı, sermaye tarafindan üretilen ve biçimlenen bir mekândan ziyade milliyetçi elitler tarafindan belirli bir mekân temsili - homojen ulusal mekân tahayyülü - doğrultusunda üretilen mekân olarak tanımlanarak bu doğrultuda Hakkari'de doktorların zorunlu kamu hizmetlerinin ele alınmasıdır. Bu açıdan, Cörüt'ün soyut mekân kavramı bir mekân temsili olarak öne çıksa da

295 Doğan, "İslamc1 Belediyelerin on Y1l1 (1994-2004): Kayseri Örneğinde Sosyo-Mekansal Bir Çözümleme".

296 Demirtaş, "Critical Moments of Social Spatialization in The Neighborhood: An Alternative Reading of The Mainstream Gecekondu History".

297 Cörüt, "An Ethnographic Account of Compulsory Public Service by Doctors in Hakkari: The Limits of the AKP Assimilation Strategy and the Production of Space". 
çalışmanın kayda değer tarafı, Lefebvre'in kuramını benimseyen çalışmaların çoğuna kıyasla, soyut mekânın politik boyutlarını ele almasıdır.

Seher Şen'in, Erken Cumhuriyet Dönemi'nde Ankara'da modernleşme, enformel pratikler ve kentliliğin inşası bağlamında mekânın üretimi süreçleri Lefebvre'in soyut mekân ve mekânsal üçlüsü bağlamında ele alan çalışması mevcut çalışmalarda öne çıkan bir diğer örnektir. ${ }^{298}$ Benzer biçimde, 1923 'ten günümüze dek planlama ve mimarinin toplumsal ilişkileri bağlamında Ankara'nın kentsel mekânının üretimini Atatürk Bulvarı, Sıhhiye, Ulus ve Kızılay Meydanları örneğinde inceleyen Feryal Ayşin Koçak'ın çalışması belirtilmelidir. ${ }^{299}$ Koçak, kuramsal tartışmasında sadece mutlak, soyut ve diferansiyel mekân kavramları ele alınmasına ve analizi genel kabul görmüş siyasal tarih dönemselleştirmelere (Erken Cumhuriyet dönemi, 1923-1950; Demokrat Parti dönemi, 1950-1960; Planlı ekonomik kalkınma Dönemi, 19601970; Ekonomik kriz dönemi, 1970-1980; Neoliberalizm dönemi, 1980-1994; Neoliberal muhafazakâr dönemi, 1994-) göre yapmasına rağmen, analizde gerek soyut mekân kavramına gerekse mekânsal üçlüye başvurması kayda değerdir.

Demirtaş-Milz ve Saraçoğlu tarafından İzmir'de Kürt göçmenlerin yoğun olarak yaşadığg Kadifekale gecekondu bölgesi ve Kadifekale Kentsel Dönüşüm Projesinin ele alınması da önem arz etmektedir. ${ }^{300}$ Kadifekale Kentsel Dönüşüm Projesi'ni soyut mekânın üretimi olarak değerlendiren bu çalışma dönüşüm projesini belirli çevrelerin soyut mekân temsili olarak tanımlamaktadır. Böyle bir tanımla soyut mekân bir mekân temsiline indirgenmesine rağmen, çalışmada Lefebvre'in kuramının her iki unsurunun kavramlarının bir arada değerlendirilmesi kayda değerdir.

Çağrı Eryılmaz'ın, Gezi Parkı ve Taksim Meydanı bağlamında Lefebvre, Harvey ile Bookchin'in kuramsallaştırmalarına dayanarak Gezi Hareketi'nin mekânsal çözümlemesini sunan, Gezi hareketini Türkiye'de neoliberal politikalar bağlamında üretilmekte olan soyut mekâna karşı bir tepki olarak tanımlayan ve hareket sırasında diferansiyel mekânın üretiminden söz eden çalışması, soyut ve diferansiyel mekân kavramlarının ve mekânsal üçlünün somut bağlamda uygunlaştırması açısından önemlidir. ${ }^{301}$

Mevcut çalışmalar arasında Lefebvre'in kuramını bir bütünlük olarak ele alıp uygulamaya çalışan araştırmalardan ayrıca Ergin'in, 2010 sorası dönem için

298 Şen, "The Production of Space and The Construction of Urbanity: Informal Practices in 1930s Ankara".

299 Koçak, "Social and Spatial Production of Atatürk Boulevard in Ankara".

300 Demirtaş-Milz ve Saraçoğlu, "Space, Capitalism and Kurdish Migrants in İzmir: An Analysis of Kadifekale's Transformation".

301 Eryılmaz, "The Spatial Analysis of Gezi Movement in Turkey". 
İstanbul örneğinde kentsel dönüşüm projelerine karşı gelişen kentsel toplumsal hareketlerini, direniş biçimlerini ve dinamiklerini ele alan çalışması, Gülkök'ün 1923-2013 arası dönem için Ankara'da Atatürk Bulvarı örneğinde kaldırımların üretimi, yeniden üretimi ve yıkım süreçlerini ele alan çalışması, Pasin'in, 1970 sonrası dönem için İstanbul, Ankara ve İzmir'de Osmanl1-Türk hamamının queered bir mekâna dönüşmesi süreçlerini ele alan çalışması belirtilmelidir. ${ }^{302}$

Son olarak konu ile ilgili Bülent Batuman'ın külliyatı dikkat çekicidir. Batuman, farklı konuları ele alınan çok sayıda çalışmasında Lefebvre'in kuramının farklı kavramsallaştırmalarına dayanan kayda değer incelemeler sunmaktadır. Bu çalışmalardan herhangi birinde Lefebvre'in kuramının bir bütünlük olarak ele alınması ve uygulaması söz konusu olmamakla birlikte bu çalışmalarda, Lefebvre'in kuramının somut bağlamlarda özgün ve verimli uygunlaştırmalar mevcuttur. ${ }^{303}$

Bu çalışması, Ankara örneğinde 1923'ten günümüze (2002 sonrası dönem üzerine özel vurguyla) mekânın üretimi süreçlerini ele almayı amaçladığı için burada Lefebvre'in kuramına farklı biçimlerde dayanan ve Ankara'yı konu eden çalışmalarına kısaca değinilmesi ele alınacak alanın söz konusu kuramsal çerçeveden ne derecede ve nasıl ele alınıp alınmadığı hususunu aydınlatarak bir sonraki tartışmalarımıza katkı sağlayabilir aynı zamanda bu çalışmanın mevcut çalışmalardan nasıl farklılaşacağını da ortaya koyabilir.

Ankara'yı konu eden ve Lefebvre'in kuramsallaştırmalarına farklı biçimlerde dayanan çalışmalara bakıldığında, en yoğun olarak ele alınan tarihsel dönem olarak 1923-1950 arası dönem öne çıkmaktadır. Söz konusu dönemde Ankara, Cumhuriyetin modernleşme projesinin mekânın üretimi süreçlerinin 'sahnesi' olduğu ve bu süreçte kentin kökten yeniden biçimlenmesi gerçekleştirildiğinden dolayı, araştırmacıların bu dönemi yoğun olarak konu etmesi tesadüf değildir. Diğer öne çıkan husus Cumhuriyetin kuruluşundan

302 Ergin, "An Analysis of Urban Struggles in the Process of Practices of Urban Commoning: Resistance on 'Uncommon Ground' 'in, for and beyond' İstanbul"; Gülkök, "Production of Sidewalks; the Case of Ataturk Bouleward"; Pasin, "A Critical Reading of the OttomanTurkish Hamam as a Queered Space".

303 Batuman, "Imagination as Appropriation: Student Riots and the (Re)Claiming of Public Space"; Batuman, "Identity, Monumentality, Security: Building a Monument in Early Republican Ankara"; Batuman, "Spaces of Counter-Hegemony: Turkish Architects and Planners as Political Agents in the 1970s"; Batuman, "The Image of Urban Politics: Turkish Urban Professionals and Urban Representation as a Site of Struggle"; Batuman, "Gezi'nin Söz Hali: Mekan, Temsil, Dil”; Batuman, “"Everywhere Is Taksim': The Politics of Public Space from Nation-Building to Neoliberal Islamism and Beyond"; Batuman, "Gazes in Dispute: Visual Representations of the Built Environment in Ankara Postcards". 
itibaren 2000'li yıllara uzanan geniş bir tarihsel dönem için Ankara'yı ele alan çalışmalardır.

Bununla beraber, özellikle çok geniş bir zaman dilimini kapsayan çalışmalar, ele aldıkları konu ile mekânsal ölçek ve benimsedikleri yaklaşım açısından şu temel özellikleri göstermektedirler. Çalışmaların bir kısmı Ankara'nın genel mekân üretimi süreçlerini ele almaktan ziyade, kentin daha küçük ölçekli mekânları üzerine yoğunlaştığı görülmektedir. Örneğin, meydanlar, anıtlar, parklar veya kente özgü bazı yapıları ele alan çalışmalar en sık karşılaşılan çalışmalardır. ${ }^{304}$

Lefebvre'in kuramının uygunlaştırılması açısından ise özellikle çok geniş tarihsel dönemi kapsayan çalışmalarda ${ }^{305}$ mekânsal üçlünün benimsendiği, ona göre analiz yapıldığı görülmektedir, oysa mekânsal dönemselleştirmesi benimsenmemekte, onun yerine Türkiye'nin siyasal tarih dönemlerine göre inceleme yapılmaktadır. Örneğin, ilgili çalışmaların hepsi 1923-1950 dönemini Erken Cumhuriyet Dönemi olarak tanımlamaktadır. Oysa dönem içerisinde daha sonra görüleceği üzere, mekân üretimi süreçleri ve üretilmekte olan mekân önemli farklılıklar göstermiştir. Ayrıca mekânsal üçlü yerine sadece soyut mekân kavramına başvuran çalışmalar ${ }^{306}$ da mevcuttur. Lefebvre'in kuramını bir bütünlük olarak ele alan ve uygulayan çalışmalar ise, ya kısa bir dönem ya da kentte küçük ölçekli bir mekân veya yapıyı ele almakta ve bu bakımdan bu çalışmalar ${ }^{307} 1923$ 'ten günümüze mekân üretimi süreçlerinin paradigmatik

304 Batuman, "Imagination as Appropriation: Student Riots and the (Re)Claiming of Public Space"; Gülkök, "Production of Sidewalks; the Case of Ataturk Boulevard"; Illkay, "The Political Struggle on and at Public Space: The Case of Kizilay Square"; Koçak, "Social and Spatial Production of Atatürk Boulevard in Ankara"; Kulözü, "Transformation of Public Space: The Case of Hacibayram Square"; Turhanoglu, "Spatial Production of Ankara as Capital City of Republican Turkey"; Gür, "Sculpting Turkish Nationalism: Atatürk Monuments in Early Republican Turkey"; Batuman, "Identity, Monumentality, Security: Building a Monument in Early Republican Ankara"; Uludağ, "The Social Construction of Meaning in Landscape Architecture: A Case Study of Gençlik Park1 in Ankara"; Şahin, "Impacts of Policies After 1980 on Public Buildings: The 'Unoccupied' Buildings of Emlakbank, Sümerbank and TEKEL in Ulus in Ankara".

305 İlkay, "The Political Struggle on and at Public Space: The Case of Kizilay Square"; Kulözü, "Transformation of Public Space: The Case of Hacibayram Square".

306 Baş, "Production of Urban Form As the Reproduction of Property Relations Morphogenesis of Yenişehir - Ankara"; Çınar, "Beyond Possibilities: Re-Reading Republican Ankara".

307 Demirtaş, "Critical Moments of Social Spatialization in The Neighborhood: An Alternative Reading of The Mainstream Gecekondu History"; Gülkök, "Production of Sidewalks; the Case of Ataturk Boulevard"; Koçak, "Social and Spatial Production of Atatürk Boulevard in Ankara"; Kural, "Parameters of Sustainability in Urban Residential Areas: A Critique of Temelli/Ankara"; Pasin, "A Critical Reading of the Ottoman-Turkish Hamam as a Queered Space"; Şen, "The Production of Space and The Construction of Urbanity: Informal Practices in 1930s Ankara". 
değişimlerini konu etmemekte ve mekân dönemselleştirmesi girişiminde bulunmamaktadırlar. ${ }^{308}$

Yukarıda ele alınan hususlar doğrultusunda, bu çalışmanın amacı şimdiye kadar yapılan çalışmalardan farklı olarak Lefebvre'in kuramının bir bütünlük olarak okunması ve uygulanmasıyla - ki "bir bütünlük" altında bir önceki kuramsal tartışmalarda ne kastedildiği belirtilmiştir - 1923'ten günümüze Ankara'da mekânın üretimi süreçleri ele alınırken gerek mekân dönemselleştirmesi gerekse mekânsal üçlü çerçevesinde ilgili süreçlerin ele alınması, bir yapı, küçük ölçekli bir mekân yerine Ankara'nın mekânı ve onun dönüşüm süreçlerinin bir bütün olarak değerlendirilmesidir.

\section{Bölüm Değerlendirmesi}

1960-70 sonrası dönem eleştirel sosyal teoride paradigmatik değişimlerin yaşandığ 1 bir dönemi teşkil ettiği söylenebilir. Genelde 'mekânsal dönüş' olarak tanımlanan bu dönem mekâna dönük ve mekânı ele alan önemli kuramsal çalışmaların ve tartışmaların ortaya çıkışına tanık olmuştur. Söz konusu çalışma ve tartışmalar ise genel olarak Marksist gelenekten gelen Harvey, Castells ve Lefebvre'in kuramsallaştırmalarına dayanmaktadır. 1960-70'li yıllarda bu çalışmaların özellikle Marksizm bünyesinde ortaya çıkması tesadüf değildi. Zira kapitalist üretim ile toplumsal ilişkilerin hüküm sürdügü düzen aynı dönemde büyük bir bunalım ve ondan çıkış yolunun arayışları içerisindeydi. Dolayısıyla mevcut durum, mekân sorunsalının ve kapitalist gelişme ile mekân arasındaki ilişkilerin yeniden değerlendirilmesi ihtiyacını doğurmuştu.

Bahsi geçen dönemde özellikle kent ile mekân sorunsalı konusunda Lefebvre'in etkisi çok büyüktür. Onun Kentsel Devrim çalışması özellikle bu dönemde dünya çapında meydana gelen değişiklikler bağlamında önem taşımaktadır. Kapitalizmin Hayatta Kalışı çalışması ise kapitalist ilişkilerin

308 Ankara'yı konu eden bazı çalışmalar, benimsedikleri yaklaşım veya ele aldıkları konulardan dolayı, kapsadıkları tarihsel dönem açısından sınıflandırılmanın uygun olmadığı hususu da belirtilmelidir. Ayrıca, bazı çalışmalarda araştırmacılarca ele aldıkları tarihsel dönem veya zaman kesiti belirlenmiş değildir, o yüzden mevcut çalışmaların hepsi belirli bir sınıflandırmaya tabi tutmanın mümkün olmadığı belirtilmelidir. Bkz. Altay, "Urban Spaces Re-Defined in Daily Practices: The Case of 'Minibar', Ankara"; Ateş, "A Spatial Impromptu: Green Resistance by Guerrilla Gardening"; Baş, "Bir (Kentsel) Ütopya Olarak "Ankara' Romanı"; Basa, "Kentsel Hafızanın Sürdürülebilirliği: Bir Mimarlık Stüdyosu Deneyimi”; Kor, "Death, Burial Culture and Spaces of Memorialization: The Case of Ankara Cebeci Cemetery"; Erol, "Re-Territorialisation and the Sites of Autogestion within the Periphery: Counter-Hegemonic Socio-Spatial Movements in Turkey."; Sarıtaş, "Video in the City Possibilities for Transformation in the Urban Space"; Wilson, "Remembering and Forgetting in the Funerary Architecture of Mustafa Kemal Atatürk: The Construction and Maintenance of National Memory". 
yeniden üretimi ile mekân arasındaki diyalektik ilişkisi açısından kayda değerdir. 1970 öncesi külliyatında genel Marksist tartışmalara, gündelik hayat ve kent ile kentleşme tartışmalarına katkılarını sunan Lefebvre, 1974'te yayınladığı Mekânın Üretimi eseriyle bir taraftan Marksist teoriye mekân boyutu katarken, diğer taraftan mekân tartışmalarına önemli Marksist açılımlar sağlamıştır. Bu çalışmasının en önemli tarafı, gerek kendisinin önceki çalışmalarına ve genel olarak Marksist kuram bünyesinde sistematik olmayan mekân analizlerine, gerekse sosyal teorideki diğer mekân analizlerine kıyasla daha kapsamlı ve çok taraflı bir mekân teorisi ortaya koymayı amaçlamasıdır.

1970'lerden beri ortaya çıkan kent, kentsel mekân ve genel olarak mekân ile ilgili tartışma ve çalışmalara bakıldığında Lefebvre'in mekân ve mekânın üretimi kuramının hem kuramsal tartışmalar hem de somut araştırmalar için önemli bir zemin oluşturduğu görülmektedir. Örneğin, Edward Soja'nın kuramsal incelemeleri ve Lefebvre'in mekân analizine dayalı çalışmaları, Brenner ve diğerlerinin mekânsal ölçek meselesi, ileri kapitalizmde mekânın üretimi olarak mekânsal yeniden ölçeklenme süreçleri ile yeni devlet mekânları üzerine çalışmaları da Lefebvre'in mekân kuramına doğrudan veya dolaylı olarak dayandığ1 görülmektedir. Gottdiener'in, Lefebvre'in mekânın üretimi kuramına dayanan ve metropolitenleşme süreçlerini bir mekân üretim süreci olarak çözümleyen, ayrıca ileri kapitalizmde mekânın rolünü ele alan çalışmaları belirtilmelidir. Neil Smith ise Lefebvre'in kuraminda dile getirilen önemli bir sorunsalı - kapitalizmde mekânın üretiminin, sistemin hayatta kalışındaki rolü ele almıştır ve Lefebvre'in argümanından esinlenerek doğanın üretimi argümanını geliştirmiştir. Bu tartışmalar, 1970 sonrası 'mekânsal dönüş’te Lefebvre'in mekân kuramının etkisinin sadece birkaç örneğidir ve bu etki kendi başına daha kapsamlı bir değerlendirmeye konu olabilir. Fakat vurgulanması gereken önemli husus, Lefebvre'in mekân kuramının ve bu kuramın öne sürüldügü ilgili eserin, genel olarak eleştirel sosyal teoride ve özel olarak mekân araştırmalarında mekân sorunsalı bağlamında yeni bir anlayışın, Kuhn'un kavramına ${ }^{309}$ başvurulursa yeni bir paradigmanın - "toplumsal olarak üretilen mekânın" paradigmasının - temellerini oluşturmasıdır.

Fakat Lefebvre'in özgü rolü "mekânın toplumsal olarak üretildiği ve bir toplumsal ürün" olduğu paradigmatik önermesiyle sınırlı olmadığı görülmektedir. Onun kuramı yapısal açıdan iki temel bileşen ve birbiriyle göreceli olarak tutarlı biçimde bağlantılı kavramsal çerçeveyle öne çıkmaktadır. Bunlar, kuramda ayrıntılı olarak ele alınan mekân dönemselleştirmesi ve mekânsal üçlü unsurları ve bunlara ilişkin kavramsal çerçevedir. Bu bağlamda kuramda öne sürülen mekân dönemselleştirmesi her üretim tarzında üretilmekte olan mekanları -mutlak, kutsal, tarihsel, soyut ile çelişkili mekân- açıklamaya

309 Kuhn, The Structure of Scientific Revolutions. 
yönelik kavramlar olarak öne çıkarken 'mekân tarihi'ni anlamlandırmaya yöneliktirler. İkinci unsur ise her toplumda toplumsal mekânın araştırılması ve mekânın üretiminin ortaya çıkarılması için Lefebvre tarafindan önerilen mekânsal üçlüdür. Fakat gerek mekân dönemselleştirmesi gerekse mekânsal üçlü unsurlarından her birinin kendi başına özgün önermeler olmadığ 1 ve Lefebvre'in kuramının ancak bu iki unsur bir arada değerlendirildiği zaman özgünlüğe kavuştuğu söylenebilir. Oysa bugün yaygın olarak görülen eğilim Lefebvre'in kuramından sadece mekânsal üçlü unsurunun, Lefebvre'in teorisi bağlamından çıkarılıp, çok farklı alanlarda benimsendiği, bazense söz konusu kuramın sadece üçlüye indirgendiği görülmektedir, mekân dönemselleştirmesine başvurulduğunda ise onun kavramsal çerçevesinin 'uygun' mecazlar olarak kullanıldığı görülmektedir.

Türkiye'ye gelince Lefebvre'in kuramının gerek kuramsal düzlemde yaygın olarak tartışıldığı gerekse somut bağlamlarda çok sayıda araştırmacı tarafından benimsenip uygulandığı görülmektedir. Türkiye'deki farklı ölçeklerde mekânı ve olayları konu eden çok sayıda çalışmaların ortak noktasının Lefebvre'in önerdiği mekânsal üçlünün ve onun unsurlarının yaygın olarak benimsenip kullanılması olduğu söylenebilir. Mekân dönemselleştirmesine ise tartışmalarda az yer verildiği ve somut bağlamlarda bir çözümleme çerçevesi olarak pek kullanılmadığı, kullanıldığında ise çoğu zaman sadece betimleyici 'uygun' mecazlar olarak benimsendiği görülmektedir. Bundan yola çıkarak bir sonraki bölümlerde Lefebvre'in kuramının temel yapısını oluşturan bu iki unsuru ve her iki unsurun temel kavramsal bileşenlerini somut bağlamda Türkiye'de Ankara örneğinde tekrardan değerlendirilmesi ve mekân teorisine Lefebvre'in özgün katkılarının uygunlaştırılması amaçlanmıştır. Aynı zamanda temel amaçlardan bir diğeri, söz konusu kuram çerçevesinde Türkiye'de Cumhuriyetin ilanından günümüze mekânın üretimi süreçlerinin Ankara örneği üzerinden yeniden değerlendirilmesidir. 



\section{BÖLÜM}

\section{TÜRKIYE'DE \\ KENTSEL MEKÂNIN ÜRETIMI: 1923-2002}





\section{TÜRKIYE'DE KENTSEL MEKÂNIN ÜRETIMI: 1923-2002}

1923'te Osmanlı İmparatorluğu coğrafyasının bir kısmında, Lozan Anlaşması'nın çizdiği sınırlar çerçevesinde Türkiye Cumhuriyeti'nin ilanına müteakip yıllarda Osmanlı'nın son dönemlerinde başlayan modernleşme süreçlerinin çeşitli dönüşümlere uğrayarak, farklı yöntem ve yaklaşımlarla cumhuriyet döneminde hayata geçirilmesi, dünyanın farklı yerlerindeki ulusdevletleşme ve modernleşme süreçlerine kıyasla benzeri görülmemiş mekân üretimi deneyimlerinden biriydi. Türkiye Cumhuriyeti'nde gerek ulusdevletleşme süreçleri ve gelişen yeni toplumsal düzen gerekse yerleşmekte olan toplumsal üretim ilişkileri birçok açıdan dünyadaki kıyaslanabilir örneklerle benzerlik göstermesine rağmen, dahası Batı'nın modernleşme deneyimi temel alınarak hayata geçirilmek istenen bir proje olmasına rağmen dünyanın farklı yerlerinde aynı dönemde gerçekleşen benzer süreçlerden çok farklı bir nitelikteydi. Bu süreçlere tekabül eden ve söz konusu süreçlere özgü mekânın üretimi de çok farklı bir nitelik taşımaktadır. Dolayısıyla çalışmanın bu kısmında Cumhuriyet'in ilanından günümüze dek Türkiye'de kentsel mekânın üretimi süreçlerinin belirlenen kavramsal ve kuramsal çerçeve bağlamında Ankara örneğinde yeniden değerlendirilmesi amaçlanmaktadır.

\section{1. İmparatorluğun Tarihsel Mekânı Egemenliğini Korurken}

"Merkezi iktidar bu mekânın içinde tüm diğer iktidarların üzerinde yükselir ve onu ortadan kaldırır. Kendini 'egemen' ilan eden bu millet de tüm diğer milliyetleri bu çerçeveden uzak tutar ve çoğu zaman ezer; bir devlet dini tüm diğer dinleri yasaklar; iktidardaki bir sınıf sınıflar arasındaki farklılıkları ortadan kaldırma iddiasında bulunur." 310

Cumhuriyet'in ilanından günümüze dek Türkiye'de üretilmekte olan kentsel mekânla ilgili doğrudan ve dolaylı olarak bağlantılı farklı dönemselleştirmeler söz konusu olmakla beraber bunların Türkiye'de siyasal tarihin genel dönemselleştirmelerine büyük ölçüde benzerlik gösterdiği 
söylenebilir. ${ }^{311}$ Ankara'da mekânın üretimi süreçlerinin de genel olarak bu dönemselleştirmeler çerçevesinde ele alındığ 1 görülmektedir. Dahası modernleşme süreçleri bağlamında mimari üretim, mekânsal temsil ve dönüşüm gibi konularda bu dönemselleştirmelerin daha çok Ankara-merkezli bir analize dayalı olduğu da söylenebilir. Ayrıca bu dönemselleştirmelerden her biri mekânın üretimini doğrudan değil (temel araştırma odağı olarak değil) farklı süreçleri açısından ele almaktadır. Oysa mekân ve onun üretimi süreçleri salt siyasi tarih, planlama ve kentleşme süreçlerine vs. tabi olmadığından dolayı Ankara örneğinde mekânın üretimi bahsi geçen dönemselleştirmelerden farkl1lık gösterdiği varsayılabilir. Ankara'da mekânın üretimi salt kentleşme, planlama, mimari üretim boyutlarıyla sinırlı tutulmayıp, ancak kapsamlı bir mekânın üretimi bağlamında ele alındığında bu farklılık ortaya konulabilir.

Böyle bir yaklaşımın temel mantığı ayrıca mekânın ataletli olma özelliği ve Lefebvre'in tanımıyla mekânın bir süreç olması hususuna dayanır; şöyle ki toplumsal tarihte herhangi bir dönüm noktası hemen hemen apayrı bir mekânın üretimine ve mekâna yol açtığı anlamına gelmeyebilir. Dolayısıyla Cumhuriyet'in kuruluşu ve Ankara'nın başkent olarak ilanı bir dönüm noktası olmakla beraber, salt bu husus bize ona özgü bir mekânın hemen ortaya çıkışı anlamina gelmeyebilir. ${ }^{312}$

311 Örneğin, kent planlama ve kentleşme literatüründe yaygın olarak başvurulan dönemselleştirmelerden Tekeli'nin önerdiği dönemler dikkat çekicidir. Buna göre, Türkiye'de üç farklı döneme ayırılmaktadır; 1923-1950 arası "köktenci modernite", 19501980 arası "popülist modernite", 1980'den günümüze kadar uzanan dönem ise "modernitenin aşınması" olarak tanımlanmaktadır. Bir diğer popüler önerme Tarık Şengül'e aittir. Şengül, Türkiye'de kentleşme süreçleriyle ilgili farklı bir dönemselleştirme önermekte; buna göre 1923-1950 arası dönem "devletin kentleşmesi”, 1950-1970 arası dönem "emek gücünün kentleşmesi”, 1980'lerden günümüze devam eden dönem ise "sermayenin kentleşmesi" dönemi olarak tanımlanmaktadır. Benzer biçimde Çavuşoğlu Türkiye'de kentleşmenin toplumsal dinamikleri ve mekân üretimi açısından dört hegemonik dönemden söz eder; uluslaşma dönemi (1923-1950), kentleşme dönemi (1950-1980), küreselleşme dönemi (1980-2000) ve İslamc1 neoliberalleşme dönemi (2000'den günümüze). Bkz. Tekeli, Modernite Aşllırken Kent Planlamast; Tekeli, "Kent Tarihi Yazımı Konusunda Yeni Bir Paradigma Önerisi"; Şengül, "On the Trajectory of Urbanisation in Turkey: An Attempt at Periodisation"; Şengül, Kentsel Çelişki ve Siyaset: Kapitalist Kentleşme Süreçlerinin Eleştirisi; Çavuşoğlu, Türkiye Kentleşmesinin Toplumsal Arkeolojisi.

312 Cumhuriyet'in kuruluşu mekânsal açıdan elbette bir dönüm noktası olarak tanımlanabilir, sonuçta Cumhuriyet'in ilanı Osmanlı'ya kıyasla yeni sınırlar çerçevesinde farklı nitelikte mekânsal bir kurumsallaşmaydı. Fakat göz önünde bulundurulması gereken husus, mekânın üretiminin - eğer üretim sözcüğü bir mecaz olarak kullanılmamaktaysa - belirli üretim ve toplumsal ilişkiler çerçevesinde, üstyapısal ve altyapısal şartlarda gerçekleşmesidir. Dolayısıyla temel sorunsal, cumhuriyete özgü mekânın üretimi için bu toplumsal şartların ne zaman yeterli düzeye kavuştuğu ve bu mekânın ne özellikler gösterdiği hususudur. 
1923 'te Cumhuriyet'in ilanından kısa bir süre önce fiilen başkentlik işlevleri olan Ankara'nın resmi olarak başkent ilan edilmesi Orta Anadolu'nun bu kasabasının tarihinde çok önemli bir dönüm noktasıydı. Bu önemli kararın etkisi sadece kendi hinterlandı ile sınırlı olan kasaba niteliğindeki bu yerleşimin yeni devletin başkentlik işlevlerinin yüklenmesiyle sınırlı değildi. Kısa bir süre sonra Cumhuriyet kadrolarının Türkiye'yi modernleştirme çabalarında Ankara'nın yeniden inşası ve Cumhuriyet'in mekân temsiline dönüştürme girişimleri, mekânın üretimi açısından ilginç sonuçlar doğurmuştur.

Osmanlı'nın modernleşme ve kapitalistleşme süreçlerinin en yoğun dönemlerinde bile bu eğilimlerden neredeyse etkilenmeyen Ankara, başkent olarak seçilmesinden ancak bir süre sonra farklı bir mekân üretim sürecine ve modern bir mekânın üretimine tanık olmaya başlamıştır. Bu yeni mekân ise artık Osmanlı'nın toplumsal düzeninden farklı olarak Cumhuriyet'in yeni toplumsal düzeni ve mekânı, dolayısıyla ona özgü mekân temsilleri, temsil mekânları ve mekânsal pratikleri ifade etmeye başlamıştır. O yüzden 1923-1950 arası yılların, mekân dâhil olmak üzere genel toplumsal süreçler açısından 'köktenci modernite'313 veya 'devletin kentleşmesi' 314 olarak tanımlanmaları bir genelleme olarak uygun olmakla beraber, Ankara örneğinde mekân üretimi açısından biraz farklı bir tablonun söz konusu olduğu kanısındayız. Örneğin, İlhan Tekeli, Türkiye kent tarihi yazımı ve planlama konusunda söz edilen dönemselleştirmeyi önerdiğinde ve tartışmalarını bu evrelere göre yürüttüğünde de "köktenci modernite projesinin kentlerin biçimlenmesine taşınmasının belli bir gecikmeyle" gerçekleştiğini belirtir. Gecikmenin nedeni ise "Cumhuriyet'in ilk yıllarında 'utangaç modernite' döneminde geliştirilmiş kurumsal yapı içinde savaştan çıkan kentlerin sorunlar[1nın] çöz[ül]meye çalışılması" olarak belirtilir. ${ }^{315}$ İlk yıllarda Ankara'da Osmanlı'dan devralınan kurumsal yapıyla birlikte Osmanlı'ya özgü toplumsal mekânın ve onun üretiminin dinamikleri de henüz baskındı ve Ankara'da mekân temsili, temsil mekânı ve mekânsal pratikler açısından henüz yeni, kökten modernist bir mekânın söz konusu olmadığı söylenebilir.

1920'li yılların Ankara'sı önceden fiilen daha sonra resmi olarak başkent konumunda olmasına rağmen, tarım ürünleri ve ticaretine dayanan bir kasaba olup, artı değerin üretimi, çevresinden toplanan ve dağıtılan ürünlerden kaynaklıydı. Ö̈zellikle başkent olmasından ve burada inşaat süreçleri hız kazandığından dolayı özel sermaye inşaat, bankacılık ve sigorta sektörlerinde

313 Tekeli, Modernite Aşılırken Kent Planlaması; Tekeli, "Kent Tarihi Yazımı Konusunda Yeni Bir Paradigma Önerisi”.

314 Şengül, "On the Trajectory of Urbanisation in Turkey: An Attempt at Periodisation".

315 Tekeli, "Kent Tarihi Yazımı Konusunda Yeni Bir Paradigma Önerisi”. 
yoğunlaşmış durumdaydı. Devletin girişimleri ise 1923'te fişek fabrikası, 1926 yılında çimento fabrikası, 1930 yılında ise mermi fabrikası kurmasıyla sınırlıydı. Ticaretin daha da canlanmasına ve sanayi sektörünün ise devlet koruması altında gelişmesine rağmen Cumhuriyet'in ilk yıllarında tarım teknolojisinde ciddi değişiklikler yaşanmamış, dolayısıyla kent pazara dönük yaygın bir üretime geçememiştir. ${ }^{316}$ Verimi düşük teknolojilere dayalı, pazardan ziyade yerel ihtiyaçlara yönelik ekonomik temellerin varlığı Ankara'da artı değer üretimi ve sermaye birikimi süreçleri için elverişli imkânlar sunmadığını göstermektedir. $\mathrm{Bu}$ nedenle, var olan sermaye çabuk kâr getiren spekülasyona yönelmiş durumdaydı. Sermayenin bu yönelimi aynı zamanda başkent işleviyle hız kazanan inşaatlar ve arsa spekülasyonlarının sunduğu imkânlardan kaynaklıydı. $\mathrm{Bu}$ gelişmenin temelinde bir diğer önemli etken, yeni kurulan düzenin kendine bağl1, iktidarın dayandırılabileceği bir kesim yaratma ereğiydi, zira "bu dönemde siyasal iktidarın kendisine bağlı bir kesime dağıtabileceği bir varsıllık kaynağı olmadığ için o dönemde siyasal olarak arsa spekülasyonu ve kentsel rantları bu yönde kullanmıştır." 317 O yüzden bu dönemde Ankara'da ilkel sermaye birikim süreçlerinin yoğun olarak yaşandığından ve bu süreçlerde mekânın önemli rol oynadığından söz edebilir. Böyle bir ilkel birikimin mekân açısından önemli bir başka boyutu da vardır.

1908'de başlayan burjuva devrim sürecinin tepe noktasını oluşturan Cumhuriyetin ilanı Müslüman/Türk kimliğine dayalı kapitalist bir ulus devlet yaratma projesinin hem çıkış noktası, hem de sonucu olmuştur. İttihat ve Terakki'nin 'milli iktisat' tahayyülü ve 'milli burjuvazi' yaratma çabaları Cumhuriyetin ilk yıllarında da sürdürüldüğü görülmektedir. ${ }^{318} \mathrm{Bu}$ şartlarda Müslüman burjuvazi dönemin şartlarından yararlanarak ve birikimi kullanarak cumhuriyetin ilk yıllarında daha fazla kâr elde etme ve genişleme firsatını buldular ve 1920'li yıllarda oluşan milli sermayedar sınıfın zenginleşmesinde temel etken gayrimüslimlerin terk ettikleri mülk ve ekonomik imkânlarından yararlanmasıydı. ${ }^{319}$ İlkel nitelikte olan bu birikim süreçlerinin mekân boyutu cumhuriyetin ilk yıllarında Ankara örneğinde özellikle kayda değerdir.

316 Şenyapıl1, "Baraka”dan Gecekonduya: Ankara'da Kentsel Mekânın Dönüşümü: 1923-1960, s. $49-50$.

317 Çınar, Dünyada ve Türkiye'de Başkentlik Sorunu, s. 212.

318 Şener, "Burjuva Uygarlığın Peşinde", s. 197.

319 Keyder, The Definition of a Peripheral Economy: Turkey, 1923-1929, s. 20; Keyder, Türkiye'de Devlet ve Sinıflar, s. 121. Erken Cumhuriyet döneminde ekonominin Türkleştirilmesi politikaları için ayrıca bkz. Aktar, "Homogenising the Nation, Turkifying the Economy”; Aktar, ““Turkification” Policies in the Early Republican Era”. Aynı dönemde gayrimüslimlerin terk ettiği mülklerin tasarrufu ve idaresine değin Emval-i Metruke Kanunları ile ilgili Akçam ve Kurt'ın incelemesi kayda değerdir. Akçam ve Kurt'un çalışmasının önemi, ilkel birikim için erken cumhuriyet döneminde hukuki ve idari 
1906 sayımına göre Türkiye'nin bugünkü sınırları içerisinde Müslüman olmayan nüfus yaklaşık \%20 iken, 1927 nüfus sayımına göre bu rakam \%2.6'ya düşmüştür. ${ }^{320} \mathrm{Bu}$ düşüş eğilimi Ankara için daha çarpıcı örnek sunmaktadır. 19. yüzyılın sonunda nüfusunun \%32.6's1 gayrimüslimlerden oluşan Ankara'da 1927 y1lı sayımına göre gayrimüslim nüfusun pay1 \%5.2 oluşturuyordu. ${ }^{321}$ Gayrimüslimlerin genelde Ankara'nın en varlıklı sınıfını oluşturduğu, zaten ticari sermayenin yoğunlaştığ ve bu birikim sayesinde kentsel mekânda en varlıklı mahallelerinde ikametlerini, ayrıca kentin ekonomik merkezinde de hâkim olduklarını ve savaşın cereyan etmediği Ankara'dan göç ettiklerini (ettirildiklerini), gerek Osmanlı'nın son dönemlerinde gerekse Cumhuriyet' in ilk dönemlerinde iktidarın 'milli iktisat' ve 'milli burjuvazi tahayyüllü' bağlamında değerlendirildiğinde bu nüfus değişikliklerinin ilkel birikim için imkânlar sağlaması açısından ne derecede önemli olduğunu gösterir. ${ }^{322}$

Mekânın, birikim süreçlerinde oynadığı önemli rolü başkent işleviyle ve hızla artan nüfus gereğince inşaat süreçlerinin hızlanmasında gözlemlenir. $\mathrm{Bu}$ bağlamda birikim süreçlerini hızlandıran ve arsaya ve konuta kârlı yatırım için imkân sağlayan, dolayısıyla kentsel mekânın gittikçe mübadele süreçlerine daha fazla dâhil olunmaya başlanması Ankara'da iki eksende söz konusuydu. Birinci eksen 1923-1930 y1llarında henüz kentin merkezini oluşturan Ulus'ta (Anafartalar caddesi çevresinde) apartmanlaşmanın başlamasıdır. Dönemin ticari sermayesinin dönüşümünün sonucu olan, genelde 4-5 katl1, her katta en fazla 2 daire olan nispeten zengin görünüşlü bu apartmanlar, kat mülkiyetinin henüz söz konusu olmadığı durumda genelde tek kişi veya aile sermayesi yatırımlarıydı ve dairelerin çoğu kiraya veriliyordu. Genelde ticari sermaye kaynaklı bu yatırımlar, merkezi konumunun vaat ettiği yüksek rantın ürünüydü ve onlar sayesinde merkez yenilenerek gelişiyordu. ${ }^{323}$ Söz konusu apartmanlaşma, üst-orta gelirli grupların konut ihtiyaçlarını ve ticari sermayenin rant paylaşımdan paylarını karşılarken, bahsi geçen dönemde Eski Kentin neredeyse hiç gelişmemesi, ayrıca genelde alt gelirli memurlar ve kente yeni gelenlerin konut ihtiyacını karşılayan, aynı zamanda kentin eski sakinlerinin yaşadığı konut dokusu söz konusudur. Bu

çerçevesinin sağlanması konusunun aydınlatılmasıdır. Bkz. Akçam ve Kurt, Kanunların Ruhu: Emval-i Metruke Kanunlarında Soykırımın İzini Sürmek.

320 Keyder, Türkiye'de Devlet ve Sinıflar, s. 102.

321 Atauz, "Kale ve Sur: Ankara Kalesi", s. 200.

$322 \mathrm{Bu}$ bağlamda Çetinoğlu'nun iddiası dikkat çekicidir. Buna göre Ankara'da en azından 4 ülkenin sefaretinin (İtalyan, İngiltere, İran ve Fransa) arsalarını, dönemin Ankara, Anadolu kökenli olmayan dört mebusu tarafindan muhtemelen emval-i metrukeden edinerek elçiliklere satılmasıdır. Bkz. Çetinoğlu, "Ermeni Emval-i Metrukeleri Üzerine".

323 Şenyapıl1, "Baraka”dan Gecekonduya: Ankara'da Kentsel Mekânın Dönüşümü: 1923-1960, s. 51-53. 
doku henüz birikim süreçlerine dahil olmayan, geleneksel yaşantıların sürdüğü mekânı oluşturmaktayd1.

Kentin fiziksel mekânda gelişme gösteren bir diğer eksen, yapılaşmaya başlayan Yenişehir'di. Başkentin yeni mekân temsilini oluşturacak bu kesim, 1929 yılında yapımı başlayan Atatürk Bulvarı'nın iki tarafında boş bir alanda yeni inşa edilen villalardan ve inşaatları devam eden birkaç kamu binasından oluşmaktaydı. Henüz hiçbir açıdan kendine yetmeyen bu doku aslında bir "yatakhane mahallesi" 324 işlevi görmekteydi çünkü kentin ekonomik, idari ve sosyal hayatı Eski Kentte yoğunlaşmış durumdaydı. ${ }^{325} 1923$ yılında Mustafa Kemal'in Çankaya Köşküne yerleşmesi, Atatürk Bulvarı'nın inşaatına başlanması ve artık Ankara'nın planlı gelişmesi konusunda somut girişimlerin ortaya çıkması Yenişehir'deki gelişmelerin temel etkenleri olmuştur. Bunların etkisiyle genelde otlak olarak kullanılan ve kismen ekilmekte olan bu alanlarda arsa edinme hırsı başladı ve spekülasyon Eski Kent'ten Yenişehir'e yayılmaya başladi. ${ }^{326} \mathrm{Bu}$ eğilim mekânın daha yaygın bir biçimde mübadele süreçlerine dâhil olması anlamına gelmekteydi; dahası bu süreç Eski Kentte mekânın dolaylı olarak, yani konut stokunun birikim süreçlerine dâhil olunmasından ziyade artık, mekânın arsa olarak doğrudan kendisi bir mübadele değeri olarak görülmesi anlamına gelmekteydi. Eskiden "her açıdan durağan bir Anadolu kasabası için 1915 yılında konut ve arsa henüz ekonomik bir anlam taşıma[yan], kütükteki belirleme sadece vergi tabanı olarak" 327 işlev gören duruma kıyasla artık mübadele ilişkilerine dâhil olunup soyutlaşan mekânın belirtileri Ankara'da yoğun olarak gözlemlenmeye başlamıştır. Söz konusu soyutlaşma sürecinde gittikçe mübadele değer temelli bir temsile maruz kalınan bir mekânın üretimi

324 Ibid., s. 54.

325 Henüz kentte pek yaygın olarak süregelmeyen, fakat belirli bir süre sonra mekânın üretimi açısından önemli gelişmelere yol açan bir süreç de aynı dönemde Eski Kent civarında (Altındağ tepesi) ve Akköprü'de barakalaşmanın başlamasıdır. Bunlar, kentte yaygınlık kazanan inşaatlarda çalışmak için ilk aşamalarda Ankara'nın yakın çevresinden gelip fakat kentte konut stokunun darlığı ve/veya kiraların yüksek olmasından dolayı kendi imkânlarıyla kendi barınma sorunlarını çözmeye çalışanların ürettiği barakalardır. Fakat bu süreç henüz ne mekânsal kapsam ne de kenti etkileme açısından önemli yer tutmaktaydı. Barakalaşma konusunda daha detaylı olarak bkz. "Baraka"dan Gecekonduya: Ankara'da Kentsel Mekânın Dönüşümü: 1923-1960.

326 Falih Rıfkı Atay "hemen spekülasyona dalmıştık. Herkes saklayıp ileride satmak üzere arsa edinmek hırsına kapılmıştı", Hıfzı Veldet Velidedeoğlu ise "Kimsenin arsa, bağ, bahçe edinme hırsına kapıldığını görmedim ve duymadım. 1922 yılı sonunda, hele 13 Ekim 1923 'te Ankara'nın hükümet merkezi olmasından sonra bu kentte bir arsa edinme hırsı başladı" diye anlatıyorlar. Atay ve Velidedeoğlu'dan akt. Şenyapıl1, "Baraka”dan Gecekonduya: Ankara'da Kentsel Mekânın Dönüşümü: 1923-1960, s. 42.

327 Tankut, Bir Başkentin Imarı: Ankara, 1929-1939, s. 51-52. 
başlanmış durumdayd1, ancak bunun egemen bir süreç olduğu söylenemez, zira mevzubahis dönemde bunun için birtakım engeller mevcuttu.

Önceden tartış1ldığ1 üzere soyut mekân nicelikselleştirilmiş, niteliksele göre nicelikseli baskın olan, böylece birikim süreçlerine tabi olan ve büyük ölçüde onlarla şekillenen bir mekândır. Mekânın nicelleştirilmesi ve birikim süreçlerinde araçsallaştırılması belirli bir mekân temsili gerektiriyor. Bu temsil ise haritacılık ve kadastro pratikleriyle beraber ve onlara dayanan belirli hukuki düzenlemeler gerektirir. Şöyle ki "haritalar... olguların mekân içinde olgusal düzenlenmesini amaçlayan soyut ve yalnızca işlevsel sistemler[dir]... Harita işdüzüm bilimi ve kadastro teknikleri, haritaları matematik açıdan dakik tasvirler haline getir[ir]. Toprakta mülkiyet haklarını, ülke sınırlarını, idare bölgeleri ve toplumsal kontrol bölgelerini, iletişim yollarını vb. gittikçe artan bir kesinlikle tanım[lar]." 328 Böyle bir temsille mekânın menkulleştirilmesi gerçekleşir ve topraktan başlayan bu menkulleştirme toprağı serbestçe elden çıkarılabilecek, piyasada istendiği gibi alınıp satılabilecek, özel mülkiyete tabi parseller halinde parçalanarak mübadele değeri haline getirir, 'pay'lar, 'hisseler' halinde satılır;

"Menkulleştirme, daha sonra mekâna, yeraltına ve yerüstündeki hacimlerine uzanır. Bütün mekân mübadele değeri edinmelidir. Oysa mübadele, kendi içinde değiş-tokuş edilebilirliği içerir. Bir malın mübadele edilebilir olması, onu, bir miktar şekere ya da kömüre denk bir meta haline getirir. Onun başka mallarla da, hatta aynı türden bütün mallarla kıyaslanabilir olması gerekir."329

Bu bağlamda dönemin Ankara'sı incelendiğinde genel olarak Türkiye için de geçerli belirli hususlar ortaya çıkar. Osmanlı' da kapitalist ilişkilerin gelişmesi açısından en önemli düzenleme 1858 yılında çıkarılan Arazi Kanunnamesi'dir. Osmanlı'da "ilk modern arazi kanunu" olarak tanımlanan bu kanun arazilerin sadece bireyler adına kaydedebileceğini öngörmüş ve kolektif toprak mülkiyeti biçimlerini yasaklamıştır ayrıca arazi devrini, miras bırakılabilmesini, alınmasını ve satılmasını kolaylaştırmıştır. ${ }^{330} \mathrm{O}$ yüzden bu kanun, arazinin menkulleşmesi ve birikim süreçlerine dâhil olunmasına yol açması açısından son derecede önemlidir. Fakat bu konuda en köklü değişim Cumhuriyet'in 1924 Anayasasıyla (Madde 70, 71, 79) özel mülkiyetin tanınması ve böylece Türkiye'de kapitalist gelişmesi için uygun hukuki çerçevenin oluşturulmasıdır.

Fakat dönemin Ankara'sında en azından mekânın kapitalist ilişkiler bağlamında tamamıyla ele alınması ve değerlendirilmesi için haritacılık ve özellikle kadastro açısından elverişli şartlar söz konusu değildi, yani hazır hukuki zemine rağmen mekânın menkulleştirilmesi için gerekli olan haritacılık ve

328 Harvey, Postmodernliğin Durumu: Kültürel Değişimin Kökenleri, s. 280-281.

329 Lefebvre, Mekânın Üretimi, s. 341.

330 Aytekin, "Kapitalistleşme ve Merkezileşme Kavşağında”, s. 49. 
kadastro temelleri mevcut değildi. Örneğin, 1927 yılında Ankara'nın imar planı için uluslararası yarışma açıldığı sırada bile yarışmacılara planlarını hazırlamak için sadece $1 / 5000$ ve $1 / 25.000$ ölçekli askeri haritalar sağlanmıştır. Sorun yarışmayı kazanan Hermann Jansen için kesin imar planını hazırladığı sırada (1932 y1l1) da devam etmiştir. Jansen'in elinde kadastro durumunu gösteren bir hâlihazır harita bulunmamaktaydı. Kentin planlı gelişmesi için de büyük sorun oluşturan bu eksiklik 1939 y1lına kadar devam etmiştir. 331

Tansı Şenyapı11, Ankara İmar Müdürlügü̈’nün karar organı olan İmar İdare Heyeti'nin belgelerini inceleyerek 1930'lu yılların başında ilginç başka bir duruma dikkat çekmektedir. Buna göre,

"Bu yıllardaki belgelerin ilginç bir yanı da kentte, gerek sosyal gerekse mekânsal ilișkilerin henüz anonim ve formel nitelikler kazanmadığını ve kentin mekânda henüz çok yaygınlaşmadığını yansıtmalarıdır. Örneğin, bu resmi belgeler, kişi ile mekân arasında '...lisesi müdürü... Beyin ...yangın yerindeki arsası' biçiminde bağlantı kurmaktadır. Bu durum mekânsal yapısı ve referans noktaları henüz oluşmamış bir kent dokusunu yansitır." 332

Ele alındığı üzere soyut mekânın baskın unsuru olan tasarlanan mekân (mekân temsili) teknokratların mekânıdır ve sadece hesaplar içermez aynı zamanda kendine özgü (ve hesapları da ifade eden) bir teknik dil (mesleki jargonu) içerir, oysa yaşanan mekân (temsil mekânı) yaşayanların ve kullananların sembollerini, imgelerini ve argo dilini içerir. Bu bağlamda teknokratik bir kurum olarak tanımlanabilecek İmar İdare Heyeti'nin belgelerinde belirli tanımlar ve referanslar için teknik jargon ve soyut referanslar (belirli bir deneyim ve somut imgelerden kopuk tanımlar) yerine farklı bir dil

331 Tankut, Bir Başkentin Imarı: Ankara, 1929-1939. Bu açıdan kapitalist üretim ilişkilerinin daha erken gelişmeye başladığı İstanbul'un ayrıcalıklı durumda olduğunu görmekteyiz. Şöyle ki 1857 yılında kurulan ve Sadaret'in altında görev yapan Altıncı Dairesi'nin (Galata, Pera ve Tophane bölgelerini kapsayan) ilk işi İstanbul'da ilk kez kadastro çalışmaların başlamasıydı. Bu çalışmalar ise planlama işlerinden ziyade vergi toplamayı kolaylaştırmak için yürütülmekteydi. İstanbul' da çok sayıda planlama ve dolayısıyla kadastro ve haritacılık işlemlerinin yürütülmesine rağmen yine de daha geniş ve kapsamlı kadastro ve haritacılık çalışmalarının söz konusu olmadığ 1 da belirtilmelidir. Bkz. Uluengin ve Turan, "İmparatorluğun İhtişam Arayışından Cumhuriyet'in Radikal Modernleşme Projesine: Türkiye'de Kentsel Planlamanın İlk Yüz Yılı”. Ankara'ya ait ilk harita ise 1924 yılında asker haritacılar tarafından hazırlanmıştır. 1/4000 ölçekli bu harita eski kentin hâlihazır durumunu saptarken daha çok yol ve yapı adaları düzeyinde bilgi içermektedir. Tankut, haritanın Ankara Şehremaneti'nin ilk icraatı saptar. İkinci görsel belge ise 24 Mart 1925 gün ve 583 sayılı yasanın (Ankara'da yaklaşık 4 milyon metrekarelik alanın kamulaştırılmasını öngören) ekinde sunulan kamulaştırma alanlarına dair ve "kadastro haritası denilen" fakat "kadastral değeri olmayan” krokidir. Bkz. Tankut, Bir Başkentin Imarl: Ankara, 1929-1939, s. 54.

332 Şenyapıl1, "Baraka”dan Gecekonduya: Ankara'da Kentsel Mekânın Dönüşümü: 1923-1960, s. 94 . 
kullanımı (belirli bir deneyim ve somutluk içeren) henüz baskın bir soyut mekânın söz konusu olmadığının bir diğer belirtisi olarak değerlendirilebilir. Böyle tanımların mevcudiyeti aynı zamanda bir önceki duruma dair değerlendirmeyi de destekler niteliktedir, yani geniş ve kapsamlı kadastro çalışmalarının ve mekânın envanterizasyonunun yokluğu nedeniyle, mekânın soyut (tasarlanan) değil, somut tanımlarla (algılanan ile) temsil edilmesidir.

1923-30 arası dönemde Ankara kenti bahsi geçen 3 eksen üzerinde gelişim gösterirken aynı zamanda ilginç bir mimari üretime de tanıklık etmektedir. Gerek bu mimari üretimi ve ona eşlik eden söylem (discourse) gerekse başkentin planlı gelişimi için yapılan belli başlı girişimler sonucunda üretilmekte olan mekân, dönemin mekân temsili, temsil mekânı ve mekânsal pratiklerine dair önemli hususlar ortaya koymaktadır.

Ankara'nın planlı gelişimi için ilk girişim olarak Carl Lörcher tarafından 1924 yılında yapılan plan bilinmektedir. Genelde Ankara imarı ve mekânın üretimi ile ilgili son dönemlere dek yapılan incelemelerde göz ardı edilen bu plan, Cengizkan'a göre Ankara'nın kamusal mekânlarını ilk kez kurgulayan ve pek çok öngörüsüyle bugün de kent mekânında varlığını sürdürdüren bir plandır. ${ }^{333}$ Fakat bu plandaki kurgu, tek taraflı biçimde alınmış karar sonucu ortaya çıkmıştır, yani plan Ankara Şehremaneti veya merkezi hükümet tarafindan sunulan istekler doğrultusunda yapılmış bir plan değildir;

"Bu aktörlerin hiçbiri, çok küçük isteklerin dışında, yeni ve yeniden kurulacak başkentin Cumhuriyet'in temsiliyetini şu veya bu yönde yüklenmesi gerektiği konusunda bir öneride bulunmamış, beklenti oluşturmamışlardır. Kurgulandırma ve tasarım, bir yönlendirme ve iktidarın yansıması biçiminde ortaya çıkmadığı gibi, iktidar ve erk araçları kurgunun ve bunun uygulama sorunlarının farkında da değildir."334

Planın gerek bu özelliği, gerekse onun kısmen uygulanması, mekân üretimi açısından birbirinden kopuk ve rastgele olarak gelişen yapılaşmalara yol açmış ve sonuç olarak makro ölçekte tutarlı bir temsiliyet üretimi söz konusu olmamıştır.

Makro ölçekte görülen tutarlı temsiliyet sorunu, Ankara'da aynı zamanda ikili bir toplumsal mekânla eșlik edilmekteydi. Tanpınar, dönemin Ankara'sını "şehir bir taraftan Milli Mücadele'deki sıkışık hayatına devam ediyor, bir taraftan da yeni baştan yapılıyordu" diye betimlemektedir. ${ }^{335}$ Bir taraftan Eski Kentte ve Kale'nin eteklerindeki mahallelerde Osmanlı'dan miras kalan toplumsal

333 Cengizkan, "Kurgu, Tasarım ve Kullanım: Cumhuriyet Dönemi Kamusal Mekânları İçin Bir Çalışma Programı”.

334 Ibid., s. 239.

335 Tanpınar, Beş Şehir, s. 15. 
mekânın varlığı, diğer taraftan Ulus'ta ve Yenişehir'de yapılmakta olan bulvar etrafinda Cumhuriyet'in modernleşme ve 'muasır medeniyetlere ulaşma' tahayyüllü doğrultusunda yeni bir mekân üretimi söz konusu olmuştur.

Yerel ölçekte ise belli başlı alanlarda kamusallığın üretimi girişimleri ve Cumhuriyeti temsil eden kamu binalarının inşaatları bu dönem hızla devam etmiş ve az çok tutarlı bir mekân temsili üretmeyi başarabilmiştir. Genelde, Ulus civarında yoğunlaşan ve çoğunlukla Türk mimarlar tarafindan tasarlanan bu kamusal binalar "imparatorluğun son dönemlerinin İstanbul'daki mimarisinin uyandırdığı daha kozmopolit ve emperyal hisleri uyandırmaktadır"336 ve bu sebeple mimari tarihçilik tarafından Osmanlı Canlandırmacılığı tarzı olarak tanımlanır. ${ }^{337}$ Mekânın mimari üretiminde böyle bir tarzın benimsenmesinin nedenlerinden biri dönemin hâkim mimari anlayışı ve tekniğiydi, şöyle ki yeni kurulan cumhuriyet ne kadar modernleşme ve onun doğrultusunda modern bir mekân yaratma tahayyüllüne sahip olsa da, ülkedeki mimarların çoğu bahsi geçen mimari üslup konusunda eğitim almış ve uzmanlaşmış bireylerdir. Ayrıca zaten ekonomik açıdan büyük sıkıntılar yaşayan bir ülkede farklı bir mimari üretim gerçekleştirmek için gerekli teknik altyapı söz konusu değildir. Dahası Osmanlı Canlandırmacılığı üslubuyla binaların inşası bile kendi kendine ciddi bir teknik, malzeme ve yetenekli emek gücü sorunu oluşturmaktaydı. Örneğin Ankara'da yeni binaların inşasında önemli rolü olan ve Türk Ocağı Binası ve Etnografya Müzesi gibi önemli eserlere imza atan mimar Arif Hikmet Koyunoğlu, dönemin tuğla ve çimento gibi malzemelerin, araç ve ustaların yokluğundan şöyle bahseder;

"Şimdi inşaat işlerine başlayacağım ancak tuğla, kiremit, kireç, çimento, usta yok... Akköprü'de üç tuğla ocağı yaptırdım. Çankaya'nın arkasındaki Firenközü köyünde bu işe uygun toprak buldum. Tuğla yapmaya başladım... İstanbul'da mimar Veliddin isminde bir arkadaş, künk yapmak için bir makine getirtmiş fakat kullanılmamış, öyle duruyordu. O makinaları getirttim ve Akköprü'de bir karo mozayik ve blok fabrikası yaptım." 338

Etnografya Müzesi'nin inşası (1925-1928) sırasında aynı sorunlarla karşılaşan Koyunoğlu'ya göre,

336 Bozdoğan, Modernizm ve Ulusun İnşası: Erken Cumhuriyet Türkiyesi’nde Mimari Kültür, s. 54.

337 Bu tarzla Ankara'da 1923-1928 arası inşa edilen en önemli binalar Ankara Palas, Vakıf Apartmanları, İş Bankası, Ziraat Bankası, Osmanlı Bankası, Dâhiliye Vekâleti, Hariciye Vekâleti, Etnografya Müzesi ve Türk Ocağı Binasıdır.

338 Akt. Şenyapıl1, “Baraka”dan Gecekonduya: Ankara'da Kentsel Mekânın Dönüşümü: 19231960, s. 47. 
"O zaman demirci, taşçı ustaları yok. Ermeniler gitti, Rumlar mübadele edildi, taşçı ustaları yok. O aralık Ankara'da ecnebilerin çalışmasına izin verdiler. Macar ustalar Ankara'ya geldi ama taşçı yok... Marmara adasından taş gelir Vagondan indirmek için vinç yok. Vagondan bir rampa ile, yaptığım arabalara kaydırırız blok taşları. Ondan sonra bu arabaları kağnıların arkasına bağlarız. İstasyondan tepeye böyle taşınır 10-20 tonluk mermerler."339

Fakat aynı zamanda Osmanlı Canlandırmacılığı mimari üslubuyla yeni bir mekân temsilinin üretiminin altında yatan temel nedenlerinden diğeri dönemin ideolojik ve siyasi denkleminin gerektirdiği sinırlamalar ve cumhuriyeti kuran kadroların bu sınırlamalar çerçevesinde hareket etme imkânlarıydı, başka bir ifade ile henüz kendi iktidarını pekiştirmemiş bir yönetim, köklü değişikliklere girişmesi için fazla meşruiyete sahip değildi. O yüzden Bozdoğan'a göre "ideolojilerin birbiriyle rekabet ettiği bir dönemde meşruiyet arayışı içinde olan cumhuriyet liderleri, üstü kapalı olarak (ve stratejik anlamda), bu üslubun İslam'a ve sultan yaptığı örtük göndermelerin, bu simgelere hâlâ bağlı olan gelenekçi halka cazip geleceğini anlamış olmalıydılar." 340 Dolayısıyla bir mekân temsili olarak Osmanlı Canlandırmacı üslubu en azında fiziksel mekânın üretimi aracılığıyla "Türk milletinin Osmanl-İslami geçmişinin ihtişamını simgelebiliyor ve böylece Osmanlı hanedanının dini patrimonyasına bağlı geleneksel halk kesimlerinin gözünde yeni milliyetçi rejimi meşrulaştırıyordu." ${ }^{341}$ Böylelikle yapılı çevrenin düzenlenmesi aracılığıyla böyle bir tasarlanan mekânın (mekân temsili) ${ }^{342}$ üretimi dönemin hâkim algılanan mekân (mekânsal pratikler aracılığıyla mekânın deneyimleme ve algılanması) ve yaşanan mekân (henüz Osmanlı'ya özgü toplumsal mekânın büyük ölçüde varlığının sürdürülmesi ve toplumun yaygın kesimlerince sahiplenilmesi) ile uyum içerisindeydi. O dönemde Ankara'nın toplumsal hayatının en yoğun olarak yaşandığı Ulus civarında yapılan bu binalar, hem geniş kitlelerin eskiden mekânsal pratikler aracılığıyla deneyimledikleri tanıdık ve alışagelmiş imgeler (algılanan mekân) ile uyum içerisindeydi ve mekânın soyut bir deneyimlenmesi ve kopuş yaratmamaktaydı, hem de halkın geniş kitlelerinin, henüz Osmanlı'nın

339 Akt. Şenyapıl1, “Baraka”dan Gecekonduya: Ankara'da Kentsel Mekânın Dönüşümü: 19231960, s. 47.

340 Bozdoğan, Modernizm ve Ulusun İnşasl: Erken Cumhuriyet Türkiyesi’nde Mimari Kültür, s. 34.

341 Ibid., s. 57.

342 Çalışmada yer yer Lefebvre'in mekân üçlüsünün belirli bileşenlerinin iki farklı (örneğin mekân temsili/tasarlanan mekân, temsil mekânı/yaşanan mekân veya mekânsal pratikler/algılanan mekân) kullanımıyla özellikle beden ve mekân etkileşimi vurgulanmak amaçlanmıştır. 
dini ve toplumsal kodlarıyla (mitler, simgeler vs.) yaşandığı bir mekânla (yaşanan mekân) uyum içerisindeydi. ${ }^{343}$

Özetle, bir taraftan Osmanlı'dan devralınan mekânın yerine modern bir cumhuriyet mekânı üretme isteği ve çabaları söz konusuydu, ${ }^{344}$ fakat aynı zamanda Osmanlı'dan miras kalan ve ona özgü dinamiklerini sürdüren mekân buna bir engel oluşturmaktaydı. Yapılı çevrenin düzenlemesi aracılığıyla ortaya çıkan böyle bir tasarlanan mekân ile beraber aynı zamanda söylem düzeyinde de kayda değer mekân temsili ile temsil mekânı söz konusuydu. Bu, dönemin yönetici kadroları ve önde gelen aydınların söylemiyle oluşan temsillerdi ve bir önceki temsilleriyle bazen uyum, bazen ise karşıtlık göstermekteydi ve zaman içerisinde bu karşıtlık daha belirgin hale gelmeye başlamıştır.

\section{Şekil 4. 1928 Yılında Ulus Meydanı Yeniden Düzenlenirken}

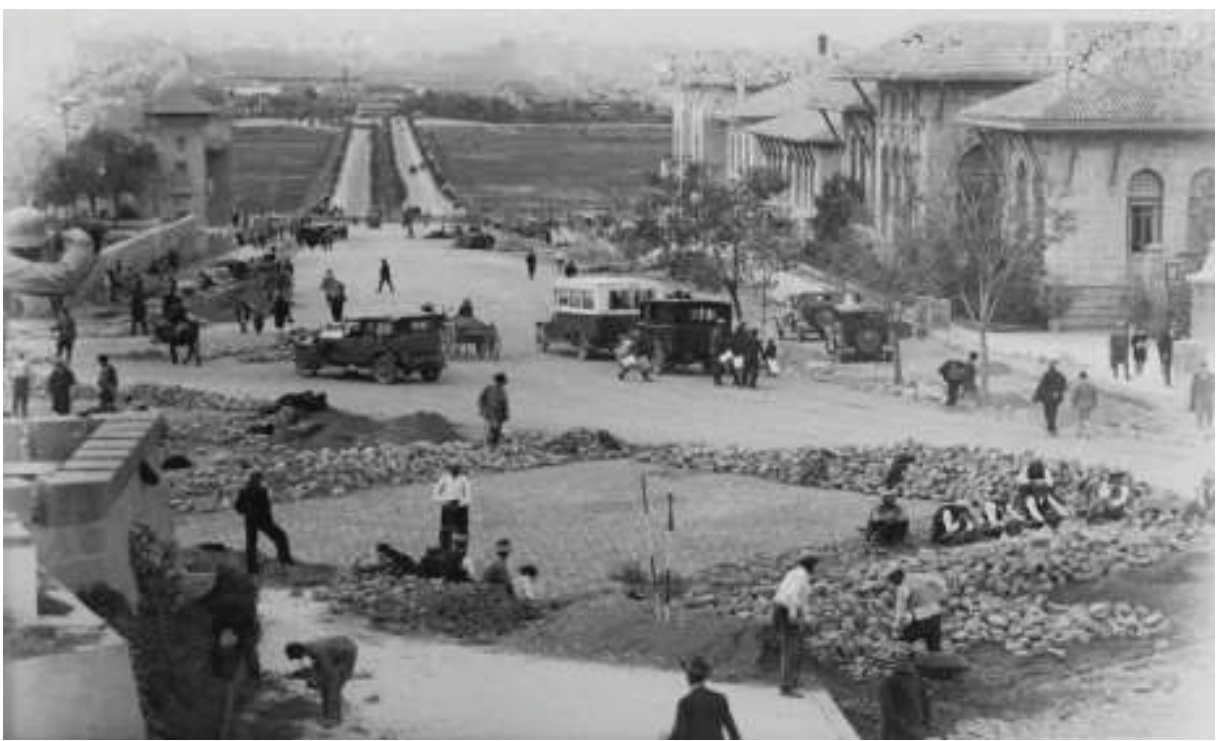

Kaynak: 22 Ekim 2016 tarihinde http://www.plan-pr.com/images/IAE/Atatürk/800/Hakimiyeti Milliye\%20Meydaniyeniden\%20duzenlenirken1928.jpg adresinden erişildi.

343 Ele alınan dönemde Ankara'daki mimari girişimleri, Lefebvre'in mekân üçlüsü çerçevesinden yola çıkarak çözümleyen farklı bir araştırma için bkz. Basa, "From Praise to Condemnation: Ottoman Revivalism and the Production of Space in Early Republican Ankara”. Osmanlı Canlandırmacılık üslubunun, dönemin ideolojik konjonktürü bağlamında daha detaylı incelemesi için bkz. Bozdoğan, Modernizm ve Ulusun İnşası: Erken Cumhuriyet Türkiyesi'nde Mimari Kültür.

344 Ankara'nın İstanbul yerine başkent olarak ilan edilmesinin temel sebeplerinden biri İstanbul'un Osmanlı'yı ve onun halifeliğini simgeleyen bir kent olmasıydı. 
Ankara'nın başkent olarak seçilmesinin birçok temel nedeni arasında "taşıdığı semboller, geçmişin "taşa yazılı" izleri ve tüm dünya devletleri nezdinde İmparatorluğu temsil ediyor olması" sebebiyle "İstanbul'da yeni bir başlangıç yapmayı olanaksız" kılmasıydı. ${ }^{345}$ Ayrıca İstanbul, "genç bir Cumhuriyet'in kodlarıyla yeniden tanımlanamayacak kadar 'geçmiş yüklü' ve ulusal birliğin sembolü olamayacak kadar kozmopolit”346 bir temsil teşkil etmekteydi, bu sayede Ankara'nın başkent olarak seçilmesiyle cumhuriyet eliti yeni bir başlangıç hedefliyordu. ${ }^{347} \mathrm{Bu}$ başlangıç için mekân üzerine söylemde Ankara ile ilgili farklı temsil mekanları oluşmaya başladı; İstanbul'un kozmopolit kimliğine karşı Ankara'nın homojen yapısı, hilafetin merkezi olan ve silueti büyük camilerden oluşturan İstanbul'a karșı minaresiz siluete sahip Ankara, emperyal güçlerin komplo merkezi olan İstanbul'a karşı Milli Mücadele sırasında Kuva-yi Milliye'ye ev sahipliği yapan fedakâr Ankara vs. ${ }^{348}$ Söylem düzeyinde oluşturulan bu temsiller ve imgelerde doğrudan toplumsal olarak üretilen mekân ile ilişkili bir temel temsil belirtilebilir; Ankara'nın mekânının ideolojiye hizmet edecek şekilde bir tabula rasa olarak temsil edilmesidir. ${ }^{349}$

1920’li y1llarda artık Osmanlı dönemindeki kozmopolit kimliğine sahip olmayan ve çok homojen bir toplumsal yapısı olan Ankara, aslında Cumhuriyetin

345 Cantek, “Yaban”lar ve Yerliler: Başkent Olma Sürecinde Ankara, s. 39.

346 Ibid., s. 69.

347 Türkiye'de başkentlik tartışmaları ve Ankara'nın başkent olarak seçilmesi konusu şimdiye kadar farklı açılardan çok sayıda çalışmanın konusu olmuştur ve konu ile ilgili zengin bir literatür birikimi söz konusudur, konu ile ilgili daha detaylı olarak bkz. Tankut, "Ankara'nın Başkent Olma Süreci”; Tankut, Bir Başkentin İmarı: Ankara, 1929-1939; Çınar, Dünyada ve Türkiye'de Başkentlik Sorunu; Kartal, "Değişen İktidar İlişkileri İçinde İki Kentin Dönüşümü: İmparatorluk'tan Cumhuriyet'e-Payitaht İstanbul'dan Makarr-1 Hükümet Ankara'ya (Dönem Basınına Yansıyan Tartışmalarla: 1920-1940)"; Cantek, "Yaban "lar ve Yerliler: Başkent Olma Sürecinde Ankara; Tekeli, “Ankara'nın Başkentlik Kararının Ülkesel Mekan Organizasyonu ve Toplumsal Yapıya Etkileri Bakımından Genel Bir Değerlendirmesi".

348 Özellikle dönemin basınında ve aydınların söyleminde oluşan Ankara temsili ile ilgili detaylı bir çözümleme için bkz. Kartal, "Değişen İktidar İlişkileri İçinde İki Kentin Dönüşümü: İmparatorluk'tan Cumhuriyet'e-Payitaht İstanbul'dan Makarr-1 Hükümet Ankara'ya (Dönem Basınına Yansıyan Tartışmalarla: 1920-1940)".

349 Batuman, 1990'lı yıllarda Cumhuriyetin ilk yılların Ankara'sı etrafında oluşan ve yeniden üretilen tarihsel temsiller konusunda da benzer bir duruma işaret eder. Ona göre Ankara'nın iki temel tarihsel temsilinden birincisi Ankara'yı ve Ankaralıları (cumhuriyet kadrolarının Ankara'ya gelmesinden önce bile) cumhuriyetçi ve Mustafa Kemal'in milliyetçi davayı destekleyenler olarak temsil eder. İkinci ise Anadolu'nun ortasında sıfırdan Ankara'nın inşa etme mitiydi. Böylece, ilk temsille Ankara'ya devrimci bir toplumsal nitelik atfedilir, ikinci mit ise başkentin tabula rasa üzerine kurulduğunu iddia ettiği için toplumsal ve fiziksel ortamın önemi reddeder ve bununla ilk temsille çelişir. Bkz. Batuman, "Early Republican Ankara': Struggle over Historical Representation and the Politics of Urban Historiography”. 
milliyetçi Türkleştirme politikaları için artık uygun bir tabula rasa oluşturmaktaydı. Dolayısıyla cumhuriyetin, Türk-İslam bileşen temelli milliyetçilikten yola çıkarak Ankara için oluşturduğu bu mekân temsili güncel gerçeği de yansıtmaktaydı. Böyle bir temsil üretimi için elverişli bir başka husus da mevcuttu; şöyle ki en azından Osmanlı döneminde "Ankara'nın önemsiz bir geçmişi olması, cumhuriyet modernleşmecilerinin onu büyük hayallerini uygulamaya geçirebilecekleri bir tabula rasa olarak algılamalarına ve tasvir etmelerine izin vermiştir." 350 Fakat buna rağmen Ankara'y1 "yeni bir başlangıç" olarak başkent ilan eden ve neredeyse hiçbiri Ankaralı olmayan "zoraki Ankaralı" 351 cumhuriyet kadroları için aynı zamanda Ankara'nın hem toplumsal yaşamda hem de fiziksel mekânda açıkça gözlemlenebilen, Osmanlı'dan miras kalan toplumsal bir mekân ve "yabani taşralılar"352 söz konusudur. Dönemin milletvekili ve yazarı Karaosmanoğlu'nun belirttiği gibi,

"tıpk1 Avrupalılar gibi giyiniyoruz, onlar gibi içiyoruz, onlar gibi düşünüyor, onlar gibi hissediyoruz, onların medenî kanunları dahilinde, onların tabi oldukları hayat şeriatı altında yaşıyoruz, fakat daima her manası ile sefil ve perişan bir Asyaî dekor içinde."353

Karaosmanoğlu'nun sözleri Ankara'nın mekânının hiç de bir tabula rasa olmadığının ve cumhuriyet kadrolarının, bu durumun farkındalıklarının bir göstergesiydi. Dolayısıyla, "halka rağmen, halk için" söylemiyle ve "uygarlaştırma misyonuyla" yola çıkan cumhuriyet kadrolarının ve aydınların temel hedefi Ankara'yı asrileştirmek ve muasır medeniyetler seviyesine ulaştırmak oldu. Bunu gerçekleştirmek içinse özellikle kentsel planlama ve mimari üretimiyle başkenti yeni çevre ve çehreye kavuşturma girişimlerine başland. ${ }^{354}$ Tercih edilen ise Eski Kentin "Asyaî dekorundan" uzak, onun güneyinde neredeyse imarsız bir alanda Yenişehir'in inşasıydı. Bu hareket,

350 Bozdoğan, Modernizm ve Ulusun İnşast: Erken Cumhuriyet Türkiyesi’nde Mimari Kültür, s. 83.

351 Cantek, "Yaban"lar ve Yerliler: Başkent Olma Sürecinde Ankara.

352 Ibid.

353 Akt. Cantek, “Yaban”lar ve Yerliler: Başkent Olma Sürecinde Ankara, s. 234.

354 Cumhuriyet modernleşmecilerinin, yapılı çevrenin üretimiyle toplumu dönüştürme çabaları ve yeni toplumsal ilişkilerin ifadesi olarak yapılı çevrenin önemsenmesi aynı zamanda SSCB'deki deneyimle de paralellik gösterir. Örneğin, 1920'li yıllarda SSCB'deki mimari jargonunda mimari bir "toplumsal yoğunlaştırıcı" olarak tanımlanmaktaydı. Bu tanıma göre ise mimari hem yeni bir toplumun yansıması hem de bireyi ve toplumu değiştirmek, düzeltmek için bir araç ve ortamd1. Anatole Kopp, Town and Revolution: Soviet Architecture and City Planning, 1917-1935, s. 12.

Aynı şekilde iki ülkede toplumu dönüştürme çabalarında mimari anlatıma başvurulması da benzerlik göstermektedir. Şöyle ki okuma yazma oranı çok düşük olduğu her iki ülkede mimari ve yapılı çevrenin üretimi olabildiğince en geniş halk kesimlerine hitap etme imkânına sahipti. 
"Asyaî dekor"un terk edilip bir tabula rasa anlayışıly tasarlanan yeni bir mekânın üretiminin habercisiydi. Yeni inşa edilecek kesimin "Yenişehir" olarak tanımlanması ise söylemsel düzlemde cumhuriyetin başkentini, bir tabula rasa olarak tasarlanarak (tahayyül ederek-conceive) inşa etmenin bir diğer göstergesiydi. 355

1920'li y1lların Ankara's1 mekânsal pratikler açısından toplumsal ilişkilerin henüz mahalle ölçeğinde geliştiği, ailelerin içe dönük bir yaşam sürdürdügü dönemdir, yani Osmanlı'nın mahalle ölçeğiyle sınırlı hayat neredeyse aynı şekilde devam etmektedir. Kamusallığın henüz gelişemediği bu dönemde tüm kent için az çok öneme sahip kamusal alanlar hala eril egemen mekânlardır ve kadın nüfusun kamusal hayata katılabilmeleri de henüz söz konusu değildi. Geleneksel yaşantıların sürdürüldüğü böyle bir ortamda Ankara'da gözlemlenebilen ve mekânsal pratiklerin önemli bir özelliği de sayılabilecek diğer husus, kamusal ile özel alanlar arasında keskin ayrımın varlığıydı. Hem mahalle ölçeğiyle sınırlı toplumsal hayatın hem de kamusal ile özel arasındaki keskin ayrımının aşınması 1930'lu yıllardan itibaren cumhuriyetin kurucu kadrolarının temel hedefi haline gelecektir. Eğer birincisi için kent planlamasına başvurulduysa, ikincisi için kültürel ve terbiye politikalarına başvuruldu.

Dönemde kentin hem fiziksel hem de toplumsal merkezi olan Ulus'un civarında, genelde Anafartalar Caddesi üzerinde yeni açılan lokanta ve barlarda toplumsal mekânın modernleşmesinin ilk izlerini sürebilmek mümkündür. Yeni düzeni temsil eden kurumların (özellikle Birinci Meclis Binası) ve Milli Mimari Rönesans üslubuna ait ilk mimari deneyimlerin de Ulus'ta bulunmasından dolay1 bu bölgenin, yeni düzenin mekân temsili olma açısından önemli bir tarafı vardır. Ayrıca Ulus'un, toplumsal mekânsal pratikler aracılığıyla yeni mekânın deneyimlenmesini sağlamak açısından önemli bir işlevi vardı, zira Basa'nın belirttiği gibi "burada farklı ekonomik ve toplumsal sınıfların günlük rutin işlerine denk gelen toplumun mekânsal pratikleri karmaşık bir kaynaşma sağlamaktaydı." 356 Fakat mekân temsili açısından Ulus'un böyle bir işlevi olmakla beraber aynı zamanda onun, algılanan mekân (temsil mekânı) açısından simgesel bir muğlaklığı da vard1, şöyle ki “Milli Mimari Rönesansı'nın simgesel muğlaklığı-ayn 1 anda hem eski imparatorluğun hem de yeni milleti imleyebilmesi-, onu bu henüz oturmamış geçiş döneminde siyasi ve ideolojik

355 Yeni inşa edilecek kesim önce Yenişehir olarak tanımlanıp sonra Yenimahalle olarak değiştirilmiştir, böylece eski Ankara'nın ihmali anlamına gelecek durumdan kaçınılmıştır. Cantek, "Yaban"lar ve Yerliler: Başkent Olma Sürecinde Ankara, s. 118.

356 Basa, "From Praise to Condemnation: Ottoman Revivalism and the Production of Space in Early Republican Ankara", s. 6. 
açıdan ehven bir seçenek haline getiriyordu." 357 Gerek yapılı çevre aracıllı̆ıyla gerekse söylemsel olarak yeni bir ulusu temsil eden bu mekân, aynı zamanda simgesel açıdan hem yeni ulusal kimliğe hem de imparatorluk geçmişine dair muğlak bir algı oluşturmaktaydı. Halkın bir kesiminin günlük rutin işlerine denk gelen mekânsal pratikler, "Osmanlı ve Cumhuriyet dönemleri arasında köprü oluşturarak ulusal kolektif belleğin devamlılı̆̆ını temsil eden" 358 bu çok uğrak mekânda kesişmesiyle ise dönemin tasarlanan mekân ile algılananın mekân arasında geçişken ve belirsiz ilişkilerini yeniden üretmekteydi. İnci Yalım, toplumsal belleğin ulus-devlet çerçevesinde kurgulanması ve yeniden üretilmesi sürecinde Ulus Meydanı'ndaki üç farklı eyleme işaret eder, ona göre;

"Birinci tür buradaki anıt ve binaların kullandığı görsel imgeler yoluyla bellek sanatının tariflediği şekilde yaratılan çağrışımlardır ve bu çağrışımlarla özdeşleşme yoluyla üst ölçekteki toplumsal çerçevenin bir parçası olunduğu hissettirilir. İkinci tür toplumsal eylemlerle ilgilidir. Burada meydanı mekân olarak kullanan anma törenleri, toplantılar ve idam seremonileri belli ritimlerle yer aldıkları zaman dilimleri sırasında toplumsal bilinci ve hatırlamayı düzenler ve ilişki kurulan geçmişin ya da geleceğin imgelerini sahneler. Üçüncü tür ise doğrudan bedensel toplumsal bellek dediğimiz kavramı şimdinin perspektifinde yeniden tanımlama çabasındadır. Hem bedensel alışkanlıklar hem de toplumda uyulması gerekli kurallar ve edinilmesi gereken zevkler uygun mekânlar yaratılarak pratik edilirler ve böylece 'modern ulus' imgesi bireyin alışkanlıklarının eğitilerek toplumsal alışkanlık haline döndürülmesi sonucunda elde edilir." 359

Bu üç eylem, mekânsal üçlü bağlamında değerlendirildiğinde tasarlanan mekân olarak bina ve anıtlar (birinci eylem) belirli bir toplumsal çerçeve veya düzene işaret edip onu temsil eder. Temsil mekânı olarak anma törenleri, toplant1lar ve idam seremonileri imgeleme hitap eder, "belli ritimlerle yer aldıkları zaman dilimleri sırasında" meydana gelseler de gündelik hayat açısından olağan değildir ve "ilişki kurulan geçmişin ya da geleceğin imgelerini sahneler." Mekânsal pratikler anlamına gelen bedensel alışkanlıklar ve toplumda uyulması gerekli kurallar ise mekânı doğrudan yaşayıp deneyimlenmesini belirleyen gündelik hayatın ve olağanın gerektirdiği mekânsal ritimleridir.

Dönemin Ankara'sında mekânın üretimi bağlamında iki önemli husus; biri Mustafa Kemal'in rolü, diğeri ise yoğun göç alan ve kentin farklı alanlarda

357 Bozdoğan, Modernizm ve Ulusun İnşası: Erken Cumhuriyet Türkiyesi’nde Mimari Kültür, s. 57.

358 Basa, "From Praise to Condemnation: Ottoman Revivalism and the Production of Space in Early Republican Ankara", s. 6.

359 Yalım, "Ulus Devletin Kamusal Alanda Meşruiyet Aracı: Toplumsal Belleğin Ulus Meydanı Üzerinden Kurgulama Çabası”, s. 181. 
formel olmayan bir mekân üretimine yol açan barakalaşma ele almadan anlamlandırılmaz. Her iki husus da gerek mevzubahis dönemde gerekse sonraki dönemlerde kentte mekânın üretimini belirleyen ve toplumsal mekânı önemli ölçüde etkileyen faktörlerdir.

1920'li yılların sonunda Ankara'da bulunan Ahmet Hamdi Tanpınar'a göre "şehrin aktüalitesi biraz bu yeni binalarla Mustafa Kemal'in hayatıydı. Bu nerede basıldığ 1 bilinmeyen, hatta hiç elinize geçmeyen, fakat sizden başka herkesin okuduğu ve her ağzın beraberce size naklettiği bir gazeteye benziyordu." $360 \mathrm{Bu}$ alıntı, dönemin toplumsal mekânında Mustafa Kemal'in önemli rolüne işaret ederken aynı zamanda Ankara'nın mekânının tasarlanan, yaşanan ve algılanan bileşenleri açısından önemli içerimler sunar.

Ankara'nın belirli bir coğrafi eksen üzerine; Çankaya sırtlarına doğru gelişmeye başlaması konusunda Mustafa Kemal tarafindan Çankaya tepesine yerleşme kararı, yeni başkentin farklı inşaatlarında hangi binanın nasıl olması gerektiği konusunda Mustafa Kemal'in doğrudan müdahil olması veya 1930'lu yıllarda Ankara'nın imarının kararlı bir şekilde yürütülmesi konusunda Mustafa Kemal'in rolü dönemin mekân üretimi süreçlerinde önemli etkenler arasında olmuşlardır. ${ }^{361}$ Fakat Mustafa Kemal'in, mekânın üretiminde ve yeni biçimlenen toplumsal mekânda ilginç birtakım 'rollerden' de söz edilebilir. Daha çok Mustafa Kemal'in kentte bulunması ve onun imgesiyle ilişkin bu roller mekân temsili, temsili mekân ve mekânsal pratikler bağlamında değerlendirildiğinde ortaya çıkmaktadır.

1920'li y1lların Ankara'sının temsilinde onun sürekli Mustafa Kemal ile özdeşleştirildiği görülmektedir, Ankara onun "evi” olarak tasvir edilir ve "ev sahibi olarak Mustafa Kemal, sesiyle, gözlerinin ve saçının rengiyle, giysileri/aksesuarlarıyla, jest ve mimikleriyle bulunduğu mekânı dolduran kişidir." 362 Aynı şekilde Mustafa Kemal ulusun babası olarak temsil edilmekte ve böylece "Mustafa Kemal ve Ankara, Mustafa Kemal'in ölümüne dek, birbirlerini temsil eden iki sembolüdürler. Ankara, Mustafa Kemal'in 'evi' olduğu için bir temsilî mekândır, Mustafa Kemal de Ankara ile özdeşleştiği için bir mekân temsiline aracilık etmiş olur." 363

360 Tanpınar, Beş Şehir, s. 16.

361 Örneğin, Tankut, Ankara'nın planlı imarının 1939 yılında artık sona erdiğini ve bunun temel faktörü olarak yapılaşma sürecinde çözümlerin imar çerçevesi dışında olduğunu belirtir. Diğer faktörler arasında ise planlı imarın en büyük savunucusu Mustafa Kemal'in de artık hayatta olmadığını vurgular. Bkz. Tankut, Bir Başkentin Imarı: Ankara, 1929-1939, s. 151.

362 Cantek, “Yaban”lar ve Yerliler: Başkent Olma Sürecinde Ankara, s. 200.

363 Ibid., s. 197.

Cantek, çalışmasında "temsili mekân" ve "mekânın temsili" kavramlarını şöyle tanımlamaktadır; "Mekân bir toplumsal ürün olarak ele alındığında, onu bir şeyler için 
$\mathrm{Bu}$ temsiliyet aracılığı salt kenti ve Mustafa Kemal'i birbirine özdeşleştirmekle ve Ankara'yı onun 'evi' olarak tasvir etmekle sınırlı kalmayıp, aynı zamanda sürekli açık mekânsal göndermeler içeren temsillere ve Ankara'nın farklı yer ve mekânlar üzerine mitlerin oluşmasına yol açtı. Bu mekânsal mitler sayesinde kısa bir süre içerisinde Mustafa Kemal, Ankara'nın yaşanan mekânın (temsil mekânının) önemli bir unsuru haline gelmişti. Bir edebiyatçı olarak Karaosmanoğlu'nun dönemin Ankara tasviri bu yaşanan mekânın iyi bir örneğini teşkil eder;

"Ankara, bütün manasıyla bir Orfe masalını yaşamaya başlamıştı ve bu masalın kahramanının, saçlarındaki güneş, gözlerindeki güneş, gözlerindeki gök parıltısıyla daima taze, daima coşkun bir ezelî gençlik kaynağı gibi yeşil Çankaya tepesinde çağladı̆̆ seyyalenin daima aşağıya doğru aktığı hissolunuyordu." 364

Çankaya Tepesi, Mustafa Kemal'in ikameti sayesinde Ankara'nın toplumsal mekânının yeni merkezi olması ötesinde, artık Türkiye'nin toplumsal mekânında da bir merkezi konum olma özelliği edinmeye başlamıştı. Bu, sadece Mustafa Kemal'in kişisel konutu değil, aynı zamanda önemli kararların alındığı ve Türkiye'nin yönetildiği bir mekândır. Böylece Çankaya aynı zamanda tasarlanan mekân olmaya yönelik eğilim göstermektedir, fakat yine de tasarlanan mekândan ziyade bir yaşanan mekân idi. İmgelemin ve mitlerin nüfuz ettiği yaşanan boyut, tasarlanan boyuta kıyasla daha baskındır ve Karaosmanoğlu'nun yukarıdaki tasviri ise bunun bir göstergesi olarak

hazırlandığı, düzenlediği, inşa edildiği, kurgulandığı fikrinden hareket edilebilir. Dolayısıyla mekânın üretilmesi sürecinde onun neyi temsil etmesinin niyetlendiği, nihai ürüne bakarak anlaşılabilir. Her zaman niyetlenen biçimiyle ortaya çıkmasa veya zamanla tam tersi istikamette gelişse de, belirli kaygılarla yapılandırılmış bir mekân "temsili mekân"dır. Temsili mekân birşeylerin sembolüdür... Temsil mekân kavramında mekân herhangi bir şeyi temsil etmek için araçtır. Bunun tersi durumda, yani mekânın temsili söz konusu olduğunda, mekân temsil edecek değer haline gelir. Mekânın temsili, söz konusu mekânın, ona kişiliğini veren özellikler, kişiler ve yapılarla anılmasıdır" (Cantek, "Yaban"lar ve Yerliler: Başkent Olma Sürecinde Ankara, s. 13-14). Görüldüğü üzere Cantek böyle bir kavramsallaştırma için Kevin Lynch'in, mekânın bir metin gibi okunabilirliği savından yola çıkar ki kendisi de bunu belirtir. Mekânın bir metin olarak okunabilirliği savı her zaman sorunsuz bir yaklaşım olmadığı (bunun için bkz. Lefebvre, Mekânın Üretimi, s. 162-166) bir kenara birakılırsa, Cantek'in, yukarıdaki alıntıda ve genelde çalışmasında Mustafa Kemal'i ve Ankara'yı temsiliyet aracılığı bağlamında ele alması ve her iki temsiliyetin de mekânsal mitlerin oluşması bağlamında değerlendirmesi temsil mekânı açısından önem taşımaktadır. Fakat aynı zamanda Lefebvre'in kavramsallaştırmasına kıyasla söz konusu iki kavramın daha dar bir kapsamı olduğu göz önünde bulundurulmalıdır, zira Lefebvre'in önerdiği mekân temsili sadece bir şeyin mekân aracılığıyla temsil edilmesiyle, temsil mekânı ise bir şeyin mekânla anılmasıyla sınırlı değildir.

364 Karaosmanoğlu, Ankara, s. 178, vurgu eklenmiştir. 
değerlendirilebilir. ${ }^{365}$ Yeni toplumsal mekânın yaşanan boyutu sadece Mustafa Kemal'in Çankaya'sıyla sınırlı değildi. Tanpınar, Ankara Kalesinden söz ederken, bize yaşanan mekânın bir diğer örneğini sunar;

“Atatürk'ün hemen herkesin gördüğü, mektep kitaplarına kadar geçmiş bir fotoğrafı vardır. Anafartalar ve Dumlupınar'ın kahramanı, son muharebenin sabahında tek başına, ağzında sigarası, bir tepeye doğru ağır ağır ve düşünceli çıkar. İşte Ankara kalesi muhayyilemde daima ömrünün en güneşli saatine böyle yavaş çıkan büyük adamla birleşmiştir. Bu şaşırtıcı terkip nasıl oldu? Eğer böyle bir şey lâzımsa vatanın her tepesine aynı şekilde tahayyül ve tasavvur etmem icabeden bir insanla bu kale bende nasıl birleştiler? Bunu hiçbir zaman izah edemem. Bu cins yaklaştırmalar insan muhayyilesinin en sırlı tarafıdır. Bildiğim bir şey varsa bir gün, bu fotoğrafa bakarken Ankara Kalesi kendiliğinden gözlerimin önüne geldi ve ben bir daha bu iki hayali birbirinden ayıramadım." 366

Böylece yukarıdaki tasvirlerde tasarlanmış olmaktan çok yaşanmış olan, ne tutarlılığa ne de bağlantıya mecbur olan, imgelemin ve sembolizmin nüfuz ettiği temsil mekânlart ${ }^{367}$ görmekteyiz. Mustafa Kemal ise Ankara'nın bu temsil mekânlarının duyumsal "çekirdeği” veya "merkezidir", çünkü onun hayatı "nerede basıldığ1 bilinmeyen, hatta hiç elinize geçmeyen, fakat sizden başka herkesin okuduğu ve her ağzın beraberce size naklettiği bir gazeteye benziyordu." 368

Çankaya Köşkü, kentin yaşanan mekânının ayrılmaz bir parçası olmakla beraber onun bir tasarlanan boyutu da söz konusuydu ve zamanla tasarlanan, yaşanana göre daha baskın olma eğilimi göstermeye başlamıştı. Burası Türkiye'nin yönetildiği merkezdi ve köşk dönemin toplumsal mekânında bir merkezlik işlevine sahipti. Bu merkezlik işlevi itibariyle köşkü ve Çankaya'yı, gündelik hayatın işleyişini denetim altında tutmayı sağlayan bir gözetleme kulesine ve Foucault'nun Panoptikona benzeştirenler mevcut. ${ }^{369}$ Ayrıca Mustafa Kemal başta olmak üzere erken cumhuriyet eliti, toplumu ve toplumsal mekânı dönüştürmeye ve 'asrileştirmeye' çalışırken bu 'misyonda' kendilerinin örnek teşkil etmesine çalışmaktaydılar. Onların evleri ve yaşayış tarzı ise öngördükleri medeni ve muasir toplumun bir mekân temsiliydi;

365 Mustafa Kemal'in ve onun aracılığıyla Çankaya'nın kutsallaştııılması ile ilgili önemli bir değerlendirme için bkz. Cantek, "Yaban”lar ve Yerliler: Başkent Olma Sürecinde Ankara, s. $181-215$.

366 Tanpınar, Beş Şehir, s. 14-15.

367 Lefebvre, Mekânın Üretimi, s. 70.

368 Tanpınar, Beş Şehir, s. 16.

369 Bkz. Cantek, "Yaban”lar ve Yerliler: Başkent Olma Sürecinde Ankara. 
"Bu evler, tüm millete yeni modern meskenlerde nasıl yaşanacağını gösteren, tüm dünyaya ise Türk bürokratların Şarklı alışkanlıklarından kurtulduklarını kanıtlayan mecralar, modernleşme ve Batılılaşma amblemleri olarak tasarlandı. Yani kullanım işlevlerinin dışında, bir bakıma yeni devletin propaganda araçları, milliyetçi gösterim teknikleri olmakla da yükümlü bir sahneydiler... Clemens Holzmeister tarafından tasarlanan ikinci Cumhurbaşkanlığı konutu, gerek şehir içindeki konumu, gerek sık sık medyada yer almasılla bunu örnekliyor."370

Yani söylem düzeyinde erken cumhuriyet elitinin, modernleşme ve Batılılaşma tahayyülleri somut mekânsal dokulara büründüler. $\mathrm{Bu}$ açıdan Lefebvre'in, "mekân temsillerinin pratik bir kapsamı olduğu, etkin bilgi ve ideolojilerin izi olan mekânsal dokuların içine bunları dönüştürerek katıldıkları"371 tespiti Çankaya köşkünün dönüşümü örneğinde anlam kazanmaktadır. Mustafa Kemal 1923 yılının Ocak ayında Çankaya tepesindeki Kasapoğlu (Kasapyan) Köşkü diye bilinen bu bağ evine yerleştikten sonra 19231924 yıllarında mimar Vedat Tek'in yaptığı ek projeyle dönemin hâkim Osmanlı Canlandırmacılığ1 üslubuyla köşke bir çıkma, bir ek kütle ve dik eğilimli bir çatısı olan sekizgen bir kule eklendi. 1930 yılında ise bina yetersiz gelmeye başladı ve ona bir ek daha yapılması kararlaştırılıp ve Mustafa Kemal tarafından Giulio Mongeri ve Clemens Holzmeister'e birer proje 1smarlanmıştır. Mongeri'nin tasarladığı yeni köşk kalın taş duvarları, dik çatıları, kemerli ve kolonadlı girişleri, köşeli çıkmaları, ortaçağı hatırlatan kulesi ve süslü bacaları olan bir projeydi ve bununla "kaynaklarında eklektik ancak temsile ait her seçiminde canlandırmacıydı." Mongeri'nin tasarısının (tarihsellik) yerine Holzmeister'inkinin (modernizm) tercih edilmesi Akçan'a göre “devlet-destekli mimarlıkta bir dönüşe tekabül ediyordu."372 Ancak bu dönüş sürecinde "Modernizmin tarihsel üsluplara tercih edilmesi sadece estetik bir tercih değildi, ilerici bir siyasi mesajla da yüklüydü." 373 Böylece, köşkün siyasi mesajla yüklü ve ideolojinin nüfuz ettiği bir mekâna dönüşmesi, onu kentin tasarlanmakta olan mekânın bir parçası kılmaktaydı, en önemlisi köşk, toplumsal mekânın merkezi olması itibarıyla bunda temsilin değişmesi kentte üretilmekte olan yeni toplumsal mekâna onun yeni temsiline de işaret etmekteydi. ${ }^{374}$

370 Akcan, Çeviride Modern Olan: Şehir ve Konutta Türk-Alman İlişkileri, s. 86-87.

371 Lefebvre, Mekânın Üretimi, s. 71.

372 Akcan, Çeviride Modern Olan: Şehir ve Konutta Türk-Alman İlişkileri, s. 89-92.

373 Bozdoğan, Modernizm ve Ulusun İnşası: Erken Cumhuriyet Türkiyesi’nde Mimari Kültür, s. 78.

374 Günümüzde Ankara'nın toplumsal mekânın dönüşümlerinde ve merkezlik kaymalarında Çankaya Köşkünün "konumunun" değişimi yine toplumsal mekânın üretiminde mekân temsillerin dönüşümüne işaret ettiğini söylenebilir. Bu husus da Çankaya Köşkünün kentin 
Tanpınar'ın, Mustafa Kemal'in hayatını herkesin okuduğu ve her ağzın beraberce birbirine naklettiği gazeteye benzetmesi dönemin mekânsal pratikleri açısından da önemli ipuçlar sunmaktadır. Cantek'in, erken cumhuriyet Ankara'sında yaşayanlarla gerçekleştirdiği sözlü tarih görüşmeleri ${ }^{375}$ de mekânsal pratikler açısından önemli ipuçları sunar ve Tanpınar'ın tasviriyle paralellik gösterir. Ankaralılar, Mustafa Kemal'i görme, onun günlük hayatının en ufak ayrıntılarını öğrenme isteği duymaktaydı. Mustafa Kemal, sadece halkın kahramanı ve ulusun "babası" olması sayesinde değil aynı zamanda kendi modern giyim kuşamı, davranış tarzları ve alışkanlıkları itibarıyla halkın ilgi odağındaydı. Onun Lincoln arabası, şapka, papyon, golf pantolon, pelerin, beyaz mendil gibi aksesuarları daha önceleri halkın hayatında olmayan ve görülmeyen aksesuarlardı ve Mustafa Kemal sayesinde ilk kez bunlar kapalı dünyası olan Ankara'nın sakinlerinin hayatına girdi. Ayrıca, Mustafa Kemal balolar, konserler gibi etkinlikler aracılığıyla halka modern ve Batılı eğlence alışkanlıkları aşılma gayreti içindeydi ve bu etkinlikler mekânsal olarak sadece kentin en uğrak yeri olan Ulus civarı eğlence mekânlarıyla (özellikle Ankara Palas) sınırlı değil, aynı zamanda dönemin gazetelerinin dikkat merkezinde olan Çankaya köşkünde de gerçekleştirilmekteydi. Böylece,

"O zamanın Ankaralıları Atatürk her an karşılarına çıkıp bir hatalarını görürse ayıplayacakmış gibi dikkatli, saygılı, terbiyeli ve bakımlı idiler... Erkekleri sanki hep lacivert takım elbise giyerdi. Kadınları, özenle tasarlanmış kısa ve 'ondüleli' saçları üzerine oturtulmuş şapkaları ile öylesine güzel ve zarif dururlardı ki..."376

Erken cumhuriyet eliti tarafindan modern kentsel yaşamın ve "muasır medeniyetin" bir belirtisi olarak tanımlanan bu alışkanlıklar, davranışlar ve giyim kuşam tarzlarının aşılmasıyla modern yaşama özgü bir kamusallık ve mekânsal pratikler yaratılmaya çalışılmaktaydı. Fakat oluşturulmaya çalışılan yeni mekânsal pratikler ile aynı zamanda hedef, gündelik hayatın mekânsal ritimlerini; içe kapalı mahalle örgütlenmelerin ve geleneksel yerel cemaat örgütlenmelerin nüfuz ettiği alanlardan devletin kontrol edebileceği yeni kamusallıklara taşınmasıydı. Dolayısıyla özellikle halkın kahramanı olarak Mustafa Kemal'in kamusal hayattaki görünürlüğ̈ bunların yaygınlaşmasına ve yeni toplumsal düzenin meşrulaştırılmasına yönelik somut girişimler olarak değerlendirilebilir. Bu bağlamda yaratılmak istenilen yeni toplumsal mekânsal pratikler açısından Mustafa Kemal'in rolü bir tür yeterlilik aşılma girişimi olarak tanımlanabilir, yeterlik ise muasır bir toplumda kamusaldan özel alana uzanan mekânsal düzlemlerde bireylerin mekânsal pratiklerinin nasıl olması gerektiği

(ayrıca Türkiye'nin) toplumsal mekânında ne derecede önemli bir temsil mekânı olduğunun bir diğer göstergesidir.

375 Bkz. Cantek, "Yaban”lar ve Yerliler: Başkent Olma Sürecinde Ankara.

376 Karaveli'den akt. Cantek, “Yaban”lar ve Yerliler: Başkent Olma Sürecinde Ankara, s. 208. 
konusunda genel bilgi, kural ve kalıplarıydı. Mustafa Kemal'in hayat tarzının ve onun kentteki mekânsal pratiklerinin (gerek kentin belirli mekânlarının kullanımı gerekse bu mekânların nasıl kullanıldığı açısından) bir performans boyutu vardı, fakat toplumdaki onun eğitici, öğretici rolü ve ulusun babası olma özelliği, onun mekânsal pratikleri, performanstan ziyade yeterlilik olarak değerlendirilebilir.

Çankaya Köşkü'nde Mustafa Kemal'in aile hayatı da konu açısından bir diğer önemli örneği teşkil etmektedir. Çankaya Köşkü'nün bir mekân temsili tarafı olmakla beraber, mekânsal pratikler açısından modern bir aile hayatının nasıl olması gerektiğine dair önemli bir örnek sunmaktadır. Mustafa Kemal'in, "ben sadece evlenmek için evlenmiyorum. Vatanımıza yepyeni bir aile hayatı yaratabilmek için önce kendim örnek olmalıyım" sözleri bir temsil oluşturmakla beraber, onun evi "mahrem bir yer değil, özel ve kamusal alan tanımlarını bulanıklaştıran bir mekân" 377 olma özelliği, Ankara'daki kamusal ile özel alanlar arasında keskin ayrım öngören geleneksel yaşamı değiştirmeye yönelik somut bir çaba olarak değerlendirilebilir. Bununla "kamusal alanda denetim altında tutulan gündelik hayat, özel alanda da aynı titizlikle denetlenmeye çalışılmıştır. Üstelik, özel alanın devletçe denetlenip yönlendirilmesi, modernleşmenin bir gerekliliği ve bu denetim ve yönlendirmeyi kolaylaştırmak için de bir vatandaşlık görevi sayılmaktadır." 378

Erken Cumhuriyet Dönemi'nde, Ankara'nın toplumsal mekânında mekân temsilleri, temsili mekânları ve mekânsal pratikleri açısından Mustafa Kemal'in rolünü kısaca ele alırken bahsi geçen üç unsurun 'sınırlarının' çok belirgin olmadığını ve çoğu kez birbiriyle iç içe geçmiş olduğunu görmekteyiz; yukarıdaki değerlendirmeden de görüldüğü üzere örneğin Çankaya Köşkü’nün temsil mekânı ile mekân temsili arasında sınırları iç içe geçmiş ve çok muğlaktır, fakat ele alınan dönemin toplumsal mekânında yine de Mustafa Kemal'in "konumunun" tasarlanandan ziyade yaşanan bir özelliği vardır. Zira Mustafa Kemal etrafında kişisel kültün oluşmasının henüz fazla ilerlemediği, ideolojik ve pratik anlamda Kemalizm'in henüz söz konusu olmadığı ve onun aracilığıyla Mustafa Kemal'in devletle henüz fazla özdeşleştirilmediği bir dönemde toplumsal mekânın üretimi süreçlerinde Mustafa Kemal'in imgesi, ideolojinin ve bilginin nüfuz ettiği tasarlanan mekândan ziyade imgelemin, duyumsallığın ve karmaşık sembolizmlerin nüfuz ettiği yaşanan mekânın önemli bir "unsur"uydu. Ayrıca Mustafa Kemal'in, Ankara'nın toplumsal hayatındaki görünürlüğü ve mekânsal pratikler aracılığıyla onun varlığının hep deneyimlenmesi (algılanan mekân) soyuttan ziyade somut bir deneyim sağlamaktayd. Özellikle bu son durumun üzerinde kısaca durulması gerekir.

377 Akcan, Çeviride Modern Olan: Şehir ve Konutta Türk-Alman İlişkileri, s. 88-89.

378 Cantek, "Yaban"lar ve Yerliler: Başkent Olma Sürecinde Ankara, s. 238. 
Bilindiği üzere Mustafa Kemal hayattayken bazı kamusal alanlar onun adıyla anılmaya veya belirli kamusal alanlarda onun heykelleri konulmaya başlamıştır. Ankara'da bunun ilk örnekleri Atatürk Bulvarı ve Etnografya Müzesi Önü Atatürk Heykeli, Sihhiye Zafer Anıtı ve Ulus Zafer Anıtı'dır. Bunlar belirli bir tasarlanan mekân oluşturmakla beraber mekânsal pratikler aracılığıyla belirli bir deneyim yaratmaya yönelik algılanan mekânlardı. ${ }^{379} \mathrm{Bu}$ bağlamda dönemin “Atatürk imgesinin en belirgin ve kalıcı göstergesinin, Atatürk'ün Kurtuluş Savaşı'ndaki rolünü ve siyasi yaşamdaki tek adamlığını görselleştiren heykeller olduğu"380 hesaba katıldığında, bu durumun, Kurtuluş Savaşı'ndan yeni çıkan ve savaş sırasında Mustafa Kemal'e ev sahipliği yapan Ankaralılar için soyut bir imge oluşturmadığı söylenebilir. Dolayısıyla, bu imgenin maddi somutlaşması olan bahsi geçen yapılı çevre unsurlarının da soyut bir deneyimden ziyade somut ve tanıdık bir deneyim sağladığını söylemek mümkündür. İşte bu açıdan da dönemin toplumsal mekânı henüz ideolojinin fazlasıyla nüfuz etmediği, "kullanım değeri münhasıran siyasi olan" bir soyut mekânın baskın olmadığını göstermektedir.

1920'li y1llardan itibaren Ankara'da kentsel mekânda morfolojik açıdan ikili bir yapı oluşmaya başlanmıştır. Eski Kent ile Yeni Kent arasındaki mekân temsili, temsil mekânı ve mekânsal pratikler açısından söz konusu olan ikili yapıya yeni bir süreç de eklenmeye başlanmıştır. Başkentte inşaat faaliyetlerine başlanması ile artan işgücü talebinin yanı sıra kır ekonomisinin savaş şartlarında daha da gerilemesi Ankara'nın yakın çevresinden kente göç başlatmıştır. Göç edenler kentteki denetimsiz arazilerde yerleşmeye başlamışlardır. Genelde kentin merkezine çok yakın olan Akköprü, Altındağ kısımlarında yerleşen göçmenler Ankara'da ilk barakaları kurmaya ve kentte enformel bir mekân üretimi süreçlerine başlamışlardır. ${ }^{381}$ Fakat başkentin ilk on yılında barakalaşma henüz yaygın bir mekân üretimi süreci teşkil etmediğinden dolay1 ${ }^{382}$ kendine özgü tutarlı bir tasarlanan, algllanan ve yaşanan taraflara sahip değildi ve bunlar açısından toplumsal mekânın ikili yapılanmada geçişken bir konumdaydı. Genelde Ankara'nın yakın çevre kırsal alanlarından göç edenler tarafından üretilen barakalar, mekân temsili, temsil mekânı ve mekânsal pratikleri açıdan Eski Kentin toplumsal mekânını yeniden üretme veya genişletmeye katkıda

$379 \mathrm{Bu}$ anıt ve heykellerin estetik, kurgu ve mekânsal bağlam açılarından detaylı bir değerlendirmesi için bkz. Gür, "Sculpting Turkish Nationalism: Atatürk Monuments in Early Republican Turkey"; Tekiner, Atatürk Heykelleri: Kült, Estetik, Siyaset.

380 Tekiner, Atatürk Heykelleri: Kült, Estetik, Siyaset, s. 66.

381 Şenyapıl1, "Baraka”dan Gecekonduya: Ankara'da Kentsel Mekânın Dönüşümü: 1923-1960.

382 Şenyapılı'ya göre bu dönemde "barakalaşmalar" henüz mahalle boyutlarına varmayan, bir iki katlı ve beş-on baraka ölçeğinde yapılanmalardır. Şenyapı11, "Baraka”dan Gecekonduya: Ankara'da Kentsel Mekânin Dönüşümü: 1923-1960, s. 76. 
bulunurken, aynı zamanda kentte yeni gelişmeye başlayan üretim ilişkileri bağlamında, bu ilişkilerin elverdiği imkânlar çerçevesinde geliştiği ve ucuz emek gücü sağlamaları sayesinde bu ilişkilere de katkıda bulunan mekânsal oluşumlardı. Planlı şekilde gelişen ve muasır bir başkente sahip olma konusunda başından beri ısrarlı olan iktidarın bu oluşumlar konusundaki yaklaşımı da önem arz etmektedir; iktidar bir taraftan bu olguyu kendilerinin çözemediği fakat çözülebilecek konjonktürel bir sorun olarak tanımlamakta aynı zamanda olgunun zor şartlarında olan ekonomiye kattığı ucuz emek boyutunun da farkındadır. ${ }^{383}$ Böylece başlangıçta büyük bir sorun teşkil etmeyen ve yapısaldan ziyade konjonktürel olan 'barakalaşma' belirli bir süre sonra ülke ekonomisindeki yapısal değişimler sonucunda önemli dönüşümlerden geçerek 'gecekondulaşma' sıfatıyla Ankara'nın toplumsal mekânının ikili yapısını daha belirginleştiren bir olgu haline gelmiştir.

Yukarıdaki değerlendirmeler 1şığında 1923-30 arası döneminde Ankara'da mekânın üretimi süreçleriyle ilgili şöyle bir genel tablodan söz edilebilir. Ulusdevletleşme ve modernleşme açısından kentsel mekânın üretimi konusunda belirli girişimler söz konusu olmakla beraber, kentte mekânın üretimi süreçlerinde henüz Osmanlı'ya kıyasla radikal bir kopuş olmaması ve Osmanlı'ya özgü toplumsal mekânın hala kentte önemli ölçüde devamlılı̆̆ını sürdürmesi söz konusudur. Kentsel mekânın mübadele süreçlerinde yaygın bir şekilde dahil olunup gittikçe soyutlaşma eğilim gösterdiği, fakat bunun daha çok bir tür ilkel sermaye birikim niteliğinde olduğu görülmektedir. Dönemin etnik açısından hayli homojenleş(tiril)miş toplumsal mekânı, ulus-devletin kendi mekânı üretme sürecinde bir taraftan uygun bir zemin oluştururken, diğer taraftan kapitalistleşme ve (ilkel) birikim süreçleri açısından önemli bir imkân sunmaktadır. Kentin etnik açısından hayli homojen toplumsal mekânı aynı zamanda mekân temsili açısından Osmanlı'dan farklı olarak ulus-devletin hayli homojen mekânını yansıtmaktadır. Bu homojenlik, Cumhuriyet öncesi ve Cumhuriyetin kuruluşuyla sonuçlanan savaş ve şiddetin sonucuyken, Cumhuriyetin ilk yıllarında onun yeniden üretimi, milliyetçilik ideolojisi benimseyen bir ulus devletin sembolik şiddet aracılığıyla sürdüğü söylenebilir. Bununla beraber mekân temsili ve mekânsal pratikler açısından Osmanlı'nın toplumsal mekânı henüz önemli devamlılığa da sahipti. "Asyaî dekor" olarak tanımlanan toplumsal mekânın bu devamlılığından, ayrıca cumhuriyet elitinin; henüz kendi iktidarını yeterli ölçüde pekiştirememesinden dolayı yeni bir mekân temsili yaratma konusunda belirli sinırlamalar söz konusuydu, o yüzden Osmanlı'ya göndermeler içeren bir mimari üslup benimsenmişti. Farklı bir üsluba başvuramamasında dönemde üretim güçlerinin ve üretim ilişkilerinin gelişmişlik düzeyinin de önemli payı vardır. 
Henüz tam anlamıyla kapitalist mülkiyet ve üretim ilişkilerinin gelişememesi, üretim güçleri açısından kaynak, teknoloji ve emek gücü yetersizlikleri belirli bir temsil doğrultusunda mekânın üretimini sınırlayan önemli etkenlerdi. Ankara, en azından Cumhuriyetin ilk on yılında ticari sermayenin hâkim olduğu, bu sermayenin spekülatif yatırımlara yöneldiği ve bu bağlamda arazi spekülasyonlarının hız kazandığı bir dönem yaşamaktaydı. Özellikle bu tür sermayenin ve yatırımların varlığı mekânı mübadele süreçlerine dâhil edip, metalaşma ve soyutlaşma eğilimine yol açmıştır. Fakat mekânın tamamıyla birikim süreçlerine dâhil olunması için henüz üretim güçlerinin ve üretim ilişkilerinin gelişmişlik düzeyi yeterli değildir. Ayrıca bunun için kurumsal çerçeve sağlayacak olan devlet, konu ile ilgili adımları yeni atmaya başlamıştır.

Bu hususlar göz önünde bulundurulduğunda 1923-1930 arası dönemde kentin toplumsal mekânının hala büyük ölçüde Osmanlı Dönemi'ndeki tarihsel mekân ile süreklilik gösterdiği söylenebilir. Mekân temsili, temsil mekânı ve mekânsal pratikler açısından Osmanlı'ya özgü toplumsal mekândan belirli kopuş görülse de henüz radikal bir kopuştan ve farklı bir hâkim mekândan söz etmek mümkün değildir. Ancak 1930'lu yıllarda kentte mekânın üretimi açısından radikal bir kopuş yaşanacağı görülecektir.

\subsection{Ulus-devletleşme ile Kapitalistleşmenin Soyut Mekânı Yerleşerek Yaygınlaşırken}

"Sizin sokaklarınızın, meydanlarınızın, caddelerinizin, buralarla ilişkisi olmayan, insanlarla ya da şeylerle de ilişkisiz, gülünç adları var. Generallerin ya da muharebelerin adları. Gösterilenlerle gösterenler arasında hiç ilişkisi yok. Şehirleriniz akli mekânı un ufak etti. Size önerilen ve sizin tarzınızda hazırlanmış olan şifre anahtarları, Batı'nın bu alanda bulduğu en iyi şeyi kapsıyor. Neye dayanıyor bu anahtar? Bir dizi dönüşüme, bir yapıya. Kafes biçimli, yarı kafes biçimli, çubuk şekilli karmaşık mekânların, basitleştirilmiş mekânlar üzerinde, ağaçlar, doğrusal çizgiler üzerinde pratik bir üstünlügü olduğunu fark etmek için sizin büyük araştırmacılarınızdan birinin ortaya çıkması gerekirdi."384

\subsubsection{0-40'lar: Mekân Üreterek Tarihe Emretmek: Ankara'da Modernleşme ve Mekân}

1931-33 y1lları Türkiye'nin toplumsal tarihinde bir dönüm noktasıdı. 1931 y1lında tek partili cumhuriyetin kuruluşu büyük ölçüde tamamlanmıştır, 
Nisan 1931'deki seçimlerinden sonra Mayıs ayında Üçüncü Büyük Kurultayını gerçekleştiren Cumhuriyet Halk Fırkası yeni bir parti programıyla Mustafa Kemal'in belirlemiş olduğu altı ilkeyi (cumhuriyetçilik, milliyetçilik, halkçılık, laiklik, devletçilik ve inkılapçılık) temel ilke olarak benimsemesiyle, Kemalizm tek partili cumhuriyetin ideolojisi haline gelmiştir. Takip eden yıllarda gittikçe daha da kurumsallaşan Kemalizm, 13 Şubat 1937 tarihli Anayasa değişikliğiyle artık devletin resmî ideolojisi haline gelecektir. Şubat 1932'de Halkevleri'nin kurulması, 'Türk Tarih Tezi' gibi çalışmaların ivme kazanması, 1933 yılı üniversiteler reformu gibi girişimlerle parti ideolojisi artık toplumsal hayatın her alanına nüfuz etmeye başlamıştır. ${ }^{385}$ Milliyetçiliği temel ilkelerinden biri olarak benimseyen, halkı ise "ayrı ayrı sınıflardan meydana gelmiş değil ve fakat kişisel ve sosyal hayat için iş bölümü bakımından türlü iş kollarına bölünmüş bir topluluk" olarak tanımlayan Kemalizm, toplumun sinıfsal yapısını reddederek sınıfsız ve kaynaşmış bir toplum hedeflemektedir. Devletçilik aracılığıyla kalkınmada devlet temel aktör olarak tanımlanıp, ona ayrıcalıklı konum sağlanarak, İnkılapçılık aracılığıyla ise 1925 yılından itibaren hayata geçirilmiş bir takım Batılılaşma ve modernleşme atılımlarının (Şapka Kanunu, tekke ve zaviyelerin kapatılması, dil reformu vs.) devamlılı̆̆ amaçlanmaktadır. 1931-33 yılları arasında devlet ile neredeyse tamamıyla bütünleşen ve iktidarı tamamıyla tekelinde bulunduran bir parti, benimsediği ideolojisiyle mekânın üretimi süreçleri ve toplumsal mekân açısından önemli sonuç ve içerimler doğurmuştur. Ankara ise, mekânın üretimi ve yeni bir toplumsal mekânın ortaya çıkışı açısından 1931-1933 yıllarında bir dönüm noktası teşkil ettiğinin en iyi örneği olarak tanımlanabilir.

1927 y1lında Ankara Şehremaneti tarafindan, Ankara'nın planlı gelişmesi doğrultusunda açılan imar planı yarışmasına katılan üç yabancı yarışmacıya bir "istekler listesi" sunulmuştur. Bu isteklere göre yarışmacilardan 50 y1llık bir gelecek için 250.000-300.000 nüfus barındırabilen, Eski Kentin dokusunu değiştirmeden ve yenilenmesini sonraki aşamalara erteleyerek kentin yeni gelişme alanı olarak güney ve batıyı belirleyen ve Kale'yi kentin hem eski hem yeni kesim için tek odak noktası olarak vurgulayan bir imar planı hazırlanması istenmiştir. Yarışmayı Hermann Jansen'in kazandığı 16 Mayıs 1929'da kamuoyuna açıklanmıştır. Yarışma sonucunda elde edilen Jansen planı bir ön projeydi ve yaklaşık üç buçuk yıl içinde hazırlanarak 27 Ocak 1932'de onaylandı ve yasal bir niteliğe kavuştu. ${ }^{386}$

385 Şener, "Burjuva Uygarlığın Peşinde".

386 Jansen planının detaylı bir değerlendirmesi için bkz. Tankut, Bir Başkentin İmarı: Ankara, 1929-1939. 
Mekânın üretimi açısından Jansen planının en önemli özelliği, Türkiye'de ilk kez batılı modern planlama anlayışıyla bir kenti bir bütünlük olarak ele alıp bir plana dayanarak yeniden biçimlendirilmesiydi, başka bir deyişle mekânın üretimi eskiden mevcut mevzi imar planı veya mimari ölçekten kent ölçeğine kaymıştı, Tankut'un da belirttiği gibi bu planla "vurgu tek yapıdan şehir ölçeğine kaymıştır." ${ }^{387} \mathrm{Bu}$ açıdan plan, Türkiye'de modern kent planlama anlayışının ve pratiğin gelişmesi açısından önemli bir dönüm noktası ve yeni bir mekân temsilinin ve mekân kodunun öncülüydü. ${ }^{388} \mathrm{Bu}$ yeni mekân temsili, mekânı üst ölçekte ele alma ve düzenleme anlayışıydı, kurumsal olarak kentsel planlama pratiğinde, maddi olarak ise planlar, paftalar, kadastro haritaları ile kendini göstermekteydi.

Sitte ekolünden ve bahçeşehir kuramının Almanya'daki deneyiminden önemli ölçüde etkilenmiş olan Hermann Jansen kentsel mekânın rasyonel olarak planlanmış, onun işlevler açıdan endüstri, konut, yeşil alanlar ve benzer bölgelemeye tabi olan işlevsel ve uyumlu bir bütünlük olması gerektiğinin savunucusuydu ${ }^{389}$ ve Ankara'nın planında da bu işlevselci ve rasyonel yaklaşımı temel olmuştur. Bu açıdan bakıldığında Jansen planı Kemalist iktidarın, akılcı olarak tanımlanmış muasır medeniyetinin bir mekân temsiliydi ve Ankara'da üretilmekte olan yeni hâkim mekânın öncülüydü.

Planın birinci özelliğiyle yakından ilişkili olan diğer kayda değer husus planın bilgi ve ideolojinin önemli bir birleşimini temsil etmesidir. Modernleşme ve batılılaşma (muasır medeniyet seviyesine ulaşmak), Kemalist iktidarın temel hedeflerinden biriydi, dolayısıyla rasyonel olarak planlanmış (muasır olmanın diğer önemli tanımı) bir başkente sahip olmak muasır bir medeniyetin temsili olacaktı. O yüzden ilk önce Batılı bir planlamacı tarafından modern bir başkent planlamasına başvuruldu. Jansen planı bir siyasi proje olarak Türkiye modernleşmesinin ürünüydü ve planın birtakım detaylarında da bu siyasi projenin ideolojik tınıları bulunmaktadır.

387 Tankut, Bir Başkentin Imarı: Ankara, 1929-1939, s. 136.

388 Yukarıda ele alındığı üzere son dönemlerde özellikle Ali Cengizkan'ın çalışmaları, Ankara kentinin gelişme eksenlerini ve gelecekte kent morfolojisini belirleme açısından Lörcher planının büyük önem taşıdığını ortaya koymaktadır. Fakat Lörcher planı "tasarımcı-özne" tarafından alınan kararlar sonucu olduğu ve merkezi veya yerel yönetimi tarafindan yönlendirilerek üretilen bir plan olmaması itibarıyla Jansen planına kıyasla mekânın üretimi açısından etkisi büyük değildi. Şöyle ki iki plan da yabancı plancı tarafindan yapılmasına rağmen, Jansen planının belirli istekler doğrultusunda yapılması, iktidarın nasıl bir mekân temsili sahip olduğu konusunda önemli ipuçları sunar. Bkz. Cengizkan, "Kurgu, Tasarım ve Kullanım: Cumhuriyet Dönemi Kamusal Mekânları İçin Bir Çalışma Programı”.

389 Akcan, Çeviride Modern Olan: Şehir ve Konutta Türk-Alman İlişkileri. 
Lefebvre'in belirttiği üzere ideolojiler belirli faaliyetlerin yerlerinin belirlenmesini buyururlar, hangi faaliyetin nerede olması gerektiğini belirlerler, fakat ideolojiler mekânı üretmezler, mekânın içindedirler, mekân sadece üretici güçler ve üretim ilişkileri tarafından üretilir. Aynı zamanda bütün belirlenmiş yerler de ideolojiye atfedilmemelidir. ${ }^{390}$ Bu açıdan Jansen'in planı rasyonaliteye, bilgiye dayanarak belirli bir mekân temsili ortaya koyarken ve üretim ilişkileriyle dolaylı ve dolaysız olarak bağlantılı mekânsal bir örgütlenme önerirken Kemalist ideolojinin belirli derecede nüfuz ettiği bir mekân temsili de içermekteydi. Bilgi ve ideolojinin nüfuz ettiği bu plan yakından incelendiğinde hem üretilmekte olan egemen mekânın hem de onun tasarlanan, yaşanan ve algılanan boyutlarıyla ilişkili önemli ideolojik tınılar göze çarpmaktadır.

Jansen, Ankara Imar Planı Raporu'nda "yeni şehir kısımlarının kurulmasını eski kısmın yayılışından tamamen ayırma" gerekliliğinden söz ederek aynı zamanda imar sürecinde eski kısmına "mümkün olduğu kadar fazla el sürmeme" ve muhafazasına vurgu yapar. ${ }^{391}$ Çünkü Jansen'e göre "bütün eski şehrin cazibe ve güzelliği, hususiyeti kat kat yükselen canlılık gösteren eski evlerde, hakim olan taç kalededir." Böyle bir kurgu ile "Ankara kalenin altında yayılacak, ebediyete kadar mavi, daima parlıyan [sic.] gök altında haşmet saçacaktır." 392

Eski ve Yeni Kenti imar sürecinde birbirinden ayırıp ve özellikle eski kentin muhafazası konusunda hem Jansen'in hem de iktidarın benzer tutumu önemli bir husus hatta görünüşte bir çelişki teşkil etmektedir. Kemalist iktidar, Ankara'yı modern bir başkent yapma konusunda kararlıdır ve modernliğin somut/maddi ifadesi olarak betonu görmektedir. Bozdoğan'ın ifadesiyle,

"Modern mimari, ülkenin kendi Osmanlı ve İslami geçmişinden kopmuş, tam anlamıyla Batılılaşmış, modern ve laik yeni bir ulus yaratmaya yönelik bu radikal programın hem gözle görülür bir simgesi hem de etkili bir aracı olarak ithal edildi. $\mathrm{Bu}$ bakımdan, erken cumhuriyet dönemi Türkiyesi'ndeki mimariye, yüksek modernist bakış açısının kelimenin tam anlamiyla "somut/betonarme" (concrete) bir tezahürü olarak bakılabilir." "393

Dönemin hâkim söyleminde ahşap mecazi ve tam anlamıyla çürümüşlüğe yatkınlık, Osmanlı'nın temsili olarak tanımlanmakta, Kemalizm ise "ahşap binaların ve ahşap kafaların yıkılması ve betonlaşması" olarak öne sürülmektedir

390 Lefebvre, Mekânın Üretimi, s. 223-224.

391 Jansen, Ankara Imar Planı Raporu, s. 6.

392 Ibid., s. 7.

393 Bozdoğan, Modernizm ve Ulusun İnşası: Erken Cumhuriyet Türkiyesi’nde Mimari Kültür, s. 18. 
ve ahşap ile beton arasındaki karşıtlık üzerinden geleneksel ile modern arasındaki karşıtlık temsil edilmektedir. ${ }^{394}$ Böylelikle, genelde ahşaptan yapılmış eski kent dokusunun korunmas1 zorunluluğu hâkim söylem karşısında bir tezat oluşturmaktayd. Bununla beraber bu tezat aynı zamanda mekân temsili açısından Kemalist iktidar için önemli bir işlevle yüklüydü. "Nazari olarak üzerine hatti zatında bir cam levhası" 395 olan eski kent altında, onu çevreleyerek gelişen yeni kent modernist ilerlemenin ve betonlaşmanın temsilini oluşturacakt1, yeni kentin her noktasında görülebilecek olan eski kent ise Kemalist iktidarın ilerleme ve modernleşme konusundaki başarısını temsil eden karşılaştırmalı bir referans noktası oluşturacaktır (bkz. Şekil 5).

\section{Şekil 5. İmar Plan Raporunda Kaleyi Kentin Temel Referans Noktası Olarak Temsil Eden Eskizler}

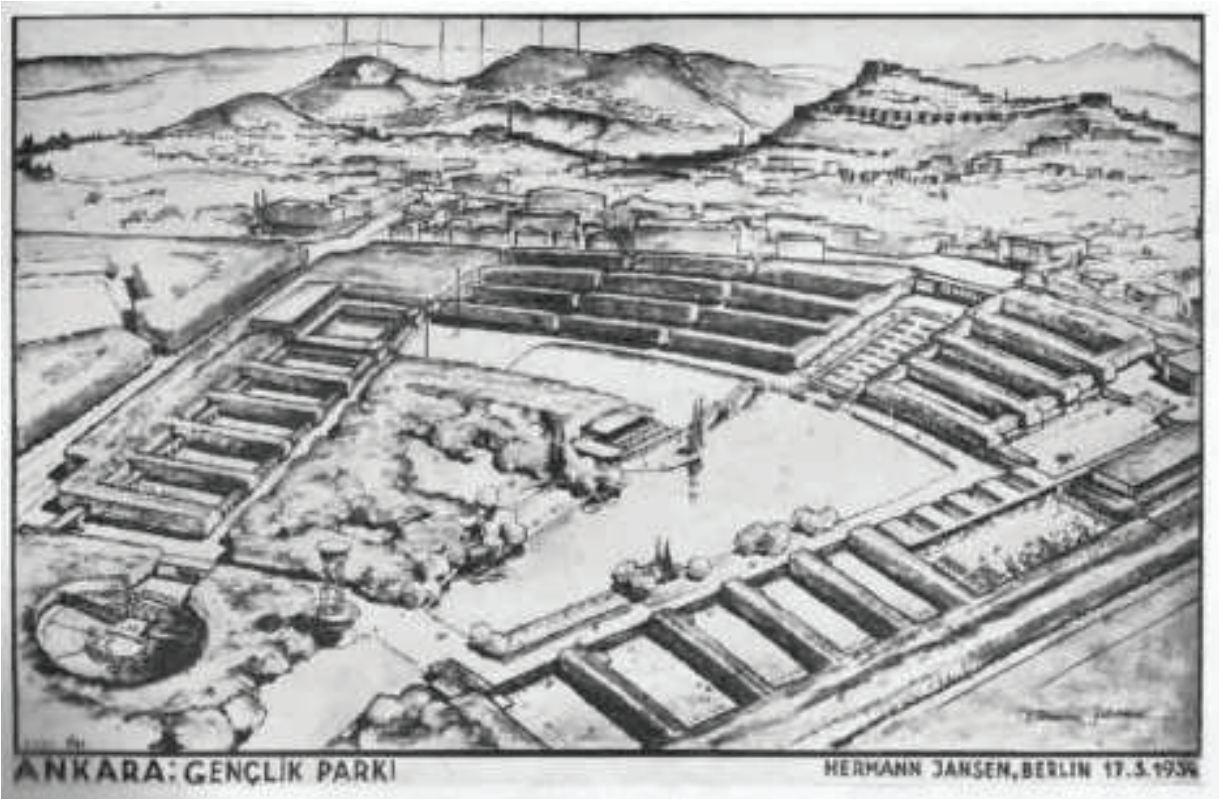

394 Cantek, "Yaban”lar ve Yerliler: Başkent Olma Sürecinde Ankara, s. 40-41.

395 Jansen, Ankara Imar Planı Raporu, s. 6. 


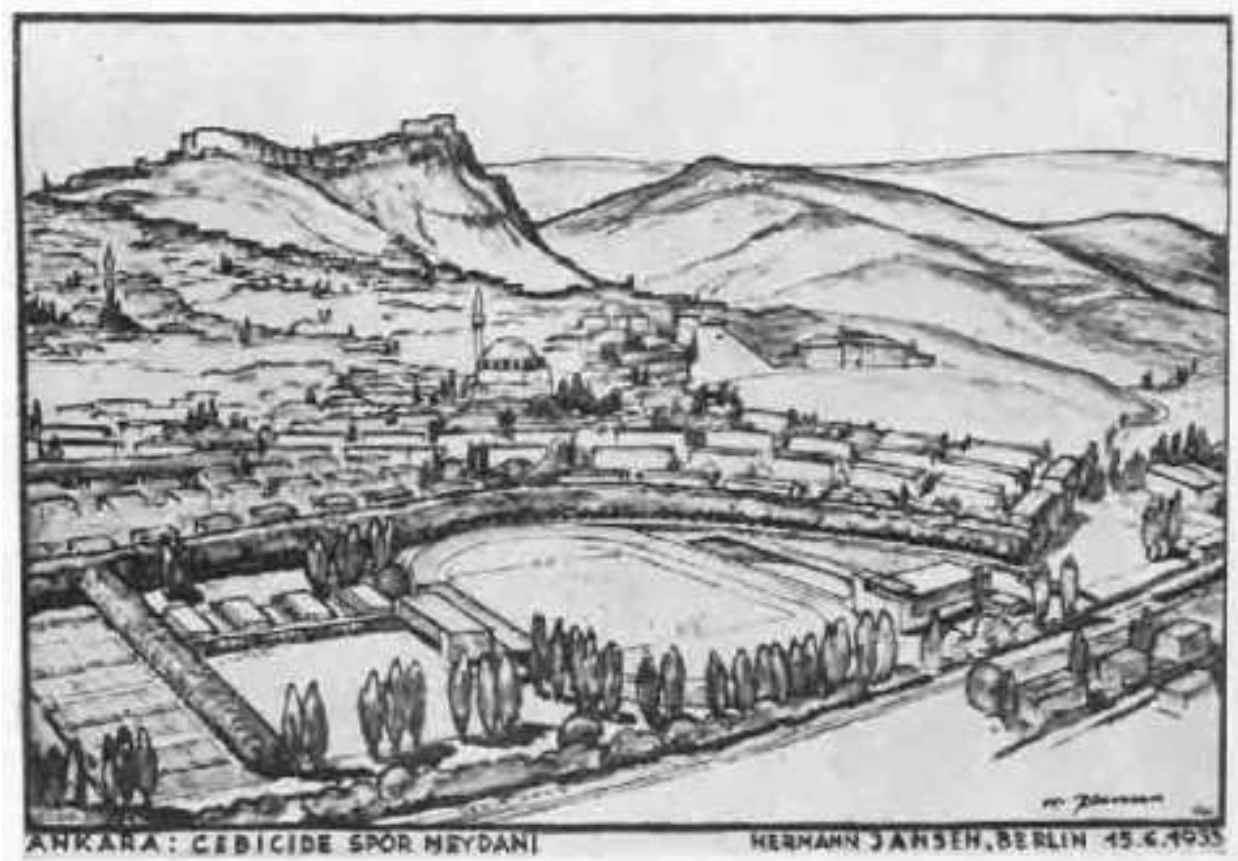

Kaynak: Jansen, Ankara İmar Planı Raporu.

Aynı zamanda böyle bir kurgu ile Kale'nin de yeni oluşan mekân temsili ve temsil mekânı bağlamında önemli bir işlevi vardı. Jansen'in planında kentin Kale ile taçlandırılması ve "tüm kent için bir simge ve referans noktası olarak düşünülmesi” imar planı hazırlanmadan önce Jansen'e sunulan bir istek olduğu hesaba katılırsa, Kale'nin tüm kent içindeki kurgusu iktidarın mekân temsiline ve temsil mekânına dair önemli ipuçları sunar. Kemalist iktidarın ulus inşa etme sürecinde tarihin yeniden kurgulanması da önemli bir güncel sorun arz etmekteydi. Tarihin bu yeniden kurgulanmasında (Türk Tarih Tezi) ise Anadolu'nun Osmanlı öncesi dönemi temel referans olarak kabul görülmekteydi. Bu açıdan, Osmanlı öncesi dönemden kalan Kale'nin tasarlanan mekânda öne çıkarılıp bir referans nokta haline getirilmesi dönemin tarih temsiline ve onunla ilişkili temsil mekânına uygun bir kurguydu. Temsil mekânı olarak eski kentin bir diğer önemi, inşa edilmekte olan yeni ulusun yakın geçmişinden kaynaklanmaktaydı ki bu husus da Jansen tarafından dile getirilmektedir; "Sade tarihî noktai nazardan İstiklal harbinin merkezi olması dolayisile ve bu hususun çok kutsî kabul edilmesi yüzünden olan merbutiyet, eski şehirden ve onun hatıralarından birdenbire ayrılmak, ... kimse tarafindan arzu edilemezdi, ve 
edilmedi." 396 Böylece, İstiklal Savaşı'nın yönetildiği bir mekân olarak eski kente kutsal bir nitelik atfedilmektedir, fakat bu bir kutsal mekân değil, modern planlama (üretim güçlerinin bilgi bileşeni) aracılığıyla üretilmekte olan mekânda belirli yerlere ideolojinin nüfuz edip onun temsil mekânı bileşenini öne çıkarması ve böylece üretilmekte olan mekânına aynı zamanda münhasıran siyasi bir kullanım değeri biçilmesidir. ${ }^{397}$

Jansen, eski ile yeni kenti birbirinden ayırma gerekliliğinden söz ederek eski kent üzerine teorik olarak bir "cam levhası"ndan söz eder. Eski kentin korunması için böyle bir mecazi tabirin kullanılması birçok araştırmacının dikkatini çekmiştir. ${ }^{398}$ Gülsüm Nalbantoğlu, "cam levhası" tabiri aslında modern Ankara'nın öteki öykülerini bastıran anıtsal öyküsünü özetleyen hayret verici bir mecaz olarak tanımlar. Ona göre başkent ilanının erken günlerinden beri eski (geleneksel, kırsal) ile yeni (modern, kentsel) Ankara arasındaki yüzleşmeler kentin düzenli ve uyumlu imgesinin oluşumunda gerilimler yaratmaktaydı ve kentin modern yüzünü temsil eden Ankara Palas ve genel olarak modern Ankara'nın steril anıtsal mekânları, yeni kentin düzenli ve uyumlu imgesini korumaya yönelik mekânlard. Bundan yola çıkarak Nalbantoğlu, eski kentin mi yoksa Ankara Palas'ın mı “cam levhası"yla örtülü olduğunu sorgular. Yarışmadan sonraki uygulama sürecinde Jansen planında eski ile yeni kent arasında öngörülen bu ayrım kentte somut bir ifade bulmaya, dahası gittikçe daha keskin bir nitelik kazanmaya başlamışt1; toplumsal mekânın üçlüsü açısından adeta iki Ankara söz konusuydu ve bu ikili yapı farklı politikalarla yeniden üretilmekteydi. ${ }^{399}$

Yenişehir' in, kentin yeni merkezine dönüşme eğilimi daha başkentin yeni ilan edildiği ve özellikle Mustafa Kemal tarafından Çankaya'ya yerleştiği zamanlarda görülmekteydi, ayrıca buranın gelişimi için 1925 yılındaki büyük kamulaştırma da önemli bir adımdı. Fakat 1932'de Jansen planı artık uygulanmaya konulunca ve kenti sistematik ve topyekûn bir planlama aracılığıyla dönüştürme çabaları yoğunlaşınca Yenişehir'in kentin yeni merkezi olma özelliği daha belirginleşti. 1935 yılında artık tüm bakanlıklar Ulus'tan

396 Ibid., s. 7.

397 Cantek de, Jansen planında mevcut çok sayıda kutsiyet atfına dikkat çekerek bilimsel temellere dayandığı varsayılan bir şehir planında çok sayıda kutsiyet atfının yer almasını yeni rejimin başkentine destansı bir nitelik kazandırma çabasının yanında, dinsel ve geleneksel değerlerinden yönlendiriciliğinden tam anlamıyla sıyrılamadığının bir göstergesi olarak tanımlar. Bkz. Cantek, "Yaban”lar ve Yerliler: Başkent Olma Sürecinde Ankara, s. 119.

398 Bkz. Cantek, "Yaban”lar ve Yerliler: Başkent Olma Sürecinde Ankara; Nalbantoğlu, "Silent Interruptions: Urban Encounters with Rural Turkey"; Uluengin ve Turan, "İmparatorluğun İhtişam Arayışından Cumhuriyet'in Radikal Modernleşme Projesine: Türkiye'de Kentsel Planlamanın İlk Yüz Yılı".

399 Bkz. Nalbantoğlu, "Silent Interruptions: Urban Encounters with Rural Turkey". 
buraya taşınmıştı. 1920'li yıllarda inşa edilen ve "hiçbirini üslûbu yanı başındakini tutmayan, çoğu mimari mecmualarından olduğu gibi nakledilmiș villalar" 400 yerine artık 4-5 katlı modern apartmanlaşma ve böylece Yenişehir çok işlevli bir kent merkezi niteliği kazanmaya başlamıştı. Dönemin merkezi ve yerel yönetiminin tüm çabaları da Yenişehir üzerine odaklanmış durumdaydı. Burada Ulus'unkinden mekân temsil ve mekânsal pratikler açısından farklı bir kamusallık üretilmeye başlanmıştı, yeni kamusal ağının merkezi ve "başkentin odağı olarak Yenişehir genç ulusun iradesini ve ideallerini temsil edecek ve aynı zamanda hem yeni idare şeklinin hem de yeni bir yaşam biçiminin mekânı olacaktır." 401 Aslında Cumhuriyet'in Osmanlı'dan kopuşunun mekânsal olarak (mekânın üretimi açısından) en iyi ifadesi Ankara'nın başkent olarak ilan edilmesinden ziyade Yenişehir'in inşası ve burada yeni bir kamusallığın üretimiydi, zira Yenişehir gerek mekân temsili gerekse mekânsal pratikler açısından Ulus'ta 1920-30 arası dönemde biçimlenen ve hala Osmanlı'nın izlerini taşıyan kamusallığından önemli ölçüde farklılaşmaktaydı.

Yenişehir'de oluşmaya başlayan ilk kamusal alan, Jansen'in planında 'Kurtuluş Meydanı' diye tanımlanan Kızılay Meydanı'dır. ${ }^{402}$ Bu meydan hem ismi hem düzenlenişi açısından ilginç bir mekân temsili teşkil etmektedir. Batuman, meydana adını veren Kızılay'ın, sivil örgütlenme olmadığına, varlıklı kişilerin gönüllü faaliyetleriyle çalışan özel statülü ve yarı resmi bir kurum olduğuna dikkat çekerek burada oluşmakta olan yeni kamusallığın önemli bir göstergebilimsel ipucunu bize sunar. ${ }^{403} \mathrm{Bu}$ ipucu, devletçiliği temel ilkelerinden biri ilan eden iktidarın, yeni oluşacak kamusallıkla ve kamusal mekânla ilişkisidir.

400 Tanpınar, Beş Şehir, s. 15.

401 Batuman, "Mekân, Kimlik ve Sosyal Çatışma: Cumhuriyet'in Kamusal Mekânı Olarak Kizilay Meydanı", s. 43.

402 Lörcher'in planında aynı mekân "Cumhuriyet Meydanı" olarak tanımlanmakta ve Jansen'inkine kıyasla daha düşük yoğunluklu ve az katlı yerleşimi kurgulamaktaydı. Fakat Lörcher planının en dikkat çekici ayrıntılardan biri onun, burası için bir cami yapılmasını öngörmesidir. Daha detaylı olarak bkz. Cengizkan, "Kurgu, Tasarım ve Kullanım: Cumhuriyet Dönemi Kamusal Mekânları İçin Bir Çalışma Programı”. Bu detay Lörcher planında söz konusu mekân temsilinin, Jansen'inkinden ve 1930'larda Kemalist iktidarın hedeflediği laik toplumun mekân temsilinden ne denli farklı olduğunu açıkça göstermektedir.

403 Batuman, "Mekân, Kimlik ve Sosyal Çatışma: Cumhuriyet'in Kamusal Mekânı Olarak Kizilay Meydanı”, s. 53. 


\section{Şekil 6. 1937 Yılında Kızılay Meydanı ve Güvenlik Anıtı}

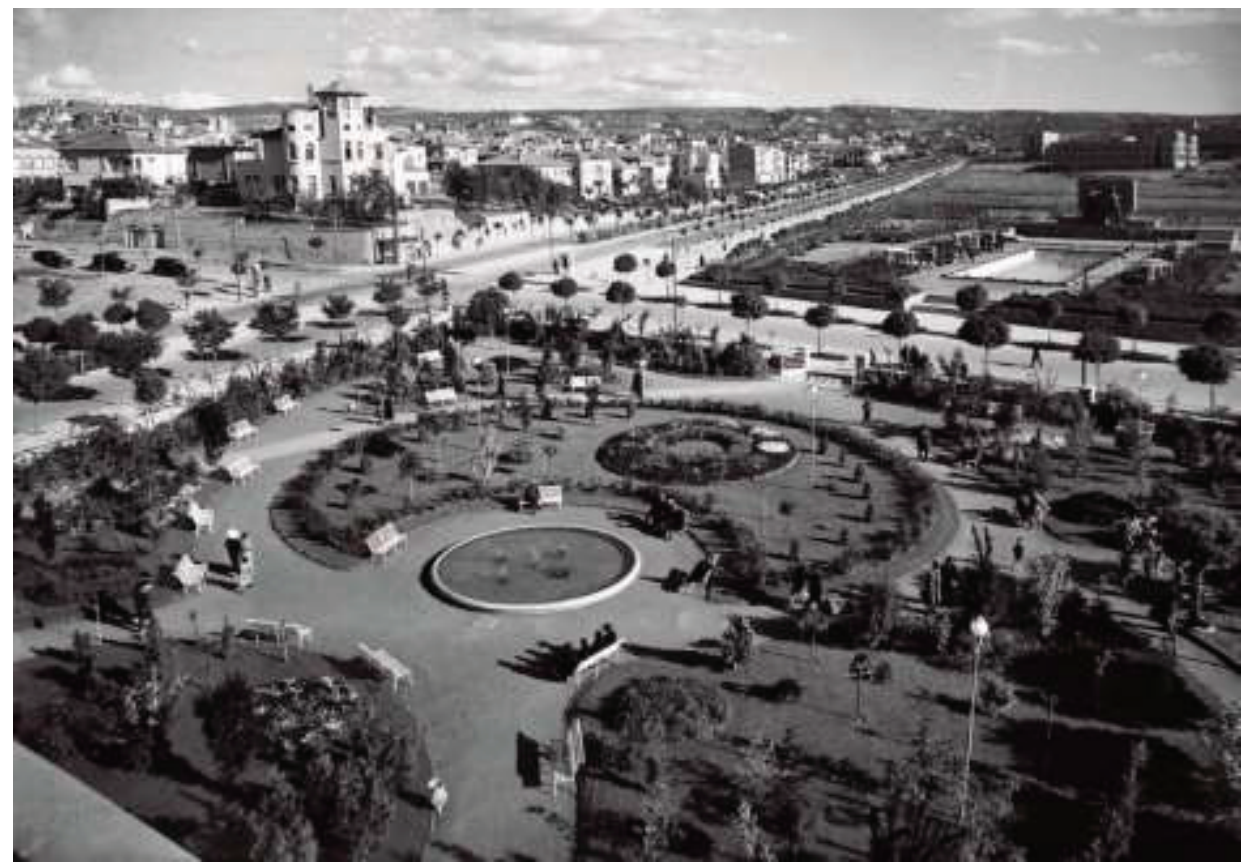

Kaynak: DGPI Archive, Flickr, 16 Eylül 2016 tarihinde https://www.flickr.com/photos/dgpi/ 16666318099 adresinden erişildi.

İsmiyle göstergebilimsel açıdan önemli bir temsil oluşturmakla beraber Kızılay Meydanı'nın, Cumhuriyetin yeni kamusal mekânını en iyi biçimde ifade eden bileşeni, burada 1935 yılında açılan Güvenlik Anıtı'ydı. Güvenlik Anıtı tasarlanan, yaşanan ve algılanan üçlemede birkaç açıdan önem arz eder. Ankara'da 1927 yılında art arda dikilen üç anıttan ${ }^{404}$ sonra 1934'e, yani Güvenlik Anıtı'nın açılışına kadar başka bir anıt dikilmemiştir ${ }^{405}$ dolayısıyla anıt estetik, kurgu ve tasarımı açısından Kemalist iktidarın radikal milliyetçi modernleşme projesinin izlerini taşımakta ve Bozdoğanın ifadesiyle "bu milliyetçi dönemin belki de en paradigmatik anıtı"nı106 teşkil etmektedir. Ankara'da 1927 yılında yapılan üç anıt da askeri üniformalı Mustafa Kemal'i ve "Kurtuluş Savaşı'ndaki

404 Daha önce belirtildiği üzere bu üç anıt/heykel Etnografya Müzesi Önü Atatürk heykeli, Sihhiye Zafer Anitı ve Ulus Zafer Anitı idiler.

405 Tekiner, Atatürk Heykelleri: Kült, Estetik, Siyaset, s. 127.

406 Bozdoğan, Modernizm ve Ulusun İnşast: Erken Cumhuriyet Türkiyesi’nde Mimari Kültür, s. 305. 
rolünü ve siyasi yaşamdaki tek adamlığını" 407 temsil etmekte ve bu temsili estetik olarak romantizm üslubuyla gerçekleştirmektedir. Oysa Güvenlik Anıtı estetik açıdan "nasyonal sosyalist/faşist sanatın ilhamıyla biçimlendirilmiştir" ve bir önceki anıtlara kıyasla "klasik anatomiyi aşan bir abartı, 'Aryan 1rk'ın temsil edildiği anatomik yapı"ya sahip, "belli bir zaman ve mekâna ait olmayan güçlü erkek figürleri" aracılığıyla "gerilimli bir güvenlik hissi uyandırır." 408 Batuman da anıtın bu özelliğine dikkat çekerek onun "güvenlik güçlerini temsil etmesi tasarlandığ 1 halde, herhangi bir ulusal yahut tarihsel bağlamdan bağımsız tasvir edilen güçlü erkek figürlerinin çıplak bedenleri böylesi somut bir özdeşleşmeyi olanaksı k1[ ddı̆̆ın1]" belirtmektedir. ${ }^{409}$ Böylece Kızılay Meydanı'nı tamamlayan ve tanımlayan Güvenlik Anıtı, mekân temsili açısından soyut bir gönderme içerirken, bu gönderme işlevini soyut bedenler aracılı̆̆ıyla gerçekleştirir. Anıtın soyut ve abartılı bedenleri dönemin beden terbiyesi politikasının vurgulanması açısından da önemli sayan Tekiner'e ${ }^{410}$ katılarak Türk modernleşmesinin kamusallığı açısından anıtın temsil ettiği önemli bir bileşenin varlığından da söz edilmelidir.

Türk modernleşmesinin temel hedeflerinden biri kadının toplumsal konumunun değiştirilmesiydi aynı zamanda. Türk kadının toplumsal konumunun yükseltilmesi hem modernleşmesinin hedefiydi hem de modernleşme sürecinin başarısı açıdan önemli bir temsil işlevi görmekteydi. Bu bağlamda modernleşen başkentin kamusal mekânlar ağının merkezinde yükselen Güvenlik Anıtı'nın güçlü erkek figürlerinin çıplak bedenleri belirgin bir fallik oluşturucu ${ }^{411}$ olarak gücü, eril doğurganlığı, erkek şiddetini ve eril iktidarını simgeleyerek aynı zamanda Yenişehir'de anıtın hemen arkasında oluşmakta olan devlet mahallesi için bir tür 'kalkan' oluşturmakta ve Türk modernleşmesinin cinsiyetini de ortaya koymaktadır. Serpil Sancar, toplumsal cinsiyet açısından Türk modernleşmesinin cinsiyet rejiminin "aile odaklı modernleşme" olarak şekillendiğini ve bunu aile politikaları aracılığıyla toplumu yönetmeyi sağlayan önemli bir iktidar stratejisi olduğunu ileri sürmektedir. ${ }^{412} \mathrm{Bu}$ bağlamda modernleşmek adına erkeklerin devlet, kadınların ise aile kurduğunu belirten Sancar'a göre;

"Süreç boyunca kadınların "ulus" olarak modern bir toplum inşasına katılımdan değil, sadece ulus devlet inşasından dışlandıklarını

407 Tekiner, Atatürk Heykelleri: Kült, Estetik, Siyaset.

408 Ibid., s. 128-129.

409 Batuman, "Mekân, Kimlik ve Sosyal Çatışma: Cumhuriyet’in Kamusal Mekânı Olarak Kızılay Meydanı", s. 52-53.

410 Tekiner, Atatürk Heykelleri: Kült, Estetik, Siyaset, s. 128.

411 Lefebvre, Mekânın Üretimi.

412 Sancar, Türk Modernleşmesinin Cinsiyeti: Erkekler Devlet, Kadınlar Aile Kurar, s. 306. 
söyleyebiliriz. Modern eğitimden geçmiş kadınların yeni kurulan devletin stratejik kurumlarına katılmamaları-dönemin ruhu açısından-olağan sayılabilir elbette. Ama devletin eğitim, sağlık ve sosyal hizmet gibi görevlerine öğretmen, hemşire ya da gönüllü çalışan olarak katılan "modern kadınlar" yani "Cumhuriyet kızları" olmadan bu alanlarda bir gelişme sağlanamayacağı açık... Kadınlar yeni inşa edilen modern kurumların karar konumlarına dahil edilmiyor; ancak modern ulus/modern toplum inşasına daha alt düzeylerden katılmalarına izin veriliyor." 413

$\mathrm{Bu}$ açıdan 'devlet mahallesi'nin ana giriş noktasında güçlü erkek figürleriyle yükselen Güvenlik Anıtı, Sancar'ın belirttiği cinsiyet rejiminin somut bir mekânsal ifadesi ve Türk modernleşmesinin cinsiyetinin bir temsil mekânı olarak değerlendirilebilir.

Diğer taraftan "tanımı belirsiz aşkın bir iktidar odağının tehditkâr bakışını, Yenişehir sakinlerinin gündelik hayatları üzerine düşür[en]"'414 anıt aynı zamanda iktidar tarafından denetlendiği kamusal mekânın bir simgesiydi ve algılanan mekân açısından önem arz etmektedir. Anıtın soyut "tehditkâr bakışı" tüm tek parti dönemi boyunca Kızılay’dan Ulus'a uzanan Atatürk Bulvarı boyunca dönemin vali ve belediye başkanı Nevzat Tandoğan’ın (1929-1946) ve tahrirat memurlarının sıkı denetimi şeklinde somut bir pratiğe dönüştü; bu halkın gündelik hayatında toplumsal mekânsal pratiklerini önemli ölçüde etkileyen ve belirleyen bir denetimdi. Kravat takmayanlara izin vermeyen, köylüler ve tulumlu işçilerin buradan geçmesini yasaklayan ve benzer uygulamalar415 sonucunda böylece Ankara' da merkez-çevre gerilimi ve mekânın ikili yapısı daha da derinleşmekteydi. Funda Şenol Cantek tarafından dönemde yaşayanlarla yapılan sözlü tarih görüşmeleri de bu uygulamaların halkın farklı kesimlerinin mekânsal pratiklerine etkilerini göstermektedir. Örneğin, Cantek'in görüştügü kişilerden dönemin yönetici sınıfı gibi İstanbul'dan Ankara'ya yerleşmiş, burada ikameti boyunca yerli halkla hiç ilişki kurmamış olan ve aynı zamanda bunu bir ayrıcalık olarak tanımlayan biri, yerliler ve köylüler Bulvar'a çıkmadığı için, Tandoğan döneminde Kızılay’a çıktıklarında büyük bir rahatlık duyduklarını anımsamaktadır.416 Görüşme yapılan kişilerin çoğu ise 1950'lilere kadar Sıhhiye'deki demiryolu köprüsünden Çankaya’ya uzanan yeni yerleşime dâhil

413 Ibid., s. 307-308.

414 Batuman, "Mekân, Kimlik ve Sosyal Çatışma: Cumhuriyet'in Kamusal Mekânı Olarak Kizılay Meydanı", s. 53.

415 Bu uygulamalar ile ilgili daha detaylı olarak bkz. Cantek, "Yaban”lar ve Yerliler: Başkent Olma Sürecinde Ankara, s. 218-224.

416 Ibid., s. 220. 
olmadıklarını veya Yenişehir ziyaretlerinin uzun yıllar tedirgin edici bir deneyim olarak yaşadıklarını belirtmektedirler. ${ }^{417}$

1930-50 yılları arasında Ankara'da modern ve muasır bir mekânın üretimi sürecinde birçok başka deneyim de söz konusuydu. Cumhuriyet'i radikal bir biçimde modernleştirmek için mimarlık ve şehircilik disiplinini etkin bir mekanizma olarak gören Kemalist iktidar Almanca konuşan ülkelerden onlarca mimar ve plancıyı ülkeye davet etmişti. ${ }^{418}$ Bunlar, 1933 yılında medrese sistemine son veren ve üniversite reformu kapsamında yeni açılan fakülte ve kürsülerde ders vermekle ve modern mimari ve planlama anlayışının yerleşmesini sağlamakla beraber etkin bir şekilde mimari üretimine de katılmaktaydı. Bu aynı zamanda Türkiye'de yeni bir mimari üslubun yerleştiğini de işaret etmekteydi. Bozdoğan'ın belirttiği gibi 1931'e geldiğinde Osmanlı Canlandırmacılığı hızla terk edilerek, Modern Hareket'e Türkiye'de verilen ithal bir "Yeni Mimari” benimsenmişti. ${ }^{419}$ Böylece bu üsluba uygun olarak Ankara'da Yenişehir kısmında yeni yapılan kamu binaları ve kamusal alanların oluşumunda etkili olan mimari deneyimlerin neredeyse tümü Türkiye'ye davet edilen yabancı mimarlar tarafindan tasarlanmaya başlanmışt1. ${ }^{420}$ Buna koşut olarak modern yaşama uygun ev ile konut tartışmaları ("kübik ev" tartışmaları) ve uygulamalarına da başlanmıştı. Birçok eğitim ve sağlık kurumlarının binalarının, spor ve dinlenme alanlarının yapımı da yabanc1 mimarlar tarafindan yürütülmekteydi. Aynı zamanda Seyfi Arkan gibi birkaç Türkiyeli mimar da aynı üslupla buna katılmaktaydı. ${ }^{421}$ Bir siyasi proje olan Türk modernleşmesinin kamusal alandan özel alana kadar uzanan mekânın üretiminin genel tablosu bundan ibaretti ve dünyadaki kıyaslanabilir başka örneklere göre "1930'lardaki Kemalist programının benzersiz yanı, şeylerin biçimini değiştirmeye yatırılan haddinden fazla zaman ve enerji ile cumhuriyete özgü görsel bir modernlik kültürünün resmen üretilmesi, denetlenmesi ve yayılmasıydı." 422

Tüm 1930-40'l1 yıllar boyunca Ankara'da bu görsel ve biçimsel modernliğin resmen üretimi, denetimi ve yayılması devam etti, zaman içerisinde

417 Ibid., s. 111.

418 Akcan, Çeviride Modern Olan: Şehir ve Konutta Türk-Alman İlişkileri, s. 9.

419 Bozdoğan, Modernizm ve Ulusun İnşast: Erken Cumhuriyet Türkiyesi’nde Mimari Kültür, s. 34.

420 Dönemin yabancı mimarlar tarafından yapılan kurumsal yapıların önemli bir değerlendirmesi için bkz. Bernd, Modern ve Sürgün: Almanca Konuşulan Ülkelerin Mimarları Türkiye'de 1925-1955.

421 "Kübik ev", modern konut, toplu konut üretimi ve dönemin mimari üretimiyle ilgili daha detaylı incelemeler için bkz. Akcan, Çeviride Modern Olan: Şehir ve Konutta Türk-Alman Iliş̧kileri; Bozdogan ve Akcan, Turkey: Modern Architectures in History; Bozdoğan, Modernizm ve Ulusun İnşası: Erken Cumhuriyet Türkiyesi'nde Mimari Kültür.

422 Bozdoğan, Modernizm ve Ulusun İnşası: Erken Cumhuriyet Türkiyesi’nde Mimari Kültür, s. 74. 
farklı milliyetçi tonlarla birleşse veya onlara göre ikinci plana itilse de tüm tek parti dönemi boyunca bu görsel ve biçimsel modernlik mekânın üretiminde de hâkim olan bir süreçti. Yukarıda kentteki merkez-çevre olarak tanımlanan mekânsal gerilimlere de yeniden geri dönülürse, bunların oluşumu da bu biçimsellik ve görselliğe "haddinden fazla zaman ve enerji" ayırmasıyla kolayca ilişkilendirilebilir. Fakat biçimsellik ve görselliğin başatllğ 1 sadece Kemalist iktidarın, mekânın üretimini propaganda amaçlı yeniden biçimlendirmesiyle açılanamaz, böyle bir biçimselliğin ortaya çıkışının sebeplerinden birini dönemin üretim güçleri ve üretim ilişkilerinde ve modern bir mekânın üretiminde bunların ne derecede yeterli olmasinda aramak gerekir.

Kemalist iktidar inkılabını toplumda yerleştirmesi için toplumsal mekânı radikal bir şekilde dönüştürmeyi amaçlamaktaydı. Modernleşme ve "muasır medeniyetler seviyesine" ulaşma temel hedef olarak belirlenmişti, zira doğrusal tarihsel gelişme anlayışına göre Türkiye'nin de bu seviyeyi yakalama zorunluluğu ve kaçınılmazlığı görülmekteydi. Bunu gerçekleştirmenin ve muasır medeniyetler seviyesine ulaşmanın - tarihe emretmenin - temel yolu kısa zaman içerisinde bütün imkânlar seferber edilerek mekâna emretmekten geçeceği varsayılıyordu. Böylece modernleşme projesi tepeden modern öncesi bir mekâna - bir taşıyıcısı olarak algılanan ve tanımlanan mekâna - dayatılarak onun dönüştürülmesi çalışıldı. Üretim güçlerinin gelişmişlik düzeyinin elverdiği imkânlar çerçevesinde modern mekân, sıfirdan, bir tabula rasa olarak tanımlanabilecek alan üzerine inşa edildi, bu modern mekân Yenişehir ve civarını kapsayan alandı. Üretim güçleri ise ilk önce modern kentsel planlama düşüncesi ve mimariydi. Aynı şekilde toplumun üstyapısını oluşturan ve mekânın üretimiyle dolaylı ilişkili olan eğitim, kültür gibi alanlarda önemli dönüşümler gerçekleştirildi. Fakat dikkat edilmesi gereken husus, üretim güçlerinin sadece bilgi boyutunun yeni mekânın üretiminde belirleyici olma hususudur. Bu bilgi boyutu ise görüldüğü üzere önemli ölçüde Kemalist ideolojinin belirlediği sınırlar çerçevesinde mekânın üretimine müdahildi.

1930'lardan itibaren Kemalizm'in devletçilik ilkesine göre korumacı ve dışa kapalı bir iktisadi politika yürütülmeye başlanmıştı, modernleşmenin maddi temelleri desteklemek açısından bu korumacılığın özel önemi tarım dışındaki alanlarda devletin asıl yatırımcı ve üretici unsur olmasıyd. Bu konuda devletin faaliyetleri ise 1934 yılında yürürlüğe giren ve 1934-38 y1llarını kapsayan Birinci Beş Yıllık Plan'a göre yürütülmekteydi ve plan beş ana sektöre (dokuma, maden, seramik, selüloz ve kimya) odaklıydı. ${ }^{423}$ Planın öngördügü 20 fabrika projesinden Ankara hiç pay almamaktaydı. 1938 yılında yürürlüğe giren İkinci Beş Yıllık Sanayi Planıyla Ankara için kimya, gıda ve su ürünleri sektöründe üç

423 Şener, "Burjuva Uygarlığın Peşinde", s. 205. 
proje öngörülmekteydi, fakat 1939 yılında İkinci Dünya Savaşı'nın ortaya çıkmasıyla bu plan uygulanamadı. ${ }^{424}$ Aynı zamanda Dünya Savaşı nedeniyle korumac1-devletçi sanayileşme politikası da kesintiye uğramıştı. ${ }^{425}$ Böylece 1930-40 yılları arasında Ankara'da üretici güçlerin maddi temellerinin gelişmesi açısından kayda değer girişimlerin söz konusu olmadığı söylenebilir. ${ }^{426}$

İşte modernleşme sürecinde Ankara'da mekânın üretimi, üretici güçlerin gelişmişliği çerçevesinden değerlendirildiğinde karşımıza çıkan görsel ve biçimsel modernlik ve bununla ilişkili mekânsal gerilimler anlaş1lır hale gelir. Tekrardan Lefebvre'ye gönderme yapılırsa, ${ }^{427}$ tek parti döneminde Ankara'da ideolojinin belirli faaliyetlerin yerlerinin belirlenmesinde etkin olan bir mekânsal organizasyon söz konusu olduğu görülmektedir. İdeolojinin, mekânsal organizasyonun biçimsel açıdan belirlenmesinde etkin bir rol oynaması ve aynı zamanda üretici güçlerin ve üretim ilişkilerinin modern bir mekânın üretimi açısından yeterince imkânlar sağlayamaması bahsi geçen biçimsel modernliğin en temel faktörüdür. Toplumun üstyapısında (eğitim, kültür, sanat vs.) Kemalizm'in radikal reformları modernleşme açısından önemli adımlar olmakla beraber üretici güçler ve üretim ilişkileri konusundaki girişimler inkılabın yerleşmesi açısından yetersizdi. Lefebvre'in belirttiği gibi,

"Yeni bir mekân üretmeyen bir devrim sonuna kadar gidemez; başarısız kalır; hayatı değiştirmez; sadece ideolojik üstyapıları, kurumları, politik aygıtları değiştirir. Devrimci bir dönüşüm, gündelik hayatta, dilde, mekânda eser yaratma kapasitesiyle doğrulanır; ama bunların ille aynı adımlarla, eşit olarak ilerlemesi gerekmemektedir." 428

1930-40'ların modernliğinin mekânın üretimi açısından biçimsel ve görsel nitelikte olması, bu bağlamda değerlendirildiğinde anlam kazanır. Modern bir mekânın üretiminde üretici güçler ve üretim ilişkilerinden ziyade ideolojinin belirleyici olması, mekânın iktidar tarafindan salt bir araç olarak görülüp modernleşme projesinin amaçlarına uygun olarak hizmete sokulması ve bunu özelden kamusala uzanan alanlarda gerçekleştirilmeye çalışması üretilmekte olan yeni mekânın en temel özelliğiydi. Türkiye'nin "muasır medeniyetler seviyesi" olarak gördüğü ve örnek aldığı Batı'nın modernlik deneyimi ve modern mekânı yüzyıllar süren sanayileşmenin, kapitalist gelişmenin ve ona özgü üretim

424 Şenyapıl1, "Baraka”dan Gecekonduya: Ankara'da Kentsel Mekânın Dönüşümü: 1923-1960, s. 80.

425 Şener, "Burjuva Uygarlığın Peşinde", s. 207.

426 Örneğin 1945 yılı itibarıyla Ankara İlinde iş kolların dağılımı açısından sanayi ve imalat sektöründe istihdam toplam istihdamın yaklaş1k \%4'ünü oluştururken, kamu hizmetlerinde ve tarımda bu rakam sırasıly $\% 9$ ve $23 \%$ idi. Bkz. Şenyapıl1, "Baraka”dan Gecekonduya: Ankara'da Kentsel Mekânın Dönüşümü: 1923-1960, s. 284.

427 Lefebvre, Mekânın Üretimi, s. 223-224.

428 Ibid., s. 82. 
ilişkilerinin ve üretici güçlerin ürünüyken, Türkiye'yle eşzamanlı olarak modernleşme konusunda ciddi adımlar atan SSCB'de sosyalist devrimin başarısı için temel vurgu üretici güçlerin geliştirilmesiyken, Türkiye'de Kemalist iktidarın, inkılabının sürdürülmesi ve yerleşmesi için temel vurgusu ise ideolojik üstyapılar üzerindeydi. Fakat modern bir mekânın üretimindeki sorunlar sadece üretici güçlerin gelişmişlik düzeyinden değil, aynı zamanda iktidarın, modern ve muasır toplumun ve onun mekânının nasıl tanımlandığından, mekân temsilinden da kaynaklıyd.

Hilmi Yavuz, ${ }^{429}$ Türk modernleşmesi ve batılllaşması semiyolojisi açısından 'metonimik' bir batılılaşma olduğunu belirtmektedir. Ona göre, Türkiye'de batılılaşma ve modernleşme semiyolojik açısından bakıldığında kavramlar üzerine değil, simgeler üzerine inşa edilmiştir, simgeler (parça) kavramların (bütünün) yerine geçmiştir ve o nedenle modernleşme ile batılllaşma temelsizdir ve Türk modernleşmesi aslında bir oryantalistleşme sürecidir;

"Fragmanter veya metonimik modernleşmenin, oryantalizm olduğunu söyleyeceğim. Oryantalizmi, semiyolojik bir okumayla, parçayı bütünün yerine koyan bir medeniyet anlayışı olarak tanımlıyorum. Batılı romantik oryantalizm nasıl harem'i, hamam'1, bütün bir Doğu ya da Osmanlı medeniyetinin yerine koyduysa, Türk modernleşmesi de, piyano çalıp Fransızca konuşmaktan, şapka giyip yazıyı değiştirmeye kadar uzanan geniş bir simgeler spektrumunu, Batı medeniyetinin yerine koydu. Batılının, metonomik bakışına karşı Türk modernleşmecilerinin metonimik bakışı, oryantalist bir bakışımda birleşti." 430

1930-40'ların Ankara'sına bakıldığında Yavuz'un tespiti mekânın üretimi açısından da geçerli olduğunu gösterebilmektedir. Dahası yapılı çevre ve genel olarak mekân, modernleşme sürecinde elde edilen başarının en somut tezahürü olarak görüldüğü için, bu metonimik ilişki en somut biçimde mekânın üretiminde görülmektedir. Ankara, Türkiye'nin modernleşme ve batılılaşması konusunda elde edilen başarının simgesi olarak sunulmaktaydı ve modern Ankara (parça), Türkiye'nin (bütün) yerine konumlandırılmakta, onun mekân temsili olarak sunulmaktaydı. Fakat bu metonimik ilişki daha çarpıcı bir şekilde Ankara ölçeğinde gözlemlenmekteydi. Yeniş̧ehir ('parça'), modern konutlar, modern yaşam tarzı, Batı ile modern olanı simgeleyebilen her unsuruyla ve özellikle anıtsal modern mimarisiyle Ankara'nın ('bütün') - geleneksel ve yereli hâkim olanın, yani "Asyaî dekorun" - yerine konumlandırılmaktaydı. Ayrıca Yenişehir'in bir anıtsal mekân olarak tasarlanmasından dolayı onun anıtsal niteliği böylesine metonimik ve metaforik ilişkinin oluşmasına hizmet

429 Yavuz, "Modernleşme: Parça mı, Bütün mü? Batılılaşma: Simge mi, Kavram mı?”.

430 Ibid., s. 217. 
etmekteydi. ${ }^{431}$ O yüzden, bu metonimik ve metaforik ilişkiler Ankara'da söz konusu olan görsel modernliğin ${ }^{432}$ mekânsal tezahürünü anlamak için önemli husus teşkil etmektedir. Fakat bunlar aynı zamanda üretilen soyut mekâna, homojen olmayan fakat 'hedef', amaç ve anlamı homojenlik olan mekâna ${ }^{433}$ da işaret etmekteydi. Modernleşme projesini gerçekleştirmeyi ve toplumsal mekânı radikal biçimde dönüştürmeyi amaçlayan iktidar tarafından Ankara' daki yerellik ve farkl1l1k önemli bir engel, bir "Asyaî dekor" olarak görülmekteydi. ${ }^{434}$ Bunu gerçekleştirmek için yeterli imkâna sahip olmayan iktidar tarafından metonimik ve metaforik (yer değiştirme, parçadan bütüne geçiş) ilişsiler içeren bir mekân temsili ve farklılığı dışlayan mekânsal strateji tercih edildi.

Yukarıdaki hususlar göz önünde bulundurarak mevzubahis dönemde Ankara'da üretilmekte olan soyut mekânın, mekânın mübadele süreçlerine dâhil olunup gayrimenkulleşme ve soyutlaşmasından ziyade üretim güçlerinin elverdiği imkânlar çerçevesinde ideolojinin belirleyiciliğinin ürünü olduğu söylenebilir. Başka bir deyişle, mevzubahis belirleyicilik, mekânın üretiminde mekânın ekonomi politiği ve onun bağlamında değişim değerinin kullanım değerine göre egemen olmasından ziyade, ideolojik düzlemde mekânın münhasıran siyasi bir kullanım değeri atfedilmesi ve tarihe emretmeyi başarmanın yolu mekâna emretmesinden geçtiği varsayımıydı;

"Ayar istasyonları, saatleri durmuş hanımların ve beylerin saatlerinin ayarlarını düzeltmek için yol üstünde uğrayacakları küçük yerlerdi. Burada genç hanımlar, beylerin, genç ve güzel delikanlılar da hanımların saatlerini küçük ve makbuz mukabil bir ücretle kurup ayarlayacaklardı. Şehrin kibar ve zengin semtlerinde kalabalık caddelerinde açlacak ilk istasyonlarından sonra yavaş yavaş daha derine, mahalle içlerine kadar girecekti." 435

Yukarıdaki paragraf Ahmet Hamdi Tanpınar'ın Saatleri Ayarlama Enstitüsü romanındandır. Cumhuriyet'in modernleşme ve batılılaşma projesinin

431 Lefebvre'ye göre her anıtsal mekânda psikanalistlerin ve dilbilimcilerin ilksel süreç olarak analiz ettikleri şu iki süreci görmek mümkündür; 1) metonimi anlamına gelen yer değiştirme, parçadan bütünde geçiş, yakınlık ve 2) yoğunlaştırma, dolayısıyla ikame, metafor ve benzerlik. Bkz. Lefebvre, Mekânın Üretimi, s. 237.

432 Bozdoğan, Modernizm ve Ulusun İnşası: Erken Cumhuriyet Türkiyesi’nde Mimari Kültür.

433 Lefebvre, Mekânın Üretimi, s. 294.

434 Ankara'ya kıyasla Türkiye'nin birçok bölgesinde bu yerellik ve farklılık sadece geleneksel ve modern öncesi toplumsal mekânla sınırlı değildi, aynı zamanda etnik temele dayalı önemli mekânsal farklılıklar da içermekteydi. Dolayısıyla modernleşme projesinden ziyade ulusal mekânın üretimi ve ulus-devletin inşası için bu farklılık mekânları da bir engel hatta tehdit olarak görüldügünün ve ulusal mekânın üretiminde devletçe şiddete yaygın olarak başvurulduğunun altı da çizilmelidir.

435 Tanpınar, Saatleri Ayarlama Enstitüsü, s. 263. 
eleştirisi olarak değerlendirilen ${ }^{436}$ bu roman Türk modernleşmesinin, mekân ve zamana siyasi bir kullanım değeri biçilmesini kurgu bir şekilde temsil etmesi açısından çok başarılı bir eserdir. Saatleri durmuş hanımların ve beylerin (geleneksel ve modern öncesi) saatlerinin ayarlarını düzeltmek için yol üstünde uğrayacakları küçük yerler aslında modern kamusallık yaratmaya yönelik çabalarının temsili, saatleri kurup ayarlayan genç hanımlar ile genç ve güzel delikanlılar ise Cumhuriyetin modernleşme sürecinde eğitimli ve modern öncül kuşağı olarak okunabilir. Kibar ve zengin semtlerinde kalabalık caddelerinde açılacak bu istasyonlar (modern kamusal alanlar, Halkevleri, Halk Odaları vs.) daha sonra mahalle içlerine kadar (modern ev, Köy Enstitüsü,) girecekti (bkz. Şekil 7). Üniformayı şart olarak gören (k1lık kıyafet reformu) saatleri ayarlama enstitüsünde üniforma, "erkeklerde vücudun bütün güzelliğini gösterecek, kadın veya kızlarda icap ederse yaşı örtmeğe ve bilhassa az çok cins dışına çıkararak güzelliği daha keskin, 1sırıcı, daha sinema yapmağa yarayacak... Daha ziyade genç erkek hali verecek bir kıyafet!" 437 Cumhuriyet' in beden terbiyesi politikası olarak okunabilecek bu kurgu aynı zamanda Türk modernleşmesinin toplumsal cinsiyetini de izah edecek nitelikte; Türk muhafazakâr modernleşme sürecinde yeni kamuda ortaya çıkan yeni modern kadın temsillerinin cinsiyetsizleştirilmesiyle ("aseksüel kamu") beraber var olan "yeniden cinsiyetlendirme" ve "kamuda gösterilen dişilik ve cinsellik." 438

Tanpınar'ın kurgusunda dikkate değer önemli mekân temsilleri ile temsil mekânları söz konusudur ve kurgu farklı okumalara çok açıktır. Fakat bizim için önemli olan, roman tarafından, tepeden inme bir modernleştirme projesi hayata geçirilen Türkiye'de ('saatleri ayarlama enstitüsü') bu sürecin yarattığı zaman/mekân deneyimlenmesinin radikal değişimi temsil etmesidir. Gündelik hayatın ritimleri ile toplumsal mekânsal pratikler, yeni mekân ve zaman temsilleri baskısı altında değişmişti; Osmanlı'nın zaman ve mekânsal heterojenliği, dolayısıyla yaşanan mekânların çeşitliliği, yerini Cumhuriyet'in tekil mekân ve zamanına bırakmıştı;

"Adım başında muvakkithaneler vardı. En acele işi olanlar bile onların penceresi önünde durarak cebinden, servetlerine, yaşlarına, cüsselerine göre altın, gümüş, sadece savatlı, kordonlu, kordonsuz, kimi bir iğne

436 Bkz. Uluengin, "Secularizing Anatolia Tick By Tick: Clock Towers in the Ottoman Empire and the Turkish Republic"; Wishnitzer, "Modern Turkey, Real Time, and Other Functional Fabrications in Tanpınar's The Time Regulation Institute".

437 Tanpınar, Saatleri Ayarlama Enstitüsü, s. 264.

438 Sancar, Türk Modernleşmesinin Cinsiyeti: Erkekler Devlet, Kadınlar Aile Kurar, s. 315-316. 
yastığ1, yahut kaplumbağa yavrusu kadar şişkin, kimi yassı ve küçük, saatlerini beslemeye çıkarırlar."439

Osmanlı'da saatlerin bu denli çeșitliliği, dolayısıyla yaşanan mekânların çeşitliliği, yerini Cumhuriyet'in 'saatleri ayarlama enstitüsü'nün üniformalı, "saatten, enstitüsünden hep aynı kelimelerle, büyük bir ihtisas iddiasıyla bahsed[en]... bilhassa bu iş için kurulmuş saatler gibi hareket ed[en]... Yani bir nevi otomatizm... Tam çalar saat gibi konuşup susacak insanlar"' $n^{440}$ tekil yaşanan mekânına bırakmıştı. Bu her bireyin ve genel olarak toplumun, zamanın ve mekânın dakik temsillerinin (tasarlanan mekân ve zaman) ve bu temsiller aracılığıyla zaman/mekânın dakik algılanmanın (algılanan mekân) oluşturduğu soyut, homojenliğe yönelen, münhasıran siyasi olan soyut zaman ve mekândl.

\section{Şekil 7. Cumhuriyet'in 'Ayar İstasyonları'}

a) Atatürk Bulvarı üzerinde Sergi Evi; dönemin önemli diğer kamusal binalarında olduğu gibi kule üzerindeki saat dikkat çekmektedir. ${ }^{441}$

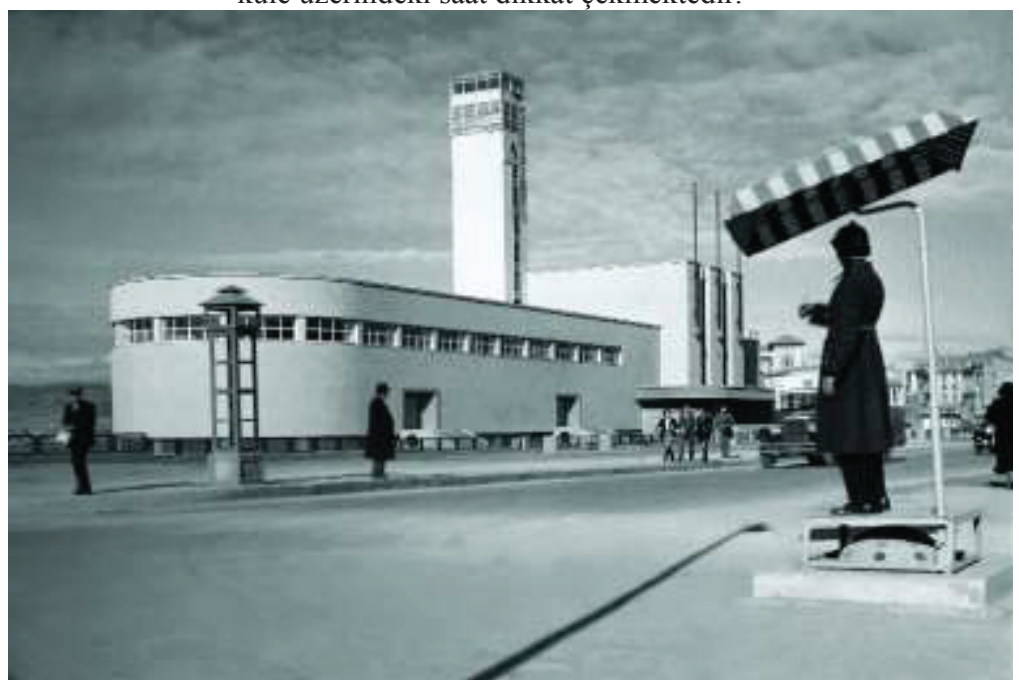

439 Tanpınar, Saatleri Ayarlama Enstitüsü, s. 25.

440 Ibid., s. 265

441 Lefebvre, Avrupa'da soyut mekânın ortaya çıkışı sürecinde ilginç bir saptamada bulunur, buna göre mübadele süreçlerinin gelişmesiyle beraber yeni, soyut zaman ve mekân temsilinin ortaya çıkışıyla bilginin ve iktidarın sembolleri de değişmeye başladı; "Kilise, katedral, pek uzak değildir; fakat bilginin ve iktidarın sembolleri taşıyan şey artık çan kulesi değildir: Gözetleme kulesi mekâna ve hatta zamana egemendir, çünkü üzerine derhal bir saat eklenecektir" (Lefebvre, Mekânın Üretimi, s. 275). Bu açıdan, cumhuriyetin radikal modernleştirme sürecinde benzer biçimde, zaman ve mekâna egemen olan minareler veya kiliselerin çan kuleleri yerine artık soyut zaman temsili olan saat kuleleri ve saatlerin ortaya çıkışı gözlenmektedir. Elbette bu süreç Avrupa'da gözlemlenenden farklı olarak bir siyasi projenin parçası olduğu da unutulmamalıdır. 
b) 1930'larda Ulus meydanı: fotoğrafin sağ tarafinda meydanda bulunan saat dikkat çekicidir

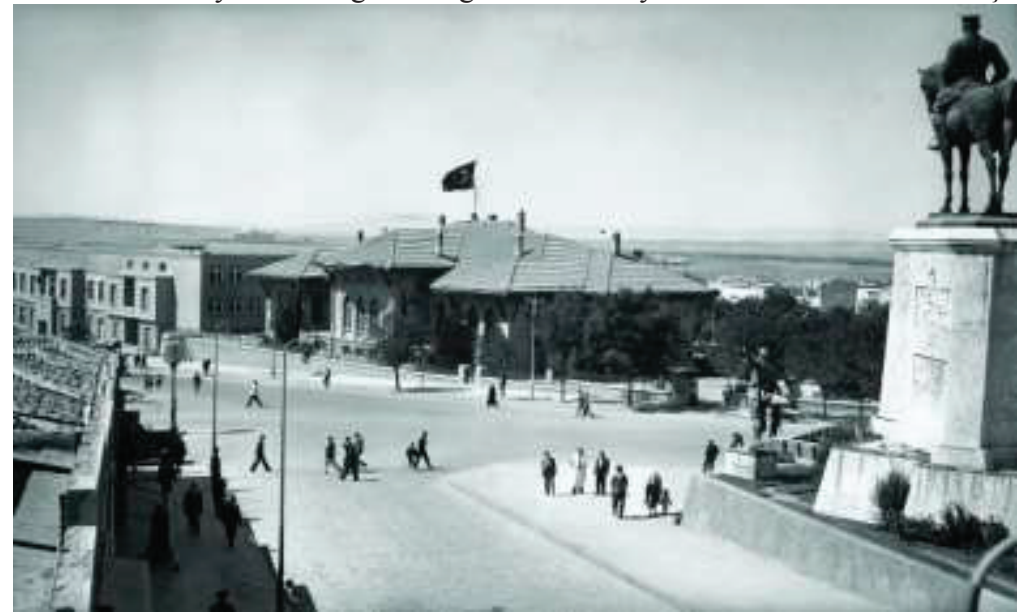

Kaynak: a) DGPI Archive, Flickr, 24 Ekim 2016 tarihinde https://www.flickr.com/photos/dgpi/ 16826593236 adresinden erişildi. b) DGPI Archive, Flickr, 24 Ekim 2016 tarihinde https://www.flickr.com/photos/dgpi/17075286852 adresinden erişildi

\subsubsection{0-70'lerde Modernliğin Durumu: Altyapısal Yeterlik, Üstyapısal Aşınma}

1945-50 yıllar1 arası dönemde Türkiye'nin toplumsal formasyonunda önemli değişimler yaşanmaktaydı. 1930'lardan itibaren geçerli olan korumac1devletçi sanayileşme politikaları yerine serbestleşmeyi temel alan ekonomi politikaları benimsenmeye başlanmıştı. Aynı zamanda Türkiye siyasal hayatında çok partili rejime geçiş yapılmış ve toplumun geniş kitleleri aktif siyasi hayata dâhil olmaya başlamıştı. Ayrıca din alanında Kemalizm'in militan laik anlayışından tavizler verilmeye de başlanmıştı. ${ }^{42}$ Toplumsal formasyondaki, farklı açılardan çok sayıda çalışmanın konusu olan bu değişimler toplumun hem altyapı hem de üstyapısı açısından bir dönüşüme işaret etmekteydi, dönüşümün doruk noktası ise 1950 seçimleriyle Demokrat Parti'nin iktidara gelmesiydi. Keyder'in de ifadesiyle "Demokrat Parti'nin 1950'de iktidara gelmesi, hangi açılardan bakılırsa bakılsın Türkiye tarihinde esaslı bir dönüm noktasıdır." 443 Mekân açısından ise bu dönüm noktası, yeni bir birikim rejiminin üretici güçleri ve üretim ilişkileri tarafından ulusal-ölçekten yerel ölçeğe uzanan mekânın (yeniden) üretimi ve farklı bir toplumsal mekânın ortaya çıkışıydı. Bu dönüm noktası önemli bir hususun örneğini teşkil etmekteydi aynı zamanda. Toplumsal

442 Bkz. Keyder, Türkiye'de Devlet ve Sinıflar; Uslu, ““'Hür” Dünyanın Saflarında”.

443 Keyder, Türkiye'de Devlet ve Sinıflar, s. 155. 
mekân, müdahale edilip biçimlendirilebilecek salt bir ortam değil, aynı zamanda toplumsal sürelere geri-tepkiyen bir etmendir. Çok partili siyasi rejime geçişiyle ve görece demokratik bir seçimleriyle Demokrat Parti'nin halkın büyük bir kesimin $(\% 52,68)$ oylarıla iktidara gelmesi ve CHP'nin, ülkenin görece daha gelişmiş batı illerinden hiç birinde kazanamaması, ${ }^{444}$ toplumsal mekânın bir geri tepkimesi olarak değerlendirilebilir. Bu bağlamda dikkat edilmesi gereken husus, Kemalist devrimin, devrimine özgü toplumsal mekânı üretemediğinin açı̆̆a çıkmasıydı, zira DP'nin başarısı salt bir popülist siyasi partinin seçim başarısı değildi. DP'nin sahip çıktığı varsayılan değer ve sermayelerin (kültürel olsun veya ekonomik olsun) başarısıydı aynı zamanda ve bu başarı DP'nin iktidara gelmesinden itibaren Türkiye'de bir önceki döneme kıyasla toplumsal mekânın önemli dönüşümlerine yol açacaktır. O yüzden DP'nin başarısı Kemalist deneyime karşı toplumsal mekânın önemli bir geri tepkimesi olarak değerlendirilebilir. Kemalist devrim, kendine uygun bir mekân üretmiş olsaydı ki çok kısa süre içerisinde çok az imkanlarla bunun gerçekleştirilmesi de adeta imkânsız görünmekteydi- kısa bir süre içerisinde hele de bir seçimle devrimin elde ettiği başarıların aşınması çok daha zor olabilirdi.

DP, iktidara geldiği dönemden itibaren tarım ve ticaretteki hâkim sınıfların temsilciliğini üstlenerek Türkiye kapitalizmini tarımsal önceliklere göre yeniden biçimlendirmeye yönelmiştir. Dönemin iktisadi rejimini tarımsal kapitalizm olarak tanımlayan Atılgan'a göre bu rejim "sadece iktisadi gelişmelerini değil, siyasal, ideolojik ve kültürel gelişmelerini de anlamanın anahtarıdır." $445 \mathrm{Bu}$ rejim aynı zamanda dünya sisteminin Türkiye ekonomisine yüklediği işlevlerin ürünüydü. 1940'ların son yıllarından itibaren Marshall Planı kapsamındaki yardımlarla Türkiye'de tarımın mekanizasyonu gerçekleşmekte, aynı zamanda ABD'nin yardımıyla karayolu yapımına ağırlık verilen bir politika da izlenmekteydi. ${ }^{446}$

Kemalist dönemde ulusal bir mekânın üretimi açısından en önemli adımlardan biri demiryolu ağıyla ülkenin farklı bölgelerini birbirine bağlayıp Ankara merkezli bir bütünleşik mekânın üretimiydi. ${ }^{447}$ Böyle bir politikanın

444 CHP'nin kazandığı neredeyse bütün vilayetler Ankara'nın doğusundaydı ve bu az gelişmiş bölgelerde CHP'nin başarısını Zürcher, CHP'ye sadık olan eşraf, aşiret reisleri ve büyük toprak sahiplerinin, kullanılan oyları denetlemiş olmalarıyla açıklamaktadır. Bkz. Zürcher, Turkey: A Modern History, s. 217.

445 Atılgan, "Tarımsal Kapitalizmin Sancağı Altında", s. 391.

446 Bunların Türkiye'yi küresel kapitalist mekânına bağlayan ve onun ekonomisine belirli işlevler yükleyerek bu küresel kapitalist mekânın yeniden üretimini sağlayan önemli politikalar olduğu da belirtilmelidir.

447 1923-1950 yılları arasında Türkiye'de toplam 3.578 kilometrelik demiryolunun 3.208 kilometresi (\%90), 1940 yılına kadar tamamlanmıştır. Cumhuriyet öncesinde demiryollarının \%70'i Ankara-Konya doğrultusunun batısında kalırken, Cumhuriyet döneminde yolların 
temel hedefi ise bütünleşmiş bir ulusal piyasa oluşturulması ve devlet otoritesinin mekânsallaştırılmasıydı; "yaşanılan yılların içinde bulunduğu ortam göz önüne alınarak, ülkenin her tarafına devlet otoritesinin ivedilikle götürülmesi ve ülke savunması gibi amaçlar göz önünde tutularak demiryolu yapımında oldukça ileri gitmiş ve memleketin dört bir yanını çelik ağlarla sarmıştır." ${ }^{448}$ DP döneminde ise kırsal kalkınmaya ağırlık verilmesi ile karayollarının yapımıyla hem ulusal mekânın çok yönlü bütünleşmesi sağlandı hem de ulusal pazarın oluşturulmasında daha ileriye gidildi. ${ }^{449}$ Bunlar, 1950'li yıllarından itibaren Türkiye'de serbestleşmeyi tercih eden ekonomik politikalar bağlamında ülke çapında yeni birikim rejiminin altyapısını oluşturmaktaydı ve aynı zamanda yerel ve bölgesel ölçeklerde mekânın üretimi ile yeniden üretimi süreçlerinde önemli etkiler yaratt1.

Tarımda mekanizasyonu hedefleyen ve gerek devlet gerekse özel bankalar tarafından ziraat kredilerinin sağlanması aracılığıyla bunu hayata geçiren ${ }^{450}$ kalkınma modeli (tarımsal kapitalizm) kısa bir süre sonra tarım işçilerinin işlerini kaybetmesine ve kentlere doğru göç dalgasına ve Türkiye'nin kentsel mekânında köklü dönüşümlerine yol açtı. ${ }^{451} \mathrm{Bu}$ arada 1950 'lerde tarımsal kapitalizmin kırda yarattı̆g 1 dönüşüm sırasında kentler henüz istihdam açısından fazla imkânlar sunmamaktayken, 1960'lardan itibaren benimsenen yeni kalkınma modeli; ithal ikameci sanayileşme, artık kentleri istihdam açısından çekici merkezlere dönüştürmektedir. Böylece tarımsal kapitalizmin kırdan emek gücünü kentlere aktarması ile ithal ikameci sanayileşmenin kentlerde yarattığı istihdam olanakları bağlamında Türkiye, kentleşme tarihinde kırdan kente doğru göçün en devinimli yıllarına - Tarık Şengül'ün ifadesiyle "emek gücünün kentleşmesi" 452 dönemi olan 1950-1970’li yıllarına - tanık olmaktadır. Bu süreç aynı zamanda emek gücünün kentleşerek kısmi proleterleşmesine ve sınıfsal ve mekânsal olanın

\%78,6's1, doğuya kaydırılmıştır ve günümüzdeki batı ve doğu arasındaki (\%46 batı, \%54 doğu) oransal dağılım elde edilmiştir. Bkz. TMH, "1923-1940 Dönemi Demiryolları", s. 25.

448 Çolak, "Atatürk Dönemi'nde Türkiye Cumhuriyeti'nin Ulaşım Politikasına Genel Bir Bakış", s. 356.

449 1948-1957 yıllarını kapsayan Dokuz Yı1lık Karayolu Programı doğrultusunda 1950 yılında ulusal bütçenin \%3,6'sı karayolu yatırımlarına ayrılıyorken, bu oran 1957 'de \%10,75'e yükselmiştir, Programın uygulaması sonucunda ise 24.624 kilometre yol yapılmıştır Bkz. TMH, “1948-1957 Dokuz Y1llık Karayolu Programı”, s. 27.

4501948 'de 7 bin 150 olan traktör sayısı, 1954'te 37 bine, 1948'de 580 olan biçerdöver sayısı ise 1954 'te 6 bin 700'e çıkmıştır. Bkz. Atılgan, "Tarımsal Kapitalizmin Sancağı Altında”, s. 395.

451 Ruşen Keleş'e göre, 1 traktörün ortalama 6 tarım işçinin tarımdan ayrılmaya zorladığ1 varsayıldığında bugüne değin bu nedenle 4-5 milyon köylünün köyünü terk etmiş olduğu söylenebilir. Tarım işçilerinin aileleriyle birlikte kente göç ettikleri ya da sonra onları götürdüğü de hesaba katıldığında 1950'den bu yana 60 milyon kentleşmiş nüfusta traktörün payının yarıyı bulduğunu varsayılmaktadır. Bkz. Keleş, Kentleşme Politikası, s. 70.

452 Şengül, "On the Trajectory of Urbanisation in Turkey: An Attempt at Periodisation"; Şengül, Kentsel Çelişki ve Siyaset: Kapitalist Kentleşme Süreçlerinin Eleştirisi. 
kesiştiği bir olguya, mekânın üretimi açısından gecekondu olgusuna yol açmıştır. Böyle bir birikim rejimi ve kalkınma modelinin dinamikleri göz önünde bulundurmadan bu süreçlerin en yoğun şekilde yaşandığı bir kent olan Ankara'da kentsel mekânın üretimini kavrayıp ele almak pek mümkün değildir.

Bu arada Castells'in Üçüncü Dünya ülkeleri (özellikle Latin Amerika) için önerdiği kavramsallaştırma Türkiye'de yaşanan kentleşme süreçleri ve gerek ulusal, gerekse bölgesel ile yerel düzeyde mekânın üretimi süreçleri açısından ufuk açıcıdır. Castells'e göre tüm toplumlar karşılıklı bağımlılık ilişkileri içerisinde olmakla beraber bu ilişkiler asimetrik bir özellik taşımaktadırlar. $\mathrm{Bu}$ asimetrik ilişkiler bağlamında ise 'emperyalizmi' her sorundan sorumlu tutmak yerine böyle bir emperyalizmin gerçek boyutlarının saptanması önem arz etmektedir. Dolayısıyla, analitik açıdan önemli soru var olan bağımlılık ilişkileri çerçevesinde 'azgelişmiş' ülkelerin emperyal metropollere olan siyasi tabiiyeti değil, bu bağımlılık ilişkilerinin söz konusu toplumların iç organizasyonuna, daha somut olarak üretim ile sınıf ilişkilerine yansımasıdır. Bu açıdan Castells, söz konusu toplumlardaki kentleşme sürecini hakimiyet ve bağımlılık ilişkilerine özgü toplumsal dinamiklerinin mekânsal düzlemdeki yansıması, yani Batı toplumlarında tarihsel olarak gelişen kapitalist üretim tarzının farklı teknolojik, ekonomik ve sosyal düzeyde olan toplumlara nüfuz etmenin yansıması olarak tanımlamaktadır. Mekân düzleminde bu nüfuzun ve bağımlılık ilişkilerinin dışavurumu ise Castells'in önerdiği bă̆ımlı kentleşme kavramıdır. ${ }^{453}$

Asimetrik ilişkilerde sömürgeci, kapitalist-ticari ile emperyalist endüstriyel ve finansal hâkimiyet biçimleri sonucunda ortaya çıkan bağımlı kentleşme, kentsel alanlarda (primate şehirlerde) aşırı yoğunlaşma yaratırken bu kentsel alanlar ile ülkenin geri kalan kısımları arasında önemli bir ayrım ortaya çıkarmaktadır, böyle bir süreç aynı zamanda ulusal mekânda işlevsel olarak karşılıklı bağımlı kentler ağında kopukluklar veya böyle bir ağın yokluğunu meydana getirmektedir. Aşırı yoğunlaşma sonucunda ortaya çıkan büyük kentsel alanlar ise Batı'daki metropoliten bölgelerden çok farklı bir nitelik kazanmaktadırlar. Şöyle ki bu alanlar önceden kentte var olan nüfus ile kentlere yeni gelen, işsiz, kentsel toplumda işlevleri belirsiz olan ve kırsal toplumla ilişkileri kesilmiş nüfusun yanyana bulunmasına tanıklık etmektedirler. ${ }^{454} \mathrm{Bu}$ açıdan 1950'lilerden itibaren Türkiye'de benimsenen kalkınma modelinin- ki uluslararası düzlemde asimetrik bağımlılık ilişkisinin ürünüydü - meydana getirdiği kentleşme süreci asimetrik ilişkilerin toplumsal iç organizasyonunun mekânsal düzlemindeki bir yansıması ve bağıml kentleşme olarak tanımlanabilir. Castells'in sınıflandırdığı hâkimiyet biçimlerinden kapitalistticari hakimiyet ile endüstriyel ve finansal hakimiyetin karışımını arz eden böyle

453 Castells, The Urban Question: A Marxist Approach, s. 43-49.

454 Ibid. 
bir asimetrik bağımlılık Türkiye'de gerek ulusal düzeyde gerekse yerel ve bölgesel düzeyde mekânın üretimi ve yeniden üretimini belirleyen önemli bir etken teşkil etmekteydi.

Tablo 2. 1955-2002 Arası Dönemde Ankara'da Gecekondulașma

\begin{tabular}{|c|c|c|c|}
\hline Yıllar & Gecekondu & Gecekondu Nüfusu & Kentsel Nüfus (\%) \\
\hline $\mathbf{1 9 5 5}$ & 12.000 & 62.400 & 21.8 \\
\hline $\mathbf{1 9 6 0}$ & 70.000 & 364.000 & 56.0 \\
\hline $\mathbf{1 9 6 6}$ & 100.000 & 520.000 & 57.4 \\
\hline $\mathbf{1 9 7 0}$ & 144.000 & 748.000 & 60.6 \\
\hline $\mathbf{1 9 7 5}$ & 202.000 & 1.156 .000 & 64.9 \\
\hline $\mathbf{1 9 7 8}$ & 240.000 & 1.300 .000 & 68.4 \\
\hline $\mathbf{1 9 8 0}$ & 275.000 & 1.450 .000 & 72.4 \\
\hline $\mathbf{1 9 9 0}$ & 350.000 & 1.750 .000 & 58.3 \\
\hline $\mathbf{1 9 9 5}$ & 450.000 & 2.250 .000 & 65.0 \\
\hline $\mathbf{2 0 0 2}$ & 500.000 & 2.500 .000 & 62.5 \\
\hline
\end{tabular}

Kaynak: Keleş, Kentleşme Politikası, s. 513.

1950'lilerden itibaren kırdan Ankara'ya doğru göçün aşırı bir hız kazanmasıyla 1960 yılında kentin nüfusu 1950'deki 288.536'dan 650.067'ye ulaşmışt $1^{45}$ bu nüfusun $\% 56$ 'sın1 ${ }^{456}$ ise gecekondu nüfusu oluşturmaktaydı. İthal ikameci sanayileşme döneminde Ankara' da gecekondulaşma eğilimi daha hızlı bir şekilde devam ederek 1980'de Ankara'nın 1 milyon 450 bin nüfusunun artık $\% 72,4^{\prime} \ddot{u}^{457}$ gecekondularda yaşamaktaydı (bkz. Tablo 2). Keyder, gecekondulaşmaya yol açan mekânsal hareketliliği ele alırken onu "fiziki mesafeleri ortadan kaldıran ve merkez ile çevrenin kültürünü hoyratça karş1 karşıya getiren ülke içi bütünleşmenin gerçek başlangıcı" olarak tanımlar. ${ }^{458}$ Kemalizm'in modern Ankara tahayyülü ve bunun doğrultusunda modern bir kentsel mekân yaratma çabaları 1950'lerden itibaren Ankara'da yaşananlar çerçevesinden değerlendirildiğinde Keyder'in, bu süreci “fiziki mesafeleri ortadan kaldıran ve merkez ile çevrenin kültürünü hoyratça karşı karşıya getiren bütünleşme" olarak değerlendirmesi özellikle Ankara için önemli ölçüde geçerli

455 Şenyapıl1, “Baraka”dan Gecekonduya: Ankara'da Kentsel MekâNin Dönüşümü: 1923-1960, s. 294

456 Keleş, Kentleşme Politikası, s. 513.

457 Ibid.

458 Keyder, Türkiye'de Devlet ve Siniflar, s. 171. 
saptama olduğu söylenebilir. Ayrıca 1950'lilerden itibaren siyasetin demokratikleşmesi ve kamusal bir karakter kazanmasıyla eskiden kültürleri, inanışları, yaşayış tarzları itibarıyla siyaset alanına dâhil edilmeyenler DP sayesinde gerek siyasete gerekse bir önceki dönemde siyasalın belirlediği ve kendilerini dışladığ1 kamusallığa katılma imkânına kavuşmuştu. 1950-70’li yıllarda Ankara'da gerek yapılı çevrenin gerekse toplumsal mekânın (mekân üzerine söylem dâhil) üretimi birbiriyle sıkı bağı olan bu iki hususun - "emek gücünün kentleşmesi" ile "modernite projesinin popülist niteliği" - belirlediği çerçevede gerçekleşmekteydi.

1950’lilere kadar yürürlükte kalan Jansen planı kentin hızla gelişmesi ve belirlenmiş sınırların dışında yapılaşması yüzünden yetersiz kalınca yeni bir imar planı yaptırma gereği görülmüştür. 1957 yılında onaylanmış olan Yücel-Uybadin Planı 1977'de Ankara'nın 750 bin nüfusu olacağ varsayımına göre yapılmıştı. 459 1958-1968 yılları arasında yürürlükte olan Yücel-Uybadin Planı, "bir nazım plana dayanmayan", "kent biçimi arama endişesi taşımayan", "kent merkezi siyasası bulunmayan" ve daha çok "arazi kullanımına önem veren" bir plandı. 460 Jansen Planı'na benzer biçimde Yücel-Uybadin Planı da kentin sınırlarını belirlemesi ve kent çevresinde yeni yapılaşmaların sınırlaması gerekliliugi üzerinde durmaktaydı. ${ }^{461}$ Fakat plan aynı zamanda "kentin büyümesine biçim vermek yerine dolambaçlı yollara ve içinde ayrık düzende az katlı yapılar bulunan dikdörtgen yapı adalarına dayalı bir tasarım önermiştir" 462 ve aslında planın temel hedefi parçacı gelişmeleri bütünsel bir makro form içerisinde kurgulamaktı. ${ }^{463} \mathrm{Bu}$ açılardan Jansen Planı'nın öngördüğü tasarlanan mekândan önemli ölçüde farklılaşıyordu. Aynı zamanda plan gecekondulaşmanın en yoğun olarak yaşandığı dönemde yapıldığı ve gecekondulaşmaya dair bir yaklaşım da içermediği; Ankara'nın en yoğun olarak gecekondulaşmış bölgelerini normal imar alanı olarak tasarladığ $1^{464}$ da düşünüldüğünde, planın büyük ölçüde dönemin mekân temsilini yansıttığı da söylenebilir. Başka bir deyişle plan, bir biçim endişesi içermediğinden, kentte hem mekânsal hem de toplumsal açıdan önemli yer tutan gecekondu sorununa bir çözüm önermediğinden dolayı, aslında

459 Geray, "Şehirciliğimiz ve Ankara”, s. 17.

460 Cengizkan, "1957 Yücel-Uybadin İmar Planı ve Ankara Şehir Mimarisi”; Günay, "Ankara Çekirdek Alanının Oluşumu ve 1990 Nazım Planı Hakkında Bir Değerlendirme".

461 Çalişkan, "Forming a Capital: Changing Perspectives on the Planning of Ankara (1924-2007) and Lessons for a New Master-Planning Approach to Developing Cities", s. 36.

462 Cengizkan, "1957 Yücel-Uybadin İmar Planı ve Ankara Şehir Mimarisi; Günay, "Ankara Çekirdek Alanının Oluşumu ve 1990 Nazım Planı Hakkında Bir Değerlendirme".

463 Çalişkan, "Forming a Capital: Changing Perspectives on the Planning of Ankara (1924-2007) and Lessons for a New Master-Planning Approach to Developing Cities", s. 34.

464 Günay, "Ankara Çekirdek Alanının Oluşumu ve 1990 Nazım Planı Hakkında Bir Değerlendirme", s. 81. 
dönemin konjonktürünü temsil edecek nitelikteydi. Cengizkan'ın da belirttiği üzere 465 Yücel-Uybadin Planı kendine özgü öngörüleri olmayan, başkentin bir önceki iki plana (Lörcher ve Jansen) kıyasla daha kalıcı ve kuramsal önermeleri içermeyen bir plandı aslında. Fakat planın tasarlanan mekân açısından en dikkat çekici tarafı, kentin gelişmesinin yayılma yoluyla değil de yerinde yükselerek gerçekleştirilmesini ve 'bölge kat nizamı' kavramının ilk kez burada dile getirilmesidir. Bunun geçerlik kazanması ise 1965 yılında kabul edilen Kat Mülkiyeti Yasası ve Bölge Kat Nizamı Planının devreye sokulmasıyla gerçekleşti. ${ }^{466} \mathrm{Bu}$ ise kentsel mekânının ve yapılı çevrenin tamamıyla gayrimenkulleşmesine yol açarak Ankara'da kentsel mekânın üretimini radikal bir şekilde etkileyen gelişmeydi.

Yukarıda ele alındığ 1 üzere Ankara'nın başkent ilan edilmesinden beri burada farklı toplumsal kesimler tarafindan süregelen bir rant arayışı söz konusu olmuştur. 1920'lerde bir tür ilkel birikim niteliği taşıyan bu tarz süreçler bir yana, Ankara'nın en planlı gelişme dönemi olarak tanımlanan, plana göre gelişen bir başkente sahip olma konusunda ciddi bir siyasi irade ve kararlılık söz konusu olan 1930'larda bile bu arayışlar hep mevcuttu. Buna rağmen 1950'li yıllarına kadar tek parsel üzerine tek ev yapılması kuralı geçerliydi ve parsel sahibi daha çok kendi kullanımı için ev yaptırmaktaydı veya yapılan çok katlı apartmanlar kira amaçlı olarak kullanmaktaydı. Böylece konut yapımında bir taraftan değişim değerine göre kullanım değeri baskındı, diğer taraftan kat mülkiyetinin söz konusu olmaması tek parselde yapılan ev veya apartmanlar kâr amaçlı olsalar da bir meta olarak arsanın ve yeraltı ile yerüstü düzenlemelerin özellikleri, mübadele süreçleri için belirli sınırlamalar oluşturmaktaydı. ${ }^{467}$ Oysa 1954 yılında Tapu Kanunu'nda yapılan düzenlemeyle bir gayrimenkul üzerinde bulunan ya da yapılacak olan binanın bir katından ya da dairesinden yararlanmak üzere irtifak hakkı kurulması kuralı getirildi. 1965 yılında çıkarılan Kat Mülkiyeti Kanunu ise kat ve daire mülkiyetine yasal bir çerçeve sağladı. ${ }^{468} \mathrm{Bu}$ kanunun da zorlamasıyla 1968'de devreye sokulan Bölge Kat Nizam Planı ise yalnızca Atatürk Bulvarı üzerine değil, bulvara çıkan yollara da 9-10 kat yükseklik, arka bölgelere ise 6 kat yükseklik tanıyınca 'yık-yap' denilen süreci başlattı ve kentin merkezinde tüm yapı stoku yıkılıp yeniden inşa edildi.

465 Cengizkan, "1957 Yücel-Uybadin İmar Planı ve Ankara Şehir Mimarisi”, s. 31.

466 Cengizkan, "1957 Yücel-Uybadin İmar Planı ve Ankara Şehir Mimarisi”; Günay, "Ankara Çekirdek Alanının Oluşumu ve 1990 Nazım Planı Hakkında Bir Değerlendirme”.

467 Herhangi bir parselin veya düzenlemenin sabit (mutlak) bir konumu vardır ve diğer metalara kıyasla taşınmaz niteliğe sahiptir. Parselin veya düzenlemenin mutlak konumu, onun üzerine mülkiyet hakkı olanlara tekel imtiyazları sağlamaktadır, zira fiziksel mekânda iki kişi veya şey birebir aynı konumu işgal edemezler. Bkz. Harvey, Social Justice and the City, s. 158.

468 Çoban, "Cumhuriyetin İlanından Günümüze Konut Politikası”, s. 85. 
Özellikle merkezi iş alanları olan Kızılay ve Kavaklıdere'deki yapı stoku tümüyle yeniden inşa edildi. Sonuçta kentte çok katlı ve yüksek yoğunluklu apartmanlaşma hâkim olmaya başladı; Yücel-Uybadin Planı'nın önerdiği 200350kişi/hektar yerine 600-650kişi/hektar yoğunluğu ortaya ç1ktı. ${ }^{469}$

1950-70 y1llarında Ankara'da yapılı çevrenin üretiminde hâkim olan bu eğilimdeki temel aktör parsel sahipleri, küçük sermaye sahibi inşaat sektörü ve k1sitlı tasarruf sahibi konut alıcılarıdır.

Böyle bir sürecin kentin biçimine, çevre koşullarına ve ömrü dolmamış yapıları yıkıp yeniden inşa ederek israfa neden olma gibi birtakım olumsuz etkileri ${ }^{470}$ şöyle dursun, daha temel bir yapısal hususa; kentsel mekânın biçimlenmesinde kullanım değerine (somut olan) göre değişim değerinin (soyut olan) ağırlık kazanmasına ve sermayenin (boyutları yerel ve sınırlı olsa da) belirleyici olmasına böylece mekânın gayrimenkulleşerek soyutlaşmasına işaret etmektedir. Böylece 1930-40'l1 yıllarda 'Bahçeşehir' konut kooperatifler aracılığıyla kısmen hayata geçirilen alçak yoğunluklu bahçeşehir ile konut hayali 1970'li yılların sonunda artık bir tarih olmuştu. Kemalist modernleşmenin, kullanım değeri açısından münhasıran politik olan ve bu özelliğiyle soyutluğa yönelen mekânın üretiminden kullanım değeri açısından mübadele edilebilir ve bu özelliğiyle soyutluğa yönelen bir mekânın üretimine geçiş gerçekleşmişti. Bu süreçte, Kemalist modernleşmenin, tarih yaratmak için mekâna emretme deneyiminin de kendisi tarih olmuştu (bkz. Şekil 8-9).

1950-70 y1lları boyunca Ankara'da apartmanlaşma devam ederken özel sermaye tarafindan bu tip konut üretimi ancak kentteki orta ve üst-orta gelir grubunu oluşturan kesimlerin konut ihtiyacını karşılamaya yöneliktir. Oysa kente göç eden yüzbinlerce işçinin konut ihtiyacı gerek kamu gerekse özel sermaye tarafından karşılanmamaktaydı. 1960'lardan itibaren benimsenen ithal ikameci sanayileşmenin kayda değer özelliklerinden biri olabildiğince azami kaynakların sınai gelişmeye tahsisiydi. Mekânın üretimi açısından bu stratejinin sonucu yapılı çevreye ve kolektif tüketim alanına özel ve kamu sermaye yatırımlarının asgariye indirilmesiydi. ${ }^{471}$ Ayrıca sanayileşme için gerekli yatırımlar yabancı sermaye ve teknoloji ithaline dayanmaktaydı, bu girdilerin yüksek maliyetini dengelemek ve kâr marjını yükseltmek için emeğin 'ucuz' olması gerekmekteydi. Bu 'ucuz emek' ise sadece doğrudan ücretler değil, kolektif tüketimin kapsadığı dolaylı ücretler anlamına gelmektedir.

469 Çalişkan, "Forming a Capital: Changing Perspectives on the Planning of Ankara (1924-2007) and Lessons for a New Master-Planning Approach to Developing Cities", s. 34; Günay, "Ankara Çekirdek Alanının Oluşumu ve 1990 Nazım Planı Hakkında Bir Değerlendirme", s. 81; Şenyap1l1, "Baraka”dan Gecekonduya: Ankara'da Kentsel Mekânın Dönüşümü: 19231960, s. 220.

470 Çoban, "Cumhuriyetin İlanından Günümüze Konut Politikası", s. 85.

471 Şengül, "On the Trajectory of Urbanisation in Turkey: An Attempt at Periodisation", s. 159. 
Şekil 8. 1950'lerde Kızılay Meydanı ve Mücavir Alanı

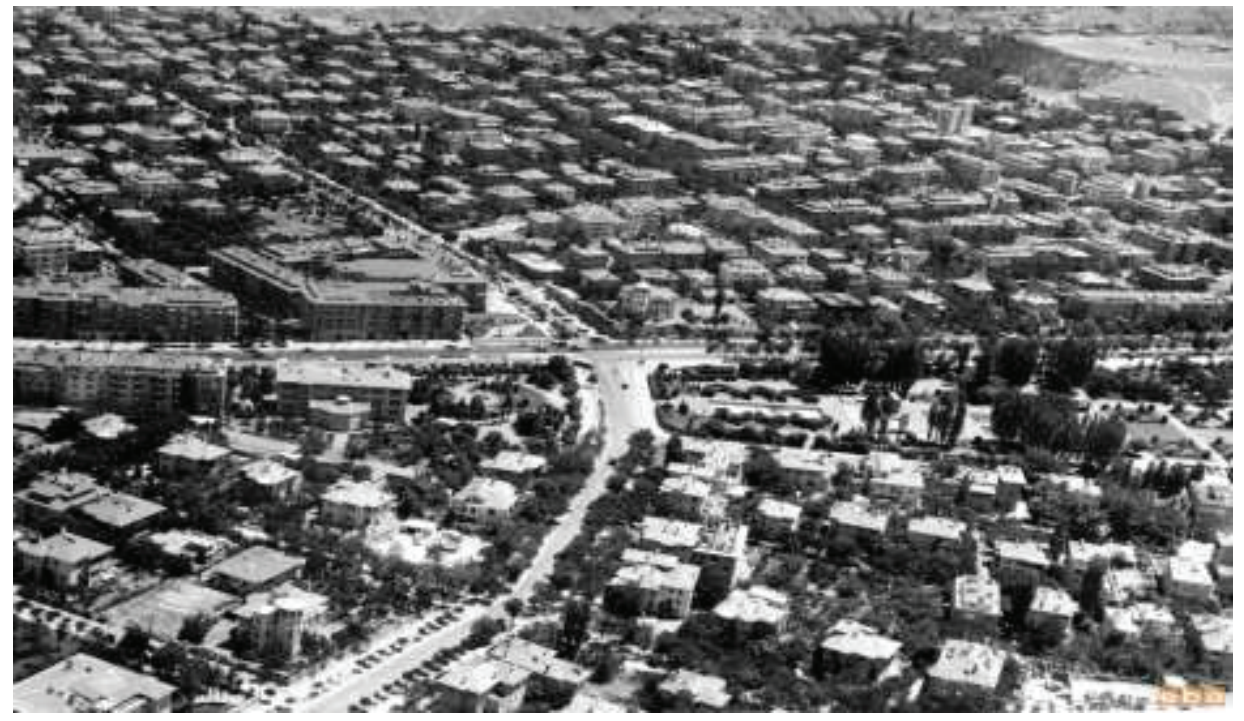

Kaynak: EBA, 24 Ekim 2016 tarihinde http://www.eba.gov.tr/gorsel/bak/83334a127ef87b0df42e 08bd8d2761e9682c25ce5a101 adresinden erişildi.

Şekil 9. 1970’lerde Kızılay Meydanı ve Mücavir Alanı

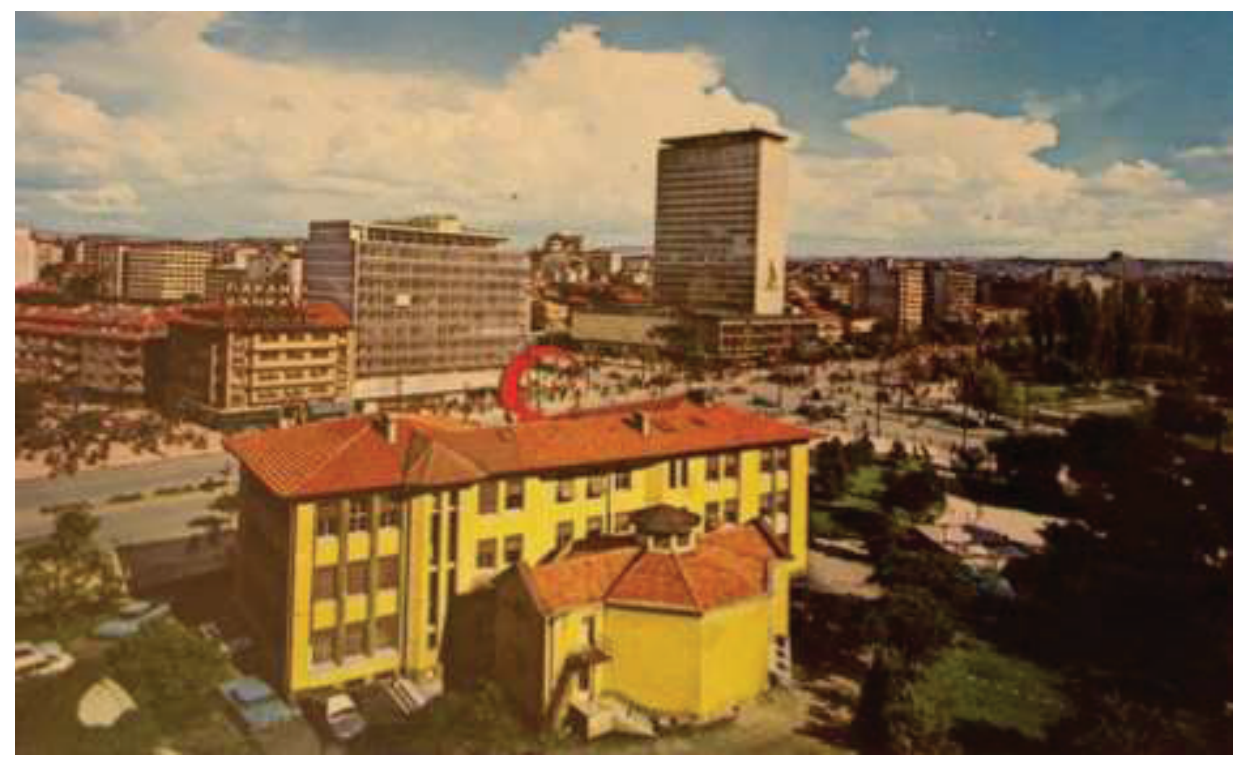

Kaynak: EGO, 24 Ekim 2016 tarihinde http://m.ego.gov.tr/FotoGaleri/Resimler/1028/ankaranostalji-fotograflari\#\&gid=1\&pid=34 adresinden erişildi. 
Böylece benimsenen birikim rejiminde gerek kamu gerekse özel sermaye, kolektif tüketim alanında "sorunları işverene ve devlete mali yük yüklemeden çözebilen bir emeğe" ihtiyaç duymaktaydı. ${ }^{472}$ Kolektif tüketimin iki ana bileşeni olan barınma/konut ile ulaşım sorununu emekçinin kendi imkânları ve emeğiyle çözmesine dayanan bu birikim rejiminin mekânın üretimi açısından sonucu ise gecekondulaşmaydı. Ankara'da kentin nüfusunun yarısını barındırdığı gecekonduların mekânsal açısından dağılımı özellikle kayda değerdir. Dünyada ve Türkiye'de farklı şehirlerde gecekondulaşma, işverenlerin kentin çeperinde yerleşmesinden dolayı gecekondular da kentin çeperlerinde yer alırken "Ankara'da çevrede işverenin olmaması, çevre ile ulaşımın özel bir düzeyde çözülüyor olması nedeniyle ilk gecekonduların merkeze en yakın ancak topografik eşik niteliği taşıdığı için plan ve denetim dışı bırakılan alanlarda geliştiği izlenir." 473

Mekânın üretimi açısından gecekondulaşmanın bir diğer kayda değer özelliği, ilk evrelerde gecekonduların oturanlar tarafından denetimsiz ve imar dışı olan, mülkiyet açısından kendilerine ait olmayan alanlarda kendi emek ve imkânlarıyla yapılması, böylelikle mekânın üretiminde mülk edinme ilişkileri yerine sahiplenme ilişkilerinin ağır basması ve mekânın üretiminin kullanım değer merkezli olmasıdır. Ankara'da gecekondulaşma ile ilgili kapsamlı bir değerlendirme sunan Şenyapılı'nın belirttiği gibi 1945-50 y1llarında "herkes kendi gecekondusunu yapıyordu, henüz ücretli işçi ya da ustalara gereksinme yoktu... olanaklar elverdiğince konutun çevresinde bahçe tarımı, ufak çapta kümes hayvancılığ yapıyordu. Ailenin bu dönemde kırla ilişkileri oldukça önem taşı[yordu]." ${ }^{474}$ Oğuz Işık ise 1950-1960 yıllarının "ilk kuşak gecekonduları"nı, taşıdıkları özelliklerinden dolayı ayırır, ona göre;

"Bu dönem gecekondularının temel özelliği, kırdan göçenlerin kamu arazisi üzerinde esas olarak kendi emekleri ile yapım sürecini gerçekleştirmeleridir. Kimi durumlarda aile yakın çevresinden yardım alınsa ve hatta belli durumlarda iş̧̧i ya da usta çalıştırllsa bile ilk kuşak gecekonduların temel özelliği, konut sahibi ile yapımcı ve kullanıcı arasında ayrışma olmamasıdır... Bu dönem gecekondularının bir diğer özelliği de kullanıcının gereksinimlerine göre zaman içinde genişletilebilmesidir. Dolayısıyla, yapım ve kullanım süreçlerindeki esneklik ilk dönem gecekondularının belirleyici özelliğidir. İlk dönem gecekondularının yapım ve kullanımında belirleyici etken, değişim değeri değil de kullanım değeridir. Bu gecekondular, piyasada satılmak üzere

472 Şenyapıl1, “Baraka”dan Gecekonduya: Ankara'da Kentsel Mekânın Dönüşümü: 1923-1960, s. 186.

473 Ibid., s. 75.

474 Ibid., s. 185. 
değil de, belirli bir kullanıcının gereksinimlerine yanıt vermek amacıyla üretilmiştir. İlk kuşak gecekondular, piyasa ilişkilerinin dışındaki mekanizmalarla üretilmiş ve bu süreçte de kullanıcıların gereksinimleri belirleyici olmuştur." 475

Bir toplumsal mekân olarak gecekonduların üretimi ve yeniden üretimi, dönemin birikim rejiminin, üretim ilişkilerinin ve genel toplumsal ilişkilerin bir ürünü olduğunu, ayrıca gecekonduların, bu ilişkilerin yeniden üretimini de sağladığı düşünülürse gecekonduların, egemen toplumsal ilişkilerden bağımsız olduğu söylenemez. Fakat ilk evrelerde böyle mekânların ortaya çıkışı belirli bir birikim rejiminin ürünü olsa da bunlar kendi başına tamamıyla farklı bir toplumsal mekân oluşturmaktaydı; buralarda piyasa dışı ilişkilerin süregeldiği, mekân ile kurulan ilişkilerde mülk edinme yerine sahiplenme ${ }^{476}$ ilişkilerinin egemen olması, gecekondularda yaşayanların çoğunun aynı köyden geldiğini ve hemşehrilik ve akrabalık ilişkilerinin yaygın olması sebebiyle dayanışma ve yardımlaşma kültürü de yaygı̀n olan mekânlardı.

Gecekonduların gerek "organik planlama anlayışı"477 ve yaşayanların ihtiyaçlarına cevap vermeye yönelik olması gerekse burada yüksek dayanışma ve yardımlaşma kültürünün ve ilişkilerin hâkim olması hem yapılı çevre hem de toplumsal mekân açısından bu mekânlar, dönemin egemen olmaya yönelim gösteren soyut tasarlanan mekânı karşısında birer yaşanan mekânı oluşturmaktayd1. Bunlar, gerek fiziksel özellikleriyle gerekse toplumsal nitelikleriyle bürokratlar, planlamacılar ve teknokratlar tarafından düşünülen, tasavvur edilen ve tasarlanan mekânlar değildi, oturanlar tarafindan kendi barınma ihtiyaçlarına cevap verebilmek için üretilmiş ve sahiplenen mekânlardı. 1950-60 yıllarında bu, başta Ankara olmak üzere Türkiye'nin çoğu gecekondularına özgü bir durumdur. ${ }^{478}$

475 Iş1k, “Kentlerde, Kentleşmeye ve 21. Yüzy1lın Eşiğinde Türkiye Kentlerine Dair”, s. 167, vurgu eklenmiştir.

476 Lefebvre, Mekânın Üretimi.

477 Işık, "Kentlerde, Kentleşmeye ve 21. Yüzyılın Eşiğinde Türkiye Kentlerine Dair".

478 Örneğin Şükrü Aslan'ın, İstanbul-Ümraniye'de bir gecekondu mahallesini konu eden araştırması, 1970'lerde mahallede ortaya çıkan örgütlenme biçimini, mevcut sosyo-mekânsal ilişkilerini detaylı bir şekilde inceleyerek mahallede alternatif ve ilginç bir mekân üretimi deneyiminin var olduğunu göstermektedir. Çalışmanın sunduğu en önemli detay mahallede katılım ve özyönetime dayalı bir örgütlenmenin (Halk Komitesi) ve piyasa dışı ilişkileri ve kullanım değeri ön plana çıkaran bir mekân üretiminin (Halk Komitesi aracılığıyla var olan arsanın eşit olarak bölüşerek tahsisi, ortak kullanıma yönelik planlı kamusal alanların yaratılmasına gayret göstermesi, tüketici kooperatif açılması vs.) varlı̆̆ıdır. 1 Mayıs Mahallesi, Türkiye'nin gecekondu deneyiminde bir istisna olduğu söylenebilir, fakat mahallede kullanım değerine odaklı mekân üretiminin ilk evredeki diğer gecekondularda da gözlemlenebilen bir durum olduğu belirtilmelidir. Bkz. Şükrü Aslan, 1 Mayıs Mahallesi: 1980 Öncesi Toplumsal Mücadeleler ve Kent. 
Hâlbuki 1970'li y1llardan itibaren gecekondular her anlamda değişerek burada mekânın üretimi ve egemen mekân açısından farklı bir süreç yaşanmaya başlamıştır. İlk kuşak gecekondular kullanıcılar tarafından kamu arazisi üzerine inşa edilirken, bu dönemde gecekondu yapmak için arsa işgal etme yerini arsa piyasasına bıraktı, şöyle ki önceden işgal edilmiş arsalar sahipleri tarafından 200$300 \mathrm{~m}^{2}$ büyüklügünde parsellere ayrılarak satışa sunulmaktadır. Ayrıca, gecekondu inşasında emek biçimi de değişerek, "ilk kuşak gecekonduların temel özelliklerinden olan yapımc1-konut sahibi özdeşliği giderek ortadan kalkmış ve gecekondular artan oranlarda başka gruplar tarafından inşa edilip, kullanıcılara satılan bir meta haline dönüşmüştür." 479 Böylece gerek mekânın doğrudan mübadele ilişkilerine dâhil olunması açısından gerekse gecekondularda mekânın üretimi süreçlerinde emek ilişkilerinin piyasa ilişkileri niteliği kazanması açısından 1970'li yıllardan itibaren gecekondu bölgelerinde gerek mekânın kendisi gerekse onun üretimi mübadele ilişkilerine dâhil olunup değişim değeri niteliği kazanarak soyutlama eğilimi göstermekteydi. Böylece mekân ile ilişkileri konusunda sahiplenme yerine mülk edinme ilişkileri yaygınlık kazanmaktaydı ${ }^{480}$ ve oturanlar tarafindan sahiplenen mekanı, piyasa dışı niteliklerini kaybederek mülk edilen mekâna dönüşmekteydi. ${ }^{481}$ Fakat bu süreçlerin henüz tam anlamıyla

479 Işık, "Kentlerde, Kentleşmeye ve 21. Yüzyılın Eşiğinde Türkiye Kentlerine Dair”, s. 168.

480 Aslında gecekondu bölgelerinde mülkiyet ilişkilerinin gelişmesi, dolayısıyla mekân ile ilişkilerde mülk edinmenin yaygınlaşması 1950'lilerde başlamıştır. Şöyle ki dönemin siyasi konjonktürünün popülist niteliği, yaygın bir seçmen kitlesi oluşturan gecekondu sakinlerini önemli bir oy tabanı olarak değerlendirmiş ve buralarda tapu verilmeye başlamıştır (bkz. Şenyapıl1, Şenyapıl1, "Baraka”dan Gecekonduya: Ankara'da Kentsel Mekânın Dönüşümü: 1923-1960). Örneğin 1954 genel seçimlerinden 1 yıl önce çıkartılan 6188 sayılı Bina Yapımını Teşvik ve İzinsiz Binalar Hakkında Kanun ile gecekondulaşmayı engellemeyi ve kamu arsalarının satılarak konut üretiminin artırılması hedeflenmiştir, bununla ise gecekondular 'meşrulaştırılmıştır'. Fakat gecekondu bölgelerinde mülkiyet ilişkilerinin düzenlenmesi açısından böyle girişimler daha önce başlamış olsa da, gecekondularda mülkiyet ilişkilerinin ve gecekondu üretiminde mübadele ilişkilerinin asıl başlangıcı 1970'lerdir.

481 Bu bağlamda 1971'de Ankara'nın en eski gecekondu bölgelerinden biri olan Altındağ' da saha araştırması yapan Kongar'ın sunduğu veriler kayda değer ayrıntılar içermektedir. Araştırmadan anlaşıldığı üzere bölgedeki halk yerleşik bir nitelik kazanmış, gecekondu tapularına sahip ve bu açıdan mülkiyet ilişkilerini önemli ölçüde benimsemiş durumdadır (ör. bölge sakinlerinin yaklaşı \%63'ü devletin veya başkasının özel mülkiyeti üzerine gecekondu yapılmaması gerektiğini düşünüyor) ve halk "özel mülkiyete devlet mülkiyetinden daha saygılıdır". Çalışmasından ayrıca "bölgenin kent ile önemli bir bütünleşme süreci içinde olduğu" ve Altındağ'da sosyal bir tabakalaşmanın da söz konusu olduğu anlaşılmaktadır. Araştırmaya göre gecekonduda yaşayanların yaklaşık \%90'ı ellerinde imkân olduğu takdirde mahalleden ayrılmayı, ayrıca çoğu bir apartman dairesine veya müstakil eve taşınmayı arzular. Saha araştırmasından elde edilen bu veri ve sonuçlar boylamsal yerine kesitsel bir araştırmanın sonucu olduğu için 1970 öncesi dönemle kıyaslamasına imkân sağlamamaktadır. Fakat veriler ve sonuçlar en azından bölgenin genel durumu için önemli 
piyasa ilişkileri çerçevesinde süregeldiği söylenemez, zira bu sürecin önemli aktörü dönemin gecekondularında faaliyet gösteren arazi mafyalarıydı, Işık'ın belirttiği gibi dönemin gecekondu piyasası "kendine özgü işleyiş kuralları olan, giriş ve çıkışların medyada yerleşmiş görünen terimi ile arazi mafyası tarafından s1k1 sıkıya denetlendiği bir piyasadır." 482 Bunlar, arazi piyasasında faaliyet göstermekle birlikte aynı zamanda gecekondu sakinleri ile yerel makamları arasındaki ilişkilerde aracı bir işlev görmekteydi ve gecekondu mahallelerine kamu hizmetleri getirmesinde, gecekondu yıkımlarının önlenmesinde de önemli rol oynayarak ${ }^{483}$ gecekondularda piyasa ilişkilerinin yaygınlaşmasıyla birlikte bu mekânların iktidar tarafından denetlenebilirliği konusunda da önemli işlev gördükleri söylenebilir.

Mübadele ve mülkiyet ilişkileri bağlamında gecekonduların kullanım değeri merkezli mekânı, mübadele değer merkezli bir mekâna dönüştüğü bu sürece koşut olarak 1960-70'lerde gecekondular ile ilgili siyasi bir mekân temsili ve temsil mekânı oluşması da söz konusuydu, mekân temsilleri dönemin mesleki tartışmalarının ürünüyken, temsil mekânı kurguları ise genelde medya tarafından üretilmekteydi.

Bülent Batuman, 1950-70'lerde kente doğru göçün ve gecekondu mekânlarının üretimi sürecinde oluşmaya başlayan mekân temsilleri konusunda iki önemli noktaya dikkat çeker; ${ }^{484}$ İlkin, kent, orta sınıfın kapalı bir sosyal çevresi olarak, göç ise köylü istilası olarak temsil edilmekteydi. İkinci olarak, göç, beden yığınlarının akışı olarak temsil edilmekteydi. Böyle bir temsil ise dönemin kentli orta sınıfın ve bu sınıfın temsilcisi olan sanatçı karikatüristlerin köylü istilasına karşı hoşnutsuzluğuydu. 1950'li yıllar ile 1960'lı yılların başlarında süregelen bu temsilde göçü imleyen beden yığınları yerine 1960-70'li

ipuçları sunar. Bkz. Kongar, “Altındağ Gecekondu Bölgesi”; Kongar, “Altındağ’da Kentle Bütünleşme".

482 Işık, "Kentlerde, Kentleşmeye ve 21. Yüzyılın Eşiğinde Türkiye Kentlerine Dair”, s. 168.

483 Bkz. Avci, "The Gecekondulu in Turkey: Representation, Identity, and the Urban Poor in the 1960s and 1970s"; Aslan, 1 Mayls Mahallesi: 1980 Öncesi Toplumsal Mücadeleler ve Kent; Erman, "Understanding The Experiences Of The Politics Of Urbanization In Two Gecekondu (Squatter) Neighborhoods Under Two Urban Regimes: Ethnography In The Urban Periphery Of Ankara, Turkey"; Avci, "The Making of a Gecekondulu Identity: Journalistic Representations of the Squatters in Turkey in the 1970".

484 Bülent Batuman'ın, 1960-70'lerde Türkiye'de kentsel siyasette ve kentsel mücadelede mimar ve plancıların rolünü konu eden doktora tezi dönemin gecekondu olgusuna dair mekân temsillerini ele alması itibariyle kayda değer bir çalışmadır. Lefebvre'in, mekân temsili tanımından yola çıkan Batuman, dönemin mimar ve planlamacılarının tartışmalarını ve yayınlarını, farklı mesleki ve güncel yayınlardaki görselleri (karikatür, fotoğraf, kolaj) inceleyerek 1960-70'lerde gecekonduların mekân temsili ile ilgili kayda değer değerlendirmelerde bulunmaktadır. Bkz. Batuman, "Spaces of Counter-Hegemony: Turkish Architects and Planners as Political Agents in the 1970s". 
yıllarda artık onların yaşadığı mekânlar - gecekondular - temsillerde öne çıktı. 485 Göç sonucunda ortaya çıkan gecekonduların, temsillerde öne çıkması ise sorunlu kentsel ortamı istila eden yığınlar yerine fiziksel çevre aracılığıyla daha iyi şekilde temsil edebilmesinden kaynaklanmaktaydı. 486 Ayrıca 1960'lardan itibaren kalkınmacı retoriğin yükseldiği, bir kalkınma aracı olarak planlamanın kurumsallaştığı ve bunun etrafında oluşan genel oydaşma bağlamında kentleşmeye ve kentte endüstrileşmenin ilerlemesine önemli bir işlev atfedilmekteydi. Dolayısıyla gecekonduların bir sorunlu mekân olarak temsilleri sorunlu kalkınmanın semptomu ve kentin nasıl olmaması gerektiği konusunda önemli bir temsil işlevi görmekteydi, aynı zamanda bu çerçevede kent planlamacılarına kentleşmenin sorunlarını çözmek için önemli işlev yüklenmekteydi. Böylece dönemin kentsel mekân temsili bir taraftan orta-sınıfın, kent ortamını 'bozan' gecekonducular ile gecekondular temsilinden, diğer taraftan teknokratların, sorunlu kalkınmanın semptomu olarak gecekondu temsilinden oluşmaktaydı. ${ }^{487}$ Tahire Erman da gecekondu araştırmalarının söylemini inceleyerek Batuman'a benzer sonuçlar ortaya koyar. ${ }^{488}$ Ona göre 1950-60'ların gecekondularının "kırsal öteki" temsili yerine 1970-80'lerde akademide "dezavantajlı öteki" temsili ağır basmaktaydı. "Kırsal öteki" temsili dönemin yapısal işlevselci ve modernleşme yaklaşımlarının ürünüydü, ülkenin modernleşme sürecinde "ötekilerin" kırsal yaşantıları ve değerlerinden vazgeçip modern kentsel toplumla bütünleşme varsayımına dayanmaktaydı. Oysa gecekondu olgusunun “dezavantajlı öteki” temsili 1970'lerde ve erken 1980’lerde yapısal-Marksist ve benzer yaklaşımları benimseyen araştırmaların ürünüydü. ${ }^{489}$

Özellikle gecekonduların "dezavantajlı ötekiler"490 veya "dezavantajl1, ezilen gruplar" gibi onların sürekli olarak yüzleştikleri şiddete referansla temsil

485 Ibid., s. 130.

486 Ibid., s. 131.

487 Ibid., s. 138.

488 Erman, çalışmasında gecekondu temsilleri konusunda Batuman gibi Lefebvre'in kavramsal çerçevesini kullanmasa da, akademik söylemi konu ederek aslında mekân temsili ortaya koymaktadır, zira Lefebvre, mekân temsilini (tasarlanan mekân) planlamacıların, teknokratların, şehircilerin ve kimi sanatçıların mekânı olarak tanımlarken aynı zamanda akademik söylemi de kastetmektedir. Dolayısıyla, bahsi geçen dönemde akademide gecekonduların mekân temsili konusunda daha detaylı analizi için Erman'ın çalışmasına da başvurulabilir. Bkz. Erman, "The Politics of Squatter (Gecekondu) Studies in Turkey: The Changing Representations of Rural Migrants in the Academic Discourse".

489 Bkz. Erman, "The Politics of Squatter (Gecekondu) Studies in Turkey: The Changing Representations of Rural Migrants in the Academic Discourse"; ayrıca krş. Batuman, "Spaces of Counter-Hegemony: Turkish Architects and Planners as Political Agents in the 1970s".

490 Erman, "The Politics of Squatter (Gecekondu) Studies in Turkey: The Changing Representations of Rural Migrants in the Academic Discourse". 
edilmesi491 ve nesnel bir biçimde kenti temsil etme yerine, gecekondu bölgelerinin ve onların mücadelesinin meşruluğu üzerine kurgulanmış kent temsilleriyle 492 aynı zamanda toplumsal mekânın üretiminde gecekondulara belirli bir işlev, misyon ve siyasi bir kullanım değeri atfedilmektedir. Özgür Avc1, 1970'lerde basında gecekondu temsillerini inceleyerek farklı ideolojik yönelimi olan tüm günlük gazetelerin (sol, sağ veya merkez) ortak noktası şüphe uyandıran, ideolojik sorumluluktan yoksun ve toplum için bir tehlike oluşturan gecekondu temsillerinin ağrı bastığını ileri sürmektedir. Aynı zamanda bu gazetelerin, devlet tarafindan gecekondu yıkımlarının temsilinde gecekondu sakinlerinin hep kurban olarak temsili dikkat çekicidir. Gecekonduların kadın veya çocuk imgeleriyle temsil edilmesi gecekonduların çaresiz, hassas ve korunmasız olduğu imgesini daha da pekiştirirken aynı zamanda, bu bölgelerin komünistlerce kandırılmış kurbanlar (sağ yönelimli gazetelere göre), yurttaşlık hakları ve sorumluluklarını yerine getirme konusunda yetersiz olan, dolayısıla koruyucu Devletin ihtiyacını duyan kurbanlar (merkez sol yönelimli gazetelere göre) veya daha uyanmamış olan ve daha geniş ölçekte mücadele için örgütlenmeye ihtiyaç duyan kurbanlar (radikal sol yönelimli gazetelere göre) olarak temsilleri hâkimdir. ${ }^{493}$

Özgür Avcı'nın ele alıp genelleştirdiği bu temsillerde mekânın üretimi açısından dikkate değer husus, gecekondulara farklı siyasi kesimler tarafindan (ki gündelik basın aynı zamanda gecekondu konusunda hâkim siyasi güçlerin temsillerini yansıtmaktaydı) belirli siyasi kullanım değeri atfedilmesi, böylece toplumsal mekânın üretiminde gecekonduların önemli bir mücadele mekânına dönüşmesidir. Gecekondular gerek sol gerekse sağ yönelimli örgütlenmeler tarafindan birer tehdit veya firsat olarak değerlendirilip gittikçe daha gerilimli, şiddetle dolu hale gelen 1970'li y1lların toplumsal mekânında önemli mücadele alanlarına dönüşmüşlerdi. 1973 Ekim ayında gerçekleşen genel seçimlerde gecekondu bölgelerinin temel tercihi soldu, böyle bir tercih 1971'den beri süren askeri rejime bir tepkiye ve aynı zamanda bu rejimin sona ermesine işaret etmektedir. Gecekondu bölgelerinin böyle bir tercihinin temel iki sebebi ise

491 Batuman, "Spaces of Counter-Hegemony: Turkish Architects and Planners as Political Agents in the 1970s"; Avci, "The Making of a Gecekondulu Identity: Journalistic Representations of the Squatters in Turkey in the 1970s"; Avci, "The Gecekondulu in Turkey: Representation, Identity, and the Urban Poor in the 1960s and 1970s".

492 Batuman, "Spaces of Counter-Hegemony: Turkish Architects and Planners as Political Agents in the 1970s", s. 161.

493 1960-70'li yıllarda gecekonduların basındaki temsillerinin detaylı ve kapsamlı bir incelemesi için Özgür Avcı'nın çalışmalarına başvurabilir, bkz. Avci, "The Making of a Gecekondulu Identity: Journalistic Representations of the Squatters in Turkey in the 1970s"; Avci, "The Gecekondulu in Turkey: Representation, Identity, and the Urban Poor in the 1960s and 1970s." 
yoğunlaşan gecekondu yıkımları ve gecekondu güzelleştirme derneklerinin kapatılmas1 ${ }^{494}$ olarak değerlendirilmektedir. Bu seçimlerden sonra gittikçe daha radikalleşen toplumsal mekânda siyasi yönelimleri sebebiyle gecekondu bölgeleri gün geçtikçe daha yoğun bir şiddete maruz kalan birer mekân haline gelmişlerdir. Yerel yönetimleri elinde tutan ve daha fazla yerel özerklik talep eden ve aynı zamanda "toplumcu belediyecilik" anlayışını savunan merkez-sol CHP ile koalisyon hükümeti oluşturan sağ yönelimli AP, MSP, MHP ve CGP'nin siyasi mücadelesinin temel odak mekânlarından biri gecekondu bölgeleridir. $\mathrm{Bu}$ dönemde gerek sol, gerekse sağc1 örgütlerin hâkimiyet arayışı ve bu süreçte yaygın bir şekilde şiddete başvurulması, siyasi kimlikleri nedeniyle belirli gecekondu mahallelerinin, paramiliter örgütlenmelerin devlet destekli şiddetine maruz kalması ve özellikle sol örgütlerin hâkim olduğu alanlarda "kurtarılmış bölgeler/mahalleler"'in oluşturulması Türkiye'de Ankara başta olmak üzere diğer kentlerin mekânının en temel özelliğiydi. ${ }^{495}$

Tahire Erman'1n Ankara'da birbirinden farklı iki gecekondu mahallesinde yaptığ1 etnografik saha araştırmasi ${ }^{496}$ Ankara örneğinde bu genel değerlendirmeyi destekleyecek niteliktedir. Saha araştırmasının ilk örnek alanı Ankara'nın kuzeyinde, kenti havaalanına bağlayan kesimde (şimdiki Kuzey Ankara Girişi Kentsel Dönüşüm Projesinin hayata geçirildiği mevki) bulunan ve çoğunlukla Sünni mezhebe ait olanlardan oluşan bir gecekondu sahasıdır. 1970'lerde sol-sağ gerilimlerinin tırmandığ süreçte bu gecekondu bölgesi 'çifte bağll1ık' pratiğiyle duruma göre gerek sol gerekse sağ örgütlere sadakat göstermekteydi. Oysa 1970'lerin sonunda gecekondu genel olarak artık aşırı milliyetçilerin kontrolü altındaydı. ${ }^{497}$ Böylece siyasi kimlik açısından sağc1 yönelim göstermesinden, mezhebi kimlik açısından ise gecekondu sakinlerin çoğunun Sünni mezhebe ait olmasından dolayı 1970'lerin sonunda milliyetçiliğin ve anti-komünizmin tırmandığ 1 bir dönemde bu gecekondu alanı yaygın siyasi şiddetten doğal olarak muaf kaldı.

Erman'ın araştırmasının ikinci örneği Ankara'nın doğusunda Tuzluçayır'da 1970'lerin toplumunda genel sol yönelimli hareketliliği bağlamında oluşan ve yaklaşı \%70'i Alevi olan gecekondu mahallesidir. 498

494 Batuman, "Spaces of Counter-Hegemony: Turkish Architects and Planners as Political Agents in the 1970s", s. 174.

495 Ozan, “İki Darbe Arasında Kriz Sarmalı", ss. 717-735; Zürcher, Turkey: A Modern History, ss. 263-264.

496 Bkz. Erman, "Understanding The Experiences Of The Politics Of Urbanization In Two Gecekondu (Squatter) Neighborhoods Under Two Urban Regimes: Ethnography In The Urban Periphery Of Ankara, Turkey".

497 Ibid., s. 92.

498 Ibid., s. 95-96. 
Mahallenin oluşma sürecinde başlangıçta gecekondu mafyası gibi davranan komşu köyün muhtarının kâr amacıyla köye ait arazileri gecekonduculara satma pratiğine sonradan karşı çıkan yaklaşık 70 aile, yakın çevrelerin yardımıyla, sol görüşlü gençlerin emeğiyle temel altyapıları (kanalizasyon, yollar vs.) inşa etmiştir. Mahallenin planı sol görüşlü mimar öğrenciler tarafindan yapılmış, ayrıca sol gençlik barınağa ihtiyacı olanlara arsa dağıtmıştır. ${ }^{499}$ Böylece gecekondu yapımı sürecinden gecekondu mafyası hariç tutularak ve bu süreçte kâr amaçlı gecekondu gelişmesi reddedilerek, yerel halk ve sol görüşlü gençler tarafından kolektif olarak bir mahalle kurulmuştur. Spontane gelişen ilk örneğe kıyasla bu mahallenin oluşumu planlanmış, politik kaynaklı ve sıkı denetlenen bir süreçti. ${ }^{500}$ Özellikle dönemin mekânın üretimi süreçlerinde egemen kapitalist ilişkiler, milliyetçi popülizm ve merkeziyetçi yaklaşım bağlamında böyle bir solcu destekli, dayanışmacı deneyimi sorun teşkil etmekteydi. 1980 askeri darbesinin ilk hedeflerinden biri ise bu mahalle olacaktı. İlk örneği oluşturan gecekondu mahallesi darbeyi sorunsuzca atlatarak, hatta Sünni kimliği sayesinde dönemin Türk-İslam sentezi bağlamında avantajlı konumda kendini bulurken, Tuzluçayır gerek sıkıyönetim döneminde gerekse darbe sonrası dönemde hem siyasi hem de mezhepsel açıdan hedef konumundaydı. Erman'ın belirttiği gibi darbeden sonra mahallede polis karakolu kuruldu ve ironik bir biçimde "Yavuz Sultan Selim Polis Karakolu" olarak isimlendirildi, halkın "Demokrasi İlkokulu" diye tanımladığı okulun ismi ise "Yavuz Sultan Selim İlkokulu" olarak değiştirildi, dahası çoğunluğu Alevilerden olan mahallede 1981'de cami kuruldu. ${ }^{501}$

Şükrü Aslan'ın, İstanbul'da 1 Mayıs Mahallesi'nde gecekondu gelişim sürecini ve mahallenin yıkımını ele alan çalışmasından ${ }^{502}$ da görüldüğü üzere mahallenin yıkımının temel sebebi gecekondu değil, gecekonduda farklı bir toplumsal düzenin, sistem karşıtı olan bir örgütlenmenin ve toplumsal ilişkilerin var olması ve onun farklı siyasi kimliğidir. Ankara'da yukarıda söz edilen iki örnek birbiriyle karşılaştırıldığında ve özellikle Tuzluçayır'daki deneyiminin 1 Mayıs Mahallesi örneğiyle benzerlik gösterdiği de göz önünde bulundurarak, Ankara'da da siyasi şiddetin hedefinin de gecekondu olmadığı söylenebilir. Tuzluçayır, sahip olduğu siyasi kimliği ve barındırdığı toplumsal ilişkileri açısından egemen tasarlanan mekândan ayrı bir mekân - karşı mekân - teşkil ve temsil etmekteydi. Lefebvre'in belirttiği üzere;

"Mübadele değeri üzerinde kurulu toplum karşısında kullanım değerinin üstünlüğü vardır. Nicelik karşısında niteliğin. Karşı-projeleri ve karşı-

499 Ibid., s. 97.

500 Ibid., s. 98.

501 Ibid., s. 99.

502 Aslan, 1 Mayls Mahallesi: 1980 Öncesi Toplumsal Mücadeleler ve Kent. 
mekânı neyin oluşturduğunu pratikten biliyoruz. Bir nüfus topluluğu, bir otobana ya da kentsel gelişme programına karşı çıktığında, oyun ve buluşma için boş meydanlar, 'donanımlar' talep ettiğinde, mekânsal gerçeğin içine bir karşı-mekânın nasıl girdiği algılanır: Göz’e ve Bakış’a karşı, niteliğe ve homojene karş1, iktidara ve kibre karş1, 'özel'in ve işletme verimliliğinin sınırsız genişlemesine karşı, özelleştirilmiş mekânlara karş1, sıkı sıkıya belirli yerlere bağlanmış işlevlere karşı." 503

1970'lerin homojenliğe yönelen, mübadele değerlerinin hâkim olan soyut mekân karşısında Tuzluçayır örneği bir karşı-mekân olma potansiyeline sahipti, "yapıtın ve yeniden sahiplenmenin potansiyelleri... direnen ve sonuç olarak (kâh bir karş1-kültür mekânı, kâh karşı-mekân ya da mevcut 'gerçek' mekânaöncellikle ütopyac1-alternatif) bir mekân projesi dayatan bedenin gerekliliklerine göre potansiyeller içer[mekteydi]." 504 O yüzden zor ve şiddet yoluyla sert ve yıkıcı müdahaleye maruz kalarak sistemin içine geri sokuldu.

Mustafa Kemal'in anıt mezarının yapılması için 1942'de açılan uluslararası mimari yarışması sonucunda elde edilen Emin Onat ile Orhan Arda'ya ait projesiyle 1943 yılında inşaatı başlayan Anıtkabir, 1953 yılında tamamland1. 505 1930-40'ların mekânının üretiminde hâkim olan mimari üslubun son örneğini teşkil eden bu anıt aynı zamanda "erken cumhuriyet döneminin simgesel bir kapanışı"506 olarak da değerlendirilmektedir. Fakat Anıtkabir'in simgelediği bu kapanışla beraber 1950'lilerden itibaren Ankara'da modern mimarinin devri kapanmad1, aksine bu dönemden itibaren modern mimarlik ikinci kez gündeme gelerek sadece dönemin değil sonraki dönemlerde de ilginç bir mimari deneyime neden oldu. Aslında 1950'lilerden itibaren Türkiye'nin gerçek anlamda modernleşmenin koşullarına tanık olduğu ve burada modern bir mekân üretiminin söz konusu olduğu söylenebilir, zira 1930-40'l1 yılların siyasi proje ve ideolojik temelli modernleşmesinin yerine 1950'li y1llardan itibaren artık modern bir mekân üretebilecek üretim güçleri ve ilişkilerin hızla gelişerek yerleşmesi söz konusuydu. 1950-60’lı dönemi detaylı olarak konu eden Akçura'nın ortaya koyduğu üzere, bu dönemde Ankara'da ülkedeki anonim şirketlerin toplam sermayesinin \%28'i yoğunlaşırken, şirket başına düşen ortalama sermaye açısından Ankara' da, başta İstanbul olmak üzere diğer kentlere kıyasla daha yüksek bir yoğunlaşma görülmektedir. Benzer yüksek yoğunlaşma

503 Lefebvre, Mekânın Üretimi, s. 381-382.

504 Ibid., s. 352-353.

505 Wilson, Anıtkabir'in Ötesi: Atatürk'ün Mezar Mimarisi: Ulusal Belleğin İnşası ve Sürdürülmesi.

506 Bozdoğan, Modernizm ve Ulusun İnşası: Erken Cumhuriyet Türkiyesi’nde Mimari Kültür, s. 26. 
bankacılık sektöründe de görülmektedir. ${ }^{507}$ Ayrıca ilk gelişmeye yakından ilişkili olarak kentte modern olarak denebilecek toplumsal kültür, tüketim alışkanlıkları ve bunların kamusal alanda dışavurumu gözle görülür hale gelmiştir. Kızılay ve civarı bölgesinin her bakımdan kentin merkezine dönüşmesiyle burada nitel açıdan daha 'Avrupai' yaşantılar ve bu yaşantılara yönelik olan mekânlar giyim, zücaciye vb. dükkanlar, pastaneler, lokanta ile büfeler, barlar, yabanc1 kültür merkezleri, tiyatro ve sinemalar, caz ve klasik müzik plağı ve enstrümanları satan dükkanlar, yabancı kitap ve dergiler satılan kitapevleri, kadın terzihaneleri ve kuaförleri, fotoğraf atölyeleri vs. - yaygınlık kazanmıştır. ${ }^{508} \mathrm{Bu}$ mekânların, orta ve üst orta sınıflara yönelik olmalarına rağmen, kamusal mekânın, 1950 sonrası dönemde halkın geniş kesimleri için 'açık' hale gelmesiyle beraber bu gelişmeler, söz konusu tüketim kalıpları, alışkanlıkları ile yaşantıların deneyimlenmesi ve geniş halk kesimlerinde belirli mekânsal pratiklerin aşılması açısından önem arz etmekte ve modernleşmenin gerçek koşullarına işaret etmekteydi.

Daha önce ele alındığı üzere 1950'lilerden itibaren Ankara'nın merkezinde apartmanlaşmanın başladığı, bu süreçte kentin imgesinin gittikçe değiştiği ve yerel ölçekli sermayenin ve yap-satçıllı̆̆n belirleyici olduğu görülmektedir. 1960'l y ylların ikinci yarısından itibaren ise kentin genel imgesi radikal değişimlere tanık oldu. $\mathrm{Bu}$ sürecin temelinde rantın maksimize edilmesi mantığı yattığına göre özellikle yap-satçılık sonucunda estetik açıdan sorunlu ve sancılı bir mimari üretim hâkimdi. Fakat yine de aynı dönemde Ankara'da gerek yerel sermaye gerekse gelişmekte olan mühendislik ve inşaat sanayisi sayesinde dönemin hâkim mimari üslubuna ("uluslararası üslup”) uygun ilginç deneyimler söz konusuydu. Örneğin, Kızılay'da 1959-65 yılları arasında yapılan Emek İşhanı bunun en iyi örneğidir. Ankara'nın ilk "gökdeleni” olan bina, perde-duvar sistemiyle üretilen ilk betonarme yapıdır ve "hem mimari niteliği hem de bu niteliği üreten yapısal sistem ve malzemesiyle Türkiye mimarlığını devingen bir arayışa yönlendir[miştir]. ${ }^{509}$ Böyle bir modern binanın yapımı gerek sermaye birikimi gerekse teknolojik gelişmişlik ve genel olarak üretim güçlerinin

507 Güven Arif Sargın'ın ise, 1950'lerde “işveren” veya “patron”un değişmesine yaptı̆̆ vurgu kayda değerdir; erken cumhuriyet döneminde gerek finansal gerekse idari açıdan "patron"/"işveren" ve bu anlamda bir tür tekel olan devletin, 1950'lilerden itibaren uluslararası bağlama eklenmesiyle, sermayenin el değiştirmesiyle ve yapısal değişiklikler sonucunda tekelcilik kırılmaya başlanmış ve sermaye ve beğenisiyle birlikte yeni burjuvazi mimari üretiminde etkin rol kazanmaya başlamıştır. Bkz. Sargın, "Kurmaca Başkentlerin İmgesel İnşası: Ankara'nın Mekânsal Siyasası Üzerine Kısa Notlar”.

508 Akçura, Ankara: Türkiye Cumhuriyeti'nin Başkenti Hakkında Monografik Bir Araştırma, s. $52,123-124 \mathrm{vd}$.

509 Sargın, "Kurmaca Başkentlerin İmgesel İnşası: Ankara’nın Mekânsal Siyasası Üzerine Kısa Notlar", s. 39. 
ilerleyişi açısından modern bir mekân üretebilmenin temsiliydi. Batuman'ın da belirttiği gibi "ekonomi-politik bir ürün olarak belli bir sermaye birikim seviyesini gerektiren (ve temsil eden) yapı, aynı zamanda yeni mekânsal pratikler de örgütler. İnşaat faaliyetinin kendisi ve teknoloji kullanımı, modernliğin iki sembolü olarak gökdelende bir araya gelir." 510 1960-70'li y1llarda benzer başka deneyimlerden özellikle Stad Oteli, Türkiye İş Bankası Kulesi, MSB yurt binaları, Büyük Ankara Oteli gibi yapılar da belirtilmelidir. Başkente imgesel çeşitlilik kazandıran bu binaların her biri mekânın üretiminde etkin olan aktörlerin çeşitliliğinin mekân temsilini teşkil ederek aynı zamanda Türkiye'de modern bir mekânın üretimi açısından üretim güçlerinin gelişmişlik düzeyini de temsil etmekteydi.

Fakat Ankara, 1950-70'li yıllarda, mekânın üretimi açısından modernleşmenin gerçek koşullarına sadece üretim güçlerinin ve ilişkilerin ilerlemesi açısından değil aynı zamanda toplumsal hareketlenme ve kamusal mekânda bunun görünür olması açısından tanık olmaktaydı. Demokrat Parti'nin iktidara gelmesi ve genel olarak demokratikleşme süreciyle siyasetin kamusal nitelik kazanması eskiden kitlesel siyasete kapalı olan kamusal mekânın politikleşmesine yol açmıştı. Daha önce ele alındığı üzere 1930-40'larda siyasi proje modernleş(tir)mesi bağlamında Ankara'nın özellikle kamusal mekânı, bir "sahne" işlevi görmekteydi; amaç ise gerek iç gerekse dış dünyaya Türkiye'nin modernleşme başarısının gösterilmesiydi. Ayrıca, "muasır medeniyet seviyesine ulaşma"da muasır bir kamusal mekânın üretimi bir araç olarak görülmekteydi. Bunun doğrultusunda kamusal mekâna münhasıran siyasi bir kullanım değeri atfeden seçkin Kemalist devlet erkânı, aynı zamanda toplumsal yaşamın her alanına nüfuz etme çabasındaydı ve kamusal mekânın kitlesel siyasete açık olması şöyle dursun toplumsal mekânsal pratikleri bile sıkı biçimde denetlenmekteydi. 1950'de "yeter söz milletindir" popülist sloganıyla iktidara gelen DP döneminden itibarense gerek siyasetin kitlesel nitelik kazanması gerekse kamusal mekânın demokratikleşmesi modern kamusal mekânın üretimi açısından bir dönüm noktası oldu. Aslında DP iktidarının, kamusal mekâna siyasi bir kullanım değeri atfetmediğini söylemek yanlış bir saptama olur, zira popülist DP'nin dayanağı kitlesel siyaset ve kitleye açık olan kamusallıktı. DP ve müteakip dönemin önemli fark1, ideolojik çerçevenin modern bir toplumsal mekânın üretiminde ve kamusallığında münhasır bir konumda olmamasıdır ve bunun sonucunda "kamusal alanın kendisi, seçkinlerin sergilediği bir gösteriden alt sınıfları da kapsayan ve geniş bir katılım hakkıyla tariflenmiş bir arenaya dönüş[mesidir]." 511 Oysa DP döneminde Ankara'da iki önemli proje dönemin

510 Batuman, "Mekân, Kimlik ve Sosyal Çatışma: Cumhuriyet'in Kamusal Mekânı Olarak Kizilay Meydanı", s. 58.

511 Batuman, "Mekân, Kimlik ve Sosyal Çatışma: Cumhuriyet'in Kamusal Mekânı Olarak Kızılay Meydanı", s. 56. 
mekân temsilini ve mekânın üretiminde saklı olan ideolojiyi temsil edecek yöndedir. Bunlardan ilki Ankara'nın merkezinde yapılması planlanan Kocatepe Camisi için 1957'de yarışma düzenlenmesi, ikinci ise yukarıda söz edilen Emek İşhanı'nın inşaatıdır. Vedat Dalokay'ın, yapılması planlanan caminin yarışmasını kazanan projesi özellikle mimari üslup açısından dikkate değerdir (Şekil 10), zira proje Türkiye'de o zamana kadar alışagelmiş cami tasarımlarından farklılaşmaktaydı ve "aşırı modern" 512 bir tasarım sunmaktaydı, bu açıdan da projeyi 1950-80'lerde Türkiye'de mimari üretimin modernist arayışları bağlamında değerlendirmek gerekir. ${ }^{513}$ Projenin temelleri atılmasına rağmen bir süre sonra ondan vazgeçildi, zira proje hem yoğun tartışmalara neden olmuştu hem de gerçekleştirilmesi için teknik açıdan sorunlar ortaya çıkmıştı. Bunun yerine 1967 yılında farklı bir tasarım, Sinan'ın Şehzade Cami’nin kopyasının inşaatına karar verildi ve yapımı 1987 'de tamamland1. 514

Gerek Kocatepe Camii gerekse Emek İşhanı kentin imgesini önemli ölçüde değiştirerek kentsel mekânın birer merkezi haline geldiler ve her biri dönemin toplumsal mekânının üretiminin belirlenmesinde öncül olan iki ana sürecin mekân temsilini oluşturmaktayd1. Gökdelen 1950'lilerden itibaren liberalleşen ve dünya sistemine gittikçe daha fazla eklenen ekonomik sistemin şartlandırdığ 1 sermaye birikimini temsil ederken, camii ise aynı dönemden itibaren dini unsurun kamusal alanda her geçen gün daha çok önem kazanmasını temsil etmekteydi.

512 Akcan, "Global Conflict and Global Glitter: Architecture of West Asia (1960-2010)".

513 Proje ile ilgili daha ayrıntılı inceleme için bkz. Imdat As, "The Digital Mosque"; Yucel, "The Routes: Cultural Identity and Architecture of Turkey, 1980-2000”.

514 Bkz. Akcan, "Global Conflict and Global Glitter..."; As, "The Digital Mosque"; Batuman, "Architectural Mimicry and the Politics of Mosque Building: Negotiating Islam and Nation in Turkey". 
Şekil 10. Vedat Dalokay'ın Kocatepe Camii Tasarımı

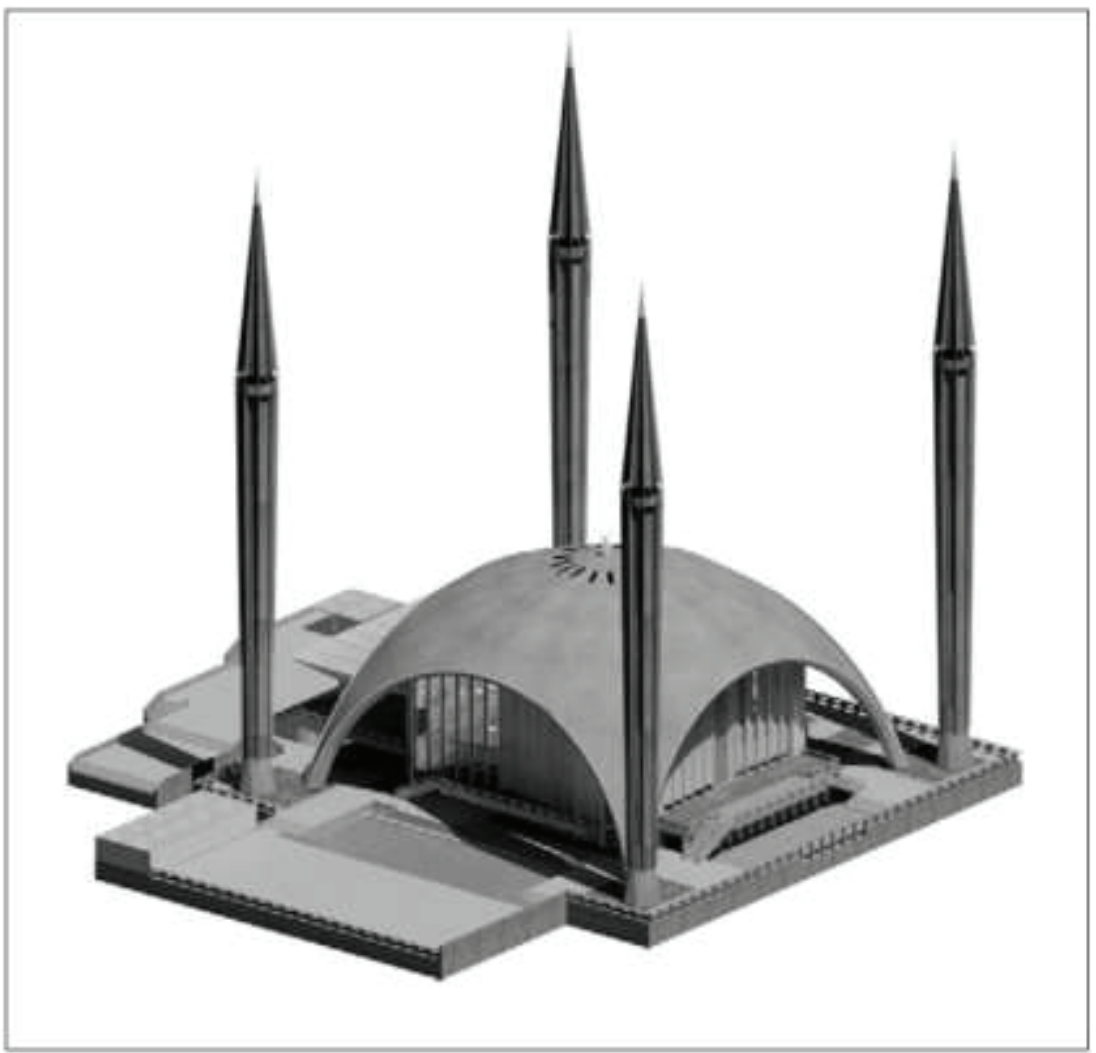

Kaynak: As, "The Digital Mosque".

Kocatepe Camii'nin kentin en hâkim tepelerinden birinde yapılması temsil mekânı açısından başka bir dikkat çekici hususu içerir. Cumhuriyetin ilk yıllarında Ankara Kalesi ve Çankaya Köşkü kentin ana ekseninin iki ucunu oluşturmaktaydı ve ele alındığı üzere bunların aynı zamanda kentin mekân temsili, temsil mekânı açısından ilginç içerimleri vardı. 1953'te inşaatı tamamlanan Anıtkabir ise kente hâkim başka bir tepe (Rasattepe) üzerine yükselerek kentsel mekânın bir diğer, hatta en önemli referans noktası haline gelmişti. "Erken cumhuriyet dönemin simgesel bir kapanış1"515 olan Anıtkabir, bu kapanışı sadece mimari üslubu açısından simgelemekle kalmayıp, kentin erken Cumhuriyet dönemi mekânsal imgesi açısından da bir kapanışı temsil eder. Algılanan, yaşanan ile tasarlanan unsurları açısından gerek Kale ile Köşk

515 Bozdoğan, Modernizm ve Ulusun İnşası: Erken Cumhuriyet Türkiyesi’nde Mimari Kültür, s. 26. 
gerekse Anıtkabir'den farklı olan, bu üç odağın oluşturduğu üçgenin neredeyse merkezinde konuşlanan Kocatepe Camii, bahsi geçen üç mekânsal temel referansa ve özellikle Anıtkabir'e karşı ağırlık olma niteliğindeydi ${ }^{516}$ ve kentin imgesinin sonraki daha radikal dönüşümünün habercisiydi. 517

Kentin merkezinde bahsi geçen iki yapı aynı zamanda toplumsal mekânsal pratiklerin değişimini de simgelemekteydi; alt katında büyük bir alışveriş merkezi bulunduran Emek İşhanı yükselen burjuvazinin ve tüketim kültürüne özgü toplumsal mekânsal pratiklerine işaret ederken, Kocatepe Camii, toplumsal mekânda ve mekânsal pratiklerinde dini unsurun ve pratiklerin yaygınlaşmasına ve kamusal mekânın farklı anlam, işlev, temsil ve pratiklere sahne olmasına işaret etmekteydi. Bunlar arasında özellikle kamusal mekânın kitlesel siyasetin odak noktasına dönüşerek politikleşmesi dönemin toplumsal mekânına damgasını vuracaktır. Gerek 1960 Mayıs darbesi sırasında, gerekse darbe sonrası siyasi eylemlerin ana odağı Kızılay bölgesi olacak, böylece kamusal mekân aynı zamanda siyasi açıdan çoğulcu kimliklerin kesiştiği yer haline gelerek artık sadece iktidarın, üzerinde kurduğu hegemonyasına maruz kalan bir alan değil aynı zamanda onun üzerine gerek mekân temsili ve temsil mekânı gerekse mekânsal pratikler açısından karşı-hegemonya stratejilerinin geliştiği alan olacaktır. Bu açıdan 1960'lardan itibaren “hükümetle protestocular arasındaki mücadele doğrudan doğruya mekân için ve onun üzerinden sürmektedir... Mekân yalnız pratiklerin değil, kimliklerin, sloganların ve temsil biçimlerinin de üretildiği bir araca dönüşmektedir." 518

Kamusal mekân, böylesi politikleşmenin doruk noktasına 1970'lerin sonunda ulaşacaktır; toplumda sağ ile sol arasındaki radikalleşen siyaset açık şiddete yönelerek, kamusal mekânı sadece bu şiddetin dışa vurulduğu bir alan değil aynı zamanda kendisi bu şiddetin hedefi haline getirmiş, "zira egemen güç blokunun kamusal mekânı kontrol altında tutma stratejisi açık şiddet yoluyla

516 Kurthan Fişek, Burası Ankara kitabında kişisel tarih açısından 1980 sonrası Ankara'y1 betimlerken eşiyle "önce Kocatepe Camii'nin 1şıkları mı yanacak, yoksa Anıtkabir'in mi?" diye yazı-tura atmasını anlatısından, kent imgesinin deneyimlenmesinde ve yaşanan mekânda bu iki yapının belirginliğini açığa çıkartmaktadır. Bkz. Fişek, Burası Ankara, s. 75.

517 Laik milliyetçilik ile İslam'ın yükselişini temsil eden bu iki yapının karşılaştırmalı bir analiz için bkz. Meeker, “Once There Was, Once There Wasn't: National Monuments and Interpersonal Exchange". Bu iki yapının çelişkili mekânsal ilişkisi için ayrıca bkz. Çınar, "The Imagined Community as Urban Reality: The Making of Ankara".

518 Batuman, "Mekân, Kimlik ve Sosyal Çatışma: Cumhuriyet'in Kamusal Mekânı Olarak Kızılay Meydanı", s. 61-62. Dönemin toplumsal ve siyasi gelişmelerinde kamusal mekânın dönüşüm sürecinin, Kızılay Meydanı örnek alanının ilginç bir değerlendirmesi için bkz. Batuman, "Mekân, Kimlik ve Sosyal Çatışma: Cumhuriyet'in Kamusal Mekânı Olarak Kizılay Meydanı". 
sosyal mekânın yıkımına yönelmiştir." 519 Böylelikle Gecekondu mahallerinde olduğu gibi, kamusal mekân da hegemonik ile karşı-hegemonik siyaset ve siyasi şiddetin süregeldiği bir mekâna dönüşmüştü. ${ }^{520}$ Her iki durumda şiddetin hedefi belirli bir mekânda belirli bir örgütlenme olmakla beraber, aynı zamanda hedefte farklı kullanım, temsil ve pratiklerine yol açabilme potansiyeli olan toplumsal mekând1. Radikal Türk milliyetçiliğinin kitlesel ve popüler bir karakter, İslamc1 siyasetin ise güç kazandığ 1 , aynı zamanda zengin bir sol ve toplumsal hareketlilik yaşandığ1 ve sol içinde sosyalizm için silahlı mücadele fikrinin ortaya çıktığ 1970 'lerin ${ }^{521}$ son y1llarında sol ile sağ toplumsal kamplaşma ve onun mekânsallaşması ülkeyi iş savaşın eşiğine getirmiş durumdaydı. Toplumda sol hareketlenme, CHP'nin ortadan sola kayması ile yerel düzeyde "sosyalist belediyecilik" hareketi ve belirli mekânlarda radikal solun, karşı-mekân niteliğinde olan 'kurtarılmış bölgeler' in varlığ 1 "komünist tehdidi" daha yakın ve görünür kılmaktaydı. Ortanın sola kayması ve bu bağlamda CHP'ye karşı Adalet Partisi'nin geliştirdiği "Orta'nın solu, Moskova yolu” sloganı genel söylem düzeyinde bu tehdidin temsiliyken, Ankara'da "Küçük Moskova" diye tanımlanan ve politik kimliği ve karşı-mekân olma itibariyle şiddete maruz kalan Tuzluçayır mahallesi ise bu tehdidin somut bir temsil mekanını oluşturmaktaydı. Sol ile sağ arasındaki eşit olmayan ${ }^{522}$ ve kâh mekân üzerine kâh mekân için sürdürülen ve gün geçtikçe daha da şiddete bürünen bu mücadele ise 1980 Eylül darbesiyle sonuçlanacaktır.

1980 Eylül darbesiyle Türkiye, yeni bir ekonomik ve ideolojik düzenin kapılarını araladı; mekânın üretimi açısından yerelden ulusal ölçeğe uzanan düzlemler ve özellikle kentsel mekânın üretimi açısından farklı sonuçlar içeren

\section{Ibid., s. 67.}

520 Örneğin, 1975-79 yıllarında İstanbul'da meydana gelen şiddet olaylarının \%40'1 sokak, durak, istasyon, otogar gibi kamusal mekânlarda cereyan ederek, işyerleri, bankalar, oteller gibi yerlerdeki toplam şiddet olayları toplamın \%13'ünü teşkil etmektedir. Ayrıca bu dönemde Ankara başta olmak üzere tüm büyük kentlerde bomba ile silahlı saldırı ve silahlı çatışmaların, meydana gelen şiddet olaylarının \%68-82'sini oluşturduğu hususu aynı zamanda şiddetin yoğunluğunu ve kentsel mekânın bir savaş alanına dönüştügünü açıkça göstermektedir. Bkz. Batuman, "Mekân, Kimlik ve Sosyal Çatışma: Cumhuriyet'in Kamusal Mekânı Olarak Kızılay Meydanı”, s. 66; Keleş ve Unsal, Kent ve Siyasal Şiddet, s. 55, 82.

521 Ozan, "İki Darbe Arasinda Kriz Sarmalı".

522 Zürcher, dönemin siyasi şiddetini konu ederken sol ile sağ arasındaki mücadelenin doğru olarak eşit olmadığını niteler, zira "1974-1977 yıllarındaki "Milliyetçi Cephe" hükümetleri zamanında, polis ve güvenlik güçleri, Türkeş'in MHP'sine tahsis edilmiş hale gelmişti ve 1978-1979'daki Ecevit hükümeti zamanında dahi bu kurumlara, Bozkurtları koruyan ve kollayan faşistler yoğun biçimde sızmış bulunuyorlardı. Solun parçalara ayrılmış bulunan grupları ise bu tür bir himaye görmemekteydi. Ecevit, ortanın solundaki tek partinin lideri olarak aşırı solun siyaset ve yöntemlerine karşı çıkmakla kalmayıp, CHP'yi siyasal şiddeti beslediği yolundaki suçlamalara açık bırakmaktan da çekinmekteydi”. Bkz. Zürcher, Turkey: A Modern History, s. 263. 
bu yeni düzen daha üst ölçekte kapitalizmin, siyasi mekânın küresel düzeyde yeniden üretiminin parçası olmaktan başka bir şey değildi.

Erken Cumhuriyet Dönemi'nde Ankara'nın toplumsal mekânında Mustafa Kemal'in imgesi daha önce ele alındığı üzere, dönemin gerek mekân temsili ve temsil mekânının gerekse mekânsal pratiklerin ayrıcalıklı bir 'unsuru'nu teşkil etmekteydi, fakat bu mekânsal üçlüde Mustafa Kemal'in imgesinin daha çok yaşanan mekân olarak öne çıktığı söylenebilir. Mustafa Kemal ve onun imgesinin yaşanan mekân olarak öne çıkması onun hayatta olduğu dönemde özellikle her bir Ankaralının kişisel tarihin (zamanın) ve kişisel mekânın ayrılmaz bir unsuru olmasından kaynaklanırken ölümünden hemen sonra naaşının Etnografya Müzesine geçici olarak konulduğu ve 1953 yılına dek orada bulunduğu sırada ise Mustafa Kemal'in toplumsal mekânda yaşanan mekân olarak baskın olması, toplumun geniş kesimleri tarafından henüz onun ölümüyle yüzleşmemesi ve yokluğunu kabullenmemesinden kaynaklanmaktaydı. Mustafa Kemal'in mezar mimarisini konu eden Wilson'un belirttiği gibi Mustafa Kemal'in Etnografya Müzesindeki geçici kabrinin minimalizmi, sadelik ve mütevazılığ kabrinin geçici olmasından veya zaman sıkıntısından ziyade kabrin, ulusunun yas sürecinde, Mustafa Kemal'in Anıtkabir mozolesinde doruğa ulaşacak kabullenme safhasının başlangıcı olmasından kaynaklanmaktadır ve Mustafa Kemal'in ölümüyle naaşının Anıtkabir'e taşınması arasında geçen 15 yılda toplum, kaybıyla yüzleşme süreci yaşamaktaydı. ${ }^{523}$

1953 yılında Anıtkabir'in inşaatının tamamlanarak Mustafa Kemal'in naaşının oraya taşınması onun ölümüyle yüzleşme ve kabullenmenin doruk noktasiyken, Anıtkabir aynı zamanda toplumsal mekânın yaşanan, algılanan ve tasarlanan üçlüsünde Mustafa Kemal'in imgesinin yer değişmesini de simgelemekteydi. ${ }^{524}$ Bundan sonra Mustafa Kemal ve onun imgesi toplumsal mekânda farklı bir konum edinmeye başladı. 1950'lilerden itibaren Mustafa Kemal'in imgesi farklı siyasi kesimlerin mücadelesinde önemli bir unsuru haline gelerek her kesim tarafindan mülk edinmek istenilen bir simgeye dönüşmüştür. CHP ve onun temsil ettiği kitle zaten Mustafa Kemal ile özdeşleştirildiği için

523 Wilson, Anttkabir'in Ötesi: Atatürk'ün Mezar Mimarisi: Ulusal Belleğin İnşası ve Sürdürülmesi, s. 81-84.

524 Anıtkabir'in yer seçimi, yapımı için açılan uluslararası mimari yarışmaya sunulan projeler ve kazanan proje taşıdıkları anlam ve temsiller açısından farklı araştırmaların konusu olmuştur. Konu ile ilgili daha detaylı bilgi için bkz. Boran, "Mekan ve Siyaset İlişkisi Bağlamında Anıtkabir (1938-1973)"; Bozdoğan, Modernizm ve Ulusun İnşast: Erken Cumhuriyet Türkiyesi'nde Mimari Kültür; Glyptis, "Living up to the Father: The National Identity Prescriptions of Remembering Atatürk; His Homes, His Grave, His Temple"; Gülpınar, "Anitkabir'in Unutulan Kabirleri"; Wilson, "The Persistence of the Turkish Nation in the Mausoleum of Mustafa Kemal Atatürk"; Wilson, Anttkabir'in Ötesi: Atatürk'ün Mezar Mimarisi: Ulusal Belleğin İnşası ve Sürdürülmesi. 
fazla çaba göstermezken, DP "kırsal kitlelerin Kemalist devrime duydukları tepkiden ayırmak, bu tepkiyi İnönü'ye ve CHP etrafinda toplanan bürokratik burjuvaziye kanalize etmek ve Atatürk imgesini kendi sinesinde yeniden anlamlandırmak iste[mekteydi]." ${ }^{525} \mathrm{Bu}$ açıdan DP döneminde kayda değer en önemli girişimler olarak iktidara geldikten hemen sonra Atatürk'ü Koruma Kanunu diye bilinen Atatürk Aleyhine İşlenen Suçlar Hakkında Kanunun çıkarılması (1951), resmi kuruluşlarda yalnız Mustafa Kemal'in resimlerinin asılmasına karar verilmesi (1950), İnönü portreli banknotların basımının durdurularak Atatürk resmi bulunan 50 liralık banknotların tedavüle girmesinden (1951) söz edilebilir. ${ }^{526} \mathrm{Bu}$ girişimlerle böylece "Atatürk kültü pekiştirirken, Atatürk'ün partilerüstü simge değeri de güçlendirilmiştir." 527 Mustafa Kemal'in daha da kültleşmesi ve onun imgesinin sembolik açidan daha da güçlenmesi sadece DP döneminde değil, 1960-70'li yıllar boyunca da devam etmiş ve toplumsal mekânın üretiminde gerek yapılı çevrede gerekse mekân üzerine söylemde hep yeniden ortaya çıkmıştır. Fakat 1950'li yıllarda toplumsal mekânın üretiminde bu imge daha çok siyasi rekabet açısından yeniden üretilmekteyse, 1960-70'li y1llarda Mustafa Kemal'in imgesi özellikle dönemin iki darbesi sırasında daha çok meşruiyet zemini olarak yeniden üretildiği görülmektedir. ${ }^{528}$ Bunlar toplumsal mekânın yaşanan, tasarlanan ve algılanan üçlüsünde, Mustafa Kemal'in imgesinin yaşanandan ziyade algılanan ve özellikle tasarlananın parçası haline gelmesi olarak değerlendirilebilir. Örneğin, Tekiner'in araştırmasına göre, 1946-1980 arası dönemde Ankara'da yapılan Mustafa Kemal' in dokuz anıtının her birinin, büyük alanlar, parklar ve meydanlarda değil, kurumlar yanında yerleştirilmesi dikkat çekicidir. Bu anıtlar kurumlar yanında konumlanırken onları temsil etme işlevi üstlenmektedir. Ayrıca Mustafa Kemal'in daha çok sivil kıyafetle betimlenmesi dikkat çekicidir. ${ }^{529} \mathrm{Bu}$ husus, Mustafa Kemal'in imgesinin aslında devleti temsil ettiğini, böylelikle onun; yaşanan mekândan ziyade tasarlanan mekânın bir parçası haline geldiği söylenebilir. Kurumlar önüne yerleştirilmiş olan bu anıtların, gündelik hayatta mekânsal pratikler aracılığıyla meydan veya park gibi kamusal alanlarda değil, kurumlarla karşılaştırıldığında deneyimlenmesi ise algılanan mekân açısından da devleti temsil eden bir imgeye işaret eder. Tekiner' in de ifade ettiği gibi,

525 Atılgan, "Tarımsal Kapitalizmin Sancağı Altında", s. 480.

526 Tekiner, Atatürk Heykelleri: Kült, Estetik, Siyaset, s. 161; Atılgan, "Tarımsal Kapitalizmin Sancağı Altında", s. 480.

527 Tekiner, Atatürk Heykelleri: Kült, Estetik, Siyaset, s. 162.

528 Anıtkabir üzerine böyle bir değerlendirme için bkz. Boran, "Mekan ve Siyaset İlişkisi Bağlamında Anıtkabir (1938-1973)".

529 Tekiner, Atatürk Heykelleri: Kült, Estetik, Siyaset, s. 166. 


\begin{abstract}
"Tek parti dönemini takip eden süreçlerde, gerek mekânsal tercihlerde gerek toplumun aidiyet duygusunu güçlendiren imge-simge düzlemindeki gerilme, siyasal olanın temsiliyetinin meşru kılınmasında da bir farklılaşmaya neden olmuştur. Daha açık bir ifadeyle, anıtlar ulus bilincini ve rejimi görselleştiren yapıdan yavaş yavaş devlet imgesine ve devletin sınır belirleyiciliğine doğru bir değişim göstermiştir." 530
\end{abstract}

1980 sonrası dönemde de toplumsal mekânda başta anıt olmak üzere farklı biçimlerle böyle bir imgenin daha baskın bir biçimde yeniden üretildiği ve "Atatürk kültü üzerinden yoğun biçimde devlet kültünün besle[n]diğii"531 görülmektedir. Bu süreç içerisinde ise genel eğilim somut olanın yerine soyut bir imgenin ortaya çıkmasıdır; her alanda olduğu gibi Mustafa Kemal'in toplumsal mekândaki imgesi somut olarak deneyimlenen, algılanan ve yaşanan bir imge yerine soyut, tasarlanan, seri halde üretilerek mübadele değeri olan ve siyasi bir kullanım değeri atfedilerek araçsallaştırılan bir imgeye dönüştüğü görülmektedir.

\title{
2.3. Neoliberal İslamcı İleri Kapitalizmin Çelişkili Mekânı Yükselirken
}

\begin{abstract}
"Devletin mekânsal rolü, geçmişte ve şimdi, aşikâr bir hal alır. Devletin idari ve siyasi aygıtları, sermaye yatırımlarına (ekonomiye) soyut olarak müdahale etmekle artık yetinmiyorlar...Bugün, devlet ve (bürokratik ve siyasal) aygıtları mekâna sürekli müdahale ediyorlar ve ekonominin bütün mercilerinde ve tüm düzeylerinde müdahale etmek için araçsal mekândan yararlanıyorlar. Öyle ki, toplumsal (genel) pratik ve siyasal pratik, mekânsal pratik içinde buluşma eğilimi gösteriyor; böylece, mantıksal bir tutarlık değilse de bir bağdaşıklık kazanıyorlar." 532
\end{abstract}

1980'lerden itibaren Türkiye'de oluşmaya başlayan yeni toplumsal düzenin temelleri 1980 Eylül darbesiyle oluşmaya başladı. Toplumsal çatışmayı durdurmak ve kamu düzenini sağlamak gerekçesiyle yapılan askeri müdahale, toplumsal muhalefeti sıkı bir denetim altında almaya çalıştı ve 1982'de anayasa değişikliğiyle demokratik hakları önemli ölçüde ortadan kaldırmıştır. Askeri rejimin bir diğer önemli girişimi emek hareketinin ve sendikalizmin bastırılmasıydı, bir önceki dönemdeki egemen birikim sürecinde ve mekânın üretiminde en önemli etken olan "emeğin kentleşmesi” ve 1970'lerin görece güçlenen örgütlü emek hareketinin böylelikle bastırılması yeni birikim rejiminin temellerini hazırlayan önemli bir etkendir. İdeolojik alanda bir önceki darbe süreçlerinde gözlemlendiği gibi askeri cunta Kemalist doktrini ön plana çıkarttı ancak bu kez Kemalizmin toplumsal hayattaki tahakkümü "daha önceki askerî

530 Ibid., s. 266.

531 Ibid., s. 267.

532 Lefebvre, Mekânın Üretimi, s. 378. 
darbelerle kıyas edilemeyecek bir şiddet ve totaliterlik düzeyine ulaşmıştır. 12 Eylül'ün ilk günlerinden itibaren, bütün kamusal pratikleri, giderek gündelik hayatın her alanını "Atatürkçü" bir şekilde düzenlemeyi vazeden bir söylem devreye girdi." 533 Ancak, Kemalizm, devlet otoritesiyle özdeşleştirildiğinden ve sivil toplumsal mutabakatın zemini olma açısından yeterli olmamasından dolayı askeri rejim, kitleye hitap edebilecek ve popüler bir ideolojik rıza üretiminden yoksundu, o yüzden Bora ve Can'ın belirttiği üzere,
"12 Eylül rejimi, blokun orta ve uzun vadeli talepleri doğrultusundaki siyasal-yasal-kurumsal düzenlemelere giriştiği evrede varlığını daha fazla hissettireceği açık olan bu yoksunluğu; dinî resmî ideolojik donanıma dâhil ederek gidermeye yöneldi. 12 Eylülün 'ideoloji teorisini' yapma bakımından onunla genel olarak en büyük uyumu sağlayan Aydınlar Ocağı çevresinin gündeme getirdiği 'Türk-İslam Sentezi' doktrini, bu ihtiyaca cevap verdi. İslam'ın resmi otoriter-faşizan ideolojiye eklemlenmesine yönelik bu adaptasyon (veya adoptasyon!), 12 Eylülün siyasal ve iktisadi düzeydeki uluslararası anlamıyla da örtüştü." 534

Böyle bir ideolojik çerçeve bağlamında örgütlü emek hareketinin bastırılmas1, sol örgütlenmelerin gerek söylem düzeyinde gerekse somut uygulamalarla marjinalleştirilmesi ve gerek darbe öncesi gerekse askeri rejimin sürdüğü dönemde toplumda oluşan siyasi bıkkınlık ve apolitizasyon sonucunda oluşan boşluğu İslami unsurları(yla) doldurmaya başla(n)dı. Bunun sonucu ise, toplumsal hayatta İslami unsurun daha görünür hale gelmesidir.

Dönemde benimsenen dişa açık ihracata dayalı büyüme stratejisi ve kalkınma modeli (24 Ocak Kararları) - ki bastırılmış örgütlü emek hareketi dolayısıyla baskılanan işçi ücretleri ve hakları uluslararası alanda rekabet edilebilirliği açısından buna en elverişli şartları sunmaktaydı - ve buna yönelik gümrük vergilerinin ve serbest ticaretin önündeki engellerin kaldırılması yabancı sermayenin doğrudan yatırım yapmasına yeni imkânlar sağlamıştır. Fakat, liberalleşmeyle birlikte devletin hala ekonomide önemli bir rolü vard1; hükümet gerek ihracatı desteklemekte gerekse iç pazara yönelik farklı alanların, sermayenin değerlendirdiği elverişli sektörler olarak öne çıkması için kredi desteklerinde bulunmaktaydı, devlet desteğiyle ulaşım, iletişim ve enerji alanlarında büyük projeler hayata geçirilmekteydi. Aynı zamanda turizm, emlak ve inşaat sektörleri büyük sermaye için önemli bir yatırım alanı haline gelmeye başladı ki bu konuda da devlet önemli kurumsal düzenlemelere giderek ve kredi

533 Bora ve Can, Devlet, Ocak, Dergâh, s. 147.

534 Ibid., s. 148. 
sağlanması açısından öncelikli alanlar tanıyarak bunları, büyük sermayenin değerlendirdiği önemli sektöre dönüştürmüştür. ${ }^{535}$

Bir önceki ithal ikameci sanayileşme rejiminden ihracata dayalı büyüme rejimine geçiş sermayenin birinci ile ikinci zincirleri arasındaki ilişkisini değiştirerek mekânın üretimi açısından önemli sonuçlar doğurmuştur. Gerek kamu gerekse özel sermayenin üretimden (sermayenin birinci zinciri) çekilmesi ve yapılı çevreye, özellikle iletişim, ulaşım, konuta yatırım yapmayı tetikledi ve kentler hem kamu hem de özel sermayenin değerlendirmesi için çekici bir alan haline gelmiştir. Aynı zamanda yerinden yönetim konusunda âdemimerkezileşme ve yerel yönetimleri daha girişimci bir niteliğe kavuşturma eğilimi başlamıştır. Belediye hizmetleri ve kolektif tüketim alanından kamunun çekilmesi veya sübvansiyonların sona ermesi, tam maliyete göre fiyatlandırma politikaları ve özelleştirmeler kentleri gerek ulusal, gerekse uluslararası sermaye için çekici ve kârlı yatırım alanı haline getirmektedir. Böyle bir süreçten dolayı Tarık Şengül, dönemin kentleşmesini haklı olarak "sermayenin kentleşmesi" olarak tanımlamaktadır. ${ }^{536}$

Birikim rejiminde ve ideolojik yapılanmada böylelikle köklü değişimlerle Türkiye, her alanda olduğu gibi mekânın üretimi konusunda da yeni bir dönemeneoliberal esnek birikimin egemen olmaya başladığı bir dönemin kapılarını araladı. 1980'lerden günümüze uzanan bu dönem, kendisi yekpare bir bütünlük arz etmediği ve bu dönem içerisinde farklı eğilim ve süreçlerin egemen olduğu bir gerçektir, fakat aynı zamanda 1980'lerden itibaren gerek neoliberal İslamcılığın ve gerek esnek birikimin daha belirginleştiği de açıktır.

Benimsenen dışa açık ve ihracata dayalı kalkınma modeli ve neoliberal politikalar çerçevesinde diğer birtakım kentlerde olduğu gibi Ankara'da da önemli yapısal ve mekânsal dönüşümler yaşanmaktadır. Gerek kurumsal birtakım düzenlemelerle gerekse yeni kalkınma modeline uygun politikalarla, bu dönüşümler özellikle 1984'ten itibaren daha etkin biçimde mekânsal bir ifadeye büründü. Genel olarak gözlemlenen en kayda değer gelişme, dönemin ihracata dayalı kalkınma modeline uygun olarak başta İstanbul olmak üzere dokuma ve giyim sektörlerinde uzmanlaşmış kentlerin öne çıkmasıdır. Ayrıca eskiden özellikle uluslararası finansal sermayenin merkezi olan İstanbul'a artık Ankara merkezli ulusal finansal sermayenin ve bankacılık sektörünün taşınması söz konusuydu. Bu açıdan Ankara finansal hizmetler açısından önemini yitirmeye başladı. Diğer bir husus, turizm sektörünün öne çıkarak ulusal ve uluslararası sermaye için çekici hale gelmesiyle gerek sermaye gerekse işgücü hareketi

535 Bkz. Buğra ve Savaşkan, Türkiye'de Yeni Kapitalizm: Siyaset, Din ve İş Dünyast; Saraçoğlu, "Tank Paletiyle Neoliberalizm".

536 Şengül, "On the Trajectory of Urbanisation in Turkey: An Attempt at Periodisation”, s. 163. 
açısından "kıyılaşma"nın yaşanmasıdır. Böylece ulusal mekânda iç pazara yönelik üretim ve hizmetlerde uzmanlaşmış olan Ankara'nın konumunun aşınmaya başlandığı gözlemlenmektir. ${ }^{537} \mathrm{Bu}$ açıdan Ankara, küresel mekâna ve uluslararası bağlama eklenmesi açısından arka plana itilmiş gözükse de yeni bağlamın Ankara örneğinde farklı bir şekilde yansıması ve 1980'lerden itibaren Ankara'da mekânın (yeniden) üretimi, kentsel mekânın makro biçiminin değişimi ve mekânsal dinamikleri açısından devingen bir süreçten geçildiği görülmektedir.

Ankara'nın mekânsal dönüşümünde ve kentin sonraki mekânsal gelişmesinde önemli rol oynayan etkenlerden biri, 1984'de 3030 sayıl1 Büyükşehir Belediyelerinin Yönetimi Hakkında Kanun çerçevesinde kentin idari açıdan yeniden yapılandırılmasıdır. $\mathrm{Bu}$ düzenleme ise mekânsal gelişimi açısından artık fiilen metropol bölge özellikleri gösteren kentin idari açıdan yeniden düzenlemesi ve mekânın üretimi olarak kentin yeniden ölçeklenmesiydi, fakat böyle bir mekânsal düzene geçiş aynı zamanda önemli bir süreci temsil etme niteliğindeydi; böyle bir düzen benimseyen dışa açık kalkınma modeli ve bu model bağlamında kentsel bölgelerin kalkınmasının önemli motoru olacağı varsayımı doğrultusunda uluslararası ölçekten yerel ölçeğe kadar her aşamada önemli mekânsal yeniden ölçeklenme süreçlerinin parçasıydı. Aynı zamanda kentin gelişmesini yönlendirmesi açısından mekânsal yeniden ölçeklenme ile ilişkili diğer önemli husus bir önceki dönemde, görece olarak bağımsız bir kurum olan ve İmar ve İskân Bakanlığı ile koordineli olarak çalışan Ankara Nazım Plan Bürosu'nun kapatılması ve nazım imar planı yapma görevinin büyükşehir belediyesine verilmesiydi. ${ }^{538}$ Fakat kentsel mekânın üretimini belirleme açısından en kayda değer husus gecekondu stokunun dönüşüme açılması ve kentin batı ile güney çeperinde yeni yerleşim alanlarının gelişmesine büyükşehir belediyesi tarafindan izin verilmesidir. $\mathrm{Bu}$ ise kentin denetlenen genişlemesinin sonu ve denetimsiz yayılmanın başlangıcı olmuştur. ${ }^{539}$

Dönemin hükümeti tarafından, Dünya Bankası ve IMF destekli liberal iktisadi politikaların önemli bir kısmı kentsel dönüşüme yöneltildi ve kurumsal bir takım düzenlemelerle gecekondu alanlarının dönüşümü ve bu bölgelerin apartmanlaşması hız kazanmıştır. Bu açıdan 1984 yılında çıkarılan 2981 sayılı İmar Affi Kanunuyla gecekondu bölgeleri sınıflandırılmış, gecekondu parseli üzerine 4 kata kadar bina yapma izni verilmiş, yasa gereğince İmar Islah Planları

537 Bkz. Eraydın ve Armatlı-Köroğlu, “Ankara'nın Yeni Gündemi: Ulus Devletin Başkentliğinden Küresel Ekonominin Düğüm Noktası olmaya Uzanan Yapısal Dönüşüm Çabaları".

538 Bkz. Batuman, “City profile: Ankara”; Günay, “Ankara Çekirdek Alanının Oluşumu ve 1990 Nazım Planı Hakkında Bir Değerlendirme".

539 Batuman, "City profile: Ankara", s. 582. 
yapılmış ve böylelikle önceki gecekondu önleme bölgeleri uygulamadan kalkarak kentsel dönüşüm projeleri hayata geçirilmeye başlanmıştır. İmar affi kapsamında aynı zamanda tapu tahsis belgelerinin uygulanmaya başlandığı görülmektedir. Böylelikle gecekondular yasal zemine kavuşmakta, alınıp satılarak veya müteahhitlere, yapılacak apartmanlardan daire elde edilme karşıllğında verilerek ciddi metalaşma ve gayrimenkulleşme eğilimine maruz kalmaktadır. ${ }^{540}$ Kentsel gelişmenin ve mekânın üretiminde kurumsal ve hukuki boyutta devletin böylelikle müdahalesinin yanısıra önemli bir başka girişim toplu konut üretimi girişimidir. 1984 yılında dar ile orta gelirli halkın konut ihtiyacını karşılamaya yönelik Toplu Konut İdaresi ve Toplu Konut Fonu kuruldu. Bu girişimin önemli tarafı, sadece müteahhit ve inşaat firmalarına değil aynı zamanda bireylere konut kredisi sağlamasıdır. ${ }^{541}$

1991 yılı itibarıyla birkaç riskli bölge hariç Ankara'nın neredeyse tüm gecekondu alanları için İmar Islah Planları hazırlanmış durumdaydı ve 2000'li yıllara gelince kentsel dönüşüm projelerinin uygulanıp uygulanmaması ile ilgili detaylar ve dönüşen mekânların profili dönüşüm süreçlerinin büyük ölçüde piyasa güçleri tarafından etkilenmesine işaret eder. Şöyle ki kentin merkezine en yakın Çankaya gecekondularında ve 1980'lerden itibaren kentin batı yönünde gelişme ekseni olarak belirlenen dolayısıyla yüksek rant vaat eden Etimesgut gecekondularında kentsel dönüşüm 1990'ların sonuna doğru tamamlanmışken, rant açısından henüz uygun koşullar sunmayan Keçiören, Altındağ ve Mamak gecekondularında dönüşüm süreçleri neredeyse yaşanmadı. ${ }^{542}$ Ayrıca hayata geçirilen kentsel dönüşüm projelerinin sonucunda ortaya çıkan bazı detaylar da ilginç tablo sunar. Örneğin, Çankaya'da bulunan Dikmen Vadisi Kentsel Dönüşüm Projesi (DVKDP), Portakal Çiçeği Vadisi Kentsel Gelişme Projesi (PÇVKDP) ve Gecekondudan Çağdaş Konuta Dönüşüm Projesi (GEÇAK) dikkate değerdir. Her üç projenin hayata geçirildiği sırada karar verme süreçlerinde özel şirketlerin daha baskın bir rol üstlendiği, halkın katılımı konusunda gecekondularda yaşayanlar açısından hakçalık ilkesinin gözetilmediği ve projenin tamamlanmasından sonra yüksek gelirli ve alt gelirli iki grup sakinlerinin bir arada bulunması sonucunda yerel ölçekli bir sosyal gerilim ortaya çıktığ 1 gözlemlenmiştir. Sonuçta ise bölgede yapılan apartmanlarda daireleri olan eski gecekondu sakinleri dairelerini satıp bölgeleri terk etmiştir. ${ }^{543}$ Kendisi bir kentsel dönüşüm projesi olmayan fakat 1973 yılından

540 Bkz. Çavuşoğlu, Türkiye Kentleşmesinin Toplumsal Arkeolojisi; Erman, "Mış Gibi Site”: Ankara'da Bir TOKİ-Gecekondu Dönüşüm Sitesi; Uzun, "Ankara'da Konut Alanların Dönüşümü: Kentsel Dönüşüm Projeleri”.

541 Balaban, "Capital Accumulation, The State and The Production Of Built Environment: The Case of Turkey", s. 100.

542 Somal1, "Reading Urban Transformation Through the Case of Mamak, Ankara", s. 57-58.

543 Uzun, “Ankara'da Konut Alanların Dönüşümü: Kentsel Dönüşüm Projeleri”, s. 213. 
beri gündemde olan ve bir gecekondu önleme bölgesi olarak öngörülen Batıkent Projesinin 1980'lerde uygulama süreci de bu açıdan kayda değerdir. Proje kamu eliyle dar gelirlilere arsa ve konut üretimi sağlayıp gecekondulaşmayı önlemeyi amaçlarken, tasarım süreci rastlantısallıklara ve kooperatiflerin seçimlerine bırakılmıştır. Uygulama sürecinde ilk ortaya atılan hedef grubun değişmesi olmuştur, zira "projenin ilk ortaya atıldığ 1 sıradaki, 'dar gelirlileri konut üretimi'ne yönelik amacı hiçbir zaman tasarım ve planlama sürecinin bir girdisi olamamışır." 544

Dönemde Ankara'da süregelen bir diğer mekânsal gelişme güney-batı ekseni doğrultusunda Eskişehir-Oran aksı üzerine üst orta ve üst gelir gruplarının, başlangıçta parçacı olarak gelişen lüks konut dokularının ortaya çıkması ve zaman içerisinde 2000'li yıllara doğru varlıklı kesimlerin ikamet ettiği görece olarak homojen ve kesintisiz bir bölgeye dönüşmesidir. Bu gelişme, Ankara'nın değişen toplumsal profilinin ve bu dönemde kent içi toplumsal hareketliliğin ve özellikle merkezde ortaya çıkan değişikliklerin ürünü olmuştur. Yeni ulusal ve uluslararası bağlamda, Ankara'nın kent merkezinde (Kavaklıdere, Gaziosmanpaşa gibi bölgeler) yükselen hizmet gereksinimlerini karşılamaya yönelik değişimler, bu mekanların konut işlevlerini kaybetmesine yol açmıştır. Kalabalıklaşan ve gerek toplumsal, gerekse mekânsal açıdan konut işlevini kaybeden merkezin yarattığı baskı üst orta ve üst gelirli grupların, kentsel donanımlar ve hizmetler açısından daha iyi bir çevreye ve bunu sağlaması açısından uygun görülen Eskişehir-Oran aksı üzerine oluşan 'güvenlikli apartmanlar' ve 'kapalı sitelerde' yerleşimine yol açmıştır. Böyle bir mekânsal hareketliliğe paralel olarak, kentin merkez-kuzey bölgesini oluşturan Altındağ, Keçiören ve Yenimahalle ilçelerinden Batıkent aksına doğru bir mekânsal hareketlilik de yaşanmıştır. Bu hareketliliğin temelinde ise genelde orta gelirli gruplar tarafından gelişmekte olan Batıkent aksı üzerinde konut sahibi olma tercihi ve çevre kullanımı ile konut özelliklerinden ziyade sosyal ilişki ağlarının önemsenmesi yatmaktayd1. ${ }^{545}$ Erken cumhuriyet dönemi Ankara'sinda kuzeygüney ekseni üzerinde üretilen ve 1980'lere dek farklı biçimlerde gözlemlenen Yenişehir ile Eski kent arasındaki 'ikili' toplumsal mekânsal ayrışma, böylelikle 1980-1990'lı yılların toplumsal mekânsal hareketliliğiyle yeniden ölçeklenerek ve batıya kayarak yeniden üretilmiştir. ${ }^{546}$ Fakat bu ayrışma salt konut ile yerleşim yeri tercihleriyle sınırlı değildi, zira buna küreselleşme bağlamında ortaya çıkan farklı sınıfsal ile kültürel tüketim kalıpları ve bunlara hizmet etmeye yönelik

544 Keskinok, “Ankara'nın Planlı Gelişmesi Açısından Batıkent Projesinin Önemi”, s. 151 vd.

545 Ataç, "A Divided Capital: Residential Segregation in Ankara”; Şenyapıl1, "Ankara Kenti "İkili” Yapısında Dönüşümler".

546 Şenyapı11, “Ankara Kenti “İkili” Yapısında Dönüşümler”. 
mekânsal ayrışmalar da eşlik ederek ${ }^{547}$ yapılı çevrede gözlemlenen ayrışma aynı zamanda toplumsal mekânın önemli bir özelliğine dönüşmekte ve ileri kapitalist gelişimin ürettiği çelişkili mekâna işaret etmektedir.

Lefebvre, ileri kapitalizmin egemen mekânı olarak çelişkili mekândan söz eder, bu mekân sadece toplumsal çelişkilerin barındırdığı bir mekân veya toplumsal çelişkilerin mekânda yansıması olarak karşımıza çıkmamaktadır aynı zamanda mekânın kendisi çelişkili hale gelmektedir. İleri kapitalizmin çelişkili mekânının en temel özelliği bütün ile parça, niceliksel ile niteliksel, mekânın üretimi ile tüketimi arasındaki ve genel olarak mekân temsili ile mekânsal pratikler arasındaki çelişkilerdir. Ankara'da 1990'lı yılların sonuna doğru mekânın üretiminde mevzu bahis çelişkilerin belirginleşmesini gözlemlemek mümkündür.

1984 'te beri Ankara metropoliten yönetim biçimine geçiş yapılmıştı. Mekânın üretiminde böyle bir yeniden ölçeklenmenin gerekçesi ise büyükşehir belediyeleri yönetiminin, hizmetlerin planl, programl, etkin ve uyum içinde yürütülmesinin sağlanması ve ölçek ekonomilerinden yararlanmasıydı. Metropoliten yönetim biçimi dolayısıyla idari açıdan bir mekân temsili olarak okunabilir. Böyle bir mekân temsili aynı zamanda Ankara başta olmak üzere "sermayenin kentleşmesi" 548 yaşanan Türkiye'nin büyük kentlerinde mekânın üretiminde en etkin aktör olarak yerel ve ulusal ölçekli sermaye ile beraber uluslararası sermayenin ihtiyaçlarına cevap verebilecek yöndeydi. Zira ileri kapitalizmde uluslararası sermayenin mekân temsilinin temelinde de mekânı daha üst ölçekte tahayyül etmesi yatmaktadır.

1980-1990'l1 yıllarda Ankara'da toplumsal mekânın önemli bir ayrışmaya maruz kaldığııı, bu ayrışmanın toplumsal mekânsal pratiklerinin hücresi olan biyolojik yeniden üretimi kapsayan konutla sınırlı olmadığını, aynı zamanda toplumsal ilişkilerin (üretim) yeniden üretimini sağlayan ve kamusal mekânda gündelik hayatın ritimleri biçiminde önümüze çıkan genel toplumsal mekânsal pratiklerin ayrışması olarak karşımıza çıktığı görülmektedir. $\mathrm{Bu}$ açıdan mevzubahis dönemde Ankara'nın kentsel mekânında en dikkat çekici gelişme bir kamusal mekân olarak alışveriş merkezlerinin yükselişi ve bu mekânların toplumun farklı kesimleri tarafindan gerek alışveriş yapılması gerekse boş zamanı değerlendirecek alanlar haline gelmesi ve geleneksel kamusal mekânların

547 Bkz. Akpınar, "Social Stratification and Consumption Profiles of Ankara: A Case Study in Ankara Residential Areas"; Akpınar, "Sociospatial Segregation and Consumption Profile of Ankara in the Context of Globalisation".

548 Şengül, "On the Trajectory of Urbanisation in Turkey: An Attempt at Periodisation"; Şengül, Kentsel Çelişki ve Siyaset: Kapitalist Kentleşme Süreçlerinin Eleştirisi. 
işlevlerini üstlenmesidir. ${ }^{549}$ Kentsel mekânda gittikçe yaygınlaşan ${ }^{550}$ ve aynı zamanda kamusal mekân niteliği kazanarak gündelik hayatın ritimleri ile toplumsal mekânsal pratiklerinin önemli bir bileşeni haline gelen AVM'lerin önemli etkilerinden biri kentin merkezinin ve kamusal alanların parçalanması ve böylece ayrışmış kamusallığın da ortaya çıkmasıdır. Aynı zamanda kamuya ait ve sahiplenilen mekân niteliği taşıyan geleneksel kamusallığın yerine mülk edinme olarak nitelendirilebilecek ve tüketim üzerine kurgulanan AVM'lerin, birer kamusal mekân olarak yükselişi de değişen kamusallığın önemli bir özelliğidir.

Böylece bir taraftan biyolojik yeniden üretimin süregeldiği varlıklı bölgelerin güvenlikli ve kapalı siteleri, ayrıca aynı işlevle yüklü olan fakat sokak, cadde ve diğer kamusal alanlardan kesin sinırlarla ayrılan diğer konut bölgeleri ortaya çıkmaktaydı. Diğer taraftan üretim ilişkilerinin yeniden üretimi ve genel olarak toplumsal ilişkilerin yeniden üretimi açısından boş vakti geçirmeye yönelik ve kentin diğer mekânlarından yine ayrıksı olarak vücut bulan ve 'kamusal' nitelik kazanan alışveriş merkezleri, yoğunlaşan trafik ve uzayan yürüyüş mesafeleri nedeniyle işlevsizleşen sokak ve kaldırımlar Ankara'da gün geçtikçe daha da bölünen ve parçalanan toplumsal mekâna işaret etmekteydi. Mekânsal pratikler açısından böyle bir parçalanmışlık ve bölünmüşlük ise egemen mekân temsiliyle -mekânı daha üst ölçekte tahayyül etme, küresel sermaye söz konusu olduğunda ise mekânı küresel ölçekte tahayyül etme, ona homojenlik atfetme - çelişkili bir ilişkiye girer, zira kullanım veya tüketim mekân temsilleriyle değil, mekânsal pratikleriyle tanımlanmakta olup, onun "her zaman yerel bir özelliği vardır. Mübadele dünya mekânını işgal etse de (dolaşımlar ve ağlar) burada ya da orada tüketilir." 551

Ankara' da yukarıdaki bütün (mekân temsili) ile parça (mekânsal pratikler) veya genel ile parsel arasındaki çelişkiye paralel olarak aynı zamanda niceliksel ile niteliksel ve mekânın üretimi ile mekânın tüketimi arasındaki çelişkilerin keskinleştiği görülmektedir. Zira egemen mekân temsili aynı zamanda mekânı homojen, mübadele edilebilir, sayısız biçimlerle parçalanarak alınıp satılabilir bir nitelik de atfetmekte, mekânı ilk önce değişim değeri ve niceliksel olarak değerlendirmesine yol açmaktadır. Oysa mekânsal pratikler her şeyden önce kullanım değerine odaklıdır. Ankara'da 1980-90'l1 y1llarda gerek kentin yapılı çevresinin üretiminde büyük sermayenin etkin hale gelmesiyle, gerekse kentsel hizmetlerin sunumunda neoliberal politikalar bağlamında piyasa

549 Bkz. Erkip, "The Shopping Mall as an Emergent Public Space in Turkey".

550 Ankara'da ilk AVM 1989 yılından kurulan Atakule'dir. 1990'ların sonuna doğru AVM'lerin sayıs1 6'ya yükseldi. Bkz. Erkip, "The Rise of the Shopping Mall in Turkey: The Use and Appeal of a Mall in Ankara".

551 Lefebvre, Mekânın Üretimi, s. 345. 
mekanizmalarının devreye girmesiyle mübadele değeri odaklı bir mekânın üretimi söz konusu olmuştur. Örneğin 1984-89 yıllarını kapsayan ANAP'lı Mehmet Altınsoy belediye başkanlığı dönemi Ankara'da ulaşım, su ile kanalizasyon gibi konularda büyük ölçekli önemli projelerin gerçekleştirildiği veya temellerinin atıldığı bir dönemdir. Fakat bunlar kamu yararı yerine özel çıkarın ve sermaye odaklı anlayışın uygulandığı bir sürecin parçası olmuştur. $\mathrm{Bu}$ dönemde özelleştirme uygulamaları sınırlı düzeyde olmasına rağmen işgücünün yeniden üretimine yönelik kentsel hizmetler kısıtlanırken, ihalecilik uygulamalarına ağırlık verilmiş ve özel sektöre önemli miktarda kaynak aktarılmıştır. ${ }^{552}$ Mübadele değeri odaklı bir mekân üretimi süreci kullanımın önemini de berberinde getirir, zira kullanımın temelinde mülkü edinme değil sahiplenme yatar. Lefebvre'in ifadesiyle "kullanım, mekân içinde, mübadeleyle keskin bir çatışmaya girerek yeniden ortaya çıkar, çünkü "mülkiyet"i değil "sahiplenmeyi" gerektirmektedir." 553 Bu açıdan 1985 y1lından beri ANAP'lı büyükşehir belediyesinin gündeminde olan, Ankara'nın merkezinde kentin en kullanışlı parklarından biri olan Güvenpark'ın yenileme projesi kayda değerdir. Alanın tarihsel kurgusunu ortadan kaldıran ve parkın altında otopark ile alışveriş merkezi öngören proje 12.02.1987 tarihinde büyükşehir belediye encümeni tarafından onaylanıp yürürlüğe girer ve uygulanmanın ön hazırlık aşamasında halk tarafından fark edilip ilgilenilmeye başlanır. Aynı zamanda "Çevre Duyarlılık Grubu" adı altında örgütlenen yurttaşlar halkın ilgisini çekmek ve projeyi durdurmak için "Otopark Değil Güvenpark!” sloganıyla bir imza kampanyası başlatmışlar ve 60 bin civarında imza toplamışlardır. Fakat belediye dilekçeyi kabul etmemiştir. Çevre Duyarlılık Grubundan 3 yurttaşın, projenin gerçekleştirilmesi için yapılan imar planı değişikliğinin iptali istemiyle idari mahkemeye başvurması ve Danıştay 6. Dairesi tarafından 1988'de imar planı değişikliği kararının "şehircilik ilkeleri, planlama esasları ve kamu yararına" aykırı olduğu gerekçesiyle bozulması ve temyizin de reddi sonucunda Güvenpark projesi uygulanamad. ${ }^{554}$ Böylece, mübadele değeri odaklı mekânın üretiminin bir parçası olan ve "Türkiye tarihinde görülmüş en önemli kentsel toplumsal hareketlerden birini oluşturan sivil inisiyatifin muhalefeti sayesinde

552 Balcı, "Kamu Yararı Kavramı ve Ankara Büyükşehir Belediye Başkanlarının Uygulamaları: Mehmet Altınsoy, Murat Karayalçın ve İ. Melih Gökçek", s. 74; Doğan, Ĕgreti Kamusallık: Kayseri Örneğinde İslamcı Belediyecilik, s. 73.

553 Lefebvre, Mekânın Üretimi, s. 359.

554 Batuman, "Mekân, Kimlik ve Sosyal Çatışma: Cumhuriyet'in Kamusal Mekânı Olarak Kızılay Meydanı”, s. 68-69; Erim, "Güvenpark Güncesi”; Keleş, Hamamcı ve Çoban, Çevre Politikası, s. 647-648; Keskinok, "Kent Planlama ve Uygulamasında Menfaat İhlali ve Dava Açma Ehliyeti (Kamu Yararı ve Mülkiyet Hakkının Sınırlanması, Kent Planlama ve Uygu lamasının Yargısal Denetimi, Kent Planlama ve Uygulamasından Etkilenme, Genişletilmiş Anlamda Menfaat İhlali, Yargı Kararları", s. 17. 
engellenmiş" 555 olan proje kentliler tarafindan reddedilerek kentsel mekânın sahiplenilmesi, kullanım değerine öncelik tanınması ve "kent hakkının" gerçekleştirilmesinin bir örneğidir.

Güvenpark projesi örneği, kullanım değeri ile mübadele değeri çelişkisinin ve süreç sonunda kullanım değerinin başat hale gelmesinin bir örneği olmasına rağmen tüm dönem boyunca kentsel mekânın mübadele değeri odaklı üretimi süregelmiştir. 1989-1994 arası dönemde Ankara'da SHP'li Murat Karayalçın'ın belediye başkanlığı döneminde, bir önceki dönemde uygulanmış olan neoliberal siyasaların etkilerini hafifletmek için Halk Ekmek, Halk Taşıt gibi birtakım girişimlere rağmen bu uygulamalar 1992'den sonra ileri götürülmemiş, hatta bir kısımından geri dönülmüştür. ${ }^{556}$ Fakat belediye hizmetlerinin sunumunda ve kolektif tüketim alanındaki 'toplumcu' uygulamalar açısından yine de Karayalçın dönemi kendinden önce ve sonra gelen dönemlere kıyasla açıkça farklılaşmaktadır. ${ }^{557} 1994$ sonrası Ankara'da, Refah Partili Melih Gökçek'in belediye başkanlığ 1 döneminde ise neo-liberal belediyecilik politikaları ve bu bağlamda mübadele değeri odaklı mekânın üretimi tepe noktasına ulaşmıştır. ${ }^{558}$ 1994 sonrası dönemde Ankara'da aynı zamanda 1980'lerden itibaren egemen ideolojik çerçeve olan Türk-İslam sentezinin ve siyasal İslamın, mekânın biçimlenmesine ve gerek mekân temsili gerekse mekânsal pratiklerde ve genel olarak kent imgesinde daha görünür hale geldiği gözlemlenmektedir. İslami unsurun; mekânın üretiminde özellikle mimari üretimi ve gündelik hayatta toplumsal mekânsal pratikler biçiminde öne çıkması olarak ele alınmasından önce dönem boyunca mekânın üretimi bağlamında nicelik ile nitelik arasındaki keskinleşen çelişkinin bir başka hususuna da değinmekte yarar vardır.

Önceden değinildiği üzere 1980 'lerin sermaye hareketliliğinin ve dişa bağımlılığın önemli taraflarından biri 'sermayenin kıyılaşması' ve gerek iç gerekse dış turizmin önem kazanmasıdır. Bu açıdan kıyı bölgeleri, devlet tarafından da uygun hukuki bir çerçeve sağlanarak ${ }^{559}$ sermayenin değerlendirdiği

555 Batuman, "Mekân, Kimlik ve Sosyal Çatışma: Cumhuriyet'in Kamusal Mekânı Olarak Kizilay Meydanı", s. 69.

556 Balcı, "Kamu Yararı Kavramı ve Ankara Büyükşehir Belediye Başkanlarının Uygulamaları: Mehmet Altınsoy, Murat Karayalçın ve İ. Melih Gökçek"; Doğan, Ĕgreti Kamusallık: Kayseri Örneğinde Íslamcı Belediyecilik.

557 "Kente karşı işlenen suç" kavramını Türkiye gündemine sokan kişinin Murat Karayalçın olduğu (İlhan Tekeli, "Kente Karşı İşlenen Suç mu? Yoksa Kentlinin Gaspedilen Hakkı mı?”, s. 24) hesaba katıldığında onun belediyecilik anlayışının bir önceki ve sonraki döneme kıyasla farklı olduğu söylenebilir.

558 Bkz. Doğan, “Gökçek'in Ankara’yı Neo-liberal Rövanşçılıkla Yeniden Kuruşu”.

559 Bu açıdan 1982 yılında 2634 sayılı Turizm Teşvik Kanunu ve onun uygulanmasına yönelik 1983 'te çıkarılan Kamu Arazilerinin Turizm Yatırımlarına Tahsisi Hakkındaki Yönetmeliği turizm amaçlı yerli ve yabancı yatırımlar için arazi tahsisini kolaylaştırmıştır. Benzer biçimde 
önemli alan haline getirildi. Aynı zamanda 1980'lerden itibaren turizmin gelişmesine paralel olarak ikinci konut gelişimi ve bunların genellikle Ege ve Akdeniz kıyılarında süregeldiği gözlemlenmektedir, ${ }^{560}$ bu ise Türkiye'de mekânın tüketimi süreçlerinin önem kazanmasına işaret eder. Gerek turizm gerekse yılın sadece birkaç ayı kullanılan yazlık-mevsimlik niteliğinde ikinci konutlar şeklinde önem kazanan mekân kullanımının; 'prestij', 'tüketim kalıpları', 'tatil yapma alışkanlıkları' gibi bağlamları olmakla beraber çelişkili mekânın yükselişinde niceliksel ile niteliksel arasındaki çelişkinin keskinleşmenin ve nitelikselin öne çıkmasının bir ifadesi olarak değerlendirilebilir. Niceliksel ile niteliksel arasındaki çelişkide kullanımın öne çıkması mübadelenin yadsınması değildir aslında, zira turizm ile ikinci konut şeklindeki kıyılaşma yine de hem sermaye aracılığıyla yapılı çevrenin üretimi olarak hem de üretici olmayan tüketim olarak mübadele değeri odaklı bir mekân üretimi teşkil etmektedir. Fakat genel olarak değerlendirildiğinde bu olgu aynı zamanda mübadele değeri odaklı kentsel mekânın üretimine, yabancılaştıran gündelik hayata ve rutine karşı kullanımın; güneşin, denizin ve genel olarak 'doğanın', gündelik ve rutin olmayanın başatlık kazanması olarak karşımıza çıkmaktadır. Böyle bir kullanım, mübadeleyi ve nicelikseli yadsımaz, zaten mübadele ilişkileri çerçevesinde gerçekleşir fakat böyle bir hareketlilik ve onun devamlılığı Türkiye'de ileri kapitalizmin mekânının niceliksel ile niteliksel arasındaki süregelen çelişkisine ve çelişkili mekânına özgü üretim mekânı, tüketim mekânı ve mekânın tüketimi arasındaki üç terimli hareketliliğine işaret eder. Mevzubahis dönemde gözlemlenmeye başlayan böyle bir hareketlilik, 2000'li yıllardan itibaren ulusal mekânda daha yaygın bir boyut kazanmakla sınırlı kalmayacak, Ankara örneğinde görüleceği üzere tek bir kent içerisinde de böyle bir mekân tüketiminin yaygınlaşması gözlemlenecektir.

Mevzubahis dönemde, Türkiye'de toplumsal mekânda gerek mimari üretim gerekse gündelik hayatta mekânsal pratikler açısından İslami unsurun öne çıkması konusunda sayısız çalışmalar bulunmaktadır. ${ }^{561}$ Kendi başına bir

1988'de çıkarılan 6331 sayılı Orman Kanunu ve 1990'da 3621 sayılı Kıyı Kanunu ise Türkiye'de özellikle kıyı bölgelerinin yapılaşmaya açılmasını kolaylaştıran önemli hukuksal düzenlemelerdi.

560 Bkz. Emekli, "İkinci Konut Kavramı Açısından Turizm Coğrafyasının Önemi ve Türkiye'de İkinci Konutların Gelişimi”.

Örneğin 1989'da Türkiye'de 102.400 olan ikinci konut sayıs1 1999'de neredeyse beş katına çıkarak 480.000'e yüksselmiştir. Emekli, "İkinci Konut Kavramı Açısından Turizm Coğrafyasının Önemi ve Türkiye'de İkinci Konutların Gelişimi”, s. 37.

561 Çınar, Modernity, Islam, and Secularism in Turkey: Bodies, Places, and Time; Cinar, "Bodies, Places and Time: Islamic Visibilities in the Public Sphere and the Contestations of Secular Modernity in Turkey"; Çınar, "The Imagined Community as Urban Reality: The Making of Ankara"; Zencirci, "Secularism, Islam, and the National Public Sphere: Politics of 
inceleme konusu olabilecek bu ve buna benzer çalışmaların temel vurgularından biri, 1980'lerden itibaren İslamın yükselişiyle ve özellikle 1990'larda siyasi İslamın gerek yerel gerekse merkezi iktidar konumuna yükselmekle birlikte mekânın politik bir temsil niteliği kazanması ile gündelik hayatta ve toplumsal mekânsal pratiklerde İslami unsurun yine de bir politik temsil olarak görünür hale gelmesidir. Mekânın önemli bir politik temsil niteliği kazandığı bu süreç içerisinde Ankara'nın özel tarihi ve deneyimi önem arz eder; laik cumhuriyetin mekân temsili olma ve gerek tasarlanan mekân gerekse mekânsal pratikler açısından cumhuriyet modernleşmesiyle özdeşleştirilen Ankara, 1990'ların egemen İslamcı ve modernist karşıtı söylemin fonunda mekânsal ve imgesel yeniden biçimlenmesini deneyimleyecektir. ${ }^{562}$

1995 'te Hitit güneşini tasvir eden kent ambleminin, Anadolu'yu, İslam'1 temsil etmediği düşüncesiyle cami, Atakule ve ay-yıldız simgelerinin birleşimi olan bir başka simgeyle değiştirilmesi, kentin imgesini değiştirmeye yönelik ilk önemli girişimlerden biriydi 563 ve yoğun tartışmalara yol açmıştı. Yeni amblemde, kentin siluetine hâkim olan ve 1989'dan beri alışveriş merkezi kısmı da bulunan Atakule siluetinin varlığından dolayı, Gürün'ün belirttiği üzere, artık kent tarihsel ve kültürel değerlerle değil, sermayenin simgesi olan alışveriş merkezi ve İslami bakışın simgesi olan camiyle anılacaktı. ${ }^{564}$ Sonradan idare mahkemesi kararıyla iptal edilen yeni amblemde küçük değişiklikler yapılarak 2011'de Ankara Büyükşehir Belediye Meclisi tarafından onaylanarak yeniden

Commemorative Practices in Turkey"; Sargin, "Sincan, a Town on the Verge of Civic Breakdown: The Spatialization of Identity Politics and Resistance"; Sargin, "Displaced Memories, or the Architecture of Forgetting and Remembrance"; Doğanay, "Türkiye'de Siyasal İslam ve Kentsel Mekânlar: Fazilet (Refah) Partili Büyükşehir Belediyesi'nin Ankara'daki Uygulamaları"; Doğan, Eğreti Kamusallı: Kayseri Örneğinde Íslamcı Belediyecilik; Doğan, "Gökçek'in Ankara'yı Neo-Liberal Rövanşçılıkla Yeniden Kuruşu”; Batuman, "Mekân, Kimlik ve Sosyal Çatışma: Cumhuriyet'in Kamusal Mekânı Olarak Kizılay Meydanı".

562 Bu bağlamda Ali Ekber Doğan'ın işaret ettiği önemli bir yerel husus da söz konusudur. Buna göre, 1994-98 döneminde Ankara büyükşehir belediyesi başkanı İbrahim Melih Gökçek tarafından Ankara’yı neoliberal rövanşçllıkla yeniden kuruşundaki önemli husus, Gökçek’in siyasal İ́lamcı bir duruşa denk düşen cepheden bir rövanşçılıktan ziyade, Gökçek’in daha çok emek, sol ve modernlik karşıtlığından kaynaklanan rövanşçılığıdır. Şöyle ki “Gökçek gibi doktriner İslamcı olmayan birini aşırı sağcı bir rövanşçı stratejiye iten şeyin Ankara'nın kentsel gelişim ve belediyecilik geçmişi olduğu söylenebilir. Bu geçmişin bir ucu Cumhuriyetin ilk yıllarında Ankara'nın imarına modern Türkiye'nin vitrini olarak özel bir önem verilmesine; diğer ucu ise 1970'lerde gelişen yeni/demokratik belediyecilik hareketinin düşünsel ve pratik anlamda en gelişkin yeri olmasına gider". Bkz. Doğan, "Gökçek'in Ankara'yı Neo-liberal Rövanşçılıkla Yeniden Kuruşu", s. 137 vd.

563 Batuman, "City profile: Ankara”; Doğanay, "Türkiye'de Siyasal İslam ve Kentsel Mekânlar: Fazilet (Refah) Partili Büyükşehir Belediyesi'nin Ankara'daki Uygulamaları”.

564 Gürün, "Impact of Shopping Centers on the Fragmentation of the City Center", s. 83-84. 
kullanılmaya başlandı. ${ }^{565}$ Amblem değişikliği ile ilgili yoğun siyasi tartışmalar ve bunların medyada yer alması bir kenara bırakılırsa ilginç diğer bir husus, akademik söylemde çoğu durumda eski ambleme kıyasla yeni amblemin İslam'1 ima ettiğinin, Ankara'ya İslami temelleri olan bir kimlik kazandırma çabasının parçası olduğunun haklı olarak belirtilmesi, fakat aynı zamanda eski amblemin nasıl bir mekân ve zaman temsilinin ürünü olduğunun gözden kaçırılmasıdır. Nitekim Hitit güneşi Kemalist seküler milliyetçi tarih yazımın ve mekân temsilinin temel unsuruydu, bu açıdan Türk-İslam sentezinin ürünü ve mekân temsili olan yeni Ankara ambleminden politik niteliğinden farklı değildir ve son kertede her ikisi de iki farklı ideolojinin kent imgesine iki farklı anlam yüklemesidir (bkz. Şekil 11). ${ }^{566}$

Kentsel mekânın yeniden biçimlenmesine yönelik diğer girişimler ise daha çok kentin belirli meydan, park ve kavşaklarında gelenekseli ve Osmanl1/Selçuklu motiflerini canlandıran farklı heykel ve peyzaj uygulamalarının konulmasıyla gerçekleşmekteydi. ${ }^{567}$ Ayrıca, 1994'ten itibaren kentte sokak isimlendirmelerinin yoğunlaştığı görülmektedir. Özkan ve Yoloğlu'ya göre 1995-2005 arası dönemde 552 adet sokağın isimlendirilmesi yapılmış, bu süreçte ilginç husus ise bunların yarısından fazlası Gökçek'in büyükşehir belediyesi başkanı olarak seçilmesine müteakip 2 yıl içinde gerçekleştirilmiş olması, toplam mahalle sayısının \%8'inde toplam isim değişikliklerinin \%28,9'unun gerçekleştirilmiş olması -ki değişikliklerin rastgele olmaması bilinçli bir süreç olduğunu göstermektedir - aynı zamanda modern burjuva kimliğini çağrıştıran isimlerin Osmanlı ve İslam'ı çağrıştıran isimlerle değiştirilmesidir; ör. Berna, Bale, Çam yerine Beyza, Bala ve Müezzin. ${ }^{568}$

565 Mahkemece iptal edilen amblemin yerine 2011'den itibaren kullanılmakta olan yeni amblemde bir öncekine kıyasla yapılan en göze çarpan ve ironik değişiklik 3 yıldız yerine 5 yıldızın yer alması ve belediye tarafindan son olarak kullanılmakta olan amblemdeki 5 yıldızın “Anadolu'da kurulan Türk Devletlerinin Başkentlerini sembolize etmektedir" diye belirtilmesidir (bkz. ABB, "Ankara'nın Yeni Amblemi Belli Oldu"; ABB, "Büyükşsehr'in Son Amblemine Mahkemeden Onay”). Amblemde Ankara Kalesi'nin temsil ettiği iddia edilen fakat amblemde neredeyse fark edilemeyen veya ima edilemeyen kale silueti, Atakule'yi temsil etmekten ziyade amblemdeki en baskın unsur olan camii için kubbe işlevi gören imge, "Anadolu'da kurulan Türk Devletlerinin Başkentlerini sembolize eden" 5 yıldızla beraber Ankara'nın belirsizleşen kent imgesinin en 'uygun' temsilidir aslında.

566 Burada belirtilmesi gereken önemli husus, söz konusu amblemin, imgelem unsurları içerdiğinden dolayı aynı zamanda bir temsil mekânı olmasıdır. Başka bir deyişle, bu amblem belirli bir imge üretme açısından iktidarın girişimi olduğu için bir mekân temsili olarak öne çıkmakta, fakat imgelem unsurları barındırdığ 1 için temsil mekânı nitelikleri de taşımaktadır.

567 Konu ile ilgili daha ayrıntılı bir inceleme için bkz. Doğan, "Gökçek'in Ankara'yı Neo-liberal Rövanşçıllkla Yeniden Kuruşu”; Doğanay, "Türkiye'de Siyasal İslam ve Kentsel Mekânlar: Fazilet (Refah) Partili Büyükşehir Belediyesi'nin Ankara'daki Uygulamaları”.

568 Bkz. Özkan ve Yoloğlu, "Bir Bellek Projesi Olarak Sokak İsimlendirmesi: Ankara Örneği”. 


\section{Şekil 11. Seküler Milliyetçi Mekân Temsilinden Türk-İslam Sentezinin Mekân Temsiline Ankara'nın Kent İmgesi}

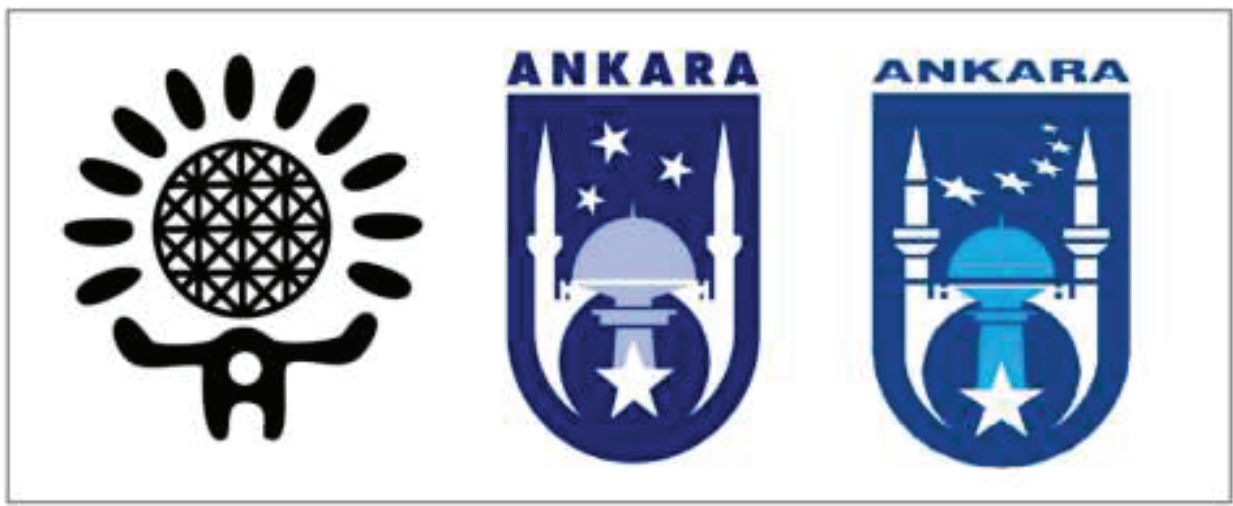

İslami unsurun baskın olduğu böyle bir tasarlanan mekân karşısında Ankara'da yaşanan mekânın gerilediği ve bu ikisi arasında aynı zamanda bir gerilimin ortaya çıktığı da söylenebilir. Bu açıdan 1990'larda erken cumhuriyet Ankara'sı ile ilgili çok sayıda biyografik eserin ortaya çıkması ve önemli bir okuyucu kitlesinin ilgisini çekmesi tesadüf değildir. ${ }^{569}$ Konu ile ilgili ayrıntılı bir inceleme sunan Batuman'a göre, bu eserler Cumhuriyetin ilk kuşağına ait ve erken cumhuriyet döneminin, çocuk veya genç olarak tanığı olan kişilerin kişisel hikâyeleriydi ve bunlarda erken cumhuriyet Ankara's1, arzu edilen "ideal ev", erken cumhuriyet yaşamı için "huzurlu barınak" ve artık kaybolmuş bir ütopya olarak temsil edilmekteydi. Daha önemlisi, 1990’ların böyle bir nostaljik anlatıda ve mekân üzerine söylemde Ankara, İslamcı belediyeyle özdeşleştirilmekte ve “Ankara'nın eğitimli orta sınıflar açısından İslamıı belediye başkanının seçimi seküler yaşam tarzının sembolü olan "Atatürk Ankara'sı"na utandırıcı bir ihanet teşkil eder." 570 Kişilerin, Ankara ile ilgili hayatları boyunca oluşturdukları böyle tasvirleri kentin yaşanan mekânı (temsil mekânı) oluştururken ${ }^{571}$, anlatının baskın nostaljik tonu onun gerilediğini, İslami unsurun baskın hale gelmesiyle ve

569 Batuman, "Early Republican Ankara': Struggle over Historical Representation and the Politics of Urban Historiography".

570 Ibid., s. 669-670.

571 Lefebvre'in belirttiği gibi yaşanan mekân, sıradan kişilerin; hayatları boyunca fiziksel dünyayla doğrudan ilişkileri sırasında kurdukları zihinsel kurgularıdır; bu mekân yaşanır, konuşur, tutku ve eylem yerlerini, yaşanan durumların yerlerini kapsar, zamanı doğrudan içerir, onun duyumsal bir çekirdeği ya da merkezi vardır; zamanı doğrudan içerdiği için bu mekânların kökeni tarihtir, bir halkın ve bu halka mensup her bir kişinin tarihi. Bu mekân, kullanıcıların her günkü edimlerinin mekânıdır, dolayısıyla özneldir. Bkz. Lefebvre, Mekânın Üretimi, s. 70-71, 364 . 
tasarlanan mekân niteliği kazanmasıyla ise bu iki oluşturucu arasında gerilimin ortaya çıktığına işaret eder.

Yaşanan ile tasarlanan arasında 1990'larda tırmanan gerilimin aynı zamanda toplumsal mekânsal pratikler aracılığıyla desteklendiği görülmektedir. Önceden belirtildiği üzere, mekânsal pratikler, temsil mekânını ve mekân temsilini bir araya getirir, genel olarak toplumun ve onun her üyesinin, toplumsal mekânla ilişkilerinde yeterlik ve performans gerektirir. Ankara bağlamında toplumsal mekânsal pratiklerin yeterlik boyutu kentlilerin ve kentsel grupların; kentsel mekânı seküler ve modern yaşam tarzına uygun biçimde kullanımıyla ilgili kodlanmış kuralları, bu kurallarıyla tanıklığı ve farkındalığı içermekteydi. Yeterlik aynı zamanda mekânı kavramaya ve bu kavrayışa göre mekânı sayısız biçimlerde kullanmaya imkân sağlar. Performans ise Ankara bağlamında somut mekân kullanımlarıydı; modern, seküler yaşam tarzına uygun sayısız toplumsal mekânsal pratikler. İşte bu yeterlik ve performans sayesinde mekânsal pratikler, 1990 öncesi toplumsal mekânda mekân temsili ile temsil mekânlarını bir araya getirip belirli ölçüde uyum sağlamıştır.

1990'larda ise bir temsil mekânı olarak "erken cumhuriyet Ankara'sı"nın nostaljik öykülenmesi, sadece baskın ve görünür olmaya başlayan mekân temsiline değil aynı zamanda mekânsal pratiklerinin değişim gösteren performans bileşenine de bir tepkiydi. Toplumsal mekânsal pratiklerin yeterlik bileşeninde henüz belirli bir süreklilik söz konusuyken, mekânın somut kullanımları anlamına gelen performans görünür bir şekilde değişim göstermekteydi. Özellikle Ankara'da 1994'ten itibaren her y1l devamlılık gösteren ve yaygınlaşan Ramazan iftar çadırları, bunun için ise 1997'ten itibaren cumhuriyetin seküler ve modern kamusallığının 'vitrini' olan Kızılay'daki Güvenpark'1n seçilmesi, toplu sünnet şölenleri, 29 Mart 1996'da Gökçek'in talimatıyla kurulmuş olan ve öteden beri farklı dini ve milli bayramlarda, kültürel etkinlik ve festivallerde hizmette bulunan mehter takımı gibi uygulamalar, toplumsal mekânsal pratikler açısından modern, seküler cumhuriyetin Ankara's1 ile ilgili yeterlik bileşeni karşısında "anlaşılamaz" bir performans anlamına gelmekteydi. Ankara'da gerek toplumsal mekânın tasarlanan ile yaşanan oluşturucuları arasındaki gerilimlerin, gerekse bu ikisi arasında aracı olup belirli ölçüde uyum sağlayan mekânsal pratiklerin yeterlik ile performans arasındaki gerilimli sürecin soğurma noktası 4 Şubat 1997 tarihinde Sincan kent merkezinde tank ve zırhlı araçların konumlanışıydı. Sincan'da böyle bir gelişme, tesadüf değildi, zira 1994'ten beri Sincan gerek mekân temsilleri ve temsil mekânları gerekse mekânsal pratikler açısından cumhuriyetin seküler düzeninin aşınmasına sahne olan örnek bir yerleşimdi. Aynı zamanda bu düzeni sağlamakla görevli Türk Silahlı Kuvvetlerinin önde gelen birimlerinden birine ev sahipliği yapmaktayd. Böylece yeterlik ile performans bağlamında Sincan'ın sokak ve meydanlarında konuşlanan askeri birimler toplumsal mekânsal pratiklerin 
yeterlik ile performansı arasındaki gerilimi gidermeye ve bu iki oluşturucu arasında erken cumhuriyet döneminden beri süregelen az çok bağdaşıklığ sağlamaya yönelikti. ${ }^{572}$

1990'ların siyasal İslamın yükselişi ve bunun beraberinde getirdiği gerilim elbette mekânsal değil, her şeyden önce toplumsal bir süreç teşkil etmekteydi fakat sürecin ancak mekân boyutu kazanarak mekânsallaşmasıyla - mekân üzerine söylem (temsiller) ve her şeyden önce mekânın farklı kullanımları anlamına gelen mekânsal pratikler aracılığıyla - bu toplumsal sürece içkin çelişkiler ve gerilimler fiili kılındı ve mekânın çelişkileri halini aldılar. ${ }^{573}$ Toplumsal-siyasal çelişkilerin; mekânsallaşarak, mekân aracılığıyla etkin hale gelerek ve nitekim toplumsal mekânın çelişkisine dönüşmesi ise 1980'lerden itibaren üretilmekte olan çelişkili mekânın bir diğer tarafıydı. Bu açıdan, neoliberal hegemonyanın mekâna yansıması olarak mekânın mübadele ile kullanım, bütün ile parça arasındaki çelişkili ilişkilerine aynı zamanda toplumsal mekânın farklı kullanımları arasındaki çelişkiye de eşlik etmekteydi ve aslında mekânın farklı kullanımları arasındaki bu çelişkili ilişkilerin, Türkiye'de üretilmekte olan çelişkili toplumsal mekânın en dikkat çekici özelliği olduğu da söylenebilir.

28 Şubat'1 takip eden süreçler, sadece İslamc1 iktidarın düşürülmesiyle sınırlı kalmadı, aynı zamanda öteden beri güçlenen İslami sermayenin gücünü kırmaya da yönelikti ve bunu belirli ölçüde başardı ancak İslamcı sermaye grupları daha sonraki dönemde kendilerini yenileyerek toparlayabilmişlerse de bu toparlanma sürecinde 'adil düzen' gibi İslamcı ideolojik temayüller yerine temel vurgu, neo-liberal birikim stratejileri üzerindeydi. Bu değişim sürecinde aynı zamanda siyasi İ́slamın muhafazakâr söylemi yerine 'demokrasi', 'insan hakları' gibi söylemler de daha ön plandayd. ${ }^{574} 14$ Ağustos 2001 tarihinde kurulan Adalet ve Kalkınma Partisi (AKP) siyasi İslam söyleminin değişimini temsil etmekteydi. Dahası 1999'da Türkiye'nin AB'ye adaylığı resmi olarak

572 1994'ten beri Türkiye'de İslamın; toplumsal mekânda gerek mekân temsilleri gerekse mekânsal pratikler olarak baskın ve görünür hale gelmesi ve böylelikle var olan seküler düzene yönelik bir karşı temsil ve karşı pratik olarak önce çıkması açısından Sincan örneğinde yapılan önemli bir çalışma için bkz. Sargın, "Sincan, a Town on the Verge of Civic Breakdown: The Spatialization of Identity Politics and Resistance.”. Bu çalışma, 4 Şubat 1997'ye götüren gerilimli süreci, gelişmelerin merkezi olan Sincan örneğinde ve özellikle mekân odaklı bir yaklaşımla ortaya koyduğu için kayda değerdir.

573 Lefebvre'in deyişiyle, "toplumsal-siyasal çelişkiler mekânsal olarak gerçekleşir. Sonuçta, mekânın çelişkileri toplumsal ilişkilerin çelişkilerini fiili kılar. Başka deyişle, mekânın çelişkileri, çıkarların ve toplumsal-siyasal güçlerin çatışmasını "ifade eder"; fakat bu çatışmalar ancak mekân içinde etkilidir, burada vuku bulurlar ve mekânın çelişkileri halini alırlar". Bkz. Lefebvre, Mekânın Üretimi, s. 366-367.

574 Bkz. Saraçoğlu, "Tank Paletiyle Neoliberalizm". 
kabul edildikten sonra $\mathrm{AKP}, \mathrm{AB}$ 'ye adaylı̆̆ süreci reformlarının devam edeceğini ve kuracağı hükümetin; AB'ye uyum sağlaması için çalışacağını ilan etmişti ki bu husus Avrupa Birliği ile ilişkilerine katkı yapmak için sürekli çaba harcayan büyük sermaye için önemli bir güvenceydi. AKP aynı zamanda 1990'lardan ders çıkarmış gibi, söyleminde İslami ekonomik kurumlarla ilgili tartışmalara çok az yer veriyordu ve partinin ekonomik liberalizmden taviz vermeyeceği bir imaj sunmaktayd1. 2001'de ise Türkiye'de meydana gelen ekonomik krizin ve buna karşı alınan önlemlerin geniş halk kesimlerinin hoşnutsuzluğuna yol açtığı bir ortamda önceki ekonomik gelişmelerde rol almayan ve yeni kurulan bir parti halka daha kolayca hitap edebilme şansına sahipti. ${ }^{575} 2002$ genel seçimlerinde AKP'nin başarısının temelinde böyle bir konjonktür yatmaktaydı ve bu seçimler ayrıca Türkiye'nin yeni bir döneme girmesinin emarelerini sunmaktaydi. Neoliberal birikim stratejilerinin daha ileri bir aşamasına, zaman içerisinde partinin devletleşmesi devletin ise partileşmesi gibi bir sürece ve ideolojik düzlemde daha muhafazakâr bir yönelime tanıklık eden bu dönem, mekânın üretimi açısından da yeni bir döneme tekabül edecektir. $\mathrm{Bu}$ yeni dönemin, Ankara örneğinde incelenmesi ise çalışmanın bir sonraki bölümünde yer bulmaktadır.

\section{Bölüm Değerlendirmesi}

1923-2002 arası dönemde Ankara'da mekânın üretimi süreçlerinin genel bir değerlendirmesi yapılırsa, dönem içerisinde üç farklı mekânsal evrenin var olduğu söylenebilir. Bunlardan ilki Cumhuriyet'in ilanından 1930'ların başına dek süren ve yaklaşık olarak 10 sene süren dönemdir. Bu dönemde Ankara' da toplumsal mekânın hala büyük ölçüde Osmanlı dönemindeki tarihsel mekân ile süreklilik gösterdiği görülmekte, mekân temsili, temsil mekânı ve mekânsal pratikler açısından Osmanlı'ya özgü toplumsal mekândan belirli kopuş görülse de henüz radikal bir kopuş ve farklı bir egemen mekânın üretimi söz konusu olmamıştır. Mekânın üretimi süreçleri önemli ölçüde ilkel birikim çerçevesinde gerçekleştiği, mekânın da bu ilkel birikim süreçlerinde önemli bir rolü olduğu görülmektedir. Mekânın gerçek üreticisi olan üretim güçleri ile üretim ilişkileri ise Osmanlı'dan kopuş sağlaması açısından yeterli seviyede olmadığı, ayrıca ulus-devlete özgü bir mekânın üretimi için üstyapısal düzlemin de Osmanlı'ya özgü toplumsal mekândan kopuş sağlayacak ve sergileyecek nitelikte olmadığı görülmektedir. Bu bakımdan 1923-1950 arası döneminin yaygın olarak "Erken Cumhuriyet" dönemi olarak tanımlanmasının mekânın üretimi ve mevcut egemen toplumsal mekân açısından büyük ölçüde elverişli bir tanım olmadığı ve bu dönemin en az ilk on yılında Ankara'da tamamen farklı bir mekânın üretimi 
süreçlerinin gerçekleştiği, bunun ise Osmanlı'nın tarihsel mekânının egemenliğinin korunduğu ve yeniden üretildiği bir dönem olduğu söylenebilir. Ancak 1930'lu yıllardan itibaren Cumhuriyetin modernleşme projesi bağlamında mekânın üretimi açısından radikal kopuş yaşandığı ve ulus-devletleşmeye özgü soyut mekân üretimi gerçekleştiği görülmektedir.

1930-1980 arası dönemde Ankara' da mekânın üretimi süreçlerine ve soyut mekânın üretimine bakıldığında, bu süreçlerin ulus-devletleşme ile kapitalistleşme bağlamında gerçekleştiği fakat her iki bağlamın tüm dönem boyunca aynı ölçüde etkili ve belirleyici olmadığı görülmektedir. $\mathrm{Bu}$ açıdan 1930-1950 arası dönemde Ankara'da üretilmekte olan soyut mekânın, mekânın mübadele süreçlerine dâhil olunup gayrimenkulleşme ve soyutlaşmasından ziyade üretim güçlerinin elverdiği imkânlar çerçevesinde ideolojinin belirleyiciliğinin ürünü olduğu görülmektedir. Mekânın üretiminde ideolojinin belirleyiciliği ise mekânın üretiminde mekânın ekonomi politiği ve onun bağlamında değişim değerinin kullanım değerine göre egemen olmasından ziyade, ideolojik düzlemde dönemin modernleşme çabaları doğrultusunda mekâna münhasıran siyasi bir kullanım değeri atfedilmesinden kaynaklandığ söylenebilir. Henüz tam olarak yerleşmemiş kapitalist üretim güçleri ve ilişkilerine (altyapısal düzlem) kıyasla üstyapısal düzlemin mekânın üretimindeki belirleyici rolü ise toplumsal mekânın algılanan, tasarlanan ile yaşanan boyutlarında önemli dönüşümler getirmekle beraber daha çok mekânsal temsillerin üretimiyle sınırlıydı. Dolayısıyla, 1930-50 arası dönemde üretilmekte olan mekânın bir soyut mekân olması, modern bir toplum yaratmak içim mekânın münhasıran politik kullanım değeri atfedilmesinden ve bu doğrultuda toplumsal mekânın algılanan, tasarlanan ile yaşanan boyutlarını yeniden biçimlendirme çabalarından kaynaklanmaktaydı.

1950-1980 arası dönemde ise mekânın üretiminde politik unsurun ve mekânın politik kullanım değerinin önemi kaybetmemesi, farklı biçimlerle öne çıkması, dahası mekânın, kitlesel siyaset alanında önem kazanmasıyla birlikte, mekânın üretimi süreçlerinde mübadele süreçlerinin önemli ve belirleyici rol kazandığı söylenebilir. 1950 sonrası dönemde benimsenen yeni birikim rejimi dünya eklenme ve kapitalist üretim güçleri ile üretim ilişkilerinin gelişmesi açısından önemli bir dönemeç olduğu ve modern bir mekânın üretimi için yeterli altyapısal dayanağı oluşturduğu görülmektedir, fakat aynı zamanda bu dönemde bir önceki dönemin modernleşme sürecinin aşınmasına da tanıklık edilmiştir. Dolayısıyla, 1950-80 arası dönemi modern bir mekân üretecek altyapısal yeterliliğe ulaşmış fakat üstyapısal aşınmanın yaşandığı dönem olarak tanımlamak mümkündür.

Böylece, 1930-80 arası dönemde mekânın üretimi süreçlerinin bir önceki döneme kıyasla birbirini takip eden iki sürecin - ulus-devletleşme ile 
kapitalistleşme - çerçevesinde gerçekleştiği, bu süreçte 1930-50 arası dönem Cumhuriyetin modernleşme projesi doğrultusunda modern bir ulus-devlete özgü, münhasıran politik bir soyut mekânın üretildiği bir dönem iken, değişen birikim rejimi ve kapitalist dünyasına eklenmesiyle kapitalistleşmenin daha ağır bastığ 1 1950-80 arası dönem ise mekânın mübadele süreçlerinde daha fazla dahil olunma ve önem kazanmasıyla soyut mekânın egemen nitelik kazandığı bir dönem olarak tanımlanabilir.

1980 sonrası dönemde ise Türkiye'de gerek altyapısal (ileri kapitalizmin esnek birikim rejimi) gerekse üstyapısal düzlemde (neoliberal İslamcılık) paradigmatik değişimleriyle Ankara'da mekânın üretimi süreçlerinin bu çerçevede gerçekleştiği ve bu bağlamda ileri kapitalizmin çelişkili mekânın ortaya çıktığı, toplumsal mekân bağlamında bu çelişkilerin kullanım ile değişim, bütün ile parça, mekân temsili ile mekânsal pratikler arasında dişa vurulduğu görülmektedir. Dönemin özelliği aynı zamanda kamusal alanda İslami unsurun görünürlük kazanmasıyla ve politik alanda siyasal İslamın yükselişiyle, toplumsal mekânın üretimi süreçlerinde mekânın algılanan, yaşanan ile tasarlanan boyutlarının her biri içerisinde çelişkili temsil ve pratikler meydana geldiği hususudur; ileri kapitalizmin ve neoliberal paradigmanın, mekânı gayrimenkulleşme süreçlerine daha fazla dahil ettirmesine paralel olarak, politik düzlemde yükselen İslami unsur, mekânı aynı zamanda farklı yönelimli kullanımlara göre yeniden tanımlanmasını beraberinde getirmiştir, bu husus ise toplumsal mekâna ilişkin temsiller ve pratiklerin kayda değer çelişkilerine yol açmıştır. Bununla beraber, bu dönem için tamamen neoliberal bir mekânsal rejim ve ona özgü birikim pratiklerinin egemenliğinden söz edilemez. Böyle bir rejimin tesisi ise gerek temsiller ve söylem gerekse pratikler açısından 2000 sonrası dönemde gerçekleşmiştir ve bu dönemde ileri kapitalizmin çelişkili mekânının özellikleri daha baskın nitelik kazanmıştır. 



\section{BÖLÜM}

\section{SONRASI DÖNEMDE ANKARA'DA MEKÂNIN ÜRETIMI}





\section{SONRASI DÖNEMDE ANKARA'DA MEKÂNIN ÜRETIMI}

Çalı̧̧manın bu bölümünde 2002 sonrası dönemde Ankara'da mekânın üretimi süreçleri ele alınacaktır. Bir önceki bölümde 1980 sonras1 dönemde mekânın üretim süreçleri neoliberal kentsel politikaları ile İslamcı siyasetin yükselişi bağlamında ele alınırken bunu Lefebvre'in önerdiği çelişkili mekân ve böyle bir mekânın algılanan, yaşanan ile tasarlanan boyutları bağlamında ana hatlarıyla değerlendirildi. Bu bölümde de benzer bir çerçeveyle AKP döneminde Ankara'yı ele alırken çelişkili mekânın temel dinamikleri bağlamında mekânın üretimi ele alınacaktır. Bu açıdan mekânın üretimi süreçleri ele alınırken özellikle iktidarların söylemi ve pratikleri mercek altında olacaktır. Burada iktidarla kast edilen ise gerek merkezi iktidarı gerekse bir yerel yönetim birimi olan Ankara Büyükşehir Belediyesi'ni elinde bulunduran Adalet ve Kalkınma Partisi'dir. Dolayısıyla mekânın üretimi süreçleri mekânsal pratikler, mekân temsilleri ve temsil mekânları bağlamında ele alındığında bu üç unsuru, iktidarın (ilk önce Büyükşehir Belediyesi olarak) mekânsal pratikleri, mekân temsilleri ile temsil mekânları olarak değerlendirilecektir. ${ }^{576}$

576 Toplumsal mekânın üretimi süreçlerini incelemek için Lefebvre'in önerdiği mekânsal üçlü çalışmamızın kuramsal bölümünde ayrıntılı olarak tartışılmıştır ayrıca Cumhuriyet tarihi boyunca farklı mekân evreleri bağlamında somut biçimde uygulanmaya çalışılmıştır. Bu bölümde ise özellikle iktidarın mekânın üretimi pratiklerine odaklanılacağı için Lefebvre'in önerdiği üçlüyü daha dar bir konu bağlamında (belediyenin mekânın üretimi politikaları) uygunlaştırmak için çok kısa bir not biçiminde yeniden tanımlama gerektirmektedir. $\mathrm{O}$ yüzden mekân temsili tanımı gereği politikacıların, planlamacıların ve tasarımcıların mekânı olduğu için bu bölümde iktidarın, mekân ile ilgili uygulamaları, pratikleri ve projeleriyle belirli mekânın ne için üretildiği, üretilen mekanların hangi amaca hizmet edeceği mekân temsili olarak tanımlanmıştır. Ayrıca mekân temsili olarak iktidar tarafından belirli mekanlara söylem düzeyinde nasıl bir işlevsellik yüklendiği kastedilmektedir. Yani somut bir uygulamayla belirli mekanların dönüşümü söz konusu olmayabilir fakat farklı mekanlara söylemsel düzeyde yeniden tanımlama gerçekleştirilebilir. Temsil mekânı ise tanımı gereği hem gerçek hem de hayali mekanlar, imgelemin nüfuz ettiği mekanlar olduğu için, burada temsil mekânı olarak farklı mekanlara belirli 'değerler' atfedilmesi, belirli olaylarla anılması veya unutturulması olarak yeniden tanımlanmaktadır. Bu durumda, herhangi bir mekâna belirli bir işlev yüklenmesinden ziyade -ki bu husus temsil mekânı ile de ilişkili olmakla beraber daha çok mekân temsili kapsamına girmekte- 'değer' yüklenme hususu kastedilmektedir. Mekânsal pratikler ise iktidar tarafından, mekânın üretimi politikaları aracılığıyla ne tür mekânsal pratiklerin aşılmaya, teşvik edilmeye çalışıldığı, gündelik hayatta kentsel mekânın günlük kullanım bağlamında ne tür mekânsal pratikler üretmek veya yeniden üretmek amaçlandığı olarak tanımlanmaktadır. Toplumsal mekânın üç boyutunu oluşturan bu unsurların yeniden tanımlamasından yola çıkarak somut bağlamda bu üç momentinin analizi 
Daha önce tartışıldığ1 üzere İbrahim Melih Gökçek 1994'ten itibaren ABB'nin belediye başkanı olarak görevini sürdürmüştür. Eski ANAP'lı olan Melih Gökçek 1994'te büyükşehir belediye başkanı olarak Refah Partisi'nden seçilmişken 1999 Yerel Seçimlerinde artık kapatılmış olan RP'nin yerine Fazilet Partisinden belediye başkanı olarak seçilmiştir. 2004 Yerel Seçimlerinde ise M. Gökçek, Ankara Büyükşehir belediye başkanı olarak artık AKP'den seçilmiştir. $\mathrm{Bu}$ süreç içerisinde farklı partilerin temsilcisi olarak M. Gökçek tarafından belediye başkanlığı görevi yürütülmesine rağmen onun belediyecilik anlayışında, yönetim tarzında ve çizgisinde fazla değişiklik olmadığı söylenebilir. Zaten kendisi siyasal İslamın daha köklü geleneklerinden gelmediği için 28 Şubat sonras1 gerilimli sürecinde ve sonrasında da görevini sürdürebilmiştir. Fakat belediyecilik ve bu bağlamda mekânın üretimi süreçleri açısından 2002 sonrası dönemde bir öncekilerden farklılaşmaktadır. Zira bir önceki dönemlerde başlatılan neoliberal belediyecilik pratikleri bu dönemde daha geniş alanlara nüfuz eden bir seviyeye taşınmıştır. Öncelikle sermaye birikimi süreçlerine hizmet eden bu pratikler sayesinde ise Ankara'nın, Cumhuriyet tarihi boyunca en köklü çevresel ve toplumsal değişimlere tanık olduğu dönemlerden biri yaşanmıştır. Fakat bu dönem başta büyük ölçekli kentsel dönüşüm projeleri aracılığıyla kentin yapılı çevresinin değişimi ile sınırlı kalmamıştır. Benimsenen büyüme stratejisi doğrultusunda kentsel mekânın dönüşümünün önemli işlev kazanmasıyla beraber mekân üzerine söylemde de daha ileriye giden girişimler görülmüsstür. Böylece bir taraftan yapılı çevrenin üretimi bağlamında Ankara'da mekân temsili ile mekânsal pratikler ilişkilerinde, diğer taraftan ise mekân üzerine söylem bağlamında kentte temsil mekânı ile mekân temsili ilişkilerinde kayda değer dinamikler söz konusu olmuştur.

\subsection{Neoliberal Mekânsal Rejim Tamamlanırken: Mekânda Üretimden Mekânın Üretimine}

"Evinin içinde bu şehirde inek besleyenler var. 'Yapma, etme, artık bak süt markette, bakkalda, şurada burada satılıyor yapmayın. Bize bunu devredin, biz buralarda güzel evler yapalım, sizi oralara yerleştirelim."” - R. T. Erdoğan 577

2002 sonrası dönemde Türkiye'nin 1980'lerden beri süregelen neoliberal rejimin ileri bir aşamasına geçmesi, bu bağlamda ise kentsel mekânın üretiminin esasen neoliberal sermaye birikim pratikleri çerçevesinde gerçekleştirilmesi akademide yaygın olarak tartışılan bir konudur. Türkiye'de bu dönemin

gerçekleştirilmiştir. Analiz sırasında aynı zamanda Lefebvre'in önerdiği çeliş̧kili mekân kavramı ve ona özgü dinamikleri Ankara bağlamı için göz önünde tutulmuştur.

577 Erdoğan, “'Büyük İstanbul Tarihi’ Adlı Eserin Tanıtım Programında Yaptıkları Konuşma”. 
kentleşme ve mekân literatürünün sayısız çalışmalarının vardığı ortak nokta, söz konusu dönemde kentsel dönüşüm projeleri aracılığıyla kentsel mekânın sermayeye devri ve bunun aracılığıyla gerçekleşen sermaye birikimidir. Burada ise sadece Lefebvre'in kavramsallaştırmalarından yararlanarak bu süreçlerin genel bir tablosu sunulmaya çalışılacaktır.

Bir siyasi program olarak neoliberalizmin, sermaye birikim pratiklerine (kapitalizme) yaklaşımı, toplumsal hayatın her alanına bu birikim pratiklerinin olabildiğince yayması (gerekirse zor yoluyla) ve toplumsal hayatın her alanının 'piyasa mekanizmaları' çerçevesine, yani mübadele ilişkileri kapsamına dahil etmesidir.578 Önceden ele alındığı üzere, Lefebvre de, mekânın gayrimenkulleşerek mübadele süreçlerine dahil olmasını ileri kapitalizmde mekânın üretimi süreçlerinin en belirgin özelliği olarak tanımlamaktadır. Bu tanımlardan yola çıkıldığında 2000 sonrası Türkiye'de mekânın üretimi süreçlerinin en belirgin özelliği bunların, esasen neoliberal sermaye birikim pratikleri çerçevesinde gerçekleştirilmesidir. 2000 öncesi döneminde mekânın farklı boyutlarda ve ölçeklerde mübadele süreçlerinde gayrimenkulleşmesi söz konusu olmaklar beraber, ancak 2000 sonrası döneminde mekânın üretimi süreçlerinde bütünsel bir neoliberal rejimden, Lefebvre'in ifadesiyle "mekânın içinde şeylerin üretiminden mekânın üretimine geçişten" söz edilebilir. Böyle bir geçiş, uygun bir kurumsallaşma, yani mekân temsili gerektirmekteydi ve 2002'de gerçekleştirilen yasal düzenlemeler mekânın birikim süreçlerine tamamıyla dahil olmasına yol açan en önemli temsil işlevi görmekteydi. 2002 sonrası dönem, aynı zamanda Lefebvre'in işaret ettiği önemli bir gelişmeyle yakından ilişkilidir. Bu gelişme, gayrimenkul ve inşaat sektörünün sermaye zincirlerinde ikincil bir dolaşım olmaktan, sanayi ve finansal kapitalizmin uzun zaman geri kalmış ek bir dalı olmaktan çıkması ve ön plana geçmesidir. ${ }^{579}$

\subsubsection{Tasarlanan, Algılanan ile Yaşanan Üçlüde Kentsel Dönüşüm ve Anakentleşme}

2000 sonras1 neoliberal kentsel rejimin mekân temsili kamu yönetim reformu bağlamında bir takım yasal düzenlemelerden oluşmaktaydı. 5216 Sayılı Büyükşehir Belediye Kanunu'yla, Büyükş̧ehir Belediyelerine kentsel dönüşüm ve gelişim projelerini uygulama yetkisi verilmiştir, ayrıca büyükş̧ehir belediyelerine verilmiş görev ve hizmetler doğrultusunda her ölçekteki imar planlarını, parselasyon planlarını ve her türlü imar uygulamasını yapmak ve ruhsatlandırmak yetkisi sağlanmıştır (Madde 7).580 5393 sayılı Belediye

578 Gilbert, "What Kind Of Thing Is "Neoliberalism"?".

579 Lefebvre, Mekânın Üretimi, s. 339 vd.

580 R.G. $23.08 .2004 / 25531$ 
Kanunu'yla, belediyelere "kentin gelişimine uygun olarak eskiyen kent kısımlarını yeniden inşa ve restore etmek; konut alanları, sanayi ve ticaret alanları, teknoloji parkları ve sosyal donatılar oluşturmak, deprem riskine karşı tedbirler almak veya kentin tarihî ve kültürel dokusunu korumak amaciyla kentsel dönüşüm ve gelişim projeleri” uygulama, kentsel dönüşüm ve gelişim projelerine konu olacak alanlar ilan etmek gibi yetkiler tanınmıştır (Madde 73). Bu kanunla, belediyelere aynı zamanda "düzenli kentleşmeyi sağlamak, beldenin konut, sanayi ve ticaret alanı ihtiyacını karşılamak amacıyla belediye ve mücavir alan sınırları içinde", imarlı ve alt yapılı arsalar üretmek; konut, toplu konut yapmak, satmak, kiralamak ve bu amaçlarla arazi satın almak, kamulaştırma yapmak, bu arsaları trampa etmek, bu konuda ilgili diğer kamu kurum ve kuruluşları ve bankalarla işbirliği yapmak ve gerektiğinde onlarla ortak projeler gerçekleştirme yetkisi tanımıştır (Madde 69). ${ }^{581} 5366$ sayılı Yıpranan Tarihi ve Kültürel Taşınmaz Varlıkların Yenilenerek Korunması ve Yaşatılarak Kullanılması Hakkında Kanunla belediyelere "yıpranan ve özelliğini kaybetmeye yüz tutmuş; kültür ve tabiat varlıklarını koruma kurullarınca sit alanı olarak tescil ve ilan edilen bölgeler ile bu bölgelere ait koruma alanlarının, bölgenin gelişimine uygun olarak yeniden inşa ve restore edilerek, bu bölgelerde konut, ticaret, kültür, turizm ve sosyal donatı alanları oluşturulması, tabiî afet risklerine karşı tedbirler alınması, tarihi ve kültürel taşınmaz varlıkların yenilenerek korunması ve yaşatılarak kullanılması"na imkan sağlanmıştır. ${ }^{582}$ Kentsel dönüşüm açısından diğer önemli altyapısal düzenlemeler, 2003'ten başlayarak farklı yasalarla Toplu Konut İdaresi ile ilgili düzenlemelerdir ${ }^{583}$. Bunlarla Başbakanlık Toplu Konut İdaresi Başkanlığı (TOKİ) Türkiye'de sadece konut kredisi sağlama ve konut üretimiyle sınırlı görevleri olmayan, farklı amacı olan yapıların üretimine girişebilen, devlet mülkündeki arsaların tasarrufunda bulunabilen ve geliştiren, gecekondu dönüşüm projesi uygulayacağı alanlarda her tür ve ölçekteki plânlar ile imar plânlarını yapmaya, yaptırmaya ve tadil etmeye, yerel yönetim birimleriyle anlaşmadan kamulaştırma gerçekleştirebilen, kentsel dönüşüm projelerine girişen en önemli aktör haline getirilmiştir. En

581 R.G. $13.07 .2005 / 25874$

582 R.G. $05.08 .2005 / 25866$

5834966 sayılı Bazı Kanunlarda ve Bayındırlık ve İskân Bakanlığının Teşkilât ve Görevleri Hakkında Kanun Hükmünde Kararnamede Değişiklik Yapılmasına Dair Kanun (R.G. 07.08.2003/25192), Toplu Konut Kanununda ve Genel Kadro ve Usulü Hakkında Kanun Hükmünde Kararnamenin Eki Cetvellerin Toplu Konut İdaresi Başkanlığına Ait Bölümünde Değişiklik Yapılması Hakkında Kanun (R.G. 12.05.2004/25460), 5273 sayılı Arsa Ofisi Kanunu ve Toplu Konut Kanununda Değişiklik Yapılması ile Arsa Ofisi Genel Müdürlügünün Kaldırılması Hakkında Kanun (R.G. 15.12.2004/25671), 5582 sayılı Konut Finansmanı Sistemine İlişkin Çeşitli Kanunlarda Değişiklik Yapılması Hakkında Kanun (R.G. 06.03.2007/26454), 5793 sayılı Bazı Kanun ve Kanun Hükmünde Kararnamelerde Değişiklik Yapılmasına Dair Kanun (R.G. 06.08.2008/26959). 
önemlisi, bu düzenlemelerle TOKİye gerek bağlı ortaklarla gerekse kamu-özel ortaklıklar aracılı̆̆ıyla kâr amacı güdülen konut üretimine girişme yetkileri sağlanmıştır. ${ }^{584}$

$\mathrm{Bu}$ düzenlemelerle neoliberal birikim pratiklerinin yeni mekânsal rejimi için kapsamlı bir kurumsal dayanak hazırlanmıştır, o yüzden bu düzenlemeleri neoliberal rejimin mekân temsili olarak tanımlamak, konumuz açısından daha yerinde olur. Böyle bir mekân temsili aracılığıyla Ankara başta olmak üzere geniş gecekondu bölgelerini içeren kentler, yapılı çevrenin üretimi aracılığıyla sermaye birikiminin sağlanması için esas mekânlara dönüşmüşler. 2000 yılı itibarıyla toplam nüfusun $\% 65$ 'ini 500 bin gecekondudan oluşan bölgelerde barındıran Ankara' da ${ }^{585}$ özellikle bu sürecin etkisiyle önemli mekânsal değişimler yaşanmaya başladı ve Türkiye'de gerek kentsel dönüşüm projelerinin kapsamı ve gerekse dönüştürülen gecekondu bölgeleri sayısı açısından Ankara öteden beri öncül bir konumdadır (bkz. Şekil 12, Tablo 3). Örneğin 2003'ten itibaren Türkiye'de TOKİ tarafından gerçekleştirilen toplam 177 kentsel dönüşüm ve gelişme projesinin 39'u (\%22) Ankara'nın payına düşerken, bu projeler aracılığıyla üretilen 91110 konutun 23470’u (\%25,7) Ankara'da üretilmiştir. ${ }^{586}$

Böylece TOKİ'nin söz konusu projelerine Ankara Büyükşehir Belediyesi tarafından söz konusu dönemde (bazıları yine TOKİ ile ortaklaşa) gerçekleştirilen ve halen gerçekleştirme aşamasında olan ve yaklaşık olarak 37 bin hektarı aşkın kentsel dönüşüm projeleri de eklenince, Ankara'daki kentsel dönüşümün boyutları açığa çıkmaktadır.

584 Türkiye'de kentsel dönüşüm ile ilgili hukuki düzenlemelerle ilgili daha detaylı olarak bkz. Daşkıran ve Ak, "6306 Sayılı Kanun Kapsamında Kentsel Dönüşüm”; Genç, "Türkiye'de Kentsel Dönüşüm: Mevzuat ve Uygulamaların Genel Görünümü”; Seydioğulları, "Yeni Yasal Düzenlemelerle Kentsel Dönüşüm"; Uzun, "Yeni Yasal Düzenlemeler ve Kentsel Dönüşüme Etkileri"; Yasin, "Kentsel Dönüşüm Uygulamalarının Hukuki Boyutu". Bu bağlamda özel olarak çıkarılan 5104 sayılı Kuzey Ankara Girişi Kentsel Dönüşüm Projesi Kanunu (R.G. 12.03.2004/25400) da belirtilmelidir, zira bu kanun aracilığıyla 'kentsel dönüşüm' kavramı Türkiye'de hukuken de yerleşmiş oldu. Söz konusu düzenlemeler bağlamında özellikle "Kentsel Dönüşüm Yasası" olarak tanımlanan 6306 sayılı Afet Riski Altındaki Alanların Dönüştürülmesi Hakkında Kanun (R.G. 31.05.2012/28309) da kentsel dönüşüm süreçlerinin önemli hukuki dayanağını oluşturan bir diğer düzenleme olarak belirtilmelidir.

585 Keleş, Kentleşme Politikası, s. 513.

586 Kentsel dönüşüm geçirmesi açısından Ankara'nın önemi, büyük gecekondu bölgeleri olan diğer iki kentle- İstanbul ile İzmir'le karşılaştırıldığında daha belirgin hale gelmektedir. Örneğin, 2003'ten beri TOKİ tarafindan İstanbul ve İzmir'de gerçekleştirilen sırasıyla 17 ve 6 kentsel dönüşüm ve gelişim projesi aracılığıyla bu iki kentte toplamda 7536 konut üretilmiştir. Benzer biçimde Türkiye'de toplam 2707 TOKİ projesi kapsamında üretilen 629612 konuttan İstanbul ve İzmir'de üretilen konut sayıs1 sirasiyla 69571 ve 12396 iken, Ankara'da üretilen konut sayıs1 87164'dir. Bkz. TOKİ, "İllere Göre Projeler". 
Şekil 12. Ankara'da Kentsel Dönüşüm Alanları

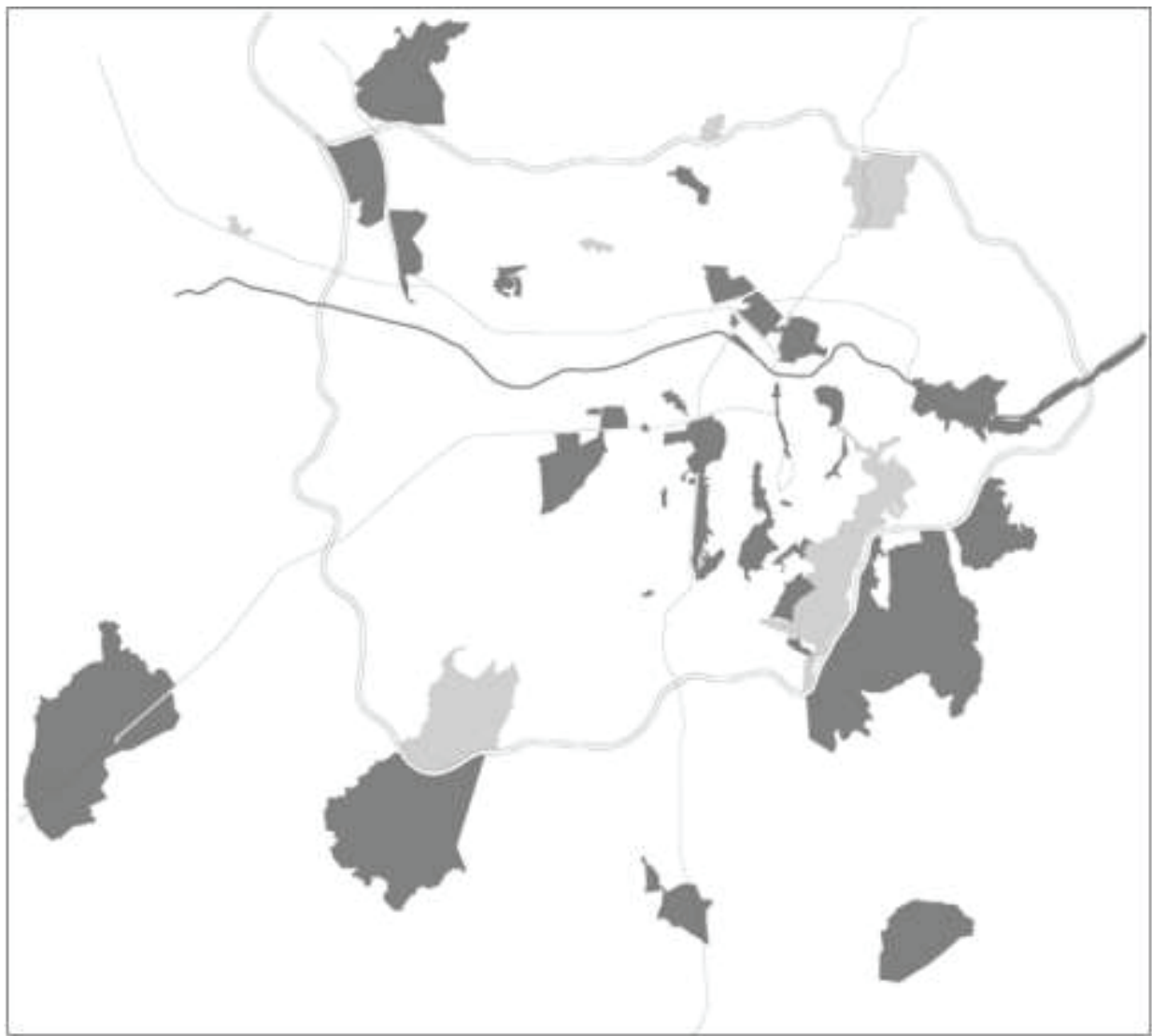

Kaynak: Batuman, "City profile: Ankara”, s. 587.

Kentsel mekânın önemli bir kısmını bazen mahalle ölçeğinde bazense daha geniş ölçekte 'sil baştan' yeniden düzenleyen, söz konusu mekânların fiziksel dokusunu ve sosyal çehresini tamamen dönüştüren bu projeler, mekânda üretimden topyekûn bir mekân üretimine geçişin örneklerini teşkil ederek, bu bağlamda ileri kapitalizmde devlet ile sermayenin, mekânı daha üst ölçekte tahayyül etme eğilimini (mekân temsili) ortaya koymaktadır. Bu bakımdan, 2002 sonrası neoliberal kentsel rejimin mekân temsili olarak tanımladığımız yasal düzenlemeler de mekânın daha üst ölçekte tahayyülünü destekleyen bir çerçeve olarak görülmelidir. Fakat bir mekân temsili olarak kentsel dönüşümün yasal çerçevesi veya mekânı daha üst ölçekte tahayyül eden kentsel dönüşüm pratikleri önemli bir başka hususa işaret etmektedir. 
Tablo 3. 2003-2017 Arası Dönemde Türkiye ile Ankara'da TOKİ Projeleri ${ }^{587}$

\begin{tabular}{|l|c|c|c|c|}
\hline \multirow{2}{*}{ Proje Tipi } & \multicolumn{2}{|c|}{ Türkiye } & \multicolumn{2}{c|}{ Ankara } \\
\cline { 2 - 5 } & $\begin{array}{c}\text { Proje } \\
\text { Sayıs1 }\end{array}$ & $\begin{array}{c}\text { Konut } \\
\text { Sayıs1 }\end{array}$ & $\begin{array}{c}\text { Proje } \\
\text { Sayı1 }\end{array}$ & $\begin{array}{c}\text { Konut } \\
\text { Sayıs1 }\end{array}$ \\
\hline İdare Konut Uygulaması & 603 & 225538 & 40 & 23280 \\
\hline Konut + Sosyal Donatı & 403 & 168599 & 49 & 30312 \\
\hline Kentsel Dönüşüm ve Gelişim Projesi & 177 & 91110 & 39 & 23470 \\
\hline Alt Gelir Grubu & 103 & 42974 & 1 & 1176 \\
\hline Afet Konutu & 110 & 31646 & 1 & 726 \\
\hline Gelir Paylaşımlı Proje & 45 & 24796 & 9 & 4916 \\
\hline Altyap1 ve/veya Sosyal Donatı & 909 & 12147 & 74 & 1854 \\
\hline Talep Organizasyon & 87 & 23076 & 3 & 324 \\
\hline Tarımköy & 41 & 5555 & - & - \\
\hline İkmal İhalesi & 38 & 3423 & 8 & 1022 \\
\hline Kamu Hizmet Binası & 117 & 603 & 18 & 84 \\
\hline Bakım ve Onarım & 14 & 144 & 7 & - \\
\hline Restorasyon & 16 & - & 1 & - \\
\hline Stadyum & 20 & - & - & - \\
\hline Hizmet Alımı & 3 & - & - & - \\
\hline Eğitim Öğretim Kurumu Binası & 2707 & 629612 & 252 & 87164 \\
\hline Diğer & & - & - & - \\
\hline Toplam & & - & 2 & - \\
\hline
\end{tabular}

Lefebvre, ileri kapitalizmde Devlet'in dönüşümünden söz ederken, devletin nitelikselden ziyade niceliksel anlamda dönüştügüne ve büyüme konusunda doğrudan veya dolaylı olarak sorumluluk üstlenmesinde, kapitalist gelişmesinin sağlanmasında ve artığın yeniden dağıtımında devletin baskın rolüne işaret eder, bunu ise devlet üretim biçimi olarak tanımlar. ${ }^{588}$ Devlet üretim biçimi tartışmalı bir kavram olmakla beraber, Türkiye'de 2002 sonrası neoliberal kentsel rejimin ortaya çıkışında devletin söz konusu rolü, kentsel mekânın

587 Tablo, Başbakanlık Toplu Konut İdaresi Başkanlığı verilerine dayanarak yazar tarafindan hazırlanmıştır. Bkz. TOKİ, "İllere Göre Projeler"; TOKİ, "Proje Tipine Göre Uygulamalar".

588 Henri Lefebvre, "Comments on a New State Form". 
kapitalist gelişme ve büyüme için gayrimenkulleşerek parsellenmesi ve piyasa mekanizmaları çerçevesinde mübadele süreçlerine dahil olması biçiminde görülmektedir. Lefebvre'ye göre, bu yeni üretim biçiminde devletin rolü üç boyutuyla, idari (gestionnaire), güvenlik sağlama (sécurisante) ve şiddet tekeli (mortelle) boyutlarıyla açığa çıkar ve bu rolü, teknokratlar, profesyonel siyasetçiler ve güvenlik uzmanları arasında farklı düzeylerden oluşan siyasi bir işbölümüyle gerçekleştirilir. ${ }^{589} \mathrm{Bu}$ bakımdan neoliberal kentsel rejimin tesisine ve pratiğine göz atıldığında 2002 sonrası dönem Ankara'nın mekânının kayda değer bir kısmının bir taraftan profesyonel siyasetçilerin ve teknokratların mekânı daha üst ölçekte tahayyül eden mekân temsili (kentsel dönüşüm mevzuatı ve kentsel dönüşüm için somut imar ve parselasyon işlemleri) doğrultusunda parselasyona maruz kaldığına tanık olunmuştur. Diğer taraftan bu süreçlerde somut dönüşüm uygulamalarında, ihtilafların, kentli ve barınma haklarının ortaya çıkışında, bölgelerde yaşayan halkın katılımı ve onların beklentilerinin göz ardı edildiği ve sorunlarının çözülmediği, onların öteden beri yaşadıkları bölgelerde yerinden edildiği, dönüşüm projelerinin halka zorla kabul ettirildiği,, 590 belediye aracılığıyla arsaların büyük ölçüde özel sermayenin ihtiyaçlarına devredildiği,591 kentsel dönüşüm projeleriyle üretilmekte olan sitelerin, kentsel mekânın bütünlügüünden soyutlanmış yerler olarak ortaya çıktığı görülmektedir. ${ }^{592}$

Böylece, bu projeler ve ortaya çıkan tasarlanan mekanlar iktidarın, üst ölçekte ve üst ölçekten mekânı tahayyül ederek mekâna müdahalesinin ürünüyken, sonuç olarak bütünsel bir mekân yerine ayrışmış ve parçalanmış bir mekân üretmişlerdir, bu süreçte ise çelişkili mekânın bütün ile parça arasındaki çelişkisini görmek mümkündür. Bu süreçte sermaye birikim pratikleri daha ön planda olduğundan dolayı aynı zamanda bu mekânların dönüşümü örneğinde çelişkili mekâna özgü değişim değeri odaklı mekân üretimi ile kullanım değeri odaklı mekân üretimi arasındaki çelişki öne çıkmaktadır. Daha önce ele alındığı üzere, 1960-70'lerin gecekondu mekanlarının üretimi süreçleri söz konusu dönemde belirli bir birikim rejiminin benimsenmesinin ve uluslararası denklemde asimetrik iliş̧kilerin ürünüydü. Bu mekânlar aynı zamanda bir süre sonra bu birikim rejimini ayakta tutan (emek gücünün yeniden üretimi bakımından) önemli mekânsal bileşenini oluşturmaktaydı.

589 Ibid.

590 Bkz. Aksoy, "Dikmen Vadisi: Sermayenin Kent Üzerinden Çevrimine Karşı Bir Başka Dayanışma Örneği"; Yaman, "Kentsel Dönüşüm Uygulamaları Ankara Büyükşehir Belediyesi: Dikmen Vadisi 3. Etap Örneği”.

591 Bkz. Y1lmaz, “An Inquiry into Different Urban Transformation Models in the Context of Rent and Property Transfer: The Case of Ankara Mamak District".

592 Bkz. Erman, “Mış Gibi Site”: Ankara'da Bir TOKİ-Gecekondu Dönüşüm Sitesi. 
2002 sonras1 neoliberal kentsel rejimindeyse bir mekân olarak gecekonduların yeni rolü, bu birikim rejiminin mekân temsilleri doğrultusunda yeniden düzenlenerek (yıkılarak) mevcut birikim rejimi için önemli bir mekânsal ayağı olmasıdır. Özellikle kentsel dönüşümün mekân temsilinin oluşumunda Avrupa Birliği ile uyum süreçlerinin etkisi593 (Akay ve Akgün, 2011; Genç, 2008) veya farklı biçimlerde kentsel dönüşüm süreçlerine uluslararası kuruluşlardan fonlar ve kredilerin sağlandığı da göz önünde bulundurulduğunda, yine bu süreçte mekânın üretiminde belirli bir asimetrik ilişkilerin varlığına işaret etmektedir. ${ }^{594}$ Sonuç ise öteden beri gecekondu mekânlarının ve genel olarak mekânın ${ }^{595}$, benimsenen birikim rejimine uygun olarak dönüşümü ${ }^{596}$ ve hakim olan birikim rejimi devamlılığı için önemli unsur olmasıdır.

Söz konusu dönemde kentsel dönüşüm projeleri bağlamında iktidarın söylemine, ki bu mekân üzerine söylem olarak görülmelidir, bakıldığında söylem düzleminde de neoliberal kentsel rejimin mekân temsilini görmek mümkündür.

593 Bkz. Akay ve Akgün, “Türkiye'de Planlamada Dönüşüm Süreci: Çevre ve Koruma mı? Kentleşme ve Yapılaşma mı?”; Genç, "Türkiye'de Kentsel Dönüşüm: Mevzuat ve Uygulamaların Genel Görünümü”.

$594 \mathrm{Bu}$ destekler açısından özellikle 6306 sayılı Afet Riski Altındaki Alanların Dönüştürülmesi Hakkında Kanunu bağlamında Avrupa Yatırım Bankası, Avrupa İmar ve Kalkınma Bankas1 ile Dünya Bankası tarafından sağlanan kredi destekleri, Dünya Bankası tarafından Türkiye'de tapu tescili ve kadastral modernleşme için yürütülen program örnek gösterilebilir. Bkz. EIB, "Isbank Urban Transformation"; Türkiye İş Bankası, "İ̧̧ Bankası'na Avrupa Yatırım Bankası'ndan 200 Milyon Euro Kredi"; EBRD, "EBRD Project Summary Documents"; World Bank, "Turkey-Cadastre Modernization Project".

595 Görülen eğilim, kentsel dönüşüm projelerinin sadece gecekondu bölgeleri için değil gerek büyük kısmını boş arsalar oluşturan bölgelerde (ör. İmrahor Vadisi Kentsel Dönüşüm Projesi) gerekse işlevsel açıdan gecekondulardan farklı nitelik taşıyan alanlarda (ör. Merkezi İş Alanı Kentsel Dönüşüm Projesi) gerçekleştirildiği görülmektedir. Benzer biçimde 2016'dan itibaren Türkiye'de şehirlerde kalan askeri alanların şehir dışına taşınmasıyla ilgili bu alanların kentsel dönüşüm kapsamında değerlendirilebileceği haberleri, özellikle büyük askeri alanlar içeren İstanbul (arazi mülkiyetinin \%10'u) ve Ankara için kentsel dönüşüm süreçlerinin bir sonraki dalgasının ipuçlarını sunmaktadır. Bunlar ise daha genel bir düzlemde kentsel dönüşüm süreçleriyle sadece gecekondu bölgelerinin sermaye tarafindan değerlendirilecek mekânlar olmadığını, bir bütün olarak kentin, sermayenin değerlendirebileceği bir mekâna dönüştügünü ve tamamen gayrimenkulleştiğini ve metalaştığını göstermektedir, bu ise neoliberal kentsel rejimin, mekânı yüksek ölçekte(n) tahayyül eden mekân temsili doğrultusunda 'mekânda şeylerin üretiminden mekânın üretimine geçiş’ hipotezini destekleyen bir diğer hususudur. Bkz. Çapa, "Boşaltılacak Askeri Araziler Konut Projelerine Mi Açılıyor?”; Evrensel.net, "Işık: Askeri Arazileri Kentsel Dönüşüm İçin Veririz".

596 Önceden de ele alındığı üzere Lefebvre'in hipotezine göre bir üretim tarzı veya birikim modundan diğerine geçiş sırasında yeni bir mekân üretilir, zira her üretim tarzı veya birikim modu kendine uygun mekâna sahiptir. Bkz. Lefebvre, Mekânın Üretimi, s. 75 vd. Bu açıdan 2002 sonrası neoliberal rejimine geçişiyle ve kentsel dönüşümle yıkılan/üretilen mekânlar bu hipotez bağlamında değerlendirilmelidir. 
Bu açıdan Haziran 2016'da "Antik Çağdan 21. Yüzyıla İstanbul” etkinliğinde katılan Cumhurbaşkanı Erdoğan'ın sözleri iktidarın mekân temsilini ve temsil mekanını özetleyecek niteliktedir;

"Evinin içinde bu şehirde inek besleyenler var. 'Yapma, etme, artık bak süt markette, bakkalda, şurada burada satılıyor yapmayın. Bize bunu devredin, biz buralarda güzel evler yapalım, sizi oralara yerleştirelim.' 'Yok, sen benim ineğimi aldığın zaman ben anama ne diyeceğim?' Mantık bu. Ve bunu İstanbul'un en nadide yerinde yapıyor, Fatih Sultan Köprüsü'ne girerken sağ tarafta. Maalesef o binalarda, o gecekondularda, o kaçak binalarda bu var. Ama inşallah devam eden ve hazırlıkları süren yeni projelerle İstanbul'u çok daha ileriye taşıyacağız." 597

Yukarıdaki ifadelerde "bu şehirde inek besleyenler var, artık bak süt markette, bakkalda, şurada burada satılıyor yapmayı" sözleri tamamen metalaştırılmış, gündelik gerçekliğin her kesitinin metalaşmış döngüler içerisinde gerçekleşen bir mekân temsilini ifade ederek, böylece toplumsal hayatın her alanının 'piyasa mekanizmaları' çerçevesine, yani mübadele ilişkileri kapsamına dahil etmeye çalışan neoliberal rejimin mekân temsilini de ifade etmektedir. "Bize bunu devredin, biz buralarda güzel evler yapalım" ifadeleriyle tekrardan karşımıza çıkan ise ilerleme, gelişme ve modernleşme söylemi bağlamındaki gecekondu karşıtı söylemidir. Fakat tekrardan öne çıkan modernleşme ve ilerleme söylemi, daha önce çalışmada ele alınan 196070'lerdeki gecekondulaşma süreciyle cumhuriyetin modernleşme süreçlerinin aşınması ile ilgili belirli gecekondu ve kent temsillerinin aksine, tekrardan öne çıkan modernleşme ve ilerleme söylemi, belirli bir üstyapısal modernleşme ve ilerlemeden ziyade tamamıyla ekonomik ilerleme ve büyümeye dayalı bir mekân temsilini ifade etmektedir. İşte bu bakımdan, AKP'nin, mekân bağlamında modernleşme ve ilerleme söylemi daha önceki modernleşme söyleminden farklılaşmakta, zira mevcut modernleşme ve ilerleme vurgusu genel olarak ekonomik büyüme ile ilerleme ve bunların somut ifadesi olan altyapı üretimiyle ilişkilidir.

Ankara örneğinde mekânın üretimi süreçleri bağlamında de benzer söylem görülmektedir. Şöyle ki ABB başkanı Melih Gökçek'in veya ABB resmi yayın organının söyleminde kentin mekânsal gelişmesiyle 'modern' ifadesinin sık sık kullanıldığ görülmektedir. 2012'de kabul edilip yürürlüğe giren 6360 sayılı kanunla ${ }^{598}$ Ankara Büyükşehir Belediyesi'nin sınırlarının Ankara il sınırlarına dayanması ve Ankara Büyükşehir Belediyesi'nin kapsadığı ilçeler sayısının

597 Erdoğan, “'Büyük İstanbul Tarihi’ Adlı Eserin Tanıtım Programında Yaptıkları Konuşma”.

598 "On Üç İlde Büyükşehir Belediyesi ve Yirmi Altı İlçe Kurulması ile Bazı Kanun ve Kanun Hükmünde Kararnamelerde Değişiklik Yapılmasına Dair Kanun”, R.G. 06.12.2012/28489 
artmasıyla ilgili konuşan Melih Gökçek, "yeni ilçelerden dolayı bize yapılacak katkıyı kat kat bu ilçelerimize hizmet olarak döndüreceğiz. Yani bize kaşıkla gelecekten, biz kepçeyle hem de misli, misli vereceğiz" 599 ifadelerindeki 'kepçe' sözcügü mecaz olarak kullanılmasına rağmen, Büyükşehir Belediyesi’nin mekân üretimi, gelişme ve ilerleme anlayışını da özetleyecek niteliktedir. Dahası Büyükşehir Belediyesi'nin resmi yayın organı - Büyükssehir Ankara - konu ile ilgili sayısının kapağı da 'kepçeli' hizmet anlayışını ifade edecek niteliktedir (bkz. Şekil 13).

Şekil 13. Büyükşehir Ankara Dergisi, Sayı 403 Kapak Sayfası
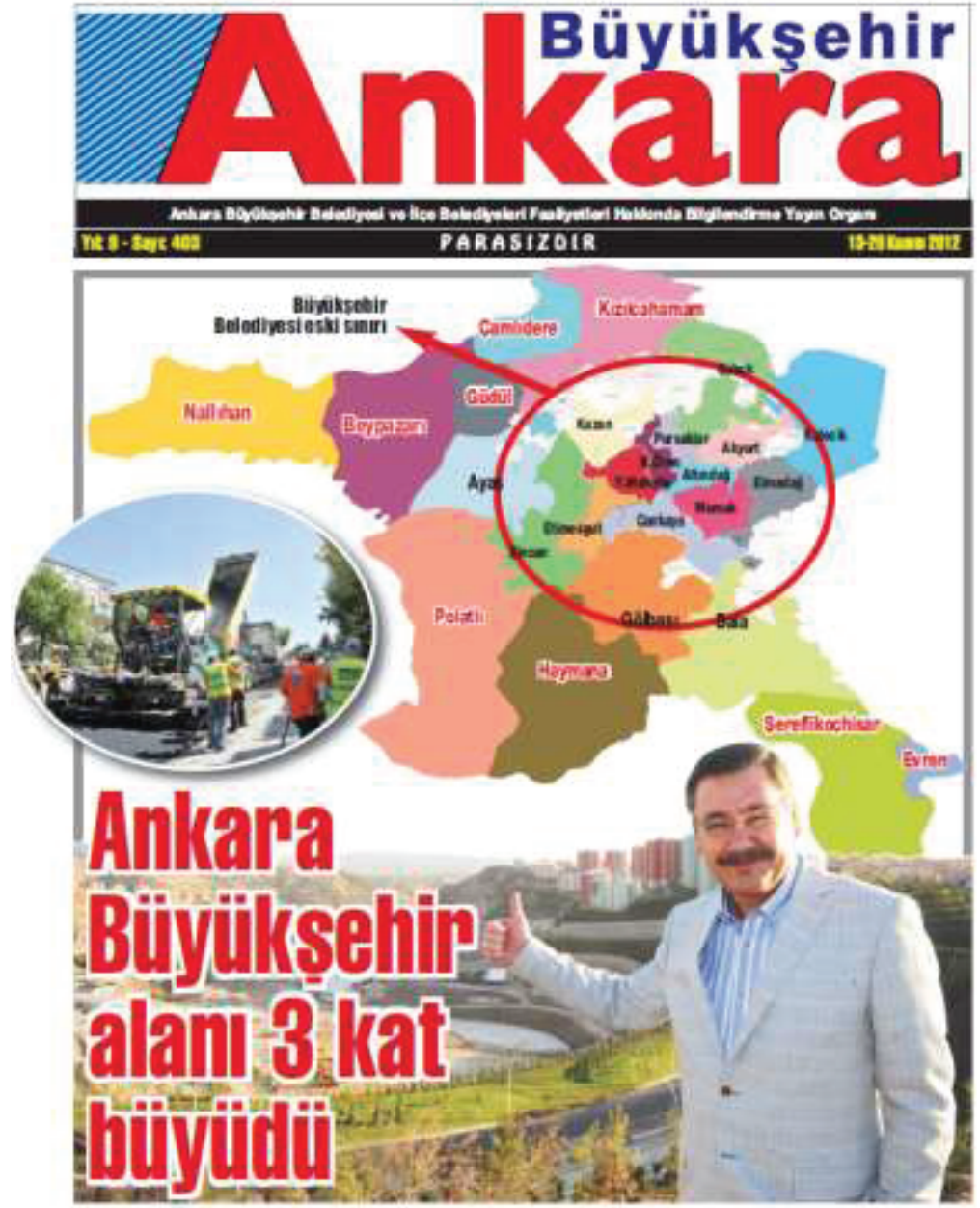

599 Turan, "Büyükşehir daha da büyüdü”, s. 6. 
Benzer biçimde aynı yayın organı, Büyükşehir Belediyesi'nin, kendi bünyesine yeni katılan ilçelerdeki altyapı çalışmalarını, "yııllardır asfalt görmemiş tozlu, topraklı, taşlı köy yolları Büyükşehir Belediyesi tarafından asfaltlanıyor, çizgileri çekiliyor ve modern bir görünüme kavuşturuluyor" ${ }^{\prime 60}$ diye betimlerken modernliğin, gelişme ve ilerlemenin asfaltlı çizgili yollara tekabül eden anlayışı ortaya koyan bir diğer örneği sunmaktadır. 601

Büyükşehir Belediye sınırlarının genişlemesinden söz ederken burada ele alınması gereken bir diğer husus, bu sınır genişlemenin de bir mekân üretimi biçimi olduğu, bu biçimin ise sadece mekânın sınırları aracılığıyla yeniden tanımlanması olarak öne çıkmadığı, somut bağlamlarda mekânın üretimi süreçleri açısından da önemli sonuç ve içerimler doğurduğunu belirtmek gerekir.

Daha önceden tartışıldığ üzere, Ankara' da metropoliten yönetim biçimine geçiş ilk kez 1984'te gerçekleştirilmiştir, ${ }^{602}$ mekânın böyle bir yeniden ölçeklendirilmesinin gerekçesi ise metropoliten yönetimin, hizmetlerin planlı, programlı, etkin ve uyum içinde yürütülmesinin sağlanması ve ölçek ekonomilerinden yararlanmasıyd. Metropoliten yönetim biçimi dolayısıyla idari açıdan bir mekân temsili olarak okunabilir. Böyle bir mekân temsili aynı zamanda

600 Semerci, “Ankara, En Ücra Köylerine Kadar Sicak Asfaltla Donatılıyor”, s. 4.

$601 \mathrm{Bu}$ bağlamda, AKP iktidarı döneminde ilerleme ve gelişme bağlamında egemen olan mekân temsilini açıklamak açısından Duru ve Turan'ın saptamaları kayda değerdir. Şöyle ki Türkiye, kentleşme sürecini 50 yıla sığdırmak zorunda kalmış bir toplum olması nedeniyle kentte yaşayan bireylerin büyük bölümü birkaç kuşak öncesi kırsal kesime dayanmaktadır, ayrıca önemli bir bölümünün geride bıraktıkları köyle ilişkileri hala sürmektedir. Böylece kır, yoksullukla ve geri kalmışlıkla çağrıştırılmaktadır. O yüzden kırsala ve doğaya yapılan her müdahale ve adım gelişme ve ilerleme olarak görülmekte ve tanımlanmaktadır. AKP'nin yerelde ve merkezde elde ettiği seçim başarılarında söz konusu algının da payı vardır. Bkz. Duru ve Turan, "Korumanın Yasal ve Yönetsel Boyutları: Bereketli Topraklardan Beton Bloklara".

$602 \mathrm{Bu}$ geçişin temel kurumsal dayanağ 1 , 195 sayılı Büyük Şehir Belediyelerinin Yönetimi Hakkında Kanun Hükmünde Kararnamesi (R.G. 23.03.1984/18350) ve söz konusu KHK'da değişiklikler getiren 3030 sayılı Büyük Şehir Belediyelerinin Yönetimi Hakkında Kanun Hükmünde Kararnamenin Değiştirilerek Kabulü Hakkında Kanun (R.G. 09.07.1984/18453) olmuştur. 3030 sayılı kanunla bir kent belediyesinin büyükşehir belediyesi olarak tanımlanabilmesi için tek bir kriter - belediye sınırları içerisinde birden fazla ilçe bulunma şartı aranmıştır (Madde 3). Bu kriterle ise İstanbul, Ankara ve İzmir'de büyükşehir belediye yönetim biçimine geçilmiştir ve bu üç bölgede iki kademeli (Büyükşehir Belediyesi, İlçe Belediyesi) bir metropoliten yönetim biçimi tesis edilmiştir. Ankara'da ise söz konusu düzenlemeyle Ankara İli'nin Altındağ, Çankaya, Yenimahalle, Keçiören ve Mamak İlçelerinden Ankara Büyükşehir Belediyesi oluşturulmuştur. Daha sonra Sincan, Gölbaşı ve ilçe statüsü edinen Etimesgut'un katılımıyla 8 metropol ilçe barındıran Ankara Büyükşehir Belediyesi 2004 yılına kadar böyle bir kapsama sahip olmuştur. Bkz. Özçağlar ve Bayar, “Ankara Büyükşehir Belediyesinin Yönetsel Sınırlarındaki Değişimin Ankara Şehrine ve Ankara İline Etkileri”; Turan, "Büyükşehir Daha Da Büyüdü". 
başta Ankara olmak üzere diğer büyük kentlerin de mekânın üretiminde en etkin aktör olarak yerel ve ulusal ölçekli sermaye ile beraber uluslararası sermayenin ihtiyaçlarına cevap verebilecek yöndeydi. O yüzden metropoliten yönetimine geçiş sermaye birikim pratikleri açısından da işlev görecek bir mekân temsilinin (mekânı daha üst ölçekte tahayyül etmenin) ürünüydü. ${ }^{603}$

İleri kapitalizmde mekânsal yeniden ölçeklendirmeye dikkat çeken Lefebvre, bu olguyu ileri kapitalizmin ürettiği çelişkili mekânın yarattığ "mekânların yaygınlaşmış dışa patlama" (generalized explosion of spaces) süreçleri bağlamında değerlendirmektedir. Şöyle ki hem tarihsel olarak gelişen ve günümüze uzanan kentlerde mekânsal dışa dönüş, bir 'dışa patlama' yaşanmakta hem de kentler ölçeğinde eskiden mevcut ve kentsel fenomeni kapsayan idari çerçeveleri dişa dönük bir patlama deneyimlenmektedir. Aynı zamanda bölgeler düzeyinde periferiler kendi özerklikleri için mücadele vermekte ve devlet, sermaye ve politik merkezileşmesine bağl1lıklarına meydan okumaktadır. ${ }^{604} \mathrm{Bu}$ bakımdan bugünlerde kentsel sorunsal 'ölçek sorunsalı' (la question d'échelle) olarak karşımıza çıkmaktadır. ${ }^{605} \mathrm{Bu}$ süreçte ise mekânın üretimi, yerel ölçekten küresel ölçeğe uzanan bir hiyerarşide farklı mekânsal ölçeklerin yeniden düzenlenmesi, kayması veya iç içe geçmesi gibi süreçleri içermektedir. 606

603 Türkiye'de 1984 'ten itibaren mevcut metropoliten yönetim sistemi, onun evrimi ve farklı boyutları (hukuki, idari, iktisadi, planlama vs.) için çok sayıda kayda değer çalışma bulunmaktadır ve bunların sayısı gün geçtikçe artmaktadır. Bkz. Alkan, "New Metropolitan Regime of Turkey: Authoritarian Urbanization via (Local) Governmental Restructuring"; Çınar, "Yerel Yönetimlerde Neoliberal Reform: Büyükşehir Belediyelerinin Yeniden Ölçeklendirilmesi”; Çınar ve diğerler, Belediyenin Sinırları; Dik, "6360 Sayılı Kanun Bağlamında Köylerin Mahalleye Çevrilmesi Sorunu"; Mengi ve Çınar, "Transformation Process of Rural Areas into Urban Areas in Turkey after 1980s"; Özçağlar ve Bayar, "Ankara Büyükşehir Belediyesinin Yönetsel Sınırlarındaki Değişimin Ankara Şehrine ve Ankara İline Etkileri"; Zengin, "Büyükşehir Belediyesi Sisteminin Dönüşümü: Son On Y1lın Değerlendirmesi”. Burada ise Ankara örneği üzerinde metropolitenleşme sürecinin herhangi bir boyutuna öncelik tanımadan, mekân üretimi açısından değerlendirilmesi amaçlanmıştır.

604 Henri Lefebvre, State, Space, World: Selected Essays, s. 190-191.

605 Brenner, "The Urban Question as a Scale Question: Reflections on Henri Lefebvre, Urban Theory and the Politics of Scale".

606 Lefebvre'in kuramsallaştırmalarına dayanarak ölçek sorunsalı konusunda daha detaylı incelemeler için konu ile ilgili en kayda değer külliyata sahip olan Neil Brenner'in çalışmalarına başvurulabilir, bkz. Brenner, "Globalisation as Reterritorialisation: The ReScaling of Urban Governance in the European Union"; Brenner, "Beyond State-Centrism? Space, Territoriality, and Geographical Scale in Globalization Studies"; Brenner, "Metropolitan Institutional Reform and the Rescaling of State Space in Contemporary Western Europe"; Brenner, New State Spaces: Urban Governance and the Rescaling of Statehood; Brenner, "The Urban Question as a Scale Question: Reflections on Henri 
Bu bakımdan, Türkiye'de 2000 sonrası dönemde neoliberal rejimin yeni bir aşamasında mekânsal yeniden ölçeklendirme sorununun tekrardan gündeme gelmesi ve 2004'te yeni bir kanunla metropoliten yönetimi biçimi için kriterlerdeki değişiklik ve bunlara göre nicel ve nitel bakımdan yeni bir metropoliten yönetimine geçişi, 2012'de ise benzer biçimde tekrardan mekânsal yeniden bir ölçeklendirme gerçekleştirilerek gerek coğrafi kapsam gerekse niteliksel açıdan daha kapsamlı bir değişiklik girişimi tesadüf değildir.

2004 y1lında yerel yönetimler reformu kapsamında Türkiye'de yeniden bir mekânsal ölçeklendirme gerçekleştirilerek ${ }^{607}$ Ankara Büyükşsehir Belediyesi'nin yetki alanı 4 kat genişletildi. Bir önceki yeniden ölçeklendirmeler gibi bu düzenleme yine ölçek ekonomileri ve daha etkin ve verimli hizmet sağlanması gibi hususlarla gerekçelendirilmekteydi ve aslında büyük ölçüde neoliberal politikalar çerçevesinde şekillenmişti. 608 Dolayısıyla bu sürecin neoliberal rejimin mekân temsilinin bir diğer ürünü olduğu söylenebilir. Ayrıca, yukarıda ele alınan kentsel dönüşüm ve gelişim süreçleri de göz önünde bulundurulduğunda ve bunların bazıları, Büyükşehir Belediyesi tarafından genişleyen alanlarda gerçekleştirilmesi de hesaba katıldığında, ölçek meselesi salt bir mekânsal gelişme olarak karşımıza çıkmamaktadır. Hizmet sağlaması için yapılı çevrenin üretimi (altyapı üretimi) kentsel gelişim ve dönüşüm projeleri ile beraber düşünüldüğünde mekânın üretimi açısından reel anlamda sonuçlar doğurduğu söylenmelidir. Dahası, Büyükşehir Belediyesi'nin neoliberal anlayış çerçevesinde hizmetlerin sunumunu neredeyse tamamen piyasa mekanizmaları çerçevesinde gerçekleştirdiği de göz önünde bulundurulduğunda, onun hizmet

Lefebvre, Urban Theory and the Politics of Scale"; Brenner, "The Limits to Scale? Methodological Reflections on Scalar Structuration".

607 Bunun kurumsal temelleri, 5216 sayılı Büyükşehir Belediyesi Kanunu, 5393 sayılı Belediye Kanunu, 5302 sayılı İl Özel İdaresi Kanunu ve 5355 sayılı Mahalli İdare Birlikleri Kanunudur. Bu doğrultuda, Büyükşehir Belediyelerinin yetki alanları için 'pergel sistemine' başvuruldu ve (İstanbul ile Kocaeli hariç) Büyükşehir Belediyesi sınırları genişletilecek her ilin valilik binası merkez olarak kabul edilerek 1 milyon nüfusa kadar olan büyükşehirlerde 20 kilometre, nüfusu 1 milyon-2 milyon arasında olanlarda 30 kilometre ve nüfusu 2 milyonun üzerinde olan Ankara ve İzmir'de 50 kilometre yarıçapın kapsadığı alan Büyükşehir Belediyelerinin görev ve yetki alanı olarak tanımlandı. Bu düzenleme ile Akyurt, Ayaş, Bala, Çubuk, Elmadağ, Kalecik, Kazan, Pursaklar ilçeleri Ankara Büyükşehir Belediyesi kapsamına dahil oldu. Bkz. Çınar, "Yerel Yönetimlerde Neoliberal Reform: Büyükşehir Belediyelerinin Yeniden Ölçeklendirilmesi”; Özçağlar ve Bayar, "Ankara Büyükşehir Belediyesinin Yönetsel Sınırlarındaki Değişimin Ankara Şehrine ve Ankara İline Etkileri”; Turan, "Büyükşehir Daha Da Büyüdü”.

608 Bkz. Çınar, "Yerel Yönetimlerde Neoliberal Reform: Büyükşehir Belediyelerinin Yeniden Ölçeklendirilmesi”. 
alanının genişlemesi de mevcut neoliberal kentsel politikaların uygulama alanlarının genişlemesini de beraberinde getirmiştir. ${ }^{609}$

Fakat Ankara'da mekânın üretimi ve neoliberal kentsel rejim açısından ölçek sorunsalı bağlamında daha kapsamlı gelişme, Ankara Büyükşsehir Belediyesi’nin görev ve yetki alanlarını Ankara İli sınırlarıyla tanımlayan 6360 say1lı yasaydı. ${ }^{610} 6360$ sayılı yasa, özellikle yukarıda ele alınan süreçler bağlamında değerlendirildiğinde, bir bakımdan 2000'lerden itibaren yerleşmekte olan neoliberal kentsel rejimin mekân temsilinin oluşum sürecini büyük ölçüde tamamladığ 1 söylenebilir. Zira bu yasayla, Türkiye'de yeni bir kentleşme dönemin, Alkan'ın tanımlamasıyla 'otoriteryen kentleşmenin'611 kapılarını aralamıştır.

6360 sayılı yasanın getirdiği ve en çok tartışılan yeniliklerden biri büyükşehir bulunan illerde büyükşehir belediyesinin sınırları il mülki sınırlarıyla tanımlanmasıyla daha önce bu illerde büyükşehir belediyesinin yetki alanında bulunmayan yerel yönetim birimlerinin tüzel kişiliklerinin kaldırılması ve mahalle olarak ilgili ilçelere bağlanmasıdır. Bu husus, özellikle Avrupa Yerel Yönetimler Özerklik Şartı ve Kent Hakkı bağlamında çok sayıda akademik eleştirilere tabi tutulmuştur, 612 aynı zamanda tartışmalarda köylerin mahalleye dönüşmesi köyün kendine özgü kimliğini yitirmesine yol açacağı üzerinde de durulmaktadır.

609 Örneğin 5216 sayılı yasa sonrasında ortaya çıkan bütünleştirme sorunlarını ele alan Çınar, Çiner ve Zengin'in araştırmasının saha çalışmasının sonuçları, Ankara'da sınırların genişlemesiyle birlikte ilk kademe belediyeleri tarafindan ASKİ'nin sorumluluk alanına girilmesine rağmen hizmetlerin sunulmasında farklılaşma olmadığı, buna rağmen ilk kademe belediyelerinde su maliyetlerinin artığı kaydedilmektedir (Çınar, Çiner ve Zengin, Büyükşehir Yönetimi Bütünleştirme Süreci, s. 275). Böylece aynı çalışmada da belirtildiği gibi bütünleştirme sürecinde kentsel hizmet alanlarının daha çok ticarileşme eğilimleri güç kazanmıştır.

610 “On Üç İlde Büyükşehir Belediyesi ve Yirmi Altı İlçe Kurulması ile Bazı Kanun ve Kanun Hükmünde Kararnamelerde Değişiklik Yapılmasına Dair Kanun” (R.G. 06.12.2012/28489). Bu yasayla, Ankara Büyükşehir Belediye sınırları Büyükşehir olarak tanımlanan diğer yerel yönetim birimleri gibi, il sınırlarına dayanmaktadır. Bu doğrultuda 2014 yerel seçimleriyle yürürlüğe giren bu kanunla Ankara İlinde bulunan Beypazarı, Çamlıdere, Evren, Güdül, Haymana, Kızılcahamam, Nallıhan, Polatlı ve Şereflikoçhisar ilçeleri Ankara Büyükşehir Belediyesi'ne katılarak Ankara metropoliten alanını 3 kat artırmıştır. Aynı zamanda, tüm ilçelere bağlı olan köylerin tüzel kişilikleri kaldırılarak mahalleye dönüştürülmüştür.

611 Alkan, "New Metropolitan Regime of Turkey: Authoritarian Urbanization via (Local) Governmental Restructuring".

612 Bkz. Çınar ve diğerleri, Belediyenin Sınırları; Duru, "Büyükşehir Tasarısı ve Kent Hakkı"; İzci ve Turan, "Türkiye'de Büyükşehir Belediyesi Sistemi ve 6360 Sayılı Yasa ile Büyükşehir Belediyesi Sisteminde Meydana Gelen Değişimler: Van Örneği”; Keleş, "Anakentlerin Dünü, Bugünü ve Yarını”; Çetin, “Türkiye'de İl Özel İdaresi Sisteminin Dönüşümü ve 6360 Sayılı Kanunun Dönüşüme Etkileri”. 
Kavramsal olarak bu süreç değerlendirildiğinde, köylerin tüzel kişiliklerinin kaldırılması ve mahalleye dönüştürülmesi belirli bir mekân temsili doğrultusunda mekânın yeniden tanımlanması olarak değerlendirilebilir, sonuç itibarıyla, bu süreç üstten müdahaleyle iktidarın mekânı yeniden tanımlama girişimidir. Fakat bu süreç gerçek anlamda da mekân temsili açısından kayda değer değişiklikler getirmiştir, şöyle ki söz konusu düzenlemeyle, mahalleye dönüşen köylerdeki yapılaşmaların önemli kayıt ve envanterizasyon işlemi öngörülmüştür. ${ }^{613}$ Daha önce belirtildiği üzere, mekânın mübadele ilişkilerine dahil olması için ilk şart, onun farklı biçimlerle envanterizasyonudur. $\mathrm{Bu}$ bakımdan söz konusu yasanın ilgili maddesi, ilk önce kayıt/ruhsatlandırma işlemiyle vergi tabanı genişletme amacı taşıyor olmasıyla beraber, ilk önce köy halkının faaliyetlerini 'piyasa mekanizmaları' gözüyle değerlendiren, onları bir 'işletme' sayan yaklaşımdır, dolayısıyla köy halkının mekân kullanımı farklı bir temsili getirmektedir - her şeyi piyasa mekanizmaları çerçevesinde düzenlenmesini öngören neoliberalizmin mekân temsili. Ayrıca, söz konusu yasayla köy halkının su, kanalizasyon, katı atık toplama ve bertarafı ve benzer hizmetlerde vergi mükellefi yapılması öngörülmüsstür. ${ }^{614} \mathrm{Bu}$ bakımdan, günümüz Türkiye'sinin neoliberal belediyecilik pratiklerine ve neredeyse tüm kentsel hizmetlerin sağlanmasında tam maliyete göre fiyatlandırma politikaları göz önünde bulundurulduğunda, söz konusu değişimlerin neoliberal kentsel

6136360 sayıl1 kanunun Geçici Madde 1'in 14. Fıkrasına göre, "mahalleye dönüşen köylerde, bu Kanunun yayımlandığ tarih itibarıyla 25/4/2006 tarihli ve 5490 sayılı Nüfus Hizmetleri Kanununa göre oluşturulan Ulusal Adres Bilgi Sistemine kayıtlı veya Bilim, Sanayi ve Teknoloji Bakanlığı tarafından uydu fotoğraflarıyla tespit edilen, entegre tesis niteliğinde olmayan tarım ve hayvancılık amaçlı yapılardaki işletmeler ile bu yerlerde oturanların ihtiyaçlarını karşılayacak bakkal, manav, berber, firın, kahve, lokanta, pansiyon, tanıtım ve teşhir büfeleri, yerleşim yeri halkı tarafindan kurulan ve işletilen kooperatifler işletme ruhsatı almış sayılır. Bu işletmelerin bulunduğu binalar ile konutlardan, bu Kanunun yayımlandığı tarihe kadar bitirilmiş olanlar, Çevre ve Şehircilik Bakanlığı veya belediye ya da üniversiteler tarafından fen ve sanat kuralları ile ilgili mevzuat hükümlerine uygun yapıldığı tespit edilenler ruhsatlandırılmış sayılır. Ayrıca bu yapılar elektrik, su ve bunun gibi kamu hizmetlerinden yararlandırılır. Ancak; bu fikranın öngördüğü uygulamaların özel kanun hükümlerine aykırı olması durumunda, özel kanun hükümleri geçerlidir.”

$614 \mathrm{Bu}$ kanunun Geçici Madde 1/15'e göre "Bu Kanuna göre tüzel kişiliği kaldırılan köylerde, bu fikranın yürürlüğe girdiği tarihten itibaren 29/7/1970 tarihli ve 1319 sayılı Emlak Vergisi Kanununa göre alınması gereken emlak vergisi ile 26/5/1981 tarihli ve 2464 sayılı Belediye Gelirleri Kanunu uyarınca alınması gereken vergi, harç ve katılım payları beş yıl süreyle alınmaz ve 31/12/1960 tarihli ve 193 sayılı Gelir Vergisi Kanununun 9 uncu maddesinin birinci fikrasının üçüncü bendi, 23üncü maddesinin birinci fikrasının birinci bendi ile beşinci bendi, 66ncı maddesinin birinci fikrasının beşinci bendi hükümleri 31/12/2017 tarihine kadar (bu tarih dâhil) uygulanmaya devam edilir. Bu yerlerde içme ve kullanma suları için alınacak ücret beş yıl süreyle en düşük tarifenin \%25'ini geçmeyecek şekilde belirlenir. 10/7/2004 tarihli ve 5216 sayılı Büyükşehir Belediyesi Kanununun geçici 2nci maddesi ile köy tüzel kişiliği kaldırılarak mahalleye dönüştürülen yerlerde de bu fikra hükmü uygulanır." 
rejimin mekân temsili doğrultusunda gerçekleştirildiği açıktır. Çınar ve diğerlerinin de belirttiği gibi,

"Türkiye'deki ölçek belirleme süreci genel olarak ekonomik bakış açısı çerçevesinde başlatılmış; özel olarak sermayenin büyüme gereksinimine yanıt verecek biçimde uygulamaya geçirilmiş; katma/birleştirme uygulamaları daha çok etkinlik ve verimlilik ilkesinden yola çıkan bir anlayış doğrultusunda sürdürülmüş; demokrasi, yerel özerklik ve halk katılımı gibi konular ise görmezden gelinmiştir. Toplumsal ve ekonomik olarak kırsal nitelik gösteren yerleşim yerlerinin birdenbire kentsel alan olarak kabul edilmeye başlanması da yukarıdaki tercihin doğal bir yansıması olarak değerlendirilmelidir."615

Türkiye'de söz konusu mekânsal yeniden ölçeklendirilmenin genel olarak sermayenin büyüme gereksinimine göre yapılmasıyla beraber, bu sürecin aynı zamanda temsil mekânı boyutu da vardır ve bu yukarıda ele alınan büyüme, ilerleme anlayışının kırsal alan temsili ve kırsal alanın az gelişmişlik, yoksulluğun temsil mekânı olarak tanımlanması bağlamında önem kazanmaktadır. "Eskiden toz, toprak ve çamur içindeki mahalleler"616 veya "tozlu, topraklı ve taşlı köy yolları" kırsal alanın, geri kalmışlığının temsil mekânıdır. Tanım gereğinceyse mekân temsili ile temsil mekânını bir araya getiren, onlar arasında uyum sağlayan mekânsal pratikler olduğu617 için söz konusu ilerlemenin temsil mekânı ile geri kalmışlığın temsil mekânını bir araya getirmenin yolu 'kepçeli' mekânsal pratiklerdir.

$\mathrm{Bu}$ bakımdan söz konusu mekânsal yeniden ölçeklendirmeyle Ankara Büyükşehir Belediyesi, tüzel kişilikleri kaldırılan ve mahalle statüsü edinen toplam 672 köyde 618 kayda değer altyapı üretimi seferberliği başlatmıştır. Bugünden geriye bakıldığında, hem yol açma ve var olan yolların yenilenmesi, asfaltlanması, hem de su ve kanalizasyon gibi altyapıların geliştirilmesi, ulaşımın yeniden düzenlenmesi bakımından ABB önemli bütünleşme ve 'mekânsal dışa patlama' seferberliği içindedir. Örneğin 2014'te Ankara' da toplam serilen asfalt miktarının yaklaşık \%21'i mahalleye dönüştürülen köylere pay düşerken, 2015'te aynı rakam yaklaşık olarak \%35'i teşkil etmiştir ve neredeyse tüm köylere asfalt serimi gerçekleştirilmiştir (bkz. Tablo 4). Asfalt serilen yolların uzunluğu da benzer oranları göstermiştir. ${ }^{619}$

615 Çınar ve diğerleri, Belediyenin Sinırları, s. 218-219.

616 Bkz. Semerci ve Bingöl, "Işste Büyükşehir Farkı".

617 Bkz. Lefebvre, Mekânın Üretimi.

618 YAYED, "Kapanacak Köy ve Beldeler Listesi (Büyükșehirler)".

619 ABB, "2014 Faaliyet Raporu”, s. 167; ABB, “2015 Faaliyet Raporu”, s. 135, 195. 
Tablo 4. 30.03.2014-04.08.2015 Döneminde İlçelere Göre Asfalt Serimi

\begin{tabular}{|l|c|l|c|}
\hline \multicolumn{1}{|c|}{ İlçe } & $\begin{array}{c}\text { Serilen asfalt } \\
\text { miktarı (ton) }\end{array}$ & \multicolumn{1}{c|}{ İlçe } & $\begin{array}{c}\text { Serilen asfalt } \\
\text { miktarı (ton) }\end{array}$ \\
\hline Akyurt & 152782 & Haymana & 97923 \\
\hline Altındağ & 346621 & Kalecik & 57119 \\
\hline Ayaş & 81594 & Kazan & 166371 \\
\hline Bala & 8647 & Keçiören & 487320 \\
\hline Beypazarı & 205000 & Kizılcahamam & 234744 \\
\hline Çamlıdere & 130662 & Mamak & 424228 \\
\hline Çankaya & 656407 & Nallıhan & 74194 \\
\hline Çubuk & 442786 & Polatlı & 185280 \\
\hline Elmadağ & 118415 & Pursaklar & 247395 \\
\hline Etimesgut & 314499 & Şereflikoçhisar & 70338 \\
\hline Evren & 22418 & Sincan & 488725 \\
\hline Gölbaşı & 369750 & Yenimahalle & 1097423 \\
\hline Güdül & 102578 & & \\
\hline Toplam & 6583219 & & \\
\hline
\end{tabular}

Kaynak: Semerci ve Bingöl, "İşte Büyükşehir Fark1", s. 9.

Tablo 5. Yıllara Göre Ankara İlçelerinde ASKİ Abone Sayılarındaki Değişim

\begin{tabular}{|l|r|r|r|r|}
\hline İlçe & \multicolumn{1}{|c|}{$\mathbf{2 0 1 2}$} & \multicolumn{1}{c|}{$\mathbf{2 0 1 3}$} & \multicolumn{1}{c|}{$\mathbf{2 0 1 4}$} & \multicolumn{1}{c|}{$\mathbf{2 0 1 5}$} \\
\hline Akyurt & 9053 & 9730 & 10508 & 12216 \\
\hline Altındağ & 134204 & 139112 & 145337 & 148415 \\
\hline Ayaş & 4995 & 5385 & 7078 & 7948 \\
\hline Bala & 3566 & 3771 & 6084 & 7510 \\
\hline Beypazarı & 0 & 0 & 24496 & 26467 \\
\hline Çamlıdere & 0 & 0 & 2056 & 2316 \\
\hline Çankaya & 350099 & 352596 & 408312 & 413421 \\
\hline Çubuk & 29016 & 30290 & 31880 & 33754 \\
\hline Elmadağ & 15499 & 15806 & 16582 & 17049 \\
\hline
\end{tabular}




\begin{tabular}{|l|r|r|r|r|}
\hline Etimesgut & 133140 & 140875 & 187156 & 19846 \\
\hline Evren & 0 & 0 & 1100 & 1118 \\
\hline Gölbaş & 38296 & 39945 & 43980 & 45463 \\
\hline Güdül & 0 & 0 & 5437 & 6282 \\
\hline Haymana & 0 & 0 & 8481 & 10740 \\
\hline Kalecik & 3511 & 3626 & 5036 & 5861 \\
\hline Kazan & 1257 & 13688 & 14864 & 16096 \\
\hline Keçiören & 303974 & 31551 & 326634 & 336018 \\
\hline Kızılcahamam & 0 & 0 & 11298 & 13164 \\
\hline Mamak & 191578 & 202426 & 214541 & 225195 \\
\hline Nallıhan & 0 & 0 & 11450 & 12772 \\
\hline Polatlı & 0 & 0 & 45675 & 49752 \\
\hline Pursaklar & 39970 & 42713 & 44949 & 47156 \\
\hline Sincan & 159724 & 164899 & 171162 & 174061 \\
\hline Şereflikoçhisar & 0 & 0 & 15825 & 17088 \\
\hline Yenimahalle & 301986 & 323879 & 252167 & 262029 \\
\hline Toplam & 1731181 & 1804251 & 2011987 & 2090351 \\
\hline Kaynak: ASKI 2015 Falis & 0507,65 & & & \\
\hline
\end{tabular}

Kaynak: ASKİ, “2015 Faaliyet Raporu”, s. 65.

Aynı şekilde su ile kanalizasyon altyapıları konusunda Büyükşehir Belediyesi tarafından yoğun kamulaştırma, içme ve atık suyu hatları döşeme gibi çalışmalar ilgili bölgelerde devam etmiş ${ }^{620}$ ve bölgede ASKİ abonelik işlemleri de büyük ölçüde tamamlanmıştır (bkz. Tablo 5).

Böylece, "dağa taşa asfalt dök[en], köylerin adeta çehresini değiştir[en]"621 veya "bu yörelerin çehrelerini değiştir[en], refah düzeylerini artır[an]"622 mekânsal pratiklerle büyükşehir bütünleștirme sürecine yeni katılan "eskiden toz, toprak ve çamur içindeki"623 veya "tozlu, topraklı ve taşlı"

620 ASKİ, "2014 Faaliyet Raporu”; ASKİ, "2015 Faaliyet Raporu”.

621 Melih Gökçek’ten akt. Turan ve Bingöl, "Başkan Gökçek: “2014 Yüz Ak1 Bir Y1l Oldu””, s. 11.

622 Semerci, Köprülü ve Abay, "Büyükşehir, 25 İlçeye 1.5 Y1lda 2.2 Milyar Liralık Yatırım Yapt1...", s. 5.

623 Semerci ve Bingöl, "İşte Büyükşehir Farkı”. 
dolayısıyla 'geri kalmış' kırsal alanlar yeni bir temsile, ilerlemenin ve gelişmenin somut tezahürü olan asfalt temsiline kavuşmuştur (bkz. Şekil 14).

Şekil 14. İlerlemenin ve Refahın Temsil Mekânı: Yeni Yollar ve Asfalt
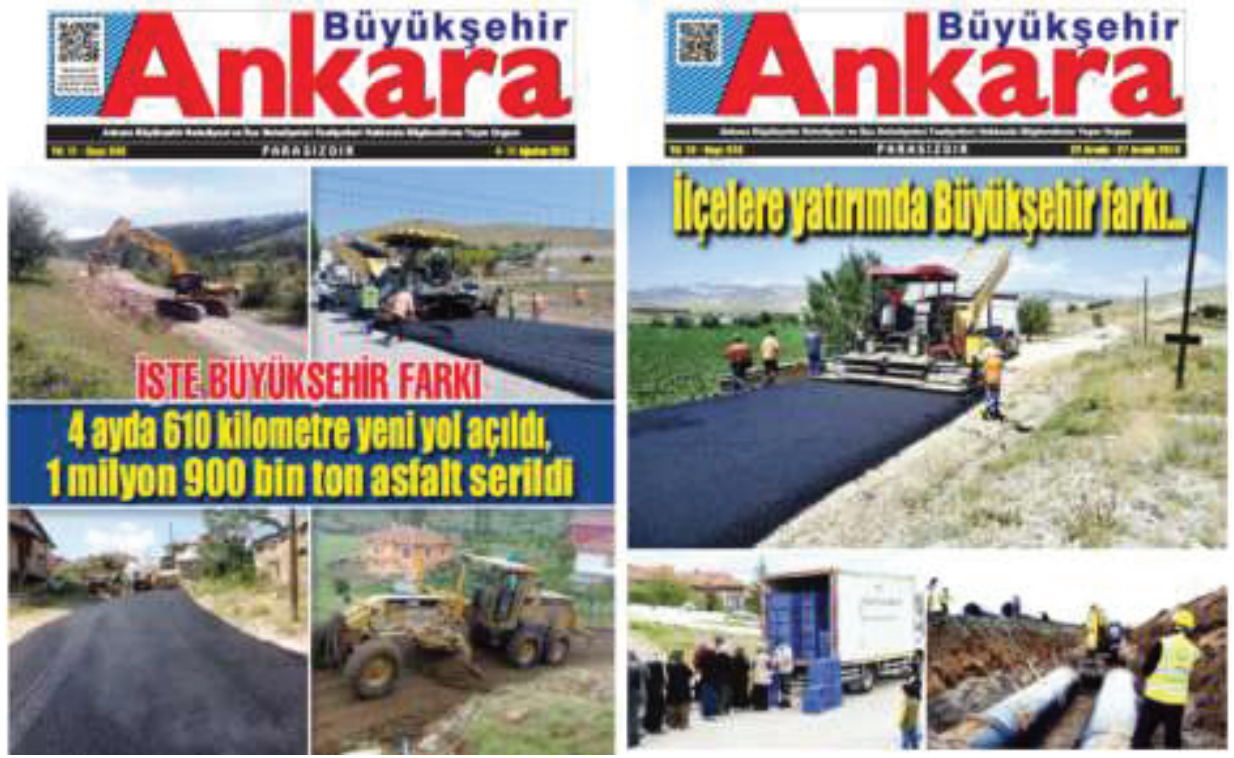

Kaynak: Büyükşehir Ankara Bülteni, 543 ile 613 sayılarının kapak sayfaları.

Yukarıda ele alınan hususlar bağlamında söylem düzleminde bir diğer kayda değer örnek, Cumhurbaşkanı Erdoğan tarafından Ankara Gölbaşı'nda 10 Nisan 2015 tarihinde Yeni Türkiye Stratejik Araştırmalar Merkezi açılış töreninde yapılan konuşmadır;

"Buraların 10 yıl önce 20 yıl önceki durumunu şimdi bir tahayyül edin, tamamıyla buralar boş, çorak arazilerdi (...) İnanıyorum ki çok kısa zaman sonradan buralar çok farklı bir mekân haline gelecek. Köydü, şimdi bakın mahalle oldu. Bu büyük Türkiye'de, yeni Türkiye'deki hedeflerimizdir. Şahsım olarak büyükşehirler projesine bütün ilçelerin katılması gerektiğini söylediğim zaman birçok insan bana güldü. Eğer büyükşehirler idealini gerçekleştirmemiş olsaydık, yani bugün 30 büyükşehrimiz olmamış olsaydı buralar köyden mahalleye dönüşmezdi. Daha ötesini söylüyorum. Artık bizim 81 büyükşehrimizin olması lazım. Yeni Türkiye'nin buna da kilitlenmesi lazım. Bunu niye söylüyorum? Hakkâri'ye şu anda siz bu haliyle bakarsanız, orası bu durumda kalmaya mahkûmdur. Ama bir büyükşehir anlayışıyla baktığınız zaman Hakkâri değişecektir. Bu değişim, şunu da iddiayla söylüyorum, birçok ilimizi adeta terörün gizlilik alanlarını 
meydana çıkaracak olan bir şehirleșme süreci olacaktır. Eğer bunu gerçekleştiremezseniz orada terör her zaman gizli kalacaktır, kendine o mekânı bulacaktır."624

Yukarıdaki ifadelerden de görüldüğü üzere köylerin mahalleye dönüştürülmesi sürecinde, kırsal alan "boş ve çorak" sıfatıyla geri kalmışlığın ve yoksulluğun temsil mekânı olarak öne çıkmaktadır, büyükşehirleşme süreciyleyse bu alanların kente bağlanması bir ilerleme süreci olarak tanımlanmakta ve bu, 'Yeni Türkiye'nin hedefi (mekân temsili) olarak belirtilmektedir. Bu hedefin, eskiden "boş ve çorak" kırsal arazi olan fakat artık parsellenerek imara kavuşmuş olan, dahası Yeni Türkiye adıyla bir stratejik araştırma merkezi bulunduran ve merkezin açılış töreninde açıklanması, söz konusu sürecin 'stratejik' niteliğine işaret eden ilginç bir temsili bağlam içermektedir aynı zamanda.

$\mathrm{Bu}$ ifadelerdeki ilginç diğer husus, 81 ilin büyükşehir olması yani bütün illerde kırsal alanların benzer süreçten geçmesi gerekliliğine yapılan vurgudur, zira böyle bir süreç "terörün gizlilik alanlarını meydana çıkaracak", aksi takdirde "terör her zaman gizli kalacaktır, kendine o mekânı bulacaktır." Bu ifadelerde böylece kırsal alan farklı bir temsil mekânı olarak da öne çıkmakta, yani iktidar tarafindan denetlenemeyen bir mekân olarak tanımlanmakta, o yüzden söz konusu denetlenemeyen "alanları meydana çıkaracak olan bir şehirleşme süreci"yle, yani belirli bir mekân temsiliyle bu mekânlar üzerine denetim sağlanacaktır. Böylece anakentleşme süreci aynı zamanda Türkiye'deki anakentleşme literatürünün şimdiye kadar neredeyse ele almadığı önemli bir hususa -politik ve askeri denetimin aracı olarak mekânı daha üst ölçekte(n) tasarlayarak denetim sağlanmasına - işaret etmektedir. ${ }^{625} \mathrm{Bu}$ tarafiyla ise böylece anakentleşme süreci devlet üretim biçiminde devletin öne ç1kan üç rolüyle - idari (gestionnaire), güvenlik sağlama (sécurisante) ve şiddet tekeli (mortelle) - ilişkilenmektedir. Mekânsal yeniden ölçeklendirme olan anakentleşme süreçlerinin temel gerekçesi olarak ölçek ekonomileri, sermayenin mekân temsili doğrultusunda mekânsal yeniden düzenleme veya bir idari birim olarak kentin yetki sınırlarını emek gücünün (yeniden) üretiminin gerçek

624 Erdoğan, "Yeni Türkiye Mücadelemiz, Bizim Kızıl Elmamızdır".

625 Söylem düzleminde böyle ifadeler aynı zamanda Stephan Graham tarafindan öne sürülen askeri kentçilik olgusuyla da ilişkilenmektedir. Askeri kentçilik ise son zamanlarda dünya çapında kentlerin mekânının güvenlikçi anlayışla yeniden düzenlenmesi ve kentlerin, önemli güvenlik altyapıları ve birimleri barındırmasıdır. Bu sadece planlama aracılığıyla mekânsal pratiklerin denetimiyle sınırlı değil, aynı zamanda kentlerde insanların biyometrik gözetimi, kapalı devre televizyon sistemleriyle (CCTV) izlenmesi, çoğalan güvenlik ve kontrol noktaları, ayrıca eskiden kentlerde görevli olan kolluk birimlerinin daha askeri bir donatımla görevlerini sürdürmesini kapsamaktadır. Daha detaylı olarak bkz. Graham, Cities Under Siege: The New Military Urbanism. 
sınırlarına yaklaştırma ${ }^{626}$ gibi hususlar olabilir; fakat mekânın politik kullanım değeri de göz önünde bulundurulmalıdır. Sonuçta 'en ücra köylere' ulaştırılan asfalt yollar oralara sadece katı atık toplama veya toplu taşıma araçlarının hızlı ve kolay ulaşabilmesi için değildir. Ya da bir köydeki farklı mekân kullanımlarının kayıt ve envanterizasyonu sadece emlak vergisi toplama gibi işlemlere hizmet edecek nitelikte değildir. Lefebvre'in, devlet üretim biçiminin çelişkili mekânı için belirttiği gibi,

"Mekân, devlet için öncelikli öneme sahip bir politik araç haline gelmiştir.

Devlet, yerlerin kontrolünü ve kendi hiyerarşisini, bütünün homojenliği ve parçaların segregasyonu garantilemek şeklinde mekânı kullanmaktadır. Bu mekân, böylece idari olarak denetlenen, hatta polisin inzibatı altında olan mekandır." $" 627$

Bu durum aynı zamanda çelişkili mekâna özgü olan ve mekânda şeylerin üretiminden mekânın üretimine geçiş olarak tanımlanan sürece ilişkilidir, onun dışavurumu olarak karşımıza çıkmaktadır. Şöyle ki çok güçlü bir politik tahakküm, pazarlara yeterli hâkimiyet sağlanmadan komşu adacıklardan hep mekânsal bir kaos doğma ihtimali mevcuttur, ${ }^{628}$ bu ise mekanda şeyler üretimi sürecinin zayıf tarafidır, o yüzden mekânı daha üst ölçeklerde(n) tahayyül edilerek bütünsel (topyekun) bir mekânın üretilmesi ihtiyacı doğar (mekân temsili), bunda ise mekânın daha üst ölçeklerde planlaması ile tasarlanması ve bununla somut pratiklerin (mekânsal pratikler) üretimi önem kazanmaktadır. Fakat bu süreçte mekâna denetim sağlamayı, "yerlerin kontrolünü ve bütünün homojenliğii"ni garantilemeye yönelik söz konusu mekân temsilleri, somut düzeyde "parçaların ayrışması"nı sağlar aslında, zira somut düzeyde yapılan işlem mekânın imara tabi tutularak parselasyonudur. Yani karşımıza çıkan, çelişkili mekânın bütün ile parça arasındaki, mekân temsili ile mekânsal pratikler arasındaki çelişkileridir.

626 Önceden ele alındığı üzere, Manuel Castells kenti araştırmak için kentin sınırlarının tanımlanmasında herhangi bir idari sınırlar yerine coğrafi olarak emek gücünün üretimi ile yeniden üretimi sınırlarıyla tanımlamıştır. Bkz. Castells, City, Class and Power; Castells, The Urban Question: A Marxist Approach. Bu bakımdan, anakentleşme süreçleri hızlı kentleşmiş bölgelerde ölçek ekonomisi aracılığıyla daha etkin ve verimli hizmetler sunumuyla gerekçelendirmenin ve anakentleşme düzenlemelerinin, kentin mevcut idari sınırları ile emek gücünün üretimi ile yeniden üretiminin sınırlarını birbirine yaklaştırma girişimi olarak da görülmelidir. Sonuçta ölçek ekonomisiyle sunulan kentsel hizmetler emek gücünün üretimi ile yeniden üretimine yöneliktir.

627 Lefebvre, State, Space, World: Selected Essays, s. 182.

628 Lefebvre, Mekânin Üretimi, s. 90. 


\subsection{2. "Dünyada En Rahat Trafik Akışı” Sağlanırken}

Ankara' da ele alınan dönemde kentsel mekânın bütünleşmesine yönelik ve kentin genel morfolojisini etkileyen bir diğer gelişme ki yukarıda ele alınan anakentleşme süreciyle de yakından ilişkilidir, ABB tarafından gerçekleştirilen ulaşım altyapısı düzenlemeleri ve Melih Gökçek'in belediye başkanlığ 1 döneminde Ankara'nın 'simgesi' haline gelen köprülü kavşak, alt üst geçit ile bulvarlardır. "Cumhuriyet tarihinin rekoru" olarak takdim edilen ${ }^{629}$ bu projeler kentin makroformunu yeniden biçimlendirmekle beraber, kentsel mekânın kullanımında günlük mekânsal pratikleri de önemli ölçüde yeniden biçimlendirdiği söylenebilir.

"Başkent yeni kavşaklarla donatılıyor", "Başkent trafiğinin can damarı, yeni yapılan geçit ve kavşaklar", "Ankara'da her gün yeni bir kavşak hizmete giriyor", "Başkent ulaşımına yeni nefes", "Batı koridor trafiğine neşter", "Anadolu Bulvarı üzerine köprülü kavşak çalışması başladı" gibi manşet veya başlıklar ABB resmi yayın organının Ankara'daki gelişmeleri aktarmasında çok s1k görülebilecek konulardan biridir. ${ }^{630}$ Böyle başlıklar, sadece belediyenin inşaat odaklı mekânsal pratiklerini göstermekle sınırlı kalmayıp, aynı zamanda kentin yapılı çevresinin hızlı değişim ve dönüşümü ve Ankaralıların çoğu tarafından mekânsal pratikleri aracılığıyla kentsel gerçekliğin hızlı değişiminin deneyimlenmesini de yansitmaktadır. Ayrıca bunlar ABB tarafindan kentsel mekânın tercih edilen kullanım biçimleri (mekânsal pratikler ile ilgili tahayyülü) de yansitmaktadır, bu tahayyül ise, kentsel mekânda araç trafiğinin hacmi ve hızının olabildiğince arttırılmasıdır. ABB tarafindan Ankara aynı zamanda büyüklüğü açısından kendisiyle kıyaslanabilir kentler arasında Türkiye şöyle dursun dünyada "en rahat trafik akışına sahip" bir kent olarak sık sık ifade edilmektedir. ${ }^{631}$ Böyle bir statü, hangi ölçütlere göre edinildiği şöyle dursun, Büyükşehir Belediyesi'nin, kentsel mekânın tercih edilen kullanım biçimi, yani mekânsal pratikler tahayyülü de ortaya koymaktadır, ayrıca Ankara'nın, "en

629 ABB, “1071 Malazgirt Bulvarı'na Muhteşem Açılış”, s. 7.

630 Bkz. Semerci, "Başkent Yeni Kavşaklarla Donatılıyor”; Bingöl, "Başkent Trafiğinin Can Damarları Yeni Yapılan Geçit ve Kavşaklar”; Bingöl, “Ankara'da Her Gün Yeni Bir Kavşak Hizmete Giriyor"; Semerci, "Başkent Ulaşımına Yeni Nefes"; ABB, "Batı Koridoru Trafiğgine Neşter”; Semerci, “Anadolu Bulvarı Üzerine Köprülü Kavşak Çalışması Başladı”.

631 Bkz. Bingöl, "Başkan Melih Gökçek Projeleri Denetledi”; Bingöl, "Başkent Trafiğinin Can Damarları Yeni Yapılan Geçit ve Kavşaklar”; Bingöl, “Ankara’da Her Gün Yeni Bir Kavşak Hizmete Giriyor”; Bingöl, “Cumhuriyet Bayramı'nda 13 Alt-Üst Geçidin Açılışıyla Çifte Bayram Yaşanacak"; Semerci ve Bingöl, "Çubuk Yolu'nda Modern Yenileme”; Bingöl, "Dünya Standartlarında Yön Lehvaları Başkent Yollarında"; Bingöl, "Başkent'e Yeni Yol Gösterici Lehvalar"; Bingöl, "Başkent Yollarında Güvenli ve Konforlu Sürüş Keyfi"; Semerci, "Başkent'te Asfalt Çalışması Dört Bir Yanda Sürüyor...”; Bingöl, "Başkent' in Yeni Can Damarları Açılış İçin Gün Sayıyor". 
rahat trafik akışına" sahip olan kent 'statü'sünü koruması için adeta bir seferberlik içinde olduğu görülmektedir ve bu doğrultuda "Ankara'da her gün yeni bir kavşak hizmete giriyor." 632 Gerek kent merkezinde gerekse çevre ilçelerinde gerçekleşen bu düzenlemelerle, Ankara'da kentsel mekânın kullanımının daha çok araç trafiği odaklı olarak düzenlendiği, bu doğrultuda trafik akışının hızının önemsenerek böylece yaya trafiğinin imkanlarının da kısıtlandığı, kentsel mekânın kullanımında hem zemin yaya geçitlerinin ortadan kalktığı ve kentlilerin, inşa edilen yaya üst geçitleri kullanmaya zorlandığı fakat bunların da işlevsiz kaldığı, ele alınan dönemle ilgili çalışmalarda sık sık dile getirilen temalardır. 633 Ayrica yaya bölgelerinin de kesintisiz bir ağ oluşturmadığ ve mevcut alanların genişlemediği, bu mekânların kent merkezinin bütünü şöyle dursun, birbirinden de soyutlandığı belirtilmelidir. Kendisiyle kıyaslanabilir kentler arasında "en rahat trafik akışına sahip" olan Ankara'da, gece yarısından sonra toplu taşıma olmaması diğer kayda değer bir husustur. $\mathrm{Bu}$ bakımdan, söz konusu süreçte kent mekânının kullanımının ritimleri sadece mekânsal açıdan değil, zaman bakımından da parçalanmışlık göstermektedir - 5 milyon nüfusu olan başkentin toplumsal yaşamı ve mekânsal ritimleri gece yarısından sonra neredeyse tamamen durmaktadır, bu ise özel araç kullanımını teşvik eden önemli bir unsurdur (bkz. Tablo 6). Bu açıdan Ankara'nın, son yıllarda 1000 kişi başına otomobil sayısı bakımından Türkiye'de birinci kent olması $^{634}$ ve kentte toplu taşıma yerine özel taşımanın önemli ölçüde artması tesadüf değildir. 635

632 Bkz. Bingöl, "Ankara'da Her Gün Yeni Bir Kavşak Hizmete Giriyor”.

633 Bkz. Atak, "Bir Başkanın Araba Sevdası ve Ankara Ulaşımında Kayıp Yıllar"; BabalıkSutcliffe, "Kent Merkezi İlkeleri Çerçevesinde "Ankara Kent Merkezi: 1985 Kentsel Ulaşım Çalışması"ndan Bugüne"; Babalık-Sutcliffe, "Sürdürülebilir Ulaşım Yaklaşımlarında Dünya, Türkiye ve Ankara Uygulamaları"; Babalık-Sutcliffe, "Urban Form and Sustainable Transport: Lessons from the Ankara Case"; Öncü, "Yetmişli Yıllardan Günümüze Ankara Kent Yönetimlerinin Ulaşım Politikaları ve Uygulamaları".

634 Örneğin, 2016 yılı itibarıyla Ankara'da 1000 kişi başına otomobil sayısı 243 iken, İstanbul'da bu rakam 179, Ankara'yla daha kıyaslanabilir bir metropoliten bölge olan İzmir'deyse bu rakam 164 olmuştur.

6352008 'de Ankara'da iş gününde yapılan yolculuklarda toplu taşımanın oranı \%69 iken, 2014'te bu rakam \%57,7'ye gerilemiştir. Bkz. Ankara Kalkınma Ajans1, "İstatistiklerle Ankara 2015”, s. $108-109$. 
Tablo 6. 2000-2016 Arası Dönemde Ankara'da Nüfus ve Araç Sayısı Dinamikleri

\begin{tabular}{|c|c|c|c|c|}
\hline Yıl & $\begin{array}{c}\text { Toplam araç } \\
\text { sayısı }\end{array}$ & Otomobil sayısı & $\begin{array}{c}\text { Toplam İl } \\
\text { Nüfusu }\end{array}$ & $\begin{array}{c}\text { 1000 kişi başına } \\
\text { otomobil araba } \\
\text { sayısı }\end{array}$ \\
\hline 2000 & 814,337 & 647,043 & $4,007,860$ & 161.4 \\
\hline 2007 & $1,143,379$ & 820,355 & $4,466,756$ & 183.7 \\
\hline 2008 & $1,193,038$ & 854,691 & $4,548,939$ & 187.9 \\
\hline 2009 & $1,234,695$ & 887,703 & $4,650,802$ & 190.9 \\
\hline 2010 & $1,285,661$ & 924,360 & $4,771,716$ & 193.7 \\
\hline 2011 & $1,367,427$ & 986,688 & $4,890,893$ & 201.7 \\
\hline 2012 & $1,436,349$ & $1,035,719$ & $4,965,542$ & 208.6 \\
\hline 2013 & $1,509,632$ & $1,093,843$ & $5,045,083$ & 216.8 \\
\hline 2014 & $1,577,134$ & $1,147,113$ & $5,150,072$ & 222.7 \\
\hline 2015 & $1,678,731$ & $1,222,519$ & $5,270,575$ & 232.0 \\
\hline 2016 & $1,777,756$ & $1,297,145$ & $5,346,518$ & 242.6 \\
\hline
\end{tabular}

Kaynak: TÜIK, Adrese dayalı nüfus kayıt sistemi (ADNKS), 2007-2016, iller düzeyi; Motorlu kara taşıt sayıları, 1994-2016, iller düzeyi; 1000 kişi başına otomobil sayısı, iller düzeyi, https://biruni.tuik.gov.tr.

Böylece Ankara'da araç trafiği odaklı mekân üretiminin, kentsel mekânın ayrışmasına katkıda bulunan önemli bir etken olduğu söylenebilir. Ayrıca, Ankara ulaşımının daha çok araç trafiği odaklı olarak düzenlenmesiyle beraber, ele alınan dönemde kentin farklı bölgelerinin arazi kullanım politikaları ve mekânsal gelişme yönelimi de kentin mekânsal parçalanmasını derinleştiren bir etken olmuştur. Kentin Batı koridorunda işlevsel açıdan karma bir arazi kullanımı söz konusuyken, ele alınan dönemde yoğun olarak gelişen Güney-Batı koridorunda mekânsal gelişim özel sektörün takdirine bırakıldığından dolayı arazi kullanımı açısından orta ve yüksek gelirli konut üretimiyle neredeyse tek işleve sahip bir mekân üretimi gerçekleştirilmiştir ve bu eğilim araç odaklı ulaşım düzenlemelerini teşvik eden bir etken olmuştur. ${ }^{636}$

Kentin ulaşımın, araç odaklı olarak düzenlemesi, köprülü kavşak, alt ve üst geçitlerle yapılı çevrenin düzenlenmesi "üretimi ve yeniden üretimi nispi bir

636 Bkz. Babalık-Sutcliffe, "Urban Form and Sustainable Transport: Lessons from the Ankara Case". 
bağl1lık içinde sürekliliği sağlayan her toplumsal oluşuma has özgül yerleri ve mekânsal kümeleri" 637 kapsayan mekânsal pratiklerin niteliğini önemli ölçüde etkilerken, bu mekânsal pratikler aracılığıyla kentsel mekânın deneyimlenmesini de önemli ölçüde değiştirdiği söylenebilir. Örneğin, 2001'de İnönü Meydanı'nda yapımı tamamlanan Akay Kavşağı, kent merkezinde araç trafiği sorununu önemli ölçüde çözerek, mekânın temsil boyutları açısından önemli tarihsel ve sembolik yapılar barındıran bu bölgenin algılanan mekân boyutunu da beraberinde değiştirmiştir. İnönü Meydanı, kentin sembolik bir meydanı olarak tasarlanmamasına rağmen, Vekaletler Mahallesi'ne doğru perspektif sunan önemli bir mekân olmuştur, oysa söz konusu kavşağın yapımıyla ve trafiğin önemli bir kısmının yeraltından geçişinin sağlanmasıyla, ${ }^{638}$ temsil boyutu açısından bir bütünlük olarak düzenlenen bölgenin algılanan boyutunu önemli ölçüde etkilediği söylenebilir. Benzer biçimde kentin en merkezi meydanı olan Kızılay Meydanı, araç odaklı trafik düzenlenmeleriyle hem kullanım hem de temsil açısından 'meydandan kavşağa' dönüşmüştür. ${ }^{639}$ Son zamanların kayda değer örneği ise 2008'de Ankara Garı önünde yapımı tamamlanan 35 Gün Altgeçidi'dir.

2008'de Ankara Büyükşehir Belediyesi, “Garın önünde trafiğgin normal akışını temin edebilmek maksadıyla" Gar Köprülü Kavşak Projesini uygulamaya koyarak 35 Gün Altgeçidi'ni inşa etti. ${ }^{640} \mathrm{Bu}$ köprülü kavşakla böylece Ankara Gar önü meydanı, meydan işlevinden hızlı trafik akışı sağlayan alt geçitli bir köprüye dönüştü ve böyle bir dönüşümle Ankara Garı'na ve Gençlik Park'ına perspektif sunan bu meydan işlevini kısmen kaybederek Gar'ın ve Gençlik Parkı'nın, perspektif bakımından soyutlanmasına yol açmıştır. $\mathrm{Bu}$ proje sayesinde, Talatpaşa Bulvarı ile Hipodrom Caddesi aksı üzerine hızlı bir trafik akışı sağlanmış, oysa meydanın, perspektif ve kullanım sürekliliği sağlama işlevi ortadan kaldırılmıştır. Bulundukları bölgede bir bütünlük olarak düşünülen ve tasarlanan Ankara Garı ve Gençlik Parkı ise hem birbirinden hem de kentin genel bütünselliğinden soyutlandı ve parçalanmış kentsel mekânda daha kopuk bir 'parça' konumu edindiler. Ankara Gar önü meydanının aynı zamanda yaya ağırlıklı bir mekân ve halkın farklı etkinlikler için toplanma buluşma meydanı olduğu da belirtilmelidir. Böylece, bu meydan, farklı etkinlikler için halen toplanma mekânı olarak işlevini sürdürse de günlük mekân kullanımında meydan

637 Lefebvre, Mekânın Üretimi, s. 63.

638 Sönmez, "A Historical and Social Analysis of an Urban Transformation: Akay Junction in Ankara".

639 Batuman, "Mekân, Kimlik ve Sosyal Çatışma: Cumhuriyet'in Kamusal Mekânı Olarak Kızılay Meydanı"; İlkay, "The Political Struggle on and at Public Space: The Case of Kizilay Square".

640 Koç, "Gar Alt Geçidi 35 Günde Trafiğe Açıldı". 
değil bir kavşak işleviyle önce çıkmaktadır. Kentsel mekânı parçalayarak soyutlayan bu süreç aynı zamanda mekânın üç momentini oluşturan mekân temsili, temsil mekânı ile mekânsal pratikler arasındaki çok yönlü çelişkileri de yansitmaktadir.

35 Gün Gar Altgeçidi projesinin hayata geçirilmesi özellikle belediyenin egemen söyleminin ve pratiklerinin bir örneği olarak kayda değerdir, zira kavşağın yapımı ABB başkanı Gökçek tarafından "35 gün gibi kısa bir sürenin içinde bir dünya rekoru kırılarak yapılan altgeçit" 641 olarak tanımlanmaktadır. Belirli mekânsal pratiklere - hızlı trafik akışı sağlamaya - yönelik olan ve mekân temsili niteliğinde olan bu projeyle önemli tarihsel bir bağlam ve temsil içeren mekânsal doku (temsil mekânı) ortadan kalkmıştır.

Aynı zamanda proje, kentin güney ile batı aksında hızlı trafik akışı aracılığıyla bütünleşmeyi sağlayarak yerel ölçekte mekânsal sürekliliğin parçalanmasıyla daha yüksek ölçekte mekânı tahayyül etmek (mekân temsili) ile yerel ölçekte mekân kullanımı (mekânsal pratikler) arasındaki çelişkiyi yansıtmaktadır. Altgeçidin ismi ise onun inşasının rekor süresini temsil ederken, aynı zamanda rekor bir sürede tarihsel bağlamın (temsil mekânı), mekân kullanımının (mekânsal pratikler) ile mekân temsilinin (mekanlar arası süreklilik) "bir dünya rekoru kırılarak" dönüştürülmesini de temsil etmektedir. Lefebvre'ye göre, "trafikten uzak buluşma yeri olan şehirdeki meydan kavşağa dönüştügünde ve buluşma yeri olmaktan çıktığında, kent yaşamı hissedilmeden ve derinden değer yitirirken, soyut mekân, dolaşımdaki atomların (yani, arabaların) kat ettiği mekân ortaya çıkar."

Bu bakımdan 35 Gün Alt Geçidi’yle Ankara Gar önü meydanı bir buluşma yeri niteliğini yine kaybetmedi, meydan parçalanmasına rağmen hala bir buluşma yeri olarak farklı etkinliklerde kullanılmaktadır. Fakat yaya ağırlıklı bir mekân yerine araç trafiği odaklı bir mekâna dönüştü, asıl değişim ise önemli bir tarihsel ve toplumsal bağlamla buluşma sağlayan ve kavşağın yapımından önce mekânsal pratikler ile (yine araba trafiği aracılığıyla) algılanan/deneyimlenen bu tarihsel ve toplumsal bağlam değerini yitirdi, zira "dolaşımdaki atomların (yani arabaların)" çoğu artık söz konusu bağlamla buluşma sağlamadan "bir dünya rekoru kırılarak yapılan altgeçit”ten geçmektedir. 
210 - Tarihsel, Soyut, Çelişkili: 1923’ten Günümüze Türkiye'de Kentsel Toplumsal Mekân

\section{Şekil 15. Gar Meydanı'ndan 35 Gün Gar Altgeçidi'ne}

2007

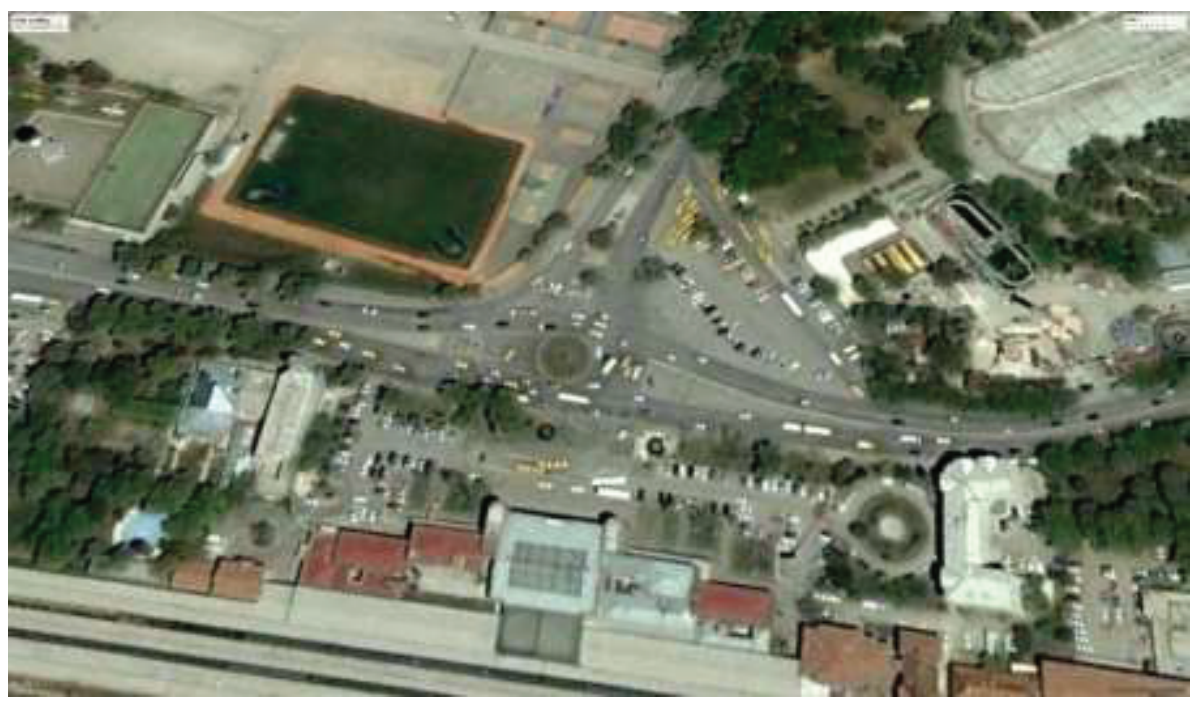

2009

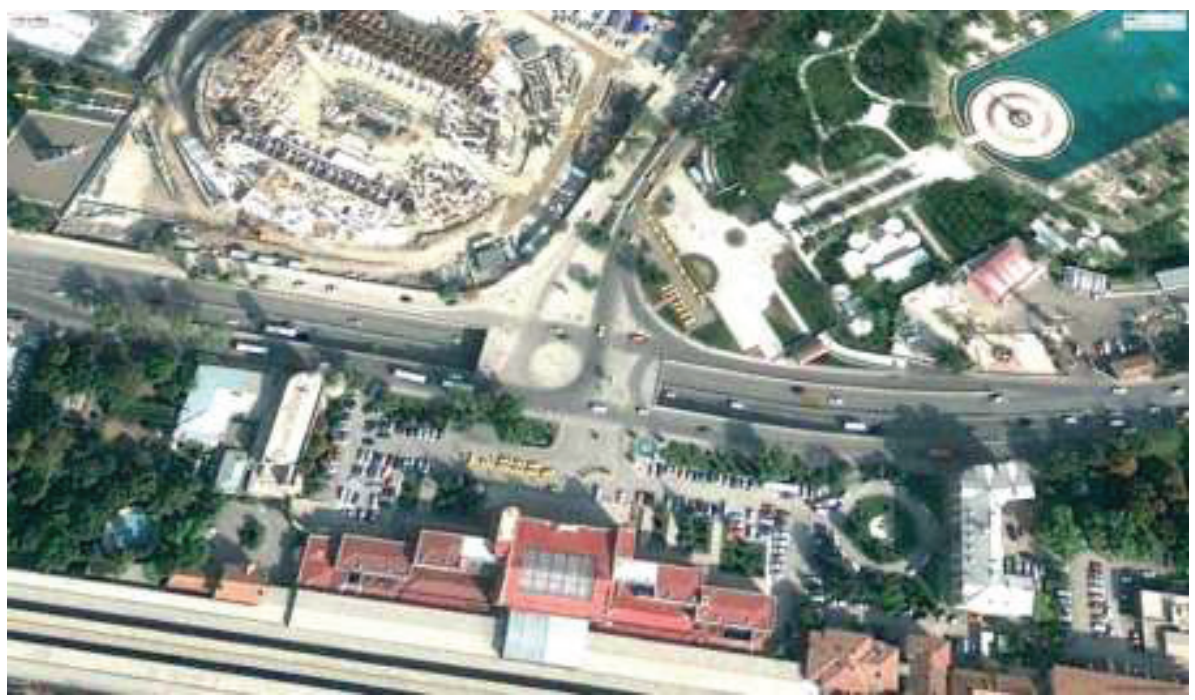

Kaynak: Google Earth Pro V 7.1.5.1557 (5.14.2007 ile 10.20.2009 tarihli çekimler). Ankara, Türkiye. $39^{\circ} 56^{\prime} 11.85^{\prime \prime}$ N 3250'39.63" E, Eye alt 3883 feet. DigitalGlobe 2016. https://www.google.com/earth/. 
Konu ile ilgili kayda değer husus, Ankara'da ele alınan dönemde ABB tarafından gerçekleştirilen bu altyapı projelerinin neredeyse hepsinin mahkemelik olması ve bu süreçte Melih Gökçek tarafından mahkemeye başvuran vatandaşlar veya meslek odaları hakkında "ideolojik bir grup", "ideolojik görüşler doğrultusunda hareket eden odalar", "ideolojik olarak karşı çıkan bazı odalar ve siyasi partiler", onların girişimleri hakkında ise "meslek odalarının ideolojik girişimleri" ve benzer değerlendirmelerde bulunmasıdır. Söz konusu grupların ideolojik görüşler doğrultusunda hareket edip etmemesi belki başka bir incelemeye konu olabilir, konumuz bağlamında belirtilmesi gereken söz konusu projelerle üretilen mekanlarda ideolojinin saklı olmasıdır, bu saklı ideoloji ise kentsel mekânın üretiminde kentin adeta barınma (biyolojik yeniden üretiminin maddi boyutu) ve altyapılara (üretim ve toplumsal ilişkilerin yeniden üretiminin maddi boyutu) indirgenmesi, başka bir deyişle kentin biyolojik yeniden üretimine yönelik konut ve toplumsal ve üretim ilişkileri yeniden üretimine yönelik yol yapımına indirgenmesidir, sokağın ve caddenin sadece "dünyanın en rahat trafiği"ni sağlayan mekân işlevine indirgemesidir, meydanların ise buluşma işlevi yerine "dolaşımdaki atomların (yani arabaların) kat ettiği mekân"a dönüşmesidir. $\mathrm{Bu}$ süreçte ise farklı form, işlev ve niteliği olan mekânların, "dünyanın en rahat trafiği"ni sağlamaya yönelik bir bulvarı kesen alan olarak tanımlanmasıdır (bkz. Şekil 16).

Projelerle üretilen bu mekanlarda saklı ideolojiye göre "dolaşımdaki atomların" trafiği hiç durmamalı, aksi takdirde bu 'atomların' dolaşımına dayanan düzen tehlikeye düşebilir. Lefebvre'in belirttiği gibi;

"Eğer sokak karşılaşma anlamını taşıyor idiyse, bunu yalnızca geçişe indirgeyerek ve yolu yayalar (sıkıştııılmış) ve araçlar (ayrıcalık verilmiş) için ikiye bölerek bu anlamını kaybetmiştir. Sokak, tüketim için/tüketim tarafindan organize edilen bir şebekeye dönüşmüştür. Tolere edilen yayaların sirkülasyon hızı, vitrinleri fark etme ve sergilenen nesneleri satın alma imkânı tarafindan belirlenir ve bu ölçülür. Zaman, "zaman-meta" (alım ve satım zamanı, alınan ve satılan zaman) haline gelir. Sokak, zamanı çalışma zamanının ötesinde düzenler; kâr ve verimlilik sistemine tâbi hale getirir. Artık sokak, zorunlu çalışma, programlanmış boş zaman faaliyetleri ve tüketim yeri olan ev arasında zorunlu bir geçiş noktasından başka şey değildir." ${ }^{643}$

Kentsel mekânda meydanlarının, "dolaşımdaki atomların (yani, arabaların) kat ettiği mekân" olarak kavşağa, buluşma ve karşılaşma yeri olan sokak, cadde ve bulvarların ise "zorunlu çalışma, programlanmış boş zaman faaliyetleri ve tüketim yeri olan ev arasında zorunlu bir geçiş noktası"na 
dönüşmesi böylece üretilen mekânda saklı ideolojiyi - neo-kapitalist tarzda örgütlenen tüketim ideolojisini - yansitmaktadır.

\section{Şekil 16. Büyükşehir Ankara Bülteni, Sayı 548 Kapak Sayfası}

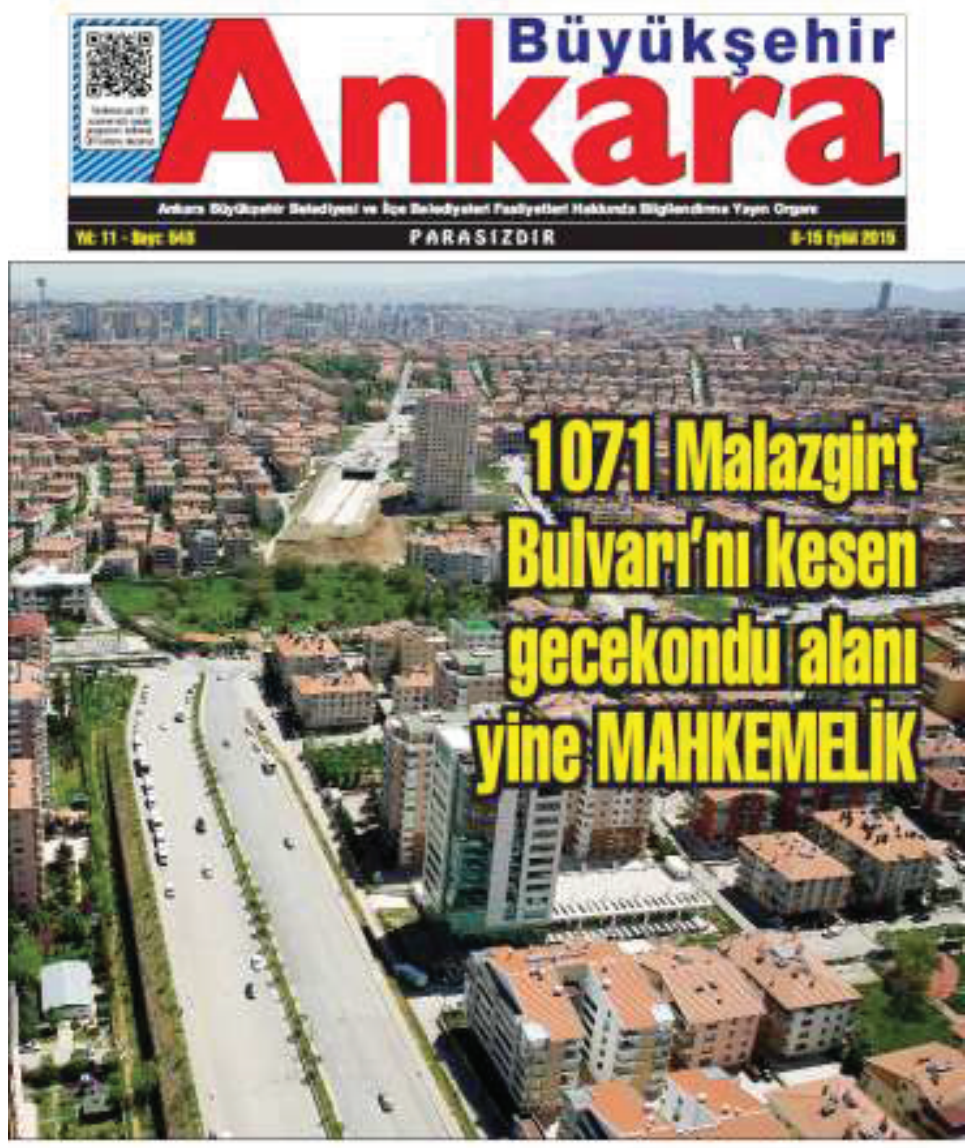

Son olarak, Büyükşehir Belediyesi'nin söyleminde söz konusu projelerin hayata geçirilmesi bağlamında önemli popülist tutumlar da belirtilmelidir. Büyükşehir Belediyesi tarafından açıklanan ve hayata geçirilen neredeyse her proje belirtildiği üzere sık sık mahkemelik olmaktadır. Bu ise söz konu projelerin kentlilerin farklı kesimlerinin katılımıyla gerçekleştirilip gerçekleştirilmediği, kentli haklarının gerçekleştirilip gerçekleştirilmediği sorusunu öne çıkartırken söz konusu ihtilaflar bağlamında ABB ile M. Gökçek'in söylemleri ele alınan dönemde özellikle iktidarın popülist söylemi bağlamında kayda değerdir. Bu 
açıdan, $\mathrm{ABB}$ tarafından, aceleci bir davranışla projelerin hayata geçirildiği ve projelerin kentsel gerçekliğin ve kentsel mekânın kullanımının önemli bir parçası hale getirildiği görülmektedir. Sonra ise meslek odalarının başvurusuyla idari yargıdan yürütmeyi durdurma veya iptal kararları çıktığında, ABB başkanı Gökçek tarafından adeta popülist bir söylemle, bu girişimlerin "vatandaşa çektirilen bir zulüm ve eziyet", "tamamen ideolojik bir tavır"644 olarak tanımlandığı, daha sonraki hukuki gelişmelerde ise "odalar kapattırd1, Ankara halkı açtırdı" 645 söylemleri görülmektedir. Bazı kesimlerin "tamamen ideolojik tavırları" sayesinde "vatandaşa çektirilen bir zulüm ve eziyet" daha sonra da görüleceği gibi AKP'nin benimsediği en yaygın söylemin - 'halktan olma' popülist söyleminin - bir tezahürü olarak okunabilir. Bu tezahürde mesleki odaların girişiminde yargıdan çıkan kararlar, "vatandaşa çektirilen bir zulüm ve eziyet” dolayısıyla 'vesayet' olarak öne çıkmaktadır. Melih Gökçek'in, yargıdan çıkan ve ABB tarafından yürütmeyi durdurmak zorunda kaldıkları kararlara karşı vatandaşın dava açma çağrıları"646 ve "odalar kapattırdı, Ankara halkı açtırdı" söylemleri ise "çektirilen bir zulüm ve eziyet"in, dolayısıyla "vesayetin kaldırılması'nın söylemsel bir tezahürü olarak öne çıkmaktadır.

\subsubsection{En Yüksek Geliri Olan Kentin En Yoksul Halleri}

Ankara'da 2000 sonrası dönemde neoliberalleşme ile neoliberal sermaye birikim pratikleri bağlamında kayda değer diğer süreç kent yoksulluğunun farklı dışavurumları ve ABB tarafından buna yönelik politikalardır. Ele alınan dönemde Ankara'da sosyo-mekânsal ayrışma ile ilgili çok sayıda araştırmalarda kent içerisinde gelir dağılımı bakımından kayda değer bir ayrışma söz konusu olduğu, bu ayrışma ise kentin toplumsal mekânının genel ayrışmasında bir taraftan kapalı ve güvenlikli siteler olarak diğer taraftan henüz kentsel dönüşüme uğramamış veya kentsel dönüşüm projeleriyle üretilen alt gelirli grupların siteleri ve mahalleleri olarak öne çıktığ görülmektedir. 1990'lardan itibaren belirginleşmeye başlayan bu sosyo-mekânsal ayrışma örüntülerinde kentin özellikle güney-batı (Eskişehir Yolu) aksı ile güneyinde (Oran aksı) üst-orta ile üst gelir gruplarının yerleştiği, diğer taraftan kuzeyde ile kuzey-doğu aksında düşük gelirli grupların yoğun olarak ikamet ettiği bölgeler olarak öne çıkmaktadır. ${ }^{647} 2000$ sonrası dönemde ise kentte yoğun olarak yaşanan kentsel dönüşüm ile gelişim projeleriyle sosyo-mekânsal ayrışma daha gözle görülür

644 Bingöl ve Abay, “Ankara'nın En Büyük Bulvarını Kapattırdılar”, s. 5.

645 Ibid., s. 4.

646 Ibid., s. 5.

647 Bkz. Şenyapılı, “Ankara Kenti “İkili” Yapısında Dönüşümler”. 
hale gelmiştir. ${ }^{648}$ Örneğin, kentin güneyinde, İmrahor Vadisi'nde Sinpaş Altınoran projesi Türkiye'de özel sektör aracılığıyla üretilen en büyük konut projesi olarak öne çıkarken, TOKİnin özel sektör ile gelir paylaşımlı projeleri olarak veya sadece özel sektörün gerçekleştirdiği lüks konut projeleri olarak öne çıkan diğer girişimler İncek Life, Kaşmir Göl Evleri, Atlantis City ve Mahall Ankara projeleridir. ${ }^{649} \mathrm{Bu}$ projelerin temel özelliği, AVM'ler, kafe ile restoranlar, bisiklet ve yürüyüş yolları, gölet ve iskeleler, spor kompleksleri gibi alanlar barındıran, kentin genelinden soyutlanmış ve steril bir yaşam için kurgulanmış, üst gelir gruplarına yönelik kapalı mekânlar olarak öne çıkmalarıdır. ${ }^{650} \mathrm{Bu}$ açıdan söz konusu projeler, parçalanan kentsel mekânda soyutlanmış adacıklar olarak öne çıkmakla sınırlı kalmamakta, bunlar aynı zamanda kentin genel ana ulaşım düzenini de etkileyerek genel morfolojisini de dönüştürmektedir. ${ }^{651} \mathrm{Bu}$ alanlara hızlı trafik akışı sağlanmasına yönelik düzenlemeler kentin diğer bölgelerini de ayrıştırarak soyutlanmasına yol açmaktadır. Ercoşkun'un belirttiği gibi, bu projelerle

"Kentsel yönetimler, direkt ana ulaşım arterine giriş-çıkış yapabilme, vadileri, tarım alanlarını yer seçme, mevcut göletlere, gevşek zeminlere yapılaşma ruhsatını vererek büyük inşaat şirketlerine destek olmaktadır.

648 Ankara'da sosyo-mekânsal ayrışma ile ilgili detaylı bir ampirik çözümleme için bkz. Yüceşahin ve Tuysuz, "Ankara Kentinde Sosyo-mekânsal Farklılaşmanın Örüntüleri: Ampirik Bir Analiz".

649 Bkz. Ercoşkun, "Ankara'daki Büyük Konut Projeleri ve Sürdürebilirlik".

650 Ercoşkun'a göre söz konusu lüks konut projelerinin sloganları incelendiğinde, doğa, yeşil, mavi gibi sözcüklerle ekolojik bir kentsel ortam vaadi görülmektedir. Ercoşkun, bu vaatleri "mümkün olmayan hayali bir dünya" (Ercoşkun, "Ankara'daki Büyük Konut Projeleri ve Sürdürebilirlik", s. 1095) olarak tanımlamakta, fakat bu vaatleri, Lefebvre'in ileri kapitalizmde üretilmekte olan çelişkili mekânı bağlamında değerlendirildiğinde çalışmamızda ele alınan bir başka hususa işaret etmektedir. Belirtildiği üzere, çelişkili mekânın en temel çelişkilerinden biri niceliksel olan (mübadele değeri) ile niteliksel olan (kullanım değeri) arasındaki çelişkidir. Bu açıdan bir taraftan mekânın gayrimenkulleşme, mübadele süreçlerine dahil olma gibi süreçlerle niteliksele tekabül eden doğa parçalanıp dağılırken ve kaybolurken, niteliksel olan yine başat hal almaktadır, "mekân giderek ender bulunan hal alan enerji, su, sşık, bitkisel ve hayvansal kimi hammaddeler gibi kaynakların aranışına bağlı olarak yeniden örgütlenir. Bu, geniş bir çatışmalı sürecinde mübadele karşısında kullanım (potansiyel olarak) yeniden değer kazanmasını sağlar”. Bkz. Lefebvre, Mekânın Üretimi, s. 353. Böyle bir çelişkinin ürünü ise günümüzde yeşilliğin, doğanın ve ekolojik yaşam sloganlarının saplantısal hal almasıdır. Fakat kullanım değerinin ile niteliksel olanın öne çıkması, doğal ya da ekolojik yaşamın saplantısal bir hal alması yine gayrimenkulleşme ve mübadele süreçleri çerçevesinde parsel parsel üretilen 'ekolojik', 'doğal' ve benzer etiketleri taşıyan yaşam alanlarının üretilip satılmasıdır. Dolayısıyla, söz konusu lüks konut projelerinin vaatleri "mümkün olmayan hayali bir dünya" olsalar da asıl olarak günümüzde üretilmekte olan mekânın temel çelişkilerinden birine işaret etmektedir.

651 Bkz. Babalık-Sutcliffe, "Urban Form and Sustainable Transport: Lessons from the Ankara Case". 
Gecekondu sahiplerine ise mekânda ayrışma yaparak başka TOKİ binalarından yer göstererek yoğun ve dikey bir hayata yönlendirmektedir. Özel araç sahipliliğini projelerde ve yakın çevresinde özendirerek katlı kavşak düzenlemeleri yapmakta, toplu taşıma seçeneklerini göz ardı etmektedir. $\mathrm{Bu}$ seçkinleştirme çalışmaları kentte başka mekânsal ayrışmalara yol açmaktadır." 652

Diğer taraftan kentte soyutlanmış adacıklar olarak gecekondu bölgelerinde yerinden edilmiş düşük gelirli kesimler için ucuz sosyal konut projeleriyle üretilen TOKİ siteleri yükselmektedir. Bu bölgeler ise sosyal donatıları açısından nispeten yoksun yaşam alanları olarak öne çıkmakta ve bu alanlarda veya onların yakın bölgelerinde daha sonra ele alınacağı üzere ABB'nin Aile Yaşam Merkezleri, Hanım Lokalleri, Gençlik Merkezleri ile Çocuk Kulüpleri gibi çeşitli kullanım değeri odaklı fakat ideolojik temayüllerle yüklü sosyal projeler öne çıkmaktadır. ${ }^{653} \mathrm{Bu}$ bölgelerde aynı zamanda ABB'nin, dar gelirli ailelere yönelik sosyal yardım girişimleri kayda değerdir.

Ele alınan dönemde Türkiye'de egemen neoliberal sermaye birikim pratiklerinin - ki bu süreçte devlet temel bir rol oynamış ve neoliberal birikim rejiminin ileri bir aşamaya taşınmasına öncül bir konumda olmuştur ${ }^{654}$ - yarattığ

652 Ercoşkun, “Ankara'daki Büyük Konut Projeleri ve Sürdürebilirlik”, s. 1096.

653 Son dönemlerde Ankara'da kentsel dönüşüm projeleri bağlamından düşük gelirli TOKİ sitelerinden biriyle ilgili en kapsamlı etnografik çalışma Tahire Erman tarafindan Kuzey Ankara Kentsel Dönüşüm Projesinin Karacaören-TOKİ bölgesinde gerçekleştirilmiştir. Erman'ın çalışmasında dönüşüm sürecinde üretilen toplumsal mekân ile ilgili önemli çözümleme ve bulgular sunulmaktadır. Daha detaylı olarak bkz. Erman, "Mış Gibi Site”: Ankara'da Bir TOKİ-Gecekondu Dönüşüm Sitesi.

654 Buğra ve Savaşkan'ın, ilgili süreçleri "devlet geri çekilmeden gerçekleşen özelleştirme” olarak nitelemesi, Türkiye'de 2004 sonrası dönemde neoliberalleşme süreçlerinde devletin rolünü özetleyecek niteliktedir. 2000'li yıllara dek özelleştirme süreci görece olarak başarısız iken, 2004'ten itibaren özelleştirmelerden elde edilen gelirin ciddi şekilde arttığ1 görülmektedir. Özelleştirmelerle beraber ilgili dönemde AKP hükümetinin, kamu ihale süreçleriyle ilgili girişimleri kayda değerdir. Bu girişimlerle kamu ihalelerini düzenleyen kurumsal çerçeve esnekleştirilerek yabancı yatırımcılara göre nispeten yeni ve tam kurumsallaşmamış yerli firmaların ihalelerde avantajlı konuma getirilerek kamu ihale süreçlerine siyasetin keyfi müdahalelerin yolu açılırken aynı zamanda daha küçük firmaların devlet ihalelerinden faydalanması sağlanmıştır. Aynı zamanda daha küçük firmaların büyük üstlenicilerin altyapı projelerinde tedarik ve taşeronluk yapmaları sağlanarak bunlardan yararlanma imkânı sağlanmıştır. Bu düzenlemelerle bir taraftan neoliberal birikim pratiklerinin daha da yerleşmesine yol açarken diğer taraftan bu birikim süreçlerinde ulusaldan yerele uzanan düzlemlerde iktidarın kurduğu yeni hegemonyanın zemini sağlamlaşmıştır. Sonuç ise hem İslamcı sermayenin daha avantajlı konuma gelmesi hem de patronaj ilişkilerinin gelişerek bu birikim pratiklerinin ayrılmaz bir parçası haline gelmesidir. Bkz. Buğra ve Savaşkan, Türkiye'de Yeni Kapitalizm: Siyaset, Din ve İș Dünyası, s. 130 vd. O yüzden bu dönemde "sermaye birikim rejimi bir yandan bir önceki iktidardan devralınan neoliberalleşme sürecinin ana hatlarıyla takip edildiği bir yandan da iktidarın siyasi ve 
olumsuz sonuçların telafisi olarak AKP'nin sosyal politikalar alanında geliştirdiği özgün bir enstrüman olarak toplumun en yoksul kesimlerine yardım amaçlı mekanizmaların devreye sokulmasıdır. Bu mekanizmalarda ise önemli unsur olarak parti teşkilatının denetiminde belediyeler, İslamcı sermaye, vakıf ve dernekle ile cemaatler ağ 1 öne çıkmıştır. Yoksul kesimlere yönelik bu enstrümanlar "neoliberal reformlar sonucu artan kent yoksulluğunu hafifletirken söz konusu kesimleri iktidar partisinin ideolojik politik etki alanına dahil etme işlevi görmüştür." ${ }^{655}$ Konu ile ilgili çok sayıda çalışmanın temel vurgusu söz konusu mekanizmaların toplumsal yaşamın her alanın neoliberal paradigma doğrultusunda 'piyasa mekanizmaları'nın işleyişsinin olumsuz sonuçlarını telafi etmesiyle beraber iktidar partisinin kendi kurduğu neoliberal-İslamc1 hegemonyanın üretimi ile yeniden üretimidir. Konuyu değerlendiren Saraçoğlu ve Yeşilbăg, söz konusu mekanizmaların sonuçlarını şöyle sıralamaktadır: ${ }^{656}$

1) Yoksullukla mücadelede devletin rolü azaltılmıştır ve bu konuda sorumluluk yerel yönetimler ve STK'lara yüklenmiştir.

2) Yerel yönetimler ve vakıfların mali açıdan denetlenmesindeki zorluklar ve 'yardıma muhtaç' ailelerin tespitindeki belirsizlikler, sosyal yardım mekanizmalarını patronaj ilişkilerine açık hale getirmiştir.

3) $\mathrm{Bu}$ yardım mekanizmaları "vatandaşlık temelinde bir haklar rejimi" yerine "hayırseverlik" ve "sadaka" kültürünü yerleştirmiştir.

4) İslamcı cemaat ve derneklerin kent yoksulları arasındaki örgütlenmeyi kolaylaştırmış ve siyasal İslam'ın toplumsal tabanını güçlendirmiştir.

5) Seçim dönemlerinde yoğunlaşan yardımlar AKP'nin sandık başarılarına katkıda bulunmuştur. ${ }^{657}$

Böylece, söz konusu yardımlar esasen neoliberal birikim pratiklerine (devletin sosyal yükümlülükleri ortadan kaldırması bakımdan) ve İslamcı siyasetin tabanda örgütlenerek güçlenmesine katkıda bulunarak neoliberalİslameı hegemonyanın oluşumunda önemli rol oynamıştır. Bu mekanizmalara etkili bir şekilde başvurmanın en iyi örneklerinden biri ise ABB olmuştur. Melih Gökçek tarafından, söz konusu yardımların "mağdur durumdaki insanlara zor şartlarda yaşam desteği" olarak tanımlanması ve bu yardımların "toplumsal barışın sağlaması"nda işlev gördügünün belirtilmesi658 de bu yardımların temelinde yatan gerekçeleri kısmen açıklayacak yöndedir.

ideolojik gündemi uyarınca gerçekleştirdiği özgün müdahaleler tarafindan şekillendiği”" tespiti oldukça yerindedir. Bkz. Saraçoğlu ve Yeşilbağ, "AKP Döneminde Türkiye: Minare İle İnşaat Gölgesinde”, s. 878.

655 Saraçoğlu ve Yeşilbağ, “AKP Döneminde Türkiye: Minare İle İnşaat Gölgesinde”, s. 878.

656 Ibid., s. 891-893.

657 Söz konusu yardımların popülist boyutları ile ilgili ayrıca bkz. Yıldırım, “AKP ve Neoliberal Popülizm".

658 Gökçek’ten akt. Atay, “Büyükşehir'den 400 Bin Aileye Yaşam Desteği”, s. 5. 
İlgili dönemde ABB'nin bu konudaki girişimlerine bakıldığında kayda değer göstergelerle karşı karşıyayız. ABB tarafından 1998'te 32.500 aileden başlayan gıda ve temizlik malzeme yardımları 2001'de 37.250'ye ulaşırken, bu yardımların gerek kapsam gerekse çeşitlilik açısından ancak 2002 sonrası dönemde kayda değer boyutlara vardığı görülmektedir. Şöyle ki 2002'de söz konusu yardımlar 180 bin aileyi kapsarken, 2015 yılı itibarıyla artık 400 bin dar gelirli aile ABB'nin farklı yardımlarından yararlanmaktadır. ${ }^{659}$ Bunlar ise sadece gıda ve temizlik malzemeleriyle sınırlı değil, aynı zamanda yakacak (kömür) yardımı, ekmek yardımı, giyim, öğrencilere kırtasiye malzemeleri yardımı, Giysi Yardım Merkezleri açılması, ${ }^{660}$ yaşl1lara ücretsiz toplu taşıma kartı, engellilere indirimli ve serbest otobüs kartları verilmesi gibi çeşitli alanları kapsamaktadır. Buna koşut olarak ABB kimsesiz yaşl1lara ücretsiz ev temizliği hizmetleri sağlama, kentin çeşitli yerlerinde sabah saatlerinde ücretsiz çorba dağıtma, dar gelirli ve sosyal güvencesi olmayan 10 binlerce hamile kadına ve hastaya ambulans servisi, 661 dar gelirli çiftler için toplu düğün merasimleri organizasyonu ${ }^{662}$ gibi yardımlarla da öne çıkmaktadır. Bu yardımlarla beraber $\mathrm{ABB}$ tarafindan BELTEK ile BELMEK kurslarının düzenlenmesi ve ele alınan dönemde yaklaşık olarak 400 bin kişinin farklı teknik alanlarda eğitilmesi kayda değerdir. .663

Bu yardım mekanizmaları ABB'nin, ${ }^{664}$ Aile Yaşam Merkezleri gibi diğer sosyal projelerle bir arada değerlendirildiğinde bunların kent yoksullarının çok büyük bir kesimini kapsadığını söylemek yerinde olur. Doğrudan gıda veya yakıt ve temel ihtiyaçlara yönelik diğer yardımları emek gücünün yeniden üretimine, farklı eğitim kursları üretim ilişkilerinin yeniden üretimine yönelikken, ABB'nin aşağıda ayrıntılı olarak ele alınacak farklı sosyal projeleri ise böylece daha genel bir düzlemde toplumsal ilişkilerin yeniden üretimine yönelik olduğunu görmekteyiz. Böylece "toplumsal barış"ın sağlanmasına yönelik olan söz konusu mekanizmalar mevcut neoliberal birikim pratiklerinden "mağdur durumdaki

659 Atay, "Büyükşehir'den 400 Bin Aileye Yaşam Desteğì".

660 Hatipoğlu, "Giysi Yardım Merkezi: Beğendiğini Al, Ödemeden Git”; Hatipoğlu, "Büyükşehir'den Dar Gelirlilere Giyisi Yardımı”; Kılıç, "Büyükşehir “Giysi Merkezi”"nde Yok Yok".

661 Dikle, "ALO 188 Ambulans Hizmeti Bir Yılda 29 Bin 580 Kişiye Ulaştı”; Dikle, “ALO 188'den 2012'de 72 Bin 661 Kişiye Hizmet”; Dikle, “Alo 188'den, 1 Y1lda 20 Bin Ambulans Hizmeti".

662 Hatipoğlu, "209 Çifte Büyük Düğün İçin Kayıtlar Başladı”; Tol, "Büyükşehir'den Bu Yıl da 211 Çifte Düğün”; Tol, "Büyükşehir’den 214 Çifte Muhteşem Dügün”; Turan, "Büyükşehir, 2015 Yilında 215 Çifti Evlendirecek".

663 Köprülü, “Büyükşehir, BELTEK ve BELMEK'lerde 400 Bin Kişiye Mesleki Eğitim Verdi”.

664 Ele alınan dönemde ilçe belediyeleri tarafından da benzer yardım mekanizmalarının yaygın olarak devreye sokulması da belirtilmelidir. 
insanlara zor şartlarda yaşam desteği” niteliği taşıyarak "toplumsal barış"1n, yani mevcut birikim rejiminin sürdürülmesinde önemli bir işlev gördüğ̈̈ söylenebilir. $\mathrm{Bu}$ yardımların mekânsal dağılımıyla ilgili fazla istatistiki veri bulunmasa da bunların dağıtımıyla ilgili belediyenin resmi yayının haberlerinden bu yardımların ya genellikle mevcut bazı gecekondu bölgelerinde ya da kentsel dönüşüm geçirmiş alanlarda gerçekleştirildiği görülmektedir. ${ }^{665}$

Fakat bu yardım mekanizmalarının bazılarının özellikle toplumsal mekânın üretimi ile yeniden üretimi, onun algllanan, yaşanan ile tasarlanan bağlamında yeniden tanımlanması bakımından kayda değerdir. Bunlar ABB tarafından her sene gerçekleștirilen Sünnet organizasyonları (her yılın rakamına eşit sayıda çocuğun Sünnet törenleri) ve Ramazan Bayramı'nda kentin neredeyse tüm önemli kamusal mekânlarında 10 binlerce insanın yararlandı̆̆ı iftar çadırlarının açılmasıdır. ${ }^{666} \mathrm{Bu}$ bakımdan özellikle iftar çadırları hem kamusal mekânın kullanımını (algılanan mekân) dönüştürmekte, hem de onun yaşanan boyutunu yeniden tanımlamaktadır, bununla ise kamusal mekân doğrudan dinle ilişkili pratikler ve temsillerin başat olduğu bir alana dönüşmektedir.

Böylece, söz konusu uygulamalar bir taraftan mevcut birikim rejiminin ki ele alındığı üzere mekânsal olarak ve mekânsal bağlamın öne çıkması açısından bu rejim ancak 2000 sonrası dönemde tamamlanmıştır - yeniden üretimi bağlamında önemli bir işlev görmekte, diğer taraftan İslamcı muhafazakâr temayüller doğrultusunda belirli temsillerle toplumsal mekânın yeniden tanımlanmasına katkıda bulunmaktadır. İronik olan ise ABB yayın organı tarafından Türkiye'de "En yüksek ortalama gelir Ankara'da" gibi bir haber manşeti kapağına taşırken, aynı yayının farklı sayılarında sık sık vurgulanan hususlardan diğeri yoksullara yardım sayıları ve kapsam açısından da ABB'nin birincil olduğu haberleridir. Birbirine çelişiyormuş gibi gözüken bu iki kent temsili (temsil mekânı) 667 ise asıl olarak ilgili dönemde mevcut birikim rejiminin Ankara'da ürettiği ayrışmış toplumsal mekânı yansıtmaktadır (bkz. Şekil 17).

665 Örneğin, ABB tarafından sabah saatlerinde gerçekleştirilen çorba ve ekmekten oluşan ücretsiz kahvaltı hizmetlerinin noktaları da mekânsal bakımdan dikkat çekicidir. Her gün yaklaşık olarak 5 bin kişinin yararlandığı bu hizmetler Ulus Anafartalar Binası ile Hacı Bayram önü, İbni Sina hastanesi, Kurtuluş Parkı ve Beşevler-Ankaray girişinde verilmektedir (bkz. Hatipoğlu, "Büyükşehir'den 5 Bin Çorba-Ekmekli Kahvaltı"). Böylece bu uygulama, alt gelirli bölgelerdeki esnafa veya halka ya da söz konusu bölgelerden kent merkezine sabah erkenden işe giden emekçilere ya da öğrencilere yöneliktir.

666 Kent merkezinde veya kamusal niteliği açısından kentin önemli yerlerinden Güven Park, Gençlik Parkı ve Abdi İpekçi Parkı gibi yerlerde söz konusu çadırların açılması kayda değerdir.

$667 \mathrm{Bu}$ iki temsili, iktidarın kent temsili (temsil mekanları) olarak sırasıyla "refahın temsil mekânı" ile "hayırseverliğin temsil mekânı" olarak tanımlanabilir. 
Şekil 17. Büyükşehir Ankara Bülteni, Sayı 514 ile 552'sinin Kapak Sayfaları
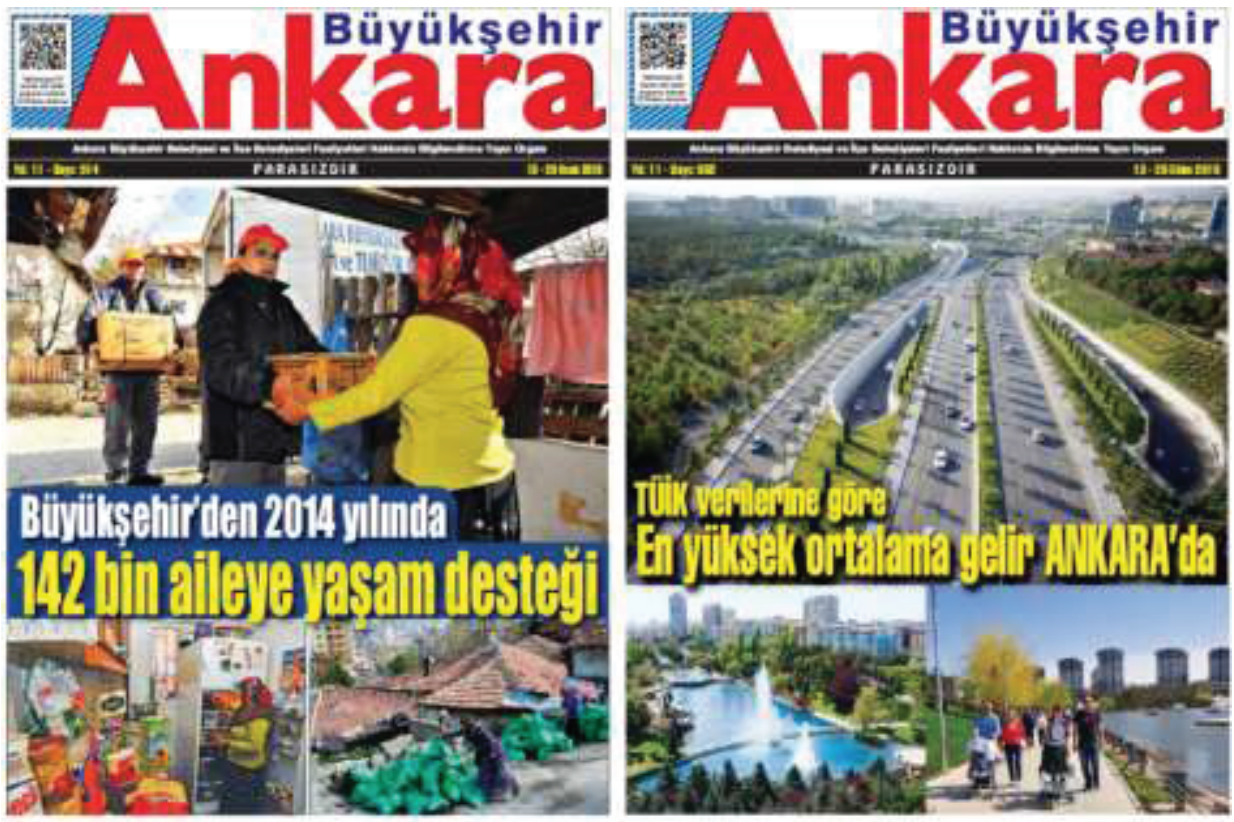

\subsection{Muhafazakarlığın Mekânsallığı: Yeniden Tanımlanan Kamusal Mekân}

2002 sonrası dönemde ABB tarafindan hayata geçirilen ve belediye tarafindan sosyal belediyecilik anlayıșıyla sunulan hizmet olarak gösterilen birkaç kayda değer proje söz konusu olmuştur. Bunlar toplumun farklı kesimlerine hitap edecek nitelikte olan Aile Yaşam Merkezleri, Hanım Lokalleri, Çocuk Kulüpleri ile Gençlik Merkezleridir. Bu projelerle belediye farklı toplumsal kesimlerin - yaşlılar, kadınlar, gençler, çocuklar- gündelik hayatlarında boş zamanların değerlendirilmesi ve farklı sosyal faaliyetler için kentin farklı bölgelerinde merkezler kurulmuştur. Bu projelerin özellikleri, kapsam1, belediye tarafından bu merkezlerin sunumu ve bu mekanlar üzerine söylem belediyenin, toplumsal mekânsal pratikler tahayyülü ile ilgili önemli ipuçları sunmaktadır. Bunlar aynı zamanda iktidarın kamusallık anlayışının ve bu anlayış doğrultusunda belirli mekânsal pratiklerin aşılmasının da ipuçlarını sunmaktadır. Söz konusu projeler kentte kamusallığın kapsam ve niteliğinin dönüşümü ile ilişkilidir. 


\subsubsection{Aile Yaşam Merkezleri}

Aile Yaşam Merkezlerinden (AYM) ilki 2003 yılında Sincan'da açılmışken, 2015'te Ankara'nın artık 9 bölgesinde bu yaşam merkezleri mevcuttur.668 ABB, 'sosyal belediyecilik' anlayışı doğrultusunda böyle merkezlerin sayısının artışını aynı zamanda kendi stratejik hedefleri arasında görmektedir. ${ }^{669}$ Sportif faaliyetlerden sosyal kültürel faaliyetlere kadar farklı konularda imkanlar sağlayan bu merkezlerin üye sayısı da merkezlerin sayısıyla artarak 2015 yılı itibariyle yaklaşık olarak 160 bin kişi olmuştur, aynı zamanda 2015 'te merkezlerden yararlanan kişi sayısı yaklaşık olarak 60 bine ulaşmıştır. ${ }^{670}$ Böylece bu yerlerin genellikle Ankara'nın çevre ilçelerinde kayda değer sayıda bir halk kesimi için gündelik hayatta boş zaman değerlendirmesi için önemli mekanlar haline geldiği belediyenin verilerinden de anlaşılmaktadır.

$\mathrm{Bu}$ bağlamda bir diğer önemli proje ve yine sosyal hizmetler açısından belediyenin stratejik hedeflerinden biri olarak tanımlanan ${ }^{671}$ Hanımlar Lokallerinin açılmasıdır. İlki 2000 yılında hizmete giren Hanımlar Lokalinin sayısı 2015 yılında 23'e ulaşmıştır. Bunlar, 18 yaş üzeri kadınlar için sosyal, sportif ve kültürel faaliyetlere yönelik mekanlar teşkil etmektedir. Aynı zamanda bu mekanlar sosyalleşme açısından önemli bir işlev de görmektedir. 2015'te ise bu lokallerden yararlanan kadınların sayısı yaklaşı 30 bin kişi olmuştur. 672 Mekânsal dağılım açısından ise lokaller daha geniş bir coğrafyayı kapsamaktadır ve merkezi ilçelerde de mevcuttur. Son olarak gündelik hayatta toplumsal mekânsal pratikleri açısından bir diğer önemli girişim ABB tarafından Gençlik Merkezlerinin ve Çocuk Kulüplerinin açılmasıdır. Bunlar ise gençlerin ve çocukların eğitsel, kültürel ve sportif faaliyetlerine yönelik hizmetler sunan mekanlardır. ${ }^{673}$

ABB tarafından bu projeler aracılığılla halkın farklı kesimleri için gündelik hayatta boş zamanın değerlendirilmesi için böyle merkezlerin yaratılması ilk önce mekânsal pratikler, yani günlük edimlerde mekân kullanımı bağlamında değerlendirilmelidir. Özellikle Aile Yaşam Merkezleri toplumsal ve

6682015 yılı itibariyle Ankara'nın 9 farklı bölgesinde bulunan Aile Yaşam Merkezleri şunlardır: Akyurt AYM, Araplar AYM, Çubuk AYM, Planet AYM, Sincan AYM, Pursaklar AYM, Kazan AYM, Kuşcağız AYM.

669 ABB, "2010 Faaliyet Raporu”, s. 162; ABB, “2015 Faaliyet Raporu”, s. 62.

670 ABB, "2015 Faaliyet Raporu”.

671 ABB, “2010 Faaliyet Raporu”, s. 198; ABB, “2015 Faaliyet Raporu”, s. 96.

672 ABB, "2015 Faaliyet Raporu”, s. 96.

6732015 yılında kentin toplam 22 Gençlik Merkezinde yaklaşık 135 bin gence, 24 Çocuk Kulübünden ise toplam 153 bin çocuğa hizmet verilmiştir. Ankara İli içerisinde bu merkezlerin coğrafi dağılımı da gerek merkez gerekse çevre ilçeleri kapsamaktadır. Bkz. ABB, “2015 Faaliyet Raporu”, s. 85. 
üretim ilişkilerinin yeniden üretimi düzleminde en temel düzeye - biyolojik yeniden üretime tekabül eden aileye- yöneliktir. Aynı zamanda bunlar, emek gücünün yeniden üretimi açısından kolektif tüketim bağlamında dolaylı ücret işlevi görmektedir ve belediye tarafından kullanım değeri odaklı mekân üretimi kapsamında değerlendirilebilir. ${ }^{674} \mathrm{Bu}$ merkezlerin açılışı, esasen değişim değeri odaklı mekânın üretimi süreçlerinin etkilerini hafifletici bir işlev görmektedir. Örneğin Nisan 2008'de Batıkent Gençlik Merkezi ve Çocuk Kulübü açılış töreninde konuşan M. Gökçek, bu projeleri sosyal belediyecilik anlayış1 doğrultusunda gerçekleştirdiklerini belirterek "biz Ankara Büyükşehir Belediyesi olarak belediyeciliği hiçbir zaman sadece yol, su, kanalizasyon yani altyap1 ve üstyapı olarak kabul etmedik" 675 şeklindeki ifadesi bu kapsamda anlam kazanmaktadır. Önceden ele alındığı üzere mevzubahis dönemde Ankara'da altyap1 ve üstyap1 ile ilgili neredeyse tüm alanların piyasa mekanizmaları çerçevesinde düzenlendiğini ve bu açıdan mekânın üretimi süreçlerinin değişim değer odaklı bir süreç çerçevesinde gerçekleştirilmiştir. Dolayısıyla ABB tarafından bu merkezlerin aç1lışı ilk ve ilk önce bu süreçleri hafifletecek nitelikte olan ve mekânın üretimi süreçlerinde kullanım değer odaklı mekân üretiminin önemli örnekleri olarak nitelendirilebilir. Fakat böyle bir kullanım değeri aynı zaman kullanım değerinin yönelimi açısından önem taşır ve bu bağlamda bu merkezlerin mekân temsili ile temsil mekânı boyutu öne çıkmaktadır.

AKP'nin muhafazakarlık söylemi ve bu doğrultuda topluma nüfuz etme çabaları akademide yaygın olarak tartışılan konulardandır. Bu bağlamda AKP gerek söylemsel düzlemde gerekse pratik alanda aile kurumunu en önemli konu olarak öne çıkarmaktadır. Şöyle ki muhafazakarlık anlayışını benimseyen ve bu doğrultuda gelenek, din ve ahlak konularını bir arada değerlendiren bu parti, söz konusu değerlerin temel taşıyıcısı olarak aileyi görmekte ve ailenin korunmasına yönelik politikalarına merkezi bir rol atfetmektedir. ${ }^{676}$ İște bu bağlamda Aile

674 Lefebvre, gündelik hayatı kavramsallaştırmak ve onun farklı bileşenlerini tanımlamak için zorunlu zaman (işe ayrılan), serbest veya boş zaman (eğlenceye ayrılan) ve zoraki zaman (iş dışındaki gerekliliklere ayrılan zaman) sınıflandırılmasına başvurmaktadır. Ayrıca buradaki boş zaman şenliklerin, yaratıcı ve özgür faaliyetin zamanından ziyade zorlamalar toplamından oluşan zaman harcamasıdır. Bkz. Lefebvre, Everyday Life in the Modern World; Lefebvre, Critique of Everyday Life, Volume 1: Introduction. Bu bağlamda Aile Yaşam Merkezlerinde halkın gündelik hayatını geçirdiği kısım boş zaman olarak değerlendirilmelidir. Fakat şu husus da önem taşır: boş zaman toplumsal ilişkilerin ve emek gücünün yeniden üretimi açısından önemli işleve de sahiptir o yüzden boş zaman ile zorunlu zaman arasındaki sınırlar çok keskin değildir. Dolayısıyla Aile Yaşam Merkezlerinin zorunlu zaman olarak kolektif tüketimi bağlamında dolaylı ücret işlevi görmesi de söz konusudur.

675 Koç, "Batıkent'e Gençlik Merkezi”, s. 8.

676 Doğanay, “AKP'nin Demokrasi Söylemi ve Muhafazakârlık: Muhafazakâr Demokrasiye Eleştirel Bir Bakış”, s. 72. 
Yaşam Merkezlerinin ya da Hanım Lokallerinin mekân temsili boyutu öne çıkmaktadır. Bunlar sadece mekânsal pratikler olarak boş zamanın değerlendirilmesi için kullanım değeri odaklı mekân üretimi örnekleri değil, aynı zamanda aile koruması politikalarını siyasi vizyonunda önemli bir hedef olarak belirleyen partinin 677 mekân temsilinin örnekleri olarak karşımıza çıkmaktadırlar. 2008'de Çubuk Aile Yaşam Merkezinin açılış töreninde "hanımların Aile Yaşam Merkezi'ndeki sosyal imkanlardan ve her türlü spor olanaklarından faydalandıkları takdirde streslerini atarak, evlerinde eşleriyle daha huzurlu bir yaşam süreceklerini (...), bu nedenle beylerden hanımlarının Aile Yaşam Merkezi'ne gitmeleri konusunda yardımcı olmalarını"678 isteyen M. Gökçek'in bu ifadeleri ele alınan bağlamda kayda değerdir ve söylemsel düzlemde iktidarın mekân temsilini ortaya koyacak niteliktedir. İlk önce 'hanım' sözcügünün kullanımı gerek Gökçek ve diğer belediye mensupları tarafından gerekse belediyenin tüm yayınlarında 'kadın' sözcüğü yerine sık sık kullanılan, aynı zamanda 'bayan' sözcüğüne eşanlamlı olarak da kullanılan bir kelimedir ve kadınlara kurumsal bir rol atfeder, bu rol ise evli bir kadın veya ev kadını olma yani aile mensubu olma kurumsal düzlemini ifade etmektedir. ${ }^{679}$ Böylece Aile Yaşam Merkezlerinin ve Hanım Lokallerinin ilk önce evli kadınlara veya ev kadınlarına, belediyenin tabiriyle "hanımlar" veya "bayanlar"a yönelik bir hizmet merkezi olması öne çıkmaktadır. Aynı zamanda Gökçek tarafından "beylerden hanımlarının Aile Yaşam Merkezi'ne gitmeleri konusunda yardımcı olmalarını" istemesi Aile Yaşam Merkezlerinin ve Hanım Lokallerinin bir

677 2012'de AKP'nin 4. olağan kongresinde dağıtılan ve partinin siyasi vizyonunu özetleyen $A K$ Parti 2023 Siyasi Vizyonu: Siyaset, Toplum, Dünya isimli kitapçıktaki parti vizyonunda ailenin konumu şöyle tanımlanmaktadır: "AK Parti, aileyi 2023 yılının Yeni Türkiyesi'nin beden ve ruh sağlığı korunan, ahlâkî ve temel değerleri sağlam bireylerden oluşması için en büyük dinamo olarak kabul etmektedir. Bu doğrultuda toplumun tüm unsurlarının aile kavramına sahip çıkmasına yönelik bir "sosyal farkındalık" iklimi üretilecektir. Bunun bir gereği olarak; evlilik kurumunun güçlendirilmesi, aile bütünlüğünün korunması, aile değerlerimizin canlı tutulması için etkin politikalar geliştirilecektir”. Bkz. AKP, AK Parti 2023 Siyasi Vizyonu: Siyaset, Toplum, Dünya, s. 35.

678 Semerci, “Aile Yaşam Merkezlerinin İkincisi Çubuk’ta Açıldı”, s. 17, vurgu eklenmiştir.

679 Örneğin ABB'nin yayın organı, Büyükşehir Ankara, tarafından Kadınlar Günü’nde ABB tarafından düzenlenen kutlamalar ile ilgili haberinde "Kadınlar Günü'nde kadınlar coștu, coşturdu" başlığı yerine "Kadınlar Günü'nde hanımlar coştu, coşturdu" (bkz. Tol, "Kadınlar Günü Coşkuyla Kutlandı”) gibi başlığın kullanımı ABB'nin, söylem düzleminde 'hanım' sözcügüne farklı bir anlam yüklemesinin bir örneği olarak görülebilir. Böyle seçici bir sözcük kullanımının bilinçli bir söylemsel pratik teşkil etmemesi de söz konusu olabilir, fakat ilginç şekilde ABB tarafından İngilizce olarak yayınlanan Ankara City Guide kent rehberinde Aile Yaşam Merkezlerini tanıtan bölümde 'Hanımlar Lokali', 'Ladies' Club' olarak geçmektedir (bkz. Ankara Metropolitan Municipality, Ankara City Guide, s. 84). İngilizce dilinde de 'woman' ve 'lady' sözcüklerinin de kurumsal, sınıfsal ve toplumsal cinsiyet açılarından belirli anlamlarla yüklü olmasından dolayı söz konusu rehberindeki seçici çeviri, ABB'nin söyleminin cinsiyetleştirilmiş olduğunun diğer göstergesidir. 
kamusal alan olarak boş zamanın değerlendirilmesi için "beylerin" rızasına dayalı cinsiyetleştirilmiş (gendered) bir kamusallık ve kamusal görünürlük olarak öne çıkmaktadır. Nihayet bu merkezlerin, kadınlar için "streslerini atarak, evlerinde eşleriyle daha huzurlu bir yaşam sürecekleri" bir yer işlevi gördüğü ve böyle bir işlev yüklendiği hususu öne çıkmaktadır. Yani bu merkezler, iktidarın kendi sahiplendiğini iddia ettiği değerlerin temel taşıyıcısı olarak tanımladığ 1 ailelerin huzurlu yaşamına katkıda bulunan dolayısıyla aile merkezli bir toplumun huzuruna da katkıda bulunan cinsiyetleştirilmiş ve kurumsallaşmış mekânlar - mekân temsilleri - olarak değerlendirilebilir.

Fakat bu mekanların tasarlanan boyutu sadece bununla sınırlı değildir. Bunlar aynı zamanda genel olarak kamusal mekânın dönüşümü bağlamında da değerlendirilebilir. Değişim değeri odaklı bir mekân temsili doğrultusunda Ankara'da kamusal mekânın dönüşümü sürecinde geleneksel kamusallığıı gerek kapsam gerekse nitelik açısından dönüşüm yaşandığ 1 ve geleneksel kamusallığın, AVM'lerin yaygınlaşmasıyla birlikte kapalı kamusallık karşısında aşındığı çalışmamızın önceki bölümlerinde ele alınmıştır. Söz konusu merkezlerin açılması da böyle bir kapalı kamusallı̆̆ın farklı bir çeşidi olarak öne çıkmaktadır. Fakat bu değişim değer merkezli bir mekân temsilinden ziyade iktidarın, kamusal mekânı yeniden tanımlayan ideolojik temelli mekân temsilinin ürünüdür ve ilk önce kamusal görünürlüğe, özellikle geleneksel kamusal mekânın kullanımına ilişkindir. Değişim değerli odaklı bir mekân temsili doğrultusunda yeniden tanımlanarak kamusal niteliği aşınan, sadece trafik işlevi gören sokak, cadde veya bulvarların veya köprülü kavşaklarla işlevini kaybeden meydanların yeniden bir tanımlanması söz konusudur. Bununla bir taraftan söz konusu geleneksel kamusal mekânların işlevsel yeniden tanımlanması gerçekleştirilirken, aynı zamanda bu mekânların temsil düzleminde yeni bir tanımlama öne çıkmaktadır, bu ise sokağın, "suç makinesi" 680 yaratan bir ortam olarak tanımlanmasıdır (temsil mekânı) ve bu temsil doğrultusunda farklı mekânsal pratiklerin aşılmasıdır. O yüzden söz konusu merkezlerden Gençlik Merkezleri ve Çocuk Kulüpleri "suç makinesi” yaratan sokak temsili karşısında "her şey belli bir program dâhilinde yürüyen" 681 gerek mecazi gerekse tam anlamıla kapalı, denetlenen ve tasarlanan bir kamusallık deneyimi olarak değerlendirilebilir.

680 Batıkent Gençlik Merkezi ve Çocuk Kulübü açılış töreninde konuşan Melih Gökçek’in şu sözleri kayda değerdir; "Sokakta bulunan çocuklara sahip çıkamıyorsanız, eğer onları bir şeylerle meşgul edemiyorsanız, üzülerek ifade ediyorum ki ya uyuşturucu alırlar ya da onun ötesinde suç makinesi haline gelirler". Gökçek’ten akt. Koç, "Batıkent’e Gençlik Merkezi”, s. 9.

681 Koç, “Gençlere Açılan Sıcak ve Dost Kapıları: Gençlik Merkezleri”, s. 19. 
Türkiye'de kentsel dönüşüm literatüründe yaygın bir anlatım olarak kentsel dönüşüme uğramış mekânların eski canlılığını yitirmesi ve TOKİ sitelerinde halkın eski alışkanlıklarını sürdürebilme çabaları ve bu doğrultuda üretilen mekanlardır. Görsel temsillerle de desteklenen bu yaygın anlatıma göre halkın farklı kesimleri kaldırımlarda, bahçe köşelerinde veya kat holünde toplanarak hem ortaklaşa iş yapmakta hem de sosyalleşme imkân bulmakta ve yaşanan mekanlarını yeniden üretmeye çalışmaktadırlar. ${ }^{682}$ Büyükşehir Belediyesi tarafından söz konusu merkezlerin açılması böyle sosyalleşme merkezleri yaratma ve kentsel dönüşüm aracılığıyla ortaya çıkan baskın tasarlanan mekâna karş1 gerileyen yaşanan mekânların bir telafisi olarak da değerlendirilebilir. Dolayısıyla belediye tarafindan bu merkezlerden bazılarının eski gecekondu bölgelerinde kurulması tesadüf değildir. ${ }^{683}$ Zira bu merkezlerin sosyalleşme açısından imkanlar sunması ABB tarafından da dile getirilmekte ve bu merkezlerin işlevlerinden biri olarak tanımlanmaktadır.

Fakat yine bu merkezler, tasarlanan boyutun daha baskın olduğu mekanlardır, zira bunların kamusal bir niteliği olmalarına rağmen sıradanlaşmış ve rutinleşmiş gündelik hayatın bir parçasıdır ve geleneksel kamusallığın doğaçlama niteliğini taşımamaktadırlar: bunlar, üyeliğe tabi olan, her imkândan yararlanmak için belirli günlük ve haftalık programlamaya tabi olan mekanlardır. ${ }^{684}$ Dahası, bu mekânlar yukarıda değinildiği üzere kentin genel toplumsal mekânın cinsiyetleştirilmiş yapısının bir parçası olmakla beraber kendi

$682 \mathrm{Bu}$ yaygın anlatımın birkaç örneği olarak bkz. Eranıl, Tuna ve Demirtaş-Milz, “A SocioSpatial Analysis of Urban Transformation at a Neighborhood Scale: The Case of the Relocation of Kadifekale Inhabitants to TOKİ Uzundere in İzmir"; Erman, "Kentin Kiyısında Kadın Olmak Gecekondudan TOKİ Kentsel Dönüşüm Sitesine Geçişte Kadın Deneyimleri”; Erman, "Mış Gibi Site”: Ankara'da Bir TOKİ-Gecekondu Dönüşüm Sitesi.

683 Örneğin Mamak’ta bulunan Araplar Aile Yaşam Merkezi, Araplar Mahallesinde, Eserkent TOKİ bloklarında kurulmuştur.

684 Tahire Erman'ın, Ankara'da Karacaören TOKİ sitesinde yaptığı etnografik araştırması bu hususu somut gözlemlerle destekleyecek niteliğindedir. Çalışmada, eski gecekondu sakinlerinin yaşadığı bir TOKİ sitesinde bulunan Hanım Lokalinin, kadınların sportif, kültürel, eğitsel ve benzer faaliyetleri için kayda değer imkanlar sunduğu, bu açıdan kullanım değeri odaklı bir mekân teşkil ettiğini görmekteyiz. Erman'ın belirttiğine göre aynı zamanda, "kültürel dönüşüm" kentsel dönüşüm projelerinin merkezinde olmadığı, fakat yine de eski gecekondu halkının yaşamına yeni unsurlar ve yeni roller eklenmesi söz konusudur, bunlar ise "AVM'de alışveriş, Hanımlar Lokali'nde spor, Lokal'in düzenlediği bedava geziler, kurslar"dır (Erman, "Mış Gibi Site”: Ankara'da Bir TOKİ-Gecekondu Dönüşüm Sitesi, s. 107, 316). Bu açıdan, Hanımlar Lokallerinin, Lefebvre'in tanımıyla gündelik hayatının rutinleşmiş ve sıradanlaşmış döngüleri olan zorunlu zaman, zoraki zaman, iş zamanı ile özel/aile zamanının bir parçası olduğu, bu döngülerde Hanım Lokallerin, boş zamanın değerlendirilmesinin sıradanlaşmış rutinlerinde bir mekân kullanımına tekabül ettiği, günlük edimlerde (mekânsal pratikler) yaşanan mekân ile tasarlanan mekânın iç içe geçtiği, fakat tasarlanan boyutun daha baskın olduğu mekânlar olarak tanımlanabilir. 
içerisinde önemli bir cinsiyetleştirilmiş yapıya sahiplerdir. Örneğin bazı Aile Yaşam Merkezlerinde bulunan yüzme havuzlarının hafta içerisinde kullanımının kadın ile erkeklere göre ayrımı ve bunu yine cins ve kurumsal kodlama içeren "bayan seans (yüzme) günler ile saatleri" ile "bay seans (yüzme) günler ile saatleri” kurallarıyla uygulanması böyle bir yapılanmanın örneğidir. Dolayısıyla bunlar birer yaşanan mekân, yani günlük edimlerde yaşanan deneyimin (lived experience) parçası olmakla beraber önemli kodlanma ve kurumsallaşma içeren tasarlanan bağlam içermekte ve iktidarın, belirli değerler doğrultusunda toplumsal mekânın tahayyülünü de göstermektedirler. ${ }^{685}$ Sonradan tartış1lacağ 1 üzere iktidar tarafından böyle bir kodlanma, kentin geleneksel kamusal mekanlarında da gözlemlenmektedir.

Son olarak bu merkezler konusunda yaygın bir durum olmayan fakat ele alınan dönemde Ankara'da söylem ve uygulamada sık sık karşılaşı1lan başka bir husus da mevcuttur. 7 Temmuz 2014'te 15 kişinin katıldığ iftar yemeğinden sonra dönemin Başbakanı tarafından Keçiören'de Kuşcağız Aile Yaşam merkezinin açılışı gerçekleştirilmiştir. Diğer merkezlerin, yukarıda ele alınan özelliklerine sahip olmakla beraber bu merkezin en önemli tarafı Türkiye'de en büyüğü olmasıdır. ${ }^{686}$

$\mathrm{Bu}$ özelliği itibariyle ise merkez farklı bir mimari tasarımla, 'Selçuklu' mimarisiyle karşımıza çıkmaktadır ve böyle bir mimari çözüm açısından da belirli bir tasarlanan boyut —içermektedir. İktidarın gerek söylem gerekse

$685 \mathrm{Bu}$ açıdan ele alınan dönemde cinsiyete dayalı mekânsal kodlama konusunda kayda değer ve zamanında çok tartışılan uygulamalardan biri 2013'te farklı illerde YURTKUR'a bağlı karma öğrenci yurtlarının, kız ve erkek öğrenci yurdu olarak ayrılması, yurtlardaki yemekhane, bahçe, çalışma salonu, spor salonu gibi ortak kullanım mekânlarının kadın ve erkek olmak üzere ayırma uygulamasına geçilmesidir (bkz. Evrensel.net, "Yurtlarda Haremlik Selamlık"; Hurriyet.com.tr, "Kız-Erkek Ortak Yurt Kalmayacak"; Radikal.com.tr, "Kırklareli'nde Haremlik Selamlık Yemekhane!"). Böyle bir uygulama sirasında yetkili makamlardan uygulamanın gerekçesinde yönelik bir açıklama olmamasına rağmen, daha sonradan dönemin Başbakanı Erdoğan'ın “bu ülkede anne babaların, ebeveynlerin, herkesin çocukları bize emanettir. Biz, kızların erkeklerin devletin yurtlarında karışık kalmasına müsaade etmedik, etmiyoruz" diye sözleri bu uygulamanın arka planının aydınlatılması açısından önemlidir. Ayrıca yurtlar açısından barınma ihtiyaçlarına cevap verilmeyen bazı yerlerde kadın ve erkek öğrencilerin aynı evlerde kalması konusuna değinen Başbakanın "buralarda güvenlik güçlerimize, emniyetimize, valiliklerimize gelen istihbari bilgiler var. Bu istihbari bilgilerden hareketle de valiliklerimiz bu durumlara müdahale ediyorlar" diye açılaması kayda değerdir. Bu noktada ilk açıklamanın kayda değer tarafi iktidar tarafından mevzunun yine aile kurumuna bağlanmasıdır. İkincisinde ise (birincisiyle bağlantılı olan aynı zamanda) önemli husus, iktidarın, bireylerin 'mahremiyet' mekanlarının denetlendiği, denetleneceğinin açıkça dile getirmesidir (bkz. Radikal.com.tr, "Komşu İhbar, Vali Müdahale Ediyor").

686 Aile Yaşam Merkezleri arasında büyüklüğü açısından 2. olacak ve halen Etlik’te inşaatı süren Osmanlı Aile Yaşam merkezi gerek mimari çözümü gerekse ismi itibariyle Osmanlı'ya gönderme içeren bir diğer kayda değer projedir. 
uygulamada sık sık öne sürdügü Osmanlı ve Selçuklu temsilini içerdiği iddia edilen, açı1ışı yapan dönemin Başbakanı Erdoğan'ın da ifade ettiği üzere Selçuklu mimarisiyle "hem Keçiören'e hem Ankara'ya gerçekten çok farklı bir hava kat[an]" 687 bu yapı, böylece yapılı çevrenin üretimi aracılığıyla toplumsal mekânın yeniden tanımlamasında ideolojik temelli belirli bir temsili, halkın gündelik rutinlerinde çok uğrak bir mekan (mekânsal pratikler) aracılığıyla yaşanan deneyimin (temsil mekânı) bir parçası haline getirmektedir. ${ }^{688}$

2002 'den sonra kentte yarı kamusal özelliği taşıyan ve kullanım değeri odaklı mekân üretimi açısından önemli örnekler oluşturan Aile Yaşam Merkezleri, Hanım Lokalleri ve benzer girişimleri ele alırken burada kentte kullanım değeri odaklı bir diğer gözle görülür gelişim $\mathrm{ABB}$ tarafindan geniş çevre düzenlemeleri aracılığıyla parklar ile rekreasyon alanlarının üretimi veya bu alanların yenilenmesidir. Şöyle ki son 20 yıl içerisinde Ankara'da farklı büyüklükte yüzlerce park yapılmıştır. Bunlar arasında hem çok geniş rekreasyon alanları hem de geniş tematik mekânlar (veya tematik parklar) yer almaktadır. Fakat ABB'nin, Ankara'ya yeşil bir imge kazandıran projeleri olarak belirtilen bu düzenlemelerden en geniş çaplı olan Göksu Park1, Gölbaşı-Mogan Park1, Mavi Göl Parkı, Karagöl, Gökçek Parkı gibi düzenlemeler genellikle kentin yaşanan alanlarından uzak olmaları sebebiyle halkın günlük edimlerinde boş zaman değerlendirmelerinin bir parçası değillerdir, o yüzden kentte mekânın üretimi süreçlerinde önemli yer almalarına rağmen her birey tarafından kullanım (mekânsal pratikler) ve deneyimleme (temsil mekânı) açısından sık sık

687 ABB, "Kuşcağız Aile Yaşam Merkezi'ni Başbakan Açtı".

$688 \mathrm{Bu}$ bağlamda burada Erken Cumhuriyet döneminin modernleşme çabaları doğrultusunda Halkevleri'nin gerek yapılı çevresinin gerekse toplumsal mekânın üretimi açısından önemli temsil ve pratikler içerdiği hususu akla gelmektedir. Halkevlerinin temel işlevleri arasında 'halk terbiyesi' ve yeni ideolojiye uygun halk kitleleri yaratma, halka cumhuriyetin benimsediği laik değerler doğrultusunda seküler bir yaşam tarzı aşılanmasıydı. Bu yapılar ayrıca dini mekânlara alternatif toplanma mekânları olmayı amaçlamaktaydı (bkz. Yeşilkaya, Halkevleri: İdeoloji ve Mimarlık). Bu açıdan Aile Yaşam Merkezlerinin toplumsal mekânın üretimindeki rolleri açısından gerek temsilleri gerekse içerdikleri pratikler açısından Halkevleriyle paralellik gösterdiği söylenebilir. Bu iki mekân, iktidarın topluma nüfuz etme ile toplumu dönüştürme yönelimleri ve toplumsal mekân tahayyülü (genel mekân temsili) açısından birbirinden çok farklı durmaktadır fakat her ikisinin de sahip oldukları temsiller ve içerdikleri pratikler açısından iktidar tarafindan mekânın üretimi aracılığıyla topluma nüfuz etme konusunda benzer yaklaşımın ürünüdür. Böylece toplumu yeniden biçimlendirmeyi amaçlayan bir tasarlanan mekân olarak Aile Yaşam Merkezleri ile Halkevleri benzerlik taşırken, temsil mekanları ile mekânsal pratikler açısından bu iki yapı veya kurum birbirinden farklılaşmaktadır; Halkevleri, Cumhuriyet'in seküler düzeninin, etnik kimliğe dayalı milliyetçiliğin mekânsal pratikleri ve temsil mekanlarını teşkil ederken, onları üreten ve yeniden üreten kurumlar iken, Aile Yaşam Merkezleri, ele alınan dönemde seküler düzenin aşınmasının, etnik kimliğinden ziyade dini unsuruna vurgu yapan toplumsal birliğin ve dini unsurun damgasını taşıyan toplumsal yaşamın temsil mekanları ile mekânsal pratiklerini ifade ettikleri söylenebilir. 
uğrayabilecekleri mekânlar oluşturmadıkları için burada bu mekânlar üzerinde fazla durulmayacaktır.

\section{Şekil 18. Selçuklu Mimarisiyle Tasarlanan Kuşcağız AYM}
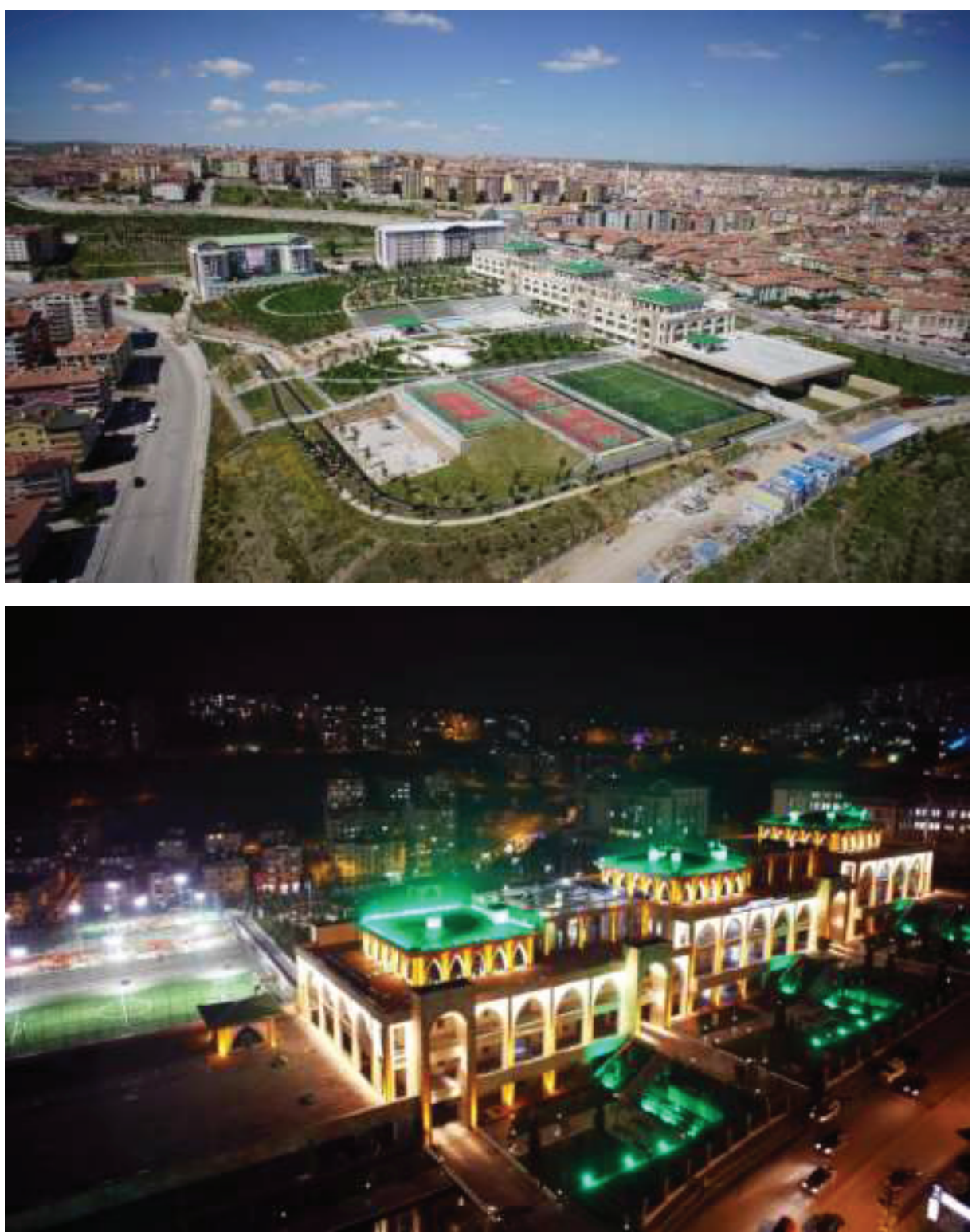

Kaynak: ABB, 07 Şubat 2017 tarihinde https://www.ankara.bel.tr/index.php?cID=6548 adresinden erişildi. 
Bahsi geçen dönemde kent merkezinde en önemli kamusal mekânı niteliğinde olan, ayrıca Cumhuriyet tarihinde Ankara'nın toplumsal ve mekânsal dokusunda önemli yer tutan Gençlik Parkı'nın yeniden düzenlemesi dikkat çekmektedir. Bu düzenlenmeyle ise Ankara'nın ilk planlarında da yer bulan fakat ancak 1943 y1lında yapımı tamamlanan ve o zamandan beri Cumhuriyet'in değerleriyle özdeşleşen bu parkın algılanan, yaşanan ve tasarlanan boyutları açısından yeniden tanımlanması gerçekleştirilmiştir.

\subsubsection{Gençlik Parkı'ndan ‘Aile Parkı'na}

1940'lı yıllarda Gençlik Parkı'nın yapımının tamamlanması, Ankara'nın kamusal mekânlar ağının gelişmesinde ve modern kente özgü gündelik kamusal mekân deneyimi yaratmasına yönelik önemli bir gelişmeydi, zira o zamana dek kentin merkezinde boş zamanların değerlendirilmesi için büyük bir kentsel park mevcut değildi. $\mathrm{O}$ zamandan beri bu park halkın gündelik hayatında önemli bir yer tutan kamusal mekân olmuştur, aynı zamanda kentin imgesini biçimlendirme açısından önemli işlevle de yüklü olmuştur. Çünkü kentin o zamanki en önemli giriş kapısı olan Ankara Garı'na komşuluğu aynı zamanda kenti ziyaret edenler için bozkırda yeşil bir kent imgesi oluşma potansiyeli de taşımaktaydı. Gençlik Parkı'nın aynı zamanda önemli diğer işlevi, modern ve seküler bir cumhuriyete özgü kamusallığın üretimi, yeniden üretimi ve bu kamusallığın sergilenmesiydi. Bunun için Park sadece bir yeşil alan değil, aynı zamanda farklı sportif etkinliklerin gerçekleştirilmesi ve boş zamanın değerlendirilmesi için uygun bir mekân oluşturmaktaydı. Zaman içerisinde, özellikle 1960'lardan itibaren işlevleri, kullanımı, barındırdığı pratikler ve temsiller açısından -ki bu dönüşümler 1950'lerden itibaren Ankara'da toplumsal mekânın dönüşümleri bağlamında değerlendirilmelidir- gözlemlenen farklı dönüşümler geçirmesine rağmen günümüze dek Gençlik Parkı Ankara'nın kentsel mekânında Cumhuriyet ile ve ona özgü seküler ve modern kamusallığıyla özdeşleşen bir temsil mekânı olarak yer almıştır. ${ }^{689}$

Gençlik Parkı'nın yenilenme projesi 2000'den sonra ABB'nin gündemine gelmiştir. Parkın yenilenmesi için hukuki ve bürokratik süreçler 2001-2005 arası dönemde sürmüş, 2005'te yenileme projesi kesinleştikten hemen sonra ise Büyükşehir Belediyesi, proje doğrultusunda harekete geçerek parkın yeniden düzenlenmesi için yıkım süreçleri başlamıştır. 2006'da yenileme süreçlerinin

689 Gençlik Parkı'nın planlama ve yapım süreçleri, tarihsel süreçte geçirdiği dönüşümlerle ilgili daha detaylı olarak bkz. Akansel, "Revealing the Values of a Republican Park: Gençlik Parkı Deciphered in Memory and As Monument"; Demir, "Toplumsal Değişme Süreci İçinde Gençlik Park1: Sosyolojik Bir Değerlendirme”; Uludağ, "The Social Construction of Meaning in Landscape Architecture: A Case Study of Gençlik Parkı in Ankara". 
tamamlanması planlanmasına rağmen yıkım süreçlerinde parktaki işletme sahipleri ile ABB arasında yargısal süreçler söz konusu olduğundan dolayı süreç uzayarak parkın kapsamlı yenilenmesine 2008'de başlanmış ve 30 Ağustos 2009'da parkın açı1ışıyla halkın kullanımına açılmıştır. ${ }^{690}$

ABB başkanı Melih Gökçek, yenileme projesinin amacından söz ederek "Gençlik Parkı yeniden Cumhuriyet'in ilk yılların hüviyetine kavuşacağını", yenileme sürecinde ise parkın içerisinde havuzundan, tarihi mekanlarına kadar hiçbir ana noktaya dokunmadıklarını belirtmiştir. ${ }^{691}$ Benzer şekilde projenin mimarı olan Öner Tokcan, parkın yenilenmesinin amacını "parkın fonksiyonunu ve estetiğini, son zamanlardaki bozulmalardan arındırarak iade etmek. İçindeki tesisleri, güncelleştirerek, yeniden hayat kazandırmak (...) Parkın son yıllarda bozulmuş olan estetiğini ve güzelliğini kazandırarak vatandaşlara iade [etmek]" ${ }^{\prime 692}$ olarak belirtmiştir. ${ }^{693}$ Melih Gökçek'in ifadelerinden görüldüğü üzere parkın ilk önce bir temsil mekânı olarak Cumhuriyet'in ilk yıllarındaki kimliğine kavuşturulması amaçlanmıştır. ${ }^{694}$ Ayrıca M. Gökçek yenilenme projesinin amacı olarak "ana hatlarıyla parkın orijinal mimarisi ve orijinal dokusuna geri döndürülmesini amaçl[adığını]" ${ }^{995}$ belirterek parkın mekân temsili boyutunun restore edilmesine de işaret etmiştir. Böylece, yukarıdaki açıklamalardan da anlaşılacağı üzere uygulamasından sonra park algılanan, yaşanan ve tasarlanan boyutları bakımından dönüşüme uğramayacağı anlaşılmaktadır.

Fakat yukarıdaki açıklamalarla çelişen birtakım başka ifadelerle $\mathrm{M}$. Gökçek sürecin aslında bir yenilemeden ziyade dönüşüm süreci olduğunun ipuçlarını da sunmuştur. "Parkın içerisinde havuzundan, tarihi mekanlara kadar

$690 \mathrm{Bu}$ sürecin bürokratik ve hukuki boyutları ile yenileme projesinin ayrıntılı detayları için bkz. Akansel, "Revealing the Values of a Republican Park: Gençlik Parkı Deciphered in Memory and As Monument".

691 Dikle ve Hatipoğlu, “Dokuzuncu Gençlik Merkezi Gençlik Parkı'nda Açıldı”, s. 4.

692 Koç ve Bingöl, "Gençlik Parkı Yeniden Doğuyor”, s. 13.

693 Burada parkın orijinal tasarım ve planı ile yenileme projesinde yer alan tasarımı birbiriyle karşılaştırarak incelenmesi yerine söylem düzleminde konuya yaklaşıp ele alınmaya çalışılmıştır. Zira planlama ve tasarım açısından hem konu incelenmiş bulunmaktadır hem de söylemsel düzeyde ortaya çıkan bazı hususlar ABB'nin, toplumsal mekânın tasarlanan, algılanan ve yaşanan momentlerine yaklaşımı ile ilgili önemli ipuçlar sunmaktadır. Fakat, uygun durumlarda yenileme projesinin tasarım ve planlama boyutlarına da değinilecektir.

694 M. Gökçek'in, bu parkın geçmişte Ankaralıların sosyal hayatında önemli bir yer tuttuğu ve kendi çocukluğunun da Gençlik Parkı'nda geçtiği dolayısıyla çok sayıda anısının da bulunduğu ifadesinden kendi kişisel tarihinde de bu parkın bir temsil mekânı olarak öne çıktığını belirtmek gerekir. Bkz. Dikle ve Hatipoğlu, "Dokuzuncu Gençlik Merkezi Gençlik Parkı'nda Açıldı", s. 3.

695 Atay, “Gökçek, İçişleri Bakanı'na Gençlik Parkı'nı Anlattı”, s. 7. 
hiçbir ana noktaya dokunmadıklarını" 696 belirten Gökçek tarafından aynı zamanda parkın "sil baştan yeniden tanzim edildiği"nin ${ }^{697}$ ifade edilmesi "parkın orijinal mimarisi ve orijinal dokusuna geri döndürülmesini amaçlaması"698 hususunu sorgulatmaktaydı. Uygulamada parkın tarihi dokusunun en önemli unsurlarının yıkılıp yeniden yapılması da projenin zaten çelişki olan söylemlerine ek olarak, uygulamanın da söz konusu söylemlerle çeliştiğini ortaya koymaktayd1. ${ }^{699}$

Fakat süreç sadece parkın tarihi dokusunun "sil baştan yeniden tanzim edilerek" özgün ve orijinal mimari dokusunun simülakrasının üretiminden ibaret değildi. Süreç aynı zamanda mekân temsili açısından önemli değişiklikler içermekteydi. Parkın ana giriş kapısı (Ulus Kap1sı) ve çevresinin Gökçek'in ifadesiyle "çok özel Selçuklu tarzında ve modernize edilmiş bir giriş kapısı"yla 700 değiştirilmesi, benzer biçimde Muhsin Ertuğrul Tiyatrosu'nun yıkılarak yine Gökçek' in ifadesiyle "Selçuklu ve Osmanlı mimarisine yakın bir tarzda"701 yeniden yapılması mekân temsili açısından parkın "yeniden Cumhuriyet'in ilk yıllarının hüviyetine kavuşturması" yerine bu hüviyetten uzaklaştırırken, temsil mekânı olarak ise Cumhuriyet'in ilk yıllarının modernist kimliği - parkın tasarımında da mevcut olan - yerine o ilk yıllarda rağbet görmeyen, dahası katiyen reddedilen Selçuklu ve Osmanlı hüviyetine kavuşturmaktadır.

Parkta temsil açısından bir diğer kayda değer ekleme - ki bu ekleme aslında Gökçek'in, "havuzundan, tarihi mekanlara kadar hiçbir ana noktaya dokunmadıklarını" belirten sözleriyle çelişen ve havuzun tasarımında da değişiklik getiren bir durumdu, parkın batı kısmında, havuzdan yer ayrılarak Cumhuriyet Meydanı oluşturulması ile meydana Cumhuriyet Anıtı'nın dikilmesidir. 12,5 metrelik iki adet el arasında çap 3 metre olan bir dünya içeren, Melih Gökçek tarafından "çok anlamlı bir anıt olan"702 bu soyut yapı Cumhuriyet'i temsil edip etmeme açısından soru işaretleri yaratırken Ankara

696 Dikle ve Hatipoğlu, “Dokuzuncu Gençlik Merkezi Gençlik Parkı'nda Açıldı”, s. 4.

697 Koç ve Bingöl, “Gençlik Parkı Yeniden Doğuyor”, s. 6.

698 Atay, “Gökçek, İçişleri Bakanı’na Gençlik Parkı'nı Anlattı”, s. 7.

699 Örneğin, parkın tarihi dokusunda en önemli ve görünür unsurlardan biri olan havuz köprüsünün yıkılıp yeniden yapılması (farklı bir tasarı çözümüyle) veya parktaki yürüyüş yollarını restore etmek yerine Türkiye'nin dört bir tarafından getirilen doğal, dekoratif özellikli taşlarla yeniden düzenlenmesi parkın, tasarım unsurları açısından dönüştürülmesinin, dolayısıyla yenilenmesinin söylem ve uygulama açısından çelişkili olduğunu gösteren sadece birkaç örneğidir.

700 Çıngır, "Gençlik Parkı Baharla Birlikte Yaşama Dönüyor”, s. 8.

701 Ibid., s. 10.

702 Koç ve Bingöl, “Özlem Bitiyor Gençlik Parkı Kapılarını Açıyor”, s. 10. 
Garı tarafından parka girildiğinde parkın perspektifli görünümü tamamen yeniden tanımlanmaktadır (bkz. Şekil 20). ${ }^{703}$

\section{Şekil 19. Gençlik Parkı'nın Selçuklu Tarzında Ulus Kapısı}

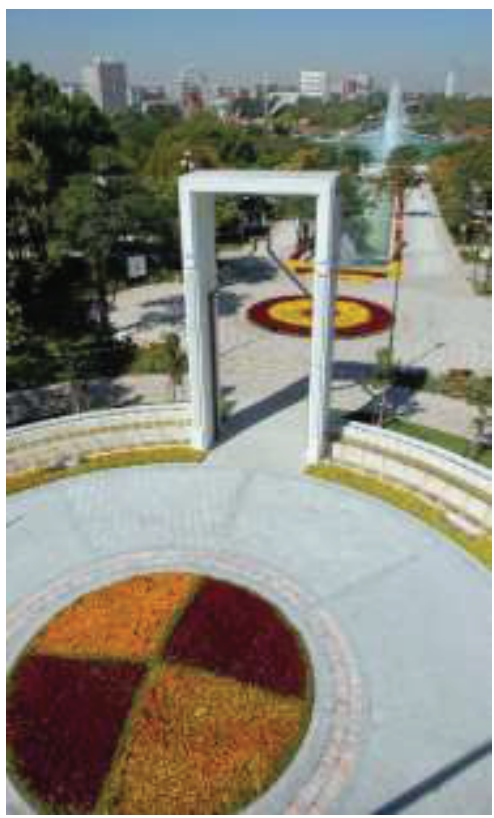

Kaynak: Koç ve Bingöl, “Özlem Bitiyor Gençlik Parkı Kapılarını Açıyor”.

Park, yenilenme projesi sürecinde temsiller açısından böyle dönüşümler geçirmekle birlikte aynı zamanda çevresinde yaşanan bazı değişimler de parkı, kentin genel mekânsal dokusu bağlamında yeniden tanımlamıştır. Yukarıda da değinildiği üzere parkın önemli ikinci kapısı Ankara Garı tarafındadır. Böyle bir komşuluk sayesinde park aynı zamanda Ankara Garı'ndan kente gelenler için kent imgesi üretimi bağlamında önemli bir işleve sahip olmuştur. Böyle bir ilişkide ise Ankara Gar önü meydanı iki önemli mekân arasında süreklilik sağlayan bir işlev görmüştür. 2008' de ABB, 35 Gün Altgeçidi inşa etmesiyle Gar önü meydanı, meydan işlevinden hızlı trafik akışı sağlayan alt geçitli bir köprüye dönüştü ve böylece Gençlik Park'ına perspektif sunan bu meydan işlevini kısmen kaybederek parkın perspektif bakımından soyutlanmasına yol açtı. Bu proje sayesinde Talatpaşa Bulvarı ile Hipodrom Caddesi aksı üzerinde hızlı bir trafik

703 Mimar Metin Yurdanur tarafindan tasarlanan anıtın üzerine Mustafa Kemal'in, "En büyük eserim Türkiye Cumhuriyeti'dir" sözleri yer almaktadır. 
sağlanarak park böylece gerek Gar'dan gerekse aksın güneyinden mekânsal süreklilik bakımından da soyutlandı ve parçalanmış kentsel mekânda daha kopuk bir konum edindi.

\section{Şekil 20. Gençlik Parkı'ndaki Cumhuriyet Anıtı}

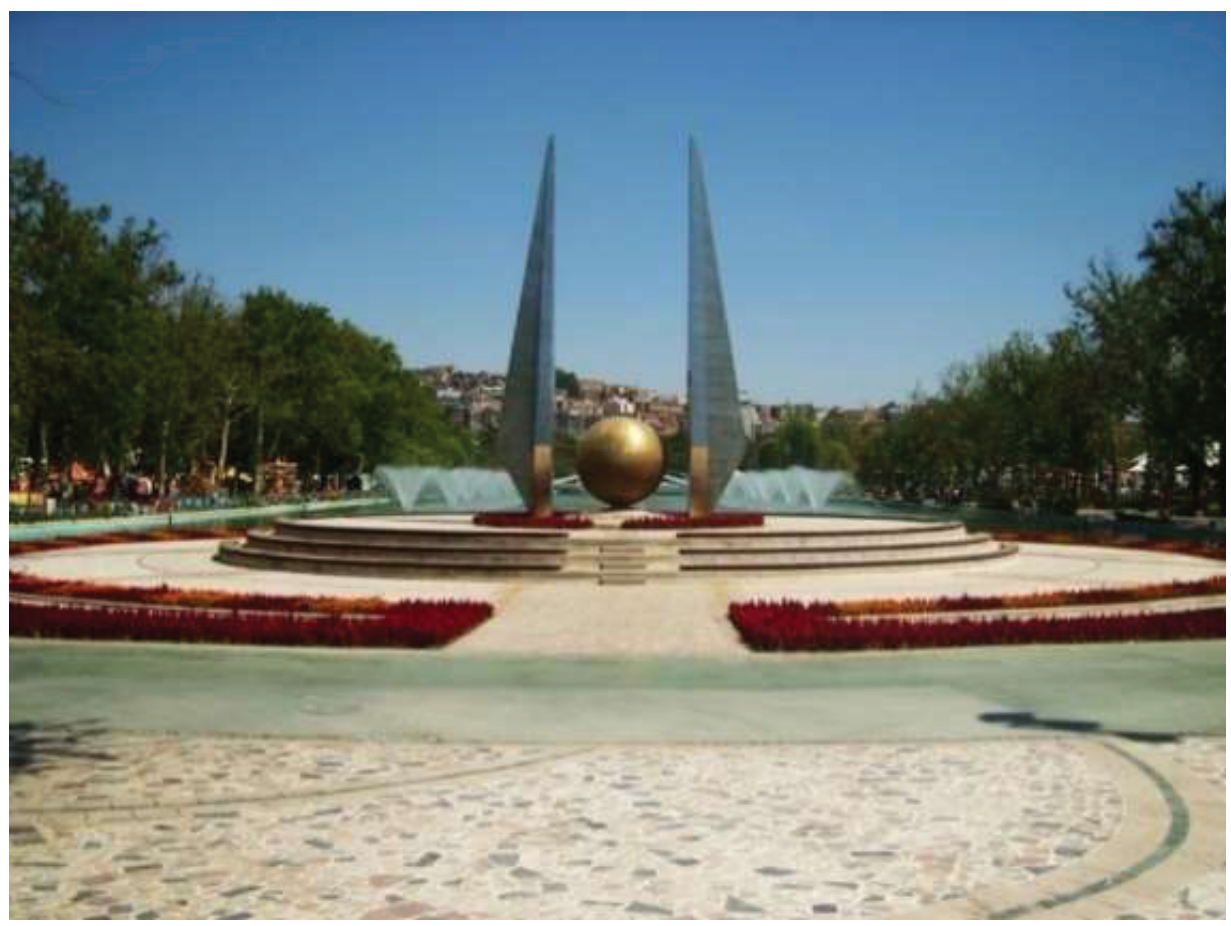

Kaynak: Koç Turgut, 2010, 10 Şubat 2017 tarihinde http://www.fotografturk.com/ankara-genclikparki-1-p34960 adresinden erişildi

Gar tarafından bu park hem mekânsal perspektif hem de mekânsal süreklilik bakımından parçalanan kentsel mekânda soyutlama yaşarken, Ulus tarafında son zamanlarda gözlemlenen bir başka gelişmenin yine onu perspektif bakımından etkilediği söylenebilir. ${ }^{704} \mathrm{Bu}$ gelişme ise Ankara Ulusal Cami ve

704 Bu gelişmeler sonucunda yukarıda ele alındığı üzere Gençlik Parkı'na benzer biçimde Ankara Garı'nın da parçalanan kentsel mekânda soyutlandığı söylenebilir. Dahası, önemli mimari ve tarihsel bir yapı ve mekân olarak Ankara Garı'na tek taraftan, Gar Meydanı'ndan perspektif bakımından erişilebilirlik olduğu ve 35 Gün Alt Geçidi'nin yapımıyla Talatpaşa-Hipodrom aksındaki trafiğin büyük bir kısmının artık altgeçitten sağlandığı durumu hesaba katılırsa Erken Cumhuriyet döneminin temsil mekânı olan bu yapının, günlük mekânsal pratiklerinde 
Kültür Merkezi Projesi çerçevesinde Gençlik Parkı'nın hemen karşısındaki İtfaiye Meydanı'nda 70 bin metrekarelik bir alanda 2013 yılından itibaren inşa edilen cami ve kültür merkezidir.

\section{Şekil 21. Ankara Ulusal Cami ve Kültür Merkezi Projesi}

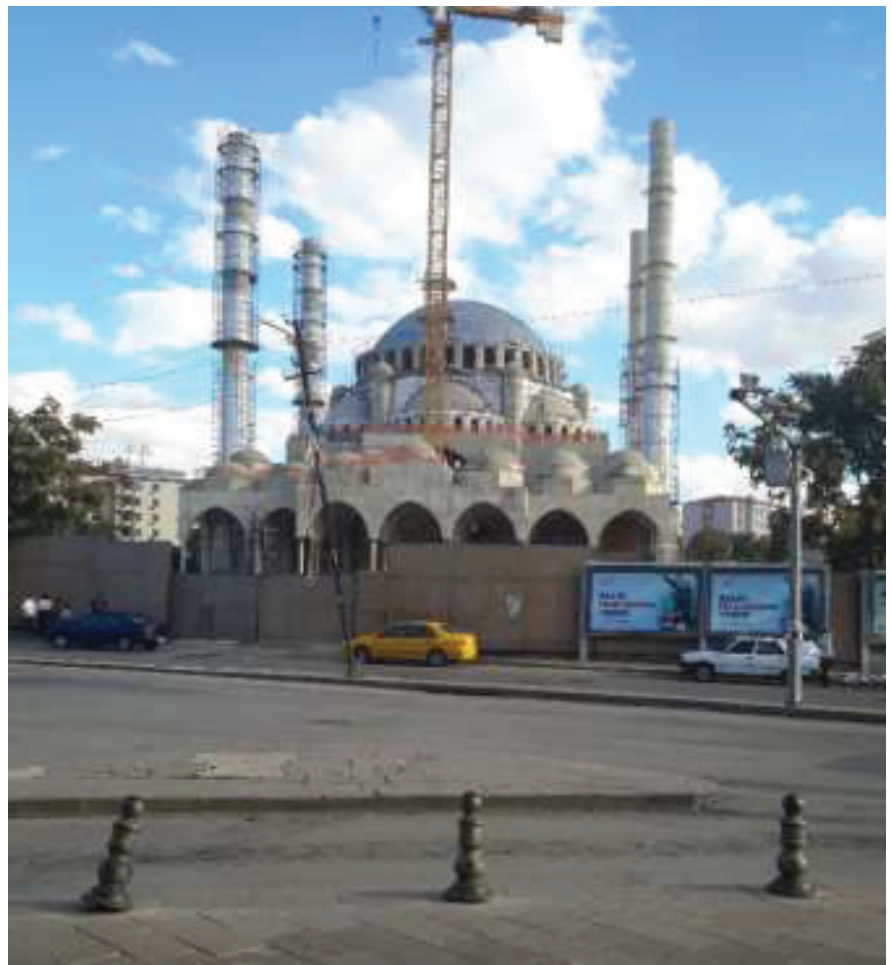

Kaynak: Yazar, 24.09.2015.

25 bin kişinin ibadetine (mekânsal pratikler) imkân sağlamaya yönelik ve "inşa edilmesi talimatını Cumhurbaşkanı Recep Tayyip Erdoğan'ın verdiğii"705 bu cami projesi (mekân temsili) Erken Cumhuriyet döneminin seküler kamusallığının mekân temsili olan Gençlik Parkı'na bir karşı ağırlık merkezi oluşturmakla yetinmeyerek aynı zamanda Selçuklu mukarnas taş süsleme sanatı ile (temsil mekânıyla) çevresinde bulunan ve Cumhuriyet'in ilk yıllarının temsil

neredeyse deneyimlenmeyen bir yapı haline geldiği ve Gençlik Parkı'na kıyasla daha soyutlandığı söylenebilir.

705 Öğüt, "Büyük Cami Talimatı Cumhurbaşkanı'ndan”. 
mekânı olan bir takım yapılara (Osmanlı Bankası binası, İller Bankası binası, Sergi Evi) ${ }^{706}$ karş1 ağırlık merkezi oluşturarak tasarlanan, algılanan ile yaşanan boyutlarıyla bölgeyi yeniden tanımlamaktadır.

Gençlik Parkı'nın, sadece içerisinde ve bulunduğu mevkideki yapılı çevre düzenlemeleriyle yeniden tanımlanması söz konusu değildir, aynı zamanda toplumsal açıdan yeniden tanımlanmaya maruz kaldığı görülmektedir. Bu yeniden tanımlanma ise iktidarın, nasıl bir kamusallık ve boş zaman değerlendirilme (mekânsal pratikler) tahayyülüne sahip olduğuna ilişkin ipuçlarını ortaya koyması bağlamında anlam kazanmaktadır.

Parkın yenilenmesi parkın kullanımı açısından yeniden tanımlanma sürecinin bir parçasıdır. Büyükşehir Belediyesi, 2005'te parkın yenileme projesiyle ilgili tanıtımda Gençlik Parkı, restoranlar ve içkili müzik performansları içeren eğlence mekanları sayesinde Ankara'nın ilk kentsel parkı olarak tarihsel süreç içerisinde ilk zamanlardaki değerlerinden uzaklaştığı, büyük bir metruk alan haline geldiği dolayısıyla parkı yeniden düzenleyerek onun tarihsel dokusunun eskisi gibi yeniden geri kazanılmasının amaçlandığını belirtmiştir. $\mathrm{Bu}$ doğrultuda aynı zamanda parkın tarihi dokusunun parçası olmayan ve parkta sonraki dönemlerde eklenen Lunapark'ın ve diğer yapıların da taşınması amaçlanmıştır. ${ }^{707}$ Oysa, 2008'de parkın yenilenmesiyle ilgili tanıtımlarda ABB, artık Lunapark'ın taşınacağı fikrinden vazgeçip onun yenileneceği, bir önceki projede hayvanat bahçesi olarak düşünülen mekân yerine artık tematik mekân niteliği taşıyan bir bilim merkezinin kurulmasının amaçlandığı, parktaki gazinoların kapatılması konusunda ise kararlı olduğu görülmektedir. 2009'da park açıldıktan sonra ise parkın tüm gazinoları artık yoktu ve parkta artık içkili mekânın olmadığı görülmektedir. Yani belediye bir taraftan parkın "yeniden Cumhuriyet'in ilk yılların hüviyetine kavuşacağını" belirtmiş ve bu doğrultuda daha sonraki zamanlarda eklenen mekanları taşınma veya kapatılmasını planlamış, fakat daha sonra ilk yılların kimliğine kavuşturma amacını tekrarlayarak bu kimlikle ilişkili olmayan başka mekânlar oluşturmuştur. İlk kimlikle de bağdaşmayan mekanlarının tasfiyesi konusunda ise seçici olarak davranıp, içkili mekanları kapatarak Lunapark'ın taşınması fikrinden vazgeçmiştir.

706 Osmanlı Canlandırmacılığı muğlak üslubuyla yapılmış Osmanlı Bankası binası, inşa edilen bu camiyle nispeten uyum içerisindeyken, camiye hemen bitişik İller Bankası binası modern mimari üslubuyla camiyle açıkça çelişen bir yapıdır (Osmanlı Bankası'nın ile İller Bankası'nın farklı dönemlerin temsili olduğu da unutulmamalıdır), o yüzden tescilli tarihi bir bina olmasına rağmen bugünlerde yıkım tehlikesiyle karşı karşıyadır. Bkz. Haber.sol.org.tr, "TMMOB Mimarlar Odası: İller Bankası Yıkılamaz, Tahrip Edenler Yargılanacak"; Mimarlar Odası Ankara Şubesi, "İller Bankası'nda Tarihi Katliam”.

707 Turan, “Gençlik Parkı'na Gençlik Aşısı”, s. 17-18. 
Melih Gökçek, farklı vesilelerle parkın yeniden düzenlenmesiyle ilgili konuşurken özellikle onun, parkın sık sık bir aile parkı olduğu vurgusu dikkat çekmektedir;

“Insanlar, aileleri ve çocuklartyla akşam iş dönüşü buluşarak Park'ta rahatça oturabilecekler ve eğlenebilecekler. Park, yeni modern görünümüyle, gece gündüz açık kalarak eski hüviyetine kavuşacak."708

"Park; tiyatroları, gezi alanları, çay bahçeleri, yeşil alanları ve diğer birçok özelliği ile tüm Ankaralıların büyük bir keyifle gelip vakit geçirecekleri tam bir aile parkı oldu." 709

Büyükşehir Belediyesi'nin yayın organı tarafından bu hususun sı sık altının çizilmesi de kayda değerdir (bkz. Şekil 22).

\section{Şekil 22. Büyükşehir Ankara Bülteni, Sayı 200’ün Manşeti}

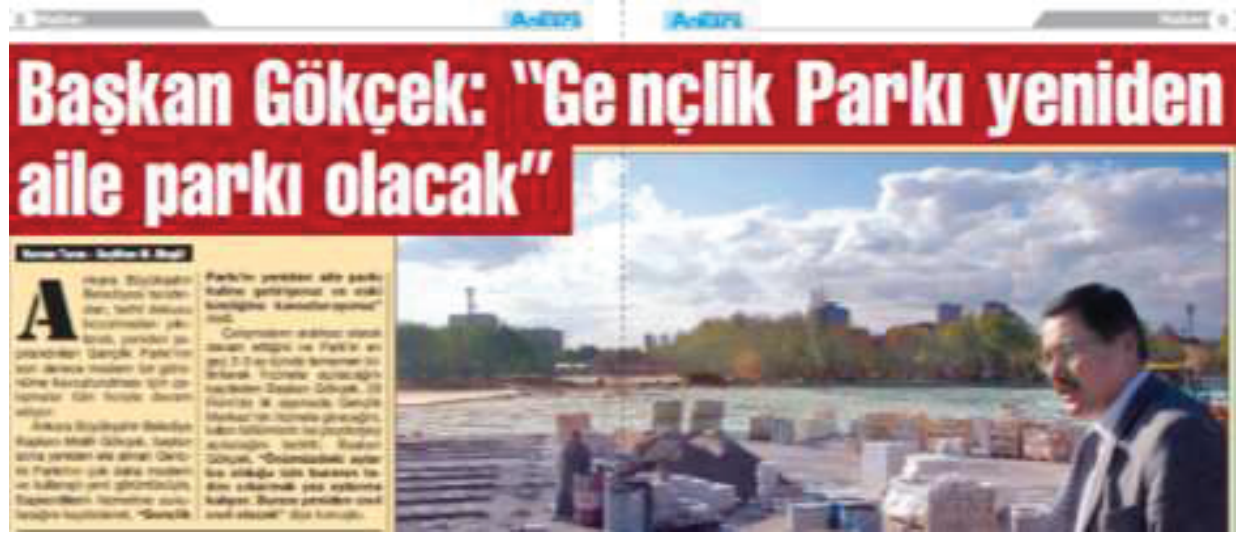

Söz konusu vurgu ise seçici koruma ve yenileme yaklaşımları bağlamında değerlendirildiğinde anlam kazanmaktadır. Geleneksel kamusal mekânların yeniden tanımlanmasında da karşımıza çıkan aile vurgusu, muhafazakarlığ temel çerçeve olarak benimseyen ve muhafazakarlık anlayışının temelinde aile kurumunu konumlandıran iktidarın, bu çerçeve doğrultusunda toplumu bireylerden ziyade ailelerden oluşan bir yap1 olarak tanımlamasından kaynaklanmaktadır. Bu yaklaşımla geleneksel kamusallık deneyimi de söylem düzleminde "tam bir aile parkı" olarak yeniden tanımlanarak belirli bir kurumsallığıyla - aile kurumuyla - ilişkilendirilmekte, böylece her bireye açık

708 Çıngır, "Gençlik Parkı Baharla Birlikte Yaşama Dönüyor”, s. 11, vurgu eklenmiştir.

709 Bingöl, "Gençlik Parkı Kapılarını "Zafer"le Açıyor", s. 10; Koç ve Bingöl, "Özlem Bitiyor Gençlik Parkı Kapılarını Açıyor”, s. 9, vurgu eklenmiştir. 
ve boş zaman değerlendirilmesine yönelik olan bir kamusal mekân "insanların, aileleri ve çocuklarıyla buluşarak rahatça oturabilecekleri ve eğlenebilecekleri" bir mekân olarak yeniden tanımlanmaktadır. Yenileme sürecinde parkta seçici koruma, ekleme ve ortadan kaldırma pratikleri bağlamında ise eskiden var olan ve toplumun belirli kesimleri için parkın algilanan ve yaşanan boyutlarının ayrılmaz parçası olarak değerlendirilen gazinoların kapatılması ise söz konusu mekânın "tam bir aile parkı"na dönüşmesinde ve pratik boyutta parkın toplumsal boyutunun yeniden tanımlamasında en kayda değer tarafı olduğu söylenebilir.

Lefebvre'in ideoloji tanımı ile Foucault'nun söylem (discourse) tanımı Gençlik Parkı'nın toplumsal olarak bu yeniden biçimlenmesi bağlamında özellikle aydınlatıcıdır. Lefebvre'ye göre,

"Gönderme yaptığı, tarif ettiği, söz dağarını ve bağlantılarını kullandığı, kodunu içerdiği bir mekân olmasa bir ideoloji nedir? (...) Daha genel olarak, "ideoloji" diye adlandırılan şey ancak toplumsal mekânda vücut bulabilmek için bu mekânın üretimine müdahil olur ve bu mekânda istikrar kazanır. "İdeoloji", kendi içinde, özellikle bu mekân üzerine bir söyleminden ibaret değil midir?"710

Foucault'un tanımlarında ise söylemler, bilgiyi oluşturma biçimleri, bu bilgilere bağlı olan sosyal pratikler, öznellik biçimleri ile iktidar ilişkileri ve bunlar arasındaki ilişkilerdir. Söylemler, düşünme ve anlam üretme biçimlerinden öte bir anlam taşımaktadır. Söylemler yönlendirmeyi (yönetmeyi) amaçladıkları öznelerin bedenin, bilinç altı ile bilincin ve duygusal yaşamın 'doğasını' oluşturmaktadır. ${ }^{711}$ Böylece, muhafazakâr değerlerin temel taşıyıcısı olarak aileyi gören iktidarın toplumsal mekânın yeniden tanımlanmasında, gazinolar içeren bir parkın, "tam bir aile parkı" olamayacağı, dolayısıyla yenileme aracılığılla somut pratiklerle park1 bu doğrultuda yeniden biçimlendirmesi hususu bu bağlamda değerlendirilebilir. Söylemsel olarak park1 aile ile s1k s1k ilişkilendirmesi ise düşünme ve anlam üretme biçimlerinden öte bir anlam taşıyan ve mekânda vücut bulan bir ideoloji olarak görülebilir. Gerek söylemsel pratikle gerekse somut müdahalesiyle bu yeniden tanımlanma ise aynı zamanda somut bir mekânda temsil mekânı ile mekân temsili boyutlarının iç içe geçtiğine işaret etmektedir.

Fakat parkın algilanan ve yaşanan boyutlarının yeniden tanımlanması bunlarla sınırlı değildir. Ramazan Bayramı sırasında parkın büyük bir etkinlik alanına dönüşmesi ve bu etkinlikler sırasında tasavvuf konserleri, Büyükşehir Belediyesi'nin açtığı iftar çadırları için parkın geleneksel bir mekân haline

710 Lefebvre, Mekânın Üretimi, s. 73.

711 Weedon, Feminist Practice and Poststructuralist Theory, s. 108. Foucault'nun söylem tanımlamaları ile ilgili ayrıca bkz. Foucault, Archaeology of Knowledge. 
gelmesi, ${ }^{712}$ dini bayram olmayan günlerdeki farklı etkinliklerde, "karargâhı" parktaki Kültür Merkezi'nde bulunan ${ }^{713}$ Büyükşehir Belediyesi Mehter Takımı'nın katılımı ve konserleri, ${ }^{714}$ Selçuklu Otağı kurarak Selçuklu Medeniyetinin Anadolu' daki izlerini tanıtan sergi gibi etkinlikler parkın yaşanan ve algılanan mekân boyutlarını yeniden tanımlayan süreçlerin örnekleridir (bkz. Şekil 23-26).

Yukarıda ele alınan bu hususlardan görüldüğü üzere nasıl bu park, Erken Cumhuriyet dönemindeki ideolojik yüklü bir mekân üretimi deneyiminin ürünüyse, benzer bir şekilde günümüzde de iktidar tarafindan ideolojik yüklü söylem, planlama ile mekânsal pratikler aracılığılla bu parkın yeniden tanımlanarak üretildiği görülmektedir. ABB, kendi ideolojik temayülleri, mekân temsili ile temsil mekânı ve tercih ettiği mekânsal pratikleri doğrultusunda hem yapılı çevrede farklı ekleme çıkarmalarla hem de farklı mekânsal pratiklerle bu mekânı önemli ölçüde yeniden tanımlamıştır. Parkın son dönüşümleri aynı zamanda iktidarın kamusal mekân tahayyülüne dair önemli ipuçları sunmaktadır.

712 ABB, "Büyükşehir'den Ramazan Etkinlikleri”; Bingöl, "Ramazan Etkinlikleri Gençlik Parkı'nda"; Tol, "Ramazan'da Gençlik Parkı Rengarenk, Cıvıl Cıvıl”; Turan, "Başkan Gökçek Gençlik Parkı'nda Ramazan Etkinliklerinde”.

713 ABB, "Büyükşehir'in Mehterleri, Gönülleri Fethediyor".

714 ABB, "Dünya Çocuk Oyunları'na Muhteşem Final". 
Şekil 23. Gençlik Parkı'nın Algılanan ile Yaşanan Boyutları Yeniden Tanımlanırken: Ramazan'da “Huzur-u Muhabbet” ve Tasavvuf Konserleri
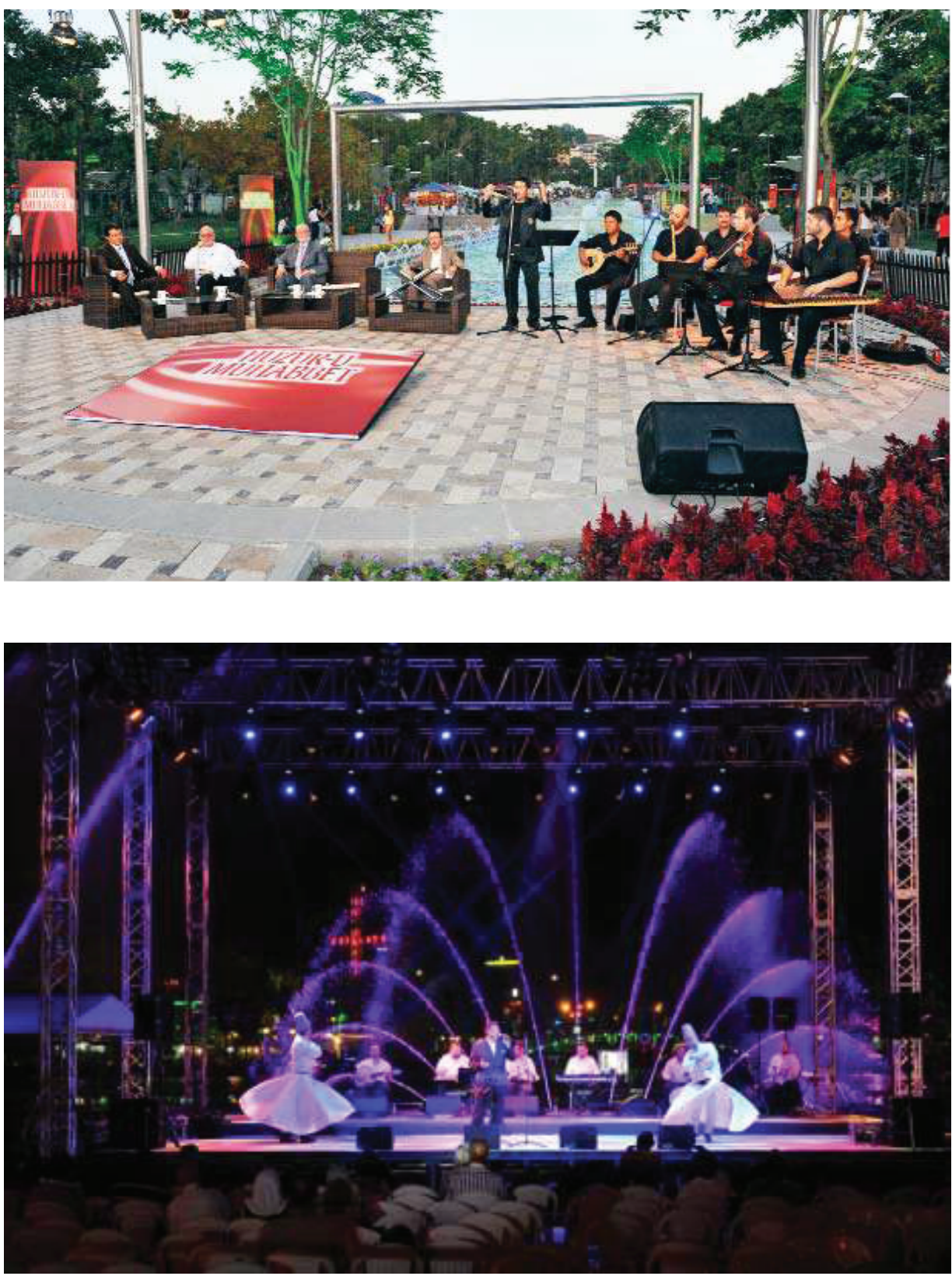

Kaynak: Bingöl, "Ramazan etkinlikleri Gençlik Park1'nda”, s. 18; ABB, "Büyükșehir'den Ramazan Etkinlikleri”. 
Şekil 24. Gençlik Parkı'nın Algılanan ile Yaşanan Boyutları Yeniden Tanımlanırken: Ramazan İftar Çadırları

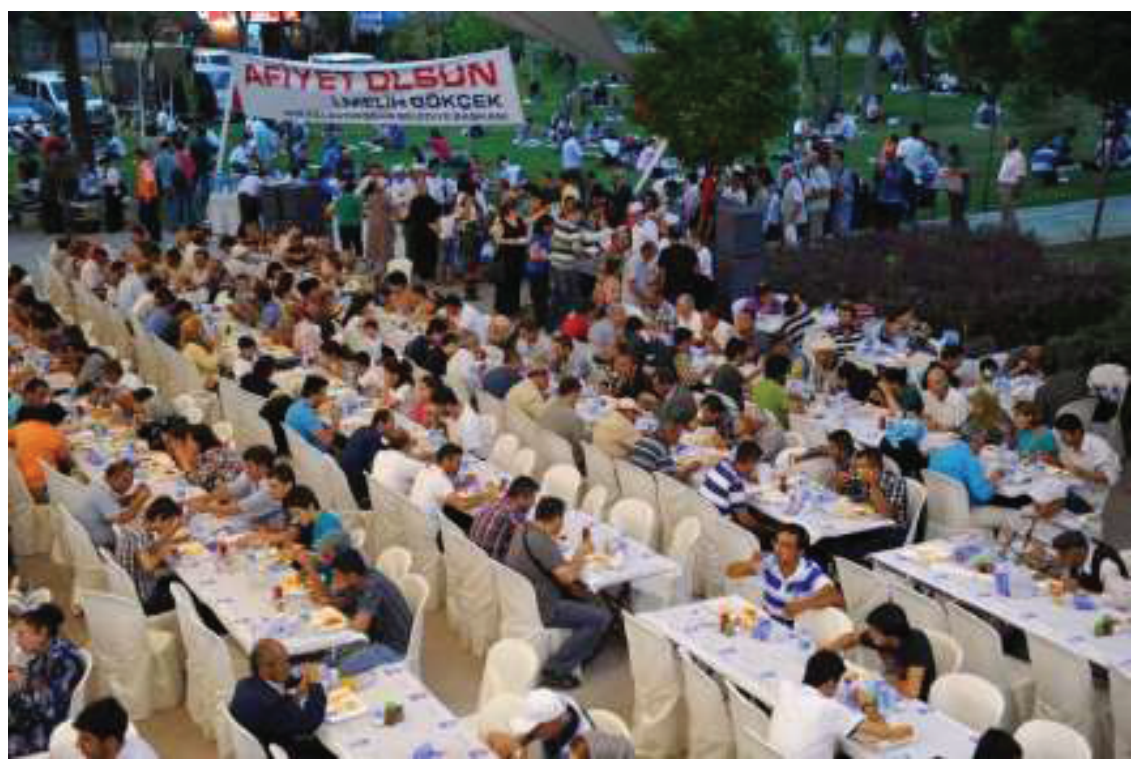

Kaynak: ABB, "Büyükşehir'den Ramazan Etkinlikleri”.

Şekil 25. Gençlik Parkı'nın Algılanan ile Yaşanan Boyutları Yeniden Tanımlanırken: Büyükșehir Belediyesi Mehter Takımı'nın Konserleri

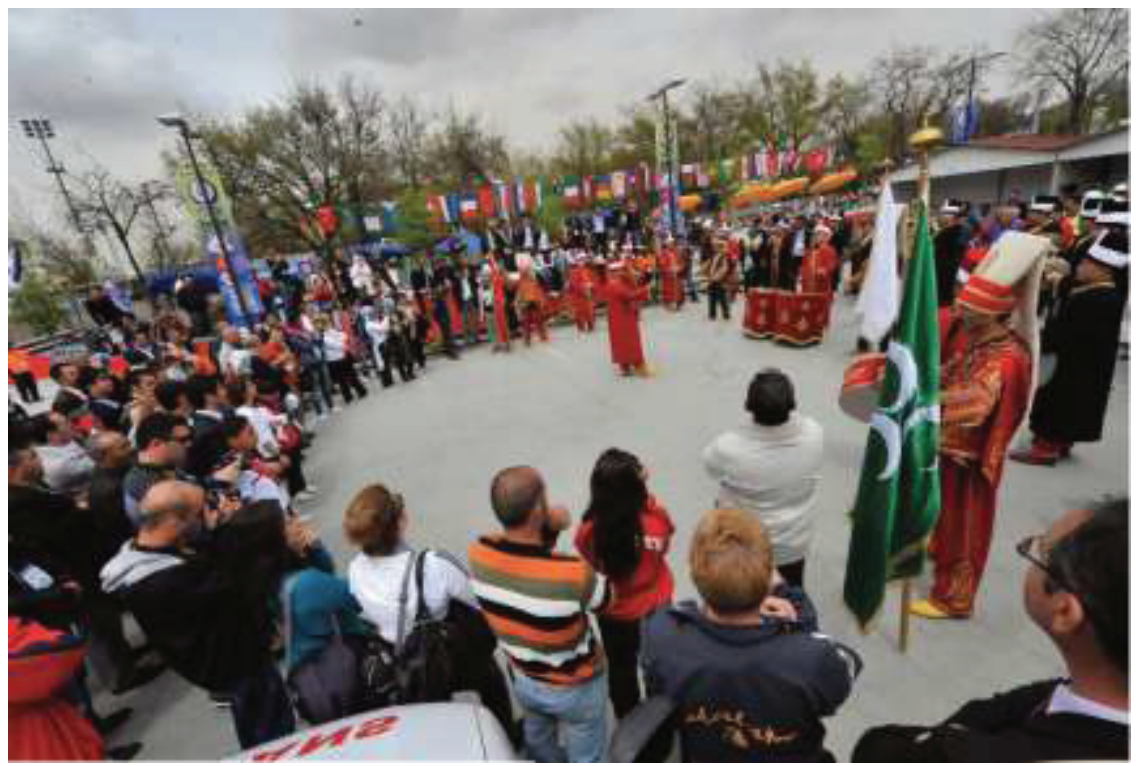

Kaynak: ABB, "Dünya Çocuk Oyunları'na Muhteşem Final”, s. 8-9. 


\section{Şekil 26. Gençlik Parkı'nda Yapılan "Selçuklu Medeniyetinin Anadolu'daki İzleri Sergisi”nin Afişi}

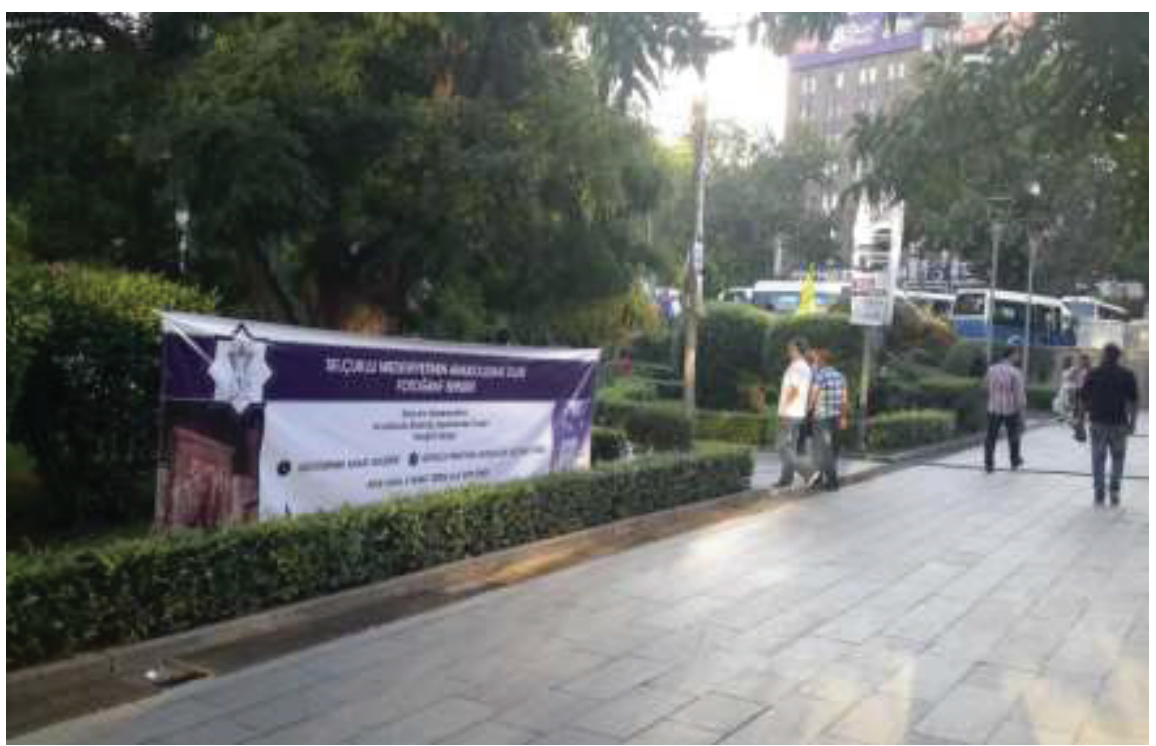

Kaynak: Yazar, 09.06.2015.

Belirtildiği üzere, 2002'den itibaren kentte Büyükşsehir Belediyesi tarafindan çok sayıda yeşil alan yapıldığı görülmektedir, ${ }^{715}$ fakat bunlar arasında özellikle kentsel parktan ziyade geniş rekreasyon alanları niteliğinde olan Göksu Parkı (Eryaman), Mogan Parkı (Gölbaşı), Harikalar Diyarı (Sincan), Mavi Göl (Mamak), Karagöl (Çubuk) gibi alanların yeniden düzenlenerek rekreasyon için önemli mekanlar haline getirilmesidir. Bunlar genellikle hafta sonu ve tatil ile bayram günlerinde halkın boş zamanını değerlendirmesi için önemli imkanlar sunmaktadır. 'Rekreasyon alanı' konseptinin çok kapsamlı niteliğine kıyasla mekânsal pratikler bağlamında daha dar anlayışla düzenlenmelerine ${ }^{716}$ rağmen

715 Büyükşehir Belediyesi tarafından, 1994'te 19 parkı olan Ankara'da son 20 sene içerisinde 366 park yapıldığı, aynı zamanda Ankara' da kişi başına düşen yeşil alan miktarının 1994'teki 2 metrekareden 2015'te 19,5 metrekareye ulaştığı belirtilmektedir. Bkz. ABB, "Ankara Ağaca, Çiçeğe ve Yeşile Bezenecek"; ABB, "İşte Yeşil Ankara".

716 Örneğin Büyükşehir Belediyesi gerek kentsel park niteliğinde olan Gençlik Parkı'nı ve gerekse yukarıda belirtilen alanları rekreasyon alanı olarak tanımlamaktadır. Bu tanımı ise Sargın'ın belirttiğine göre sorunlu bir tanımdır zira bu yaklaşım modern rekreasyon kavramına uygun olmamakla birlikte, kentsel pratikleri basite indirgemekte ve ancak popüler nitelikli kentsel pratikleri öne çıkarmakta, çağdaş metropollere özgü 'rekreasyon' tanımına denk düşmemektedir (bkz. Sargın, “Atatürk Kültür Merkezi Alanı Değerlendirme Raporu”). 
bu mekânlar önemli imkanlar sunmakta ve Büyükşehir Belediyesi’nin, ele alınan dönemde giriștiği kullanım değeri odaklı mekân düzenlemelerinden diğer önemli ekseni teşkil ettiği söylenebilir. ${ }^{717}$ Fakat bu süreçte kayda değer husus, ABB ile Melih Gökçek tarafından konu ile ilgili popülist bir söylem benimsenmesidir.

\subsubsection{Eymir Gölü’nü ‘Halka Açmak'}

ODTÜ’ye ait olan Eymir Gölü, yaya girişiyle bir kısıtlama veya ücret söz konusu olmadan öteden beri halka açık ve sadece araç girişleri için kısıtlı olan ve Ankara'nın önemli doğal alanlarından biridir. Ayrıca bu alan doğal SíT alanı ve sulak alan statüsüyle beraber sportif ve bilimsel faaliyetler için öteden beri önemli bir alan teşkil etmiştir. Oysa ABB Başkanı Melih Gökçek tarafından gerek sosyal medyada gerekse diğer medya aracılığıyla bu alanı "halka açmak" popülist söylemleriyle Eymir Gölü ile ilgili zaman zaman tartışmalara yol açtığı görülmektedir. Benzer bir popülist söylemin aynı zamanda ABB yayın organı tarafından benimsendiği de görülmektedir (Şekil 27-28).

Bu bakımdan neredeyse tüm söz konusu mekanlarda popüler nitelikli mekânsal pratiklerin öne çıktığı ve rekreasyon konseptinin diğer boyutlarının söz konusu olmadığı görülmektedir.

717 Burada kullanım değeri odaklı mekân düzenlemeleri veya üretimi vurgularken, bu süreçlerin değişim değeri boyutu olmadığı anlamına gelmediği de belirtilmelidir. Söz konusu süreçlerde mevzubahis park düzenlemeleri önemli miktarda kamu kaynaklarının özel şirketlere aktarılma süreçlerini de içermektedir, çünkü bu alanların yeniden düzenlemesinden onları yeşillendirmek ve ağaçlandırmak için gerekli ağaçların yurtdışından ithallerine kadar uzanan süreçlerin neredeyse hepsini $\mathrm{ABB}$ ihale aracılığıyla gerçekleştirmekte ve bazen bu süreçler 'rant' amaçlı olarak da değerlendirilmektedir (bkz. Cansu, "Gökçek'in Fidanları Para Açtı!'). Kullanım değeri odaklı mekânın üretimi altında burada kast edilen, bu süreçlerde üretilen mekânların herkesin kullanımına açık oldukları hususudur. Yani, mekânın üretimi süreçlerinin nihai aşaması satılacak ve özel mülkiyet olarak kullanım değeri olan bir yap1 veya mekân değil, herkesin yararlanabileceği mekânlardır, bu sürecin farklı aşamalarında değişim değeri odaklı süreçler önem kazanabilir, fakat nihai ürün herkesin kullanımı aracılığıyla değerlendirilecek mekânlardır. 
Şekil 27. Mekân Üzerine Popülist Söylemin Halleri: Büyükşehir Ankara Bülteni, Sayı 192, 372 ve 509'un Haber Manşetleri
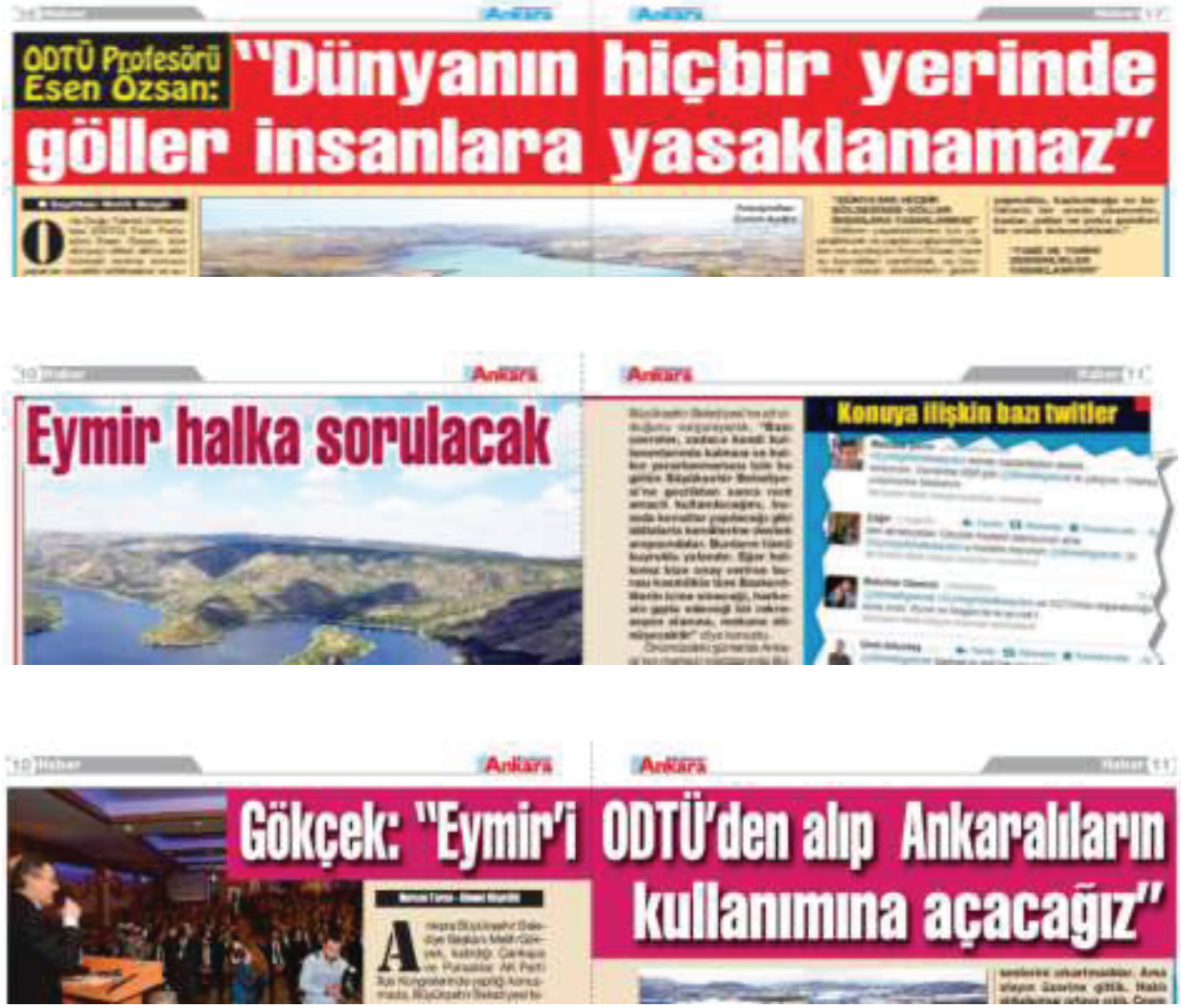

2008'den itibaren ABB ve Melih Gökçek tarafindan Eymir Gölü'nü "halka açmak", "bir azınlığın parkı olmaktan çıkartıp tüm Ankaralılara mal etmek" gibi popülist söylemlerle bu doğal SİT alanının ABB tasarrufuna girmesi amaçlandığı görülmektedir. 2014'te bu doğal alanın SïT derecesinin düşürülmesi ile ilgili süreçler burada turistik amaçlı yapılaşma ile ilgili süreçlerin ipuçlarını sunmakla birlikte söz konusu popülist söylemin altında yatan gerekçeleri de açıklayacak yöndedir. ${ }^{718}$ Fakat burada söz konusu süreçlerin altında yatan gerekçe ne olursa olsun, özellikle 'halka açmak' gibi söylem konumuz açısından önem taşımaktadır, zira ele alınan dönemde gerek yapılı çevrenin üretiminin farklı somut örneklerinde gerekse söylemsel düzlemde farklı mekânların yeniden tanımlanmasında 'halka açmak' gibi popülist söylemin önemli yer tutuğu ve ele

718 Bkz. Birgun.net, "Eymir Gölü Risk Altında"; Evrensel.net, "Eymir Gölü Adım Adım Ranta Açılıyor”; Evrensel.net, "ODTÜ Arazisi İmara Açılıyor". 
alınan dönemde mekânın üretimine eşlik eden önemli söylemsel pratik teşkil ettiği görülmektedir.

Şekil 28. Mekân Üzerine Popülist Söylemin Halleri: Büyükşehir Ankara Bülteni, Sayı 507 Kapak Sayfası

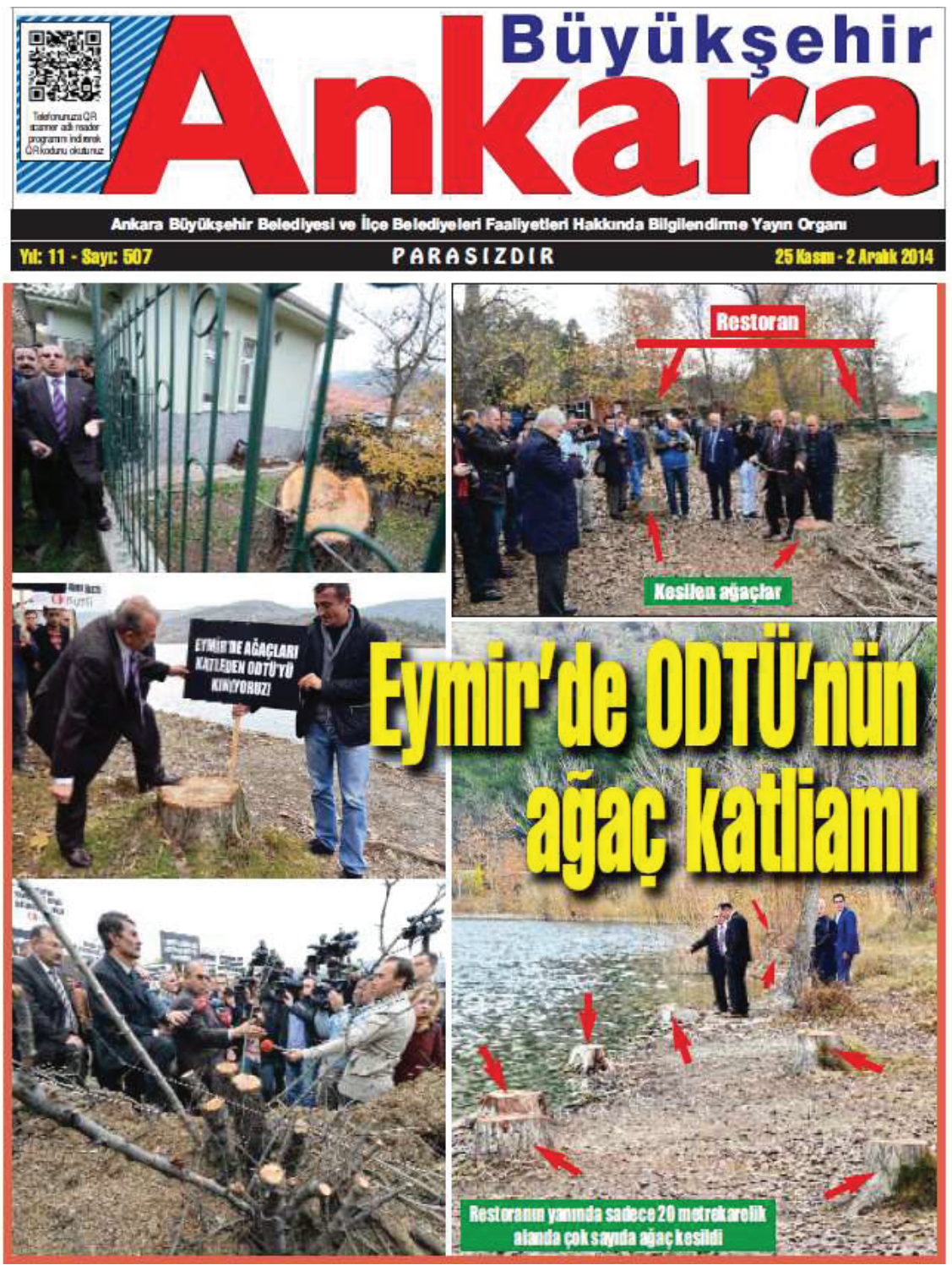




\section{Şekil 29. Mekân Üzerine Popülist Söylemin Halleri: Sosyal Medya}

Q1

fbrahim Melih Golkceok o

s. noter

Bu yollar istense de istenmese de yapilacak. Eymir halka açılacak. Umarım ki sorunlariodtu yetkilileri ile anlayıș içerisinde çozeriz.

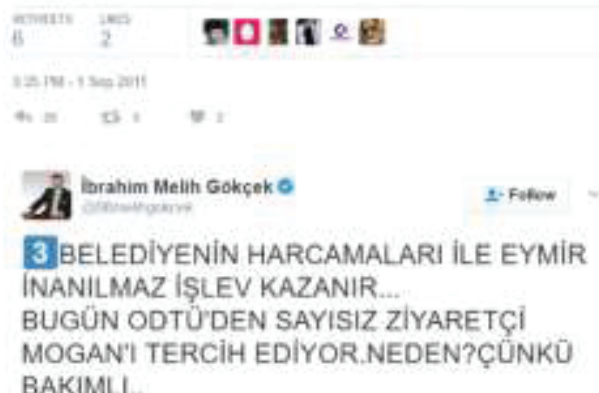

BAKIMLI

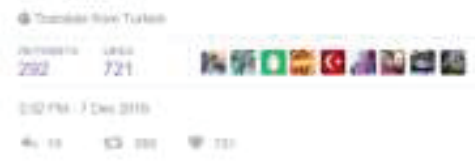

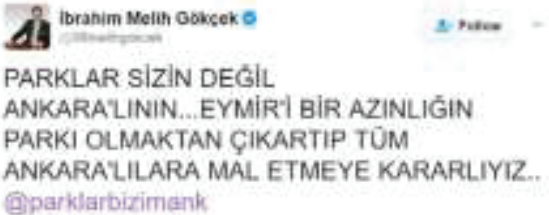

Giparklarbizimank

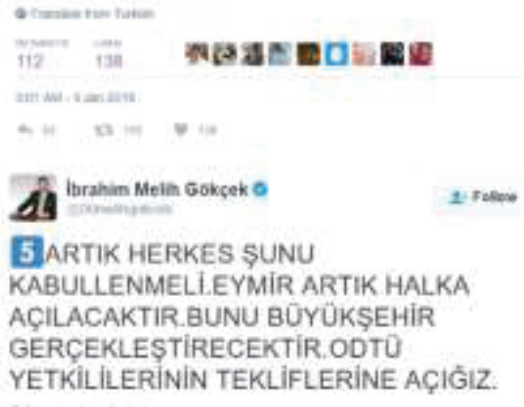

YETKILILERININ TEKLIFLERINE AÇIĞIZ.

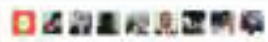

Kaynak: Melih Gökçek'in Twitter hesab1, https://twitter.com/06melihgokcek

\subsection{Popülizmin ve Oryantalizmin Mekânsal Tezahürleri719}

"Nasıl İstanbul deyince yedi tepesindeki yedi cami aklımıza geliyorsa İnşallah Ankara'yı da aynı özelliğe kavuşturuyoruz. Bunun gayreti içindeyiz. İşte Kocatepe ve Beştepe.” - R. T. Erdoğan 720

Ele alınan dönemde, Ankara' da mekânın üretimi süreçlerinde kayda değer diğer boyut söylemsel düzlemde veya temsil üretimiyle bir bütün olarak kentin ve onun farklı mekânlarının yeniden tanımlanması ve kentsel mekânın algılanan ile yaşanan boyutlarının yeniden biçimlendirilmesidir. Bu bağlamda kentin farklı mekânlarının yeniden isimlendirilmesi, farklı mekânlara belirli temsiller yüklenmesi ile yapılı çevrenin üretimiyle birlikte kent imgesinin yeniden tanımlanma süreçleri öne çıkmaktadır.

719 Bu bölümde geliştirilen fikirler ilk kez New Perspectives on Turkey dergisinde Spatialization of the Islamist, Populist and Neo-Ottoman Discourses in the Turkish Capital Under AKP Rule başlıklı makalede yayınlanmıştır. Bkz. Ghulyan, Husik. "Spatialization of the Islamist, Populist and Neo-Ottoman Discourses in the Turkish Capital Under AKP Rule". New Perspectives on Turkey 61, 2019. https://doi.org/10.1017/npt.2019.15.

720 Hurriyet.com.tr, "Erdoğan, Beştepe Millet Camii Açılışında Konuştu". 


\subsubsection{Temsil ile Karşı Temsil Mekânları Olarak Yer İsim Değişiklikleri}

ABB Numarataj Şube Müdürlügü verilerine göre 2013-2015 yıllarında Ankara'da toplam olarak 7227 sokak, cadde, bulvar ve meydan ismi değişikliği gerçekleştirilmiştir. ${ }^{721}$ Bunlardan 5979'u (toplam değişikliklerin \%82,7'si) farklı sokak veya caddelerin statü değişikliğini oluşturmuştur (sokaktan caddeye veya caddeden sokağa değişiklikleri). Dolayisıyla söz konusu dönemde isim değişikliği niteliği taşıyan isimlendirmelerin toplam sayıs1 1248 olmuştur. $\mathrm{Bu}$ son rakamın çoğunluğu ise (1028 isimlendirme) yeni yerleşim yerlerinde veya kentsel dönüşüm yaşanan yerlerde yeni kurulan sokak veya caddelere verilen isimlerdir (bkz. Tablo 7).

Toplam değişikliklerin ancak 167'si var olan sokak, cadde, bulvar veya meydanların yeniden isimlendirilmesini teşkil etmiştir. Konumuz açısından önemli olan husus, ilk ismi numara olup değişiklikle numara yerine isim verilen, mevcut ismi yerine başka bir isim verilen, ayrıca ilk isim olarak sıfirdan isim verilen değişikliklerdir. Bu üç çeşit değişiklik ise söz konusu örneklemde toplam 301 adet değişikliğe tekabül etmiştir.

Tablo 7. 2013-2015 Arası Dönemde Ankara'da Yer İsim Değișiklikleri

\begin{tabular}{|l|l|r|r|}
\hline \multicolumn{2}{|l|}{ Değişiklik biçimi } & Sayı & \multicolumn{1}{c|}{$\%$} \\
\hline \multirow{4}{*}{ Statü değişikliği } & aynı isim (sokaktan caddeye) & 5976 & $99.95 \%$ \\
\cline { 2 - 4 } & aynı isim (caddeden sokağa) & 3 & $0.05 \%$ \\
\cline { 2 - 4 } & Toplam & 5979 & $100.00 \%$ \\
\hline \multirow{4}{*}{ Illk isimlendirme } & ilk isim (isim) & 191 & $17.58 \%$ \\
\cline { 2 - 4 } & ilk isim (numara) & 891 & $82.42 \%$ \\
\cline { 2 - 4 } & Toplam & 1081 & $100.00 \%$ \\
\hline \multirow{5}{*}{ İsim değişiklikleri } & isimden isime & 32 & $19.16 \%$ \\
\cline { 2 - 4 } & numaradan isime & 78 & $46.71 \%$ \\
\cline { 2 - 4 } & numaradan numaraya & 167 & $33.53 \%$ \\
\cline { 2 - 4 } & isimden numaraya & $100.00 \%$ \\
\cline { 2 - 4 } & Toplam & $160 \%$ \\
\hline
\end{tabular}

Söz konusu 301 isim değişikliği veya isimlendirme örneğine bakıldığında şöyle bir tablo karşımıza çıkmaktadır. Bu değişikliklerin toplamının yaklaşık

721 ABB, "Değişen Cadde ve Sokak İsimleri”. 
\%23'ü AKP'nin sahiplendiği tarih yazımıyla veya İslamiyet'le yakından ilişkili olan farklı ideolojik yüklü isimler olduğu görülmektedir. Özellikle bunlar arasında en sık karşılaşılan yer isimleri olarak Osmanlı ile Selçuklu tarihine, farklı İslam alimlerine gönderme içeren isimler mevcuttur. Örneğin, Osmanlı ve Selçuklu tarihine veya Osmanlı dönemine gönderme yapan isimlendirme veya isim değişiklikler olarak Melikşah, Oruç Reis, Uluç Ali Paşa, Salah Reis, Seydi Ali Reis, Çandarlı Halil Paşa vs., farklı tarihsel dönemlerde öne çıkan İslami alimler olarak Akşemseddin, Abdullah Faruki, Alaaddin Fersafi, Mustafa Asım Köksal, Aziz Mahmud Hüdayi, Tapduk Emre, İmam Gazali, Mehmet Zahit Kotku, Saltuk Buğra vs. veya doğrudan İslam'a gönderme içeren isimler olarak Ehlibeyt, Safahat, Hafiz, Hicaz, Bedir, İhvan, Kandil, Nisa gibi isimler görülmektedir. İncelenen veriler çok kısa bir dönemi kapsamasından dolayı bu veriler çok iddialı saptamalar veya daha derinleştirilmiş ve çok yönlü analiz (ör. coğrafi dağılım) yapmaya elverişli olmamakla beraber toplam değişikliklerde söz konusu isimlerin önemli bir yüzdesini (\%23) oluşturması yine de bu değişikliklerin belirli bir temsil niteliği taşıdığını göstermektedir. Dolayısıyla ABB tarafından yapılan bu değişiklikler iktidarın temsil mekânı ile ilgili bazı ipuçları sunmaktadır. Elbette bu değişikliklerin bazıları veya çoğu ABB tarafindan bilinçli bir şekilde sahiplenilen tarih yazımı veya temsiller doğrultusunda kentsel mekânın temsil boyutunu (yeniden) tanımlama çabaları da olmayabilir, fakat genel olarak ele alınan dönemde iktidarın, Ankara'da belirli yer isimlendirme girişimleri ve onlara eşlik eden tartışmalarda öne çıkan tutum, bu süreçlerin rastlantısal olmadığını kanıtlayacak niteliktedir. Bu durum açık bir şekilde bir takım önemli mekânlar üzerine söylem bağlamında ortaya çıkmaktadır. ${ }^{722}$

Örneğin, 2013'te yapımı başlayıp 4 ay içerisinde tamamlanan, Eskişehir Yolu ile Anadolu Bulvarı'nı Konya Yolu'na bağlayan ve 'ODTÜ Yolu' olarak bilinen bulvarın adının "1071 Malazgirt Bulvarı" olarak değiştirilmesi bu açıdan ABB'nin temsil mekânını ortaya koyma yönündedir. Bulvara söz konusu ismin

722 Suavi Aydın, Ankara'da yer isim değişiklikleriyle ilgili kayda değer karşılaştırmalı bir tablo sunmaktadır. Ona göre, Cumhuriyet'in erken dönemlerinde Ankara'yı planlanırken sokak isimlerini belirli bir sistematiğe göre vermeye çalışılmıştır, örneğin Sıhhiye bölgesindeki sokaklara genellikle çiçek isimleri, Küçükesat ve Kavaklıdere bölgesindeki sokak isimlerinin B harfi ile Çankaya bölgesindeki bazıları N ve K harfiyle, Kızılay civarındaki sokakları ise $\mathrm{K}$ harfi ile başlamasına özen gösterilmiştir, son dönem belediye yönetimleri ise politik yönelimlerine uygun düşen yer isimlendirmeleriyle bir taraftan bu sistematiği bozmuş, diğer taraftan şehri kendi kimliğinden uzak, ne şehirle ne de odağı olduğu coğrafyayla ilişkisi olan bir takım isimlerle adresleyerek şehirdeki yabancılaşmayı daha da arttırmışlardır. Bkz. Aydın, "Ekolojik Tahribat ve Kültürel Çöküş: Bir Şehir Yaratma Projesinin İflası Olarak Ankara", s. 92-93, dipnot 81 . 
verilmesi $\mathrm{ABB}$ Meclisi'nin oy birliğiyle kabul edilmesine ${ }^{723}$ rağmen ayn1 zamanda belirli toplumsal kesimlerin tepkisine yol açmış ve tartışmalara sebep olmuştu. ${ }^{724} \mathrm{Bu}$ tepki ve tartışmaların var olmasını da toplumsal farklı kesimler tarafından iktidarın, farklı temsil mekânları üretimi aracılığıyla belirli tarih yazımını egemen kılmasına yönelik bir tepki olarak da değerlendirmek gerekir. Melih Gökçek, bulvarın ismiyle ilgili açılamada bulunurken "Türklerin Anadolu'ya giriş tarihini hatırlatmak amacıyla bu ismi uygun gördüklerini""725 belirtmiştir, aynı zamanda mekân semiyolojisi açısından bu yolun Anadolu Bulvarı'nın devamı olduğu ve Türklerin Anadolu'ya girişinin de 1071 tarihinde Malazgirt'te olduğu için yol isminin anlamlı olduğunu da belirtmiştir. ${ }^{726}$

1071 Malazgirt Bulvarı'nın adlandırılması konusu iktidarın bir temsil mekânı üretme girişimi olmakla beraber Türklerin Anadolu'ya giriş tarihini simgelemesi dolayısıyla popülist milliyetçilik ve daha geniş toplumsal kesimlere hitap edebilme niteliği de unutulmamalı, bu açıdan bulvarın isminin Büyükşehir Meclisi'nin oybirliğiyle kabul edilmesi de tesadüf değildir, aynı zamanda olay, mevcut bir yer isminin değiştirilmesi olmadığı için temsil mekânı ile karşı temsil mekânı etrafinda gelişen siyasi bir tartışmaya da neden olmadı. Oysa aynı dönem Ankara'da bir başka önemli mekânın adının değiştirilmesi iktidarın, kendi sahiplendiği ulusal tarih anlatısının temsil mekanını üretme açısından kayda değerdir.

13 Nisan 2015'te Ankara Büyükșehir Belediyesi Meclisi'nin AKP'li üyelerinin Tandoğan Meydanı'nın ismini “Anadolu Meydanı” olarak değiştirme önergesi doğrultusunda Büyükşehir Belediye Meclisi'nin kararıyla meydanın ismi Anadolu Meydanı olarak değiștirildi. ${ }^{727}$ ABB Meclisi'nde konu ile ilgili tartışmalar ve oylama bu açıdan kayda değerdir. ABB Meclisi'nin CHP'li üyeleri değişikliğe karşı çıkıp, MHP'li üyeleri ise çekimser oy kullanırken değişikliğin gerçekleştirilmesi için yeterli 3'te 2 oy oranını sağlayamayan AKP'li ve 3 bağımsız meclis üyesine BBP'li İbrahim Uyar'ın katılmasıyla meydanın isminin değiştirilmesine karar verildi. Aynı zamanda BBP'li Uyar'ın değişikliği olumlu bulmasının sebebi, Nevzat Tandoğan tarafından Anadolu halkına 'öküz' diyerek

723 Köprülü, “ODTÜ Yolu'na, “1071 Malazgirt Bulvarı” Ad1 Verildi”.

724 Yıldırım, "Malazgirt Atışması”.

725 Ibid.

726 Köprülü, “ODTÜ Yolu'na, "1071 Malazgirt Bulvarı” Ad1 Verildi”, s. 17. Bulvarda aynı zamanda 8 adet alt geçit bulunduğu ve bunlardan 7'sine Sultan Alparslan Köprüsü, Sultan Alparslan altgeçidi, 1. Alaaddin Keykubat Köprüsü, 2. Kılıçarslan Köprüsü, 1. Giyasettin Keyhüsrev Köprüsü ve Melikşah Köprüsü isimleri verildiği de belirtilmelidir. Bkz. ABB, “1071 Malazgirt Bulvarı'na Muhteşem Açılış”, s. 8.

727 Semerci, "Tandoğan Meydanı, "Anadolu Meydanı" Oldu”. 
hakaret edilmesini belirterek 728 böylece meydanın isminin neden 'Anadolu' olarak değiştirilmesinin sebebini de dolaylı olarak açıklamıştır. ${ }^{729} \mathrm{Bu}$ süreç genel düzeyde şu hususla ilişkilendirilebilir. AKP'nin 'halktan olma' vurgusu hem siyasi polemiklerde hem de bu partinin yakın tarih anlatısında popülist söylemindeki en temel unsurlarından biri olmuştur. Koyuncu'nun da belirttiği gibi,

“AK Parti’nin kullandığı popülist söylem yakın tarihi bir tarafı ‘halk’ yani 'ulusun gerçek sahipleri', diğer tarafı ise 'onların kalkınmasını istemeyen' ve 'onları aşağılayan' düşmanlar olan bir mücadele olarak yeniden yazmaktadır. Bu söylem birincisinin temsilcisi ve ikincisinin karşısındaki tek güç olarak AK Parti'nin çeşitli alanlardaki politikaları için gerekli meşruiyeti sağlamakta, dahası kendisine karşı yapılan muhalefet için bir koruma kalkanı oluşturmaktadır." 730

Meydan isminin değişikliği için önerge verildiğinde Nevzat Tandoğan tarafından uzun yıllar valilik ve belediye başkanlığ 1 görevi yapıldığı, görev süresince halkı kılık kıyafeti nedeniyle Ankara'ya girişine izin vermediği dolayısıyla "böyle bir ismin demokrasi adına insanlık adına yakışmadı̆̆ı", Anadolu halkına 'öküz' diyerek hakaret ettiği gibi söylemler Koyuncu'nun yukarıdaki saptamadaki 'halk' yani 'ulusun gerçek sahipleri' ile 'onları aşağılayan' düşmanlar söylemi kapsamına girmekte ve AKP'nin 'halktan olma' söylemini yeniden üretmektedir. Böyle bir söylemde somut mekân olarak Tandoğan Meydanı ise 'halkı aşağılayanlar'1 temsil eden bir mekân yani temsil mekânı olarak öne çıkmaktadır (tanımlanmaktadır). O yüzden meydanın ismi değiştirilerek bu temsil mekânı ortadan kaldırılmak istenmektedir. Meydanın

728 Bkz. Cnnturk.com, “Tandoğan Meydanı'nın İsmi “Anadolu Meydanı” Olarak Değiştirildi”.

729 2012'de de bu meydanın isminin değiştirilmesi gündemde olmuştur ve o zaman değişikliğin önergesini sunan ABB Meclisi bağımsız üyesi Hüseyin Günay gerekçe olarak Nevzat Tandoğan tarafindan Ankara'da 18 yıl valilik ve belediye başkanlığı yaptığını, görevi sürecinde Anadolu halkını ikinci sınıf gördüğünü dolayısıyla "demokrasiye karşı odaklarla mücadele eden bir ülkenin başkentinde böyle bir ismin demokrasi adına insanlık adına yakışmadığı"nı belirtmiştir. Ayrıca, Nevzat Tandoğan tarafından kılık ve kıyafetinin uygun olmadığı gerekçesi ile Aşık Veysel'in Ankara'nın girişinde bekletilmesi ve Ankara'ya alınmaması gibi örnekleri de vererek Tandoğan Meydanı'nın isminin “İstiklal, Cumhuriyet ve Demokrasi Meydanı" olarak değiştirilmesini önermiştir. Fakat 2012'de “vatandaşların Tandoğan Meydanı ile Nevzat Tandoğan arasında bire bir ilişki kurmadıkları, Tandoğan Meydanı'nın akla Nevzat Tandoğan'ı getirmediği ve gereksiz tartışmaların meydana gelmemesi, vatandaşın eski, yeni isim karmaşasına sürüklenip mağdur edilmemesi açısından" meydanın isminin tamamen değiştirilmesi yerine sadece 'Nevzat' ismi çıkarılmış ve 'Tandoğan Meydanı' olarak isimlendirilmiştir. Bkz. Hurriyet.com.tr, "Tandoğan Meydanı'nın İsminin Değişmesi İçin Teklif”; Radikal.com.tr, “Tandoğan Meydanı'nın İsmi Değişti”.

730 Koyuncu, “Benim Milletim...”: AK Parti İktidarı, Din ve Ulusal Kimlik, s. 175. 
isminin 'Anadolu' olarak değiştirilmesi ise 'halkı aşağılayanlar'lara karşı bir temsil üretme girişimidir ve bu girişimin sonucu olan Anadolu Meydanı iktidarın 'halktan olma' popülist söyleminin üretmeye çalıştı̆̆ 1 bir karşı temsil mekânıdır. ${ }^{731}$

Bu arada 2007'de AKP'ye karşı ulusalc1-milliyetçi güç merkezleri ve laik duyarlılıkları olan geniş toplumsal kesimlerin bir gövde gösterisi niteliği taşıyan, Ankara, İstanbul ve İzmir' de düzenlenen “Cumhuriyet Mitingleri”nden ilki ve en kalabalığı olan 14 Nisan Cumhuriyet Mitingi'nin Tandoğan Meydanı'nda gerçekleștirildiği, ${ }^{732}$ bununla bu meydanın bir temsil mekânı olarak sadece Nevzat Tandoğan'ın ismiyle sınırlı olmadığı, aynı zamanda somut mekânsal pratikler aracılı̆̆ıyla meydanın temsil mekânı boyutunun yeniden üretildiği de belirtilmelidir. Bu mitingin, AKP iktidarına karşı bir gövde gösterisi niteliği taşıdığı da hesaba katılırsa meydanın isminin değiştirilmesi bu yeniden üretilen temsil mekânı boyutunu ortadan kaldırmaya yönelik bilinçli bir girişim olmamakla beraber bilinçaltı düzleminde iktidar tarafından belirli bir temsili bastırma, unutturma çabası olarak da okunabilir.

\subsubsection{Söylemsel, Toplumsal ile Anıtsal Düzlemlerde Ankara'nın ‘Külliye’leri}

Söz konusu dönemde kentsel mekânın temsil boyutunun üretimi ile yeniden üretimi devam ederken aynı zamanda farklı toplumsal kesimler tarafından tepkiye ve tartışmalara neden olmuştur. ${ }^{733}$ Bazıları siyasi konjonktüre

731 Koyuncu'nun yukarıdaki tezine göre, AKP'nin bu popülist söylemi farklı politikalar için meşruiyet de sağlamaktadır ve kendisine karşı yapılan muhalefet için bir koruma kalkanı oluşturduğu da belirtilmektedir (bkz. "Benim Milletim...": AK Parti İktidarı, Din ve Ulusal Kimlik, s. 175). Yine ilgili meydan isminin değişikliğinin görüşüldüğü Büyükşehir Belediye Meclis tartışmalarına dönülürse bu tezin geçerli olduğu ve iktidarın söyleminin popülist niteliği açıkça görülebilir. Meydan isminin değişikliği ile ilgili önerisine çekimser oy veren MHP'lilere ABB Başkanı Gökçek, "CHP grubu ideolojik olarak karşı çıkıyor, bunu anlıyorum. Ama MHP grubu neden karşı çıkıyor anlamıyorum. Çıkacağım televizyonlarda 'MHP Tandoğan isminin değişmesine karşı çıktı' diyeceğim”' diye tepki göstermiş, MHP'li üyeler, değişikliğe karşı çıkmadıklarını, seçim sonrasına ertelenip halka sorulması gerektiğini savunmuşlardır. Bkz. Cnnturk.com, "Tandoğan Meydanı'nın İsmi “Anadolu Meydanı” Olarak Değiştirildi”.

732 Saraçoğlu ve Yeşilbağ, “AKP Döneminde Türkiye: Minare ile İnşaat Gölgesinde”, s. 923.

733 Bunlar arasında kayda değer örnekler olarak Ankara Garı önü meydanında düzenlenen Barış Mitingi'ne yönelik terör saldırısından sonra kimi kesimler tarafından meydanın isminin "Barış Meydanı" olarak önerilmesi fakat ABB tarafından "Demokrasi Meydanı" olarak isimlendirilmesi ve ilgili tartışmalar, 15 Temmuz darbe girişimi sonrasında Kızılay Meydanı'nın isminin “15 Temmuz Demokrasi Meydanı” olarak değiştirilmesi ve takip eden tartışmalar verilebilir. Bkz. Diken.com.tr, “AKP’ye “Barış” Fazla Geldi: Gar Meydanı’nın 
bağlı olan bazıları ise belirli yakın veya uzak bir tarih anlatımı içeren yukarıdaki örnekler ya da yaşadığımız dönemde söz konusu olan değişiklik ve tartışmalar temsil ile karşı temsil mekânı üretimi süreçleri olmakla beraber bunlarda toplumsal mekânı tanımlayarak yeniden üretimi belirli kişiler veya olaylar aracılığıyla gerçekleştirildiği görülmektedir. Fakat mevzubahis dönemde iktidarın mekân üzerine söyleminde ontolojik bakımdan kayda değer önemli bir vurgunun ortaya çıktığı da görülmektedir, bunda ise mekânı belirli olay, kişilerle tanımlayarak bir temsil üretme girişiminden ziyade mekânın da kendisinin ontolojik açıdan yeniden tanımlanmasıdır.

7 Ocak 2015'te Yıldırım Beyazıt Üniversitesi Esenboğa Kampüsü ve Sağlık Temel Bilimleri Binası açı1ış törenine katılan Cumhurbaşkanı Erdoğan konuşması sırasında yapılacak üniversitenin yerleşkesinin tanımlaması için şu açıklamalarda bulunmuştur:

"Yine bugün burada temel atma törenini gerçekleştireceğimiz
üniversitemizin, az önce Milli Eğitim Bakanımızla aramıda, mütalaa
diyebiliriz, müzakere diyebiliriz, "kampus" kelimesiyle ilgili bir müzakere
oldu. Acaba bu isim böyle mi olsa? Yoksa bu ismi "mahalle" mi koysak.
Sonra aklıma tarihimize dönmek geldi, dedim ki, herhalde buna "külliye"
daha güzel olur. Bu bir yeni dönemde ilk olur. Dolayısıly Esenboğa
Kampusu yerine Esenboğa Külliyesi temel atma töreni çok daha isabetli
olur."734

Böylece Cumhurbaşkanı, üniversitenin bulunduğu mekânı tanımlamak için Türkçeye yerleşmiş olan 'kampüs' veya Türkçedeki 'yerleşke' yerine Arapça kökenli 'külliye' sözcügünün kullanılmasının "çok daha isabetli olduğu"nu ve "bu bir yeni dönemde ilk olacağı"nı belirtmiştir. Tanımsal düzlemde bakıldığında, 'külliye'nin "bir caminin çevresinde cami ile birlikte kurulmuş medrese, imaret, sebil, kitaplık, hastane vb. yapıların bütünü" 735 anlamına geldiği ve Cumhurbaşkanı'nın göndermede bulunduğu Osmanlı'da toplumsal hayatın yoğunlaştığı, gerek kurumsal olarak gerekse yapısal olarak bir caminin etrafinda örgütlenen, bütünleşen, camiyle tümlenmiş mekanlardır, bu açıdan 'külliye' sözcüğünün 'tüm', 'bütün', 'tamlık' veya 'bütünlük' anlamına gelen Arapça 'kül' kökünden türemesi ${ }^{736}$ tesadüf değildir ve sözel düzlemde de

Ad1 "Demokrasi Meydanı" Olarak Değiştirildi”; Hurriyet.com.tr, "Gar Meydanı Demokrasi Meydanı Oldu”; Bayhan, “Kızılay Meydanı’nın Adının Değiştirilmesiyle İlgili Mimarlar Odası'ndan Açıklama”; Birgun.net, “Kızılay Meydanı'na Dokunma, Parsel Parsel Satışı Açıkla".

734 Erdoğan, "Yıldırım Beyazıt Üniversitesi’nde Yaptıkları Konuşma".

735 TDK, "Külliye".

736 Nişanyan, "Külliye". 
külliye belirli bir mekân temsili (aynı zamanda imgeleme hitap ettiği için bir temsil mekânı) ifade etmektedir. ${ }^{737}$

Cumhurbaşkanı tarafından bir üniversite yerleşkesinin 'külliye' olarak tanımlanmas1, söylem düzleminde belirli bir dünya imgesi, mekân temsili ve belirli bir imgelem içeren temsil mekânı doğrultusunda toplumsal mekânı yeniden tanımlama girişimi- olarak okunabilir. Fakat bu aynı zamanda iktidarın her üniversite kampüsü için birer cami yapma uygulamaları hesaba katıldığında, bu söylemin aynı zamanda belirli mekânsal pratiklerin aşı1ma ve böylece toplumsal mekânı bütünsel olarak yeniden tanımlama girişimi olarak da okunabilir. Şöyle ki 2014 Kasım ayında açıklamalarda bulunan Diyanet İşleri Başkanı Mehmet Görmez, Türkiye'de 80'i aşkın üniversitede cami inşaatlarının sürdüğünü, bunlardan 14'ünün ibadete açıldığını, 50'sinin ise 2015'te açılacağııı belirtmiştir. Bu bağlamda Görmez' in, “camilerin müesseseleşmesini istiyoruz. Sadece ibadet vaktinde, namazdan önce aç1lıp kapanan mekân olmaktan çıkarmak istiyoruz"738 ifadeleri kayda değerdir. ${ }^{739} \mathrm{Bu}$ açıdan, üniversitelerde camilerin müesseseleşmesini ve sadece ibadet için açılıp kapanan mekân değil, üniversite hayatıyla bütünleşmiş bir mekân haline getirilmek istenmesi, bunun doğrultusunda her bir üniversitede birer cami yapılması girişimi göz önünde bulundurulduğunda Cumhurbaşkanı Erdoğan'ın, 'kampüs' yerine 'külliye' sözcüğünü kullanması sadece söylemsel bir tanımlama değil, Lefebvre'in belirttiği gibi toplumsal mekânda vücut bulabilmek için bu mekânın üretimine müdahil olan ve bu mekânda istikrar kazanmaya çalışan dolayısıyla sadece mekân üzerine bir söylemden ibaret olmayan ideoloji ${ }^{740}$ olarak değerlendirilebilir. Yani, bu söylem ve girişimler, sadece belirli tarihsel geçmişe göndermede bulunan ve bu itibariyle temsil mekânı olarak tanımlanabilecek bir ifade değil, aynı zamanda belirli bir mekân temsili doğrultusunda üniversite hayatını camilerle bütünleştirerek ve belirli mekânsal pratikler aşılarak toplumsal mekânın yeniden tanımlanmasına işaret etmektedir. "Camilerin müesseseleşmesi” istemi ise üretilmekte olan külliyelerdeki toplumsal yaşamı belirli bir kurumsallığa tabi tutturma çabasını ifade ederek bununla bu

737 Lefebvre'in kavramlarından yola çıkılırsa, külliyelerin, Osmanlı'nın kutsal mekanının birer mikrokozmunu oluşturduğu, bir makrokozm olan Osmanlı'nın kutsal mekanının mekânsal hiyerarşisinde birer merkez olarak öne çıktığı söylenebilir.

738 Bkz. Hurriyet.com.tr, "Görmez: 80 Üniversitede Cami Olacak".

739 Aynı zamanda 2012'de dönemin başbakan yardımcısı Bekir Bozdağ'ın “üniversitelerimizin kampüslerinde camilerin bulunması, fakültelerin bulunması kadar ehemmiyetlidir. Birini öbürüne tercih etmek doğru bir yaklaşım değildir" şeklindeki ifadeleri, iktidarın mekân temsili açısından önemli ipuçları sunan bir diğer örneğidir. Bkz. Cumhuriyet.com.tr, "Cami, Fakülte Kadar Önemli!”.

740 Lefebvre, Mekânın Üretimi, s. 73. 
mekânların, aslında külliyen iktidarın tasarlanan mekânı (mekân temsili) haline getirme çabalarını ifade etmektedir.

2016 Ocak ayında yeni dönem çalışmaları için toplanan Meclis Başkanlık Divanı için Meclis Genel Sekreterliği tarafından hazırlanan belgelerde 'TBMM yerleşkesi' yerine 'TBMM külliyesi' kullanılmasi ${ }^{741}$ mekân üzerine söylemde söz konusu temsilin yerleştirilmeye çalışılması açısından bir diğer örneği oluştururken asıl dönüm noktası yeni Cumhurbaşkanlığı Sarayı'nın resmen 'Cumhurbaşkanlığı Külliyesi' olarak tanımlanmaya başlamasıdır.

Ankara'da AOÇ arazisinde 18. yüzyıla özgü Osmanl1-İslami mimari çözümüyle Başbakanlık hizmet binası olarak inşa edilmeye başlanan ${ }^{742}$ ve 2014 Cumhurbaşkanlığı seçimlerinden sonra seçilmiş Cumhurbaşkanı Erdoğan'ın yerleştiği Beştepe'deki yeni Cumhurbaşkanlığı Sarayı, Türkiye siyasi tarihinde önemli bir dönüm noktasını temsil etmekteydi. ${ }^{743}$ Seçimlerden hemen sonra Cumhurbaşkanı Erdoğan'ın Cumhurbaşkanlığı Sarayı'na yerleşmemesi ${ }^{744}$ ve 29 Ekim 2014 Cumhuriyet Bayramı münasebetiyle Cumhurbaşkanı tarafından tebriklerin, Beştepe'deki yeni Cumhurbaşkanlığı Sarayında kabul edilmesi bu dönüm noktasını simgelemekteydi ve 29 Ekim 2014 aynı zamanda yeni sarayın resmi olarak kullanılmaya başlandığı tarihtir. ${ }^{745}$ İkinci bölümde ele alındığı üzere Çankaya Köşkü Mustafa Kemal tarafindan ikametgâh olarak seçilmesinden sonra farklı dönüşümler yaşamasına rağmen mekânsal olarak bir ağırlık merkezi oluştururken, daha sonralarda bu niteliğinin aşınmasına rağmen özellikle zihinsel düzlemde bir temsil mekânı olarak hep bir merkezlik ifade etmiştir, aynı zamanda Köşkün geçirdiği dönüşümler toplumsal dönüşümleri temsil edecek nitelikte olmuştur. Nitekim Çankaya Köşkü ve genel olarak Çankaya hep Cumhuriyet'le özdeşleşen bir mekân olarak devamlılığını sürdürmüştür. 1950'lerden sonra ise Anıtkabir'in yükselmesi kentin genel imgesinde bir başka ağırlık merkezi haline gelip Çankaya Köşkü'yle kentin Cumhuriyet'le özdeşleşen imgesine katkıda bulunurken 1980'lerden sonra bu imge özellikle Kocatepe Camisiyle önemli ölçüde değişmiştir. Bu bağlamda Beştepe'deki Cumhurbaşkanlığı Sarayı'nın

741 Bkz. Radikal.com.tr, "TBMM "Külliye” Oldu”.

742 AOÇ arazisi üzerine Cumhurbaşkanlığı Sarayı'nın inşası sürecinin planlama ve hukuki boyutlarıyla ilgili bkz. Kimyon ve Serter, “Atatürk Orman Çiftliği’nin ve Ankara'nın Değişimi Dönüşümü’. Saray'ın mimari ve simgesel açıdan değerlendirilmesi için bkz. Orhan, "Reflection of Political Restructuring on Urban Symbols: The Case of Presidential Palace in Ankara, Turkey".

743 Orhan, "Reflection of Political Restructuring on Urban Symbols: The Case of Presidential Palace in Ankara, Turkey".

744 Cumhurbaşkanı Erdoğan, 7 Aralık 2015'te Çankaya'daki eski Dışş̧leri Konutu'ndan Cumhurbaşkanı Sarayı sınırları içerisindeki Devlet Konukevine taşınmıştır. Bkz. Hurriyet.com.tr, "Cumhurbaşkanı Erdoğan, Beştepe'deki Devlet Konukevi’ne Taşındı”.

745 Hurriyet.com.tr, "29 Ekim Resepsiyonu İptal”. 
2014'te tamamlanması ve Türkiye'nin tarihinde ilk seçili cumhurbaşkanı ikametgahı haline gelmesiyle 1980'lerden sonra kentin, imgesel açıdan en köklü dönüşümü yaşadığı söylenebilir (bkz. Şekil 30). ${ }^{746}$ Ayrıca özellikle 29 Ekim 2014 Cumhuriyet Bayramı münasebetiyle tebriklerin Cumhurbaşkanı tarafindan, bu yeni mekânda kabul edilmesi ve bu özel günde buranın resmen kullanıma başlanması bu dönüşümü ifade eden önemli simgeselliğe sahiptir.

Fakat Saray, kentin yapılı çevresinin bir unsuru olarak sadece 18. yüzyıla özgü Osmanl1-İslami mimari çözümle ${ }^{747}$ başkentin imgesini değiştiren bir gelişme değildir. Sarayın tanımı için resmen kullanılmaya başlayan 'külliye' ifadesi söylemsel açıdan birtakım içerimler sunmaktadır.

\section{Şekil 30. İmgesel Değișim Bağlamında Ankara'nın Yeni Silueti}

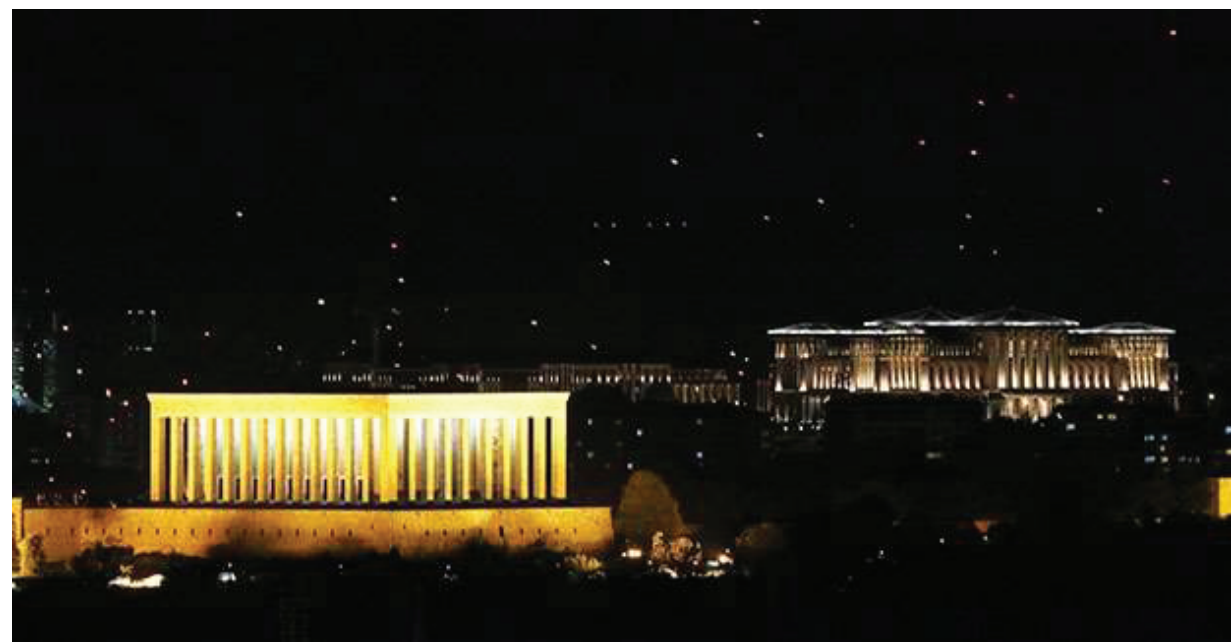

Kaynak: Radikal.com.tr, “Ankara'nın Yeni Silueti”.

746 Daha sonra, 3 Temmuz 2015'te Cumhurbaşkanlığı Sarayı içerisinde yapılan Beştepe Millet Camii'nin açılışında konuşan Cumhurbaşkanı Erdoğan tarafından "Nasıl İstanbul deyince yedi tepesindeki yedi cami aklımıza geliyorsa inşallah Ankara'yı da aynı özelliğe kavuşturuyoruz. Bunun gayreti içindeyiz. İşte Kocatepe ve Beştepe" ifadeleri AKP iktidarının, Ankara ile ilgili temsil mekânı ve mekân temsiline işaret edecek ve kentin son dönemlerdeki imgesel dönüşümleri bağlamında iktidarın çabalarını açıklayacak niteliktedir. Bkz. Hurriyet.com.tr, "Erdoğan, Beştepe Millet Camii Açılışında Konuştu".

747 Orhan, "Reflection of Political Restructuring on Urban Symbols: The Case of Presidential Palace in Ankara, Turkey”, s. 216. 
3 Temmuz 2015'te Cumhurbaşkanlığı Sarayı içinde yer alan Beştepe Millet Camii'nin ibadete açılıșından sonra 7 Temmuz 2015'te Cumhurbaşkanlığı Sarayı resmen "Cumhurbaşkanlığı Külliyesi" olarak anılmaya başlandı. ${ }^{748}$ Cami'ye daha sonra kavuşan dolayısıyla külliye'nin, "bir caminin çevresinde cami ile birlikte kurulmuş binalar bütünü" tanımına ironik bir şekilde uymayan bu tanım, bir başka ironi olarak İslami bir toplumsal-mekânsal organizasyon için kullanılan 'külliye' tanımının laik bir cumhuriyetin cumhurbaşkanlığ makamının ikametgâhı olan bu mekân için kullanılmasıdır. Fakat bu ironik durum dolaylı olarak şu hususun ipuçlarını vermektedir - cami söz konusu mekânın merkezi olmadığı, yani söz konusu caminin, bulunduğu mekânda bir merkezliği ve tanımlayıcı boyutu olmadığı, mekânın asıl merkezini Cumhurbaşkanlığı Sarayı teşkil ettiği için, bu durum bir temsil mekânı olarak aslında Türkiye'de siyasal İslam'ın dönüşümünü ve gelindiği noktaya işaret etmektedir. Cumhurbaşkanı Külliyesi olarak tanımlanan mekânın merkezi aslında bir cami değil, iktidarın ikametgahıdır, camii ise o ikametgâh için sadece bir temsili işlev görmektedir, zira söz konusu mekânı tanımlayan temel unsur cami değil, iktidarın ikametgahıdır. Başka bir ifadeyle Cumhurbaşkanlığı Külliyesi, 1980 sonrası dönemde kamusal ve siyasal alanı yeniden tanımlamayı amaçlayan bir toplumsal ve siyasal hareket olan İslamcılı̆̆ın (siyasal İslam'ın) iktidara 'yürüyüşünün' ve dönüşümünün temsil mekânını teşkil etmektedir; toplumsal bir mekân olarak külliyenin merkezi ve tanımlayıcı unsuru bir camii yerine iktidar ikametgahıdır.

Fakat, genel anlamda Cumhurbaşkanlığı Sarayının bir külliye mekânı olarak adlandırılması söylemsel bir tanımlama değil, önemli bir gerçekliği yansıttığı da söylenebilir. Belirtildiği üzere külliye sözcüğü Arapçadan kaynaklanmakta ve 'tüm', 'bütün', 'tamlık' veya 'bütünlük' anlamına gelmektedir. Bu açıdan Cumhurbaşkanlığı Külliyesi başta Ankara dahil olmak üzere tüm ulusal mekâna egemen olan bir mekân işlevi görecektir. Şöyle ki Cumhurbaşkanlığı Külliyesinde yer alacak merkez Türkiye'nin 81 ilinde mevcut MOBESE kameralarının görüntülerine, İnsansız Hava Araçlarının edindiği fotoğraflara ulaşabilecek, merkezdeki üç büyük serverde Türkiye'nin tüm MOBESE kayıtları arşivlenecek, televizyon kanalları ve 3G iletimleri denetlenebilecek, aynı zamanda bu merkez Jandarma Genel Komutanlığ 1 , Afet ve Acil Durum Yönetim Başkanlığı, Bilgi Teknolojileri ve İletişim Kurumu ve Millî İstihbarat Teşkilatı'yla irtibat halinde olacak. ${ }^{749}$ Bunlar Cumhurbaşkanı Külliyesinin, tüm ulusal mekân üzerine denetim sağlayabilecek bir panoptikon işlevi göreceğine işaret ederken aynı zamanda bu mekânın külliye sözcügüyle tanımlanması aslında bir gerçekliği yansıttı̆̆ını göstermektedir.

748 Hurriyet.com.tr, "Erdoğan, Beştepe Millet Camii Açılışında Konuştu”; T24.com.tr, "Saray Artık Resmen 'Külliye' Oldu".

749 Bkz. Taştekin, “'Big Brother' to Move Into Erdogan’s Palace”. 
Cumhurbaşkanlığı Sarayı henüz resmen külliye olarak tanımlanmadığı sırada Cumhurbaşkanı Erdoğan, sarayın 'Cumhurbaşkanı Külliyesi' olacağına ilişkin açıklamalarda bulunurken, onun şu ifadeleri kayda değerdir;

"Sadece şu içinde bulunduğumuz Cumhurbaşkanlığı Sarayı, şu anda saray
ama kısa bir süre sonra burası Cumhurbaşkanlığı Külliyesi olacak. Niye
külliye olacak? Çünkü hemen yanımızda bir kongre merkezi şu anda inşa
ediliyor. Kongre merkezinin hemen arka tarafinda bölgede şöyle büyük bir
cuma camisi yok, böyle bir cami inşa ediyoruz. Niye, aynı şekilde kongre
merkezinin bana göre sağ tarafinda çok amaçlı 2 bin kişinin katılacağı bir
toplantıyı aynı anda yapabileceğimiz, yemekli toplantıy kast ediyorum, bir
salon da orada olacak ve hedefimiz bazı büyük çaplı yemekli toplantıları
orada yapmak. Muhtarlarımızın buraya rahatlıkla gelip gideceği bir yeri
burada hazırlayalım istiyoruz." 550

Cumhurbaşkanı'nın ifadelerinden de görüldüğü üzere sarayın, farklı mekânsal düzenlemelerle çok donanımlı bir yer haline getirilmesiyle "muhtarların rahatlıkla gelip gideceği bir yere" dönüşmesi amaçlanmaktadır. Cumhurbaşkanı'nın muhtarlarla geleneksel hale gelen buluşmaları, muhtarların aynı zamanda mahalle ve köy düzeyinde halka en yakın basamağı olmaları göz önünde bulundurulduğunda Cumhurbaşkanlığı Külliyesi'ndeki düzenlemelerle bu mekanın, muhtarların rahatça gelip gidecekleri bir alana dönüştürülmesi böylece ulusal mekânda halkla külliyen bütünleşmiş bir cumhurbaşkanlığ makamı olma iddiasına işaret ederken AKP'nin 'halktan olma' popülist iddialarının ve bu iddialarla Cumhuriyet tarihiyle hesaplaşmanın mekân üzerine söylem olarak bir diğer dişavurumudur. Benzer biçimde, 28 Ekim 2015'te Cumhuriyet Bayramı'nın 92'inci yıldönümü münasebetiyle yapılan resepsiyonda Cumhurbaşkanlığı Külliyesinin sembolik niteliğine değinen Cumhurbaşkanı Erdoğan şunları ifade etmiştir;

"Bir yanda frakll, valsli, şampanyalı Cumhuriyet Bayramı kutlamaları yapılırken, kapının hemen dışında, ayağına giyecek ayakkabı, sırtına ceket bulamayan, yarı aç-yarı tok hayatını sürdürmeye çalışan bir millet, şaşkınlıkla bu manzarayl seyretmektedir (...) Cumhuriyet adı kullanılarak, yine Cumhur'un, milletin iradesine saldırıldı. Vesayeti korumak adına demokrasiye, özgürlüklere, hukuka; yani milletin tüm kazanımlarına yönelik hücumların kılıfı olarak hep Cumhuriyet lafzı kullanıldı. Cumhuriyetin özüyle, ruhuyla en küçük bir ilişkisi bulunmayanlar, kendi ideolojilerinin, kendi nüfuzlarının, kendi çıkarlarının gizli iktidarını sürdürmek adına, bu kavramı istismar ettiler (...) İçinde bulunduğumuz Cumhurbaşkanlığı Külliyesi de, devletle milletin buluşmasının, Cumhuriyetin sahibinin şu kurum veya bu kesim değil bizzat Cumhur olduğunun sembolüdür (...) Artık Cumhuriyetin sahibi milletimizin

750 Milliyet.com.tr, “Cumhurbaşkanlığı Sarayı Külliye Oluyor”, vurgu eklenmiştir. 
kendisidir, sembolü de işte bu Cumhurbaşkanlığı Külliyesi'dir (...) Geçmişte Cumhurbaşkanlığı makamı tek bir kimliğin, tek bir anlayışın, tek bir hayat biçiminin hâkim olduğu, kapısından sadece bu formata sahip kişilerin girebildiği bir yer olmuştur. Bugün Cumhurbaşkanlığı makamı, işte bugün olduğu gibi, ülkenin her bölgesinden, milletin her kesiminden vatandaşımızın geldiği, ağırlandığı, el üstünde tutulduğu bir yerdir.",751

Önceki tartışmalarda görüldüğü üzere yine 'halktan olma' popülist söylemi bağlamında belirli bir mekân bağlamında "ulusun (milletin) gerçek sahipleri" ile "onların kalkınmasını istemeyenler", 'vesayetçiler' arasındaki ayrıma vurgu yapılmakta, aynı zamanda 'halkın' temsilcisi ve 'vesayetçilerin' karşısındaki tek güç olarak AKP konumlandırılmaktadır. Böyle bir yakın tarih anlatımında ise Cumhurbaşkanlığı Külliyesi 'vesayet odakları' karşısına verilen mücadelenin bir ürünü, "Cumhuriyetin gerçek sahibi olan milletin” bir temsil mekânı olarak öne çıkarılmaktadır.

Lefebvre'ye göre anıtsal mekânlar, “bir toplumun her üyesine kendi aidiyetinin ve toplumsal yüzünün imgesini sunar; bireyselleştirilmiş bir aynadan daha "doğru" olan kolektif bir aynadır o." Bu kolektif ayna etkisiyle, bu mekânlar aynı zamanda bir "konsensüs" gerçekleştirmektedir ve bu "konsensüsü" pratik ve somut kılmaktadır. ${ }^{752} \mathrm{Bu}$ bağlamda, Cumhurbaşkanı'nın “devletle milletin buluşmasının, Cumhuriyetin sahibinin şu kurum veya bu kesim değil bizzat Cumhur olduğunun sembolü”, Cumhuriyetin sahibinin artık millet olduğu, bunun sembolünün ise Cumhurbaşkanlığı Külliyesi olduğu şeklindeki ifadeleri, toplumun bir kesimine kendi aidiyetini ve toplumsal imgesini sunma arzusu, bir başka yerde ifade ettiği "burası şahsıma ait değil milletin evi... Bu eserle beraber dünyaya farklı bir görüntüyü vermektir. $\mathrm{Bu}$ eser bu milletin azametini göstermektedir" sözleri, ${ }^{753}$ bu mekânın bireyselleştirilmiş bir aynadan daha "doğru" olan kolektif bir ayna olarak, toplumun belli bir kesimi için bir "konsensüs" sağlayan, bu "konsensüsü" somut ve pratik k1lan bir anitsal mekân üretimi çabası olarak da değerlendirilmelidir.

751 Erdoğan, "Cumhuriyetin Sahibi Milletimizin Kendisidir, Sembolü de Cumhurbaşkanlığı Külliyesidir", vurgu eklenmiştir.

752 Lefebvre, Mekânın Üretimi, s. 232-233.

753 Radikal.com.tr, "Erdoğan: Bu Girişimdekilere Ben 'Mankurt' Diyorum”. 
Şekil 31. "Cumhuriyetin Gerçek Sahibi Olan Milletin" ve "Devletle Milletin Buluşmasının” Temsil Mekânı Olarak Cumhurbaşkanlığı Külliyesi (29 Ekim 2015 Cumhuriyet Bayramı)
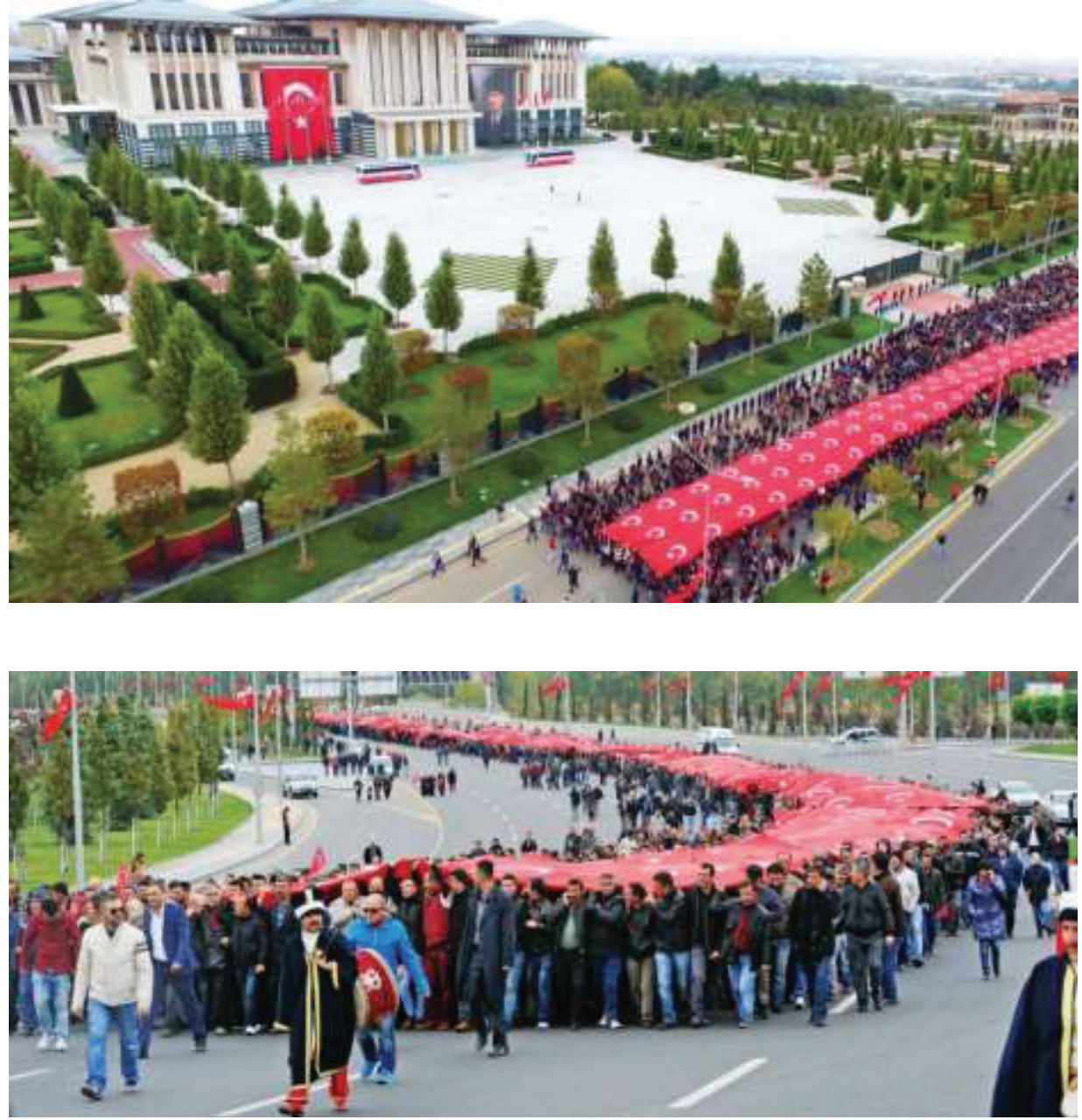

Kaynak: Büyükşehir Ankara Bülteni, Sayı 556

\subsubsection{Oryantal Bir Kent İmgesine Doğru}

Mevzubahis dönemde mekânın farklı temsiller (mekân temsili ile temsil mekânı) açısından dönüşüm süreçleri ve genel olarak kent imgesinin değişimi (değiştirme) süreçleri sadece yukarıda ele alınan örneklerle sınırlı değildir. Kayda değer bir diğer girişim Kuzey Ankara Girişi Kentsel Dönüşüm ve Gelişim Projesi alanında inşaatı süren Kuzeykent Merkez Camii ve Külliyesidir. ABB 
tarafindan yapılan bu proje cami, kütüphane, misafirhane, bedesten, kültür merkezi, kongre merkezi içermektedir ve bu açıdan tamamlandığında tam anlamıyla bir külliye teşkil edecektir. ABB başkanı Melih Gökçek, bu projeyle "Cumhuriyet tarihinin en görkemli inanç ve kültür merkezini Ankara'ya kazandırmak amacında olduklarını" belirtmektedir, ${ }^{754}$ Gökçek’e göre projeyle aynı zamanda "Osmanlı döneminin yaygın geleneklerinden biri olan külliye kültürünün de yeniden yaşatılacağı alan Ankara'ya kazandır[1lacaktır].”755

\section{Şekil 32. Kuzeykent Merkez Camii ve Külliyesi}

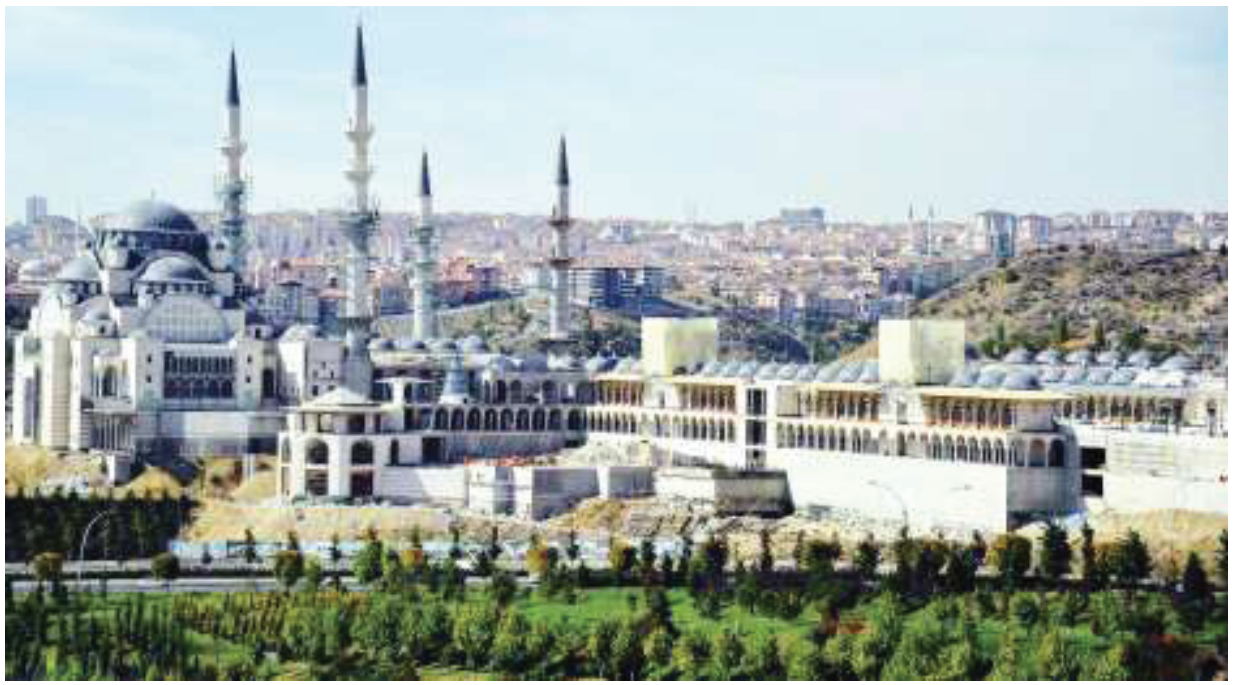

Kaynak: Turan, “Kuzey Yıldızı Külliyesi hızla ilerliyor”, s. 4-5.

Projenin merkezi unsuru olan ve 15 bin kişiye ibadet sağlayacak camiinin Osmanlı'nın Mihrimah Sultan Camii, 2. Beyazıt Camii, Süleymaniye Camii ve Nuriosmaniye Camilerinden esinlenerek tasarlandığ 1 da belirtilmektedir. ${ }^{756}$ Proje, bu özelliklerle birkaç önemli husus içermektedir. İlkin, "Cumhuriyet tarihinin en görkemli inanç ve kültür merkezi” olacak bu proje, Osmanlı tarihinde sosyo-mekânsal organizasyonun biçimi olan bir külliye mekânı olarak tasarlanmış ve bir mekân temsili olarak Cumhuriyet'e değil, Osmanlı'ya gönderme içermektedir. Bu gönderme ise bu mekânın sadece söylem düzleminde külliye olarak tanımlanması ve külliyelere özgü ve farklı işlevsel niteliği olan

754 Nursen Turan, "Kuzey Yıldızı Külliyesi Hızla İlerliyor”.

755 Ibid., s. 6.

756 Ibid. 
yapılar içermesiyle sınırlı değil, bu göndermeyi destekleyen bir diğer önemli unsur bu mekânın merkezi unsuru olan ve onu tanımlayan camiinin Osmanlı dönemindeki önemli bir takım camilerin melez simülakrası olmasıdır. Aynı şekilde mekânsal pratikleri (mekânın kullanımı) açısından projenin hedefi "Osmanlı döneminin yaygın geleneklerinden biri olan külliye kültürünün de yeniden yaşatı1[masıdır]", yani mekânsal pratikler açısından yine Osmanlı'nın kamusal mekân organizasyonuna özgü mekânsal pratiklerine gönderme söz konusudur. Bu özellikleri itibarıla "Cumhuriyet tarihinin en görkemli inanç ve kültür merkezi”nin, Ankara'nın en önemli giriş noktalarından birinde, yani Esenboğa Havaalanı'ndan kente giriş kısmında görünür bir tepede yapılması tesadüfi bir tercih değildir elbette, zira söz konusu cami ve külliye, havayolu aracılığıyla Ankara'ya gelenler için kentin ilk deneyimlenmesini sağlayacak bir mevkide olması sayesinde Cumhuriyet Ankara'sının imgesi yerine farklı bir Ankara imgesi yaratma potansiyeli taşımaktadır.

Benzer yönde ABB tarafından Ankara'nın Esenboğa, Samsun, Konya, Eskişehir ile İstanbul yolunda büyük kapılar inşa edilerek kentin imge sunumunu önemli ölçüde etkileyen bir girişimde bulunulmuştur. Ankara'nın "5 simge kapısı" olarak ifade edilen bu yapıların, Selçuklu ve Osmanlı mimarisinden esintiler taşıdığı belirtilmektedir. ${ }^{757} 15$ Mart 2014'te söz konuş kapılarının açılış töreninde konuşan Melih Gökçek’e göre,

"Kapılarımızın hepsi Selçuklu ve Osmanlı mimarisinden esintiler taşıyor, yani tarihimizi yansitıyor. Bezemelerdeki ve süslemelerdeki işlemeler Anadolu'da yaşamış medeniyetlerin, Selçuklu'nun, Osmanlı'nın günümüze ulaşmış kültür miraslarıdır. Bu miras modern imalat tekniği olan çeliğin üzerine yeniden işlenerek Selçuklu ve Osmanlı izleri ağırlıklı olacak şekilde uygulanmışıtır. Her bir kapımız ismini taşıdıkları şehirlerin tarihi izlerini taşıor." 758

Ankara'nın, Roma öncesinden başlayarak Cumhuriyet dönemine kadar farklı medeniyetlerin ve toplumsal formasyonların izlerini taşıyan bir kent olmasına rağmen, Gökçek tarafından Anadolu'da yaşamış medeniyetler olarak sadece Selçuklu ve Osmanlı medeniyetlerine yaptığı vurgu ve "Selçuklu ve Osmanlı izleri ağırlıklı olacak şekilde uygulanarak" dikilen 5 kapı ABB'nin uzak tarih anlatısı bağlamında tercih edilen kent temsilini ortaya koyarken aynı zamanda kentin ana giriş noktalarına yapılması ABB tarafından söz konusu temsili aşılama çabası olarak değerlendirilebilir. ${ }^{759}$

757 Köprülü, “Ankara’nın Simge 5 Kapısına Konserli Açılış”.

758 Ibid., s. 11-12, vurgu eklenmiştir.

759 Mayıs 2008'de, ABB tarafindan yürütülen Ulus Tarihi Kent Projesi çerçevesinde Hacı Bayram ve çevresindeki restorasyon ile yenileme çalı̧̧malarından söz eden Melih Gökçek, 
ABB Başkanı Melih Gökçek başta olmak üzere ele alınan dönemde AKP'li iktidarın temsilcileri tarafından benimsenen mekân üzerine söylemde ayrıca yapılı çevrenin üretimiyle sonuçlanan girişimlerde en çok vurgulanan husus böylece Osmanlı ve Selçuklu mimarisi veya Osmanlı ve Selçuklu sosyomekânsal örgütlenmesi olduğunu söylemek abartı olmaz. Bu söylem ve pratikler belirli bir mekân temsili ve temsil mekânı ortaya koymak ve empoze etmekle beraber bu temsillerle ilgili önemli bir sürecin varlığına işaret etmektedir oryantalist bir mekân temsilinin egemenliği ve öz-oryantalistleşme aracılığıyla kentsel mekânın yeniden üretimi. Bu oryantalistleşme, Edward Said'in işaret ettiği üzere, Batı (Oksident) tarafından Şark'ın (Oryant) egzotik ve bir düş coğrafyası olarak, Şark'ın gerçek şartlarından kopuk ve soyut temsilleri yerine Şark tarafından kendini gerçek şartlardan kopuk ve soyut imgelerle temsil edilmesi yani öz-oryantalistleşmesidir (self-orientalisation). Nasıl Batı, Şark'1 temsil etmek için somut bağlamdan kopuk klişe imgelerden yararlanarak farklı işlevleri olan imgeler ürettiyse, ${ }^{760}$ günümüzde de Doğu, kendi gerçek şartlarından kopuk, egzotik imgeler ve temsiller üreterek kendi özoryantalistleşmesine katılmaktadır. ${ }^{761} \mathrm{Bu}$ açıdan, ele alınan örneklerden çoğunda görülen ve Selçuklu-Osmanlı tarzında olduğu iddia edilen yapılardaki kümbetler, çini süslemeler, kemerler, çeşmeler olsun veya bir mekân olarak külliye olsun hepsi birer oryantalist mekân temsillerini teşkil etmekte ve Batı'nın günümüze dek süren klişe Şark temsillerinden farklılık göstermemektedir. Bunlar, Şark'ın öz-oryantalistleşme örneği olarak değerlendirilebilir.

“Hacı Bayram'da bulunan Roma mimarisi tarzındaki dükkanlar yıkılacak, yerine yeni dükkanlar yapılıp, oradaki dükkân sahipleri mağdur edilmeden yerlerine yerleşecekler" (Koç ve Çıngır, "Kentin Tarihi Ulus'ta Yeniden Canlanıyor", s. 9) diye belirtmiştir. Yenileme ile restorasyon çalışmalarından sonra, Mayıs 2015'te Hacı Bayram Camii ve Kitapçılar Çarşısı açılış töreninde konuşan Gökçek bölgedeki çalışmaların tarihine uygun bir şekilde yapıldı̆̆g, bunun doğrultusunda “Roma mimarisini andıran Kitapçılar Çarşısı'nın da yıkılarak, Selçuklu Mimarisi'nde yeniden yapıldı̆̆ı"nı (Turan ve Bingöl, "Büyükşehir'in 38 Dev Eserini Cumhurbaşkanı Erdoğan Açtı", s. 8) belirtmiştir. Bu ifadelerde görülebileceği üzere Gökçek, belirli bir yapının yıkılmasından söz ederek Roma mimarisine vurgu yapmaktadır. Yani söylemsel olarak öne çıkan vurgu, söz konusu yapının - Kitapçılar Çarşısı'nın - yıkılmasının temel gerekçesi onun Roma mimarisi tarzında olması, dolayısıyla yıkılıp Selçuklu tarzıyla yeniden yapılmasını görmekteyiz. Bu husus ise kentin farklı mekânlarının üretimi ve yeniden üretimi süreçlerinde ABB'nin mekân temsili ve temsil mekânı ortaya koyan bir diğer örneğidir.

760 Örneğin, Batı'nın, Osmanlı ve Türkiye ile ilgili oryantalist temsillerde Osmanl1-Türk hamamı veya haremi, temel öğe veya imgeler olarak öne çıkmaktadır ve bu temsillerde ise hamam gelenekleri ve günlük gerçekliğinde hamamların kullanımın temsili yerine hamamın gerçeklikten kopuk temsili egemendir. Daha detaylı bir inceleme için bkz. Pasin, "Dişil bir Temsili Mekân Olarak Türk Hamamı”; Pasin, "A Critical Reading of the Ottoman-Turkish Hamam as a Queered Space"; Pasin, "A Critical Reading of The Ottoman-Turkish Hammam as a Representational Space Of Sexuality".

761 Said, Orientalism. 
Şekil 33. Kent İmgesinin Oryantalistleşmesi: Ankara Giriş Kapıları

Samsun Yolu Kapis1

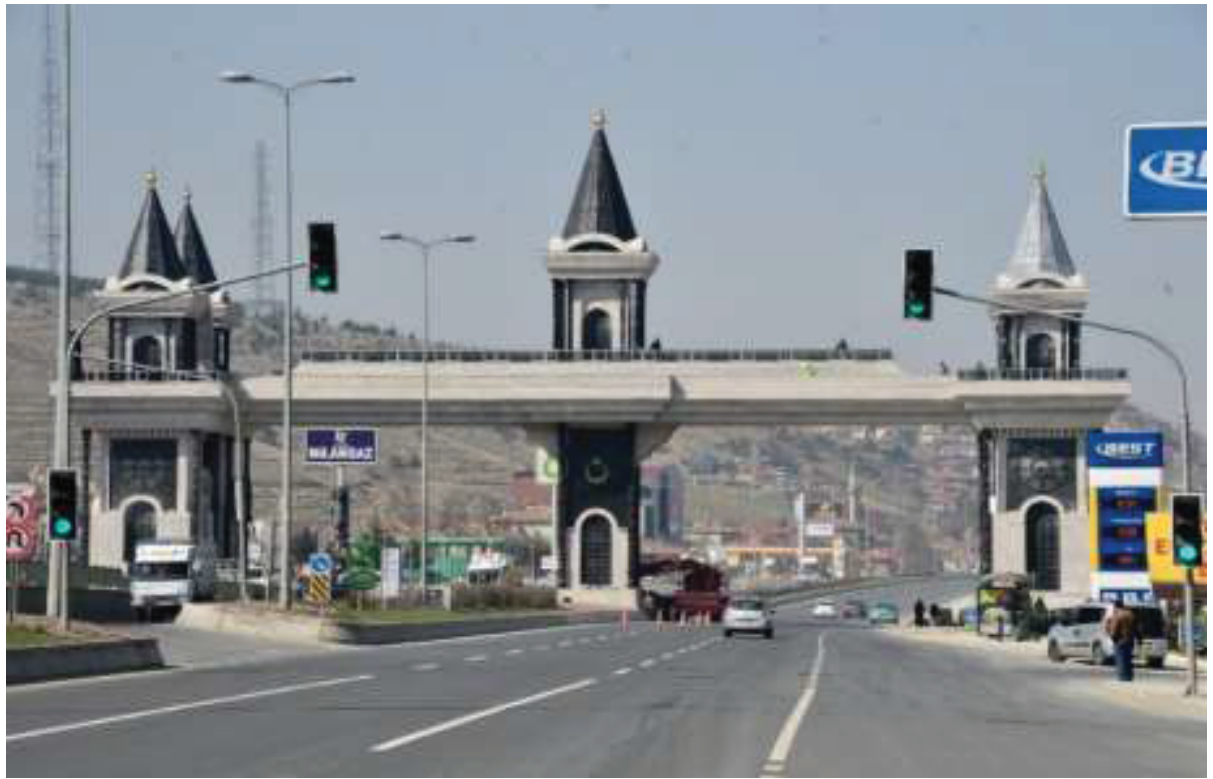

Eskişehir Yolu Kapısı

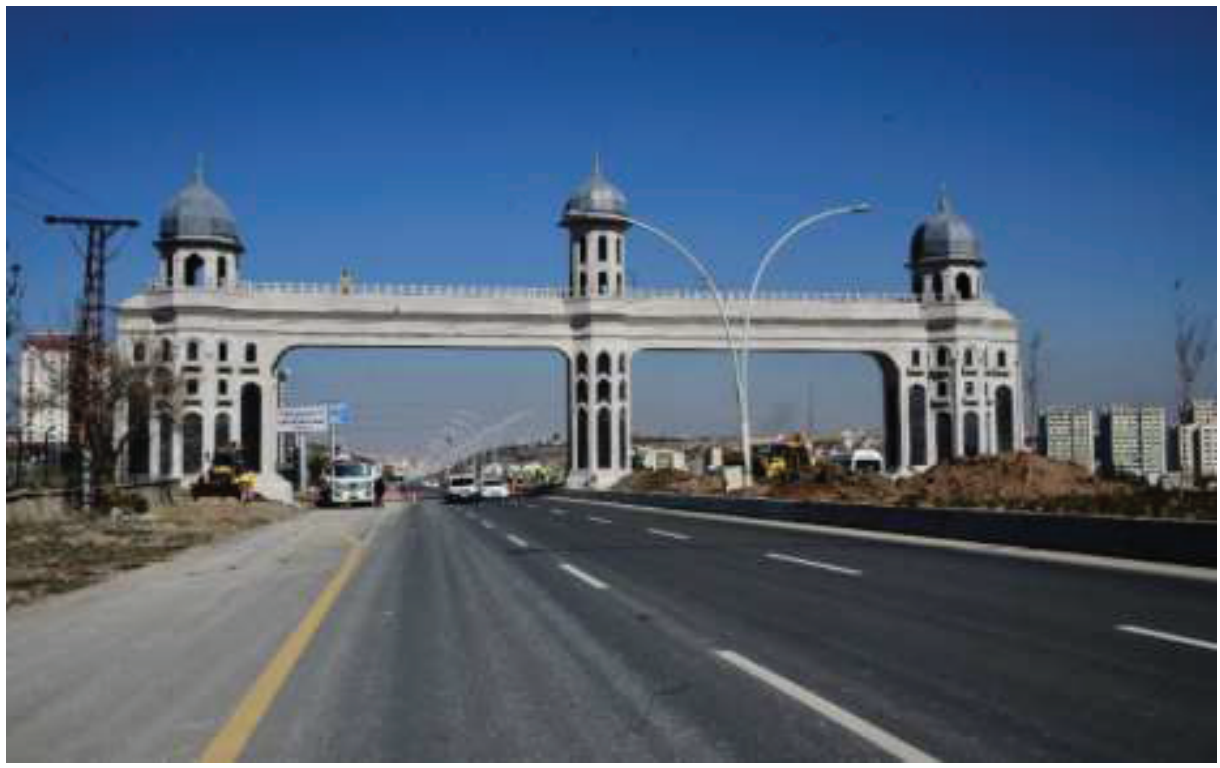

Kaynak: ABB, 20 Şubat 2017 tarihinde http:/www.ankara.bel.tr/haberler/ankaranin-simgekapilari-15-mart-aciliyor adresinden erişildi. 
Daha genel bir düzlemde bu gelişmeler AKP döneminde kentsel mekânın üretimi süreçlerinin çelişkili olduğu ve çelişkili mekânın egemenliğine birkaç açıdan işaret ettiği söylenebilir. Belirtildiği üzere bunlar ideolojik bir temsilin ürünüdür ve böylece mekân temsilleri olarak karşımıza çıkmaktadır. Bu açıdan kentsel mekânda bu yapılar insanların günlük edimlerde mekân kullanımı ve bu kullanım aracılığıyla oluşan temsil mekanlarıyla çelişki içerisindeler. Gerek ABB yayın organının, "Başkan Gökçek projelerini anlattı" gibi anlatımları, gerekse "Gökçek'in projeleri" gibi yaygın olan anlatımları kentlilerin, kendi yaşadıkları kentin biçimlenmesinde rolü olmadığını gösterirken aynı zamanda bu projelerin, kentlilerin kendi istekleri doğrultusunda olup olmadığı açısından sorular yaratmaktadır. Bu durum ise iktidarın tasarlanan mekânı ile halkın yaşanan mekânı arasındaki çelişkiyi ifade eder. İktidar, belirli oryantalist temsiller doğrultusunda kentin imgesini değiştirerek ve bu girişimlerle üretilmekte olan mekânı, o halkın tarihini temsil ettiğini belirterek aslında bu oryantalist temsillerle sadece soyut bir mekân deneyimi üretmektedir zira o temsiller halkın gündelik gerçekliğinde ve yaşanan mekânında var olmayan temsillerdir, sonuçta ortaya çıkan kentsel gerçeklik ile gündelik gerçeklik arasındaki çelişkidir.

Bir diğer önemli çelişki kullanım ile değişim arasındaki çelişkidir. Büyükşehir Belediyesi tarafından girişilen bu projeler genelde ihale aracilığıyla gerçekleşmektedir ve kamu kaynaklarını özele aktarma süreci karşımıza çıkmaktadır. Örneğin, sadece Ankara Giriş Kapıları ve kentin farklı yerlerinde yapılacak saat kuleleri için ABB özel bir şirketle 36 milyon TL'lik sözleşme imzalamıştır. ${ }^{762}$ Temsil, estetik gibi açılardan soru işaretleri içeren bu projelerin, işlevsel açıdan da sorunlu olduğu göz önünde bulundurulduğunda Büyükşehir Belediyesi tarafından girişilen bu projelerin, kamu kaynaklarının özel sermayeye aktarılması açısından önemli işlev gördüğünü, dolayısıyla kullanım değeri odaklı bir süreç yerine değişim değeri odaklı mekân üretimi süreçlerine işaret etmektedir. Bununla ilişkin diğer önemli husus, bazı projelerin mekân tüketimi odaklı projeler olmasıdır. Bunların bir mekân üretimi olduğu fakat esasen mekân tüketimine hizmet edeceği söylenebilir. Örneğin ABB tarafından "prestij projesi" olarak tanıtılan ${ }^{763}$ Kuzeykent Merkez Camii ve Külliyesi Projesine bakıldığında, bir mekânı kullanımı - yani mekânsal pratikler - öngören bu projenin (tasarlanan mekân) asıl amacı olarak turizme hizmet edeceğini ve bir tür mekân tüketimi ile tüketim mekânı olacağı görülmektedir. Şöyle ki proje, dini turizme hizmet edecek, bu doğrultuda yapılan arastalarda din turizminin organizasyonlarının yapıldığı şirketler yer alacak, ayrıca proje üst düzey misafirlerinin ağırlanacağı

762 Radikal.com.tr, "Hoş Geldin Parası: 25 Milyon TL".

763 Turan, “Türkiye’nin En Görkemli Camisi ve Külliyesi Esenboğa Yolu Kuzey Yıldızı'na İnşa Ediliyor", s. 5. 
çay ve kahve köşklerini, hediyelik eşyaların satılacağı kapalı çarşıları, geleneksel sanatların yer alacağı sergi-satış alanlarını kapsamaktadır. ${ }^{764} \mathrm{Bu}$ açıdan $\mathrm{ABB}$ tarafindan bir "prestij projesi" olarak tanımlanması anlam kazanmaktadır. Dolayısıyla, kentliler tarafından günlük hayatta kullanılan ve bu açıdan üretim ile tüketim mekânı olmasından ziyade bu mekânın asıl işlevi olarak farklı bir mekân kullanımını içeren mekân tüketimine yönelik olduğu söylenebilir. $\mathrm{Bu}$ durum ise Büyükşehir Belediyesi'nin bir diğer mekân temsiline işaret etmektedir - gerek ulusal gerekse uluslararası alanda kenti pazarlamak amacıyla değişim değeri odaklı mekânın üretimi, bir mekân temsili olarak bu husus, kenti daha üst ölçekte tahayyül etmeyi ve buna göre onu yeniden biçimlendirmesidir. Oysa, bu projeyle, ele alındığı üzere bu mekân, "Osmanlı döneminin yaygın geleneklerinden biri olan külliye kültürünün de yeniden yaşatılacağı alanı" haline getirilmek istenmektedir. Belirli bir kültürün yaşatılması ise - eğer temsili bir işlev veya değişim değeri odaklı bir amaç taşımamaktaysa - yerel ölçekte kullanım değer odaklı somut mekân kullanımı (mekânsal pratikler) içereceğinden dolayı, bu pratikler ile söz konusu daha üst ölçekli mekân temsili - kenti pazarlama - arasında bir çelişkiye işaret etmektedir.

Sonuçta üretilen mekânlar ve mekânsal düzenlemeler ise ABB'nin söyleminde s1k s1k "eser" olarak tanımlanmasının" 765 aksine, her yerde seri olarak üretilebilecek ve çoğaltılabilecek, zaman ile mekân bağlamı olmayan oryantalist yap1 ve imgelerdir ya da farklı tarihsel eserlerin kopyası niteliği olan, yaşanılan boyutundan yoksun, sadece Göz tarafından 'tüketilmek' için üretilen oryantalist simülakralardan oluşan dolayısıyla soyut niteliği taşıyan mekanlardır. M. Gökçek, Ankara Giriş Kapılarının, “özellikle Ankara’ya gelen ziyaretçilerin altından geçerken mutlaka durup bakacağı, anı fotoğrafları çektireceği, muhteşem güzellikteki kapıların Ankara'daki güzelliğin birer aynası olacağını"766 belirterek, bu kapıların Göz'le 'tüketilmeye' yönelik bir mekân olacaklarına da işaret etmiştir. Fakat "Ankara'daki güzelliğin birer aynası olacağı" belirtilen bu kapılar oryantalist bir klişe imgesi olarak aslında Bozdoğan'ın, başka bağlamda fakat konumuz açısından da geçerli olan bir

764 Ibid.

765 Örneğin gerek Melih Gökçek gerekse ABB yayın organları tarafından taksi durakları, meydan saatleri şöyle dursun, yol, kanalizasyon, köprülü kavşak ve benzer yapıların Ankara'ya kazandırdıklarından söz edildiği sırada bile, bu yapıları sık sık 'eser' sözcügüuyle tanımlanmaları kayda değerdir. Bu husus Gökçek'in 'bizim işimiz laf üretmek değil eser üretmektir” sözleriyle beraber gerek Melih Gökçek'in gerekse ABB'nin eser anlayışını da açıkça ortaya koymaktadır. Bkz. ABB, "Büyükşsehir'den 2014'te 214 Esere Coşkulu Açılış"; ABB, "Metrolar Peş Peşe Hizmete Girdi".

766 Bingöl, “Ankara'nın 5 Girişine 5 Kapı”, s. 13. 
ifadesiyle "Şark'ın mevcut karmaşıklığg ve çeşitliliğgi indirgemekte", ${ }^{767}$ aynı zamanda bunlar, "Ankara'ya gelen ziyaretçilerin altından geçerken mutlaka durup bakacağı, anı fotoğrafları çektireceğì" yapılar olarak tasarlandı̆̆ "Şark'1 biçimsel bir dağarcığa, serbestçe tüketilmek için hazır olan imgeler kataloğuna dönüştürmektedir", 768 bu ise soyut mekânın üretiminden başka bir şey değildir.

Son olarak, söz konusu dönemde mekânın üretimiyle doğrudan ilişkili olmayan fakat kent temsiliyle doğrudan ilişkili bir başka önemli gelişme de görülmektedir. 1978'te Ankara Belediyespor olarak kurulan futbol kulübü, zaman içerisinde farklı isim değiş̧iklikleri geçirerek (Ankara Büyükşehir Belediyespor, Büyükşehir Belediye Ankaraspor), 2005'te ise ABB bünyesinden çıkartılarak 2014'e dek Ankaraspor A.Ş. olarak varlığını devam ettirmiştir. 20142015 sezonu öncesinde ise Ankaraspor, Osmanlıspor Futbol Kulübü olarak ismini değiştirdi, aynı zamanda logosu ve formasını da yeniledi. ${ }^{769}$

Atletik takımların ve genelde sporun, yerin (place) ekonomik politiğinde önemli bir işlevi olduğu artık uzun zamandır farklı kuramsallaşmalara konu olmuştur. Şöyle ki ulusal ve uluslararası düzlemde kentler arası ve bölgeler arası rekabette yerel medya, siyasetçiler, üniversiteler, tiyatro ve sergiler, profesyonel spor kulüpleri gibi birtakım aktörler yerin/bölgenin gelişmesinde ve gerek ulusal gerekse uluslararası düzlemde rekabet edilebilmesi, yerin imajının yükseltilmesi açısından "büyüme koalisyonları" (growth coalitions) oluşturduğu ve buna göre hareket ettikleri belirtilmektedir.770 Profesyonel takımlar kentler için gerek ulusal gerekse uluslararası düzeyde kentin imajını yükselterek turist akımları çekmek, dolayısıyla gerçek gelir sağlayan önemli işlevleri vardır. Fakat bu takımlar aynı zamanda yerin ve bölgenin 'gelişmesine' dair "kentli şovenliğin" aşılanmasında olağanüstü mekanizmalardır, belirli bir kent ölçeğinde ise bunlar şovenlik aracılığıyla yaşanılan yere hayranlık aşılanmasında önemli ideolojik işlev görmektedirler. ${ }^{771}$

$\mathrm{Bu}$ açıdan ABB Başkanı Melih Gökçek'in onursal başkanı olduğu Osmanlıspor, yerin ekonomik politiği ve imajı bağlamında değerlendirilebilir, zira hem ABB Başkanı'nın bu kulübün onursal başkanı olması ve bir belediye başkanı sıfatıyla takımla ilgilenmesi, hem de ABB resmi yayın organı tarafindan bu takımın Osmanlıspor olarak tescillenmesinden sonra kendi sayfalarında

767 Bozdogan, "Journey to the East: Ways of Looking at the Orient and the Question of Representation", s. 39.

768 Ibid., s. 43.

769 Uçar, "Ankaraspor, Osmanlıspor Oldu".

770 Logan ve Molotch, Urban Fortunes: The Political Economy of Place; Molotch, "The City as a Growth Machine: Toward a Political Economy of Place".

771 Logan ve Molotch, Urban Fortunes: The Political Economy of Place, s. 79-80; Molotch, "The City as a Growth Machine: Toward a Political Economy of Place", s. 315. 
onunla ilgili haberlere önemli bir yer ayırması, böyle bir bağlamın varlığına işaret etme yönündedir (bkz. Şekil 33). Osmanlıspor'un, yerin ekonomik politiği bağlamında ne derecede rolü olup olmadığı tartışabilir bir konu niteliğindedir aslında, fakat en azından kent temsili, kentin 'gelişmesine' dair 'kentli şovenliğin" aşılanması açısından bu takımın belirli işlevler yüklendiği söylenebilir.

Takımın sadece eski 'Ankaraspor' yerine 'Osmanlıspor' olarak tescillenmesi veya eski 'leoparlar' takma adı yerine 'yeniçeriler' olarak tanımlanması temsil değişikliğini ifade etmemekle kalmaktadır, özellikle takımın logosunun değişim ve yeni logosunun ifade ettiği ideolojik içerimleri kayda değerdir. İdeolojik anlamda nötr bir temsil - Anadolu'da yaşayan Anadolu pars1 (leopar) - yerine Osmanlı devletinin 6 yüzyıl hüküm sürmesini ifade eden 6 hilalden, 6 hilalin etrafinda bulunan ve Allah'ın 99 ismini ifade eden 99 noktadan, dış yüzeyinde bulunan ve Osmanlı Devleti'nde padişahlık yapanları temsil eden 36 noktadan oluşan, Osmanlı zamanında çok kullanılan mor ve sarı renkli yeni logosu münhasıran ideolojik yüklü bir simgeselliğe sahiptir (bkz. Şekil 35).

$\mathrm{Bu}$ bakımdan yeni logo sadece "kentli şovenliğì" destekleyecek bir simgesellikle sınırlı kalmamaktadır, Ankara'nın farklı bir kent temsili sunma potansiyeline de sahiptir, böylece bu olgu çalışmanın önceki bölümlerinde ele alınan Ankara ambleminin değiştirilmesi hususuna da paralellik göstermektedir. Fakat futbol gibi bir olgunun popüler niteliği göz önünde bulundurulduğunda, ABB'nin resmi amblemine kıyasla bir futbol takımının böyle bir ideolojik yüklü simgeselliği, temsiller üretme ile yeniden üretme ve bunların geniş toplumsal kesimlerce sahiplenilme sağlanması açısından daha güçlü potansiyele sahip olduğu söylenebilir, zira sadece Göz'e hitap eden belediye amblemine kiyasla futbol izlenir, konuşulur, tartışılır, bir atletik takım tutulur. ${ }^{772}$

772 Büke Koyuncu, AKP'nin iktidarı döneminde ulusal kimliğin yeniden tanımlanması ve üretimini ele alırken, bu dönemde örneğin İstanbul'un fetih kutlamalarının niteliğinin değiştiğini, bu kutlamaların önceki dönemin muhalif bir pratikten merkeze taşındığını, kutlamaların sivilleştiğini ve festivalleşerek popülerleştiğini belirtmektedir. Bu etkinliklerin sivilleşerek popülerleştiğinin ve geniş toplumsal kabul kazanmasının önemli bir faktörü ise kutlamalardaki söylemin değişmesi (mücahitlik ve fetih vurgusundan hoşgörü diline geçiş) ve kutlamaların niteliğinin değişmesiydi (militarist bir etkinlikten popüler şarkıcıların verdiği konserlere). Bkz. Koyuncu, "Benim Milletim...": AK Parti Iktidarl, Din ve Ulusal Kimlik, s. 80-110. 
Şekil 34. "Kentli Şovenliğin” Aşılanmasında Yerel Medya, Siyaset ve Spor Takımın Koalisyonu
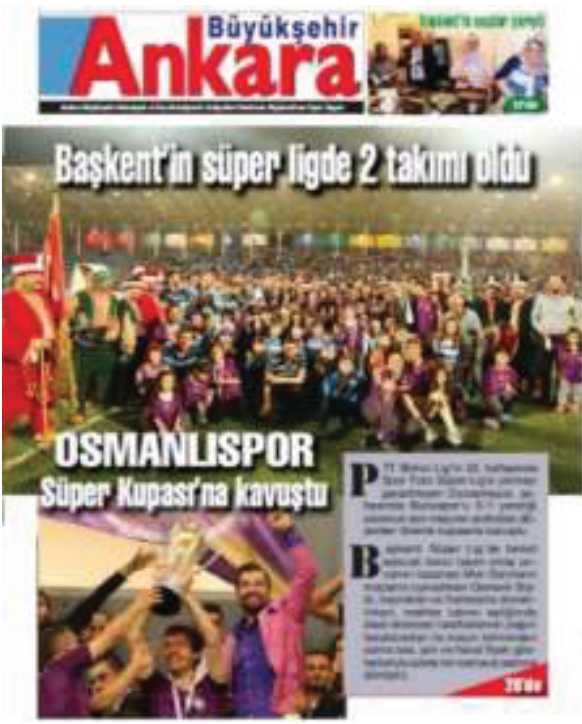
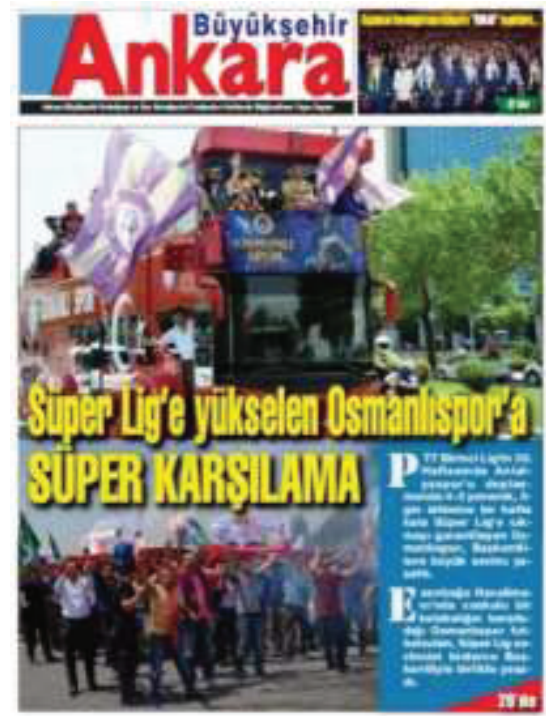

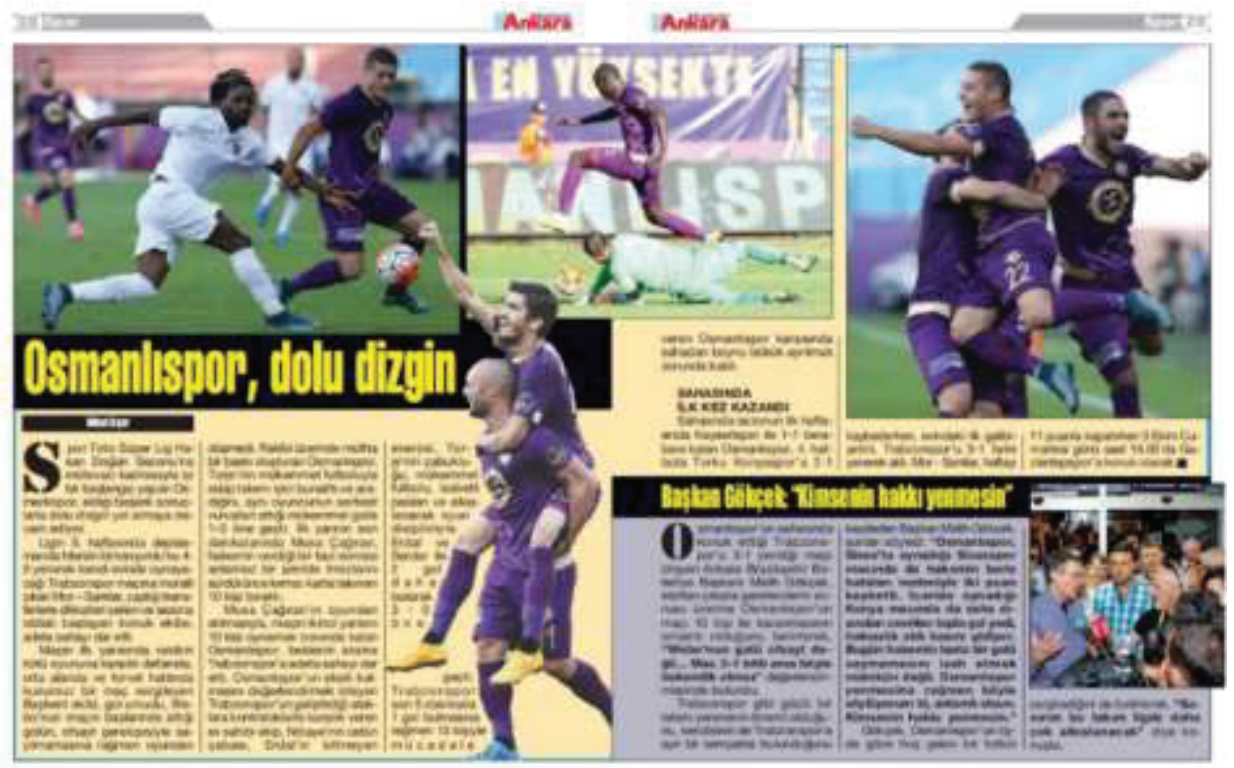

Kaynak: Büyükşehir Ankara Bülteni, Sayı 532, 533, 550 


\section{Şekil 35. Ankaraspor'un 'Anadolu' Temsilinden Osmanlıspor’un İdeolojik}

\section{Temsiline}

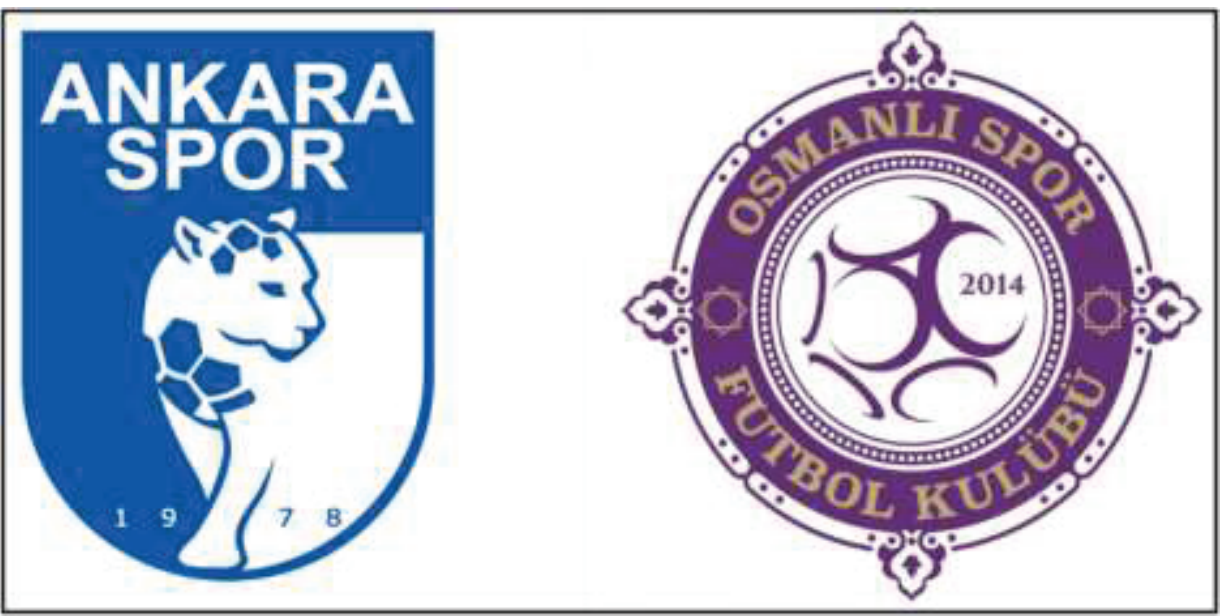

\subsection{Küresel Ölçekte Kenti Temsil Etmek: Ankara'nın 'Markalaşması'}

Kentsel mekânın parça parça oryantal temsiller aracılı̆̆ıyla bir meta, pazarlanabilecek, satılabilecek bir imgeye dönüştürülmesi veya 'büyüme koalisyonları' aracılığıyla kentin tamamının pazarlanması bağlamında, ele alınan dönemde kayda değer diğer ve en öne çıkan örnek Ankara'nın bir alışveriş kenti ve turizm merkezine dönüştürülmesi hedefidir ve bu doğrultuda Haziran 2012'de ilk kez Ankara'da "Shopping Fest" alışveriş festivali gerçekleştirilmiştir. Hazırlıkları daha önceden başlayan ve ABB'nin katkıları ile Ankara Ticaret Odasının organizasyonuyla, Kültür ve Turizm Bakanlığı, Kalkınma Bakanlığı, Türkiye Odalar ve Borsalar Birliği, Ankara Sanayi Odası, STK'lar, Ankara Esnaf Odaları Birliği gibi kurumların desteğiyle düzenlenip gerçekleştirilen ${ }^{773}$ Ankara Shopping Fest, Ankara'yı "marka" ve "turizm" kenti yapmak, ${ }^{774}$ "alışveriş cennetine dönüştürecek ve alışverişin de marka şehri haline getirmek", ${ }^{775}$ "alışverişin ve ticaretin de marka şehri yapmak"776 gibi amaçlar taşıdığı belirtilmiştir. ABB Başkanı Melih Gökçek, Ankara'ya gelen yıllık turist sayısının 800 bin olduğunu bu rakamın ise son derece az olduğunu, o yüzden Ankara

773 ABB, “Ankara Shopping Fest Gümbür Gümbür Geliyor”, s. 4.

774 Turan ve Tol, “Ankara Alışveriş Festivali Haziran'da Başlıyor”, s. 3.

775 ABB, "Ankara Shopping Fest Gümbür Gümbür Geliyor", s. 3.

776 Bingöl ve Tol, “Ankara "Shopping Fest”e Sık1 Hazırlanıyor”, s. 4. 
Shopping Fest'in kente gelen turist sayısını artırmasına yönelik adımlardan birini teşkil ettiğini belirtmiştir. ${ }^{777}$ Ankara Ticaret Odası başkanı Salih Bezci ise “Ankara'yı bir Marka şehir haline getirerek dünyanın önemli alışveriş, turizm ve kültür merkezleri arasına sokmak düşüncesi”yle Ankara Shopping Fest için 2012'de 1 milyon turist, 3,6 milyar lira ciroyu hedef olarak ortaya koydukların,, beş y1l sonrası için ise hedeflerinin 5 milyon turist, 5 milyar lira olduğunu belirtmiştir. 778

2012-2015 arası dönemde her sene gerçekleştirilen festivallerde yukarıda belirtilen kuruluşların organizasyon, tanıtım için çabaları, ayrıca festivaller sırasında Ankara Minibüsçüler Esnaf Odası, Otelciler Birliği gibi kuruluşların festivallere katılanlara ulaşım, konaklama gibi konularda sağladığı indirim imkanlar1779 hepsi beraber daha önce ele alınan "büyüme koalisyonları" bağlamında kentler arası rekabette kenti pazarlamak ve bir 'marka' olarak kenti 'satmak' biçiminde birleşen kurum ve kuruluşların bir "büyüme koalisyonu" olarak değerlendirilebilir. ${ }^{780}$ Söz konusu alışveriş festivallerin amacı sadece Ankara'yı "alışverişin ve ticaretin marka şehri yapmak"la sınırlı olmadığı da belirtilmelidir. Dönemin Kültür ve Turizm Bakanı Ertuğrul Günay festivaller bağlamında ticaretle beraber “Ankara'nın geleneksel ve tarihi alışveriş merkezlerinden, Kale İçi, Ulus, Anafartalar Çarşısı, Saman-pazarı gibi yerlerin dokusunu bozmadan cazibe merkezi haline getirme" gerekliliğine de vurgu yapmıştır. ${ }^{781} \mathrm{ABB}$ Başkanı Melih Gökçek ise benzer biçimde festivaller ve kentin markalaşması bağlamında turizm sektörüne büyük katkı sunacak bazı yatırımlarla ilgili şunları belirtmiştir:

“AOÇ'ye bir temapark ve hayvanat bahçesi yapıyoruz. Yıl sonuna kadar bitirmiş olacağız. Bir rekor kıracağız. Amerika ve Avrupa'da gezdiğiniz Disney Park gibi yerlere nazaran çeşitlilik açısından onun daha da üstünde olacak. Öncelikli olarak yurt içinden turist çekeceğimize inanıyorum.

777 ABB, “Ankara Shopping Fest Gümbür Gümbür Geliyor”, s. 7.

778 Ibid., s. 8-9.

779 Örneğin, hotellerde 3 günde konaklayan misafirlerden 2 gün ücreti almak gibi indirimler. Bkz. Bingöl ve Tol, "Ankara "Shopping Fest"e S1k1 Hazırlanıyor", s. 7.

780 Benzer biçiminde, ABB başkanı Melih Gökçek tarafindan Radyo, Televizyon, İnternet ve Gazete Yayıncılar Federasyonuna bağlı Anadolu Basını Birlikleri ile buluştuğunda "Haziran ayında Ankara'da Shopping Fest adı altında çok önemli bir Alışveriş Festivali düzenleyeceğiz. Bu konuda oldukça iddialı bir şekilde hazırlanıyoruz. Bu sadece Türkiye'nin değil Dünyanın en büyük festivali olacak. Bu konuda hepinizin desteğini isteyeceğiz. Bizim sizlerden istediğimiz, illerinizde festivalin tanıtımını yapmanız" şeklindeki istekleri (Turan, "Gökçek: "Shopping Fest İçin Anadolu Basınından Destek Bekliyorum”", s. 16), söz konusu büyüme koalisyonuna yerel ve bölgesel medyayı dahil etme çabası olarak değerlendirilmelidir.

781 Turan ve Tol, “Ankara Alışveriş Festivali Haziran'da Başlıyor”, s. 6. 
Minimum 3 milyon kişiyi hedefliyoruz. Neler yaptığımızı gördüğünüz zaman buna siz de inanacaksınız. Güzel bir başka avantaj da Hacı Bayramı Veli ve civarı. Hidırlıktepe'ye yapılacak müze ile 50 bin metrekare kapalı alanı olan dev bir tesis kuruluyor. Tesis Hacı Bayram ve Kaleyle birleşince çok ciddi turist alacak."782

Festivallerde kenti tanıtmak için ayrıca bazı arkeolojik kazı alanları öne çıkarılmaya çalışılmıştır, örneğin 3. Ankara Shopping Fest'te Gordion tarihi bölgenin tanıtımı için Amerikalı 350 bilim adamının Ankara'da ağırlanması amaçlanmıştır. ${ }^{783}$ Böylece, söz konusu "büyüme koalisyonu"nun mevzubahis girişimi kentte sadece belirli tüketim pratiklerinin (tüketim mekânı) üretimi çabaları değil, bu girişimlerle aynı zamanda kentin mekanının da kendisinin tüketim 'nesnesine' dönüştürülmesi ve mekânın tüketimi pratiklerinin üretimi amaçlandığ söylenebilir.

Bir kenti pazarlamak (marketing) ve "alışverişin ve ticaretin de marka şehri yapmak" (branding) aslında bir mekân temsili olarak, post-Fordist esnek birikim rejiminde ve mekânsal yeniden ölçeklenmesinde bölgeler/kentler arası rekabetin öne çıkması ve kentler/bölgelerin, ulusal ve uluslararası ölçekte süregelen rekabetinde önemli aktörler haline gelmesinin bir ürünüdür. Bu rekabet ortamındaysa herhangi bir kenti markalaştırma girişimi - ki bu girişimlerde yukarıda ele alınan "büyüme koalisyonları" önem kazanmaktadır - ulusal ve uluslararası alanı aslında bir oyun tahtası olarak varsayıp (bir çeşit 'dünya düzdür' mekân temsili, mekânı daha üst ölçekte temsil etme vs.) bu alanda daha avantajlı konuma yükselme girişimi niteliği taşımaktadır. Söz konusu kentler/bölgeler arası rekabet ise bir oyun teşkil ettiği itibarıyla, elbette kazanan ve kaybedenleri de içermektedir. Fakat bu oyunlarda kazanan ve kaybedenler bağlamında güçlü rekabet ile zayıf rekabet hususları ve kentlerin bu seçeneklerden hangisine göre pazarlanıp markalaştırılması önem taşımaktadır. Zayıf rekabet stratejisi genellikle mübadele düzleminde işlemektedir ve kentler, mübadele ağlarında en iyi hammadde, teknoloji, işgücü, hizmetler vs. en düşük fiyatlarda arz etme girişiminde bulunmaktadır. Oysa, güçlü rekabet stratejisinde rekabet, kentleri rakiplerine karşı avantaj sağlamak için var olan şartları aşmak, sürekli yenilikçiliğe girişmek ve böylece rekabet avantajlarını sürekli yeniden üretmeye yöneltmektedir. Yani kentler, var olan şartlarda işgücü, ürün, teknoloji gibi alanlarda yeniden düzenlemelerle yetinmeyip mübadele düzleminden öteye geçip rekabet üstünlüğü elde etmek için üretimi, hizmetleri vs. kökten değiştirmeye girişmektedirler. Böylece kentler arası rekabette zayıf rekabet stratejisi aslında sıfır-toplamlı rekabet teşkil etmektedir, çünkü bir kentin başarılı olduğu takdirde bu kente kısa vadeli bir sermaye akışı sağlanmaktadır, başka

782 Tol, "Başkan Melih Gökçek’ten Marka Kent Projeleri”, s. 18.

783 Tol, "3. Shopping Fest 6 Haziran'da Başlayacak”, s. 11. 
yerlerde daha avantajlı bir durum ortaya çıktığında ise söz konusu sermaye nitekim kenti terk edecektir. O yüzden zaylf rekabette mutlaka kazanan ve kaybedenler mevcuttur. Oysa, güçlü rekabet, potansiyel olarak artı toplamlı bir stratejidir, zira kentin genel yapısal rekabetçiliğini yükseltmektedir. ${ }^{784}$

Bugünden geriye bakıldığında, 2012'den itibaren art arda gerçekleştirilen Ankara Shopping Fest etkinliklerinden her birinin bir öncekinden daha sönük gerçekleştirildiği, ilk senede hedeflenen turist sayısı sağlanmış olunsa da (ki bu turist sayısı söz konusu etkinliklerin sonucu da olmayabilir) 5 sene sonra 5 milyon turist ağırlamayı hedefleyen Ankara'nın söz konusu hedefine ulaştığı şöyle dursun, hedefin \%50 düzeyde bile gerçekleştirilmediği görülmektedir. Örneğin, 2015 y1lı verilerine göre Ankara' da turizm işletme belgeli konaklama tesisleri ile belediye belgeli konaklama tesislerine gelen konukların sayıs toplam 1 milyon 975 bini teşkil ederken, bunların sadece 500 bini (\%25) yabanc1 olmuştur. Benzer biçimde Ankara'da hava yoluyla gelenlerin sayısı aynı senede 829 bini teşkil etmiştir ve gelenlerin sadece \%44'ü yabancıdır (bkz. Şekil 36). Gerek havayolu aracılığıyla Ankara'ya gelenlerin gerekse turizm işletme ve belediye belgeli konaklama tesislerinde konaklayanlarının hepsinin gerçek anlamda turist olmadığ göz önünde bulundurulduğunda yukarıdaki hedefin gerçekleşmediği daha açık şekilde karşımıza çıkmakta ve bir oyun olan kentleraras1 rekabette Ankara'nın kaybedip kaybetmeme sorusunu sormaya yöneltmektedir. Sadece turistik ziyaretler sayıs1 ile ilgili kaba veriler ve hedeflenen düzeylerin uyumsuzluğu açısından Ankara'nın kaybeden durumda olduğu açıkken, daha derin bir düzeyde konuyu ele almak da gerekmektedir, bu düzey ise benimsenen pazarlama ve markalaşma stratejisinin ve onun ürünü olan mekânların niteliğidir.

ABB Başkanı Melih Gökçek, söz konusu pazarlama girişiminde "Ankara ticarette bir numara olsun" diye yola çıktıklarını, bu konuda ise özellikle alışveriş merkezlerine her türlü desteği verdiklerini belirtmiştir, ${ }^{785} \mathrm{ABB}$ ise büyük alışveriş merkezlerinin çoğalmasını "stratejik hedef" olarak belirlemiştir. ${ }^{786}$ Ankara'nın, alışveriş merkezlerinin çoğalması ve bin kişiye düşen AVM alanı açısından Türkiye'de birinci olması ABB tarafindan gururla "şampiyonluk" olarak tanımlanırken, ${ }^{787}$ Melih Gökçek ise destekleriyle AVM'leri çoğaltarak bu konuda Ankara'nın bir numara olan konumunu korumasını "önemli” olarak tanımlamıştır. ${ }^{788}$

784 Cox, "Globalisation, Competition and the Politics of Local Economic Development", s. 218 vd.; Konu ile ilgili ayrica bkz. Jessop, "The Narrative of Enterprise and the Enterprise of Narrative: Place Marketing and the Entrepreneurial City".

785 Turan ve Tol, "Ankara Alışveriş Festivali Haziran'da Başlıyor”, s. 6.

786 ABB, “2010 Faaliyet Raporu”, s. 280.

787 Ibid.

788 Turan ve Tol, “Ankara Alışveriş Festivali Haziran'da Başlıyor”, s. 6. 
Kenti pazarlamak açısından sadece AVM'leri çoğaltarak, festivaller düzenleyip farklı indirim ve destek kampanyalarıyla ticareti özendiren bu strateji, kentler aras1 rekabette zaylf rekabet stratejisidir, zira sadece mübadele düzleminde belirli bir avantaj elde etmeyi amaçlamaktadır. Benzer biçimde, Ankara'ya turist 'çekmek' için ABB tarafından çok iddialı bir girişim olarak Ankapark projesinin gerçekleştirilmesine bakıldığında bir temapark ve hayvanat bahçesi içeren bu proje her ne kadar "rekor kıracağız", benzer yerlere "nazaran çeşitlilik açısından onun daha da üstünde olacak" diye belirtilse de, özgünlüğünden yoksun, dünyanın birçok metropolünde bulunabilen bir temapark taklididir, benzer yerlere göre rekabetçilik açısından avantajlara sahip olabilse de yine zayıf rekabet stratejisi olarak öne çıkmaktadır. Ankara'yı pazarlamak için benimsenen ve sadece kazanma ile kaybetme seçenekleri olan bu zayif rekabet stratejileri, mevcut veriler bağlamında Ankara'nın, ortaya atılan hedefler bakımından kaybedenler arasında olduğunu göstermektedir. 


\section{Şekil 36. 2002-2015 Yıllarında Ankara'ya Turistik Ziyaretlerin Dinamikleri ${ }^{789}$}

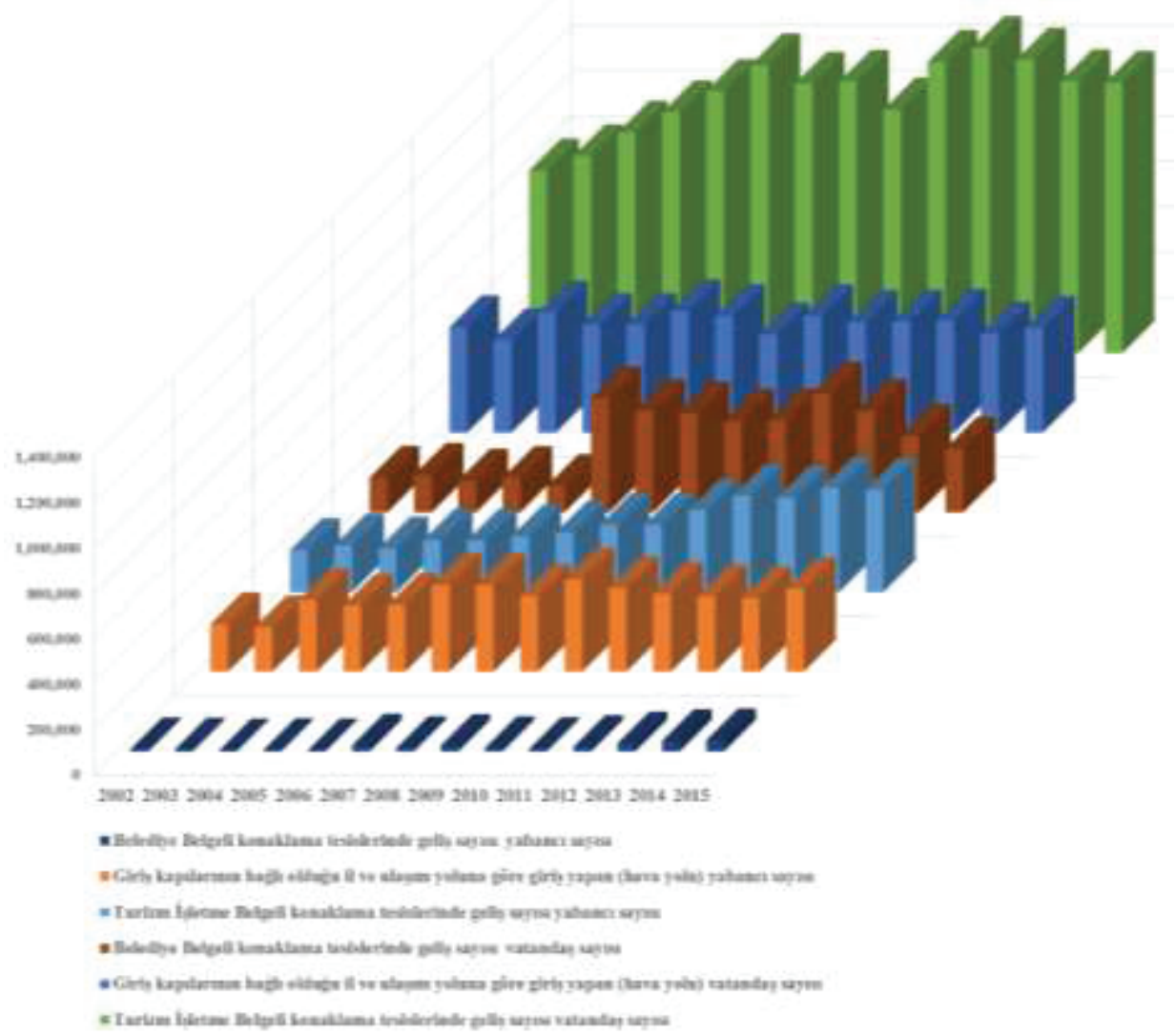

Ankara' da çoğalan AVM'ler, kenti “alışverişin ve ticaretin marka şehri”ne dönüştürme ve kente senelik 5 milyon turist kazandırma hedefine ulaşma konusunda başarısız olsa da Ankara, "Türkiye'nin yeni alışveriş cenneti" 790 olma konusunda başarıya ulaştığı söylenebilir. 2002'de toplam 8 AVM bulunan

789 Bu çizelge, TÜIKK verilerine dayanarak yazar tarafından hazırlanmıştır, bkz. TÜİK, Bölgesel İstatistikler, Turizm, 2002-2015, Düzey3 (İller), TR510-Ankara, https://biruni.tuik.gov.tr. TÜİK'in sınıflandırmasına göre, yabancılar Türkiye Cumhuriyeti pasaportu taşımayan ve sınır kapılarından ülkeye giriş-çıkış yapan ziyaretçilerdir, vatandaşlar ise Türkiye Cumhuriyeti pasaportu taşıyan ve sınır kapılarından ülkeye giriş-çıkış yapan ziyaretçilerdir.

790 “Türkiye'nin Yeni Alışveriş Cenneti” 2012'de Ankara Shopping Fest'in sloganıydı. Bkz. ABB, “Ankara Shopping Fest Gümbür Gümbür Geliyor", s. 9. 
Ankara'da, bugünlerde bu sayı 40'a yaklaşmıştır, bin kişiye düşen AVM alanı açısından ise $246 \mathrm{~m}^{2}$ ile Ankara Türkiye'de bir numara konumundadır. ${ }^{791}$ Kentin bazı alışveriş merkezlerine ziyaretçi sayısı ise daha ilginç bir tablo sunmaktadır - bazı büyük AVM'lere aylık ziyaretçi sayısı 1 milyonu aştığı görülmektedir (bkz. Tablo 8).

AVM'lerin çoğunda sinemalar, çocuk oyun alanları, yetişkinlerin de boş zaman değerlendirmesi için uygun oyun alanları, hatta bazı AVM'lerde tiyatroların varlığ da hesaba katıldığında kentte AVM'lerin, baskın bir kamusal mekân niteliği kazandığı, bununla ise tüketim odaklı bir egemen kamusallığın üretildiği ve kamusal mekânın bir tüketim mekanına dönüştüğü söylenebilir.

Tablo 8. Ankara'da Bazı AVM'lerin Aylık Ziyaretçi Sayısı ${ }^{792}$

\begin{tabular}{|l|c|c|c|c|}
\hline & $\begin{array}{c}\text { Kuruluş } \\
\text { Yılı }\end{array}$ & $\begin{array}{c}\text { Arsa Alanı } \\
\mathbf{( m}^{\mathbf{2}} \mathbf{)}\end{array}$ & $\begin{array}{c}\text { Kiralanabilir } \\
\text { Alan } \mathbf{( m}^{\mathbf{2}} \mathbf{)}\end{array}$ & $\begin{array}{c}\text { Aylık ziyaretçi } \\
\text { sayısı }\end{array}$ \\
\hline Ankamall AVM & 1999 & 126,000 & 108,000 & $1,550,000$ \\
\hline CEPA Ankara AVM & 2007 & 53,191 & 73,242 & $1,375,000$ \\
\hline Optimum Ankara AVM & 2004 & 31,000 & 42,500 & $1,135,000$ \\
\hline Forum Ankara AVM & 2008 & 171,000 & 86,300 & $1,125,000$ \\
\hline Gordion AVM & 2009 & 30,000 & 50,000 & 865,000 \\
\hline Antares AVM & 2008 & 440,000 & 82,750 & 835,000 \\
\hline Carrefour Ankara AVM & 2001 & 71,941 & 32,665 & 690,000 \\
\hline Karum Ankara AVM & 1991 & 18,000 & 23,500 & 575,000 \\
\hline
\end{tabular}

Böylece "Türkiye'nin yeni alışveriş cenneti" sloganı ve bin kişiye düşen AVM alanı açısından Ankara'nın "şampiyonluğu" bu dönüşüm sürecini temsil ederken, esas olarak neo-kapitalist tarzda örgütlenen tüketim ideolojisinin temsil mekanları olarak öne çıkarken, kenti pazarlayarak bir markaya dönüşmesine yönelik stratejiler söz konusu tüketim stratejisinin mekân temsiline tekabül etmektedir. Fakat üretilmekte olan mekânlar kayda değer bir çelişki içermektedir, bu çelişki ise sermaye birikim pratikleri doğrultusunda daha üst düzeyde mekânın tahayyül edilmesinin (ticaretin ve alışverişin marka kenti) ve yerel düzeyde bu birikimin gerçekleştirilmesinin (çoğalan AVM'ler) ironik çelişkisidir. Kenti bir markaya dönüştürmesi, 'marka'nın tanımı gereğince özgünlük, ayırt edici nitelikler üretilmesini gerektirirken, kentte çoğalan AVM'lerde pazarlanan ve sergilenen ürünler, AVM'lerdeki mekânın kullanımı

791 AYD, "AYD-ICSC Turkey Shopping Center Fact Sheet".

$792 \mathrm{Bu}$ tablo Maji Network'un verilerine dayanarak derlenmiştir, bkz. http://www.majinetwork.com. 
pratikleri ve AVM'lerin kendileri dünyanın herhangi bir metropolünde bulunabilecek ürün, pratik ve mekânlar olarak karşımıza çıkmaktadır. Bu ise benimsenen kent pazarlama stratejisinin mekân temsili (marka kenti) ile mekânsal pratikler (AVM'leri çoğaltmak) arasındaki ironik çelişkiyi yansıtmaktadır. 2012'de Ankara'yı "alışverişin ve ticaretin marka şehri”ne dönüştürmeye yönelik Ankara Shopping Fest'in tanıtım yüzü olarak dünyaca ünlü Hollandalı bir mankenin seçilmesi ise bu ironik çelişkiyi ifade edecek niteliğindedir. Dünyaca ünlü bir model aracılığıyla sermayenin ve tüketim pratiklerinin temsil edilerek (özendirilerek), bu festivalde 500TL'lik alışveriş yapanlara "misket oynayan maskot bir kedi" hediye edilmesi ise küresel ölçekte sermaye akışlarının temsil mekânı (ünlü bir model) ile yerel ölçekte sermaye birikiminin gerçekleştirilmesinin temsil mekânı (misket oynayan maskot kedi) arasındaki ironik ama zorunlu çelişkiyi ifade etmektedir böylece.

Benzer biçimde mekân temsili, temsil mekânı ve mekânsal pratikler açısından Ankara'nın mekânsal dokusunun özgün bir parçası olan AOÇ’nin imara açılarak üzerine bir tematik parkın inşası ironik çelişkilerin dışavurumu olarak öne çıkmaktadır. Ankara'ya yurtdışından minimum 3 milyon kişi çekmesi hedeflenen ${ }^{793}$ fakat aynı zamanda Amerika ve Avrupa'da da benzer örnekleri bulunan bu mekân, özgünlük ve ayırt edicilik bakımından 'marka kenti'nin tanımıyla çelişmektedir. Fakat asıl çelişki 'marka kenti' olmak doğrultusunda mekânın daha üst ölçekte temsil edilerek yeniden biçimlenmesi (mekân temsili) ile kentin özgün tarihsel ve toplumsal bir mekânı (temsil mekânı) arasındadır. AOÇ, kendisi de bir mekân temsili (Erken Cumhuriyet döneminin modernleşme çabaları çerçevesinde planlama aracılığıyla toplumsal dönüşümün mekân temsili) olmakla beraber - aynı zamanda söz konusu modernleşme sürecinin ve Erken Cumhuriyet tarihini temsil eden özgün bir temsil mekânıdır. Böylelikle, kenti pazarlayarak 'marka kenti' yaratmak amacıyla söz konusu mekânı parselleyerek onun yerine bir tematik parkın inşası sermaye birikimine dönük bir mekân üretimi örneğini oluştururken esas olarak mekân tüketimine işaret etmekte, bu süreçte Cumhuriyet Ankara'sının kayda değer bir temsil mekanının ortadan kalkmasına yol açmıştır. ${ }^{794} \mathrm{Bu}$ ise bir temsil mekânı olarak ve tekrarlanabilirlik

793 Tol, "Başkan Melih Gökçek’ten Marka Kent Projeleri”, s. 18.

794 Ele alınan dönemde Erken Cumhuriyet döneminin temsil mekânı niteliği taşıyan ve bugünlerde yok olma tehlikesi altında olan mekânlar açısından Atatürk Orman Çiftliği sadece tek örnek değildir. Daha önce de ele alındığı üzere bir diğer örnek İller Bankası binasıdır. Bir başka kayda değer örnek ise Erken Cumhuriyet döneminin önemli simgelerinden Çubuk Baraj Gazinosu'nun 2016'da 'oldu bittiyle' yıkılmasıdır (bkz. Doğan, “'Mimari Vandalizm”: Marmara Köşkü'nden Sonra Çubuk Baraj Gazinosu da Y1kıldı”). İronik bir şekilde 2011'de ABB yayın organı tarafından "Çubuk-1 Barajı yeniden doğuyor" ve "Cumhuriyet döneminin ilk barajı eski haline kavuşacak" manşetiyle barajın yenilenmesini, temizlenerek eski haline getirilmesini ve yeni bir rekreasyon alanına dönüştürülmesi aktarılırken aynı zamanda barajın 
ile yeniden üretilebilirlik açısından özgün olan bir mekânın (AOÇ), bir yapılı çevre ve toplumsal mekân olarak dünyanın her yerinde yeniden üretilebilirliğin ve tekrarlanabilirliğin ürünü olan tematik bir parkın (Ankapark) çelişkisidir. Ankara'yı ve Ankara'nın tarihinin bir kesitini tanımlayan ve özetleyen bir mekânda bugünlerde yeniden üretilebilirliği ve tekrarlanabilirliği esas olarak ise sermayenin dolaşımını temsil eden "dünyanın en büyük roller coasterları"795 dolaşmaktadır. Söz konusu tematik parkın, "Selçuklu Mimarisi'nin hakim olduğu giriş kapısı" 796 ise 2002'den sonra öne çıkan Selçuklu-Osmanlı söylemi ve bunun mekânsallaşmasını temsil etmekle sınırlı kalmamakta, "dünyanın en büyük roller coasterlar'”na girişi sağlayan 'Selçuklu kapısı', 2002' den günümüze 'Selçuklu-Osmanlı mimari' söylemleriyle kentin algılanmasının, 1071 Malazgirt veya Yavuz Sultan Selim Bulvarlarıyla "dünyanın en rahat trafiği” sağlanarak kentin deneyimlenmesinin yeniden biçimlenmesini ve Ankara' da yaşamanın fiziksel, zihinsel ve toplumsal açılardan adeta bir 'roller coaster'e binme deneyimi haline gelmesini temsil edecek niteliktedir.

tarihi önemine de vurgu yapılmıştır. İlgili haberde barajın tarihi önemine vurgu yapılması ise sadece söz konusu barajın, Türkiye'nin ilk barajı olma hususundan kaynaklandığı görülmektedir, zira bu haberde "Ankaralıların mesire alanı ve gelen yabancı konukların da ağırlandığı bir yer" (Turan, "Çubuk-1 Barajı Yeniden Doğuyor", s. 4) olduğu hususu belirtilmesine rağmen Baraj Gazinosu'ndan hiç söz edilmemektedir. 2016'ya geldiğinde ise Kemalist modernleşme projesinin gerek mekân temsili gerekse temsil mekânı olan Çubuk Baraj Gazinosu yıkıldı. 2011'den beri baraj altında (gazinonun bulunduğu alanda) bir rekreasyon alanı oluşturma projesi gündemdedir ve yine 'dinozorlar' içeren bir temapark öngörülmektedir (bkz. Melihgokcek.com. "ÇUBUK 1 Barajı Rekreasyon Alanı Projesi"), böylece belirli tarihsel anlamla yüklü ve ilk önce bir temsil mekânı olan Baraj Gazinosu AOÇ ile aynı kaderi - 'dinozorlu' temapark olma kaderi - paylaşmaktadır. Kemalist militan laik modernleşmenin ürünü olan bu mekânlar şöyle dursun, kent merkezinde bulunan, “1940'ların ortalarından sonra Türkiye mimarlığında neoklasik üsluba ve 'Türk evinin' daha geleneksel yorumlarına doğru bir dönüş”ün (Akcan, Çeviride Modern Olan: Şehir ve Konutta TürkAlman İlişkileri, s. 361) ürünü olan Saraçoğlu Mahallesi'nin örneği de dikkat çekicidir. Mimari üslubu bakımdan daha geleneksel yorumların ve 1940'ların mimari tartışmaları ve uygulamalarında "Türk evi” (milliyetçi) söyleminin ürünü olup bu bakımdan Osmanlı'nın tarihsel birikimine özgü üslubuna daha yakın olmasına rağmen Saraçoğlu Mahallesi bir temsil mekânı olarak yine yok olma riski altındadır. Ele alınan dönemde kentin birtakım yerlerinde kentin tarihsel dokusunun yenilenme ve restorasyonuna yönelik kayda değer çalışmalar yapıldığı söylenebilir, Hamamönü veya Hacıbayram bölgeleri ise bu çalışmaların en öne çıkan örnekleridir, dahası bu mekanlarda en temel korunacak unsurlar olarak geleneksel "Ankara evleri" ("Türk evleri") ve belirli ibadet alanları öne çıkmaktadır. Bunlar hepsi bir arada değerlendirildiğinde restorasyon, yenileme veya koruma süreçlerinde Cumhuriyet öncesi dönemin dokularının restore edildiği veya taklit biçiminde yeniden üretilip korunduğu, Cumhuriyet dönemindeki belirli tarihsel dokuların ise yavaş yavaş aşınmaya ve yıkılmaya terk edildiği veya doğrudan yıkıldığı söylenebilir. Bunlar ise seçici koruma ve restorasyon ile seçici yıkım pratiklerine - belirli ideolojik temsiller doğrultusunda mekân üretimine - işaret etmektedir.

795 Turan ve Bingöl, "Başkan Gökçek: "2014 Yüz Akı Bir Yıl Oldu””, s. 7.

796 Ibid. 


\section{Bölüm Değerlendirmesi}

2000 sonrası dönemde Ankara'da mekânın üretimi süreçlerinin eğilimlerine dair bir genelleme yapılırsa şöyle bir genel tablodan söz edilebilir. 2000 sonrası dönemde mekânın üretimi süreçleri bir önceki evrede benimsenen neoliberal birikim rejimi çerçevesinde devam ettiği, fakat neoliberal kentsel rejimin ancak bu dönem içerisinde tamamlandığı görülmektedir. Başka bir deyişle neoliberal rejim mekânsal olarak ve mekân bağlamında ancak bu dönem içerisinde tamamlanmıştır.

2002-2016 arası dönemde Ankara'da mekânın üretimi süreçlerinden yapılı çevrenin üretimi ile yeniden üretimi boyutlarına bakıldığında iki önemli sürecin yaşandığg görülmektedir. Bunlar bir önceki dönemde de görülen fakat 2002'den sonra boyut ile kapsam açısından çok yoğun olarak gözlemlenen kentsel dönüşüm projeleri ve kentin fiziksel altyapısındaki değişimlerdir. Aynı zamanda yapılı çevrenin üretimi ile ilgili önemli bir gelişme mekânsal yeniden ölçeklenme teşkil eden anakentleşme sürecidir. Bu gelişmelerin gerek mekân üzerine söylemleri gerekse temsiller açısından önemli içerimleri olduğu görülmektedir. $\mathrm{Bu}$ açıdan bir önceki dönemin neoliberal birikim rejiminin ürünü olarak ortaya çıkan çelişkili mekânın belirtileri 2000'den sonra daha belirgin biçimde öne çıktığı görülmektedir. Mevcut birikim rejiminin mekânsal sonuçlarının en temel özelliği ise genel olarak ileri kapitalizme ve özel olarak neoliberal rejime özgü bir mekân temsili doğrultusunda 'mekânda şeylerin üretiminden mekânın üretimine' geçiştir. Kurumsal düzlemdeki düzenlemeler, söylemsel pratikler ile somut uygulamalar aracılığıyla gerçekleşen bu geçişin ürünü olarak Türkiye'de Ankara örneğinde bütünsel bir neoliberal kentsel/mekânsal rejim meydana gelmiştir, bu kentsellik ise sadece nicel anlamda değil, nitel anlamda da gerçeklik kazanmıştır. Nicel anlamda bu kentsellik mekânsal olarak bütünselliğe yönelen bir kentleşmeyle, nitel anlamda ise mekânın sadece bir 'arsa' biçiminde gayrimenkulleşerek değil, aynı zamanda toplumsal yaşamın ve buna denk düşen mekânsal üç temel düzlemin - biyolojik yeniden üretimi, emek gücünün yeniden üretimi ile toplumsal ilişkilerin yeniden üretimi - tamamen metalaşmış döngüler çerçevesinde gerçekleştiği söylenebilir. Üretilmekte olan mekân böyle bir nicel ve nitel bütünselliğe ve bütünleşmeye yönelirken aynı zamanda somut düzeyde mekânın ayrışıp parçalandığı, bu parçalanmanın hem mekânın gayrimenkulleşme biçiminde hem de üretim ile toplumsal ilişkilerin yeniden üretimini sağlamasına yönelik mekânsal pratiklerin nispeten ayrışmış döngülerde gerçekleştiği söylenebilir. Bu eğilim ise ileri kapitalizmin çelişkili mekânın bütün ile parça arasındaki çelişkilerinin somut bir ifadesi olarak tanımlanabilir.

Tamamen gayrimenkulleşme ve metalaşmaya yönelen dolayısıyla değişim değer odaklı mekân üretimi eğilimleri karşısında kullanım değeri odaklı mekânın 
üretimi süreçlerinin geri planda olduğu görülmektedir. Kullanım değeri odaklı mekân üretimi süreçleri söz konusu olunca ise bunların incelenmesi bu örneklerin önemli politik kullanım değeri barındırdığı, bunlar aracılığıyla belirli muhafazakâr tahayyüller doğrultusunda toplumsal mekânın yeniden tanımlandığı görülmektedir. Ayrıca, bu süreçlerde muhafazakâr söylem ve pratikler bağlamında popülist söylemsel pratiklerin de yer aldığ söylemin mekansallaştı̆g 1 görülmektedir. Kullanım değer odaklı mekân üretimi örnekleri aracılığıyla ayrıca farklı toplumsal mekânsal pratiklerin (yeniden) üretildiği görülmektedir.

Mekân üzerine söylemde ise mekânın farklı temsil ve karşı temsil üretimi süreçlerine yoğun biçimde maruz kaldığı söylenebilir. $\mathrm{Bu}$ açıdan, mevcut ilerleme ve gelişme anlayışı doğrultusunda 'modernin' tamamen yapılaşmış bir kentsel çevrenin eşanlamı olarak öne sürüldüğü, yapılaşmanın 'ilerleme' ve 'kalkınma'nın temsil mekânı olarak öne çıkarıldığ 1 görülmektedir. Böyle bir söylem ve onun ürünü olan pratikler ise aynı zamanda ileri kapitalizmin mekân temsilini de destekleyecek niteliktedir ve tamamen gayrimenkulleştirilmiş, metalaşmış, imarlaşarak parsellenmiş mekân üretimi süreçlerine cevap verebilir niteliktedir.

Fakat mekân üzerinde söylemde (temsil mekânı) öne çıkan diğer baskın eğilim, farklı bir tarih yazımı öne çıkartılarak farklı temsiller aracılığıyla mekânın yeniden tanımlanmasıdır (üretimidir). Bir taraftan ulusal kimliğin yeniden tanımlanması bağlamında farklı bir uzak tarih anlatısının (Selçuklu/Osmanlı dönemi) öne çıkarıldı ̆̆ı, diğer taraftan Cumhuriyet' in belirli tarihsel dönemleriyle kayda değer 'hesaplaşma' gerçekleştiği görülmektedir, bunun ise somut mekânlar üzerine söylem aracıllğıyla gerçekleştirildiği görülmektedir. Böyle bir hesaplaşma aynı zamanda dönem boyunca ağır basan popülist söylemlerin de parçası olduğu için egemen popülist söylemin mekânsallaşması veya popülist söylemin temsil mekanları olarak tanımlanmalıdır. Diğer taraftan, toplumsal mekânın ontolojik bakımdan yeniden tanımlanması girişimlerinden söz edilebilir. Ele alınan dönemin özellikle son yıllarında sık sık öne çıkan 'külliye' söylemi - ki ilk önce mekân üzerine bir söylem niteliğindedir - toplumsal mekânın farklı biçimleri söylemsel olarak yeniden tanımlama, yani yeni temsil mekanları üretme çabası olarak görülmelidir. Fakat söz konusu yeniden tanımlamalar söylemsel boyutla sınırlı değildir aynı zamanda önemli pratik boyutu da içermektedir ve farklı mekân temsilleri ve mekânsal pratikler üretme doğrultusundadır.

Söylemsel pratikler aracılığıyla mekânın yeniden tanımlanmasına aynı zamanda yapılı çevrenin yeniden üretiminin eşlik ettiği görülmektedir. $\mathrm{Bu}$ açıdan, Ankara'da kentsel mekânın farklı biçimlerinin dönüşüm süreçlerinde Selçuklu/Osmanlı olarak iddia edilen mimari çözümlerin sık sık öne çıkarıldığı, 
aynı zamanda kentin imgesini değiştirmesine yönelik sistematik çabaların söz konusu olduğu görülmektedir. Bu süreç bir taraftan kente ideolojik yüklü yeni bir imge kazandırma çabası olarak öne çıkarken diğer taraftan mekânın parça parça veya bütün olarak 'markalaşması' biçiminde mekânın oryantalistleşmesi biçiminde gerçekleşmiştir. Bu bağlamda tarihi yaşatmak amacıyla yola çıkarak üretilebilirlik ve yeniden üretilebilirlik çerçevesinde sadece tarihsel taklitler üreterek kentin yaşanan mekânının dağıldığı, onun yerine ideolojik yüklü projelerin, teknisyenlerin ve planlamacıların tasarlanan mekanlarının yükseldiği söylenebilir. Bu ise kentsel mekânın son 15 y1l içerisindeki en temel çelişkiyi ve üretilen çelişkili mekânın özünü oluşturmaktadır. Mekânı daha üst ölçekte tahayyül ederek kenti bir turizm merkezine (zira merkezliğe kavuşmak daha üst ölçekli tahayyül gerektirmektedir) dönüştürmek amacıyla somut düzeyde mekâna müdahale eden bu projeler ise kentlisi olmayan bir somut soyutluklar niteliğindedir ve toplumsal mekânda gündelik gerçekliğin ile kentsel gerçekliğin, toplumsal mekânın algılanan ile yaşanan boyutlarının çelişkilerine işaret etmektedir.

Bu süreçlerin ürünü olarak ortaya çıkan toplumsal mekân böylece şu temel çelişkilerle karşımıza çıkmaktadır:

1) Belirli bir mekân temsili - neoliberal ileri kapitalizmin mekânı üst ölçekte tahayyül etmenin - doğrultusunda bütünselliğe yönelen fakat aynı zamanda parçalanmış ve parsellenmiş mekân, tamamen metalaşmış ve mübadele süreçlerinin egemen olduğu bütünsel fakat parçalanmış bir mekânsal rejim.

2) Mübadele süreçlerinin egemen olmasına rağmen kullanım değeri odaklı kayda değer mekân üretimi girişimlerinin söz konusu olduğu, fakat mevcut girişimlerin farklı ideolojik yüklü temsillerle yüklü olduğu, dolayısıyla kullanım değerinin münhasıran politik olduğu mekânlar ve bunun ürünü olarak farklı temsillerin çelişkileriyle dolu bir toplumsal mekân.

3) Kâh belirli bir tarih yazımının öne çıkarılması veya tarihi yaşatma kâh kent ile mekânın 'markalaştırma' çabaları doğrultusunda üretilmekte olan mekânlar, birer mekân üretimi süreçleri olmakla beraber esasen mekânın tüketimine yönelik olan, kenti parça parça veya bir bütün olarak 'pazarlama' stratejilerinin ürünüdür ve asıl olarak birer öz-oryantalleşme örneği teşkil etmektedir. 
SONUÇ 



\section{SONUÇ}

Temel araştırma sorunsalı Türkiye'de Ankara örneğinde mekânın üretimi süreçlerinin Lefebvre'in mekânın üretimi kuramı çerçevesinde ele alınması olan bu çalışmada iki temel amaç güdülmüştür: İlki, eleştirel sosyal teorideki mekân tartışmalarında Lefebvre'in mekân kuramının rolünü ele alarak mekânın üretimi süreçlerini araştırmak için bu kuramın sunduğu imkanların değerlendirilmesi, bu kuramın yapısal ve kavramsal açıdan bütünsel bir okumasının gerçekleştirilmesi, böyle bir okumayla ise bu kuramın temel saptama, varsayım, kavramsal çerçeveler ile yapısal bileşenlerinin yeniden değerlendirilerek somut bir araştırma için işlevselleştirilmesi amaçlanmıştır. İkincisi, çalışmada Ankara örneğinde Türkiye'de mekânın üretimi süreçlerinin değerlendirilmesiyle hem ilgili kuramın somut bir bağlamda uygulanması hem de Türkiye'de mekânın üretimi süreçleri ile ilgili somut tartışmalara yeni bir bakış açısının - Lefebvre'in kuramsallaştırmaları çerçevesinden Türkiye'de mekân ve mekânın üretimi sunulması amaçlanmıştır.

Mekâna dair kuramsal tartışmalara dair bu çalışmanın katkısı olarak Lefebvre'in mekân kuramının detaylı bir okumasıyla kuramda dağınık olarak mevcut kavramsallaştırmaların yeniden ele alınması ve bunların bir bütünlük olarak yeniden değerlendirilmesidir. Çalışmada temel argüman olarak Lefebvre'in mekân kuramının iki temel yapısal bileşeninden oluşması ve bu iki bileşenin ancak beraber değerlendirildiği zaman söz konusu kuramın özgün bir önerme olarak tanımlanabileceği öne sürülmüştür. Bu argümana göre bu kuramın parçacı okumalar ile uygulamalarıyla, onu bir veya iki saptama veya kavrama indirgemeyle hem söz konusu kuramın özgünlüğü ortadan kalkmakta hem de böyle bir yaklaşım bu kuramın temel özelliğiyle -mekân ve mekânın üretiminin bütünsel bir teorisi olma özelliğiyle - çelişmektedir. Çalışmamızın bu argümanı ise sadece kuramsal değerlendirmelere dayanmamış, bu argüman ayrıca çalışma kapsamında Türkiye ile ilgili 'mekânın üretimi' literatürünün sistematik ve kapsamlı bir değerlendirmesiyle desteklenmiştir. Bu sistematik değerlendirme aynı zamanda Türkiye'de mekân tartışmalarına çalışmamızın diğer katkısıdır. Türkiye ile ilgili olan ve Lefebvre'in mekâna dair kuramsallaştırmalarını farklı biçimlerle benimseyen akademik çalışmaların taranarak ele alınmasıyla hem Türkiye ile ilgili mekân tartışmalarında Lefebvre'in kuramsallaştırmalarının uygulanış biçimleri, bu çalışmaların zaman kapsamları veya mekânsal ölçekleri 
ele alınmaya, hem de mevcut tartışmaların genel eğilimleri değerlendirilmeye çalışılmıştır.

Ankara, Türkiye'deki kent, kentleşme ve mekân araştırmalarında yoğun olarak ele alınan bir kenttir ve mevcut çalışmalar Ankara'ya ve onun mekânın üretimine farklı bakış açıları sunmaktadır. Bu çalışma da en azından 1923-2000 arası dönemin mekânın üretimi süreçlerini değerlendirmek için mevcut literatür birikimine dayanmıştır, fakat bununla beraber çalışmada Ankara'yı ve onun mekanını planlama, mimarlık, sosyoloji, tarih, coğrafya, yerel yönetimler gibi alanlara indirgemeyerek, bir bütün olarak toplumsal mekânı ve onun dönüşümü ele alınmaya çalışılmıştır.

Değerlendirmeler sonucu, çalışmanın Ankara'da 1923'ten günümüze dek mekân üretimi süreçlerinin tarihsel mekân (1923-30 aras1 dönem), soyut mekân (1930-80 arası dönem) ile çelişkili mekânın (1980 sonrası dönem) üretildiği dönemlerden oluştuğu varsayımı doğrulanmıştır. ${ }^{797} \mathrm{Bu}$ bakımdan Lefebvre'in önerdiği mekân dönemselleştirmesi çerçevesi birbirine müteakip tarihsel mekân (birikim mekanı), soyut mekân ile çelişkili mekân olarak Cumhuriyet'in kuruluşundan günümüze dek Ankara'da üretilmekte olan mekân bağlamına büyük ölçüde uymaktadır. ${ }^{798}$

797 Mevcut literatürde farklı araştırmacılar tarafından önerilen dönemeçler çalışmamızdaki dönemeçlerle örtüşebilir. Örneğin, Bozdoğan'ın Erken Cumhuriyet Türkiye'sinde mimari kültür ve paradigmaları konu eden çalışması (Bozdoğan, Modernizm ve Ulusun İnşası: Erken Cumhuriyet Türkiyesi'nde Mimari Kültür) 1923-1930 arası dönemi farklı bir dönemeç olarak tanımlamaktadır. Ya da kentleşme ile kent literatüründe 1980 sonrası dönem neredeyse tüm çalışmalarda bir dönemeç olarak karşımıza çıkmaktadır. Bu bakımdan çalışmamızın önerdiği dönemeçler açısından mevcut literatür birikiminden farklılaşmasa da, mevcut mimari, planlama, kentleşme ve kent literatüründen farklı olarak ilgili dönemler tamamen Lefebvre' in kuramsallaştırmalarına ve onun önerdiği kavramsal çerçevelere göre ele alınmaktadır ve bu itibariyle konu ile yakından ilgili diğer çalışmalardan farklılaşmaktadır.

798 Ele alındığ 1 üzere Lefebvre'in kuramında ulus-devletleşme ile kapitalistleşmenin mekânı soyut mekân, ileri kapitalizmin mekânı ise çelişkili mekân olarak tanımlanmaktadır. Bu bakımdan çalışmamızda Cumhuriyet'in kuruluşundan günümüze uzanan süreçte mekânın üretimi süreçleri açısından 1930-1980 arası dönemin soyut mekân veya 1980 sonrası dönemin ise çelişkili mekân olarak tanımlanması aşikâr bir husus olarak değerlendirilebilir. Fakat çalışmada belirli dönemlerin tarihsel, soyut veya çelişkili mekân üretimi dönemleri olarak tanımlanması için her dönemde ilgili mekânın üretim süreçlerine odaklanılmış ve ilgili tanımlara başvurulması 'kapitalizmin ürettiği mekân zaten soyut mekâna tekabül etmektedir' gibi "fetişist" ve indirgeyici bir mantık yürütmeye değil, her döneme özgü üretim ilişkilerinin, toplumsal mekânın algılanan, yaşanan ile tasarlanan boyutlarının analizine dayanmıştır. Başka bir deyişle, örneğin 1930-1980 arası dönem Türkiye'de ulus-devletleşme, kapitalistleşme ve kapitalist toplumsal ilişkilerin yerleşip geliştiği dönem olduğu, Lefebvre'in ise böyle süreçlerde üretilen mekân için soyut mekân tanımını önerdiği hususundan yola çıkarak çalışmada ilgili dönemin Türkiye'de soyut mekânın (yeniden) üretildiği bir dönem olarak tanımlanmasından ziyade, ilgili dönemde soyut mekânın üretiminin nasıl gerçekleştiği, 
1923 'ten günümüze Ankara'nın mekân tarihinin birbirine müteakip tarihsel mekân, soyut mekân ile çelişkili mekân evrelerinden oluştuğu doğrulanmış varsayımına dair bir genel değerlendirme yapılırsa bu üç döneme ve her dönemde üretilmekte olan özgün mekâna dair şunlar belirtilmelidir. Bunlardan ilki Cumhuriyet'in ilanından 1930'ların başına dek süren ve tarihsel mekânın (birikim mekanının) egemen olduğu dönemdir. Bu dönemde Ankara'da toplumsal mekânın hala büyük ölçüde Osmanlı'nın son dönemindeki tarihsel mekân (birikim mekânı) ile süreklilik gösterdiği görülmekte, bir kapitalist ulusdevlet olarak Cumhuriyet'in kuruluşu ve buna göre Ankara'da mekân temsili, temsil mekânı ve mekânsal pratikler açısından Osmanlı'ya özgü toplumsal mekândan belirli kopuş görülse de henüz radikal bir kopuş ve farklı bir egemen mekânın üretimi söz konusu olmamıştır. Çalışmadaki değerlendirmeler bu evrede Ankara'da mekânın üretimi süreçlerinin önemli ölçüde ilkel birikim çerçevesinde gerçekleştiğini, mekânın da bu ilkel birikim süreçlerinde önemli bir rolü olduğunu göstermiştir. Özellikle böyle bir birikimin varlığı açısından bu dönemin mekânı Lefebvre'in önerdiği tarihsel mekân (birikim mekânı) tanımına uymaktadır. Bu dönemde mekânın gerçek üreticisi olan üretim güçleri ile üretim ilişkilerinin Osmanlı'dan kopuş sağlaması açısından yeterli seviyede olmadığı, ayrıca ulus-devlete özgü bir mekânın üretimi için üstyapısal düzlemin de Osmanlı'ya özgü toplumsal mekândan kopuş sağlayacak nitelikte olmadığı saptanmıştır.

Ankara'nın toplumsal mekânının değerlendirmesinin sonucu olarak 19231950 arası dönemin, toplumsal mekânın algılanan, yaşanan ile tasarlanan boyutları açısından süreklilik arz eden bir dönem olmadığı, bu dönem için mevcut literatürde yaygın olarak kullanılan "Erken Cumhuriyet" dönemi olarak tanımlanmasının mekânın üretimi ve o zamanlarda mevcut egemen toplumsal mekân açısından büyük ölçüde elverişli bir tanım olmadığı ve bu dönemin en az ilk on yılında Ankara'da tamamen farklı bir mekânın üretimi süreçlerinin gerçekleştiği saptanmıştır. Bu dönem ise Osmanlı'nın son döneminin tarihsel mekânının (birikim mekânı) egemenliğinin korunduğu ve yeniden üretildiği bir dönemi teşkil etmekteydi. Ancak 1930'lu yıllardan itibaren Cumhuriyet'in modernleşme projesi bağlamında mekânın üretimi açısından radikal bir kopuşun yaşandığ1 ve ulus-devletleşmeye özgü soyut mekân üretiminin gerçekleştiği saptanmıştır.

Çalışmada 1930-1980 arası dönemde Ankara'da mekânın üretimi süreçlerinin analiziyle, bu dönemde söz konusu süreçlerin iki eksende - ulusdevletleşme ile kapitalistleşme bağlamında -gerçekleştiği ve buna göre soyut mekânın yükselerek yaygınlaştığı saptanmıştır. Fakat ulus-devletleşme ile

bunun ekonomi politiği, toplumsal mekânın algılanan, yaşanan ile tasarlanan boyutları bağlamında soyut mekânın nasıl dışa vurulduğu gibi hususlara odaklanılmıştır. 
kapitalistleşme süreçlerinin bu uzun dönem boyunca mekânın üretiminde aynı ölçüde etkili ve belirleyici olmadığı görülmüştür. Bu bakımdan, çalışmada 19301950 arası dönemde Ankara'da üretilmekte olan soyut mekânın, mekânın mübadele süreçlerine dahil olunup gayrimenkulleşme ve soyutlaşmasından ziyade üretim güçlerinin elverdiği imkânlar çerçevesinde ideolojinin belirleyiciliğinin ürünü olduğunu göstermiştir. Mekânın üretiminde ideolojinin belirleyiciliği ise bu dönemin modernleşme çabaları doğrultusunda mekâna münhasıran siyasi bir kullanım değeri atfedilmesinden kaynaklandığı saptanmıştır. $\mathrm{Bu}$ dönemde henüz tam olarak yerleşmemiş kapitalist üretim güçleri ve ilişkilerine (altyapısal düzlem) kıyasla üstyapısal düzlemin mekânın üretimindeki belirleyici rolü ise toplumsal mekânın algilanan, tasarlanan ile yaşanan boyutlarında önemli dönüşümler yaratmakla beraber daha çok mekânsal temsillerin üretimiyle sınırlı olduğu görülmektedir. ${ }^{799}$ Dolayısıyla, 1930-50 aras1 dönemde üretilmekte olan mekânın bir soyut mekân olmas1, modern bir toplum ve homojen bir ulus yaratmak için mekâna münhasıran politik kullanım değeri atfedilmesinden ve bu doğrultuda toplumsal mekânın algılanan, tasarlanan ile yaşanan boyutlarını yeniden biçimlendirme çabalarından kaynaklanmaktaydı.

1950-1980 arası dönemin analizi ise mekânın üretiminde politik unsurun ve mekânın politik kullanım değerinin önemini kaybetmemesini, farklı biçimlerle öne çıkmasını, dahası mekânın, kitlesel siyaset alanında önem kazanmasıyla birlikte, mekânın üretimi süreçlerinde mübadele süreçlerinin önemli ve belirleyici rol kazandığını göstermiştir. Bu dönemin analizi, benimsenen yeni birikim rejimleri (1950'lilerin 'tarımsal kapitalizm' ile 196070'lilerin ithal ikameci sanayileşme birikim rejimi), kapitalist dünyaya eklenme ve kapitalist üretim güçleri ile üretim ilişkilerinin gelişmesi açısından önemli bir dönemeç olduğunu, bu açıdan modern bir mekânın üretimi için yeterli altyapısal dayanağın oluştuğunu, fakat aynı zamanda bu dönemde bir önceki dönemin modernleşme sürecinin aşınmasının da yaşandığını göstermektedir. Dolayısıyla, 1950-80 arası dönem modern bir mekân üretecek altyapısal yeterliliğe ulaşıldığ fakat üstyapısal aşınmanın yaşandığ 1 bir dönem olarak tanımlanmıştır.

$799 \mathrm{Bu}$ açıdan, ilgili dönemin incelenmesi Lefebvre'in öne sürdüğü önemli iki varsayımın değerlendirilmesine imkân sağlamıştır. Lefebvre'in belirttiği üzere ideolojiler belirli faaliyetlerin yerlerinin belirlenmesini buyururlar, hangi faaliyetin nerede olmasi gerektiğini belirlerler, fakat ideolojiler mekânı üretmezler, mekânın içindedirler, mekân sadece üretici güçler ve üretim ilişkileri tarafindan üretilir (Lefebvre, Mekânın Üretimi, s. 223-224). Aynı zamanda Lefebvre'ye göre "yeni bir mekân üretemeyen bir devrim sonuna kadar gidemez; başarısız kalır; hayatı değiştiremez; sadece ideolojik üstyapıları, kurumları, politik aygıtları değiştirir" (Lefebvre, Mekânın Üretimi, s. 82). Cumhuriyet'in modernleşme çabaları doğrultusunda 1930-1950 arası dönemde mekânın üretimi süreçlerinde ideolojik düzlemin belirleyici olmas1, üretim güçleri ile ilişkilerinin ise bu süreçleri destekleyecek kapasitede olmaması ve 1950 sonrası dönemde modernleşme projesinin aşınması, Lefebvre'in bu iki varsayımını belirli ölçüde doğrulayacak yöndedir. 
Genel bir sonuç olarak, böylece 1930-80 arası dönemde mekânın üretimi süreçlerinin bir önceki döneme kıyasla birbirini takip eden iki sürecin - ulusdevletleşme ile kapitalistleşme - çerçevesinde gerçekleştiği, bu süreçte 1930-50 arası dönem Cumhuriyet' in modernleşme projesi doğrultusunda modern bir ulusdevlete özgü, münhasıran politik bir soyut mekânın üretildiği bir dönem olduğu, değişen birikim rejimi ve kapitalist dünyaya eklenmesiyle kapitalistleşmenin daha ağır bastığı, 1950-80 arası dönemde ise mekânın mübadele süreçlerine daha fazla dahil olma ve önem kazanmasiyla soyut mekânın egemen nitelik kazanıp yaygınlaştı̆̆ bir dönem olduğu görülmektedir. Bu bakımdan Türkiye'de 193080 arası dönemde soyut mekânın üretimi birbirini takip eden iki evrede, farklı üstyapısal ve altyapısal denklemlerde gerçekleşmesi itibarıyla üretilmekte olan bu soyut mekân, Lefebvre'in önerdiği soyut mekân tanımından farklılaşmaktadır, zira Lefebvre'in "Avrosentrik" şemasındaki soyut mekân Avrupa'da birbirini takip eden değil, paralel olarak ilerleyen ulus-devletleşme ile kapitalistleşme süreçlerinin ürünüdür.

1980 sonrası dönemin analizi, Ankara'da mekânın üretimi süreçlerinin hem altyapısal düzlemde (ileri kapitalizmin esnek birikim rejimi) hem de üstyapısal düzlemde (neoliberal İslamcılık) yaşanan paradigmatik değişimler bağlamında ilerlediğini, bu bakımdan Ankara'da ileri kapitalizmin çelişkili mekânının ortaya çıktığını, toplumsal mekân bağlamında bu çelişkilerin kullanım ile değişim, bütün ile parça, mekân temsili ile mekânsal pratikler arasında dişa vurulduğunu göstermiştir. Bu dönemde kamusal alanda İslami unsurun daha fazla görünürlük kazanmasıyla ve politik alanda siyasal İslamın yükselişiyle toplumsal mekânın algılanan, yaşanan ile tasarlanan boyutları arasında (bazense bunların her birisi içerisinde) çelişkili temsil ve pratikler meydana gelmesi dönemin çelişkili mekânın diğer temel özelliği olarak saptanmıştır. İleri kapitalizmin ve neoliberal paradigmanın, mekânı gayrimenkulleştirme süreçlerine daha fazla dahil etmesine paralel olarak, politik düzlemde yükselen İslami unsurun, mekânı aynı zamanda farklı yönelimli kullanımlara göre yeniden tanımlamasını beraberinde getirmiştir, bu husus ise toplumsal mekâna ilişkin temsiller ve pratiklerin kayda değer çelişkilerine yol açmıştır.

Türkiye'de Cumhuriyetin kuruluşundan günümüze Ankara'nın mekânı ve onun üretiminin Lefebvre'in kuramı bağlamında ele alınması, Lefebvre'in mekân dönemselleştirmesi önermesinden yola çıkarak Ankara'da birbirine müteakip üç mekân evresinin - tarihsel mekân (1923-30 arası dönem), soyut mekân (1930-80 arası dönem) ile çelişkili mekân (1980 sonrası dönem) - var olduğu varsayımının doğrulanması böylece Türkiye'de mekân tartışmalarına bu çalışmanın temel katkısı olmuştur. Çalışma kapsamında Türkiye ile ilgili 'mekân üretimi' literatürünün sistematik tarama ile değerlendirmesinin sonuçlarına (bkz. 1.5 Bölüm ve EK 1) bakıldığında benzer kuramsal çerçeve benimseyen mevcut çalışmalar tarafından böyle bir yaklaşım benimsenmediği hesaba katıldığında 
çalışmanın bu yaklaşımı, önerme ve değerlendirmelerinin Türkiye'de mekân ve mekânın üretimi tartışmalarına yeni bir bakış açısı sağladığı söylenebilir.

Çalışmamızda belirlenen amaçlardan diğeri 2000 sonrası dönemde Ankara'da mekân üretimi süreçlerini detaylı olarak değerlendirerek bu dönemde Ankara'nın toplumsal mekânının algılanan, yaşanan ile tasarlanan boyutlarının dönüşümlerinin anlamlandırılması olmuştur. $\mathrm{Bu}$ bağlamda öne sürülen varsayıma göre ilgili dönemde Türkiye'de egemen neoliberal İslamcı üstyapısal paradigma ile ileri kapitalizmin esnek birikimi bağlamında Ankara örneğinde neoliberal bir kentsel rejimin inșasının tamamlandığı ve mekânda üretimden mekânın üretimine geçişin gerçekleştiği varsayımı incelemelerle doğrulanmıştır. İlgili dönemde neoliberal rejimin kayda değer bir mekân boyutu kazandiğ 1 ve toplumsal mekânın algılanan, yaşanan ile tasarlanan boyutlarında farklı biçimlerde dışa vurulduğu gösterilmiştir.

2000 sonrası dönemde mekânın üretimi süreçlerine dair çalışmamızın diğer temel varsayımı 2000 sonrası dönemde sık sık öne çıkan İslamcı ile Osmanl1-Selçuklu söyleminin gerek yapılı çevrenin üretimi gerekse mekân üzerine söylem bağlamında baskın bir nitelik kazanması ve mekânsallaşmasıdır. $\mathrm{Bu}$ varsayıma göre söz konusu söylem ve buna uygun politikalar aynı zamanda kentsel mekânın algilanan, yaşanan ile tasarlanan boyutlarında önemli değişimlere yol açarak toplumsal mekânda mekân temsili, temsil mekânı ile mekânsal pratikler arasında ve bu üç unsurun her biri içerisinde kayda değer çelişkilerin ortaya çıkmasına yol açmıştır. İlgili döneme dair çalışmadaki incelemeler söz konusu varsayımı büyük ölçüde doğrulamıştır. Bu bakımdan yapılan incelemelerden yola çıkarak 2000 sonrası dönemde Ankara'da mekânın üretimi süreçlerinin ve üretilmekte olan egemen mekânın şu temel eğilimler ve özelliklerinden söz edilebilir:

a) 2000 sonrası dönemde Ankara'da mekânın üretimi süreçlerinin bir önceki evreden beri süregelen neoliberal rejim çerçevesinde devam ettiği, fakat neoliberal rejimin mekânsal olarak ancak 2000 sonrası dönemde tamamlandığ görülmektedir. Başka bir deyişle neoliberal rejim mekânsallaşma ve mekânsal bağlam edinme bakımından ancak bu dönem içerisinde baskın bir nitelik kazanmıştır. Aynı zamanda, belirli mekân temsilleri doğrultusunda bu dönemde tamamen neoliberal bir kentsel rejimin tesisi tamamlanmıştır.

$\mathrm{Bu}$ dönemin mekânın üretimi süreçlerinin yapılı çevrenin üretimi ile yeniden üretimi boyutlarına bakıldığında iki kayda değer sürecin yaşandığı görülmektedir. Bunlar bir önceki dönemde de görülen fakat 2002'den sonra boyut ile kapsam açısından çok yoğun olarak gözlemlenen kentsel dönüşüm projeleri ve kentin fiziksel altyapısındaki değişimlerdir. Aynı zamanda yapılı çevrenin üretimi ile ilgili önemli bir gelişme mekânsal yeniden ölçeklenme teşkil eden anakentleşme sürecidir. Bu gelişmelerin gerek mekân üzerine söylem 
gerekse temsiller açısından önemli içerimleri olduğu saptanmıştır. Mevcut birikim rejiminin mekânsal sonuçlarının en temel özelliği genel olarak ileri kapitalizme ve özel olarak neoliberal rejime özgü bir mekân temsili doğrultusunda 'mekânda şeylerin üretiminden mekânın üretimine' geçiştir. Kurumsal düzlemdeki düzenlemeler, söylemsel pratikler ile somut uygulamalar aracılığıyla gerçekleşen bu geçişin ürünü olarak Türkiye'de Ankara örneğinde bütünsel bir neoliberal kentsel/mekânsal rejimin meydana geldiği, bu kentselliğin ise sadece nicel anlamda değil, nitel anlamda da gerçeklik kazandığ saptanmıştır. Nicel anlamda bu kentsellik mekânsal olarak bütünselliğe yönelen bir kentleşmeye yönelimliyken, nitel anlamda ise mekânın salt bir 'arsa' biçiminde gayrimenkulleşmesiyle beraber toplumsal yaşamın tamamen metalaşmış mekânsal döngüler çerçevesinde gerçekleşmesine yönelmesidir. Neoliberal rejimin mekân temsili doğrultusunda üretilmekte olan toplumsal mekân böyle bir bütünselliğe ve bütünleşmeye yönelirken aynı zamanda somut düzeyde mekânın ayrışıp parçalandığı, bu parçalanmanın hem mekânın gayrimenkulleşmesi biçiminde hem de üretim ile toplumsal ilişkilerin yeniden üretiminin sağlamasına yönelik mekânsal pratiklerin nispeten ayrışmış döngülerde gerçekleştiği saptanmıştır. Bu eğilim ise ileri kapitalizmin çelişkili mekânın bütün ile parça ve mekân temsili ile mekânsal pratikler arasındaki çelişkilerinin Ankara'daki somut bir ifadesi olarak tanımlanabilir. Böylece bir önceki dönemin neoliberal birikim rejiminin ürünü olarak ortaya çıkan çelişkili mekânın belirtilerinin 2000'den sonra daha belirgin biçimde öne çıktığ 1 görülmektedir.

b) Çalışmanın diğer saptaması ilgili dönemde tamamen gayrimenkulleşme ve metalaşmaya yönelen dolayısıyla değişim değeri odaklı mekân üretimi eğilimleri karşısında kullanım değeri odaklı mekân üretimi süreçlerinin geri planda olması hususudur. Kullanım değeri odaklı mekân üretimi süreçleri söz konusu olunca ise bunların incelenmesi bu örneklerin önemli politik kullanım değeri barındırdığını, bunlar aracılığıyla belirli muhafazakâr tahayyüller doğrultusunda toplumsal mekânın yeniden tanımlandığını göstermiştir. Ayrıca, bu süreçlerde muhafazakâr söylem ve pratikler bağlamında popülist söylemsel pratiklerin de yer aldığı ve popülist söylemin mekânsal bağlam kazandığ1 saptanmıştır. Kullanım değeri odaklı mekân üretimi örnekleri aracılığıyla ayrıca farkl1 toplumsal mekânsal pratiklerin (yeniden) üretildiği görülmektedir.

c) 2000 sonrası dönemde mekân üzerine egemen söylemin incelemesi ise mekânın farklı temsil ve karşı temsil üretimi süreçlerine yoğun biçimde maruz kaldığını göstermektedir. $\mathrm{Bu}$ açıdan, mevcut ilerleme ve gelişme anlayışı doğrultusunda 'modernin' tamamen yapılaşmış bir kentsel çevrenin eşanlamı olarak öne sürüldüğ̈̈, yapılaşmanın 'ilerleme' ve 'kalkınma'nın temsil mekânı olarak öne çıkarıldığı saptanmıştır. Böyle bir söylem ve onun ürünü olan pratikler ise aynı zamanda ileri kapitalizmin mekân temsilini de destekleyecek nitelikte 
olduğu ve tamamen gayrimenkulleştirilmiş, metalaşmış, imarlaşarak parsellenmiş mekân üretimi süreçlerine cevap verebilir nitelikte olduğu söylenebilir.

Fakat mekân üzerine söylem ile ilgili (temsil mekânı) bu dönemde saptanan diğer baskın eğilim, farklı bir tarih yazımı öne çıkartılarak çeşitli temsiller aracılığıyla mekânın yeniden tanımlanmasıdır (üretimidir). Bir taraftan ulusal kimliğin yeniden tanımlanması bağlamında farklı bir uzak tarih anlatısının (Selçuklu/Osmanlı dönemi) öne çıkarıldığı, diğer taraftan Cumhuriyet'in belirli tarihsel dönemleriyle kayda değer 'hesaplaşma' gerçekleştiği, bunun ise somut mekânlar üzerine söylem aracılığıyla gerçekleştirildiği görülmektedir. Böyle bir hesaplaşma aynı zamanda dönem boyunca ağır basan popülist söylemlerin de parçası olduğu için egemen popülist söylemin mekânsallaşması veya popülist söylemin temsil mekanları olarak tanımlanmıştır. Diğer taraftan, toplumsal mekânın ontolojik bakımdan yeniden tanımlanması girişimlerinden söz edilebilir. Ele alınan dönemin özellikle son yıllarında sık sık öne çıkan 'külliye' söylemi - ki ilk önce mekân üzerine bir söylem niteliğindedir - toplumsal mekânın farklı biçimlerini söylemsel olarak yeniden tanımlama, yani yeni temsil mekanları üretme çabası olarak tanımlanmıştır. Fakat söz konusu yeniden tanımlamanın söylemsel boyutla sinırlı olmadığı, önemli pratik boyutu da içerdiği ve farklı mekân temsilleri ve mekânsal pratikler üretme doğrultusunda olduğu saptanmıştır.

ç) Söylemsel pratikler yani temsil mekanları üretimi aracılığıyla mekânın yeniden tanımlanmasına aynı zamanda yapılı çevrenin yeniden üretiminin eşlik ettiği görülmektedir. Bu açıdan, Ankara'da kentsel mekânın farklı biçimlerinin dönüşüm süreçlerinde Selçuklu/Osmanlı olarak iddia edilen mimari çözümlerin sık sık öne çıkarıldığı, aynı zamanda kentin imgesini değiştirmesine yönelik sistematik çabaların söz konusu olduğu görülmektedir. Bu süreç bir taraftan kente ideolojik yüklü yeni bir imge kazandırma çabası olarak öne çıkarken diğer taraftan mekânın parça parça veya bütün olarak 'markalaşması' biçiminde mekânın oryantalistleşmesi biçiminde gerçekleşmiştir. Bu bağlamda tarihi yaşatmak amacıyla yola çıkarak üretilebilirlik ve yeniden üretilebilirlik çerçevesinde sadece tarihsel taklitler üreterek kentin yaşanan mekânının dağıldığı, onun yerine ideolojik yüklü projelerin, teknisyenlerin ve planlamacıların tasarlanan mekanlarının başat hale geldiği söylenebilir. Bu ise kentsel mekânın son 15 yıl içerisindeki en temel çelişkiyi ve üretilen çelişkili mekânın özünü oluşturmaktadır: bir bütün olarak kent mekanının yaşanan ile tasarlanan boyutları arasındaki çelişki. Mekânı daha üst ölçekte tahayyül ederek kenti bir turizm merkezine (zira merkezliğe kavuşmak daha üst ölçekli bir tahayyül gerektirmektedir) dönüştürmek amaciyla somut düzeyde mekâna müdahale eden çeşitli projeler, aslında kentlisi olmayan somut soyutluklar niteliğindedir ve toplumsal mekânda gündelik gerçekliğin ile kentsel gerçekliğin, 
toplumsal mekânın algılanan ile yaşanan boyutlarının çelişkilerine işaret etmektedir.

Böylece 2000 sonrası dönemde Ankara'da mekânın üretimi süreçlerinin ürünü olarak ortaya çıkan toplumsal mekânın incelemesi, söz konusu mekânın şu genel özelliklerden dolayı çelişkili nitelikte olduğuna işaret etmektedir:

1) Belirli bir mekân temsili - neoliberal ileri kapitalizmin mekânı üst ölçekte tahayyül etmesinin - doğrultusunda bütünselliğe yönelen fakat aynı zamanda parçalanmış ve parsellenmiş mekân, tamamen metalaşmış ve mübadele süreçlerinin egemen olduğu bütünsel fakat parçalanmış bir mekânsal rejim.

2) Mübadele süreçlerinin egemen olmasına rağmen kullanım değeri odaklı kayda değer mekân üretimi girişimlerinin söz konusu olduğu, fakat mevcut girişimlerin genellikle farklı ideolojik temsillerle yüklü olduğu, dolayısıyla kullanım değerinin münhasıran politik olduğu mekânlar ve bunun ürünü olarak farklı temsillerin çelişkileriyle dolu bir toplumsal mekân.

3) Kâh belirli bir tarih yazımının öne çıkarılması veya tarihi yaşatma kâh kent ile mekânın 'markalaşma' çabaları doğrultusunda üretilmekte olan mekânlar, birer mekân üretimi süreçleri olmakla beraber esasen mekânın tüketimine yönelik olan, kentin parça parça veya bir bütün olarak 'pazarlama' stratejilerinin ürünü olan ve asıl olarak birer öz-oryantalleşme örneği teşkil eden mekânlar. 

KAYNAKÇA 



\section{KAYNAKÇA}

ABB. "1071 Malazgirt Bulvarı'na Muhteşem Açılış”. Büyükşehir Ankara 10, S. 470 (2014): 3-11.

ABB. “2010 Faaliyet Raporu”. Ankara, 2011.

ABB. “2014 Faaliyet Raporu”. Ankara, 2015.

ABB. "2015 Faaliyet Raporu”. Ankara, 2016.

ABB. "Ankara'nın Yeni Amblemi Belli Oldu", 2011. 15 Ekim 2016 tarihinde https://www.ankara.bel.tr/haberler/ankarann-yeni-amblemi-belli-oldu/ adresinden erişildi.

ABB. "Ankara Ağaca, Çiçeğe ve Yeşile Bezenecek", 2013. 12 Mart 2017 tarihinde http://www.ankara.bel.tr/haberler/ankara-agaca-cicege-ve-yesile-bezenecek adresinden erişildi.

ABB. "Ankara Shopping Fest Gümbür Gümbür Geliyor”. Büyükşehir Ankara 8, S. 378 (2012): 1-11.

ABB. "Batı Koridoru Trafiğine Neşter". Büyükşehir Ankara 7, S. 336 (2011): 1-7.

ABB. "Büyükşehir'den 2014’te 214 Esere Coşkulu Açılış”. Büyükşehir Ankara 10, S. 464 (2014): 4-21.

ABB. "Büyükşehir'den Ramazan Etkinlikleri”, 2013. 12 Şubat 2017 tarihinde http://www.ankara.bel.tr/haberler/buyuksehirden-ramazan-etkinlikleri adresinden erişildi.

ABB. "Büyükşehir'in Mehterleri, Gönülleri Fethediyor", 2016. 12 Şubat 2017 tarihinde http://www.ankara.bel.tr/haberler/buyuksehir-mehterleri-gonulleri-fethediyor adresinden erişildi.

ABB. "Büyükşehr'in Son Amblemine Mahkemeden Onay", 2014. 15 Ekim 2016 tarihinde http://www.ankara.bel.tr/haberler/buyuksehir-son-amblemine-mahkemedenonay adresinden erişildi.

ABB. "Değişen Cadde ve Sokak İsimleri". 13 Şubat 2017 tarihinde https://www.ankara.bel.tr/genel-sekreter-yardimcisi-vedat-ucpinar/fen-isleridairesi-baskanligi/numarataj-sube-mudurlugu/degisen-cadde-ve-sokak-simleri adresinden erişildi.

ABB. "Dünya Çocuk Oyunları'na Muhteşem Final”. Büyükşehir Ankara 7, S. 323 (2011): 3-17.

ABB. "İşte Yeşil Ankara", 2014. 12 Mart 2017 tarihinde http://www.ankara.bel.tr/ haberler/iste-yesil-ankara adresinden erişildi.

ABB. "Kuşcağız Aile Yaşam Merkezi'ni Başbakan Açtı”. Büyükşehir Ankara 10, S. 489 (2014): 1-9.

ABB. “Metrolar Peş Peşe Hizmete Girdi”. Büyükşehir Ankara 10, S. 473 (2014): 3-9. 
Açar, Adem. "Küresel ve Yerel akışlar Kavşağında İstanbul'da Mekanın Yeniden üretimi: Gökdelenler Örneği”. Yayınlanmamış Doktora Tezi, Marmara Üniversitesi, Sosyal Bilimler Enstitüsü, İstanbul, 2013.

Ağlargöz, Ozan. "'We are at this campus, there is nothing in this campus ...": Socio-spatial analysis of a university campus". Tertiary Education and Management 23, S. 1 (2016): 69-83.

Akansel, Can. "Revealing the Values of a Republican Park: Gençlik Parkı Deciphered in Memory and As Monument". Unpublished Master's Thesis, Middle East Technical University, Graduate School of Natural and Applied Sciences, Ankara, 2009.

Akaslan, Pınar. "Etkinliğini Yitirmiş Kentsel Mekanların Kent Yaşamına Katılması". Yayınlanmamış Yüksek Lisans Tezi, İstanbul Üniversitesi, Fen Bilimleri Enstitüsü, İstanbul, 2006.

Akay, Aslı ve Fatma Kaldıran Akgün. "Türkiye'de Planlamada Dönüşüm Süreci: Çevre ve Koruma mı? Kentleşme ve Yapılaşma mı?”. Amme Idaresi Dergisi 47, S. 4 (2011): 93-115.

Akcan, Esra. Çeviride Modern Olan: Şehir ve Konutta Türk-Alman Illişkileri. 1. bs. İstanbul: YKY, 2009.

Akcan, Esra. "Global Conflict and Global Glitter: Architecture of West Asia (1960-2010)". E. G. Haddad ve D. Rifkind (Ed.), A Critical History of Conetemporary Architecture: 1960-2000 içinde (ss. 317-343). Ashgate, 2014.

Akçam, Taner ve Ümit Kurt. Kanunların Ruhu: Emval-i Metruke Kanunlarında Soykırımın İini Sürmek. 1. bs. İstanbul: İletişim, 2012.

Akçura, Tuğrul. Ankara: Türkiye Cumhuriyeti'nin Başkenti Hakkında Monografik Bir Araştırma. Ankara: ODTÜ Mimarlık Fakültesi, 1971.

Akgün, Berrin. "Mekansal İmge-Mekansal Pratik İlişki/lilişkisizliğinin Bursa'da 1950-1951 ve 1989 Bulgaristan Göçmenleri Üzerinde İncelenmesi”. Yayınlanmamış Doktora Tezi, Gazi Üniversitesi, Fen Bilimleri Enstitüsü, Ankara, 2001.

Akgün Gültekin, Asiye ve Alper Ünlü. "Analysis of The Environmental Effects of Gated Communities on the Neighborhood in the Context of Environmental Stress". Megaron 10, S. 3 (2015): 343-354.

AKP. AK Parti 2023 Siyasi Vizyonu: Siyaset, Toplum, Dünya, 2012. 20 Şubat 2017 tarihinde https://www.akparti.org.tr/site/akparti/2023-siyasi-vizyon adresinden erişildi.

Akpınar, Figen. "Social Stratification and Consumption Profiles of Ankara: A Case Study in Ankara Residential Areas". Unpublished PhD Thesis, Middle East Technical University, Graduate School of Natural and Applied Sciences, Ankara, 2005.

Akpınar, Figen. "Sociospatial Segregation and Consumption Profile of Ankara in the Context of Globalisation". METU Journal of the Faculty of Architecture 26, S. 1 (2009): 1-47.

Aksoy, Ebru Z. "Dikmen Vadisi: Sermayenin Kent Üzerinden Çevrimine Karşı Bir Başka Dayanışma Örneği”. Dosya 28: Büyük Projeler, Temmuz (2012): 85-94. 
Aksoy, Esma Selen. "Kent Ritmi ve Kamusal Alan İlişkilerinde Metro İstasyonları". Yayınlanmamış Yüksek Lisans Tezi, İstanbul Teknik Üniversitesi, Fen Bilimleri Enstitüsü, İstanbul, 2015.

Aktar, Ayhan. "Homogenising the Nation, Turkifying the Economy". R. Hirschon (Ed.), Crossing the Aegean: An Appraisal of the 1923 Compulsory Population Exchange Between Greece and Turkey içinde (ss. 79-95). Berghahn Books, 2004.

Aktar, Ayhan. "“Turkification” Policies in the Early Republican Era”. C. Dufft (Ed.), Turkish Literature and Cultural Memory: "Multiculturalism" as a Literary Theme after 1980 içinde (ss. 29-62). Wiesbaden: Harrassowitz Verlag, 2009.

Alkan, Ayten. "New Metropolitan Regime of Turkey: Authoritarian Urbanization via (Local) Governmental Restructuring". Lex localis - Journal of Local Self-Government 13, S. 3 (2015): 845-873.

Altay, Deniz. "Urban Spaces Re-defined in Daily Practices: The Case of "Minibar", Ankara". Unpublished Master's Thesis, Middle East Technical University, Graduate School of Natural and Applied Sciences, Ankara, 2004.

Ankara Kalkınma Ajansı. "İstatistiklerle Ankara 2015”. Ankara, 2015.

Ankara Metropolitan Municipality. Ankara City Guide. Ankara: Ankara Metropolitan Municipality, 2014.

As, Imdat. "The Digital Mosque”. Journal of Architectural Education 60, S. 1 (2006): 5466.

ASKI. "2014 Faaliyet Raporu”. Ankara, 2015.

ASKI. "2015 Faaliyet Raporu”. Ankara, 2015.

Aslan, Pınar Yurdadön. ““Aaahh Belinda” Filmini Lefebvre İle Okumak Nasıl Olurdu?”. Posseible, S. 6 (2014): 8-19.

Aslan, Pınar Yurdadön. "Söylem ve Deneyimde Kamusal Mekânın Dönüşümü: Bursa Kent Meydanı Örneği”. Yayınlanmamış Yüksek Lisans Tezi, İstanbul Üniversitesi, Sosyal Bilimler Enstitüsü, İstanbul, 2012.

Aslan, Şükrü. 1 Mayıs Mahallesi: 1980 Öncesi Toplumsal Mücadeleler ve Kent. 5. bs. İstanbul: İletişim, 2016.

Aslankan, Ali. "Mixed-use High-rise [Residential] Complexes: A New Urban Form(ation) in Istanbul". Unpublished PhD Thesis, Middle East Technical University, Graduate School of Natural and Applied Sciences, Ankara, 2014.

Atabey, Melek. "Representing a (Post-)Modern City: The Portrayal of Istanbul in Recent Turkish Films". H. Zapf ve Ş. Toplu (Ed.), Redefining Modernism and Postmodernism içinde (ss. 99-109). Newcastle upon Tyne: Cambridge Scholars Publishing, 2010.

Ataç, Ela. "A Divided Capital: Residential Segregation in Ankara". METU Journal of the Faculty of Architecture 33, S. 1 (2016): 187-205.

Atak, Eser. "Bir Başkanın Araba Sevdası ve Ankara Ulaşımında Kayıp Yıllar". Planlama 2005/4 (2005): 102-111. 
Atauz, Akın. "Kale ve Sur: Ankara Kalesi". Şehrin Zulası: Ankara Kalesi içinde (ss. 61220). İstanbul: İletişim, 2004.

Atay, Alican. "Büyükşehir'den 400 Bin Aileye Yaşam Desteği”. Büyükşehir Ankara 4, S. 192 (2008): 4-7.

Atay, Alican. “Gökçek, İçişleri Bakanı'na Gençlik Parkı'nı Anlattı”. Büyükşehir Ankara 4, S. 184 (2008): 6-7.

Ateş, Burcu. "A Spatial Impromptu: Green Resistance by Guerrilla Gardening". Unpublished Master's Thesis, Middle East Technical University, Graduate School of Natural and Applied Sciences, Ankara, 2015.

Atıcı, Melike. "The Construction of Public Realm in Contemporary Art: Reading on International Istanbul Biennial”. Unpublished Master's Thesis, Istanbul Technical University, Graduate School of Science Engineering and Technology, İstanbul, 2014.

Atılgan, Gökhan. "Tarımsal Kapitalizmin Sancağı Altında”. G. Atılgan, C. Saraçoğlu ve A. Uslu (Ed.), Osmanlı'dan Günümüze Türkiye'de Siyasal Hayat içinde (ss. 387514). İstanbul: Yordam Kitap, 2015.

Avci, Ozgur. "The Gecekondulu in Turkey: Representation, Identity, and the Urban Poor in the 1960s and 1970s". PhD Thesis, The University of Wisconsin- Milwaukee, ProQuest Dissertations \& Theses Global, 2011.

Avci, Özgür. "The Making of a Gecekondulu Identity: Journalistic Representations of the Squatters in Turkey in the 1970s". Journal of Urban History 40, S. 2 (2014): 211231.

AYD. "AYD-ICSC Turkey Shopping Center Fact Sheet", 2013. 17 Mart 2017 tarihinde http://www.ayd.org.tr:80/EN/DataBank.aspx adresinden erişildi.

Aydın, Suavi. "Ekolojik Tahribat ve Kültürel Çöküş: Bir Şehir Yaratma Projesinin İflası Olarak Ankara". F. Ş. Cantek (Ed.), Cumhuriyet'in Ütopyası: Ankara içinde (ss. 57-96). Ankara: Ankara Üniversitesi Yayınevi, 2012.

Aytekin, Attila. "Kapitalistleşme ve Merkezileşme Kavşağında". G. Atılgan, C. Saraçoğlu ve A. Uslu (Ed.), Osmanlı'dan Günümüze Türkiye'de Siyasal Hayat içinde (ss. 39-87). İstanbul: Yordam Kitap, 2015.

Babalık-Sutcliffe, Ela. "Kent Merkezi İlkeleri Çerçevesinde "Ankara Kent Merkezi: 1985 Kentsel Ulaşım Çalışması"ndan Bugüne". T. Şenyapılı (Ed.), "Cumhuriyet"in Ankara'sı içinde (2. bs., ss. 286-308). Ankara: ODTÜ Yayıncılık, 2006.

Babalık-Sutcliffe, Ela. "Sürdürülebilir Ulaşım Yaklaşımlarında Dünya, Türkiye ve Ankara Uygulamaları”. Dosya 11: Yerel Yönetimler, Ulaşım ve Su, Bülten 67 (2009): 3746.

Babalık-Sutcliffe, Ela. "Urban Form and Sustainable Transport: Lessons from the Ankara Case". International Journal of Sustainable Transportation, 7, October (2013): 416-430.

Balaban, Osman. "Capital Accumulation, The State and The Production Of Built Environment: The Case of Turkey". Unpublished PhD Thesis, Middle East Technical University, Graduate School of Natural and Applied Sciences, Ankara, 2008. 
Balcı, Fatma Şule. "Kamu Yararı Kavramı ve Ankara Büyükşehir Belediye Başkanlarının Uygulamaları: Mehmet Altınsoy, Murat Karayalçın ve İ. Melih Gökçek". Yayınlanmamış Yüksek Lisans Tezi, Ankara Üniversitesi, Sosyal Bilimler Enstitüsü, Ankara, 2006.

Basa, İnci. "From Praise to Condemnation: Ottoman Revivalism and the Production of Space in Early Republican Ankara". Journal of Urban History 41, S. 4 (2015): 711-738.

Basa, İnci. "Kentsel Hafızanın Sürdürülebilirliği: Bir Mimarlık Stüdyosu Deneyimi”. Sanat ve Tasarım, S. 15 (2015): 27-42.

Basa, İnci. "Producing Representational Spaces for the Republican Memory in Samsun, Turkey.". Turkish Historical Review 7, S. 1 (2016): 1-32.

Baş, Miray. "Reading Sulukule As a Social Production of Space: Ownership/Possession and Boundaries of the Dwelling". Unpublished Master's Thesis, Middle East Technical University, Graduate School of Natural and Applied Sciences, Ankara, 2008.

Baş, Yener. "Bir (Kentsel) Ütopya Olarak "Ankara” Romanı”. ODTÜ Mimarlık Fakültesi Dergisi 32, S. 2 (2015): 79-98.

Baş, Yener. "Production of Urban Form As the Reproduction of Property Relations Morphogenesis of Yenişehir - Ankara". Unpublished PhD Thesis, Middle East Technical University, Graduate School of Natural and Applied Sciences, Ankara, 2010.

Batuman, Bülent. "Architectural Mimicry and the Politics of Mosque Building: Negotiating Islam and Nation in Turkey". The Journal of Architecture 21, S. 3 (2016): $321-$ 347.

Batuman, Bülent. "City profile: Ankara”. Cities 31 (2013): 578-590.

Batuman, Bülent. “'Early Republican Ankara': Struggle over Historical Representation and the Politics of Urban Historiography". Journal of Urban History 37, S. 5 (2011): 661-679.

Batuman, Bülent. "“Everywhere Is Taksim”: The Politics of Public Space from NationBuilding to Neoliberal Islamism and Beyond". Journal of Urban History 41, S. 5 (2015): 881-907.

Batuman, Bülent. "Gazes in Dispute: Visual Representations of the Built Environment in Ankara Postcards". The Journal of Architecture 20, S. 1 (2015): 21-46.

Batuman, Bülent. “Gezi'nin Söz Hali: Mekan, Temsil, Dil”. Dosya 33: Kimlik ve Yer 2014/1 (2014): 46-51.

Batuman, Bülent. "Identity, Monumentality, Security: Building a Monument in Early Republican Ankara". Journal of Architectural Education 59, S. 1 (2005): 34-45.

Batuman, Bülent. "Imagination as Appropriation: Student Riots and the $(\mathrm{Re})$ Claiming of Public Space". Space and Culture 6, S. 3 (2003): 261-275.

Batuman, Bülent. "Mekân, Kimlik ve Sosyal Çatışma: Cumhuriyet'in Kamusal Mekânı Olarak Kızılay Meydanı”. G. Sargın (Ed.), Ankara’nın Kamusal Yüzleri: Başkent Üzerine Mekân-Politik Tezler içinde (ss. 41-76). İletişim, 2002. 
Batuman, Bülent. "Spaces of Counter-Hegemony: Turkish Architects and Planners as Political Agents in the 1970s". PhD Thesis, State University of New York, Graduate School of Binghamton University, ProQuest Dissertations \& Theses Global, 2006.

Batuman, Bülent. "The Image of Urban Politics: Turkish Urban Professionals and Urban Representation as a Site of Struggle". Journal of Architectural Education 62, S. 2 (2008): 54-65.

Baydar, Gülsüm, Murat Komesli, Ahenk Yılmaz ve Kıvanç Kılınç. “Digitizing Lefebvre's Spatial Triad". Digital Scholarship in the Humanities. 2016. doi:10.1093/llc/fqw061.

Bayhan, Bahar. “Kızılay Meydanı'nın Adının Değiştirilmesiyle İlgili Mimarlar Odası'ndan Açıklama". Arkiteria.com, 2016. 15 Şubat 2017 tarihinde http://www.arkitera.com/haber/27289/kizilay-meydaninin-adinin-degistirilmesikarariyle-ilgili-mimarlar-odasindan-aciklama adresinden erişildi.

Berber, Özlem. "Metropol Mimarlık ve Yerleşme Sorunu”. Yayınlanmamış Doktora Tezi, İstanbul Teknik Üniversitesi Fen Bilimleri Enstitüsü, İstanbul, 2010.

Bernardoni, Moira. "Graffiti: Spatial Misuse and Social Production of Urban Space". L. Borriello ve C. Ruggiero (Ed.), The Unexpected Impertinence of Urban Creativity içinde (ss. 29-44). ArtiGraficheBoccia, 2013.

Bernd, Nicolai. Modern ve Sürgün: Almanca Konuşulan Ülkelerin Mimarları Türkiye'de 1925-1955. (Y. P. Zander, Çev.). Ankara: Mimarlar Odası Yayınları, 2011.

Bingöl, Seyithan Melih. “Ankara'da Her Gün Yeni Bir Kavşak Hizmete Giriyor”. Büyükşehir Ankara 4, S. 196 (2008): 12-14.

Bingöl, Seyithan Melih. "Ankara'nın 5 Girişine 5 Kapı”. Büyükşehir Ankara 10, S. 465 (2014): 10-13.

Bingöl, Seyithan Melih. "Başkan Melih Gökçek Projeleri Denetledi”. Büyükşehir Ankara 4, S. 179 (2008): 4-7.

Bingöl, Seyithan Melih. "Başkent'e Yeni Yol Gösterici Lehvalar". Büyükşehir Ankara 8, S. 398 (2012): 18-20.

Bingöl, Seyithan Melih. "Başkent'in Yeni Can Damarları Açılış İçin Gün Sayıyor". Büyükşehir Ankara 9, S. 443 (2013): 1-9.

Bingöl, Seyithan Melih. "Başkent Trafiğinin Can Damarları Yeni Yapılan Geçit ve Kavşaklar". Büyükşehir Ankara 4, S. 194 (2008): 16-18.

Bingöl, Seyithan Melih. "Başkent Yollarında Güvenli ve Konforlu Sürüş Keyfi”. Büyükşehir Ankara 9, S. 417 (2013): 10-11.

Bingöl, Seyithan Melih. "Cumhuriyet Bayramı'nda 13 Alt-Üst Geçidin Açılışıyla Çifte Bayram Yaşanacak”. Büyükşehir Ankara 4, S. 201 (2008): 4-7.

Bingöl, Seyithan Melih. "Dünya Standartlarında Yön Lehvaları Başkent Yollarında". Büyükşehir Ankara 6, S. 271 (2010): 4-7.

Bingöl, Seyithan Melih. "Gençlik Parkı Kapılarını "Zafer"le Açıyor". Büyükşehir Ankara 5, S. 242 (2009): 10-13. 
Bingöl, Seyithan Melih. "Ramazan Etkinlikleri Gençlik Parkı'nda”. Büyükşehir Ankara 9, S. 436 (2013): 16-19.

Bingöl, Seyithan Melih ve Sercan Abay. “Ankara'nın En Büyük Bulvarını Kapattırdılar”. Büyükşehir Ankara, 11, S. 545 (2015): 1-15.

Bingöl, Seyithan Melih ve Nevruz Tol. "Ankara "Shopping Fest"e Sıkı Hazırlanıyor". Büyükşehir Ankara 8, S. 372 (2012): 1-7.

Birgun.net. "Eymir Gölü Risk Altında", 18 Temmuz 2014. 12 Mart 2017 tarihinde http://www.birgun.net/haber-detay/eymir-golu-risk-altinda-65633.html adresinden erişildi.

Birgun.net. “Kızılay Meydanı'na Dokunma, Parsel Parsel Satışı Açıkla”, 28 Temmuz 2016. 15 Şubat 2017 tarihinde http://www.birgun.net/haber-detay/kizilay-meydani-nadokunma-parsel-parsel-satisi-acikla-121955.html adresinden erişildi.

Boer, Roland. Marxist Criticism of the Hebrew Bible. 2. bs. Bloomsbury Publishing, 2015.

Bora, Tanıl ve Can, Kemal. Devlet, Ocak, Dergâh. 6. bs. İstanbul: İletişim, 2000.

Boran, Tunç. "Mekan ve Siyaset İlişkisi Bağlamında Anıtkabir (1938-1973)". Yayınlanmamış Doktora Tezi, Ankara Üniversitesi, Türk İnkılap Tarihi Enstitüsü, Ankara, 2011.

Bozdogan, Sibel ve Esra Akcan. Turkey: Modern Architectures in History. Reaktion Books, 2013.

Bozdogan, Sibel. "Journey to the East: Ways of Looking at the Orient and the Question of Representation". Journal of Architectural Education 41, S. 4 (1988): 38-45.

Bozdoğan, Sibel. Modernizm ve Ulusun Inşası: Erken Cumhuriyet Türkiyesi'nde Mimari Kültür. İstanbul: Metis Yayınları, 2002.

Brenner, Neil. "Beyond State-Centrism? Space, Territoriality, and Geographical Scale in Globalization Studies". Theory and Society 28, S. 1 (1999): 39-78.

Brenner, Neil. 'Decoding the Newest 'Metropolitan Regionalism' in the USA: A Critical Overview". Cities 19, S. 1 (2002): 3-21.

Brenner, Neil. "Global, Fragmented, Hierarchical: Henri Lefebvre's Geographies of Globalization". Public Culture 10, S. 1 (1997): 135-167.

Brenner, Neil. "Globalisation as Reterritorialisation: The Re-scaling of Urban Governance in the European Union". Urban Studies 36, S. 3 (1999): 431-451.

Brenner, Neil. "Metropolitan Institutional Reform and the Rescaling of State Space in Contemporary Western Europe". European Urban and Regional Studies 10, S. 4 (2003): 297-324.

Brenner, Neil. New State Spaces: Urban Governance and the Rescaling of Statehood. Oxford: OUP, 2004.

Brenner, Neil. "State Territorial Restructuring and the Production of Spatial Scale: Urban and Regional Planning in the Federal Republic of Germany, 1960-1990". Political Geography 16, S. 4 (1997): 273-306.

Brenner, Neil. "The Limits to Scale? Methodological Reflections on Scalar Structuration". Progress in Human Geography 25, S. 4 (2001): 591-614. 
Brenner, Neil. "The Urban Question as a Scale Question: Reflections on Henri Lefebvre, Urban Theory and the Politics of Scale". International Journal of Urban and Regional Research 23, S. 2 (2000): 371-378.

Brenner, Neil. "Urban Governance and the Production of New State Spaces in Western Europe, 1960-2000". Review of International Political Economy 11, S. 3 (2004): 447-488.

Brenner, Neil ve Stuart Elden. "Henri Lefebvre on State, Space, Territory". International Political Sociology 3, S. 4 (2009): 353-377.

Brenner, Neil ve Christian Schmid. "Towards a New Epistemology of the Urban?". City 19, S. 2-3 (2015): 151-182.

Buğra, Ayşe ve Osman Savaşkan. Türkiye'de Yeni Kapitalizm: Siyaset, Din ve İş Dünyası. (B. Doğan, Çev.). 3. bs. İstanbul: İletişim, 2015.

Burkett, Paul. Marx and Nature: A Red and Green Perspective. New York: St. Martin's Press, 1999.

Cansu, Burcu. "Gökçek'in Fidanları Para Açtı!". Muhalefet.org, 30 Mayıs 2013. 12 Mart 2017 tarihinde http://www.muhalefet.org/haber-gokcekin-fidanlari-para-acti-126398.aspx adresinden erişildi.

Cantek, Funda Şenol. "Yaban”lar ve Yerliler: Başkent Olma Sürecinde Ankara. 2. bs. İstanbul: İletişim, 2003.

Casier, Marlies. "Beyond Kurdistan? The Mesopotamia Social Forum and the Appropriation and Re-Imagination of Mesopotamia by the Kurdish Movement.". Journal of Balkan \& Near Eastern Studies 13, S. 4 (2011): 417-432.

Cassirer, Ernst. An Essay on Man: An Introduction to a Philosophy of Human Culture. Yale University Press, 1944.

Castagno, Cory Alexander. (2015). "Lightning in the Night: Transgression in Urban Design". Master's Thesis, University of Washington. ProQuest Dissertations \& Theses Global, 2015.

Castells, Manuel. City, Class and Power. (E. Lebas, Çev.). New York: St. Martin's Press, 1978.

Castells, Manuel. The Urban Question: A Marxist Approach. (A. Sheridan, Çev.). 2. bs. Edward Arnold, 1976.

Cengizkan, Ali. "1957 Yücel-Uybadin İmar Planı ve Ankara Şehir Mimarisi”. T. Şenyapılı (Ed.), "Cumhuriyet"in Ankara'sı içinde (2. bs., ss. 24-59). Ankara: ODTü Yayıncılık, 2006.

Cengizkan, Ali. "Kurgu, Tasarım ve Kullanım: Cumhuriyet Dönemi Kamusal Mekânları İçin Bir Çalışma Programı”. G. A. Sargın (Ed.), Ankara’nın Kamusal Yüzleri: Başkent Üzerine Mekân-Politik Tezler içinde (ss. 215-243). İstanbul: İletişim Yayınları, 2002.

Cengizkan, Ali. "The Production of a Mise En Scène for a Nation and Its Subjects: Clemens Holzmeister et al. in the Ministries Quarter for Ankara, Turkey". The Journal of Architecture 15, S. 6 (2010): 731-770. 
Ceylan, Hande. "The Impacts of Post-disaster Spatial Structure on Low Income Women: the Case of Düzce". Unpublished Master's Thesis, Middle East Technical University, Graduate School of Social Sciences, Ankara, 2015.

Chomsky, Noam. Aspects of the Theory of Syntax. Cambridge, Mass.: MIT Press, 1965.

Cil, Ela. "Exploring the Construction of the Identities of Kula, a Place in Aegean Anatolia". PhD Thesis, The University of Michigan. ProQuest Dissertations \& Theses Global, 2005.

Cinar, Alev. "Bodies, Places and Time: Islamic Visibilities in the Public Sphere and the Contestations of Secular Modernity in Turkey". PhD Thesis. University of Pennsylvania. ProQuest Dissertations \& Theses Global, 1998.

Cnnturk.com. "Tandoğan Meydanı'nın İsmi ‘Anadolu Meydanı' Olarak Değiştirildi”, 13 Nisan 2015. 14 Şubat 2017 tarihinde http://www.cnnturk.com/haber/ turkiye/tandogan-meydani-nin-ismi-anadolu-meydani-olarak-degistirildi/ adresinden erişildi.

Cox, Kevin R. "Globalisation, Competition and the Politics of Local Economic Development". Urban Studies 32, S. 2 (1995): 213-225.

Cörüt, İlker. "An Ethnographic Account of Compulsory Public Service by Doctors in Hakkari: The Limits of the AKP Assimilation Strategy and the Production of Space.". Z. Gambetti ve J. Jongerden (Ed.), The Kurdish Issue in Turkey: A Spatial Perspective içinde (ss. 105-135). Routledge, 2015.

Crampton, Jeremy ve Elden, Stuart (Ed.). Space, Knowledge and Power: Foucault and Geography. Ashgate Publishing, 2007.

Cumhuriyet.com.tr. "Cami, Fakülte Kadar Önemli!”, 1 Ağustos 2012. 16 Şubat 2017 tarihinde http://www.cumhuriyet.com.tr/haber/diger/361190/_Cami_fakulte_ka dar_onemli_.html adresinden erişildi.

Çalişkan, Olgu. "Forming a Capital: Changing Perspectives on the Planning of Ankara (1924-2007) and Lessons for a New Master-Planning Approach to Developing Cities". Footprint, S. 5 (2009): 23-54.

Çapa, Ezgi. "Boşaltılacak Askeri Araziler Konut Projelerine Mi Açılıyor?”. Cnnturk.com, 11 Ağustos 2016. 1 Mart 2017 tarihinde http://www.cnnturk.com/turkiye/ bosaltilacak-askeri-araziler-konut-projelerine-mi-aciliyor adresinden erişildi.

Çavuşoğlu, Erbatur. Türkiye Kentleşmesinin Toplumsal Arkeolojisi. İstanbul: Ayrıntı, 2014.

Çelik, Özlem. "The Pattern and Process of Urban Social Exclusion in İstanbul". Unpublished Master's Thesis, Middle East Technical University, Graduate School of Social Sciences, Ankara, 2008.

Çetinoğlu, Sait. "Ermeni Emval-i Metrukeleri Üzerine". Birikim, 8 Haziran 2009. 2 Kasım 2016 tarihinde http://www.birikimdergisi.com/guncel-yazilar/746/ermeni-emval-imetrukeleri-uzerine adresinden erişildi.

Çınar, Alev. Modernity, Islam, and Secularism in Turkey: Bodies, Places, and Time. Minneapolis: University of Minnesota Press, 2005.

Çınar, Alev. "The Imagined Community as Urban Reality: The Making of Ankara". A. Çınar ve T. Bender (Ed.), Urban Imaginaries Locating the Modern City içinde (ss. 151181). Minneapolis: University of Minnesota Press, 2007. 
Çınar, Tayfun. Dünyada ve Türkiye'de Başkentlik Sorunu. Ankara: Mülkiyeliler Birliği Vakfı Yayınları, 2004.

Çınar, Tayfun. "Yerel Yönetimlerde Neoliberal Reform: Büyükşehir Belediyelerinin Yeniden Ölçeklendirilmesi”. Toplum ve Hekim 24, S. 4-5 (2009): 280-288.

Çınar, Tayfun, Can Umut Çiner ve Ozan Zengin. Büyükşehir Yönetimi Bütünleştirme Süreci. 1. bs. Ankara: TODAlE, 2009.

Çınar, Tayfun, Bülent Duru, Can Umut Çiner ve Ozan Zengin. Belediyenin Sınırları. 1. bs. Ankara: TODAIE, 2013.

Çınar, Zelal. "Beyond Possibilities: Re-Reading Republican Ankara". International Journal of Social, Behavioral, Educational, Economic, Business and Industrial Engineering 8, S. 4 (2014): 1137-1142.

Çıngır, Alp Aykut. "Gençlik Parkı Baharla Birlikte Yaşama Dönüyor”. Büyükşehir Ankara 5, S. 215 (2009): 6-11.

Çoban, Aykut Namık. "Cumhuriyetin İlanından Günümüze Konut Politikası". Ankara Üniversitesi SBF Dergisi 67, S. 3 (2012): 75-108.

Çolak, Filiz. "Atatürk Dönemi'nde Türkiye Cumhuriyeti'nin Ulaşım Politikasına Genel Bir Bakış". Turkish Studies 8, S. 2 (2013): 345-364.

Çolak, Nihat. "Kent Belleği Mekânlar: Ankara Pasajları". Yayınlanmamış Yüksek Lisans Tezi, Başkent Üniversitesi, Sosyal Bilimler Enstitüsü, Ankara, 2014.

Çolpa, Zeynep Murat. "Convivial Urban Spaces: The Case of Sakarya Street, Ankara”. Unpublished Master's Thesis, Middle East Technical University, Graduate School of Natural and Applied Sciences, Ankara, 2015.

Daşkıran, Filiz ve Duygu Ak. "6306 Sayılı Kanun Kapsamında Kentsel Dönüşüm”. Journal of Management and Economics Research 13, S. 3 (2015): 264-264.

Demir, Erol. "Toplumsal Değişme Süreci İçinde Gençlik Parkı: Sosyolojik Bir Değerlendirme”. Planlama 2006/4 (2006): 69-77.

Demirel, Sinem. "'Production of Space' in The Post Earthquake Region: Three Cases From Düzce". Unpublished Master's Thesis, Middle East Technical University, Graduate School of Natural and Applied Sciences, Ankara, 2005.

Demirkol, Gökhan. "Gündelik Hayat ve Basın: Gırgır Mizah Dergisinde Gündelik Hayatın Dönüşümü, 1972 - 1989”. Yayınlanmamış Doktora Tezi, Gazi Üniversitesi, Sosyal Bilimler Enstitüsü, Ankara, 2015.

Demirtaş-Milz, Neslihan ve Cenk Saraçoğlu. "Space, Capitalism and Kurdish Migrants in İmir: An Analysis of Kadifekale's Transformation”. Z. Gambetti ve J. Jongerden (Ed.), The Kurdish Issue in Turkey: A Spatial Perspective içinde (ss. 185-212). Routledge, 2015.

Demirtaş, Fatma Aslıhan. "Artificial Nature: Water Infrastructure and Its Experience as Natural Space". Unpublished Master's Thesis, Massachusetts Institute of Technology, Department of Architecture, Cambridge, Massachusetts, 2000.

Demirtaş, Neslihan. "Critical Moments of Social Spatialization in The Neighborhood: An Alternative Reading of The Mainstream Gecekondu History". Unpublished PhD Thesis, Bilkent University, The Institute of Economics and Social Sciences, Ankara, 2007. 
Dik, Esra. "6360 Sayılı Kanun Bağlamında Köylerin Mahalleye Çevrilmesi Sorunu”. Mülkiye Dergisi 38, S. 1 (2014): 75-102.

Diken.com.tr. “AKP'ye 'Barış' Fazla Geldi: Gar Meydanı'nın Adı 'Demokrasi Meydanı' Olarak Değiştirildi”, 15 Ekim 2015. 15 Şubat 2017 tarihinde http://www.diken.com.tr/akpye-baris-fazla-geldi-gar-meydaninin-adi-demokrasimeydani-olarak-degistirildi/ adresinden erişildi.

Dikle, Nebi. "Alo 188'den, 1 Yılda 20 Bin Ambulans Hizmeti”. Büyükşehir Ankara 12, S. 563 (2015): 18-19.

Dikle, Nebi. "ALO 188 Ambulans Hizmeti Bir Yılda 29 Bin 580 Kişiye Ulaştı". Büyükşehir Ankara 8, S. 369 (2012): 10-11.

Dikle, Nebi. “'ALO 188'den 2012'de 72 Bin 661 Kişiye Hizmet”. Büyükşehir Ankara 9, S. 411 (2013): 12-13.

Dikle, Nebi ve A. Tarık Hatipoğlu. "Dokuzuncu Gençlik Merkezi Gençlik Parkı’nda Açıldı”. Büyükşehir Ankara 5, S. 207 (2008): 3-4.

Dobb, Maurice. Studies in the Development of Capitalism. New York: International Publishers, 1946.

Dobb, Maurice, Paul Sweezy, Lefebvre Geogres, Giuliano Procacci, John Merrington, Christopher Hill, Eric Howsbawm ve Kohachiro Takahashi. The Transition from Feudalism to Capitalism. Verso, 1985.

Doğan, Ali Ekber. Eğreti Kamusallık: Kayseri Örneğinde İslamcı Belediyecilik. İstanbul: İletişim, 2007.

Doğan, Ali Ekber. "Gökçek'in Ankara'yı Neo-liberal Rövanşçılıkla Yeniden Kuruşu”. Planlama 2005/4 (2005): 130-138.

Doğan, Ali Ekber. "İslamcı Belediyelerin on Yılı (1994-2004): Kayseri Örneğinde SosyoMekansal Bir Çözümleme”. Yayınlanmamış Doktora Tezi, Ankara Üniversitesi, Sosyal Bilimler Enstitüsü, 2005.

Doğan, Ali Ekber ve Bediz Yılmaz. "Ethnicity, Social Tensions and Production of Space in Forced Migration Neighbourhoods of Mersin: Comparing the Case of the Demirtaş Neighbourhood with Newly Established Ones". Journal of Balkan and Near Eastern Studies 13, S. 4 (2011): 475-494.

Doğan, Rıfat. “'Mimari Vandalizm': Marmara Köşkü’nden Sonra Çubuk Baraj Gazinosu Da Yıkıldı". Diken.com.tr, 7 Haziran 2016. 23 Nisan 2017 tarihinde http://www.diken.com.tr/mimari-vandalizm-marmara-koskunden-sonra-cubukbaraji-gazinosu-da-yikildi/ adresinden erişildi.

Doğanay, Ülkü. "AKP'nin Demokrasi Söylemi ve Muhafazakârlık: Muhafazakâr Demokrasiye Eleştirel Bir Bakış". Ankara Üniversitesi SBF Dergisi 62, S.1 (2007): 65-88.

Doğanay, Ülkü. "Türkiye'de Siyasal İslam ve Kentsel Mekânlar: Fazilet (Refah) Partili Büyükşehir Belediyesi'nin Ankara'daki Uygulamaları". Çağdaş Yerel Yönetimler Dergisi 9, S. 1 (1999): 3-19.

Duru, Bülent. "Büyükşehir Tasarısı ve Kent Hakkı”. Bianet.org, 18 Ekim 2012. 4 Mart 2017 tarihinde http://bianet.org/bianet/kent/141531-buyuksehir-tasarisi-ve-kent-hakki adresinden erişildi. 
Duru, Bülent ve Menaf Turan. "Korumanın Yasal ve Yönetsel Boyutları: Bereketli Topraklardan Beton Bloklara”. Koruma ve Peyzaj Mimarlığı Sempozyumu. 12-13 Mayıs, Ankara: Peyzaj Mimarları Odası, 2011.

EBRD. "EBRD Project Summary Documents". 1 Mart 2017 tarihinde http://www.ebrd.com/work-with-us/project-finance/project-summarydocuments.html?1=1\&filterCountry=Turkey adresinden erişildi.

EIB. "Isbank Urban Transformation", 2014. 1 Mart 2017 tarihinde http://www.eib.org/ projects/pipelines/pipeline/20120620 adresinden erişildi.

El-Kazaz, Sarah. "Building Politics: Urban Transformation and Governance in Cairo and Istanbul". PhD Thesis. Princeton University. ProQuest Dissertations \& Theses Global, 2014.

Emekli, Gözde. "İkinci Konut Kavramı Açısından Turizm Coğrafyasının Önemi ve Türkiye'de İkinci Konutların Gelişimi”. Ege Coğrafya Dergisi 23, S. 1 (2014): 2542.

Eranı, Demirli Meltem, Ultav Zeynep Tuna ve Neslihan Demirtaş-Milz. "A Socio-spatial Analysis of Urban Transformation at a Neighborhood Scale: The Case of the Relocation of Kadifekale Inhabitants to TOKI Uzundere in İzmir". Cities 48 (2015): 140-159.

Eraydın, Ayda ve Bilge Armatı-Köroğlu. “Ankara'nın Yeni Gündemi: Ulus Devletin Başkentliğinden Küresel Ekonominin Düğüm Noktası olmaya Uzanan Yapısal Dönüşüm Çabaları". T. Şenyapılı (Ed.), “Cumhuriyet"in Ankara'sı içinde (2. bs., ss. 266-284). Ankara: ODTÜ Yayıncılık, 2006.

Ercan, Neslihan. "Türkiye Sinemasında Müphemleşen Mekân: A Ay ve Karanlık Sular". Yayınlanmamış Yüksek Lisans Tezi, Ankara Üniversitesi, Sosyal Bilimler Enstitüsü, Ankara, 2011.

Ercoşkun, Özge Yalçıner. "Ankara'daki Büyük Konut Projeleri ve Sürdürebilirlik". 2nd International Sustainable Buildings Symposium. 28-30 Mayıs, Ankara, 2015.

Erdi-Lelandais, Gülçin. "Citizenship, Minorities and the Struggle for a Right to the City". Citizenship Studies 17, S. 6-7 (2013): 817-836.

Erdi-Lelandais, Gülçin. "Right to the City as an Urban Utopia? Practices of Every Day Resistance in a Romani Neighbourhood in Istanbul". G. Erdi-Lelandais (Ed.), Understanding the City: Henri Lefebvre and Urban Studies içinde (ss. 69-89). Cambridge Scholars Publishing, 2014.

Erdi-Lelandais, Gülçin. "Space and Identity in Resistance against Neoliberal Urban Planning in Turkey". International Journal of Urban and Regional Research 38, S. 5 (2014): 1785-1806.

Erdoğan, Recep Tayyip. “'Büyük İstanbul Tarihi' Adlı Eserin Tanıtım Programında Yaptıkları Konuşma", 18 Haziran 2016. 24 Şubat 2017 tarihinde http://tccb.gov.tr/konusmalar/353/45462/buyuk-istanbul-tarihi-adli-eserintanitim-programinda-yaptiklari-konusma.html adresinden erişildi.

Erdoğan, Recep Tayyip. "Cumhuriyetin Sahibi Milletimizin Kendisidir, Sembolü de Cumhurbaşkanlığı Külliyesidir”, 28 Ekim 2015. 17 Şubat 2017 tarihinde http://www.tccb.gov.tr/haberler/410/35788/cumhuriyetin-sahibi-milletimizinkendisidir-sembolu-de-cumhurbaskanligi-kulliyesidir.html adresinden erişildi. 
Erdoğan, Recep Tayyip. "Yeni Türkiye Mücadelemiz, Bizim Kızıl Elmamızdır", 10 Nisan 2015. 15 Temmuz 2015 tarihinde http://www.tccb.gov.tr/haberler/410/30102/ yeni-turkiye-mucadelemiz-bizim-kizil-elmamizdir.html adresinden erişildi.

Erdoğan, Recep Tayyip. “Yıldııım Beyazıt Üniversitesi'nde Yaptıkları Konuşma”, 8 Ocak 2015. 31 Temmuz 2015 tarihinde https://www.tccb.gov.tr/konusmalar/ 353/2971/yildirim-beyazit-universitesinde-yaptiklari-konusma.html adresinden erişildi.

Ergin, Nezihe Başak. "An Analysis of Urban Struggles in the Process of Practices of Urban Commoning: Resistance on 'Uncommon Ground' 'in, for and beyond' İstanbul". Unpublished PhD Thesis, Middle East Technical University, Graduate School of Social Sciences, Ankara, 2014.

Ergin, Nezihe Başak. "Grassroots Resistance Against Urban Renewal: The Case of Güzeltepe, İstanbul”. Unpublished Master's Thesis, Middle East Technical University, Graduate School of Social Sciences, Ankara, 2006.

Erim, Aydan. “Güvenpark Güncesi”. Planlama 1988/1 (1988): 10-12.

Erkip, Feyzan. "The Rise of the Shopping Mall in Turkey: The Use and Appeal of a Mall in Ankara". Cities 22, S. 2 (2005): 89-108.

Erkip, Feyzan. "The Shopping Mall as an Emergent Public Space in Turkey". Environment and Planning A 35, S. 6 (2003): 1073-1093.

Erkılıç, Hakan ve Ulaş Bayraktar. "Resimli ve Temsili Bir Triyalektik Mekân Okuması Olarak Ekümenopolis”. Illeti-ş-im, S. 23 (2015): 113-134.

Erman, Tahire. "Kentin Kıyısında Kadın Olmak Gecekondudan TOKİ Kentsel Dönüşüm Sitesine Geçişte Kadın Deneyimleri”. F. Ş. Cantek (Ed.), Kenarın Kitabı içinde (ss. 89-119). İstanbul: İletişim, 2014.

Erman, Tahire. “Mış Gibi Site”: Ankara'da Bir TOKI-Gecekondu Dönüşüm Sitesi. İstanbul: İletişim, 2016.

Erman, Tahire. "The Politics of Squatter (Gecekondu) Studies in Turkey: The Changing Representations of Rural Migrants in the Academic Discourse". Urban Studies 38, S. 7 (2001): 983-1002.

Erman, Tahire. "Understanding The Experiences Of The Politics Of Urbanization In Two Gecekondu (Squatter) Neighborhoods Under Two Urban Regimes: Ethnography In The Urban Periphery Of Ankara, Turkey". Urban Anthropology and Studies of Cultural Systems and World Economic Development 40, S. 1/2 (2011): 67-108.

Erol, Duygu. "Kamusal Alanda Muhalif Beden”. Yayınlanmamış Yüksek Lisans Tezi, İstanbul Teknik Üniversitesi, Fen Bilimleri Enstitüsü, İstanbul, 2015.

Erol, Ertan. "Re-Territorialisation and the Sites of Autogestion within the Periphery: Counter-Hegemonic Socio-Spatial Movements in Turkey". METU Studies in Development 41, S. 3 (2014): 465-481.

Eryılmaz, Çağrı. "The Spatial Analysis of Gezi Movement in Turkey”. Public Spaces: Times of Crisis and Change, 15 (2016): 191-219.

Evrensel.net. "Eymir Gölü Adım Adım Ranta Açılıyor", 16 Aralık 2014. 12 Mart 2017 tarihinde https://www.evrensel.net/haber/99952/eymir-golu-adim-adim-rantaaciliyor adresinden erişildi. 
Evrensel.net. “Işık: Askeri Arazileri Kentsel Dönüşüm Için Veririz", 18 Ocak 2017. 1 Mart 2017 tarihinde https://www.evrensel.net/haber/304466/isik-askeri-arazilerikentsel-donusum-icin-veririz adresinden erişildi.

Evrensel.net. "ODTÜ Arazisi Imara Açılıyor”, 17 Temmuz 2014. 12 Mart 2017 tarihinde https://www.evrensel.net/haber/88466/odtu-arazisi-imara-aciliyor adresinden erişildi.

Evrensel.net. "Yurtlarda Haremlik Selamlık", 27 Temmuz 2013. 7 Şubat 2017 tarihinde https://www.evrensel.net/haber/63225/yurtlarda-haremlik-selamlik adresinden erişildi.

Fişek, Kurthan. Burası Ankara. 2. bs. Ankara: Phoenix Yayınevi, 2012.

Fırat, Begüm Özden. “'Ve madem ki sokaklar kimsenin değil'”: Talan, dolandırıcılık ve hırsızlığa karşı kentsel müşterekler yaratmak". Eğitim Bilim Toplum Dergisi 9, S. 36 (2011): 96-116.

Foucault, Michel. Archaeology of Knowledge. (A. M. Sheridan Smith, Çev.). Routledge, 1995.

Foucault, Michel. Discipline and Punish: The Birth of the Prison. (A. Sheridan, Çev.). 2. bs. New York: Vintage Books, 1995.

Foucault, Michel. "Of Other Spaces: Utopias and Heterotopias". N. Leach (Ed.), Rethinking Architecture: A Reader in Cultural Theory içinde (ss. 330-336). New York: Routledge, 1997.

Foucault, Michel. "Questions on Geography". C. Gordon (Ed.), Power/Knowledge: Selected Interviews and Other Writings 1972-1977 içinde (ss. 63-77). New York: Pantheon, 1980.

Foucault, Michel. Security, Territory, Population: Lectures at the College de France 19771978. (G. Burchell, Çev.). 1. bs. Picador, 2007.

Friedman, Thomas L. The World Is Flat: A Brief History of the Twenty-First Century. New York: Farrar, Straus and Giroux, 2005.

Gegelioğlu, Aslaner Fatmagül ve Semra Aydınlı. "Mimarlık Üretimi Üzerine Bir İç Hesaplaşma: Tüketim Dinamiklerinin Uzantısında Mimari Bir Duruş". Tasarım+Kuram 10, S. 17 (2014): 54-72.

Genç, Fatma Neval. "Türkiye'de Kentsel Dönüşüm: Mevzuat ve Uygulamaların Genel Görünümü”. Yönetim ve Ekonomi 15, S. 1 (2008): 115-130.

Genç, Fırat. "Politics in Concrete: Social Production of Space in Diyarbakir, 1999-2014". Unpublished PhD Thesis, Boğaziçi University, Atatürk Institute for Modern Turkish History, İstanbul, 2014.

Geray, Cevat. "Şehirciliğimiz ve Ankara". Mulkiye Dergisi XXXII, S. 261 (2008): 9-26.

Gilbert, Jeremy. "What Kind Of Thing Is "Neoliberalism"?". New Formations, S. 80/81 (2013): 7-22.

Glyptis, Leda. "Living up to the Father: The National Identity Prescriptions of Remembering Atatürk; His Homes, His Grave, His Temple". National Identities 10, S. 4 (2008): 353-372. 
Gottdiener, Mark. "Disneyland: A Utopian Urban Space”. Urban Life 11, S. 2 (1982): 139_ 162.

Gottdiener, Mark. "Lefebvre and the Bias of Academic Urbanism: What Can We Learn from the 'new' Urban Analysis?". City 4, S. 1 (2000): 93-100.

Gottdiener, Mark. "Socio-Semiotics and the New Mega Spaces of Tourism: Some Comments on Las Vegas and Dubai". Semiotica 183, S. 1/4 (2011): 121-128.

Gottdiener, Mark. "Space as a Force of Production: Contribution to the Debate on Realism, Capitalism and Space". International Journal of Urban and Regional Research 11, S. 3 (1987): 405-416.

Gottdiener, Mark. "The Consumption of Spaces and the Spaces of Consumption". M. Gottdiener (Ed.), New Forms of Consumption: Consumer, Culture and Commodification içinde (ss. 265-286). Lanham, MD: Rowman and Littlefield, 2001.

Gottdiener, Mark. The Social Production of Urban Space. 2. bs. Austin: University of Texas Press, 1994.

Gottdiener, Mark. The Theming of America: American Dreams, Media Fantasies, and Themed Environments. 2. bs. Westview Press, 2001.

Graham, Stephen. Cities Under Siege: The New Military Urbanism. London: Verso, 2010.

Grönlund, Bo. Lefebvre's Ontological Transformation(s) of Space. Stockholm: Nordplan, 1993.

Gulhan, Sinan Tankut. "The Honorable Exception: State and the Social Production of Concrete Space in Istanbul". PhD Thesis, State University of New York, the Graduate School of Binghamton University. ProQuest Dissertations \& Theses Global, 2014.

Gurel, Meltem Havva. "Domestic space, modernity, and identity: The apartment in mid20th century Turkey". PhD Thesis, University of Illinois at Urbana-Champaign, Graduate Collage. ProQuest Dissertations \& Theses Global, 2007.

Gülkök, Işıl. "Production of Sidewalks; the Case of Ataturk Bouleward". Unpublished Master's Thesis, Middle East Technical University, Graduate School of Natural and Applied Sciences, Ankara, 2013.

Gülpınar, Turgay. "Anıtkabir'in Unutulan Kabirleri”. P. M. Y. Parmaksız (Ed.), Neye yarar Hatıralar? Bellek ve Siyaset Çalışmaları içinde (ss. 81-150). Ankara: Phoenix Yayınevi, 2012.

Günay, Baykan. "Ankara Çekirdek Alanının Oluşumu ve 1990 Nazım Planı Hakkında Bir Değerlendirme". T. Şenyapılı (Ed.), "Cumhuriyet"in Ankara'sı içinde (2. bs., ss. 60-118). Ankara: ODTÜ Yayıncılık, 2006.

Gündoğan, Azat Zana. "Space, State-making and Contentious Kurdish Politics in the East of Turkey: the Case of Eastern Meetings, 1967". Journal of Balkan \& Near Eastern Studies 13, S. 4 (2011): 389-416.

Gür, Berin F. "Spatialisation of Power/Knowledge/Discourse Transformation of Urban Space Through Discursive Representations in Sultanahmet, Istanbul". Space and Culture 5, S. 3 (2002): 237-252. 
Gür, Faik. "Sculpting Turkish Nationalism: Atatürk Monuments in Early Republican Turkey". PhD Thesis. The University of Texas at Austin, Graduate School. ProQuest Dissertations \& Theses Global, 2006.

Gürün, Banu Aksel. "Impact of Shopping Centers on the Fragmentation of the City Center". Unpublished PhD Thesis, Middle East Technical University, Graduate School of Natural and Applied Sciences, Ankara, 2009.

Haber.sol.org.tr. "TMMOB Mimarlar Odası: İller Bankası Yıkılamaz, Tahrip Edenler Yargılanacak", 9 Kasım 2016. 11 Şubat 2017 tarihinde http://haber.sol.org.tr/toplum/tmmob-mimarlar-odasi-iller-bankasi-yikilamaztahrip-edenler-yargilanacak-175133 adresinden erişildi.

Harvey, David. Explanation in Geography. New York: St Martin's Press, 1969.

Harvey, David. Justice, Nature and the Geography of Difference. Wiley, 1997.

Harvey, David. Postmodernliğin Durumu: Kültürel Değişimin Kökenleri. (S. Savran, Çev.). 5. bs. İstanbul: Metis Yayınları, 2010.

Harvey, David. Rebel Cities: From the Right to the City to the Urban Revolution. 1. bs. Verso, 2012.

Harvey, David. Social Justice and the City (Revised Ed.). Athens, Georgia: The University of Georgia Press, 2009.

Harvey, David. The Condition of Postmodernity: An Enquiry into the Origins of Cultural Change. Oxford: Blackwell, 1989.

Harvey, David. The Limits to Capital. (Blackwell, Ed.). Oxford, 1982.

Harvey, David. "Space as a Keyword". D. Gregory ve N. Castree (Ed.), David Harvey: A Critical Reader içinde (ss. 270-293). Oxford: Blackwell, 2006.

Hatipoğlu, A. Tarık. "209 Çifte Büyük Düğün Için Kayıtlar Başladı”. Büyükşehir Ankara 5, S. 229 (2009): 18-19.

Hatipoğlu, A. Tarık. "Büyükşehir'den 5 Bin Çorba-Ekmekli Kahvaltı". Büyükşehir Ankara 5, S. 208 (2008): 12-13.

Hatipoğlu, A. Tarık. "Büyükşehir'den Dar Gelirlilere Giyisi Yardımı”. Büyükşehir Ankara 5, S. 245 (2009): 12-13.

Hatipoğlu, A. Tarık. "Giysi Yardım Merkezi: Beğendiğini Al, Ödemeden Git”. Büyükşehir Ankara 4, S. 197 (2008): 6-7.

Hornstein, Naomi. "Spatial Perspectives of Contention: Space, Place, and Policing in the 2013 Gezi Park Protests". Unpublished Senior Thesis, Brandeis University, Faculty of the School of Arts and Sciences, Waltham, Massachusetts, 2015.

Hurriyet.com.tr. "29 Ekim Resepsiyonu İptal”, 29 Ekim 2014. 17 Şubat 2017 tarihinde http://www.hurriyet.com.tr/29-ekim-resepsiyonu-iptal-27477903 adresinden erişildi.

Hurriyet.com.tr. "Cumhurbaşkanı Erdoğan, Beştepe'deki Devlet Konukevi'ne Taşındı”, 19 Aralık 2015. 17 Şubat 2017 tarihinde http://www.hurriyet.com.tr/cumhurbaskanierdogan-bestepedeki-devlet-konukevine-tasindi-40029315 adresinden erişildi. 
Hurriyet.com.tr. "Erdoğan, Beştepe Millet Camii Açılışında Konuştu”, 3 Temmuz 2015. 17 Şubat 2017 tarihinde http://www.hurriyet.com.tr/erdogan-bestepe-millet-camiiacilisinda-konustu-29450429 adresinden erişildi.

Hurriyet.com.tr. "Gar Meydanı Demokrasi Meydanı Oldu", 15 Ekim 2015. 15 Şubat 2017 tarihinde http://www.hurriyet.com.tr/gar-meydani-demokrasi-meydani-oldu-3032 3097 adresinden erişildi.

Hurriyet.com.tr. "Görmez: 80 Üniversitede Cami Olacak", 21 Kasım 2014. 16 Şubat 2017 tarihinde http://www.hurriyet.com.tr/gormez-80-universitede-cami-olacak-27615 626 adresinden erişildi.

Hurriyet.com.tr. “Kız-Erkek Ortak Yurt Kalmayacak”, 12 Ağustos 2013. 7 Şubat 2017 tarihinde http://www.hurriyet.com.tr/kiz-erkek-ortak-yurt-kalmayacak-24504666 adresinden erişildi.

Hurriyet.com.tr. “Tandoğan Meydanı'nın Isminin Değişmesi Için Teklif”, 18 Nisan 2012. 14 Şubat 2017 tarihinde http://www.hurriyet.com.tr/tandogan-meydaninin-isminindegismesi-icin-teklif-20369695 adresinden erişildi.

İlkay, Yasemin. "The Political Struggle on and at Public Space: The Case of Kizilay Square". Unpublished Master's Thesis, Middle East Technical University, Graduat School of Social Sciences, Ankara, 2007.

İzci, Ferit ve Menaf Turan. “Türkiye'de Büyükşehir Belediyesi Sistemi ve 6360 Sayılı Yasa ile BüyükşehirBelediyesi Sisteminde Meydana Gelen Değişimler: Van Örneği”. Süleyman Demirel Üniversitesi Iktisadi ve İdari Bilimler Fakültesi Dergisi 18, S. 1 (2013): 117-152.

Işık, Oğuz. "Kentlerde, Kentleşmeye ve 21. Yüzyılın Eşiğinde Türkiye Kentlerine Dair". Toplum ve Hekim 14, S. 3 (1999): 163-175.

Işıklılar, Damla. "Heterotopic Practice of Space: Taksim Gezi Park Revisited". Unpublished Master's Thesis, Middle East Technical University, Graduate School of Natural and Applied Sciences, Ankara, 2016.

Jansen, Hermann. Ankara Imar Planı Raporu. İstanbul: Alaeddin Kıral Basımevi, 1937.

Jessop, Bob. "The Narrative of Enterprise and the Enterprise of Narrative: Place Marketing and the Entrepreneurial City". T. Hall ve P. Hubbard (Ed.), The Entrepreneurial City: Geographies of Politics, Regime and Representation içinde (ss. 77-99). Chichester: Wiley, 1998.

Jongerden, Joost. The Settlement Issue in Turkey and the Kurds: An Analysis of Spatial Policies, Modernity and War. Leiden, The Netherlands: Brill, 2007.

Jongerden, Joost. "Yer Siyaseti: Türkiye Kürdistanı'nda Devlet ve Toplumun Mekânsal Düzenlenişi". Toplum ve Kuram, S. 2 (2009): 213-230.

Kahya, Güzin Yeliz. "Spatio-Temporal Structuration of Art and Cultural Events Mediated Urban Experience in Beyoğlu". Unpublished PhD Thesis, Middle East Technical University, Graduate School of Natural and Applied Sciences, Ankara, 2015.

Karakaya, Emel. "Construction of the Republic in City Space: From Political Ideal to Planning Principles". Unpublished Master's Thesis, Middle East Technical University, Graduate School of Natural and Applied Sciences, Ankara, 2010.

Karaosmanoğlu, Yakup Kadri. Ankara. 32. bs. İstanbul: İletişim, 2015. 
Karasulu, Ahu. "If a Leaf Falls, They Blame the Tree': Scattered Notes on Gezi Resistances, Contention, and Space". International Review of Sociology 24, S. 1 (2014): 164-175.

Kartal, Cemile Burcu. "Değişen İktidar İlişkileri İçinde İki Kentin Dönüşümü: İmparatorluk'tan Cumhuriyet'e-Payitaht İstanbul'dan Makarr-ı Hükümet Ankara'ya (Dönem Basınına Yansıyan Tartışmalarla: 1920-1940)". Yayınlanmamış Doktora Tezi, İstanbul Üniversitesi, Sosyal Bilimler Enstitüsü, İstanbul, 2012.

Kayalıgil, Pınar Karababa. "Spaces of Conflict: Memory, Musealization and Heterotopia in the City of Sivas, Turkey". Unpublished PhD Thesis, Middle East Technical University, Graduate School of Social Sciences, Ankara, 2015.

Kaypak, Şafak. "Atatürk'ün Kent ve Kentleşmeye Bakışı; Ankara'nın Kentleşmesi”. Mustafa Kemal Üniversitesi Sosyal Bilimler Enstitüsü Dergisi 13, S. 27 (2014): 349-365.

Kaypak, Şafak. “Türk Aydınlanması'nın Kent ve Kentleşmeye Bakışı”. Akademik Sosyal Araştırmalar Dergisi 2, S. 1 (2014): 121-143.

Keleş, Ruşen. "Anakentlerin Dünü, Bugünü ve Yarını”. Kentsel ve Bölgesel Araştırma Sempoyumu-3. 6-7 Aralık, Ankara, 2012.

Keleş, Ruşen. Kentleşme Politikası. 13. bs. Ankara: İmge Kitabevi, 2013.

Keleş, Ruşen, Can Hamamcı ve Aykut Çoban. Çevre Politikası. 7. bs. Ankara: İmge Kitabevi, 2012.

Keleş, Ruşen ve Artun Unsal. Kent ve Siyasal Şiddet. Ankara: Ankara Üniversitesi SBF Yayınları, 1982.

Kennedy, Nilgün Fehim. "The Ethos of Architects Towards an Analysis of Architectural Practice in Turkey". Unpublished PhD Thesis, Middle East Technical University, Graduate School of Social Sciences, Ankara, 2005.

Keskinok, Çağatay H. "Ankara'nın Planlı Gelişmesi Açısından Batıkent Projesinin Önemi”. T. Şenyapılı (Ed.), “Cumhuriyet”in Ankara'sı içinde (2. bs., ss. 120-152). Ankara: ODTÜ Yayıncılık, 2006.

Keskinok, Çağatay H. "Kent Planlama ve Uygulamasında Menfaat İhlali ve Dava Açma Ehliyeti (Kamu Yararı ve Mülkiyet Hakkının Sınırlanması, Kent Planlama ve Uygu lamasının Yargısal Denetimi, Kent Planlama ve Uygulamasından Etkilenme, Genişletilmiş Anlamda Menfaat İhlali, Yargı Kararları". M. Ersoy ve Ç. H. Keskinok (Ed.), Mekân Planlama ve Yargı Denetimi içinde (ss. 13-28). Ankara: Yargı Yayınevi, 2000.

Keyder, Caglar. The Definition of a Peripheral Economy: Turkey, 1923-1929. Cambridge University Press, 1982.

Keyder, Çağlar. Türkiye'de Devlet ve Sınıflar. 19. bs. İstanbul: İletişim, 2014.

Khakee, Abdul ve Laura Grassini. "Understanding Multiple Aspects of Present Space With the Help of Future Scenarios: The Case of Izmir, Turkey". Foresight 17, S. 6 (2015): 588-598.

Kimyon, Deniz ve Gencay Serter. "Atatürk Orman Çiftliği'nin ve Ankara'nın Değişimi Dönüşümü”. Planlama 25, S. 1 (2015): 44-63. 
Kılıç-Çalgıcı, Pınar. "Gündelik Hayatın Tiyatrosu: Alsancak’ta Teatral Etkinlikler". lidealkent, S. 2013/10 (2013): 256-271.

Kılıç, Fatih. "Büyükşehir "Giysi Merkezi”nde Yok Yok”. Büyükşehir Ankara 11, S. 548 (2015): 16-17.

Koç, Figen. "Batıkent'e Gençlik Merkezi”. Büyükşehir Ankara 4, S. 174 (2008): 8-9.

Koç, Figen. "Gar Alt Geçidi 35 Günde Trafiğe Açıldı”. Büyükşehir Ankara 4, S. 181 (2008): 24-25.

Koç, Figen. "Gençlere Açılan Sıcak ve Dost Kapıları: Gençlik Merkezleri”. Büyükşehir Ankara 5, S. 211 (2009): 18-19.

Koç, Figen ve Seyithan Melih Bingöl. "Gençlik Parkı Yeniden Doğuyor”. Büyükşehir Ankara 4, S. 182 (2008): 6-13.

Koç, Figen ve Seyithan Melih Bingöl. "Özlem Bitiyor Gençlik Parkı Kapılarını Açıyor”. Büyükşehir Ankara 5, S. 243 (2009): 4-13.

Koç, Figen ve Alp Aykut Çıngır. "Kentin Tarihi Ulus'ta Yeniden Canlanıyor”. Büyükşehir Ankara 4, S. 177 (2008): 4-11.

Koçak, Feryal Ayşın. "Social and Spatial Production of Atatürk Boulevard in Ankara". Unpublished PhD Thesis, Middle East Technical University, Graduate School of Social Sciences, Ankara, 2008.

Kongar, Emre. "Altındağ Gecekondu Bölgesi”. Amme Idaresi Dergisi 6, S. 3 (1973): 109_ 138.

Kongar, Emre. "Altındağ'da Kentle Bütünleşme”. Amme Idaresi Dergisi 6, S. 4 (1973): 59_ 84.

Kopp, Anatole. Town and Revolution: Soviet Architecture and City Planning, 1917-1935. (T. E. Burton, Çev.). New York: George Braziller, 1970.

Kor, Burcu. "Death, Burial Culture and Spaces of Memorialization: The Case of Ankara Cebeci Cemetery". Unpublished Master's Thesis, Middle East Technical University, Graduate School of Natural and Applied Sciences, Ankara, 2013.

Koyuncu, Bertan. "Yeni Bir Kentsel Mekanın Göstergesi Olarak Taksim Gezi Parkı Eylemleri”. Yayınlanmamış Yüksek Lisans Tezi, İstanbul Teknik Üniversitesi, Fen Bilimleri Enstitüsü, İstanbul, 2015.

Koyuncu, Büke. "Benim Milletim...”: AK Parti Iktidarı, Din ve Ulusal Kimlik. 1. bs. İstanbul: İletişim, 2014.

Köprülü, Ahmet. “Ankara'nın Simge 5 Kapısına Konserli Açılış”. Büyükşehir Ankara 10, S. 473 (2014): 10-13.

Köprülü, Ahmet. "Büyükşehir, BELTEK ve BELMEK'lerde 400 Bin Kişiye Mesleki Eğitim Verdi”. Büyükşehir Ankara 11, S. 542 (2015): 10-13.

Köprülü, Ahmet. "ODTÜ Yolu'na, ‘1071 Malazgirt Bulvarı’ Adı Verildi”. Büyükşehir Ankara 10, S. 469 (2014): 16-17.

Kuhn, Thomas. The Structure of Scientific Revolutions. 3. bs. Chicago: The University of Chicago Press, 1996. 
Kulözü, Neslihan. "Transformation of Public Space: the Case of Hacibayram Square". Unpublished Master's Thesis, Middle East Technical University, Graduate School of Natural and Applied Sciences, Ankara, 2008.

Kural, Nerkis. "Parameters of Sustainability in Urban Residential areas: A Critique of Temelli/Ankara". Unpublished PhD Thesis, Middle East Technical University, Graduate School of Natural and Applied Sciences, Ankara, 2009.

Kutlar, Fatma S. (2005). "Sa'dâbâd Şiirlerinde Mekân". Illmî Araştırmalar: Dil, Edebiyat, Tarih Incelemeleri, S. 19 (2005): 93-118.

Lefebvre, Henri. "Comments on a New State Form". Antipode 33, S. 5 (2001): 769-782.

Lefebvre, Henri. Critique of Everyday Life, Volume 1: Introduction. (M. John, Çev.). London: Verso, 1991.

Lefebvre, Henri. Everyday Life in the Modern World. (R. Sacha, Çev.). New York: Harper Torchbook, 1976.

Lefebvre, Henri. Kentsel Devrim. (S. Sezer, Çev.). 4. bs. İstanbul: Sel Yayıncılık, 2015.

Lefebvre, Henri. La Production de l'Espace. Paris: Éditions Anthropos, 1974.

Lefebvre, Henri. Mekânın Üretimi. (I. Ergüden, Çev.). 2. bs. İstanbul: Sel Yayıncılık, 2014.

Lefebvre, Henri. State, Space, World: Selected Essays. (M. Gerald, N. Brenner ve E. Stuard, Çev.). Minneapolis: University of Minnesota Press, 2009.

Lefebvre, Henri. Survival of Capitalism: Reproduction of the Relations of Production. (B. Frank, Çev.). New York: St. Martin's Press, 1976.

Lefebvre, Henri. The Production of Space. (D. Nicholson-Smith, Çev.). Cambridge, Mass.: Blackwell, 1991.

Lefebvre, Henri. The Urban Revolution. (R. Bononno, Çev.). The University of Minnesota Press, 2003.

Lefebvre, Henri. Writings on cities. (E. Kofman ve E. Lebas, Çev.). Oxford: Blackwell Publishers, 1996.

Logan, John R. ve Harvey Molotch. Urban Fortunes: The Political Economy of Place. Berkley: University of California Press, 1987.

Meeker, Michael E. “Once There Was, Once There Wasn't: National Monuments and Interpersonal Exchange". S. Bozdoğan ve R. Kasaba (Ed.), Rethinking Modernity and National Identity in Turkey içinde (ss. 157-191). Seattle: University of Wales Press, 1997.

Melihgokcek.com. "ÇUBUK 1 Barajı Rekreasyon Alanı Projesi”. 23 Nisan 2017 tarihinde http://www.melihgokcek.com/proje-detay/cubuk-1-baraji-rekreasyon-alaniprojesi-145.html adresinden erişildi.

Mengi, Ayşegül ve Tayfun Çınar. "Transformation Process of Rural Areas into Urban Areas in Turkey after 1980s". E. Hepperle, R. Dixon-Gough, R. Mansberger, J. Paulsson, F. Reuter ve M. Yilmaz (Ed.), Challenges for Governance Structures in Urban and Regional Development içinde (ss. 49-57). Zurich: VDF Hochschulverlag, 2015.

Merrifield, Andy. Henri Lefebvre: A Critical Introduction. New York: Routledge, 2013. 
Merrifield, Andy. The Politics of the Encounter: Urban Theory and Protest Under Planetary Urbanization. University of Georgia Press, 2013.

Mert, Ceren. "Postyapısalcı Mekan Analizine Doğru: İstanbul, Kent ve Müzik". Yayınlanmamış Doktora Tezi, Mimar Sinan Güzel Sanatlar Üniversitesi, Sosyal Bilimler Enstitüsü, İstanbul, 2013.

Milliyet.com.tr. "Cumhurbaşkanlığı Sarayı Külliye Oluyor”, 16 Ocak 2015. 17 Şubat 2017 tarihinde http://www.milliyet.com.tr/cumhurbaskanligi-saray-kulliye/siyaset/detay /1999587/default.htm adresinden erişildi.

Mimarlar Odası Ankara Şubesi. “iller Bankası'nda Tarihi Katliam”, 1 Şubat 2017. 11 Şubat 2017 tarihinde http://www.mimarlarodasiankara.org/?Did=8546 adresinden erişildi.

Mirze, Z. Esra. “Disorientation: 'Home' in Postcolonial Literature”. PhD Thesis. University of Nevada, Reno. ProQuest Dissertations \& Theses Global, 2005.

Molotch, Harvey. "The City as a Growth Machine: Toward a Political Economy of Place". American Journal of Sociology 82, S. 2 (1976): 309-332.

Mumford, Lewis. Tarih Boyunca Kent: Kökenleri Geçirdiği Dönüşümler ve Geleceği. (G. Koca ve T. Tosun, Çev.). 2. bs. Ayrıntı, 2013.

Nalbantoğlu, Gülsüm Baydar. "Silent Interruptions: Urban Encounters with Rural Turkey". S. Bozdoğan ve R. Kasaba (Ed.), Rethinking Modernity and National Identity in Turkey içinde (ss. 192-210). University of Washington Press, 1997.

Narkar, Poonam. "Urban [Dis]order: Reinventing Urban Spaces, Case of Istanbul, Turkey". Unpublished Master's Thesis, University of Cincinnati, Division of Research and Advanced Studies, Cincinnati, Ohio, 2006.

Nişanyan, Sevan. "Külliye". NişanyanSözlük: Çağdaş Türkçenin Etimolojisi, 15 Şubat 2017 tarihinde http://nisanyansozluk.com/?k=külliye\&x=0\&y=0 adresinden erişildi.

Orhan, Ezgi. "Reflection of Political Restructuring on Urban Symbols: The Case of Presidential Palace in Ankara, Turkey". Journal of Architecture and Urbanism 40, S. 3 (2016): 206-219.

Ozan, Ebru Deniz. “íki Darbe Arasında Kriz Sarmalı”. G. Atılgan, C. Saraçoğlu ve A. Uslu (Ed.), Osmanlı'dan Günümüze Türkiye'de Siyasal Hayat içinde (ss. 657-746). İstanbul: Yordam Kitap, 2015.

Öğüt, Uğur. "Büyük Cami Talimatı Cumhurbaşkanı'ndan”. Gazetehabervaktim.com, 28 Ocak 2017. 11 Şubat 2017 tarihinde http://www.gazetehabervaktim.com/buyukcami-talimati-cumhurbaskanindan-17182h.htm adresinden erişildi.

Öncü, Ayça. "Yetmişli Yıllardan Günümüze Ankara Kent Yönetimlerinin Ulaşım Politikaları ve Uygulamaları". Dosya 11: Yerel Yönetimler, Ulaşım ve Su, Bülten 67 (2009): 4-19.

Önder, Sara Pınar. "A Tale of an Uneven Urban Development: The Socio-Economic and Socio-Cultural Contradictions of Tarlabasi Renewal Project". Unpublished Master's Thesis, Lund University, Graduate School, Lund, 2012. 
Önez Çetin, Zuhal. "Türkiye'de İ Özel İdaresi Sisteminin Dönüşümü ve 6360 Sayılı Kanunun Dönüşüme Etkileri”. Süleyman Demirel Üniversitesi Íktisadi ve Idari Bilimler Fakültesi Dergisi 20, S. 2 (2015): 247-266.

Özaksoy, Gonca. "Urbanizaton and Social Thought in Turkey". Unpublished Master's Thesis, Middle East Technical University, Graduate School of Social Sciences, Ankara, 2005.

Özaloğlu, Serpil. "Transformation of Ankara Between 1935-1950 in Relation With Everyday Life and Lived Spatiality". Unpublished PhD Thesis, Middle East Technical University, Graduate School of Natural and Applied Sciences, Ankara, 2006.

Özaloğlu, Serpil. "The Lived Spatiality of Ankara (1935-1950) through the Memories of its Citizens". P. François, T. Syrjämaa ve H. Terho (Ed.), Power and Culture: New Perspectives on Spatiality in European History içinde (ss. 19-43). Pisa: PlusPisa University Press, 2008.

Özçağlar, Ali ve Rüya Bayar. "Ankara Büyükşehir Belediyesinin Yönetsel Sınırlarındaki Değişimin Ankara Şehrine ve Ankara İline Etkileri”. TÜCAUM VIII. Coğrafya Sempozyumu içinde (ss. 175-188). Ankara, 2014.

Özgün, Emine Şirin. "The Sounds of Political Actions in the Streets of Istanbul". Unpublished Master's Thesis, Istanbul Technical University, Graduate School of Arts and Social Sciences, İstanbul, 2012.

Özkan, Derya. "The Misuse Value of Space: Spatial Practices and the Production of Space in Istanbul". PhD Thesis. University of Rochester, The College of Arts and Sciences. ProQuest Dissertations \& Theses Global, 2008.

Özkan, Miray ve Ali Cenap Yoloğlu. "Bir Bellek Projesi Olarak Sokak İsimlendirmesi: Ankara Örneği”. Planlama 2005/4 (2005): 54-60.

Öztürk, Duygu C. "Socio-spatial Practices of the Pro-Kurdish Municipalities: The Case of Diyarbakır". Unpublished Master's Thesis, Middle East Technical University, Graduate School of Social Sciences, Ankara, 2013.

Öztürk, Mesut. "Enformel Siyasi Ağların Gecekondu Üretim Biçimlerine Etkileri: Güzeltepe-Çayan Mahallesi Örneği”. Yayınlanmamış Yüksek Lisans Tezi, İstanbul Bilgi Üniversitesi, Fen Bilimleri Enstitüsü, İstanbul, 2016.

Pasin, Burkay. "A Critical Reading of the Ottoman-Turkish Hamam as a Queered Space". Unpublished PhD Thesis, Middle East Technical University, Graduate School of Natural and Applied Sciences, 2014.

Pasin, Burkay. "A Critical Reading of the Ottoman-Turkish Hammam as a Representational Space Of Sexuality". METU Journal of the Faculty of Architecture 33, S. 2 (2016): 121-138.

Pasin, Burkay. "Dişil bir Temsili Mekân Olarak Türk Hamamı". T. Balcıoğlu ve G. Baydar (Ed.), Tasarım tarihinin ötekileri içinde (ss. 55-66). İzmir: 4T Türkiye Tasarım Tarihi Topluluğu, 2009.

Pasin, Burkay. "Femaleness, Femininity and Feminotopia: The Female Hamam as a Homosocial Space". Kadın/Woman 14, S. 1 (2013): 55-77.

Pekasil, Tahir. "Mardin Süryanilerinde Belleğin Teolojik-Kültürel Çerçevesi". Tarih Kültür ve Sanat Araştırmaları Dergisi 5, S. 2 (2016): 26-58. 
Penpecioglu, Mehmet. "The Political Construction of Urban Development Projects: The Case of Izmir". Unpublished PhD Thesis, Middle East Technical University, Graduate School of Social Sciences, Ankara, 2012.

Penpecioglu, Mehmet. "Büyük Ölçekli Kentsel Projeler, Mekanın Üretimi ve Neo-liberal Hegemonya”. Megaron 8, S. 2 (2013): 97-114.

Penpecioğlu, Mehmet. "Kapitalist Kentleşme Dinamiklerinin Türkiye'deki Son 10 Yılı: Yapılı Çevre Üretimi, Devlet ve Büyük Ölçekli Kentsel Projeler”. Birikim, S. 270 (2011): 62-73.

Pirenne, Henri. Medieval Cities: Their Origins and the Revival of Trade. (F. D. Halsey, Çev.). 4. bs. Princeton, NJ: Princeton University Press, 1946.

Radikal.com.tr. “Ankara'nın Yeni Silueti”, 26 Nisan 2015. 17 Şubat 2017 tarihinde http://www.radikal.com.tr/turkiye/ankaranin-yeni-silueti-1343956/ adresinden erişildi.

Radikal.com.tr. “Erdoğan: Bu Girişimdekilere Ben ‘mankurt' Diyorum”, 19 Ekim 2015. 18 Şubat 2017 tarihinde http://www.radikal.com.tr/turkiye/erdogan-bu-girisimde kilere-ben-mankurt-diyorum-1454938/ adresinden erişildi.

Radikal.com.tr. "Hoş Geldin Parası: 25 Milyon TL", 1 Şubat 2014. 21 Şubat 2017 tarihinde http://www.radikal.com.tr/turkiye/hos-geldin-parasi-25-milyon-tl-1173595/ adresinden erişildi.

Radikal.com.tr. "Kırklareli'nde Haremlik Selamlık Yemekhane!”, 2 Ağustos 2013. 7 Şubat 2017 tarihinde http://www.radikal.com.tr/turkiye/kirklarelinde-haremlik-selamlikyemekhane-1144601/ adresinden erişildi.

Radikal.com.tr. "Komşu İhbar, Vali Müdahale Ediyor", 6 Kasım 2013. 7 Şubat 2017 tarihinde http://www.radikal.com.tr/turkiye/komsu-ihbar-vali-mudahale-ediyor1159226/ adresinden erişildi.

Radikal.com.tr. “Tandoğan Meydanı'nın İsmi Değişti”, 14 Mayıs 2012. 14 Şubat 2017 tarihinde http://www.radikal.com.tr/turkiye/tandogan-meydaninin-ismi-degisti1088027/ adresinden erişildi.

Radikal.com.tr. "TBMM 'külliye' Oldu”, 28 Ocak 2016. 16 Şubat 2017 tarihinde http://www.radikal.com.tr/turkiye/tbmm-kulliye-oldu-1501072/ adresinden erişildi.

Said, Edward W. Orientalism. New York: Vintage Books, 1979.

Sakal, Ali. "İstanbul Kentsel Mekanında Gündelik Taktikler”. Yayınlanmamış Yüksek Lisans Tezi, İstanbul Teknik Üniversitesi, Fen Bilimleri Enstitüsü, İstanbul, 2015.

Salah, Ebru. "Sayfiye to Banlieue: Suburban Landscape Around Anatolian Railways, from Mid-Nineteenth Century to the World War II". Unpublished PhD Thesis, Middle East Technical University, Graduate School of Natural and Applied Sciences, Ankara, 2013.

Salman, Cemal. "Didem Madak Şiirinde Zaman ve Mekân”. E. Bora ve N. Zorlu (Ed.), Didem Madak'ı Okumak içinde (ss. 217-250). İstanbul: Metis Yayınları, 2015.

Sancar, Serpil. Türk Modernleşmesinin Cinsiyeti: Erkekler Devlet, Kadınlar Aile Kurar. 4. bs. İstanbul: İletişim, 2014.

Sandıkcı, Özlem. "Strolling Through Istanbul's Beyoğlu: In-Between Difference and Containment". Space and Culture 18, S. 2 (2015): 198-211. 
Saraçoğlu, Cenk. "Tank Paletiyle Neoliberalizm". G. Atılgan, C. Saraçoğlu ve A. Uslu (Ed.), Osmanlı'dan Günümüze Türkiye'de Siyasal Hayat içinde (ss. 747-869). İstanbul: Yordam Kitap, 2015.

Saraçoğlu, Cenk ve Melih Yeşilbağ. "AKP Döneminde Türkiye: Minare ile İnşaat Gölgesinde”. G. Atılgan, C. Saraçoğlu ve A. Uslu (Ed.), Osmanlı'dan Günümüze Türkiye'de Siyasal Hayat içinde (ss. 871-957). İstanbul: Yordam Kitap, 2015.

Sargin, Güven Arif. "Displaced Memories, or the Architecture of Forgetting and Remembrance". Environment and Planning D: Society and Space 22, S. 5 (2004): 659-680.

Sargın, Güven Arif. "Atatürk Kültür Merkezi Alanı Değerlendirme Raporu”. Ankara, 2005. 12 Mart 2017 tarihinde https://gasmekan.wordpress.com/2014/08/23/ataturkkultur-merkezi-alani-degerlendirme-raporu/ adresinden erişildi.

Sargın, Güven Arif. “Kurmaca Başkentlerin İmgesel İnşası: Ankara'nın Mekânsal Siyasası Üzerine Kısa Notlar”. F. Ş. Cantek (Ed.), Cumhuriyet'in Ütopyası: Ankara içinde (ss. 147-172). Ankara: Ankara Üniversitesi Yayınevi, 2012.

Sargın, Güven Arif. "Sincan, a Town on the Verge of Civic Breakdown: The Spatialization of Identity Politics and Resistance". A. Çınar, S. Roy ve M. Yahya (Ed.), Visualizing Secularism and Religion: Egypt, Lebanon, Turkey, India: Egypt, Lebanon, Turkey, India içinde. Ann Arbor: The University of Michigan Press, 2012.

Sarı, Tüba. "Türk Sinemasında Sosyal Yaşam Kurgusunun Mekan Kullanımına Yansıması". Yayınlanmamış Yüksek Lisans Tezi, İstanbul Teknik Üniversitesi, Fen Bilimleri Enstitüsü, İstanbul, 2010.

Sarıtaş, Ezgi. "Video in the City Possibilities for Transformation in the Urban Space". Unpublished Master's Thesis, European Urban Cultures (POLIS), 2007.

Sarıyıldız, Hatice Özlem. "Graffiti and Urban Space in Istanbul”. Unpublished Master's Thesis, Middle East Technical University, Graduate School of Social Sciences, Ankara, 2007.

Selen, Eser. "The Stage: A Space for Queer Subjectification in Contemporary Turkey”. Gender, Place \& Culture 19, S. 6 (2012): 730-749.

Selen, Eser. "The Work of Sacrifice: Gender Performativity, Modernity, and Islam in Contemporary Turkish Performance (1980s-2000s)". PhD Thesis. New York University, Department of Performance Studies. ProQuest Dissertations \& Theses Global, 2010.

Selvi Ünlü, Tülin. "Mersin'de İki Kamusal Mekân Üzerine Bir Mekân Kavramsallaştırması Denemesi". Y. S. Levent ve M. Uçar (Ed.), Mersin'den Mimarlık Planlama Tasarım Yazıları içinde (ss. 137-157). Mersin: Mersin Üniversitesi yayınları, 2015.

Semerci, Tansel. “Aile Yaşam Merkezlerinin İkincisi Çubuk'ta Açıldı”. Büyükşehir Ankara 4, S. 173 (2008): 16-17.

Semerci, Tansel. "Anadolu Bulvarı Üzerine Köprülü Kavşak Çalışması Başladı". Büyükşehir Ankara 9, S. 428 (2013): 8-9.

Semerci, Tansel. "Ankara, En Ücra Köylerine Kadar Sıcak Asfaltla Donatılıyor". Büyükşehir Ankara 10, S. 503 (2014): 3-9. 
Semerci, Tansel. "Başkent'te Asfalt Çalışması Dört Bir Yanda Sürüyor...”. Büyükşehir Ankara 9, S. 438 (2013): 3-7.

Semerci, Tansel. "Başkent Ulaşımına Yeni Nefes". Büyükşehir Ankara 5, S. 211 (2009): 10-13.

Semerci, Tansel. "Başkent Yeni Kavşaklarla Donatılıyor". Büyükşehir Ankara 4, S. 176 (2008): 16-18.

Semerci, Tansel. “Tandoğan Meydanı, 'Anadolu Meydanı' Oldu”. Büyükşehir Ankara 11, S. 528 (2015): 28-29.

Semerci, Tansel ve Seyithan Melih Bingöl. "Çubuk Yolu'nda Modern Yenileme". Büyükşehir Ankara 5, S. 242 (2009): 16-19.

Semerci, Tansel ve Seyithan Melih Bingöl. "Işte Büyükşehir Farkı”. Büyükşehir Ankara 11, S. 543 (2015): 1-9.

Semerci, Tansel, Ahmet Köprülü ve Sercan Abay. "Büyükşehir, 25 İlçeye 1.5 Yılda 2.2 Milyar Liralık Yatırım Yaptı...". Büyükşehir Ankara 12, S. 557 (2015): 3-9.

Senel, Sidika Aslihan. "Unfixing Place: A Study of Istanbul Through Topographical Practices". PhD Thesis, University College London, Department of Architecture. ProQuest Dissertations \& Theses Global, 2008.

Serin, Bilge. "The Promised Territories: The Production of Branded Housing Projects in Contemporary Turkey". European Journal of Turkish Studies [Online] 23, January (2016): 1-23, 2016. http://ejts.revues.org/5383 adresinden erişildi.

Seydioğulları, Hatice Selcen. "Yeni Yasal Düzenlemelerle Kentsel Dönüşüm”. Planlama 26, S. 1 (2016): 51-64.

Shields, Rob. Lefebvre, Love, and Struggle: Spatial Dialectics. London: Routledge, 2005.

Smith, Neil. Uneven Development: Nature, Capital, and the Production of Space. 3. bs. Athens, Georgia: The University of Georgia Press, 2008.

Soja, Edward. My Los Angeles: From Urban Restructuring to Regional Urbanization. Berkeley: University of California Press, 2014.

Soja, Edward. Postmetropolis: Critical Studies of Cities and Regions. Wiley-Blackwell, 2000.

Soja, Edward. Postmodern Geographies: The Reassertion of Space in Critical Social Theory. London: Verso, 1989.

Soja, Edward. "The Socio-Spatial Dialectic". Annals of the Association of American Geographers 70, S. 2 (1980): 207-225.

Soja, Edward. "Thirdspace: Expanding the Scope of the Geographical Imagination". D. Massey, J. Allen ve P. Sarre (Ed.), Human Geography Today içinde (ss. 260278). Cambridge: Polity Press, 1999.

Soja, Edward. Thirdspace: Journeys to Los Angeles and Other Real-and-Imagined Places. Oxford: Basil Blackwell, 1996.

Somalı, Fatma Süphan. "Reading Urban Transformation Through the Case of Mamak, Ankara". Unpublished PhD Thesis, Middle East Technical University, Graduate School of Social Sciences, Ankara, 2013. 
318 • Tarihsel, Soyut, Çelişkili: 1923’ten Günümüze Türkiye'de Kentsel Toplumsal Mekân

Sönmez, Çağlayan. "A Historical and Social Analysis of an Urban Transformation: Akay Junction in Ankara". Unpublished Master's Thesis, Middle East Technical Univesity, Graduate School of Natural and Applied Sciences, Ankara, 2005.

Şahin, Özge. "Impacts of Policies After 1980 on Public Buildings: The "Unoccupied" Buildings of Emlakbank, Sümerbank and TEKEL in Ulus in Ankara". Unpublished Master's Thesis, Middle East Technical University, Graduate School of Natural and Applied Sciences, Ankara, 2008.

Şen, Seher. "The Production of Space and The Construction of Urbanisty: Informal Practices in 1930s Ankara". Unpublished PhD Thesis, Bilkent University, Institute of Economic and Social Sciences, Ankara, 2008.

Şener, Mustafa. "Burjuva Uygarlığın Peşinde”. G. Atılgan, C. Saraçoğlu ve A. Uslu (Ed.), Osmanlı'dan Günümüze Türkiye'de Siyasal Hayat içinde (ss. 195-339). İstanbul: Yordam Kitap, 2015.

Şengül, H. Tarik. "On the Trajectory of Urbanisation in Turkey: An Attempt at Periodisation”. International Development Planning Review 25, S. 2 (2003): 153 168.

Şengül, H. Tarık. Kentsel Çelişki ve Siyaset: Kapitalist Kentleşme Süreçlerinin Eleştirisi. 2. bs. Ankara: İmge Kitabevi, 2009.

Şengül, H. Tarık. "Gezi Başkaldırısı Ertesinde Kent Mekânı ve Siyasal Alanın Yeni Dinamikleri”. ODTÜ Mimarlık Fakültesi Dergisi 31, S. 1 (2015): 1-20.

Şentürk, Yıldırım. "Contradictory Spaces of Labor: The Social and Spatial Practices of Work Life in Istanbul". G. E. Lelandais (Ed.), Understanding the City: Henri Lefebvre and Urban Studies içinde (ss. 189-211). Cambridge Scholars Publishing, 2014.

Şenyapılı, Tansı. "Ankara Kenti 'İkili' Yapısında Dönüşümler”. T. Şenyapılı (Ed.), "Cumhuriyet"in Ankara'sı içinde (2. bs., ss. 216-244). Ankara: ODTÜ Yayıncılık, 2006.

Şenyapılı, Tansı. “Baraka”dan Gecekonduya: Ankara'da Kentsel Mekânın Dönüşümü: 1923-1960. 1. bs. İstanbul: İletişim Yayınları, 2004.

Şişmanoğlu, Şehnaz. "Behçet Necatigil ve Şiirin Ev Hali". Yayınlanmamış Yüksek Lisans Tezi, Bilkent Üniversitesi, Ekonomi ve Sosyal Bilimler Enstitüsü, Ankara, 2003.

T24.com.tr. "Saray Artık Resmen 'Külliye' Oldu”, 7 Temmuz 2015. 17 Şubat 2017 tarihinde http://t24.com.tr/haber/adi-resmen-cumhurbaskanligi-kulliyesi-oldu,302106 adresinden erişildi.

Tankut, Gönül. “Ankara’nın Başkent Olma Süreci”. ODTÜ Mimarlık Fakültesi Dergisi 8, S. 2 (1988): 93-104.

Tankut, Gönül. Bir Başkentin Imarı: Ankara, 1929-1939. Ankara: Anahtar Kitaplar, 1993.

Tanpınar, Ahmet Hamdi. Beş Şehir. 34. bs. İstanbul: Dergâh Yayınları, 2015.

Tanpınar, Ahmet Hamdi. Saatleri Ayarlama Enstitüsü. 26. bs. İstanbul: Dergâh Yayınları, 2015.

Taş, Oğuzhan ve Tuğba Taş. "Ankara'da Sokak Sanatı: Kent Hakkı, Protesto ve Direniş". Mülkiye Dergisi 39, S. 2 (2015): 85-114. 
Taştekin, Fehim. "'Big Brother' to Move into Erdogan's Palace”. Al-Monitor, 13 Mart 2015. 17 Şubat 2017 tarihinde http://www.al-monitor.com/pulse/originals/2015/03/ turkey-big-brother-erdogan-palace.html adresinden erişildi.

Tataroğlu, Enis Guvenç. "Conceptual Analysis of Tourism: The Case of Marmaris Town in Turkey". Unpublished PhD Thesis, Middle East Technical University, Graduate School of Social Sciences, Ankara, 2006.

TDK. "Külliye". Güncel Türkçe Sözlük. Türk Dil Kurumu. 16 Şubat 2017 tarihinde http://www.tdk.gov.tr/index.php?option=com_gts\&kelime=Külliye adresinden erişildi.

Tekeli, İlhan. “Ankara'nın Başkentlik Kararının Ülkesel Mekan Organizasyonu ve Toplumsal Yapıya Etkileri Bakımından Genel Bir Değerlendirmesi”. E. Yavuz ve Ü. N. Uğurel (Ed.), Tarih Içinde Ankara: Eylül 1981 Seminer Bildirileri içinde (ss. 321-332). Ankara: ODTÜ, 1984.

Tekeli, İlhan. "Kent Tarihi Yazımı Konusunda Yeni Bir Paradigma Önerisi”. T. Şenyapılı (Ed.), "Cumhuriyet”in Ankara'sı içinde (2. bs., ss. 1-21). Ankara: ODTÜ Yayıncılık, 2006.

Tekeli, İlhan. "Kente Karşı İşlenen Suç mu? Yoksa Kentlinin Gaspedilen Hakkı mı?”. Ege Mimarlık Dergisi, S. 12 (1994): 24-26.

Tekeli, İlhan. Modernite Aşılırken Kent Planlaması. Ankara: İmge Kitabevi, 2001.

Tekiner, Aylin. Atatürk Heykelleri: Kült, Estetik, Siyaset. 4. bs. İstanbul: İletişim Yayınları, 2014.

Tirben, Elif Gül. "Lived Space of White Collar Indsutrial Employees: A Case From Kocaeli”. Unpublished Master's Thesis, Middle East Technical University, Graduate School of Social Sciences, Ankara, 2007.

TMH. "1923-1940 Dönemi Demiryolları". Türkiye Mühendislik Haberleri 2-3, S. 442-443 (2006): 24-25.

TMH. "1948-1957 Dokuz Yılık Karayolu Programı”. Türkiye Mühendislik Haberleri 2-3, S. 442-443 (2006): 26-27.

TOKI. "Illere Göre Projeler”. 26 Şubat 2017 tarihinde http://www.toki.gov.tr/illere-goreprojeler adresinden erişildi.

TOKI. "Proje Tipine Göre Uygulamalar". 26 Şubat 2017 tarihinde http://www.toki.gov.tr/ proje-tipine-gore-uygulamalar adresinden erişildi.

Tol, Nevruz. "3. Shopping Fest 6 Haziran'da Başlayacak”. Büyükşehir Ankara 10, S. 480 (2014): 10-11.

Tol, Nevruz. "Başkan Melih Gökçek’ten Marka Kent Projeleri”. Büyükşehir Ankara 9, S. 408 (2012): 18-19.

Tol, Nevruz. “Büyükşehir'den 214 Çifte Muhteşem Düğün”. Büyükşehir Ankara 10, S. 486 (2014): 22.

Tol, Nevruz. "Büyükşehir'den Bu Yıl da 211 Çifte Düğün”. Büyükşehir Ankara 7, S. 319 (2011): 20.

Tol, Nevruz. "Kadınlar Günü Coşkuyla Kutlandı”. Büyükşehir Ankara 7, S. 315 (2011): 1619. 
Tol, Nevruz. "Ramazan'da Gençlik Parkı Rengarenk, Cıvıl Cıvıl”. Büyükşehir Ankara 8, S. 388 (2012): 8-11.

Tunç, Gülçin. "Transformation of Public Space: The Case of Migros Akkopru Shopping Center". Unpublished Master's Thesis, Middle East Technical University, Graduate School of Social Sciences, Ankara, 2003.

Turan, Deren. "Mekan-Müzik İlişkisi Açısından Türkiye'de 'Taverna'”. Yayınlanmamış Yüksek Lisans Tezi, Dokuz Eylül Üniversitesi, Güzel Sanatlar Enstitüsü, İzmir, 2011.

Turan, Nursen. “Başkan Gökçek Gençlik Parkı'nda Ramazan Etkinliklerinde”. Büyükşehir Ankara 8, S. 389 (2012): 20-21.

Turan, Nursen. "Büyükşehir, 2015 Yılında 215 Çifti Evlendirecek”. Büyükşehir Ankara 11, S. 539 (2015): 12-13.

Turan, Nursen. "Büyükşehir Daha da Büyüdü”. Büyükşehir Ankara 9, S. 403 (2012): 3-9.

Turan, Nursen. "Çubuk-1 Barajı Yeniden Doğuyor”. Büyükşehir Ankara 7, S. 311 (2011): $1-7$.

Turan, Nursen. "Gençlik Parkı'na Gençlik Aşısı”. Büyükşehir Ankara 1, S. 27 (2005): 1718.

Turan, Nursen. “Gökçek: 'Shopping Fest İçin Anadolu Basınından Destek Bekliyorum”'. Büyükşehir Ankara 8, S. 371 (2012): 16-17.

Turan, Nursen. "Kuzey Yıldızı Külliyesi Hızla İlerliyor". Büyükşehir Ankara 13, S. 609 (2016): 3-7.

Turan, Nursen. “Türkiye'nin En Görkemli Camisi ve Külliyesi Esenboğa Yolu Kuzey Yıldızı'na İnşa Ediliyor”. Büyükşehir Ankara 10, S. 493 (2014): 4-7.

Turan, Nursen ve Seyithan Melih Bingöl. "Başkan Gökçek: "2014 Yüz Akı Bir Yıl Oldu””. Büyükşehir Ankara 11, S. 528 (2015): 1-21.

Turan, Nursen ve Seyithan Melih Bingöl. "Büyükşehir'in 38 Dev Eserini Cumhurbaşkanı Erdoğan Açtı”. Büyükşehir Ankara 11, S. 534 (2015): 3-9.

Turan, Nursen ve Nevruz Tol. "Ankara Alışveriş Festivali Haziran'da Başlıyor”. Büyükşehir Ankara 8, S. 369 (2012): 3-9.

Tureli, İpek A. "Istanbul, Open city: Exhibiting Anxieties of Urban Modernity". PhD Thesis, University of California, Berkeley, Graduate Division. ProQuest Dissertations \& Theses Global, 2008.

Turhanoglu, F. A. K. "Spatial Production of Ankara as Capital City of Republican Turkey". International Journal of Interdisciplinary Social Sciences 5, S. 5 (2010): 309-318.

Turkan, Işıl. "Alış-Veriş-Tüketim Mabetleri: Sosyoekonomik Açıdan Mekân Tüketiminde Türkiye Örneği”. İleti-ş-im, Özel Sayı 2 (2012): 85-104.

Türkiye İş Bankası. "İş Bankası'na Avrupa Yatırım Bankası'ndan 200 Milyon Euro Kredi”, 2014. 1 Mart 2017 tarihinde http://www.isbank.com.tr/TR/hakkimizda/haberlerve-medya/haberler/sayfalar/haberler.aspx?4DDCBC12-B456-4049-8BDAFB3415CAE7E1 idCol=1538 adresinden erişildi.

Uçar, Nihat. “Ankaraspor, Osmanlıspor Oldu”. Büyükşehir Ankara 10, S. 495 (2014): 30. 
Uludağ, Zeynep, Nur Çağlar ve Zeynep Tuna Ulutav. "Conservation: Re-building an Urban Consiousness". Studies in the History of Gardens \& Designed Landscapes: An International Quarterly 25, S. 1 (2005): 23-39.

Uludağ, Zeynep Sökmen. "The Social Construction of Meaning in Landscape Architecture: A Case Study of Gençlik Parkı in Ankara". Unpublished PhD Thesis, Middle East Technical University, Graduate School of Natural and Applied Sciences, Ankara, 1998.

Uluengin, Mehmet Bengü. "Secularizing Anatolia Tick By Tick: Clock Towers in the Ottoman Empire and the Turkish Republic". International Journal of Middle East Studies 42, S. 1 (2010): 17-36.

Uluengin, Mehmet Bengü ve Ömer Turan. "İmparatorluğun İhtişam Arayışından Cumhuriyet'in Radikal Modernleşme Projesine: Türkiye'de Kentsel Planlamanın İlk Yüz Yılı”. Türkiye Araştırmalar Literatür Dergisi 3, S. 6 (2005): 353-436.

Unwin, Tim. "A Waste of Space? Towards a Critique of the Social Production of Space...". Transactions of the Institute of British Geographers 25, S. 1 (2000): 11-29.

Uslu, Ateş. "“Hür” Dünyanın Saflarında”. G. Atılgan, C. Saraçoğlu ve A. Uslu (Ed.), Osmanlı'dan Günümüze Türkiye'de Siyasal Hayat içinde (ss. 341-386). İstanbul: Yordam Kitap, 2015.

Ustundag, Zulal Nazan. "Belonging to the Modern: Women's Suffering and Subjectivities in Urban Turkey". PhD Thesis, Indiana University, Department of Sociology. ProQuest Dissertations \& Theses Global, 2005.

Uzun, Nil C. "Ankara'da Konut Alanların Dönüşümü: Kentsel Dönüşüm Projeleri”. T. Şenyapılı (Ed.), "Cumhuriyet”in Ankara’sı içinde (2. bs., ss. 198-215). Ankara: ODTÜ Yayıncılık, 2006.

Uzun, Nil C. "Yeni Yasal Düzenlemeler ve Kentsel Dönüșüme Etkileri”. Planlama 2006/2 (2006): 49-52.

Uzunali, Görkem. "Zeki Demirkubuz Sinemasında Mekân Kullanımı". Yayınlanmamış Yüksek Lisans Tezi, Hacettepe Üniversitesi, Sosyal Bilimler Enstitüsü, Ankara, 2015.

Varlı-Görk, Reyhan. "The Making of a "City of Culture": Restructuring Antalya". Unpublished PhD Thesis, Middle East Technical University, Graduate School of Social Sciences, Ankara, 2010.

Varlı-Görk, Reyhan. "The Transformation of Antalya into a "City of Culture": An Attempt at Rhythmanalysis". G. Erdi-Lelandais (Ed.), Understanding the City: Henri Lefebvre and Urban Studies içinde (ss. 139-168). Cambridge Scholars Publishing, 2014.

Weedon, Chris. Feminist Practice and Poststructuralist Theory. Oxford: Blackwell, 1987.

West-Pavlov, Russell. Space in Theory: Kristeva, Foucault, Deleuze. New York: Rodopi, 2009.

Wilson, Christopher S. Anıtkabir'in Ötesi: Atatürk’ün Mezar Mimarisi: Ulusal Belleğin Inşası ve Sürdürülmesi. (M. Beşikçi, Çev.). 1. bs. İstanbul: Koç Üniversitesi Yayınları, 2015. 
Wilson, Christopher S. "Remembering and Forgetting in the Funerary Architecture of Mustafa Kemal Atatürk: The Construction and Maintenance of National Memory". Unpublished PhD Thesis, Middle East Technical University, Graduate School of Natural and Applied Sciences, Ankara, 2007.

Wilson, Christopher S. "The Persistence of the Turkish Nation in the Mausoleum of Mustafa Kemal Atatürk". M. Young, E. Zuelow ve A. Sturm (Ed.), Nationalism in a Global Era: The Persistence of Nations içinde (ss. 82-103). Routledge, 2007.

Wishnitzer, Avner. "Modern Turkey, Real Time, and Other Functional Fabrications in Tanpınar's The Time Regulation Institute". Journal of the Ottoman and Turkish Studies Association 2, S. 2 (2015): 379-400.

World Bank. "Turkey-Cadastre Modernization Project". Washington, DC: World Bank, 2007. 1 Mart 2017 tarihinde http://documents.worldbank.org/curated/ en/128381468108879761/Turkey-Cadastre-Modernization-Project adresinden erişildi.

Yalım, İnci. "Ulus Devletin Kamusal Alanda Meşruiyet Aracı: Toplumsal Belleğin Ulus Meydanı Üzerinden Kurgulama Çabası”. G. A. Sargın (Ed.), Ankara’nın Kamusal Yüzleri: Başkent Üzerine Mekân-Politik Tezler içinde (ss. 157-214). İstanbul: İletişim Yayınları, 2002.

Yaman, Murat. "Kentsel Dönüşüm Uygulamaları Ankara Büyükşehir Belediyesi: Dikmen Vadisi 3. Etap Örneği”. Yayınlanmamış Doktora Tezi, Ankara Üniversitesi, Sosyal Bilimler Enstitüsü, Ankara, 2011.

Yardımcı, Sinem. "Transformation of Urban Sphere: Hacıbayram Square and Its Environment, Ankara". Unpublished Master's Thesis, Middle East Technical University, Graduate School of Natural and Applied Sciences, Ankara, 2008.

Yasin, Melikşah. "Kentsel Dönüşüm Uygulamalarının Hukuki Boyutu". Türkiye Barolar Birliği Dergisi, S. 60 (2005): 105-137.

Yavuz, Hilmi. "Modernleşme: Parça mı, Bütün mü? Batılılaşma: Simge mi, Kavram mı?”. T. Bora ve M. Gültekingil (Ed.), Modern Türkiye'de Siyasî Düşünce 3. Cilt Modernleşme ve Batıcılık içinde (4. bs., ss. 212-217). İstanbul, 2007.

YAYED. "Kapanacak Köy ve Beldeler Listesi (Büyükşehirler)". 4 Mart 2017 tarihinde http://www.yayed.org/id315-incelemeler/kapanacak-koy-ve-beldeler-listesibuyuksehirler.php adresinden erişildi.

Yazıcı Yakın, Aslı. "Vilayetim Angara: Ankara Oyun Havaları ve Pavyon”. Kebikeç, S. 40 (2015): 37-62.

Yelsalı Parmaksız, Pınar Melis. "From Ars Memoria to Postmnemonic Society: In Search of Lost Times in Levent-Gültepe". Moment Journal 1, S. 2 (2014): 34-56.

Yeşil, Sinem Şahin. "Psikocoğrafya ve Bir Şehir Gezgininin Anıları". Monograf, S. 2016/5 (2016): 124-149.

Yeşilkaya, Neşe Gurallar. Halkevleri: Ideoloji ve Mimarlık. 1. bs. İstanbul: İletişim, 1999.

Yildiz, Ugur. "'Precarity' of the Territorialized State: Immigrants Re-drawing and ReMapping the Borders". Journal of Borderlands Studies 31, S. 4 (2016): 521-536.

Yıldırım, Deniz. "AKP ve Neoliberal Popülizm”. İ. Uzgel ve B. Duru (Ed.), AKP Kitabı: Bir Dönüşümün Bilançosu içinde (ss. 66-107). Ankara: Phoenix Yayınevi, 2009. 
Yıldırım, Uğur. "Malazgirt Atışması". Sabah.com.tr, 19 Şubat 2014. 14 Şubat 2017 tarihinde http://www.sabah.com.tr/ankara-baskent/2014/02/19/malazgirtatismasi adresinden erişildi.

Yılmaz, Ayşenur. "Gezi Movement: An Analysis in the Context of Place/Space, the Discursive Practices and the Society". Unpublished Master's Thesis, Middle East Technical University, Graduate School of Natural and Applied Sciences, Ankara, 2015.

Yılmaz, Mahir. "An Inquiry into Different Urban Transformation Models in the Context of Rent and Property Transfer: The Case of Ankara Mamak District". Unpublished Master's Thesis, Middle East Technical University, Graduate School of Social Sciences, Ankara, 2011.

Yucel, Sebnem. "The Routes: Cultural Identity and Architecture of Turkey, 1980-2000". PhD Thesis. Arizona State University. ProQuest Dissertations \& Theses Global, 2003.

Yüceşahin, Murat ve Suat Tuysuz. "Ankara Kentinde Sosyo-Mekânsal Farklılaşmanın Örüntüleri: Ampirik Bir Analiz”. Coğrafi Bilimler Dergisi 9, S. 2 (2011): 159-188.

Yüksekli, Berrin Akgün ve Aysu Akalin. "Space as a Projection of Spatial Practices: An Urban Park in Western Anatolia in the Early-Republican Period". Middle Eastern Studies 47, S. 4 (2011): 641-654.

Yüksekli, Berrin Akgün. "Balıkesir Atatürk Parkı: Erken Cumhuriyetten Günümüze Türkiye'de Değişen Söylem ve Tasarımın Bir Kent Park Üzerinden Örneklenmesi”. Uluslararası Sosyal Araştırmalar Dergisi 6, S. 25 (2013): 33-46.

Zencirci, Gizem. "Secularism, Islam, and the National Public Sphere: Politics of Commemorative Practices in Turkey". A. Çınar, S. Roy ve M. Yahya (Ed.), Visualizing Secularism and Religion: Egypt, Lebanon, Turkey, India içinde (ss. 93-109). Ann Arbor: The University of Michigan Press, 2012.

Zengin, Ozan. "Büyükşehir Belediyesi Sisteminin Dönüşümü: Son On Yılın Değerlendirmesi”. Ankara Barosu Dergisi 2 (2014): 91-116.

Zürcher, E. J. Turkey: A Modern History, Revised Edition. I. B. Tauris, 2004. 

EKLER 



\section{EKLER}

\section{EK 1: Türkiye'de Mekânın Üretimi Literatürünün Değerlendirmesine Dair Not ve Açıklamalar}

Çalışma kapsamında gerçekleştirilen literatür değerlendirmesinde amaç Lefebvre'in mekânın üretimi kuramsal çerçevesini farklı biçimlerde temel alan ve Türkiye'yi konu eden çalışmaların ortaya çıkarılıp kapsamlı olarak değerlendirilmesi olmuştur. Sosyal bilimlerde mekân ile ilgili çalışmaların sistematik değerlendirilmeye tabi tutulması aslında ihtiyatla yaklaşılması gereken bir yöntem olduğu önceden belirtilmelidir, zira sosyal bilimler özü itibarıyla böyle bir değerlendirme yapmasına fazla imkân sağlamamaktadır. Temel bilimlerde farklı konular ile ilgili araştırmaların sistematik değerlendirmeye tabi tutulmasının çok yaygın bir yaklaşım olduğu görülmektedir, çünkü bu alanlarda bilimsel bilginin biçim ve formlar1 ${ }^{800}$ göreli olarak daha net bir şekilde formüle edilebildiği ayrıca bunların formüle edilmesi için daha elverişli imkanlar söz konusu olduğu için somut araştırmalarda bu bilgi biçimlerinin uygunlaştırılmasını takip etmek fazla sorun arz etmemektedir. Oysa sosyal teoride böyle bir yaklaşım bazen imkansızdır, yapıldığında ise konuya çok ihtiyatla yaklaşılmalıdır, zira paradigması olmayan sosyal bilimlerde ${ }^{801}$ her bir bilgi biçiminin uygunlaştırması ve işlevselleştirilmesi çok özgün bir durum olarak karşımıza çıkmaktadır. Konu ise çok soyut düzeyde kavramsallaştırmalarda bulunan Lefebvre gibi bir kurame1 olunca onun kavramsal çerçevesine dayanan araştırmaları ayırt edip değerlendirmek birtakım sorunları içermektedir.

Bununla birlikte burada böyle bir yönteme başvurulması çalışmanın temel teorik çerçevesi olan mekânın üretimi kuramının özelliklerinden kaynaklanmaktadır. Çalışmanın kuramsal tartışmalarında ele alındığ 1 üzere Lefebvre'in mekânın üretimi kuramı yapısalcı bir nitelik taşımakta ve az çok tutarlı bir kavramsal çerçeveyle karşımıza çıkmaktadır, dolayısıyla her bağlamda bu kavramların somut kullanımı ve uygunlaştırması çok farklı olmakla beraber Lefebvre'in kuramının somut araştırmalarda kullanımlarının genel bir değerlendirmesinin yapılmasına imkân tanımaktadır.

800 Burada bilimsel bilginin biçim ve formları altında, veri, sorunsal, kavram, hipotez, teori, paradigma kast edilmektedir.

801 Kuhn, The Structure of Scientific Revolutions. 
Lefebvre'in, kuramında öne sürdüğü kuramsal çerçeve ve birbiriyle karş11ıklı ilişkide bulunan kavramlar bir bütünlük arz etmesiyle beraber, bugünlerde akademide bu tutarlı kuramın farklı bileşenlerinin ayrı ayrı kullanıldığ 1 , tartışıldığ 1 ya da söz konusu kuramın bir veya iki kavrama indirgendiği görülmektedir (bkz. Birinci Bölümdeki tartışmalara, özellikle ilgili bölümün 5. alt bölümü). Dolayısıyla, somut araştırmalarda bu kuramı farklı biçimlerde benimseyerek, araştırmalarını ona dayandıran çalışmaların kapsamlı bir değerlendirilmeye tabi tutulması en azından iki soruya cevap verebilir:

1) Söz konusu kuram ne tür bağlamlarda uygunlaştırılmakta, yani hangi mekânsal ölçekler veya dönemler için uygunlaştırılmakta veya hangi olay ya da olguların incelenmesi için benimsenmektedir.

2) Benimsenen kavram(lar) nasıl uygunlaştırılmaktadır, yani söz konusu kuramın nasıl bir okuması gerçekleştirilmekte, böylelikle ilgili kavramlara nasıl bir içerik atfedilerek kullanılmaktadır.

$\mathrm{Bu}$ iki soruya cevap aranması söz konusu kuramın uygulama derecesini ortaya çıkartabilir, bu ise hem bu çalışma için yönlendirici bir işleve sahip olur hem de başka araştırmalara da yardımcı nitelikte genel bir tablo sunabilir. Dahası, bu soruların cevabı daha genel ve kuramsal bir sorunsala katkıda bulunur: Lefebvre'in mekân kuramının nasıl ele alındığı ve tartışıldığg sorusuna belirli ölçüde cevap verebilir.

Dolayısıyla Türkiye'de mekân veya mekânın üretimini konu eden çalışmaları sistematik bir biçimde değerlendirerek Türkiye'de hangi mekânsal ölçeklerde ve hangi tarihsel dönemler veya hangi olgu ya da olaylar için Lefebvre' in kuramına başvurulduğu, bunu yaparak onun kavramsal çerçevesinin nasıl yorumlandığı incelenmiştir, bu ise bir taraftan bu kuramın nasıl ele alındığını, var olan araştırmaların kuramın hangi bileşenlerini benimseyip benimsemediklerini, genel olarak Türkiye bağlamında bu kuramın ne derecede işlendiğini göstermiştir. Başka bir deyişle, böyle bir değerlendirme Türkiye bağlamında mekânın üretimi kuramının benimsenme ve tatbikinin kapsamını ortaya çıkarmıştır. Böyle bir değerlendirmenin sonuçları ise Türkiye'de Lefebvre'in kuramının ele alınmasının ve Türkiye'de mekânın üretimi araştırmalarının genel bir tablosunu ortaya koyarak özellikle çalışmanın yürütülmesine belirli ölçüde yardımcı olmuştur.

Konu ile ilgili çalışmaların değerlendirilmesi için ilk önce belirli tarama kriterleri seçilmiştir ve buna göre ilk önce mevcut çalışmalar ortaya çıkarılmıştır ve müteakip tarama ve filtreleme sürecinden sonra belirlenen çalışmaları değerlendirmek için sorulacak sorular belirlenmiştir. 
İlk önce farklı akademik veri tabanlarında ${ }^{802}$ Lefebvre, Türkiye ve mekân anahtar sözcüklerinin Türkçe ve İngilizce versiyonlarıyla tüm metin içerisinde tarama yapılarak ortaya çıkan yayınlar listelenmiştir. ${ }^{803}$ Fakat anahtar sözcükler çok genel nitelikte olduğu için ikinci etapta her çalışmanın başlı̆̆ı, özeti veya tüm metni inceleyerek Türkiye'yi konu eden, mekân ile ilgili olan ve Lefebvre'yi ele alan çalışmalar listeden ayrılmıştır. Bunu yaparken şu husus önemli bir kriter olmuştur: değerlendirmemiz, Lefebvre'in mekân kuramının Türkiye bağlamında uygulanışını ortaya çıkarmayı amaçlandığı için listelenen çalışmalarda Lefebvre'in Mekânın Üretimi çalışmasına referans verilerek bu kurama göndermede bulunup kuramın benimsenmesi şartı aranmıştır. Bunun gerekçesi ise Mekânın Üretimi kitabının, Lefebvre'in mekân kuramının en temel kaynağı olma hususudur. 804 Burada parantez açarak önemli başka bir hususa değinilmelidir. $\mathrm{Bu}$ değerlendirmede değerlendirilecek çalışmalarda özellikle Lefebvre'in kavramsal çerçevesinin kullanılıp kullanılmamasına ve kullanışın biçimine odaklanılmıştır. Lefebvre'in kuramına çok yaygın olarak başvurulduğunu, onun farklı saptamalarının somut bağlamlara uygunlaştırıldığını iddia eden fakat Lefebvre'in hiçbir kavramına başvurmayan çalışmalar değerlendirilmemiştir. ${ }^{805}$ Böyle bir anlayıştan yola çıkarak özellikle

802 Tarama için EBSCOhost, ProQuest Dissertations \& Theses Global, Akademik Google ve YÖK Ulusal Tez veri tabanları kullanılmıştır, basılı yayın ve kataloglara başvurulmamıştır, dolayısıyla ortaya çıkarılan çalışmalar konu ile ilgili tüm literatürü tamamıyla kapsamadığı hususu öncelikle belirtilmelidir.

803 İlk etapta belirlenen anahtar sözcüklerin kullanımıyla EBSCOhost veri tabanında 5953 sonuç, ProQuest Dissertations \& Theses Global veri tabanında 3008 sonuç, Google Scholar veri tabanında ise 6833 sonuç elde edilmiştir. Ayrıca YOK Ulusal Tez Veri tabanında tüm metin içerisinde arama imkânı olmadığı için daha detaylı anahtar sözcükler kullanılarak (Lefebvre, mekânın üretimi, mekânsal pratikler, mekân temsili, temsil mekânı vs.) 97 çalışma listelenmiştir. Burada belirtilmesi gereken husus, söz konusu taramaların 2016 yılı içerisinde gerçekleştirildiği ve 2016 yıl sonu itibarıyla taramaların tamamlandığı, dolayısıyla söz konusu veri tabanlarında taramalardan sonra yeni çalışmaların eklendiği ve değerlendirmemize dahil olamadıklarıdır. Ayrıca, 2016 yılı öncesine ait yayınların daha sonraki dönemlerde veri tabanlarına eklendiği de görülmektedir. Örneğin Google Scholar veri tabanı belirli bir algoritmaya dayanarak tarama gerçekleştirmektedir ve daha önce yayınlanmış olan çalışmaları veri tabanına dahil etmektedir, o yüzden daha önce yayınlanmış olup Google Scholar veri tabanına daha sonra eklenen çalışmaların bulunduğu ve bunların elde ettiğimiz sonuçlara dahil olmama ihtimali de hesaba katılmalıdır.

804 Örneğin, diğer çalışmalarda da Lefebvre, mekân konusunda çok sayıda saptamalarda ve önermelerde bulunur, fakat bunlara onun tüm eserlerinde dağınık bir biçimde rastlanmaktadır ve bunlarda mekân kuramı sistematik bir biçimde ele alınarak tartışılmamaktadır. Dolayısıyla Lefebvre'in "heterotopia", "kent hakk1" ve benzer kavramları mekanla dolaylı veya dolaysız biçimde ilişkili olmalarına rağmen Mekânın Üretimi çalışmasında ele alınmadığı için bu kavramlara dayanan somut araştırmalar inceleme dışı bırakılmıştır.

805 Örneğin akademide Lefebvre'in "her toplum kendi mekânını üretir" veya "mekân toplumsal bir üründür” gibi saptamalarına sayısız çalışmalarda rastlanabilir. Bu çalışmaların bir kısmı 
Lefebvre'in kuramını genel saptamalar niteliğinde değil belirli temel kavramlar aracılığıyla uygulayan çalışmalar değerlendirilmiştir.

Yukarıda belirtilen kriterlere dayanarak ortaya çıkarılan çalışmalar ${ }^{806}$ şu sorular doğrultusunda incelenmiştir:

1) Lefebvre'in mekân kuramının temel kuramsal çerçeve olarak benimsenmesi, diğer kuramsal çerçevelerle beraber kullanılması veya Lefebvre'in mekân kuramında öne çıkan belirli kavramların benimsenip uygulanması,

2) Çalışmada yer alan incelemelerin kapsadığı zaman dilimi ve mekânsal ölçeği,

3) Çalışmada somut zaman dilimi veya mekânsal ölçek söz konusu değilse, incelenen olay veya olgu,

4) Lefebvre'in kuramında yapısal olarak önce çıkan iki unsura - mekân dönemselleştirmesi veya mekânsal üçlü - veya bu iki unsurun bileşenlerinin ele alınıp alınmaması; onlara göre inceleme yapılıp yapılmaması.

$\mathrm{Bu}$ sorular doğrultusunda incelenen çalışmalar aşağıda tablo şeklinde sunulmuştur (bkz. Tablo A).

kendi inceleme ve değerlendirmelerinin söz konusu saptamalara dayandığını belirtse de görülen yaygın eğilim bunlarda Lefebvre'in önerdiği neredeyse hiçbir kavramsallaştırmanın benimsenmemesi hususudur.

806 Ele alınan kriterlere uyan çalışmaların sayısı veri tabanlara göre şöyledir: EBSCOhost - 19 çalışma, ProQuest Dissertations \& Theses Global - 19 çalışma, Akademik Google - 83 çalışma ve YÖK Ulusal Tez Veri tabanı -26 çalışma. 


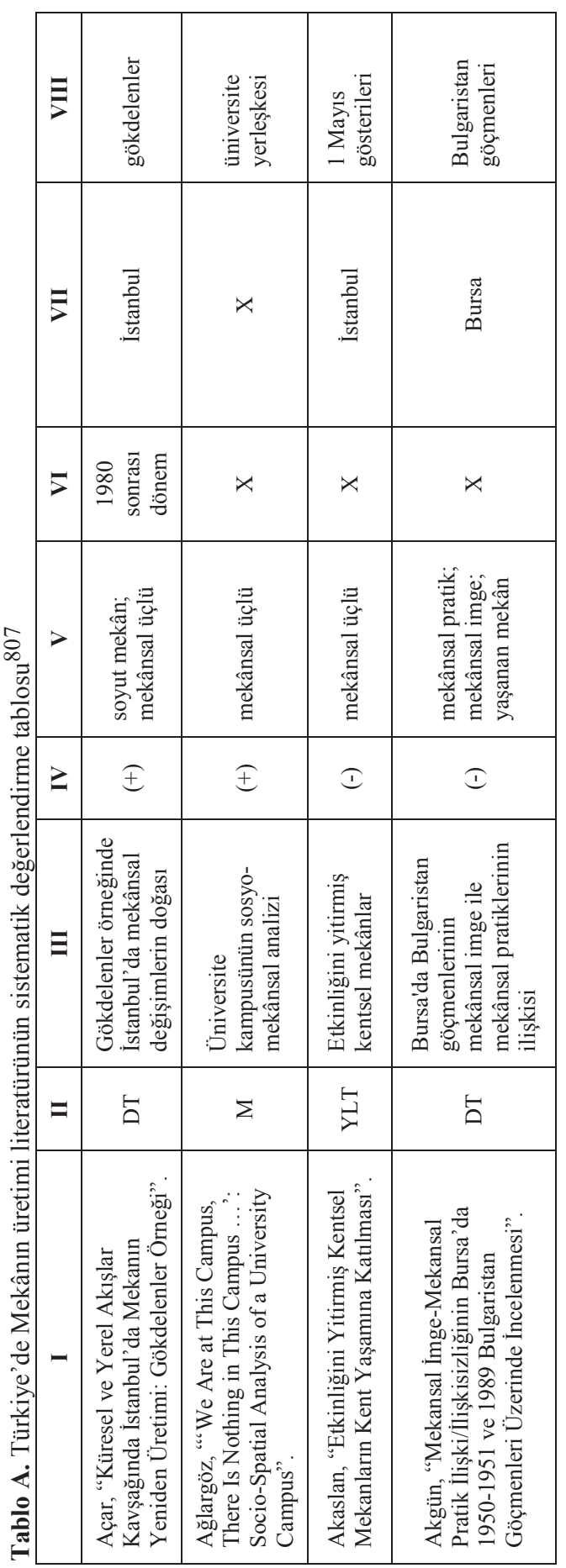

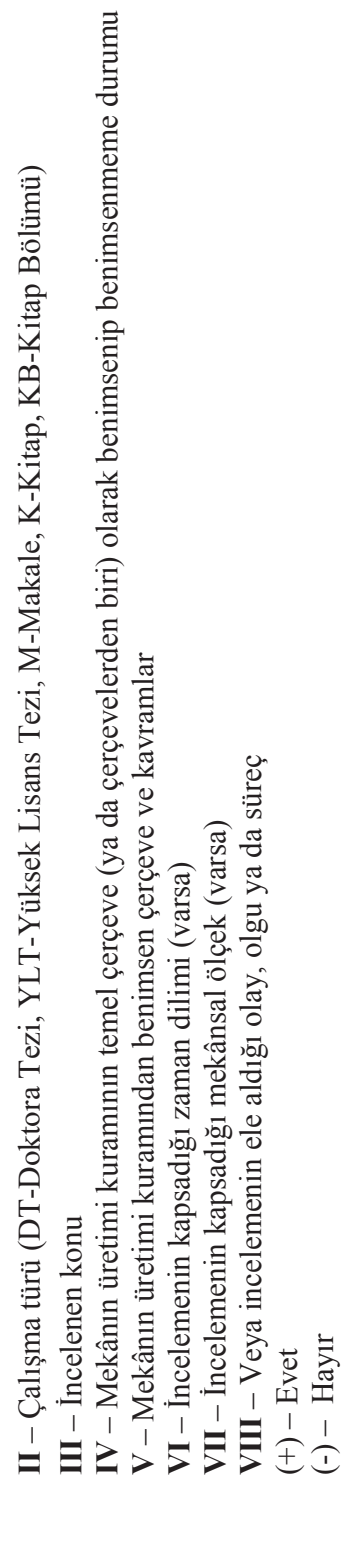


332 • Tarihsel, Soyut, Çelişkili: 1923'ten Günümüze Türkiye'de Kentsel Toplumsal Mekân

\begin{tabular}{|c|c|c|c|c|c|c|}
\hline$\equiv$ & 竞 & 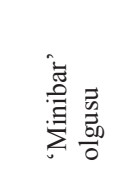 & $x$ & 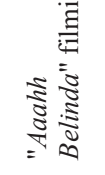 & $x$ & 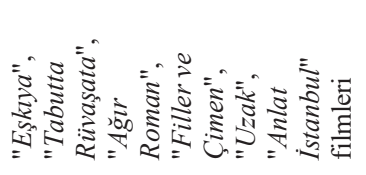 \\
\hline $\bar{z}$ & 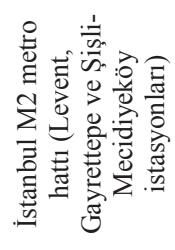 & 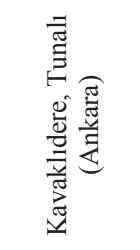 & 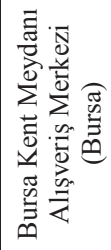 & $x$ & 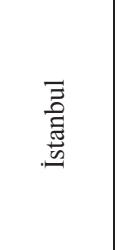 & $x$ \\
\hline 5 & $x$ & $x$ & $x$ & $x$ & $x$ & 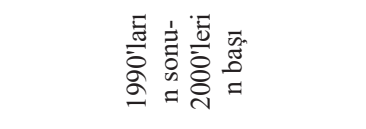 \\
\hline$>$ & 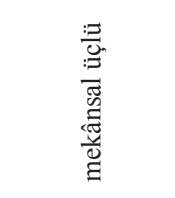 & 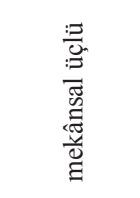 & 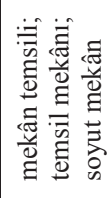 & 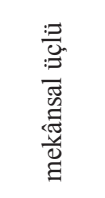 & 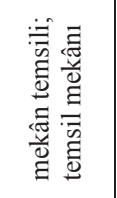 & 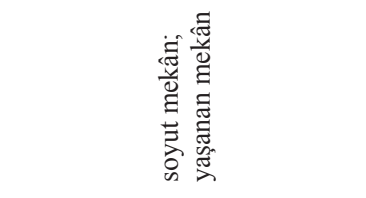 \\
\hline$z$ & I & I & ક & I & I & I \\
\hline$\Xi$ & 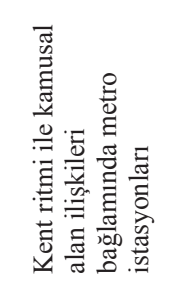 & 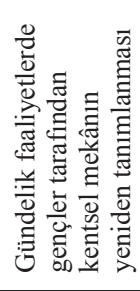 & 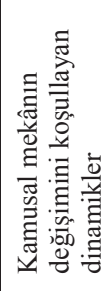 & 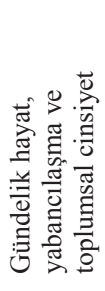 & 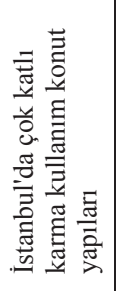 & 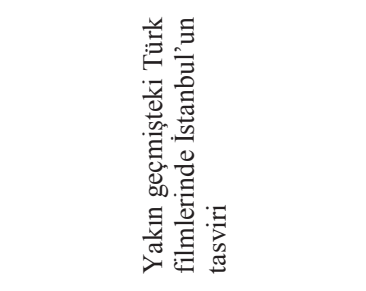 \\
\hline$=$ & $\stackrel{5}{\sqsupset}$ & 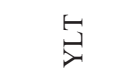 & $\stackrel{\vec{Z}}{\vec{\gamma}}$ & $\Sigma$ & 穴 & 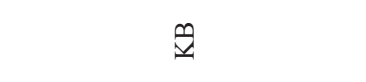 \\
\hline- & 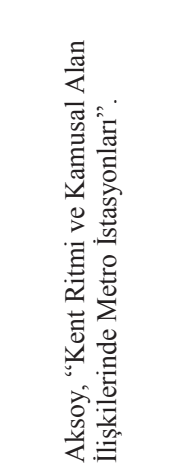 & 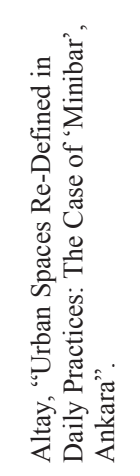 & 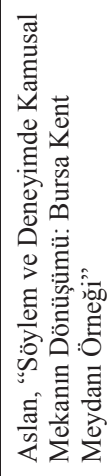 & 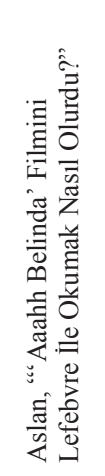 & 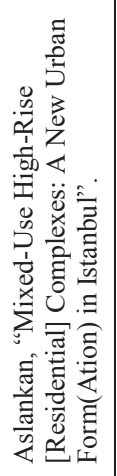 & 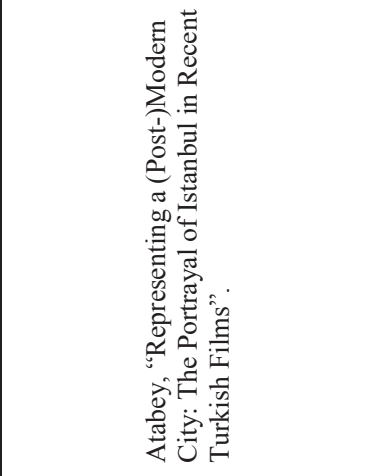 \\
\hline
\end{tabular}




\begin{tabular}{|c|c|c|c|c|c|c|}
\hline $\bar{\nabla}$ & 荡 & 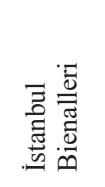 & $x$ & $x$ & 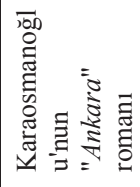 & 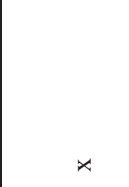 \\
\hline $\bar{\nabla}$ & 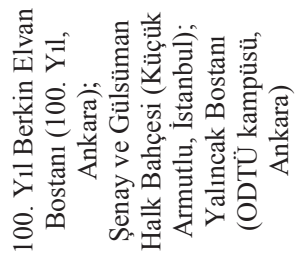 & $x$ & 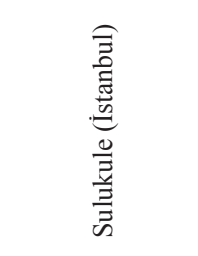 & 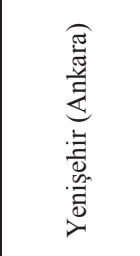 & 莺 & 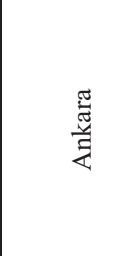 \\
\hline 5 & $x$ & $x$ & $x$ & ळ̊ & $x$ & 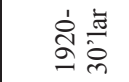 \\
\hline$>$ & 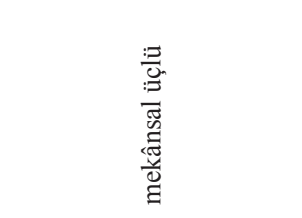 & 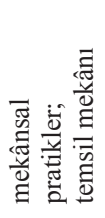 & 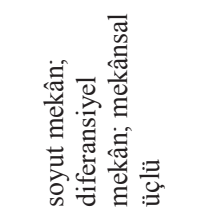 & 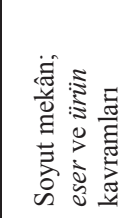 & 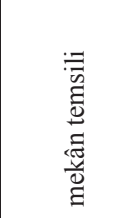 & 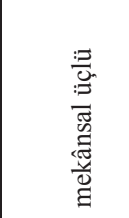 \\
\hline$\geq$ & I & I & ક & ક & I & ક \\
\hline$\Xi$ & 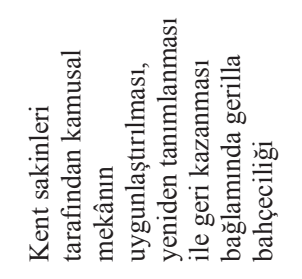 & 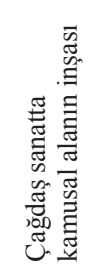 & 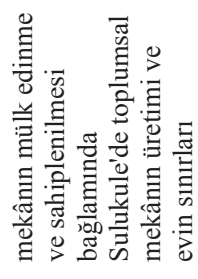 & 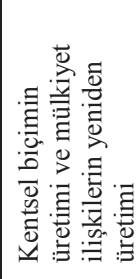 & 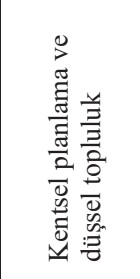 & 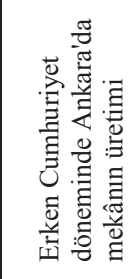 \\
\hline$=$ & $\stackrel{5}{\sqsupset}$ & $\stackrel{5}{\sqsupset}$ & $\stackrel{5}{二}$ & 穴 & $\Sigma$ & $\Sigma$ \\
\hline- & 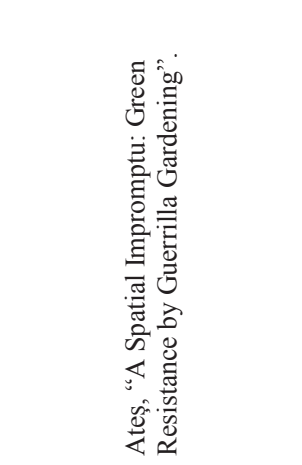 & 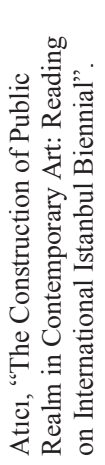 & 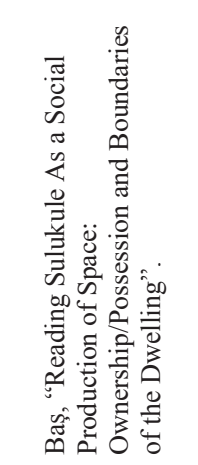 & 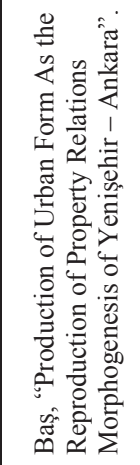 & 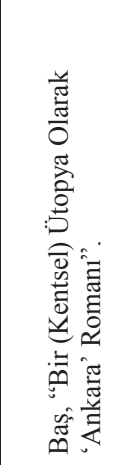 & 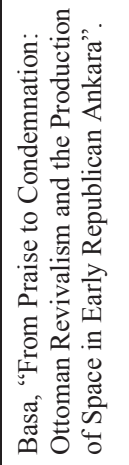 \\
\hline
\end{tabular}


334 • Tarihsel, Soyut, Çelişkili: 1923'ten Günümüze Türkiye'de Kentsel Toplumsal Mekân

\begin{tabular}{|c|c|c|c|c|c|c|c|}
\hline 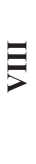 & 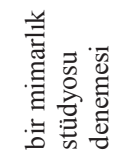 & $x$ & $x$ & 层声 & $x$ & $\rtimes$ & 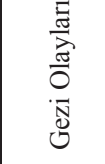 \\
\hline $\bar{\nabla}$ & 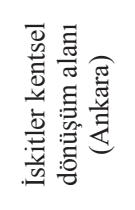 & 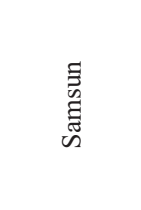 & 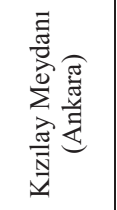 & 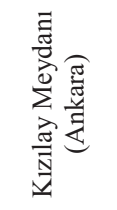 & 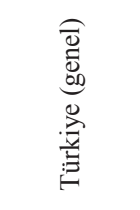 & $x$ & 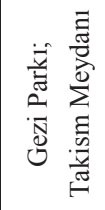 \\
\hline$>$ & $x$ & $x$ & 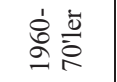 & 光 & 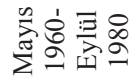 & 㝘 & $x$ \\
\hline$>$ & 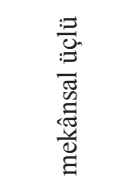 & 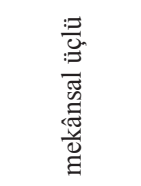 & 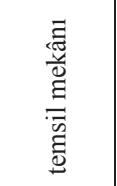 & 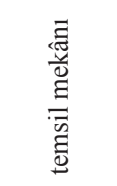 & 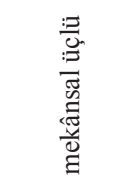 & 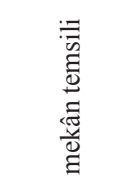 & 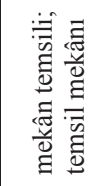 \\
\hline$z$ & ક & I & I & I & I & I & I \\
\hline$\Xi$ & 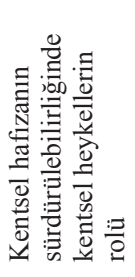 & 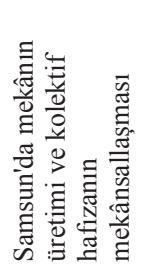 & 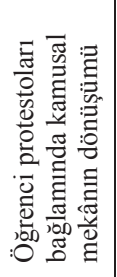 & 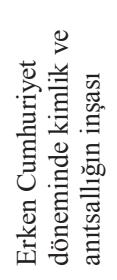 & 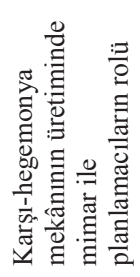 & 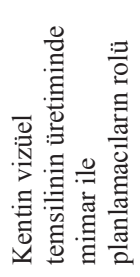 & 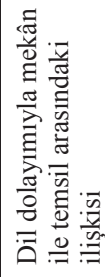 \\
\hline$=$ & $\Sigma$ & $\Sigma$ & $\Sigma$ & $\Sigma$ & 占 & $\Sigma$ & $\Sigma$ \\
\hline- & 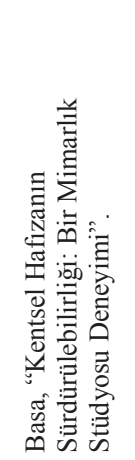 & 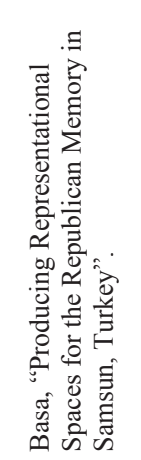 & 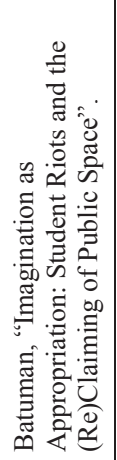 & 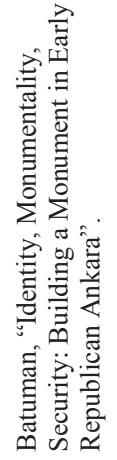 & 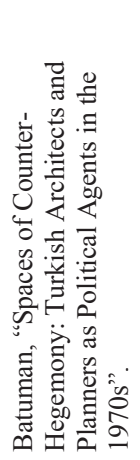 & 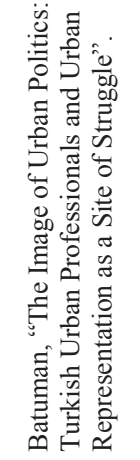 & 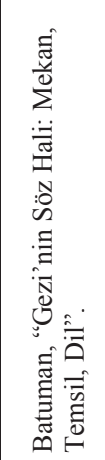 \\
\hline
\end{tabular}




\begin{tabular}{|c|c|c|c|c|c|}
\hline$\Xi$ & 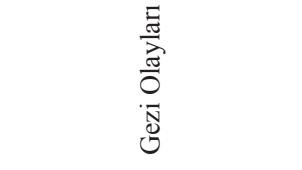 & 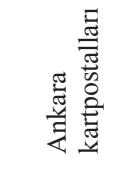 & $x$ & $x$ & $x$ \\
\hline $\bar{\nabla}$ & 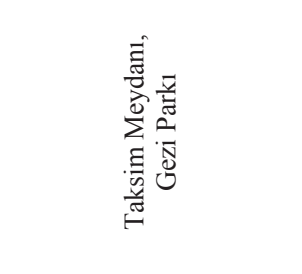 & $\frac{\tilde{a}}{\tilde{y}}$ & 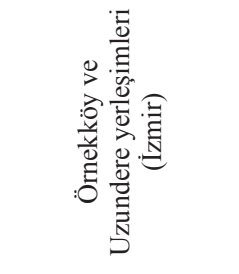 & 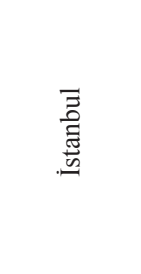 & 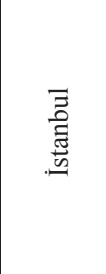 \\
\hline 5 & $x$ & 灾 & $x$ & 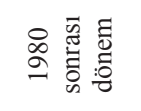 & $x$ \\
\hline$>$ & 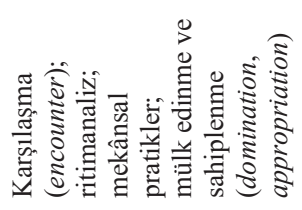 & 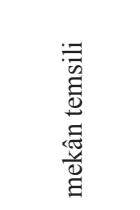 & 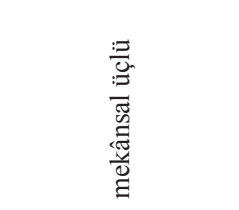 & 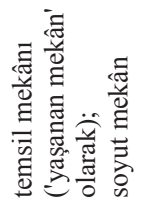 & 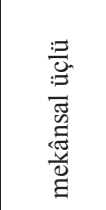 \\
\hline 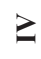 & I & I & ક & I & ક \\
\hline$\Xi$ & 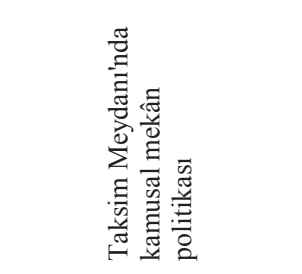 & 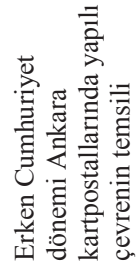 & 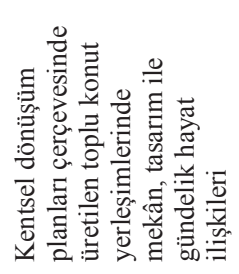 & 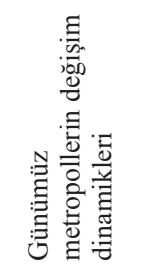 & 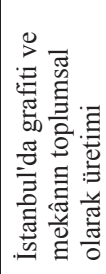 \\
\hline$=$ & $\Sigma$ & $\Sigma$ & $\Sigma$ & 占 & $\stackrel{n}{ }$ \\
\hline- & 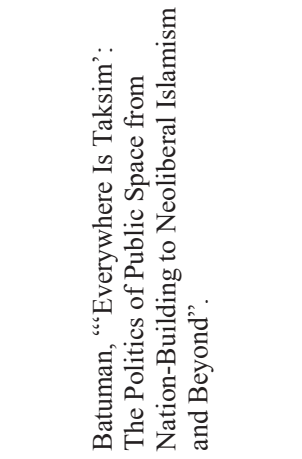 & 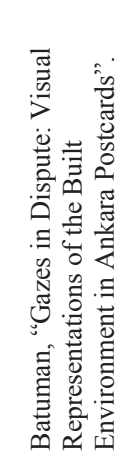 & 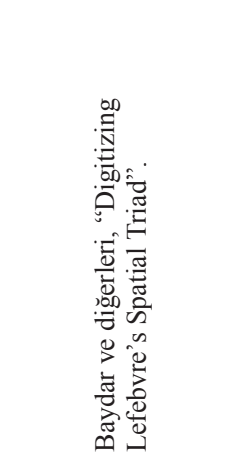 & 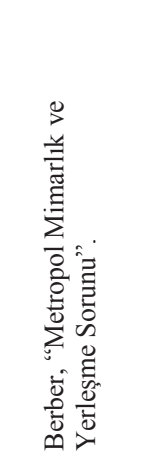 & 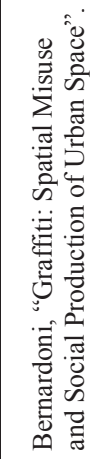 \\
\hline
\end{tabular}


336 • Tarihsel, Soyut, Çelişkili: 1923'ten Günümüze Türkiye'de Kentsel Toplumsal Mekân

\begin{tabular}{|c|c|c|c|c|c|c|}
\hline$\Xi$ & 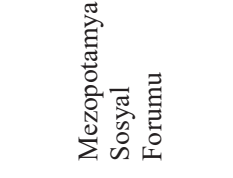 & 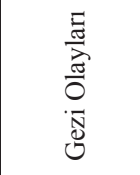 & $x$ & $x$ & $x$ & $x$ \\
\hline $\bar{\nabla}$ & $x$ & $\rtimes$ & 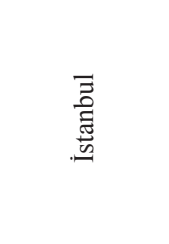 & 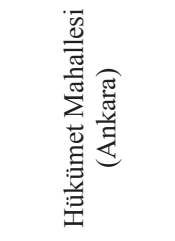 & 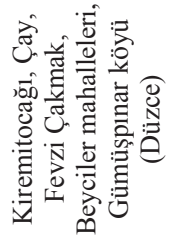 & 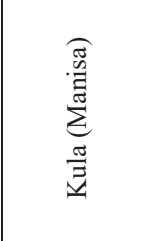 \\
\hline$>$ & $x$ & $x$ & 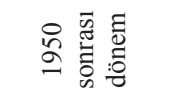 & 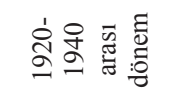 & $x$ & 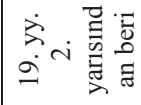 \\
\hline$>$ & 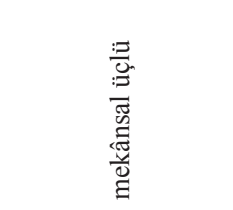 & 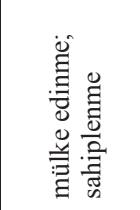 & 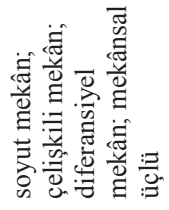 & 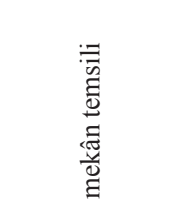 & 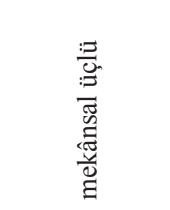 & 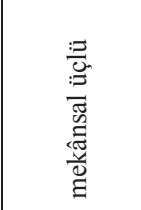 \\
\hline$\geq$ & I & I & I & I & I & I \\
\hline$\Xi$ & 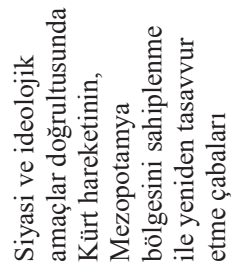 & 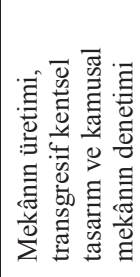 & 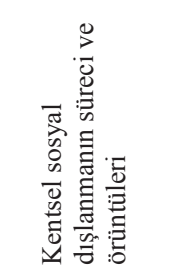 & 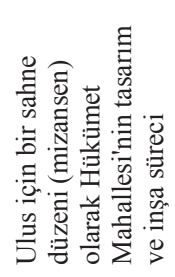 & 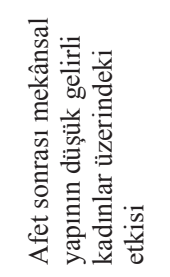 & 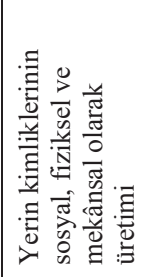 \\
\hline$=$ & $\Sigma$ & $\stackrel{⿱ ⺊ 尸}{コ}$ & $\stackrel{5}{コ}$ & $\Sigma$ & 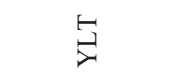 & 点 \\
\hline- & 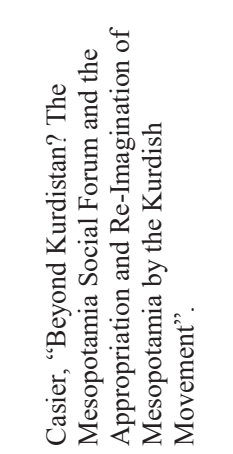 & 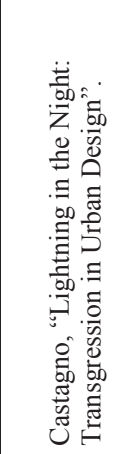 & 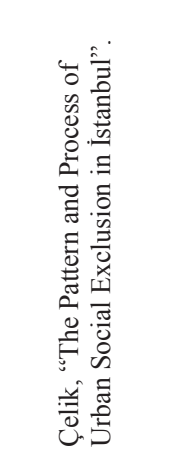 & 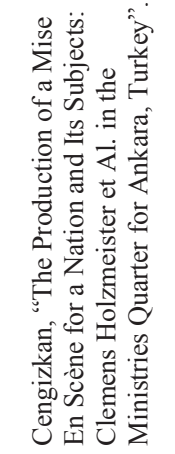 & 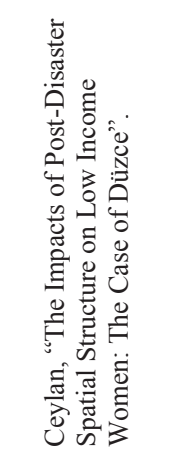 & 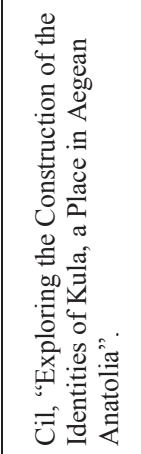 \\
\hline
\end{tabular}




\begin{tabular}{|c|c|c|c|c|c|c|}
\hline$\equiv$ & 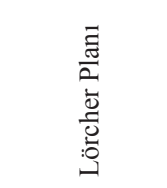 & 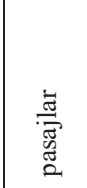 & $x$ & $x$ & 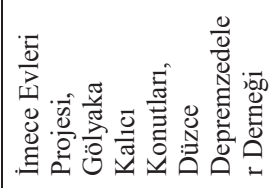 & 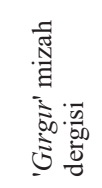 \\
\hline 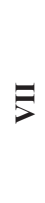 & $\begin{array}{l}\text { 喾 } \\
\text { 妾 }\end{array}$ & 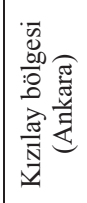 & 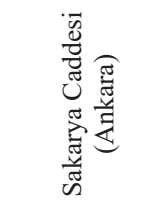 & 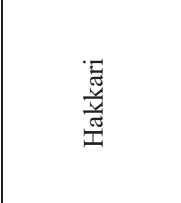 & 芯 & $x$ \\
\hline 5 & 芯 & $x$ & $x$ & $x$ & $x$ & $x$ \\
\hline$>$ & 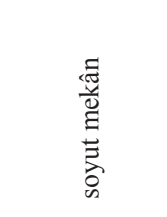 & 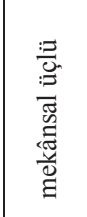 & 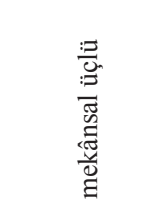 & 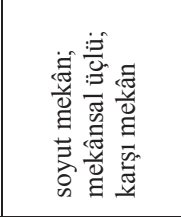 & 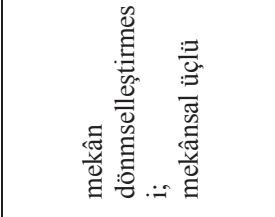 & 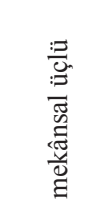 \\
\hline$z$ & 玉 & I & I & ક & $\mp$ & I \\
\hline$\Xi$ & 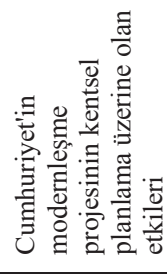 & 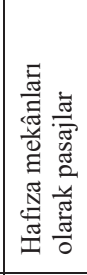 & 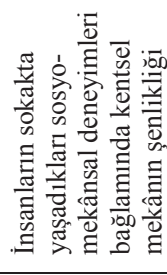 & 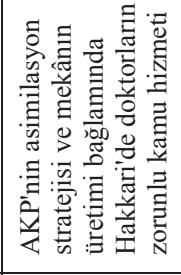 & 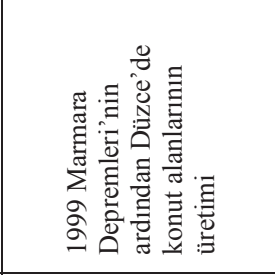 & 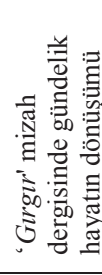 \\
\hline$=$ & $\Sigma$ & $\underset{\nearrow}{\stackrel{⿹}{二}}$ & $\stackrel{5}{2}$ & $\underline{y}$ & $\stackrel{\vec{\nu}}{二}$ & $\grave{0}$ \\
\hline- & 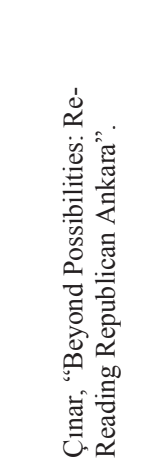 & 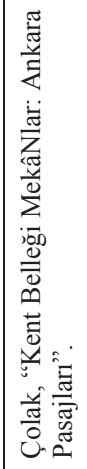 & 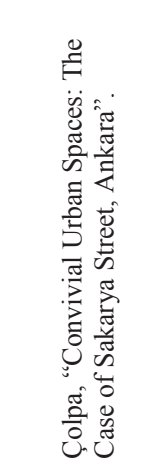 & 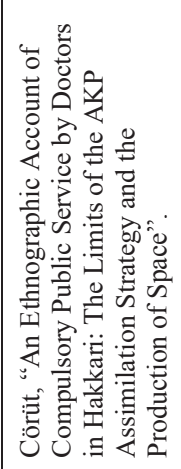 & 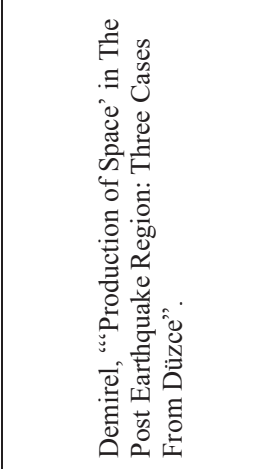 & 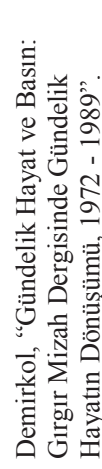 \\
\hline
\end{tabular}


338 • Tarihsel, Soyut, Çelişkili: 1923'ten Günümüze Türkiye'de Kentsel Toplumsal Mekân

\begin{tabular}{|c|c|c|c|c|c|c|}
\hline 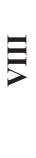 & $x$ & $x$ & 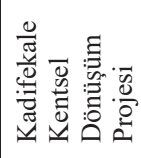 & $x$ & $x$ & 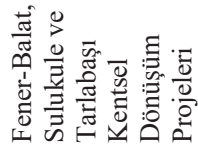 \\
\hline $\bar{\nabla}$ & 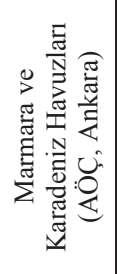 & 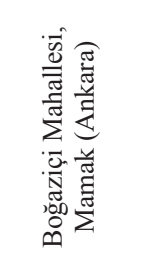 & 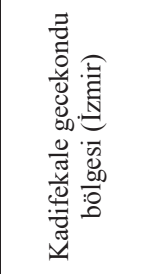 & 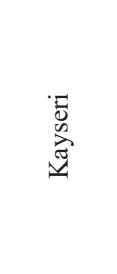 & 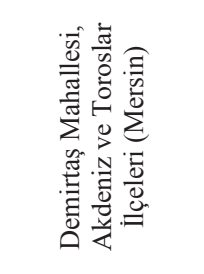 & 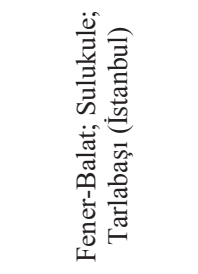 \\
\hline$>$ & 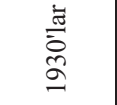 & 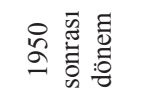 & $x$ & 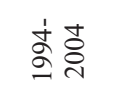 & 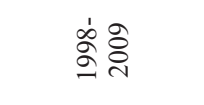 & \&̊ \\
\hline$>$ & 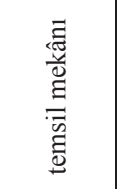 & 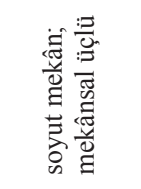 & 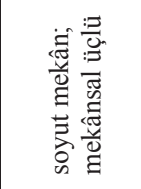 & 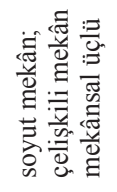 & 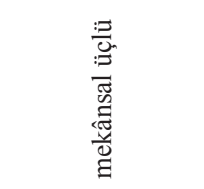 & 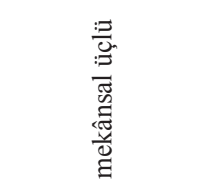 \\
\hline$\geq$ & I & I & I & I & I & I \\
\hline$\Xi$ & 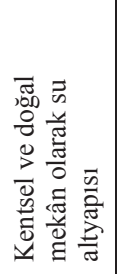 & 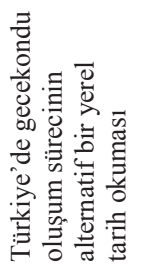 & 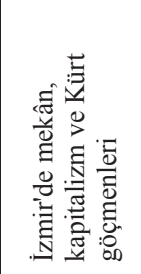 & 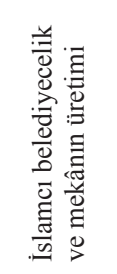 & 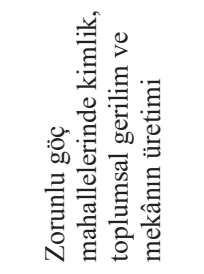 & 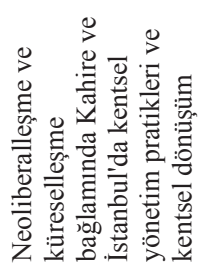 \\
\hline$=$ & $\stackrel{\leftrightarrows}{\sqsupset}$ & 苛 & 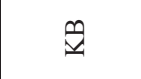 & 穴 & $\Sigma$ & 苛 \\
\hline- & 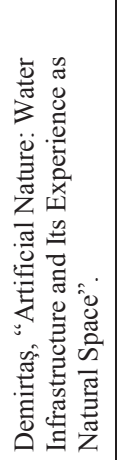 & 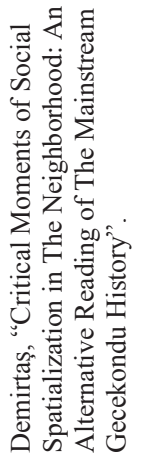 & 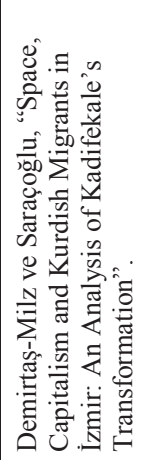 & 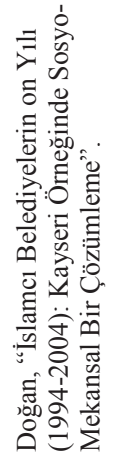 & 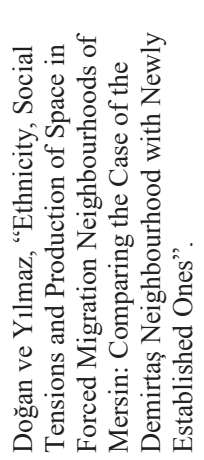 & 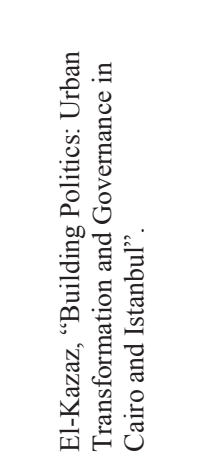 \\
\hline
\end{tabular}




\begin{tabular}{|c|c|c|c|c|c|c|}
\hline$\equiv$ & 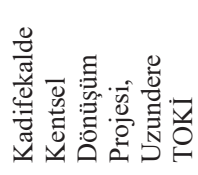 & 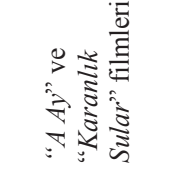 & $x$ & $x$ & $x$ & 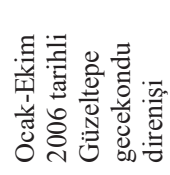 \\
\hline $\bar{\Sigma}$ & 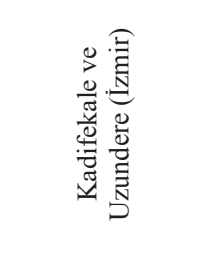 & $x$ & 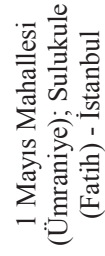 & 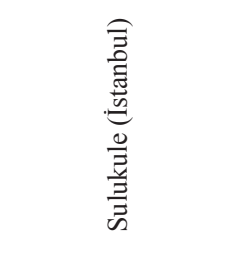 & 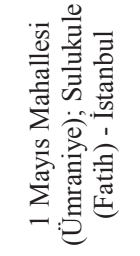 & 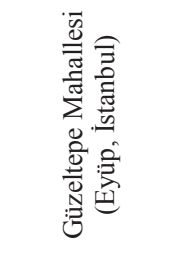 \\
\hline 5 & $x$ & $x$ & $x$ & $x$ & $x$ & $x$ \\
\hline$>$ & 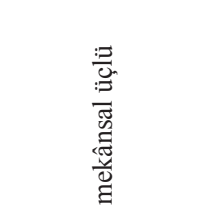 & 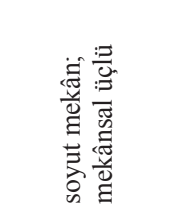 & 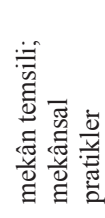 & 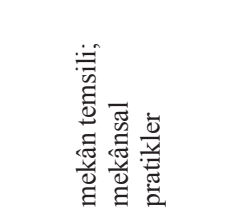 & 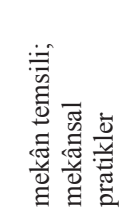 & 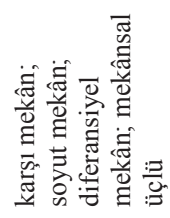 \\
\hline$\geq$ & I & I & I & I & I & ક \\
\hline$\Xi$ & 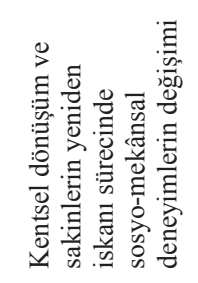 & 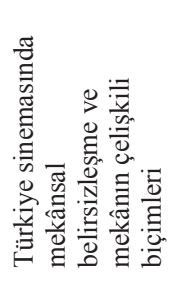 & 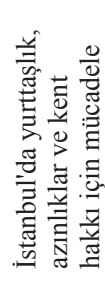 & 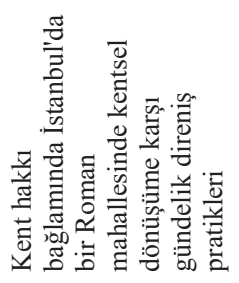 & 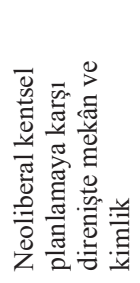 & 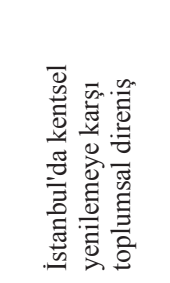 \\
\hline$=$ & $\Sigma$ & $\stackrel{5}{\underset{\gamma}{二}}$ & $\Sigma$ & $\underline{v}$ & $\Sigma$ & $\underset{\nu}{\stackrel{⿹}{二}}$ \\
\hline- & 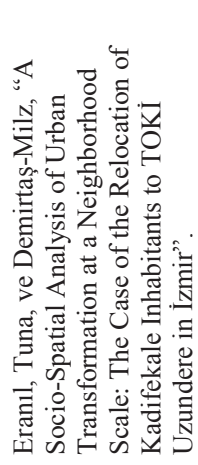 & 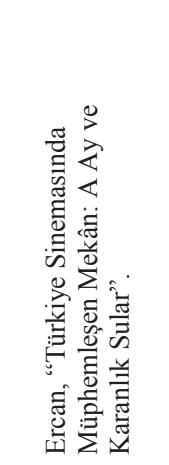 & 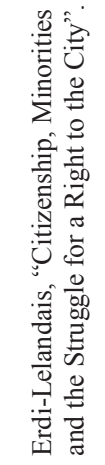 & 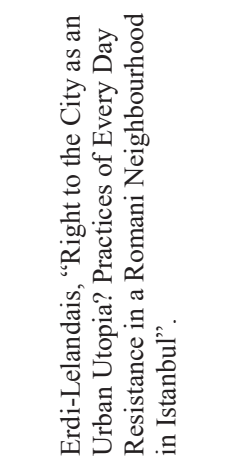 & 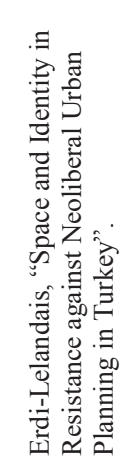 & 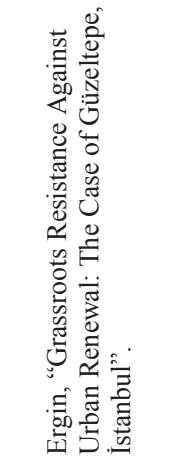 \\
\hline
\end{tabular}


340 • Tarihsel, Soyut, Çelişkili: 1923'ten Günümüze Türkiye'de Kentsel Toplumsal Mekân

\begin{tabular}{|c|c|c|c|c|c|}
\hline$\equiv$ & 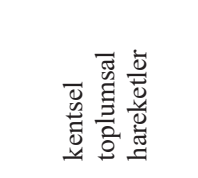 & 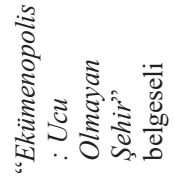 & 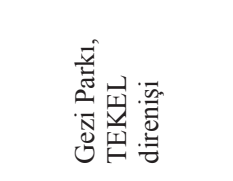 & 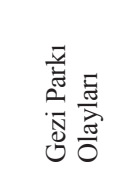 & 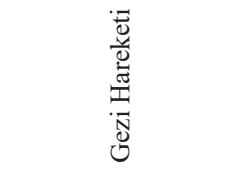 \\
\hline $\bar{\nabla}$ & 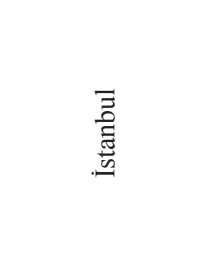 & $x$ & $x$ & 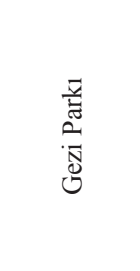 & 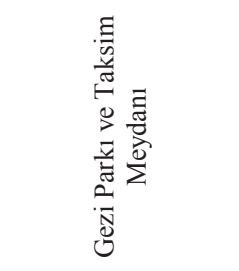 \\
\hline 5 & 을 胥 & $x$ & $x$ & $x$ & $x$ \\
\hline$>$ & 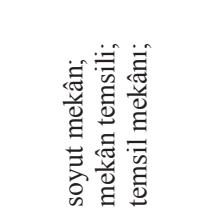 & 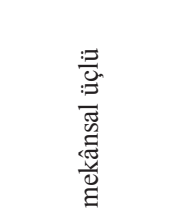 & 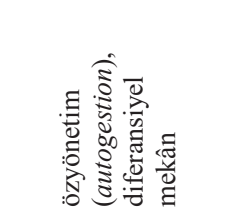 & 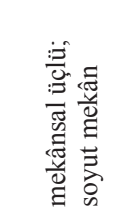 & 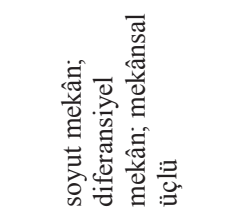 \\
\hline$\geq$ & I & I & I & I & I \\
\hline$\Xi$ & 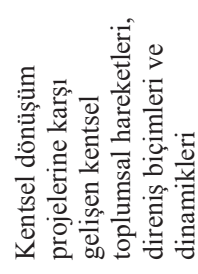 & 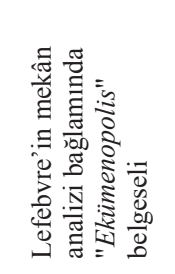 & 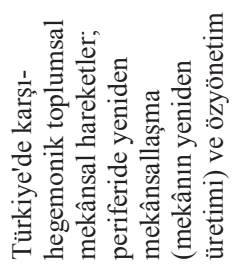 & 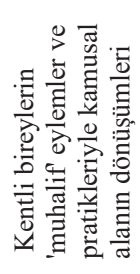 & 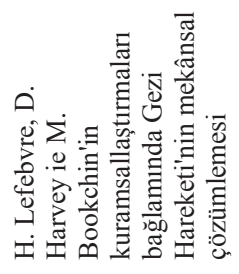 \\
\hline$=$ & 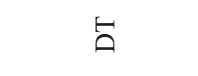 & $\Sigma$ & $\Sigma$ & $\underset{⿱ ㇒ 士}{コ}$ & $\Sigma$ \\
\hline- & 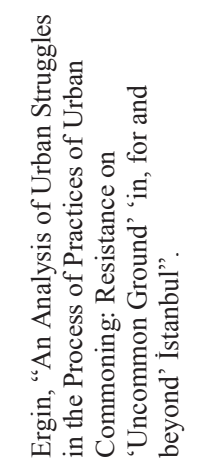 & 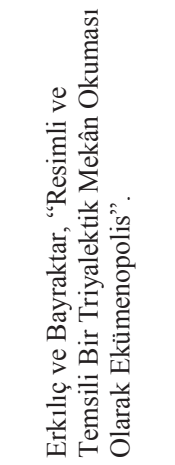 & 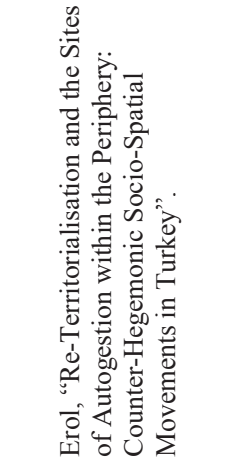 & 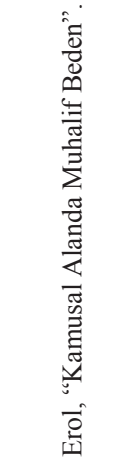 & 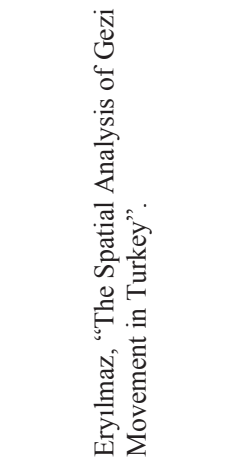 \\
\hline
\end{tabular}




\begin{tabular}{|c|c|c|c|c|c|c|}
\hline $\bar{\nabla}$ & 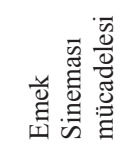 & 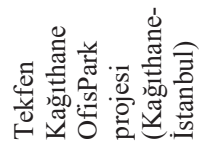 & $x$ & $x$ & 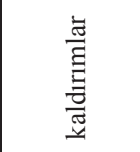 & $x$ \\
\hline $\bar{\nabla}$ & $x$ & $x$ & 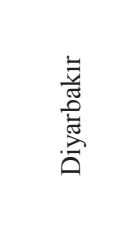 & 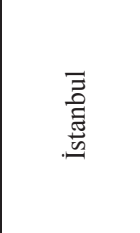 & 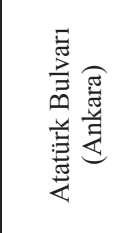 & 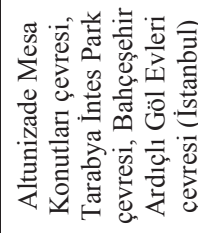 \\
\hline 5 & $x$ & $x$ & ڤें & 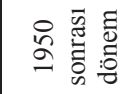 & $\stackrel{\overbrace{}}{2} \stackrel{m}{\overrightarrow{2}}$ & $x$ \\
\hline$>$ & 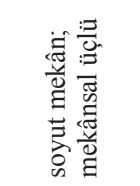 & 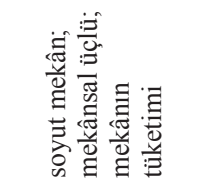 & 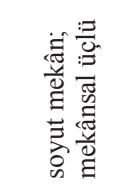 & 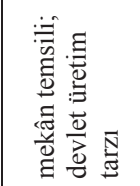 & 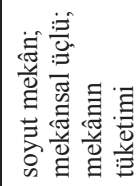 & 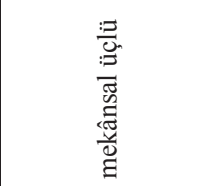 \\
\hline$\geq$ & I & I & ક & ક & I & I \\
\hline$\Xi$ & 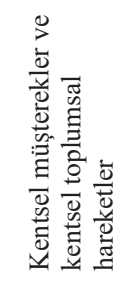 & 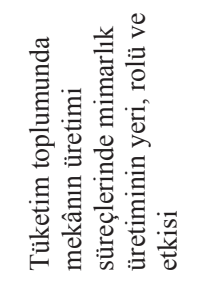 & 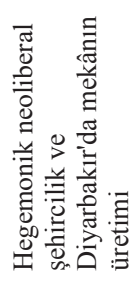 & 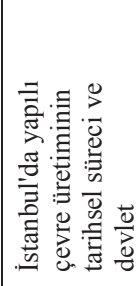 & 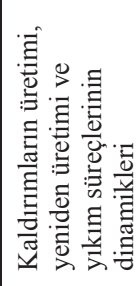 & 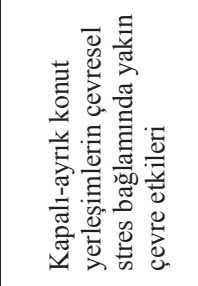 \\
\hline$=$ & $\Sigma$ & $\Sigma$ & 点 & $\stackrel{5}{\circ}$ & 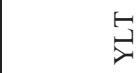 & $\Sigma$ \\
\hline- & 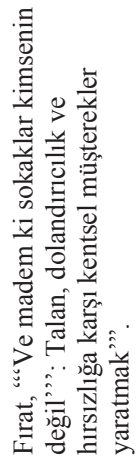 & 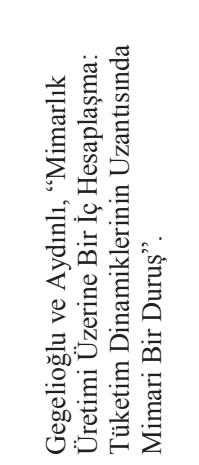 & 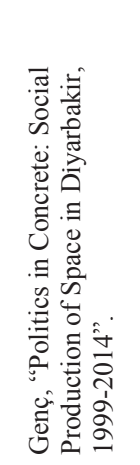 & 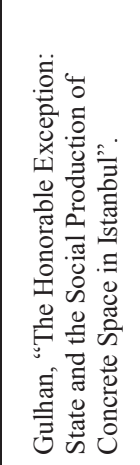 & 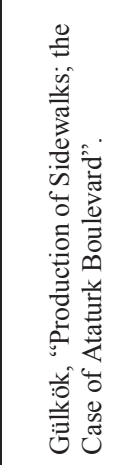 & 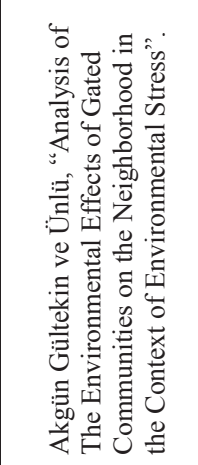 \\
\hline
\end{tabular}


342 • Tarihsel, Soyut, Çelişkili: 1923'ten Günümüze Türkiye'de Kentsel Toplumsal Mekân

\begin{tabular}{|c|c|c|c|c|c|}
\hline $\bar{\nabla}$ & 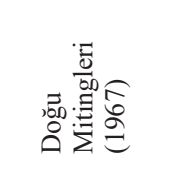 & $x$ & 咅 & 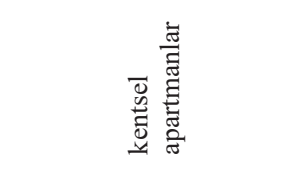 & $\begin{array}{l}\frac{5}{\sqrt{5}} \\
\frac{\pi}{0} \\
. \bar{N} \\
0 \\
0\end{array}$ \\
\hline $\bar{\nabla}$ & 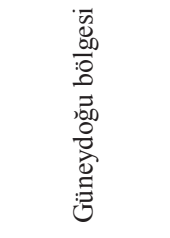 & 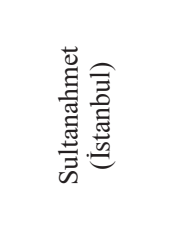 & $x$ & $x$ & 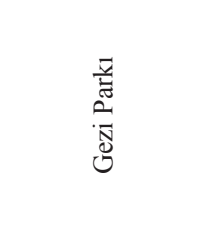 \\
\hline 5 & $\begin{array}{l}\text { పే } \\
\overline{0} \\
\stackrel{0}{\circ}\end{array}$ & $x$ & 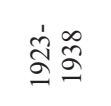 & $\begin{array}{l}\text { 它。 } \\
2 \\
2\end{array}$ & $x$ \\
\hline$>$ & 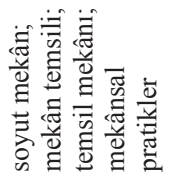 & 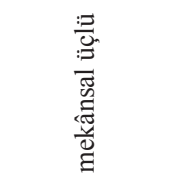 & 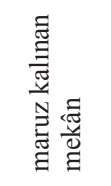 & 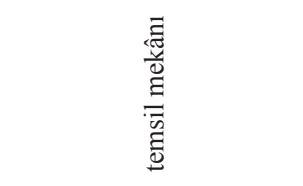 & 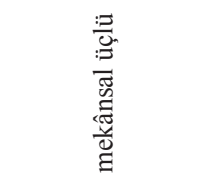 \\
\hline$z$ & I & I & I & I & I \\
\hline$\Xi$ & 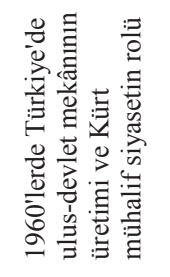 & 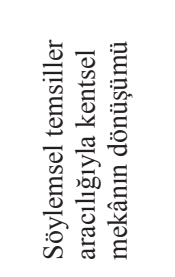 & 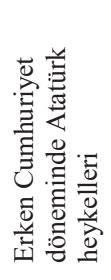 & 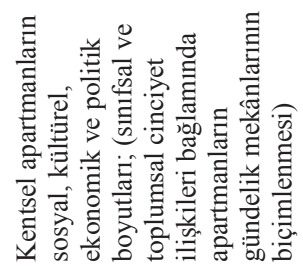 & 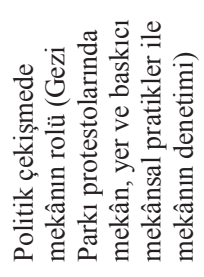 \\
\hline$=$ & $\Sigma$ & $\Sigma$ & 苛 & 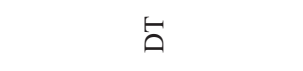 & $\underset{⿱ ㇒}{\leftrightarrows}$ \\
\hline- & 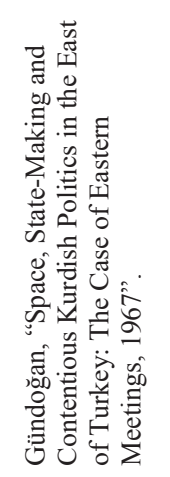 & 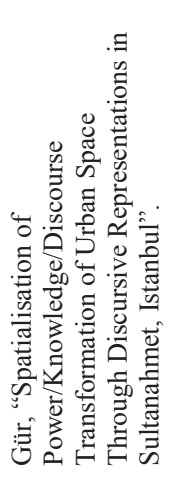 & 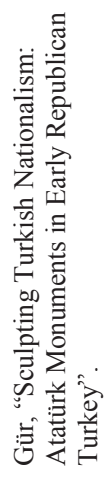 & 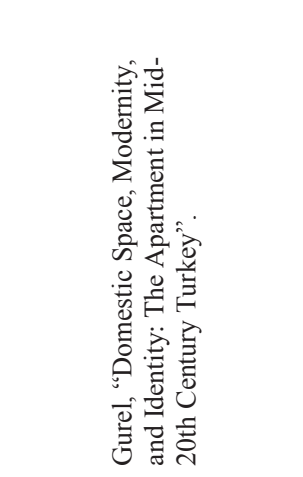 & 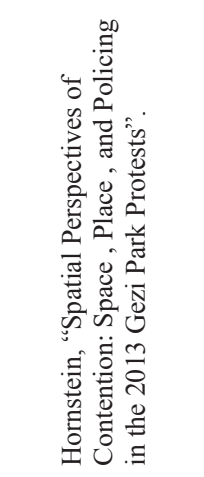 \\
\hline
\end{tabular}




\begin{tabular}{|c|c|c|c|c|c|}
\hline$\Xi$ & $x$ & 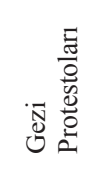 & $x$ & 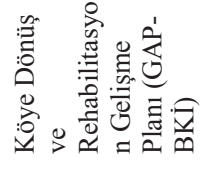 & 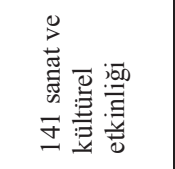 \\
\hline $\bar{\nabla}$ & 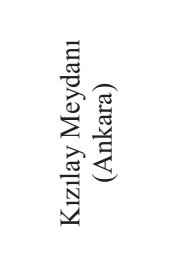 & 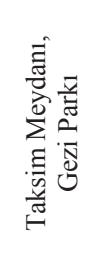 & 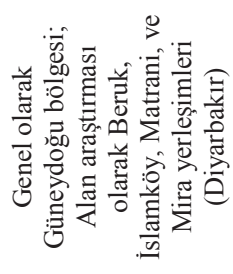 & 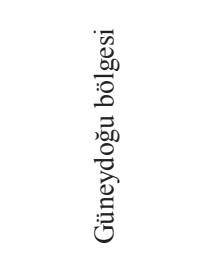 & 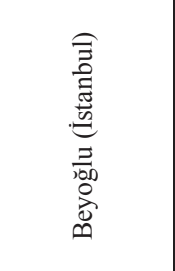 \\
\hline$>$ & 离: & $x$ & 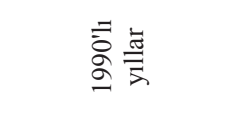 & $x$ & $x$ \\
\hline$>$ & 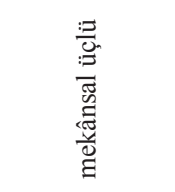 & 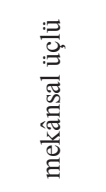 & 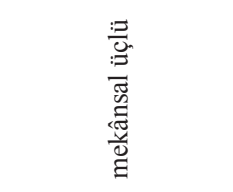 & 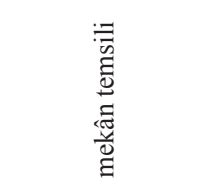 & 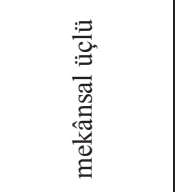 \\
\hline$\geq$ & I & I & $\mp$ & I & I \\
\hline$\Xi$ & 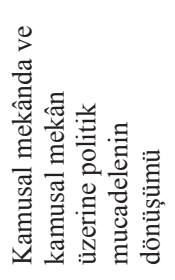 & 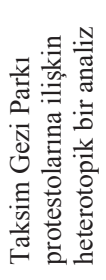 & 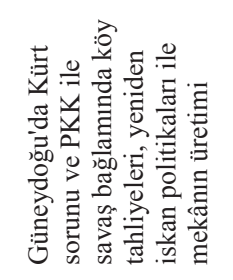 & 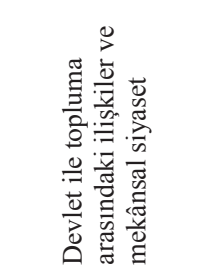 & 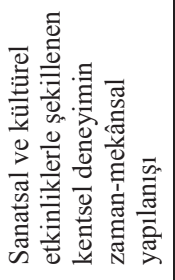 \\
\hline$=$ & $\stackrel{5}{\leftrightarrows}$ & $\stackrel{5}{二}$ & $\forall$ & $\Sigma$ & 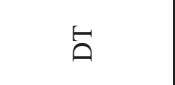 \\
\hline- & 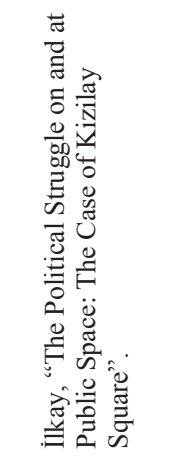 & 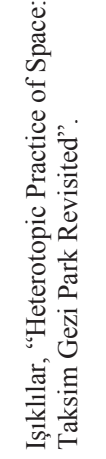 & 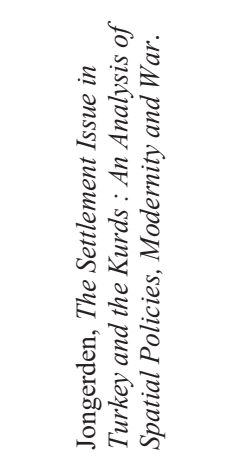 & 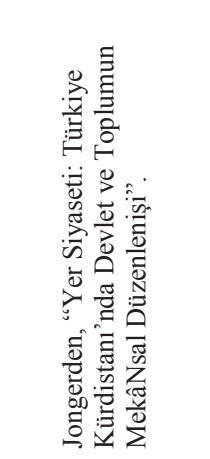 & 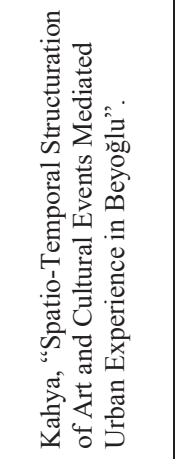 \\
\hline
\end{tabular}


344 • Tarihsel, Soyut, Çelişkili: 1923'ten Günümüze Türkiye'de Kentsel Toplumsal Mekân

\begin{tabular}{|c|c|c|c|c|c|c|}
\hline$\Xi$ & $x$ & 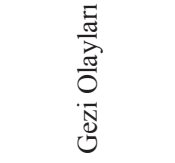 & $x$ & $x$ & $x$ & $\begin{array}{l}\text { 离 } \\
\text { 晜 }\end{array}$ \\
\hline $\bar{\nabla}$ & $x$ & 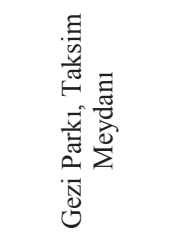 & 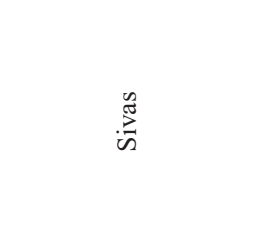 & $\frac{\widetilde{\pi}}{\tilde{\Xi}}$ & $\frac{\widetilde{a}}{\frac{\pi}{\pi}}$ & $x$ \\
\hline 5 & 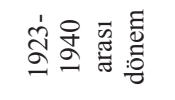 & $x$ & 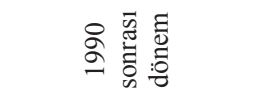 & $\stackrel{\sim}{2} \cong$ & $\underset{\check{a}}{\infty}$ & $x$ \\
\hline$>$ & 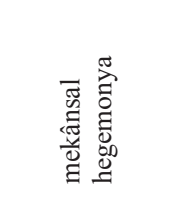 & 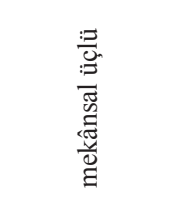 & 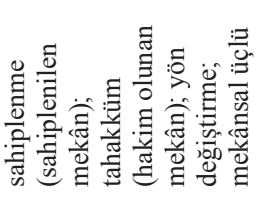 & 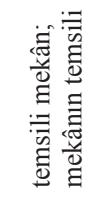 & 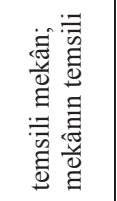 & 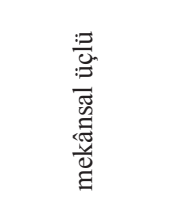 \\
\hline$\geq$ & I & I & ક & I & I & I \\
\hline$\Xi$ & 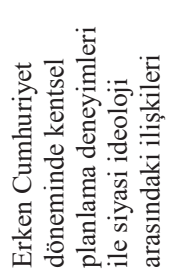 & 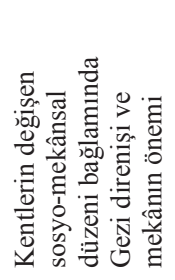 & 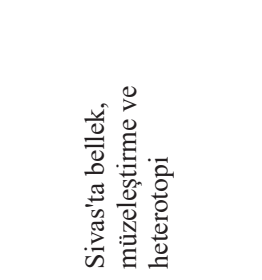 & 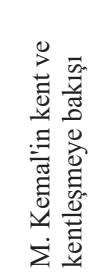 & 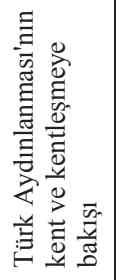 & 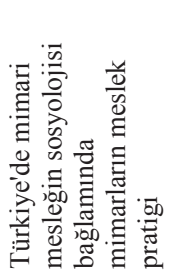 \\
\hline$=$ & $\underset{⿱ 乛 士 ㇒}{~}$ & $\Sigma$ & 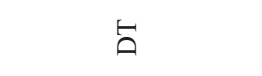 & $\Sigma$ & $\Sigma$ & 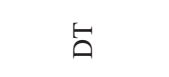 \\
\hline- & 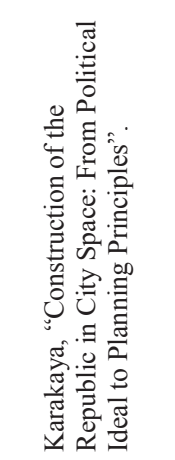 & 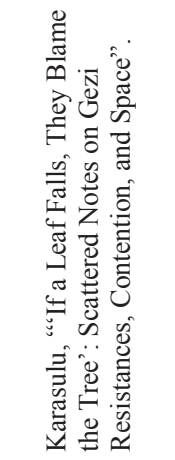 & 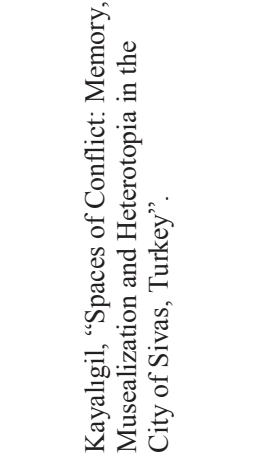 & 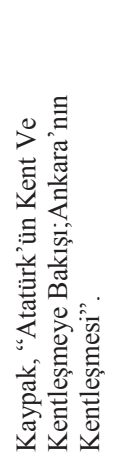 & 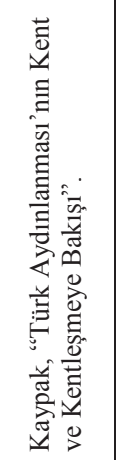 & 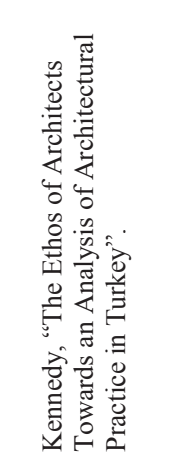 \\
\hline
\end{tabular}




\begin{tabular}{|c|c|c|c|c|c|}
\hline 寻 & $x$ & 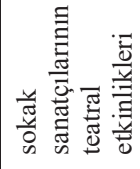 & $x$ & 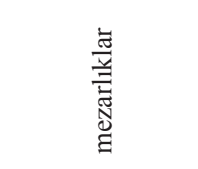 & 式 \\
\hline $\bar{\nabla}$ & 昙 & 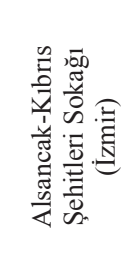 & 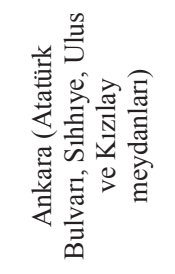 & 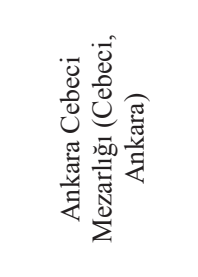 & 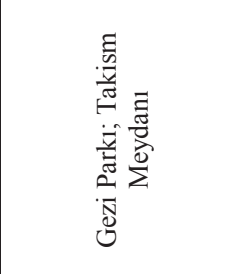 \\
\hline 5 & $x$ & $x$ & ڤૂ'ڤ & $x$ & $x$ \\
\hline$>$ & 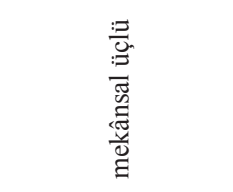 & 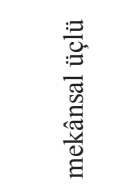 & 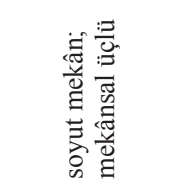 & 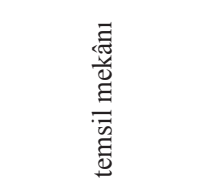 & 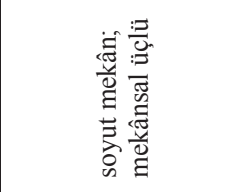 \\
\hline$\geq$ & I & I & I & I & I \\
\hline$\Xi$ & 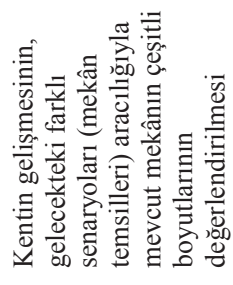 & 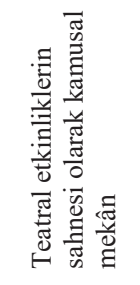 & 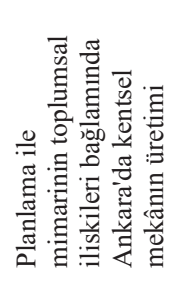 & 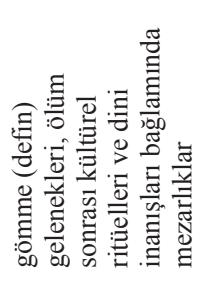 & 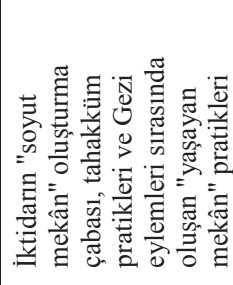 \\
\hline$=$ & $\Sigma$ & $\Sigma$ & 它 & $\stackrel{5}{\searrow}$ & 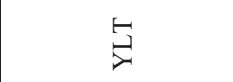 \\
\hline- & 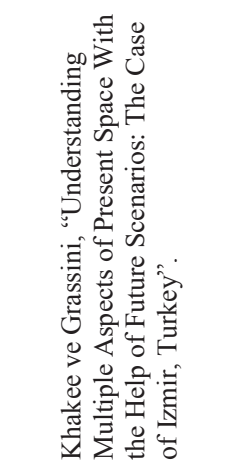 & 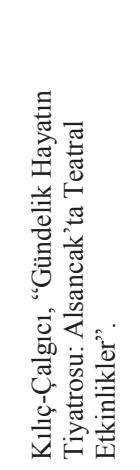 & 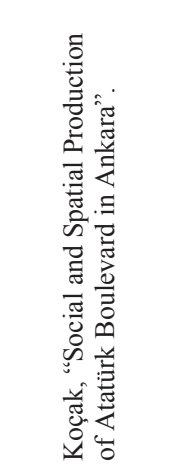 & 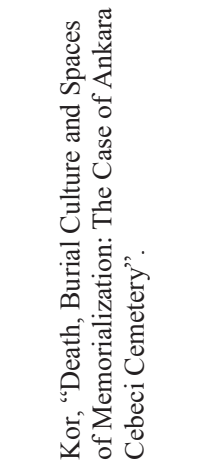 & 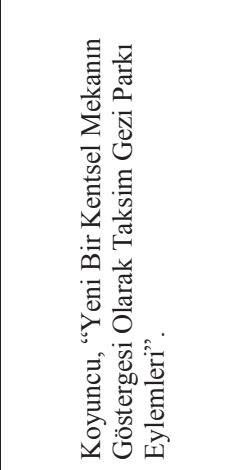 \\
\hline
\end{tabular}


346 • Tarihsel, Soyut, Çelişkili: 1923'ten Günümüze Türkiye'de Kentsel Toplumsal Mekân

\begin{tabular}{|c|c|c|c|c|c|c|}
\hline 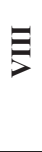 & $x$ & $x$ & $x$ & $x$ & 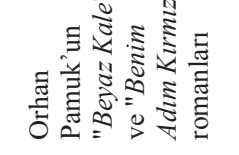 & $x$ \\
\hline $\bar{\nabla}$ & 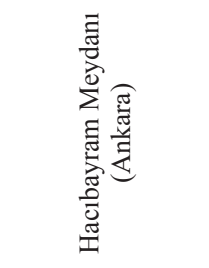 & 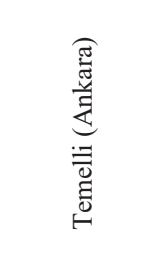 & 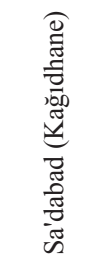 & $x$ & $x$ & 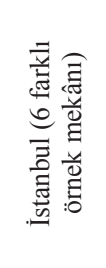 \\
\hline 5 & 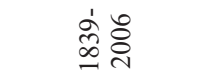 & $x$ & $x$ & $x$ & $x$ & $x$ \\
\hline$>$ & 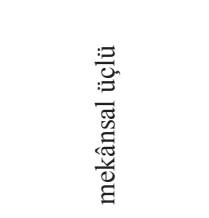 & 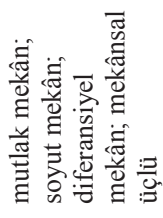 & 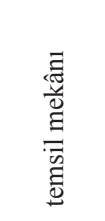 & 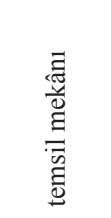 & 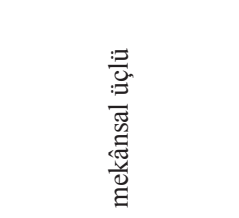 & 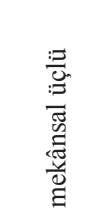 \\
\hline$\geq$ & I & $\overparen{ \pm}$ & I & I & I & I \\
\hline$\Xi$ & 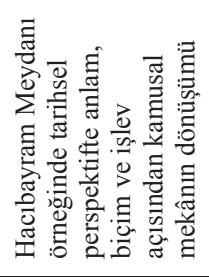 & 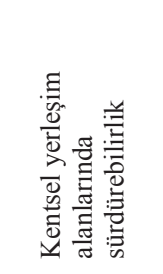 & 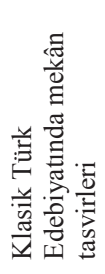 & 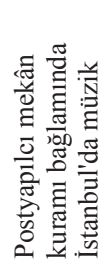 & 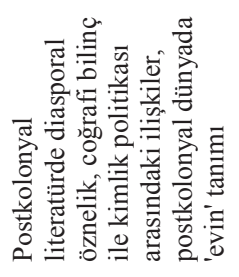 & 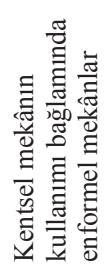 \\
\hline$=$ & $\stackrel{与}{コ}$ & 它 & $\Sigma$ & 苛 & 节 & 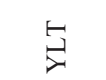 \\
\hline- & 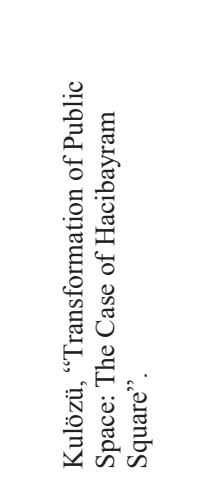 & 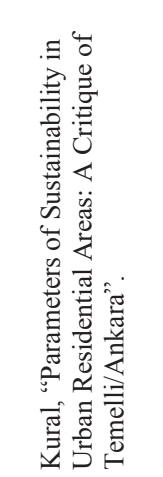 & 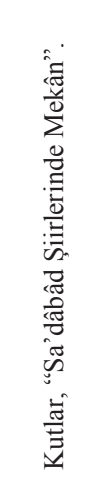 & 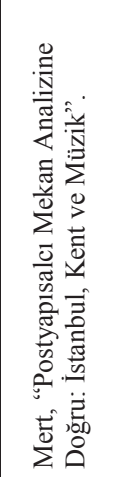 & 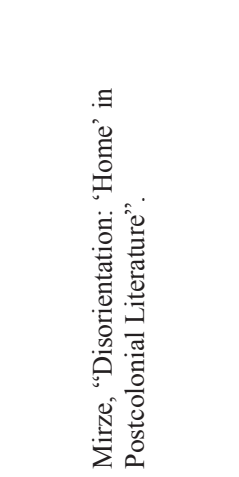 & 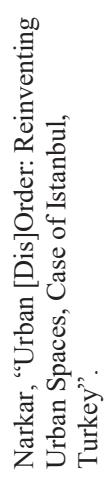 \\
\hline
\end{tabular}




\begin{tabular}{|c|c|c|c|c|c|c|}
\hline$\Xi$ & 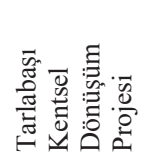 & 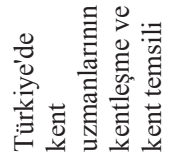 & $x$ & $x$ & $x$ & $\begin{array}{l}\vec{y} \\
\frac{0}{0} \\
\overline{0} \\
\overrightarrow{0} \\
0\end{array}$ \\
\hline $\bar{\nabla}$ & 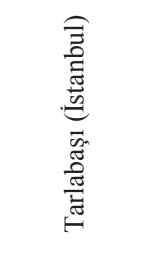 & $x$ & 莺 & 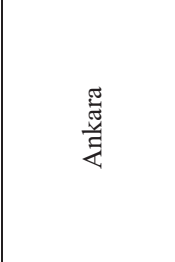 & 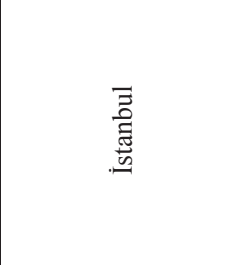 & 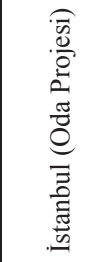 \\
\hline 5 & 官규 & $x$ & ஸ்่ & ஸे & $x$ & 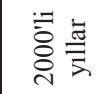 \\
\hline$>$ & 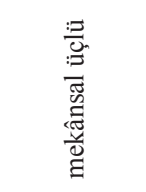 & 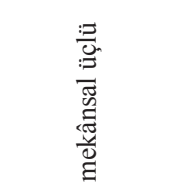 & 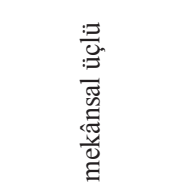 & 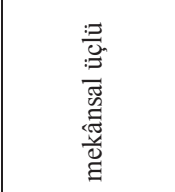 & 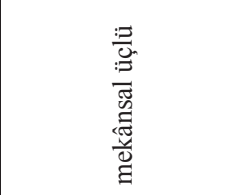 & $\rtimes$ \\
\hline$\geq$ & I & ક & I & I & I & ક \\
\hline$\Xi$ & 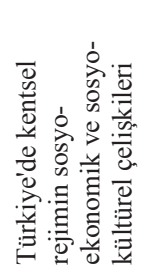 & 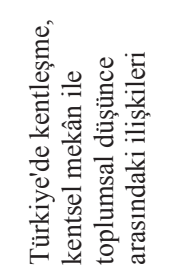 & 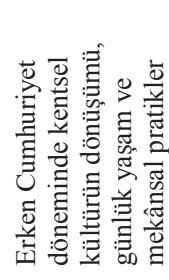 & 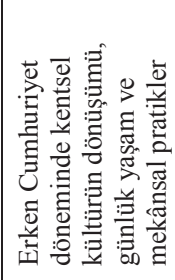 & 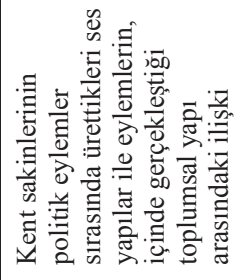 & 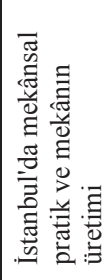 \\
\hline$=$ & $\stackrel{5}{二}$ & $\stackrel{5}{二}$ & 它 & $\vartheta$ & $\stackrel{5}{二}$ & 它 \\
\hline- & 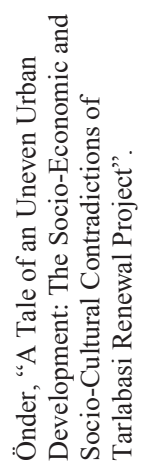 & 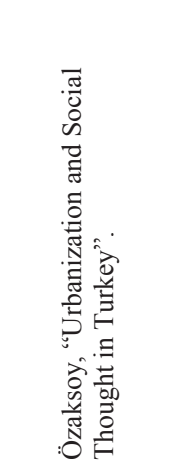 & 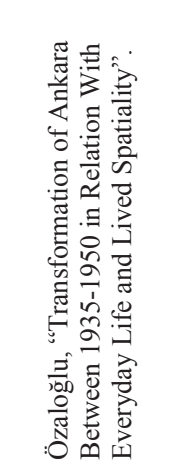 & 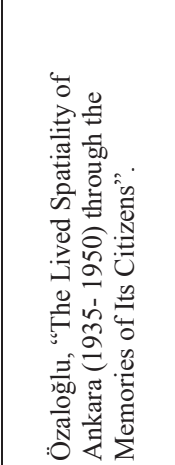 & 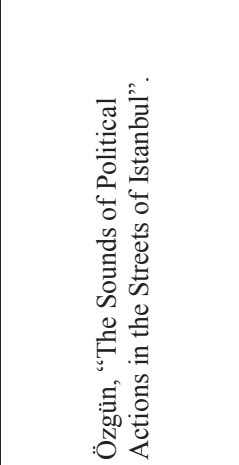 & 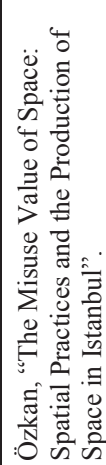 \\
\hline
\end{tabular}


348 • Tarihsel, Soyut, Çelişkili: 1923'ten Günümüze Türkiye'de Kentsel Toplumsal Mekân

\begin{tabular}{|c|c|c|c|c|c|c|c|}
\hline $\bar{\nabla}$ & $x$ & $x$ & 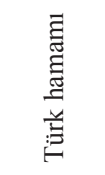 & 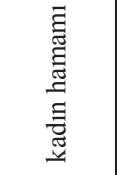 & 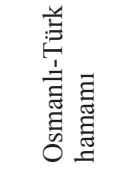 & 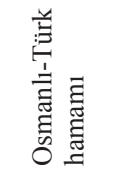 & 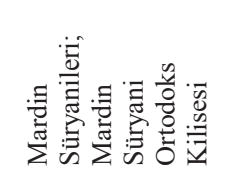 \\
\hline $\bar{\nabla}$ & 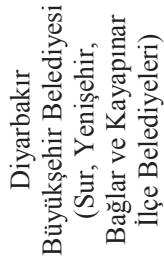 & 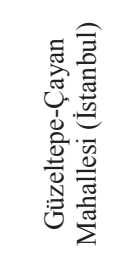 & $x$ & $x$ & 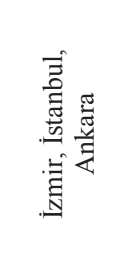 & $x$ & $x$ \\
\hline 5 & 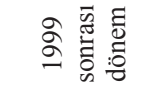 & ồ & $x$ & $x$ & 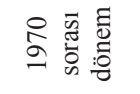 & $x$ & $x$ \\
\hline$>$ & 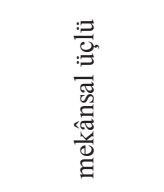 & 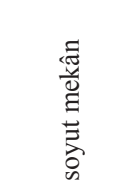 & 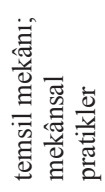 & 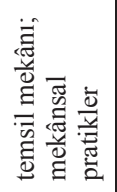 & 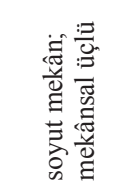 & 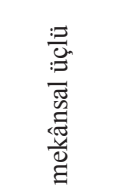 & 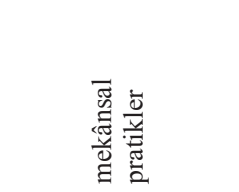 \\
\hline Z & I & I & I & I & I & I & I \\
\hline$\Xi$ & 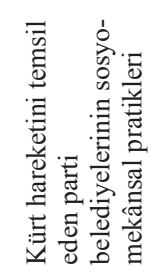 & 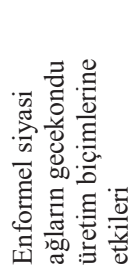 & 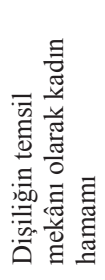 & 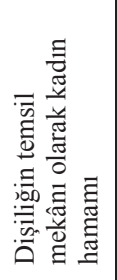 & 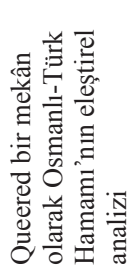 & 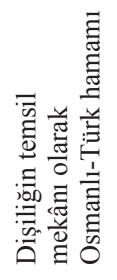 & 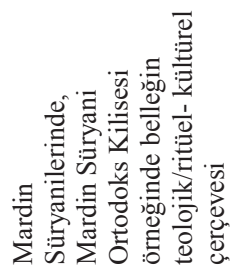 \\
\hline$=$ & $\stackrel{⿱ 乛 士}{二}$ & $\stackrel{\leftrightarrows}{コ}$ & $\ddot{v}$ & $\Sigma$ & 苛 & $\Sigma$ & $\Sigma$ \\
\hline- & 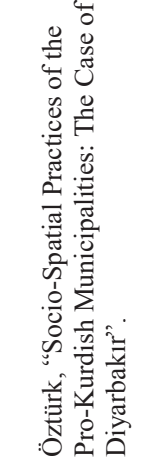 & 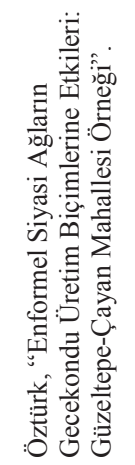 & 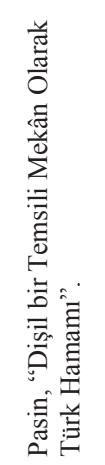 & 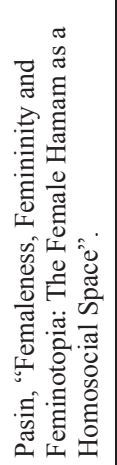 & 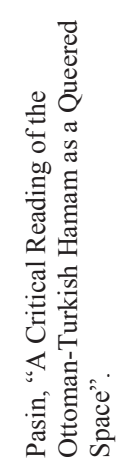 & 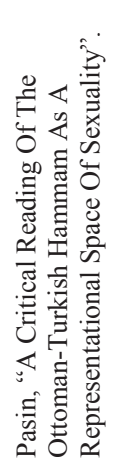 & 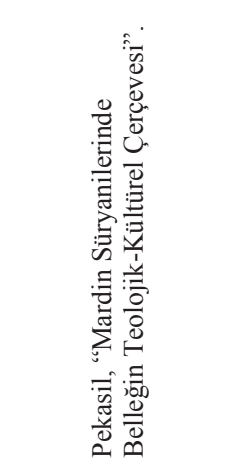 \\
\hline
\end{tabular}




\begin{tabular}{|c|c|c|c|c|c|}
\hline $\bar{\nabla}$ & $x$ & 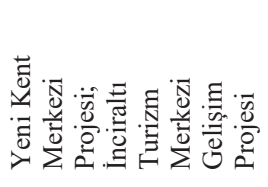 & $x$ & 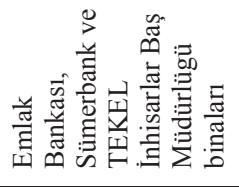 & $x$ \\
\hline $\bar{\nabla}$ & $x$ & 志 & 栉 & 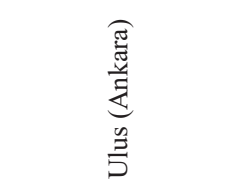 & $x$ \\
\hline$>$ & 咅离 & 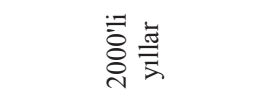 & 号 & 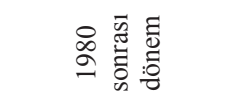 & $x$ \\
\hline$>$ & 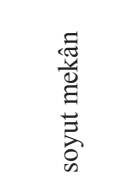 & 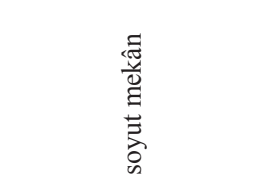 & 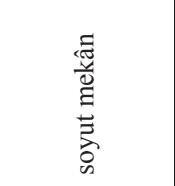 & 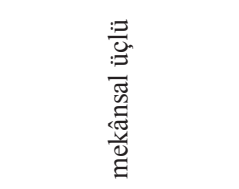 & 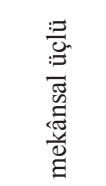 \\
\hline$\geq$ & I & I & I & I & I \\
\hline$\Xi$ & 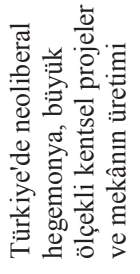 & 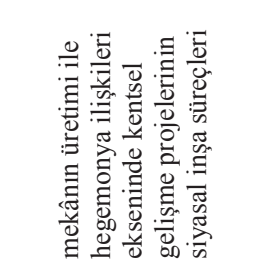 & 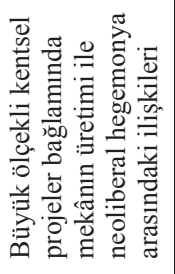 & 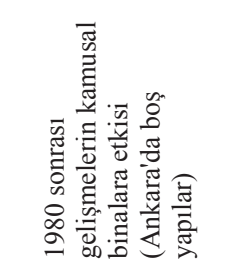 & 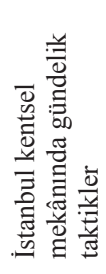 \\
\hline$=$ & $\Sigma$ & 常 & $\Sigma$ & 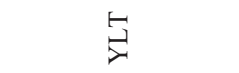 & 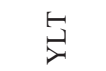 \\
\hline- & 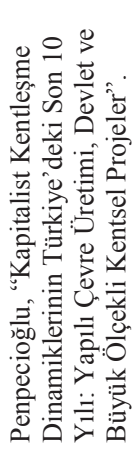 & 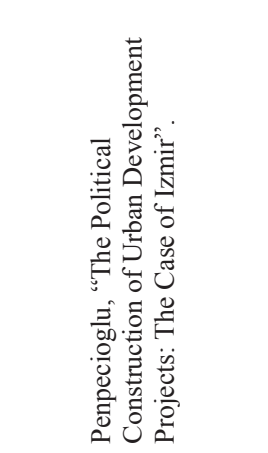 & 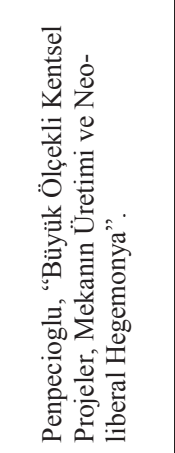 & 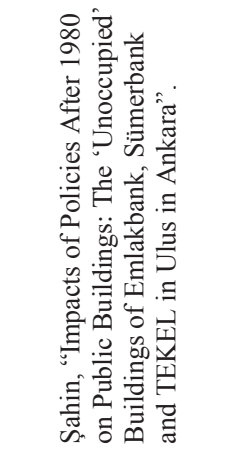 & 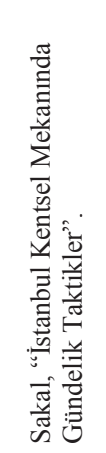 \\
\hline
\end{tabular}


350 • Tarihsel, Soyut, Çelişkili: 1923'ten Günümüze Türkiye'de Kentsel Toplumsal Mekân

\begin{tabular}{|c|c|c|c|c|c|c|}
\hline 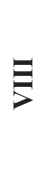 & $x$ & 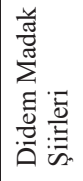 & $x$ & 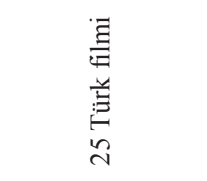 & 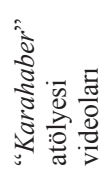 & 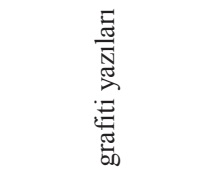 \\
\hline $\bar{\nabla}$ & 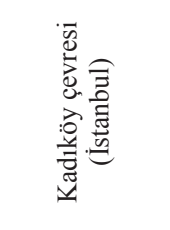 & $x$ & 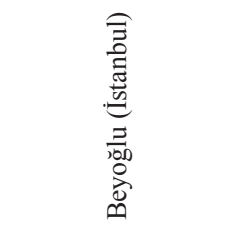 & $x$ & $x$ & $\begin{array}{l}\bar{\Xi} \\
\bar{\Xi} \\
. \tilde{\Xi}\end{array}$ \\
\hline$>$ & 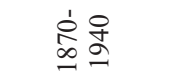 & $x$ & $x$ & $\begin{array}{l}1 \\
0 \\
0\end{array}$ & $x$ & $x$ \\
\hline$>$ & 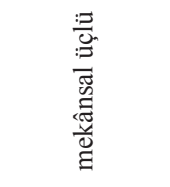 & 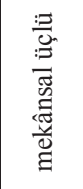 & 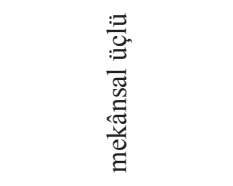 & 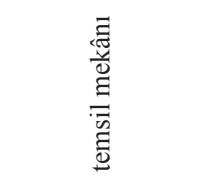 & 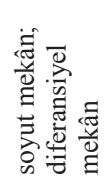 & 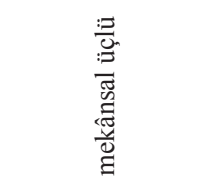 \\
\hline$\geq$ & I & I & I & I & I & I \\
\hline$\Xi$ & 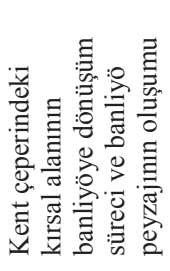 & 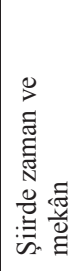 & 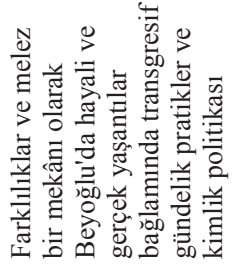 & 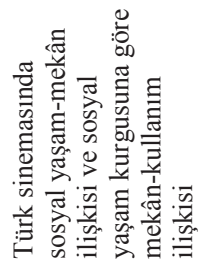 & 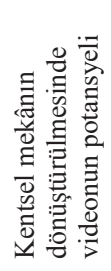 & 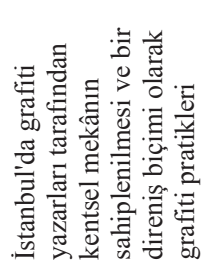 \\
\hline$=$ & 苛 & $\underline{v}$ & $\Sigma$ & $\stackrel{与}{\sqsupset}$ & $\stackrel{5}{\leftrightarrows}$ & $\stackrel{5}{\leftrightarrows}$ \\
\hline- & 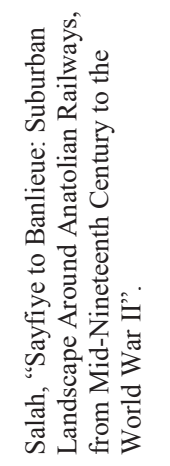 & 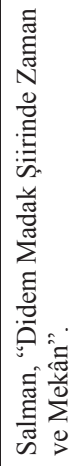 & 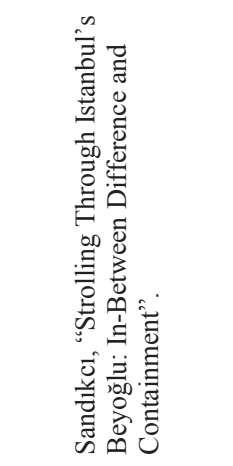 & 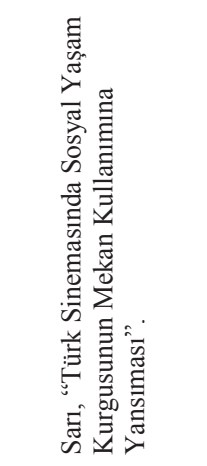 & 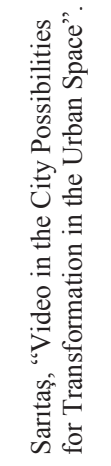 & 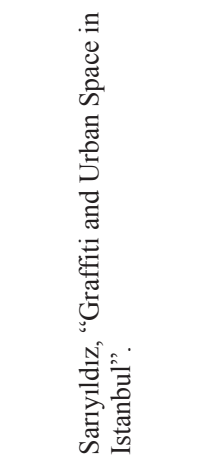 \\
\hline
\end{tabular}




\begin{tabular}{|c|c|c|c|c|}
\hline$\Xi$ & 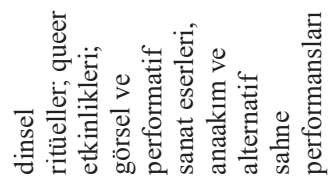 & 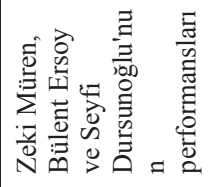 & $x$ & $x$ \\
\hline $\bar{\nabla}$ & $x$ & $x$ & 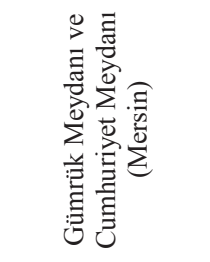 & 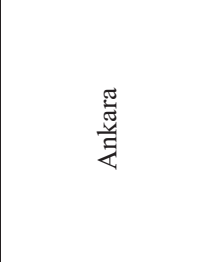 \\
\hline 5 & $x$ & $x$ & 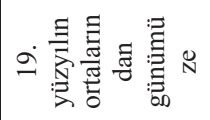 & 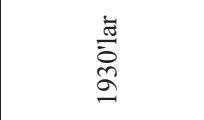 \\
\hline$>$ & 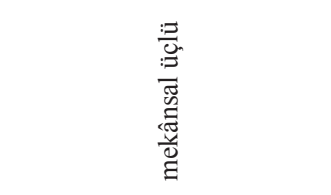 & 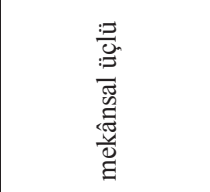 & 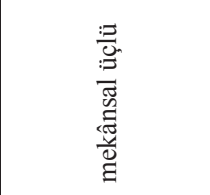 & 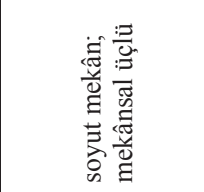 \\
\hline$\geq$ & I & I & I & I \\
\hline$\Xi$ & 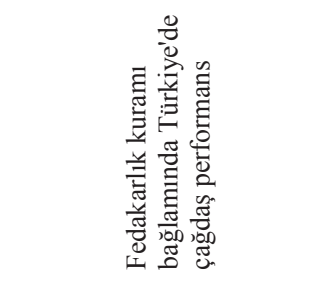 & 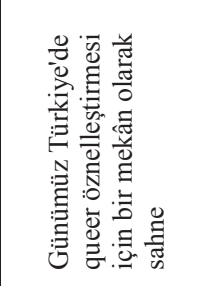 & 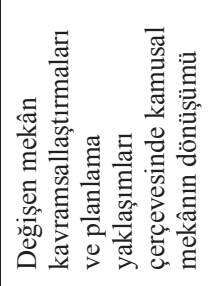 & 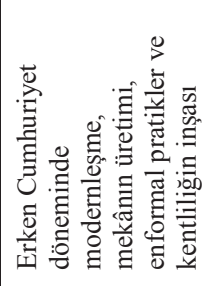 \\
\hline$=$ & 它 & $\Sigma$ & $\stackrel{\vartheta}{ }$ & 穴 \\
\hline- & 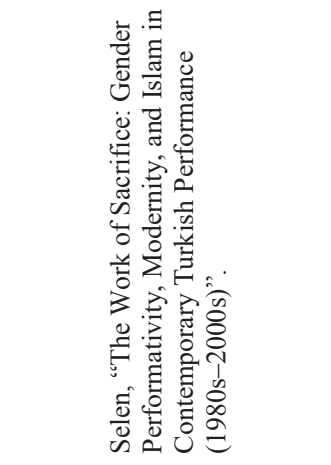 & 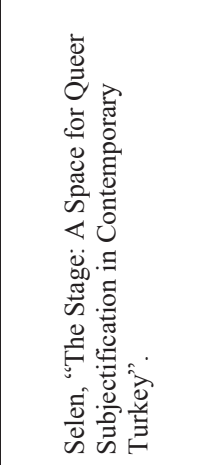 & 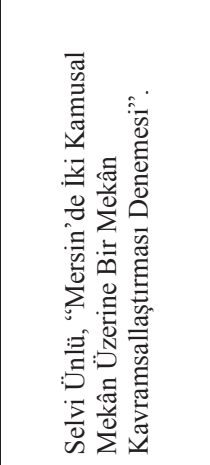 & 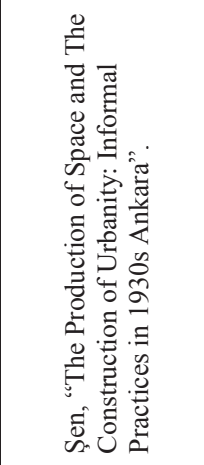 \\
\hline
\end{tabular}


352 • Tarihsel, Soyut, Çelişkili: 1923'ten Günümüze Türkiye'de Kentsel Toplumsal Mekân

\begin{tabular}{|c|c|c|c|}
\hline 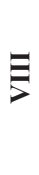 & 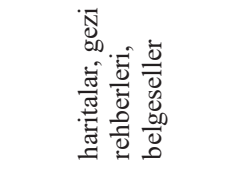 & $\begin{array}{l}\frac{\mathrm{E}}{\mathrm{a}} \\
\frac{\mathrm{a}}{0} \\
. \bar{N} \\
0 \\
0\end{array}$ & 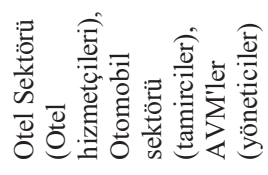 \\
\hline $\bar{\nabla}$ & $\begin{array}{l}\bar{\Xi} \\
\bar{E} \\
. \mathbb{E}\end{array}$ & $x$ & 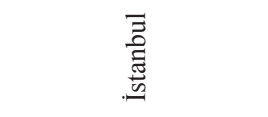 \\
\hline$>$ & 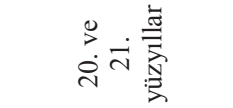 & $x$ & $x$ \\
\hline$>$ & 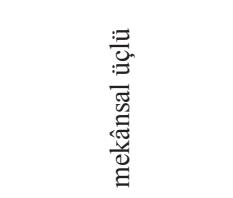 & 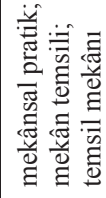 & 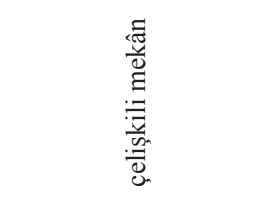 \\
\hline$\geq$ & I & I & I \\
\hline$\Xi$ & 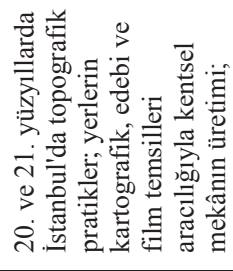 & 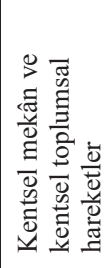 & 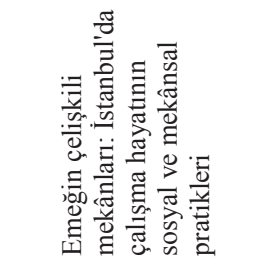 \\
\hline$=$ & 它 & $\Sigma$ & 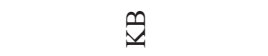 \\
\hline - & 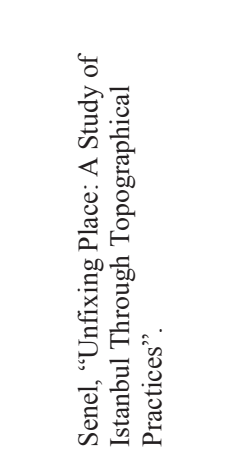 & 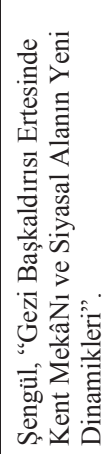 & 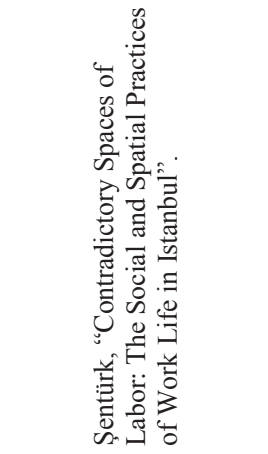 \\
\hline
\end{tabular}




\begin{tabular}{|c|c|c|c|c|}
\hline$\Xi$ & 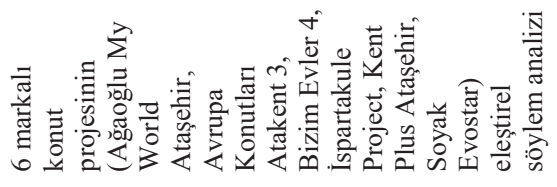 & 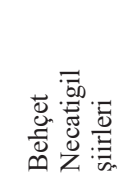 & $x$ & $x$ \\
\hline $\bar{\Sigma}$ & $\rtimes$ & $x$ & $\frac{\text { है }}{\text { है }}$ & 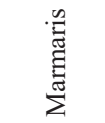 \\
\hline 5 & 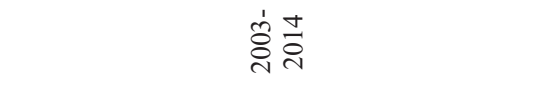 & $x$ & 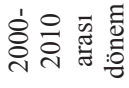 & $x$ \\
\hline$>$ & 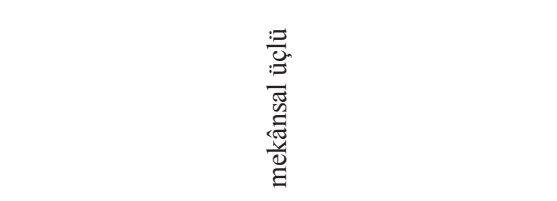 & 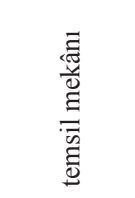 & 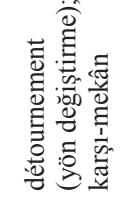 & 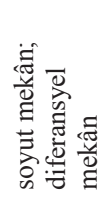 \\
\hline Z & I & I & I & I \\
\hline 三 & 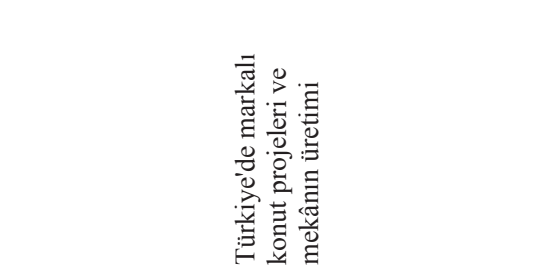 & 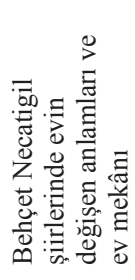 & 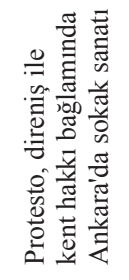 & 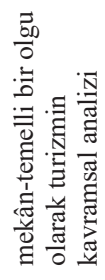 \\
\hline$=$ & $\Sigma$ & 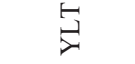 & $\Sigma$ & $\stackrel{5}{\circ}$ \\
\hline- & 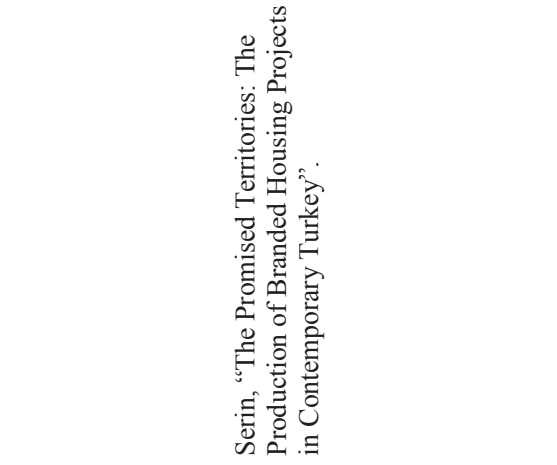 & 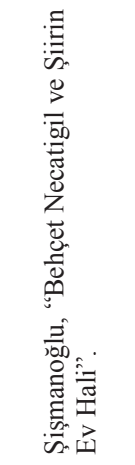 & 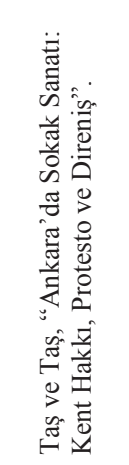 & 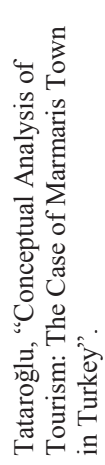 \\
\hline
\end{tabular}


354 • Tarihsel, Soyut, Çelişkili: 1923'ten Günümüze Türkiye'de Kentsel Toplumsal Mekân

\begin{tabular}{|c|c|c|c|c|c|c|c|}
\hline 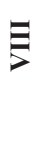 & $x$ & 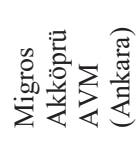 & 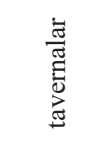 & $x$ & $x$ & $x$ & $x$ \\
\hline $\bar{\nabla}$ & $\begin{array}{l}\bar{\Xi} \\
\tilde{J} \\
\stackrel{0}{1} \\
\end{array}$ & $x$ & $x$ & 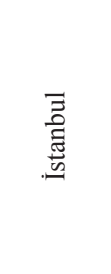 & 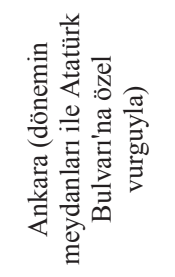 & 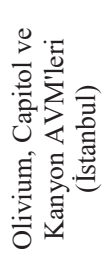 & 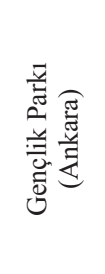 \\
\hline 5 & $x$ & $x$ & $x$ & 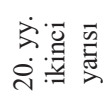 & 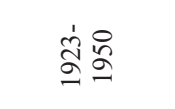 & $x$ & 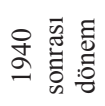 \\
\hline$>$ & 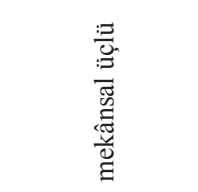 & 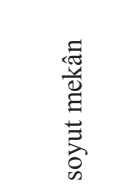 & 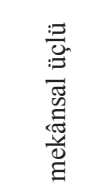 & 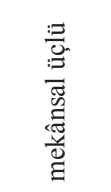 & 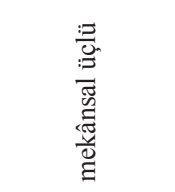 & $\begin{array}{l}\text { 音自 } \\
\text { 总 } \\
\text { 窇 }\end{array}$ & 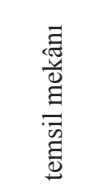 \\
\hline$\geq$ & I & I & I & I & I & I & I \\
\hline$\Xi$ & 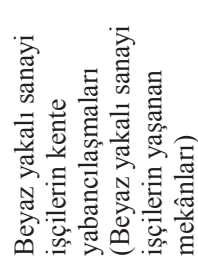 & 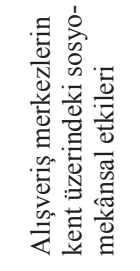 & 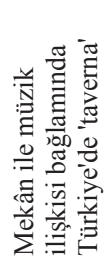 & 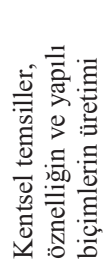 & 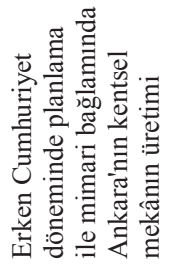 & 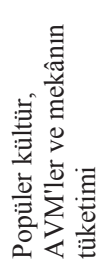 & 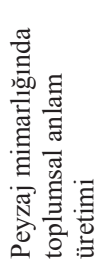 \\
\hline$=$ & $\stackrel{5}{7}$ & $\stackrel{\leftrightarrows}{\leftrightarrows}$ & $\stackrel{\leftrightarrows}{コ}$ & 它 & $\Sigma$ & $\Sigma$ & 泀 \\
\hline- & 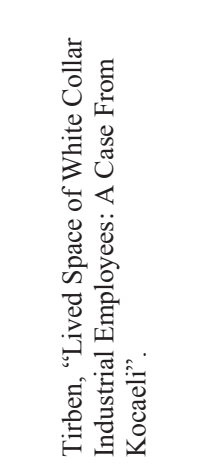 & 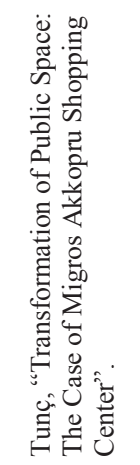 & 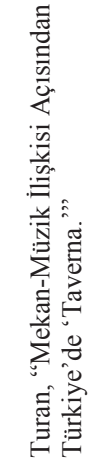 & 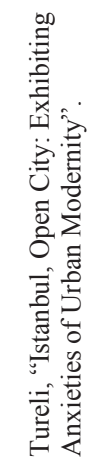 & 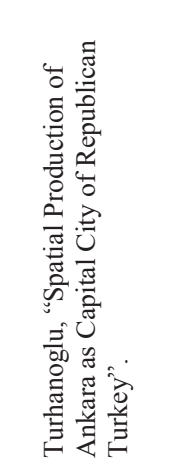 & 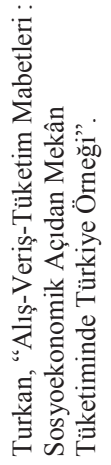 & 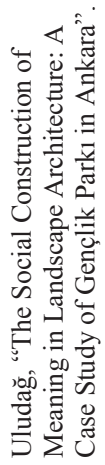 \\
\hline
\end{tabular}




\begin{tabular}{|c|c|c|c|}
\hline $\bar{\nabla}$ & $x$ & 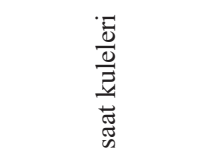 & $x$ \\
\hline $\bar{\nabla}$ & 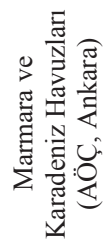 & $x$ & 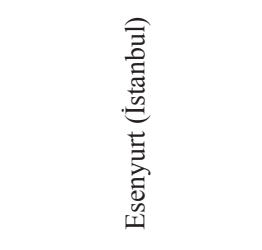 \\
\hline$>$ & ๙ิ่ & 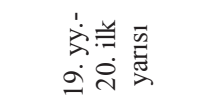 & $x$ \\
\hline$>$ & 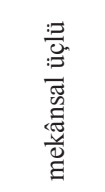 & 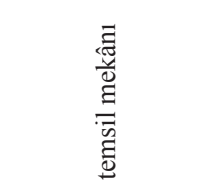 & 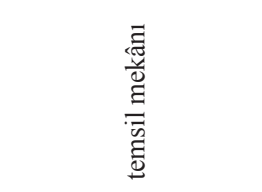 \\
\hline$\geq$ & I & I & I \\
\hline$\Xi$ & 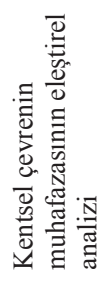 & 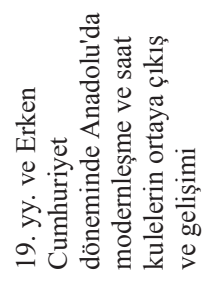 & 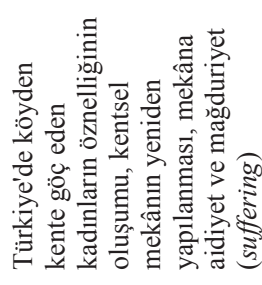 \\
\hline$=$ & $\Sigma$ & $\Sigma$ & 占 \\
\hline- & 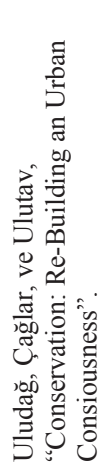 & 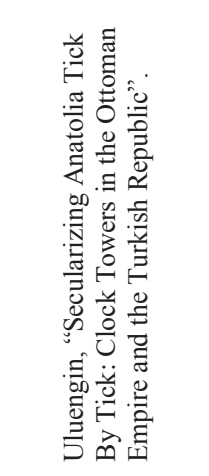 & 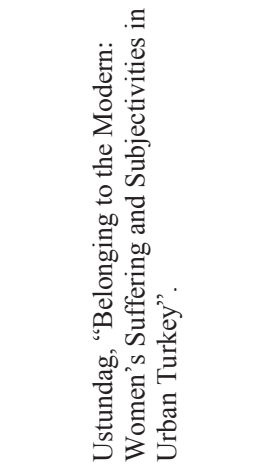 \\
\hline
\end{tabular}


356 • Tarihsel, Soyut, Çelişkili: 1923'ten Günümüze Türkiye'de Kentsel Toplumsal Mekân

\begin{tabular}{|c|c|c|c|c|}
\hline$\Xi$ & 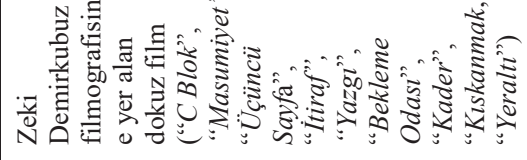 & $x$ & $x$ & 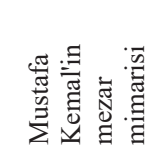 \\
\hline $\bar{z}$ & $x$ & 茎 & 苞 & $x$ \\
\hline 5 & $x$ & 昙咅 & 宅 完 & $x$ \\
\hline$>$ & 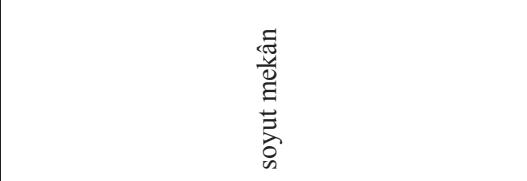 & 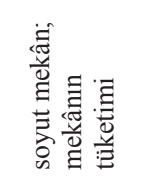 & $\begin{array}{l}\text { 䓌: } \\
\text { 惫 } \\
\text { 总 }\end{array}$ & 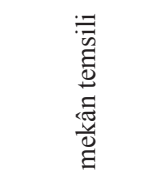 \\
\hline$\geq$ & I & I & I & I \\
\hline$\Xi$ & 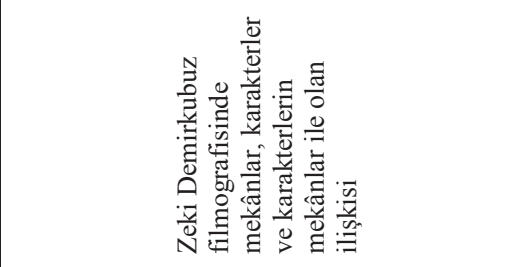 & 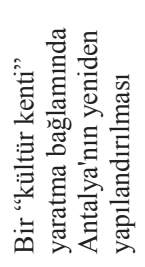 & 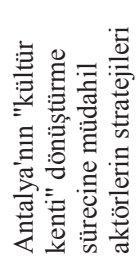 & 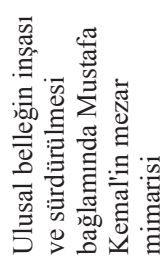 \\
\hline$=$ & 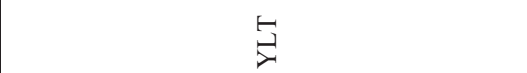 & 占 & $\stackrel{m}{\underline{y}}$ & 占 \\
\hline- & 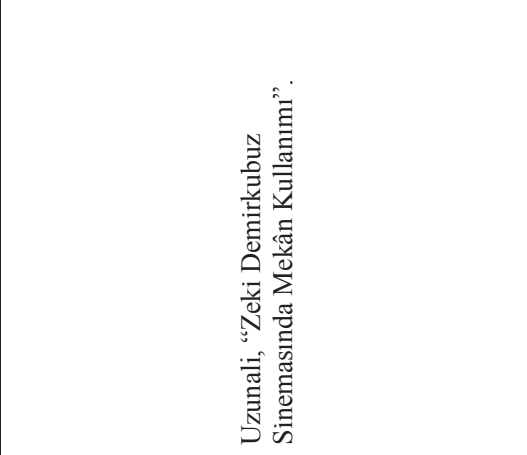 & 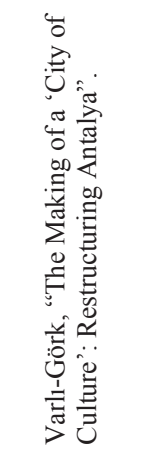 & 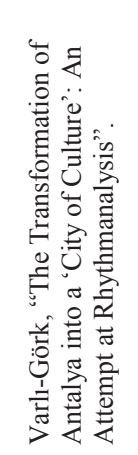 & 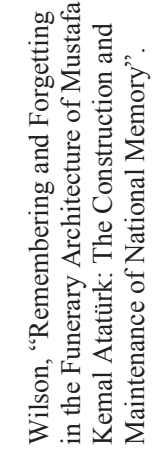 \\
\hline
\end{tabular}




\begin{tabular}{|c|c|c|c|c|c|c|}
\hline$\Xi$ & 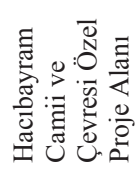 & 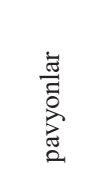 & $x$ & 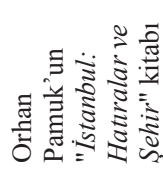 & 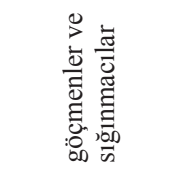 & 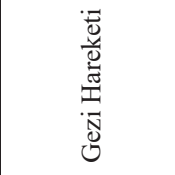 \\
\hline 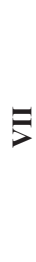 & 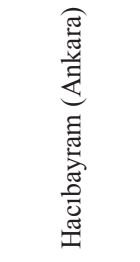 & $\frac{\widetilde{\pi}}{\tilde{\Xi}}$ & 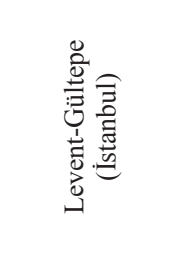 & $x$ & $x$ & $x$ \\
\hline 5 & 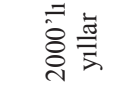 & $x$ & $x$ & $x$ & $x$ & $x$ \\
\hline$>$ & 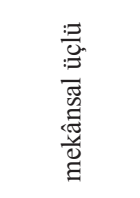 & 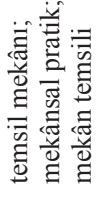 & 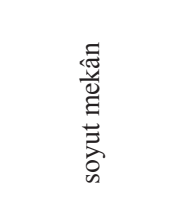 & 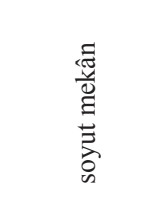 & 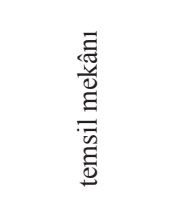 & 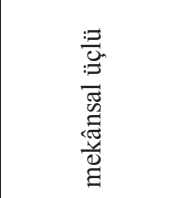 \\
\hline$\geq$ & I & I & I & I & I & I \\
\hline$\Xi$ & 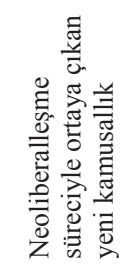 & 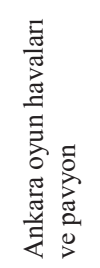 & 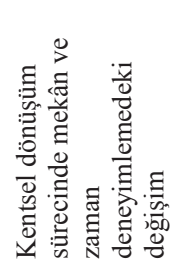 & 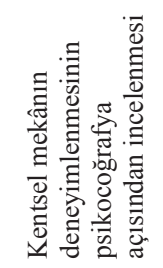 & 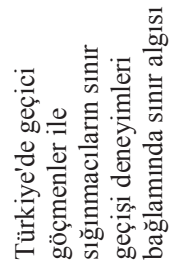 & 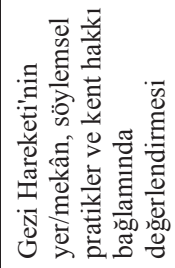 \\
\hline$=$ & 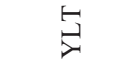 & $\Sigma$ & $\Sigma$ & $\Sigma$ & $\Sigma$ & $\stackrel{\bullet}{二}$ \\
\hline- & 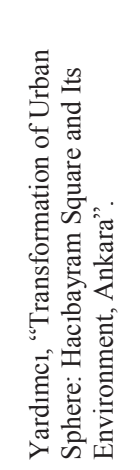 & 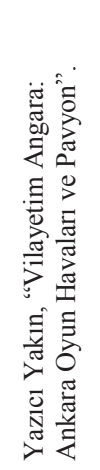 & 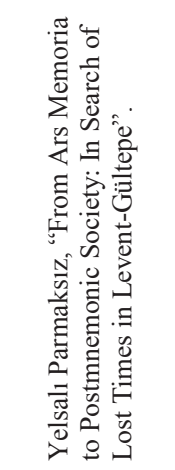 & 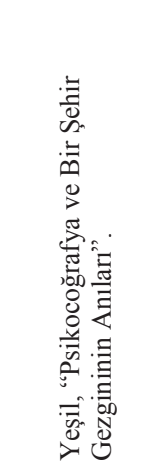 & 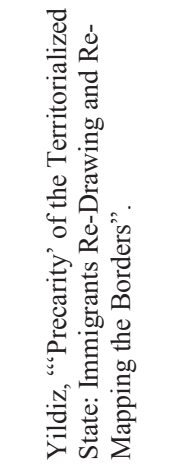 & 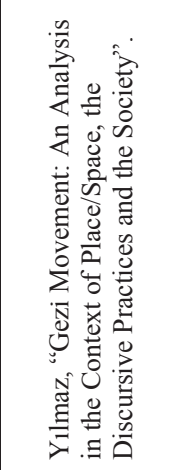 \\
\hline
\end{tabular}


358 • Tarihsel, Soyut, Çelişkili: 1923’ten Günümüze Türkiye'de Kentsel Toplumsal Mekân

\begin{tabular}{|c|c|c|}
\hline 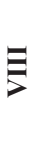 & $x$ & 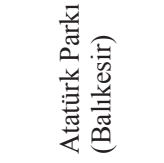 \\
\hline $\bar{\nabla}$ & 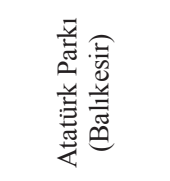 & $x$ \\
\hline 5 & 守莳灾客 & 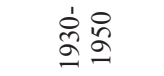 \\
\hline$>$ & 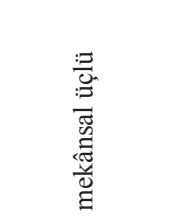 & 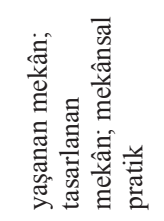 \\
\hline$\geq$ & I & I \\
\hline$\Xi$ & 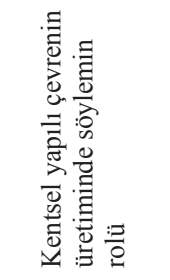 & 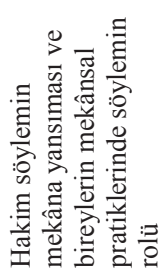 \\
\hline$=$ & $\Sigma$ & $\Sigma$ \\
\hline- & 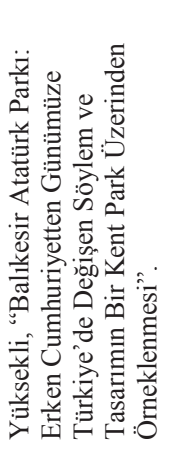 & 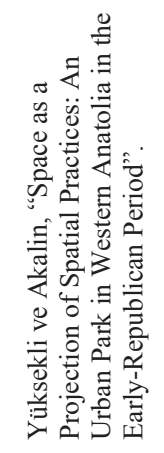 \\
\hline
\end{tabular}



e-ISBN: 978-605-136-531-2

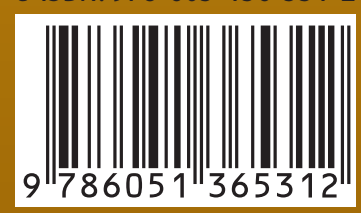

Ankara Üniversitesi Basımevi

http://basimevi.ankara.edu.tr 